$$
\begin{aligned}
& \text { 3. }
\end{aligned}
$$

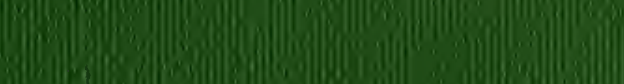$$
\text { (I) }
$$ 


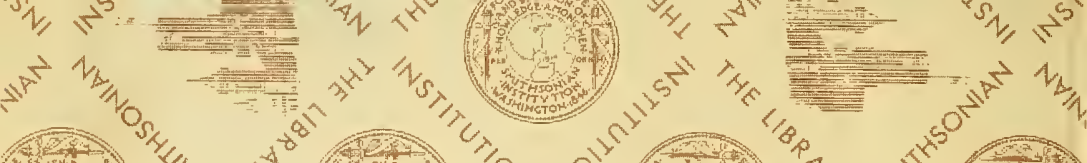

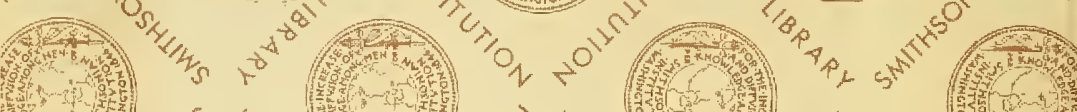

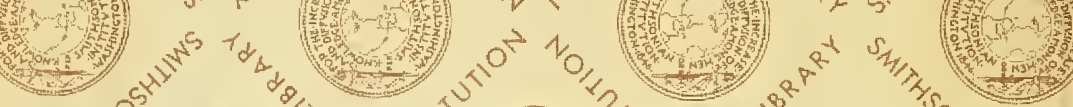

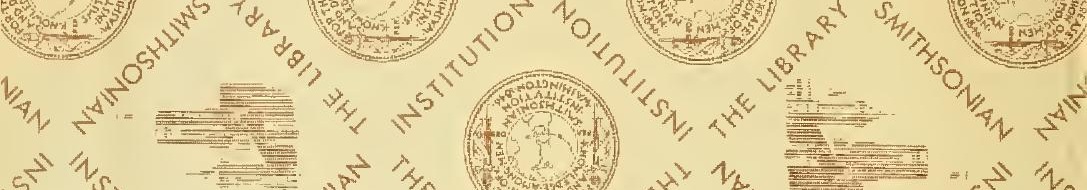

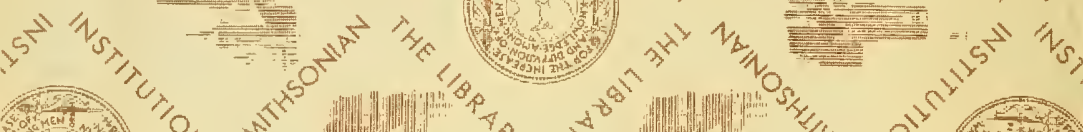
$x_{0} p^{2} x_{0}$

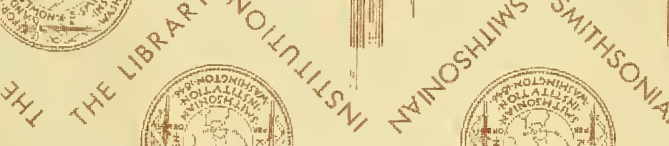

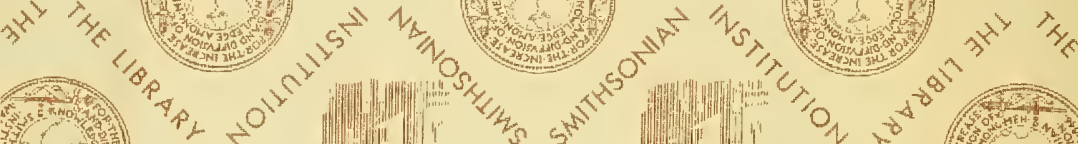

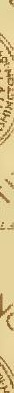
(5)

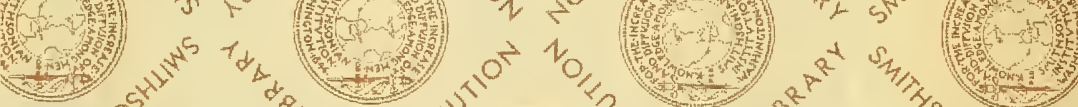

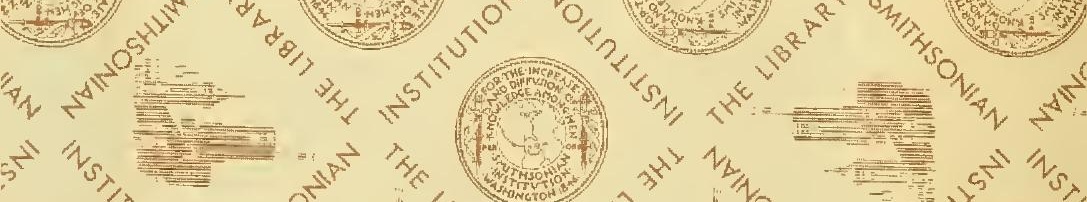

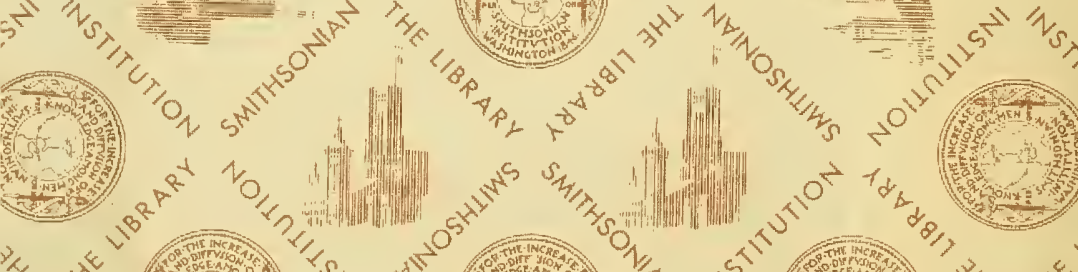

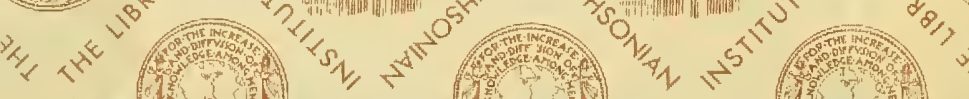

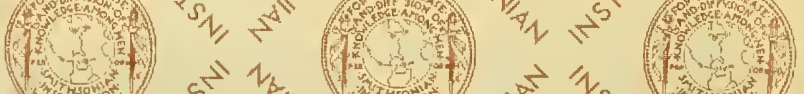




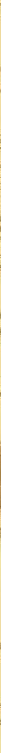

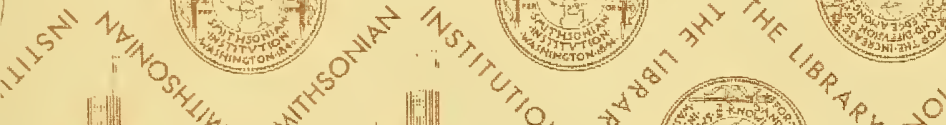

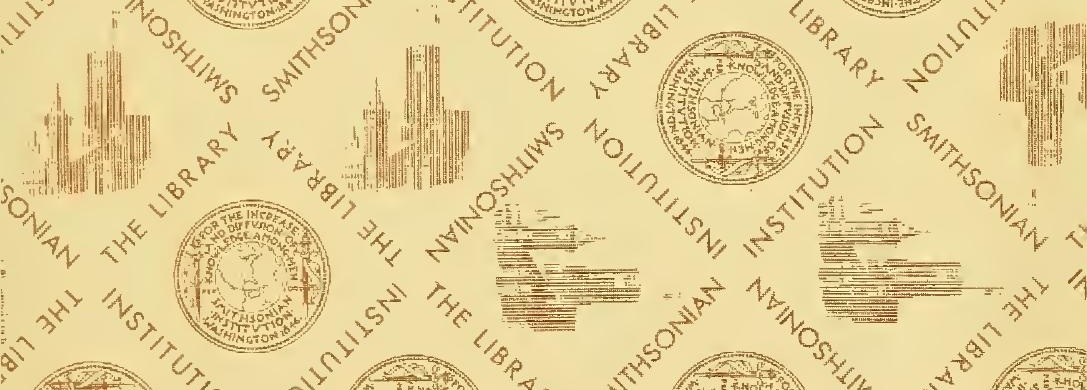

(1)

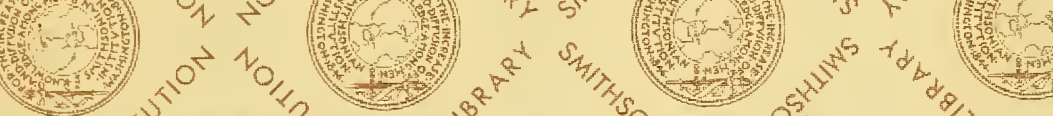

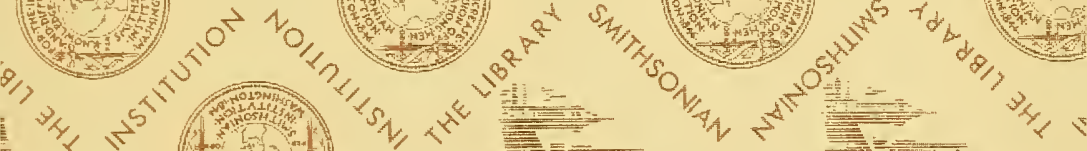

5

F

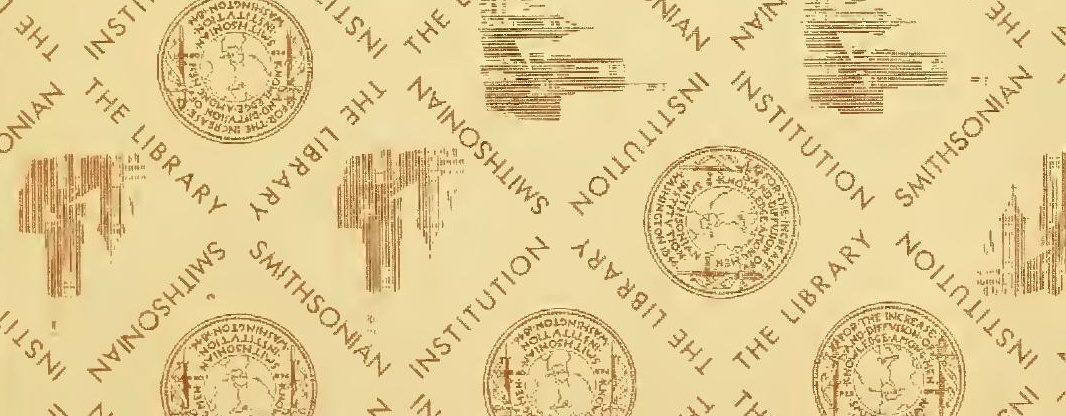









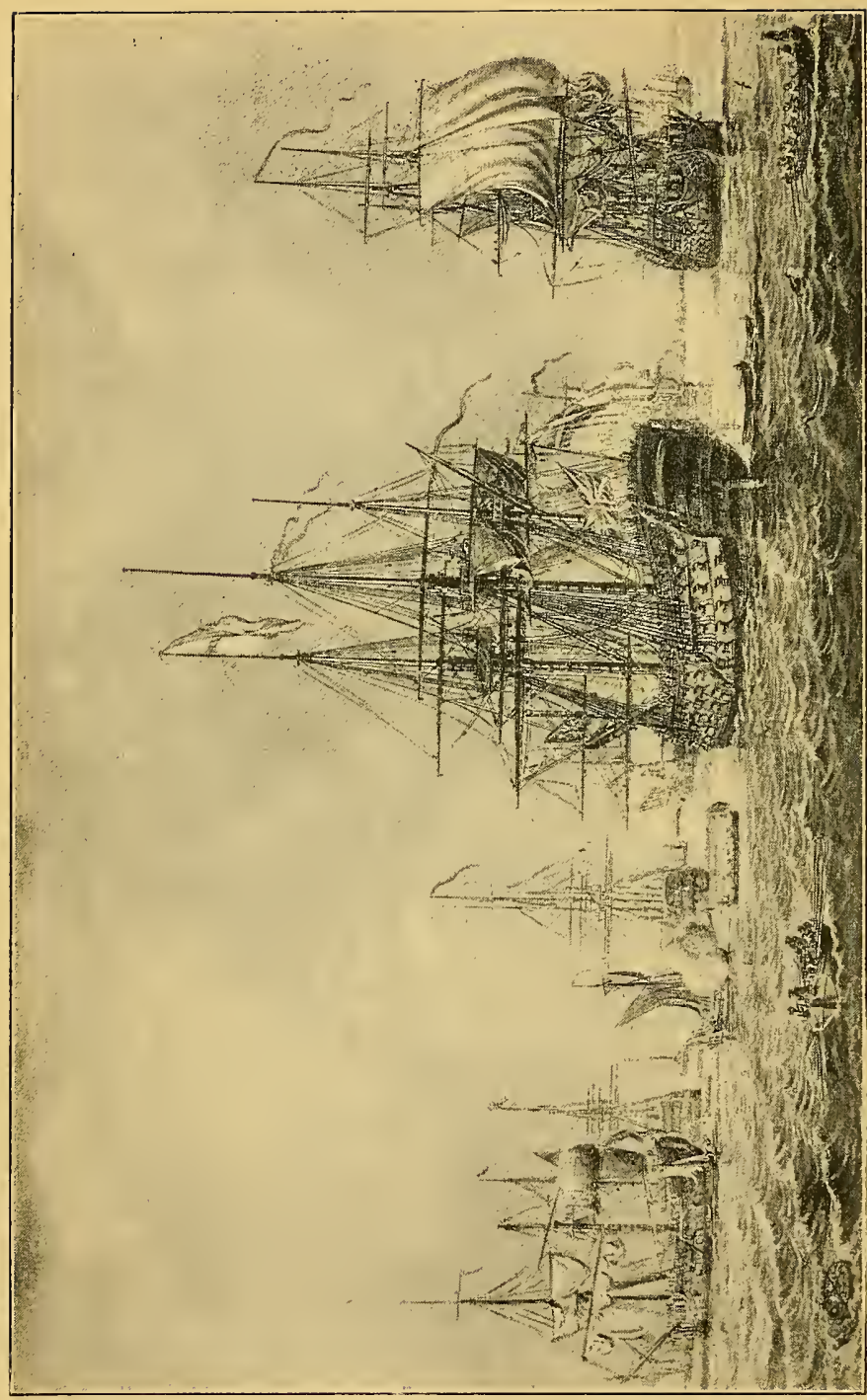

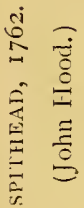




\section{THE BRITISH FLEET}

THE GROWTH, ACHIEVEMENTS AND

DUTIES OF THE NAVY OF

THE EMPIRE

BY

Commander CHARLES N. R'OBINSON, R.N.1844Assistant Editor of the "Army and Navy Gazette"

Author of "The Sea Service," etc., etc.

WITH ABOUT ONE HUNDRED AND FIFTY REPRODUCTIONS OF PAINTINGS, PRINTS, AND DRAWINGS ILLUSTRATIVE OF BATTLES,

SHIJP, PERSONS, CUSTOMS, AND SOCIAL

LIFE IN THE NAVY

\section{$5 \quad /$ LONDON/}

GEORGE/BELL/\& SONS, YORK ST., COVENT GARDEN AND 66, FIFTH AVENUE, NEW YORK 


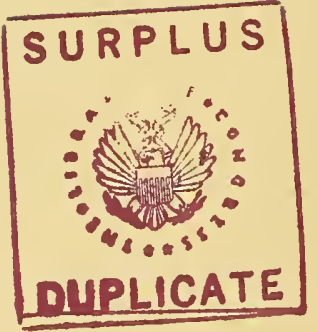

CHISWICK JRESS:-CHARLFS WHITTINGHAMT AND CO TOOKS COURT, CHANCERY I.ANE, LONDON.

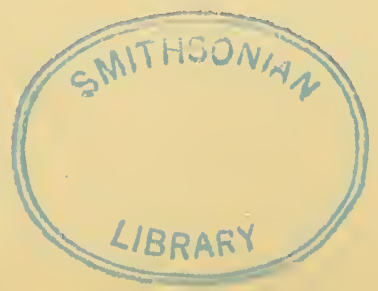


TO

H.R.H. GEORGE DUKE OF YORK, K.G., CAPTAIN R.N.,

THIS WORK IS DEDICATED

WITH

HIS ROYAL HIGHNESS'S GRACIOUS PERMISSION. 



\section{PREFACE.}

MANY books have been written about the British Navy and its achievements, but none of these give a general view of the origin, character, functions, organization, and administration of the sea service. To fill the gap in our naval literature is the purpose of this volume.

It is now universally recognized that without the maritime arm as a defensive and fostering factor the British Empire can neither continue nor further grow. For this reason it seemed desirable to issue a manual, which should in some measure approach to completeness, illustrating the use and nature of this naval force.

In order to place clearly before the reader the genesis, management, and system of the fleet, I have deemed it advisable to divide the work into sections. These deal respectively with its functions, its administration, its material, and its personnel, both historically and in their existing aspect.

An attempt has been made in the first section to show why and how the British Navy grew, and the character of the influence it has exercised in the protection of our shores, and the expansion of our dominion and our commerce. In other words, it has been sought, without burdening the pages with dates and chronicles of events, 
to deduce the broad and weighty lessons of naval history. These speak to us with no uncertain sound, and carry conviction to the mind that what the Navy has been to us, it must continue, with the greater reason, to be. In the fourth chapter it is shown from a survey of the present situation, geographical and political, and the nature of our responsibilities, why an all-powerful Navy is essential for the protection of our shores, the safeguarding of our food supplies and floating commerce, and finally for the maintenance of the Empire.

The second section is devoted to an exposition of the development of our naval administration from the earliest times, until we see it at length in the form in which this administration exists to-day. It is believed that the story of the gradual expansion of an organization so complex and far-reaching as that of the British Navy cannot fail to prove interesting, and certainly not a few lessons are suggested thereby. In the chapters of this section will also be found historical sketches of the naval establishments, offices, and departments, and a brief description of some of the laws and customs by which the Navy is governed.

In the same way, in the third section will be found an account of the growth of the material part of the Navy. Here an endeavour has been made to show, step by step, the progress of naval architecture from the earliest times, and how, from new conditions and fresh requirements, continuous developments have resulted. Thus it is finally seen how our battle-ships, cruisers, and torpedo craft are the lineal descendants, embodying the latest achievements of science and shaped by modern special needs, with new characteristics of offensive and defensive power, of the primitive craft of our early ancestors. 
The fourth section deals in a precisely similar way with the personal constitution of the Navy. It is explained how the new characters of ships and the introduction, first of sail-power and then of steam, with the change in offensive means, have resulted in changing the functions and specializing the duties both of officers and men. Here also a full explanation is given of the past and present systems of manning and officering the fleet. A good deal of interest it is hoped will be felt in the particulars which are given of the history of naval costume and uniform, and of conditions of life afloat both in the old times and in the present day.

It will be observed that the volume, while thus dealing with the development and services of the Navy, is at the same time a pictorial illustration of them. No such representative collection of naval pictures as that which will be found in these pages has ever been brought together. Wherever it has been possible, each action, ship, uniform, or other matter depicted, has been illustrated by the reproduction of the work of some contemporary artist. Thus, in an unique fashion, is illustrated both the British Navy and our most famous artists and caricaturists. The subject-matter of the illustrations, and brief accounts of the artists whose work I have laid under contribution, will be found in the appendix.

I take this opportunity to gratefully acknowledge the hearty co-operation of those gentlemen whose assistance has added most materially to whatever value the work may be found to possess.

To Mr. John Leyland, my colleague on the staff of the "Army and Navy Gazette," and my collaborateur in other walks of literature, and to Mr. Edward Fraser, sub-editor and naval writer of the "Daily Graphic," my 
warmest thanks are due for most cordial and efficient help. In addition to assisting in the labour of editing, the former gentleman has worked most materially in the production of the first section; while for the verification of the facts presented in the third section the latter has been at great pains to consult all the books and manuscripts from which my information is gathered, and has helped me to clear up many doubtful points in the evolution of the naval war machine.

In the second section I am indebted to Mr. Frank Miller, the superintendent of the Victoria Victualling Yard at Deptford, who has made the particular branch of the subject there treated his special study. About ten years ago Mr. Miller drew up for official purposes a memorandum of the origin and constitution of the Admiralty and Navy Boards, with an account of the various buildings in which the business of the Navy has been transacted from time to time. His work was embodied in a pamphlet, but this has never been within the reach of the public, and I am grateful to hin. , sot only for giving me the benefit of his knowledge and advice, but also for allowing me to draw largely upon this source of information.

In the preparation of the fourth section, I have 1 assisted by my cousin, Staff Paymaster W. C. A. J. R, son, R.N., whose father, a captain in the $\mathrm{Nav}_{j}, 1_{\mathrm{id}}$, eserved a number of books and letters descriptive of life in the service as experienced by our ancestors for five generations. From many other friends I have received help in various ways, either by the loan of books or pictures; and a catalogue of the numerous works, papers, etc., consulted by myself and my colleagues, would make a rather formidable naval bibliography. 
For permission to use some of their illustrations of shipping I am indebted to the proprietors of the "Illustrated London News" and "Graphic;" for those of marine engines and boilers, from a work by Mr. G. C. V. Holmes, and for Mr. R. C. Leslie's drawings from "Old Sea Ways, Wings, and Words," to Messrs. Chapman and Hall, Limited; for the reproductions of ordnance (pp. 269, $27 \mathrm{I}, 273,28 \mathrm{I})$ to the firm of Sir William Armstrong, Mitchell, and Co., of Elswick and Newcastle-on-Tyne, and for photographs of the Royal Sovereign (p. 224), the Melampus, a cruiser which the Duke of York once commanded (p. 263), and those of the guns of the Blenheim (pp. 267, 279), taken during the manœuvres of I893, to Messrs. Gregory, Opticians, Strand, W.C. To all these gentlemen I beg to tender my sincere thanks for their kindness.

It is not necessary to enlarge here upon the obligation which rests upon every citizen, who aspires to the name of patriot, to make himself acquainted in some measure with the du "s and purpose of that force on the efficiency and sufficiency of which the maintenance of the stability of the vast imperial fabric chiefly depends. Up to the present time, however, so far as I am aware, only one her attempt has been made to set before the public in ndy form the essential facts. In $184 \mathrm{I}$ a book iptive of the Naval Service of England was written by Mr. E. Mịiles, with the assistance of a naval officer, and published by Messrs. Ackermann. It has long been out of print, but I mention it because it appears to be the only work of similar scope to my own. I have reproduced the eight illustrations, by Mr. Knell, which it contains.

The materials for a naval history worthy of the great 
service to which I have the honour to belong are indeed profuse; they lie ready in our Rolls and Record offices, in public and private libraries and muniment rooms, but so far the history remains unwritten. There is no pretence here to supply this most desirable addition to our national literature, but with the earnest hope that it may be found useful to the publicist and student, as well as interesting to the general reader this work has been undertaken.

CHARLES N. ROBINSON.

August, 1894 . 


\section{CONTENTS.}

PART I.-NAVAL POWER.

Chap. I. The Origin of the Navy . Page

II. The Dawn of Sea Power. . . . . . . . . . 17

III. The Sovereignty of the Seas . . . . . . . . 33

IV. The Navy and the State. . . . . . . . . . 49

V. The Navy: its Relation to Discovery and to the

Public Service . . . . . . . . . 69

VI. Flags and Signals . . . . . . . . . 85

PART II.-NAVAL Administration.

CHAP. I. The Lord High Admiral and the Board of Ad.

miralty . . . . . . . . . . . . . IOI

II. The Equipment of the Fleet . . . . . . . II 5

III. The Victualling of the Fleet . . . . . . . I3I

IV. Admiralty Buildings . . . . . . . . . . I47

V. The Laws and Customs of the Navy . . . . . 167

VI. Concerning the Names of our Ships. . . . . 185

PART III.-NAVAL MATERIAL.

CHAP. I. The Evolution of the Ship-of-war. . . . . . . 20 I

II. The Development of the Sailing battle-ship . . . 2 I 5

III. The Transcendence of Wood, Canvas, and Hemp in Marine Architecture . . . . . . . . 235

IV. The Royal Navy of To-day . . . . . . . . . 257

V. The Development of Offensive Power . . . . . 267

VI. The Development of Defensive Power . . . . . 283

VII. Steam on Board Ship. . . . . . . . . . 293 
PART IV.--The PERSonNel of The NAVy.

Chap. I. The Seamen and Mariners of England. . . . . 3 I 5

II. Sea Officers from Blake's Day to Nelson's . . . 339

III. Warrant and Inferior Officers, Seventeenth and

Eighteenth Centuries . . . . . . . . 373

IV. The Tars who Made the Empire . . . . . . 4 I I

V. Our Officers To-day . . . . . . . . . . . 441

VI. Blue-jackets and Marines . . . . . . . 463

VII. Naval Costume . . . . . . . . . . 485

Appendix ON THE Illustrations . . . . . . . . 517

INDEX. • • • . . . 


\section{LIST OF ILLUSTRATIONS.}

SUBJECT.

ARTIST OR SOURCE.

PAGE

Spithead in 1762 . . . . . Hood . frontispiece

Viking ship, rooo . . . . . . Arenhold . . . . 3

Boat Action, 1667 . . . . . . . Van der Velde . . . 9

Battle off Malaga, I704 . . . . Sailmaker. . . . . 13

Capture of Princesa, 1740 . . . . Monamy . . . . . 17

Capture of $N i n f a, 1747$. . . . . Brooking . . . . . 21

Quiberon Bay, 1759 . . . . . . R. Paton . . . . 27

H.M.S. Hector, 1782 . . . . . . Rowlandson . . . 30

H.M.S. Rodney, 1840 . . . . . . Knell . . . . . . 32

Boarding a Privateer . . . . . Drummond . to face 32

Cape St. Vincent, I78o . . . . . T. Luny . . . . . 33

Battle off Dominica, 1782 . . . . Paton . . . . . 46

Jack's Quid of Comfort, 1795 . . . . . . . . . . . 48

Capture of Gamo, 1801 . . . . . Pocock . . . . . . 49

H.M.S. Brambie, 1840 . . . . . Knell . . . . . . 52

The Naval Brigade at El Teb, I884. Melton Prior . . . 59

An Inn Yard, 1747. . . . . . Hogarth . . . . 66 H.M.S. Pique, I840 . . . . . . Knell . . . . . . 68

The Mutiny of the Bounty, 1789 . . Dodd . . . . . . 69

H.M. Ships Racchorse and Carcass,

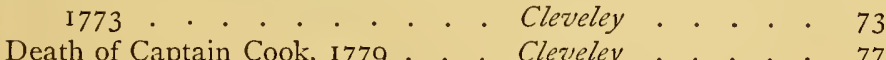

Old Time Slaver . . . . . . . Leslie. . . . . . 8 I

Arab Dhow . . . . . . . Leslie. . . . . 84

Byng's Council of War, 1756 . . Boitard . . . . . 85

Sprit-Topmast . . . . . . . Leslie . . . . . 93

Home-coming of Charles II., 1660. Van der Velde to face 96

Mid. on Half-Pay . . . . . . . Heath . . . . . 98

Sheerness and Chatham Dockyards . . . . . . . 100 
SUBJECT.

Admiralty Office, I754

British Hercules, 1737

105

Admiralty Board-Room, I 808 .

Pugin .

Seamen of H.M.S. Argonaut, I789 .

I I I

H.M.S. Firebrand, I 843

Leslie

I I 4

The Navy Office, I $75^{\circ}$

Cole.

I I 5

Portsmouth and Devonport Dock-

yards .

Portsmouth Point, I799

H.M.S. Queen, r840 .

Rowiandson.

I 2 I

H.M.S. Britamia, I72I .

Knell

127

Deptford and Woolwich Dockyards

Baston

I 3 I

Greenwich Hill, 1756

I 35

Midshipmen's Berth, 184I . . . De Berenger

I 4 I

Admiralty Waiting-Room, I 820

Cruikshank

Forecastle, H.M.S. Prince George,

I 779

Stothard

I 53

Midshipmen's Berth, I 854

The Tower Tender, London, I790

H.M.S. Arrow

Singleton

159

Jack's Keepsake, i795

Crossing the Line

Leslie

160

H.M.S. Phonix, I781.

H.M.S. Vernon, 1840

H.M.S. Pilot, I 840 .

Daniell

I63

I 66

Elliot

I67

Knell

Knell

185

186

H.M.S. Vesta, I 840

Knell

188

H.M.S. Victory', I780.

Elliot

191

H.M.S. Spider, I840.

Knell

192

H.M.S. Collingwood, I 886

J.R. Wells

I 95

Paid off, I797

Cruikshank

English Ship, 1200

Arenhold.

198

Sailor's Palm and Needle

Leslie

201

Ship's Binnacle.

Leslie

203

English Ship, I 300 .

Arenhold.

207

Nocturnal .

Leslic

209

Midshipman, I8I 5 .

Harry Grace d̀ Dieu, I 5 I5 .

Arenhold.

2 I 2

Astrolabe

Leslie

214

215

H.M.S. Royal Sovereign, I 893

Gregory 
H.M.S. Royal Sovereign, 1637 Arenhold

Sprit-sail . Leslie

232

Cartridge Case.

Leslie

234

H.M.S. Alurm, r78r .

Elliot

235

H.M.S. Marlborough, 178I

Elliot

24 I

H.M.S. London, I781.

Elliot

245

H.M.S. Liverpool, 1863

Groom

$25 \mathrm{I}$

Midshipman, 1827

H.M.S. Warrior, 1863

256

H.M.S. Achilles, r 868

J.R. Hells

257

H.M.S. Captain, 1870

J.R. Wells

259

H.M.S. Melampus, I 893

J. R. Wells

261

H.M.S. Thunderer, r88o

Gregory

J. R. Wells

263

A Traverse Board.

22-ton Gun in Blenheim

Leslie

265

12-ton Muzzle-loading Gun

6-inch Quick-firer .

Target Practice, I 889

22-ton Gun

H.M.S. Hercules, 1870

Firing 22-ton Gun

6 -pounder Hotchkiss.

H.M.S. Rattlesnake, I887

H.M.S. Thrush, 1890

H.M.S. Edgar, ISgr .

Yarrow Water-tube Boiler.

Gregory

266

Elswick

269

Elswick

271

J.R. Wells . to face 272

Elswick . . . . 273

J. R. Wells . . . . 277

Gregory

279

Elswick

251

283

285

J.R. Wells . . . . 291

Side-lever Engine.

Maudslay's Paddle Engine

Engines of $A$ mphion, 1844 .

Torpedo Boat Attack, 1892

Triple-expansion Engines

Section of Boiler

Water-tube Boiler, Thornycroft

Seamen of H.M.S. Edgar, 1785 .

Seaman, Fifteenth Century

Preventive Service Man, I 829

Revenue Cruiser Seaman

Prince William, I779

Seaman and Quadrant

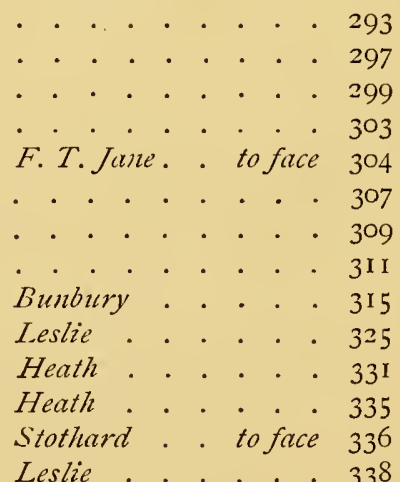


W. H. Overend to face 368

Captain, R.N., I797-I8I2 Rowlandson.

The Tars Triumphant, I 768 Collett.

Goni

to face 432

Captain of Marines, I787-97

Rowlandson .

Master, 1828-33.

Goni

French and English, I 854 Doiby

Cutting out Cherrette, I80 I

Loutherbourg 461

Ship's Boy, I8oo

Rowlandson.

463

Smugglers, I 840

$G$. Jones

Boatswain, $1828-33$

Goni

467

Colonial Visit, I 886

W. L. Wyllie Rowlandson.

Alken

Jack's Wedding-day, I 826 . Seamen, I693

The Sailor's Return, I 840

Seamen, I779

Midshipman, I787-1812

An Ocean Swell, I790

Lieutenant, I828-33

Boitard

I. P.

480

Midshipman, I828-33

Rowlandson. 484 485

Seamen, I779

Paid off at Chatham, I790 . Wheatley. 
PART I.-NAVAL POWER 



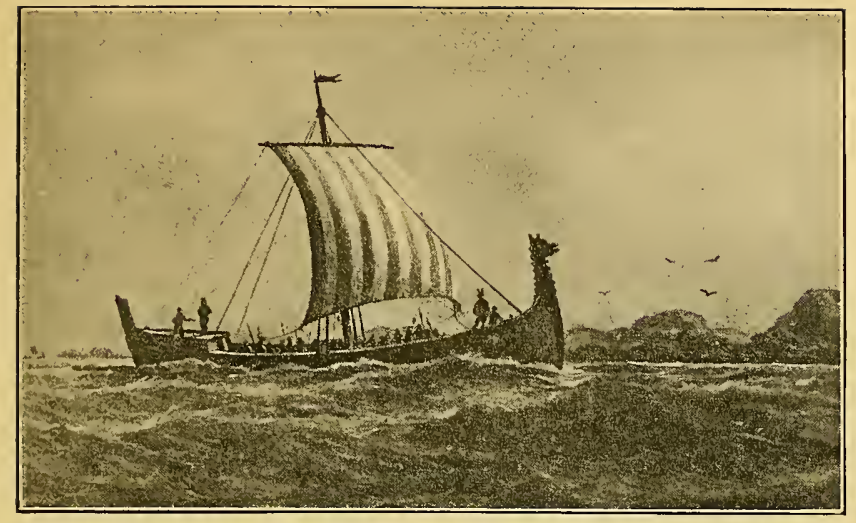

SHIP OF THE VIKINGS, A.1). I0O0.

(Arenhold.)

\section{THE BRITISH FLEET.}

\section{CHAPTER I.}

THE ORIGIN OF THE NAVY.

THE Conditions of Sea Pozver.-The purpose of this book is to give a view of the British Navy in its rise, its present state, and in what we may forecast of its future development, and this not only in its material elements, and the personal elements by which these are controlled, but in regard also to its duties and services. Here, then, at the outset, it is fitting that we should deal with some general conditions touching our Sea Power-conditions which have relation to the historical significance and present value of the Navy. 
One thought will be with us throughout this preliminary survey. It is that, by the very circumstances of our geographical situation, this Sea Power has in every case been, as it still is, and must continue to be, an allimportant factor in our security. The consideration lies, with almost equal plainness, upon the surface of our inquiry that it has been not less an essential condition of our colonial expansion. I shall endeavour, indeed, to make it plain that only by the possession of maritime strength has the development of England, and the growth of Greater Britain, with its world-wide commerce, been made possible. From these considerations - of security and expansion-a third will necessarily arise, namely, that not without the existence or exercise of our Naval Power can the prosperity of the mother country be made sure, and the stability of the Empire be maintained.

Now these things may be best elucidated by a survey of the broad and general drift of naval history. Professor Seeley has well said that history should end with something which might be called a moral. "Some large conclusion ought to arise out of it." " And I believe that, if we make a study of naval history, we shall reach the very definite conclusions foreshadowed above. We shall cease to regard the Navy as a subsidiary or auxiliary element in our history, and shall come to see that it has been quite a determining factor therein. With some surprise we may therefore ask ourselves how it has happened that our modern historians have had so little to say about this matter? The answer would seem to be that they have been so intently engrossed with our

1 "Expansion of England," Lecture I. 
constitutional and internal development, and so little with the expansion of the Empire, that, with few exceptions, the significance of Sea Power has almost escaped them. Professor Seeley ${ }^{2}$ to some extent has recognized the true place of the Navy in our history, but no writer has so ably expounded the real meaning of naval history as Captain A. T. Mahan, of the United States Navy, ${ }^{2}$ while Vice-Admiral P. H. Colomb ${ }^{3}$ is our chief authority for the ruling principles by which the Navy has exercised its influence.

This thought - of the relation of Sea Power to colonial expansion-leads us to consider the fact that we must not seek the effective beginning of British Sea Power, as we know it to-day, in any century before that which saw the westward journey of Columbus and the eastern seafaring of Vasco da Gama. We may be right in thinking that there is a nautical elenent in our national character; but the truth is that this characteristic was not developed until the day of the great explorers-the earliest and several of the greatest of whom it may be useful to remember were not Englishmen-and of the hardy seamen who were the pioneers of commerce in the New World. Fighting fleets we had doubtless possessed before, but these never exercised, nor were intended to exercise, the power which our Navy has since effectively wielded. Upon their brilliant achievements early jurists have, indeed, based our claim to a shadowy sovereignty of the seas as far back as the reign of John, but, as Admiral Colomb has pointed out, the claim had to do with rights

1 "Expansion of England."

2 "The Influence of Sea Power upon History," and "The Influence of Sea Power upon the French Revolution and Empire."

3 "Naval Warfare." 
of fishery, traffic, anchorage, and so forth, and was apart from any ideas of water-command for military purposes even so late as Charles's days. ${ }^{2}$ Moreover, we must remember that our early fighting fleets cannot speak to us so plainly of maritime power as the later sea-keeping vessels which have made possible our absolute and sustained command of the sea.

Nevertheless, the early history of the Navy is fruitful in lessons, and they are lessons that all later history deepens and enforces. It cannot escape us, in the first place, that the Navy has been called forth by emergency, and has been maintained as the value or necessity of it has appeared. Secondly, we may say that it has tended to grow with the growth of commerce, and that it has always been based upon commerce, and upon the existence of a merchant marine; and, most important to be observed, it will be seen that, in long periods of peace, or of internal preoccupation, there has ever been a tendency among Englishmen to forget the value of the Navy, with an effect dangerous or harmful to the commonweal. We shall not fail to discern, moreover, that, though the Navy has been used for attack, and, indeed, for oversea attack is plainly essential, its primary function has been, and must be, defence. ${ }^{2}$

The coming of the Saxons, and of the Dancs.-It was

1 "Naval Warfare," p. 2.

${ }^{2}$ The right character of defence needs to be understood. History has no plainer teaching than that the defence is most effective which assumes the aspect of offence. This is especially true of naval history, for the function of the Navy being to protect our land and possessions from attack, it has necessarily assailed the armaments of the enemy, and has often exercised this function by destroying them at long distances from our shores. 
by the possession of maritime power, by their ability to establish and maintain their communications across the Northern Sea, and in what afterwards became the English Channel, that the Angle and other Teutonic kinsfolk first became Englishmen. ${ }^{1} \quad$ It might have been expected that they would maintain the power by which they had prevailed. But what do we find? Being preoccupied in the work of conquest, in conflict among themselves, in the consolidation of the English State, they forgot the great factor by which their island history had begun. And we may say, in their case, perhaps almost necessarily so, for the need of maintaining open communications with the old homeland existed no longer, and the idea of maritime defence had not yet been conceived. The circumstances of the Saxons thus laid them open to the seafaring attacks of the Danes. As Mr. Green has well said, "the first sight of the Northmen is as if the hand on the dial of history had gone back three hundred years." From the fiords of the Scandinavian peninsula, and the islands and coasts of the Baitic, such piratical fleets came forth as had swept the seas in the days of Hengest and Cerdic. "There was the same wild panic as the black boats of the invaders struck inland along the river-reaches, or moored around the river islets, the same sights of horror, firing of homesteads, slaughter of men, women driven off to slavery or shame, children tossed on pikes or sold in the market-

${ }^{1}$ It has not been deemed necessary, in this brief sketch of a great subject, to go back to an earlier period for illustrations of the value of Sea Power. Yet it should not be overlooked that not until the seafaring allies of the Britons--the Veneti at the mouth of the Loire-had been crushed, did the invasion of Britain by Cæsar become possible. 
place, as when the English invaders attacked Britain." The steps of this terrible harrying, by the Vikings or "creekmen," from the plundering raids which began about 787 , to the partial Danish conquest, and finally to the political rule of Canute, need not detain us. What I would point out is, that, when the Danish assaults began, there were none as yet afloat to resist the withering storm. It remained for Alfred to grapple with the evil. The Peace of Wedmore was made, and the bulk of England remained with the strangers; but Alfred had leisure to create an effective fleet in place of the scattered remnants that had been wasted. The statesmanlike policy was pursued by Edward the elder, Athelstan, and Edgar. Ethelred the Unready, though far from careless of his fleet (which he organized and raised, it should be noted, by ship-levy) was powerless before the mightier organized bands of Northmen under Swein, whose son Canute, it is well to remember, was chosen king "by all the fleet" and remained a seafaring king. ${ }^{2}$

So far, then, the invasion and occupation of England had been accomplished through the possession and exercise of Sea Power. Without this same power its defence had become impossible. We have now to consider what was the relation of maritime strength to the invasion of William the Norman.

The Norman Conquest: its Naval Lesson.-As England had been won by seamen from the Britons, so had the Norman dukedom been wrung much later from the hands of Charles the Simple by the searoving followers of Rolf. But the Normans, having

1 "Short History," I. sec. 5.

${ }^{2}$ In I028 Canute conquered Norway with fifty ships of English thegns. 
ceased to be rovers, allied themselves with the Danish hosts which were dealing so hardly with the Englishmen. They gave them the hospitality of Norman ports, and it was to requite this act that Ethelred vainly despatched a fleet across the Channel. The lessons of this seafaring history were not lost upon William. How he profited

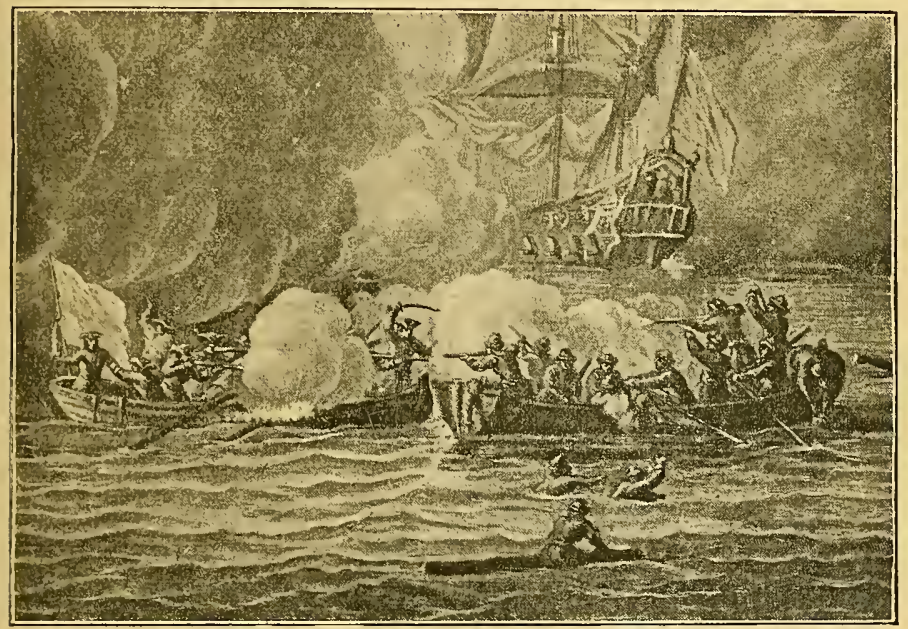

A BOAT ACTION IN THE THAMES, JUNE, I667.

(W. Van der Velde.)

by them is sufficiently known. He built a powerful fleet, with the indomitable energy which was his effective power, and, when the favourable breeze wafted him, with his vast armament, from Saint Valery, he landed, as is believed, unopposed upon the shore of Pevensey Bay. Thus was the Norman Conquest begun.

We may easily be led to cast blame upon Harold for neglecting, at this critical pass, to secure the maritime 
approaches to his realm. But let us remember that history nowhere depicts England in such a hard strait as this. It probably never entered into the calculations of Harold Godwineson, nor into the fondest hopes of William, that, even when the Norman fleet weighed anchor from the harbourage of Saint Valery, the squadrons of Harold Hardrada, aided by the treachery of Tostig, should already have poured forth their ruthless hosts upon the defenceless shores of the North. Such ships as Harold was able to bring together in the Channel vanished ere the host of William was sighted, and we may well believe that treachery such as assisted the designs of Harold Hardrada secured for William his easy landing upon the coast of Sussex. What it is important to note concerning this great event is that, from whatever cause, England was certainly impotent against maritime attack, and that William and Harold of Norway alike gained their purpose of invading our shores by the possession of Sea Power.

The Work of the Mediaval Navy.-It is unnecessary here to trace the steps by which the Norman kings secured their new dominion, but it was by the maintenance of sufficient fleets that the last efforts were paralyzed of the half-barbarous sca-rovers of the North. With the Norman Conquest a new. condition was created in our naval affairs. William was both an English king and a Norman duke, and the consequent relations with the continent were long maintained. An immense development of trade ensued. Commercial communities grew, the seas were covered with ships carrying English wool to the looms of the continent, and thronging our eastern and southern ports, bringing the woven fabrics of Flanders, and the products of the 
vineyards of Gascony and Acquitaine. Thus, in commerce and a merchant marine, was created the sure base for the growth of naval power. The ports of Kent, which had long been a chief maritime resource of the Saxon kings, and had been a primary object of attack to the Danes, ${ }^{1}$ received new privileges, and ultimately furnished the Royal Navy of the Cinque Ports, upon which the trust of Englishmen for many generations rested. $^{2}$

The country was more than once threatened with invasion in the reigns that followed the Conquest; but, when Normandy was lost by John, the naval service received, in the emergency of a new danger, a significant and greater development. The English king no longer ruled beyond the sea, and the dangers which his control of the Channel had made slight, grew suddenly grave and serious to his shrunken dominion. But John, justly though Englishmen contemn his memory, possessed to the full all the marvellous energy and mental capacity of his family. He was equal to the emergency. Everywhere we perceive new life given to the naval service. The Cinque Ports were bidden to be on the alert; ships were arrested for the king's use; no vessel might be transferred to a foreign flag. The French king was foiled by the ravaging of his coasts by the Earl of Salisbury in 1213, and his invasion of England was averted by the cutting out and burning of his vast armament collected in the harbour of Damme. But the tyranny of John bore its fruit, and his arm was shortened

1 The sons of Swein were driven off from Dover and Sandwich in 1069 .

2 See "The Cinque Ports," hy Professor Montagu Burrows, Captain R.N., in the "Historic Towns" Series. 
by the refusal of the barons to follow him. The Channel began to fill with the ships of the French, and Louis, crossing the sea, escorted by a powerful squadron under Eustace " the -Monk," was able to gain a temporary footing in south-eastern England, welcomed by a large part of the English baronage. ${ }^{1}$

Yet the engine which John had repaired and renewed was sufficient, in the beginning of his son's reign, in the celebrated battle of Dover Straits (May 2oth, I216)which, in its far-reaching effects, deserves to be ranked with Quiberon Bay or Trafalgar-to scatter the vast armament which the renegade Eustace was bringing to the aid of Louis; and the Frenchman had no choice but to retire discomfited from the country he had sought to win. This great battle, the first important fleet engagement of Englishmen, gained by their superior seamanship, gives to Hubert de Burgh, who was in command, a foremost place among the naval heroes of the country.

It was due rather to the maritime weakness of France than to the strength of England that disaster did not await us during the divided counsels and internal conflicts that shook the realm in the reign of Henry III. An expedition abandoned because of want of transport; the dispersal of a fleet with supplies on the coast of Gascony; the communications of the king cut at sea ; these tell the miserable tale. Now, too, we note a condition of things that speaks just as plainly. I mean the growth of piracy. The lawlessness of the country during the Barons' War affected even the Cinque Ports' men, and we read of robbery and murder committed by them at sea. The

"See Sir Harris Nicolas's "Hist. Navy." 
adventurous seafarers of Flanders and the Baltic, Frenchmen moved by national hatred, the seamen of the Iberian Peninsula, and even the merchant craft of the Mediterrancan, were strangling the growing commerce of western Europe upon the high seas and in port, and, instead of an English fleet being employed to check the

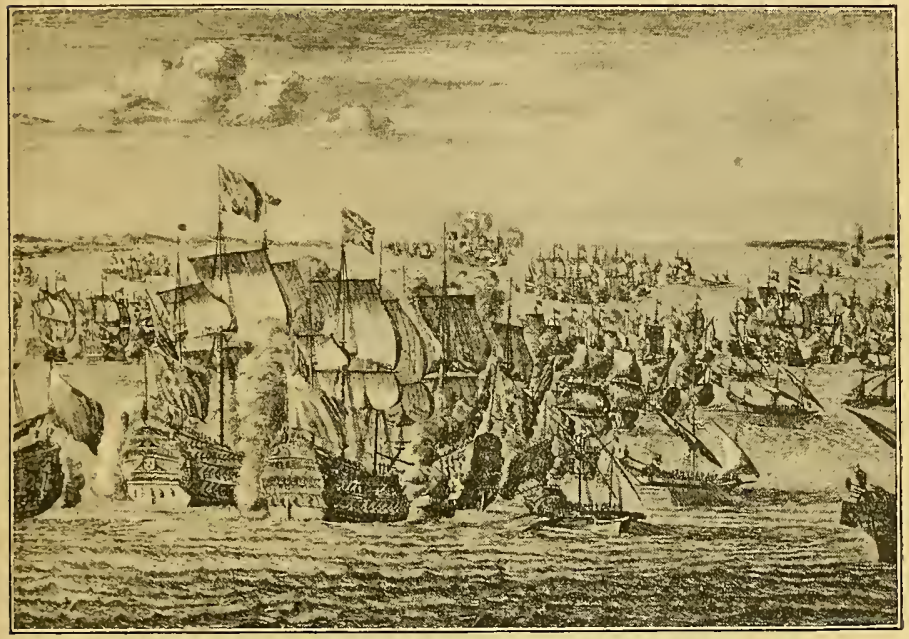

ROOKE AND SHOVELL WITH DE TOULOUSE OFF MALAGA, AUGUST, I7O4. (Isaac Sailmaker.)

scourge, we plunged into the Serbonian bog of individual reprisal and retaliation. ${ }^{1} \quad$ Now we find the barons of the Cinque Ports levying private war upon the citizens of Bayonne; and again, leagued with these in unauthorized

1 For a host of instances see the "Calendar of the Close Rolls of Edward II.," now in course of publication under the authority of the Master of the Rolls. 
operations against the men of Ferdinand of Castile. Even in the strong reign of Edward I. the spectacle of dead Englishmen hanging, with the carcasses of hogs; from the yard-arms of Norman vessels inflamed the sailors of the Cinque Ports to private war, which ended in the pitched battle off Saint Mahé ( I 293), pre-arranged by challenge, when the English, re-enforced by Irish, Gascons, and others, defeated the Normans with their Flemish, French, and Mediterranean allies.

The reigns of Edward I. and his son afford an illustration of the dangers attending a lawless condition, and a disputed command of the sea, for, though foreign operations were undertaken, it was possible for the enemy to sweep down upon our coasts, and in I 295 Dover was burned by the French. Again the impotence of our enemies alone saved us from disaster, especially during the wars with the Scots. Nor did the succeeding years greatly change the conditions; for, though the Cinque Ports' seamen gave Boulogne to the flames, the Frenchmen visited Portsmouth and other harbours of the Channel with fire and sword.

Yet the advance of navigation, and the consequent progress of the art of shipbuilding, were adding new elements of stability to the Navy; and, still more, the expansion of conmerce was providing an ever-widening base for Sea Power. The king no longer relied almost entirely upon the Cinque Ports to furnish his fleet, but was able to levy ships from every commercial port in the kingdom. The disasters that marked the early part of the reign of Edward III. were speedily repaired. Raising a numerous flotilla, he passed over the narrow seas and gained the great victory of Sluys (1340), wherein the outnumbering squadrons of Philip were 
almost wholly destroyed. It is a victory Englishmen know little of, but its importance was not less than that of the victories of Crecy and Poitiers. We may gravely doubt, indeed, if without it these could ever have taken place, for it gave Edward the full command of the Channel which was necessary for the prosecution of his war with France. Henceforth he was well styled "King of the Seas," and his power was established by the victory known as "Lespagnols sur mer," and his checking of the lawlessness of the seas, which was largely brought about by his reduction of the pirate stronghold of Calais (1347). You may find in Froissart the graphic touches which give a life-like picture of Edward riding the Channel, confidently awaiting the foe; of John of Gaunt, a boy, hastening to the fray from his mother's knee; of Sir John Chandos, inspiriting the seamen by trolling his latest German songs.

I must pass rapidly along, without mentioning a host of incidents, in order to reach the greater developnents of our Sea Power. The fleets which Edward had orought together were not maintained, and consequent disaster clouded his later years. The French ravaged IVinchester, and Portsmouth was given to the flames; and in 1372 the English suffered a terrible defeat it the hands of the Castilians off Rochelle. There are .ew more telling episodes in our naval history, for by this defeat the communications between England and Guienne were cut, and, as a result, save Bordeaux and Bayonne, the whole of southern France was lost to the English crown. Corresponding disasters marked the opening of the next reign, when the defenceless shores of Kent were wasted, and fire and sword were carried iinland by the Spaniards and the French. It remained 
for Henry $\mathrm{V}$. to repair the evil that had been done. With prodigious energy he undertook the restoration of the fleet, and the yards were busy with the building of his ships. In what manner Henry employed his Sea Power during his expedition to France, and his reduction of Harfleur, calls for no recital here. The impulse which he gave to naval concerns did not fail like that which had been imparted by Edward III.; but England and France alike were soon plunged into the vortex of civil strife, and were wholly engrossed in internal affairs. When England emerged from the Wars of the Roses, Edward IV. found means to add to his fleet ships of newer build and character sufficient for the protection of his dominions, and although, until the reign of Elizabeth, there was small demand for active service, the policy was steadfastly pursued by the Tudors, with the result of protecting us from interference from without. We have reached, however, a point at which this brief survey may pause. When we open a new chapter, it will be to unfold the lessons of a newer and a greater history-of the maritime history not of England only, not of the British Islands, but of Greater Britain, including our Empire beyond the seas. 


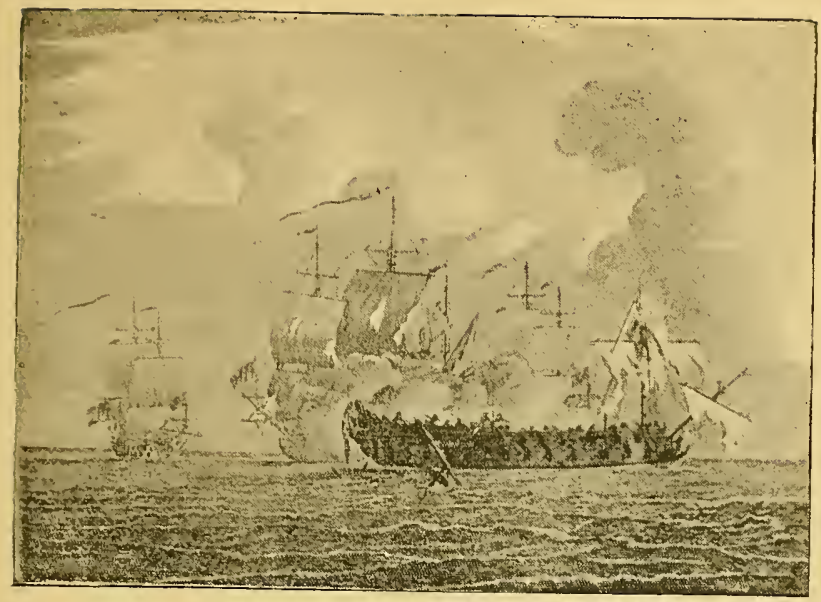

CAPTURE OF THE "PRINCESA" BY H.M. SHIPS "LENNOX," "KENT," AND "ORFORD," APRIL, I74O.

(P. Monamy,)

\section{CHAPTER II.}

THE DAWN OF SEA POWER.

THE stimulus of Discovery.-If we seek the most important operating causes in the development of the British Navy, we shall find them in the explorations of the great navigators. These were causes that operated in two ways-by bringing about an immense development in the seaman's art and craft, and in the material means at the seaman's disposal, and by creating conditions which imperatively called for the exercise, on a vastly greater scale, of Sea Power. When the captains of Prince Henry the Navigator first began 
that series of discoveries upon the western coast of Africa which led up to the greater achievements of Bartholomew Diaz and Vasco da Gama, seamen, in ill-found craft little capable of keeping the seas, were wont to hug the land, and ventured in peril beyond the sight of shore. But what do we find a hundred years later? Navigators in seaworthy vessels had then already traversed the ocean route to the Indies and beyond; Columbus had made the great journeys across the Atlantic which were to revolutionize the world ; Englishmen under Cabot had swept the coast of North America even to Labrador and Hudson's Strait; and, at the southern end of the new continent, Magellan had pushed through the tortuous way which bears his name; and Juan Sebastian del Cano had traversed the great ocean beyond, and, first of these seafaring explorers, had circumnavigated the globe.

If such was the new development of the seaman's craft, how was it in regard to the circumstances which called for the exercise of it? Here, indeed, was a hundred-fold greater cause for the expansion of naval power. That ocean which before had been a limit now became a pathway. The discovery of the New World effected a complete revolution in the Old, and the centre of gravity in affairs, which before had lain upon Italy, and had given their mediæval importance to Florence, Venice, and Genoa, was thereafter removed westward to the countries that bordered the Atlantic. The door to new possessions was now open, and those who would went in. The expansion of our race, and the growth of our Navy, were alike due to the attempt which ensued to wrest from the hand of the foreigner the advantages of monopolized commerce, and of distant commercial 
regions, upon which he had laid his hand, and to gain for Englishmen so much as still remained unoccupied or unclaimed.

Now and henceforth the Navy became the great instrument of our influence and dominion. As Professor Seeley says, answering the question, "By whom was the invasion of the Armada met?"- "Not by the Hotspurs of mediæval chivalry, nor by the archers who won Crecy for us, but by a new race of men such as mediæval England had not known, by the hero buccaneers, the Drakes and Hawkinses, whose lives liad been spent in tossing upon that ocean which to their fathers had been an unexplored, umprofitable desert. Now for the first time might it be said of England-what the popular song assumes to have been always true of her - that 'her march is on the Ocean wave.'

The War with Spain.-Passing over the maritime events of the reigns of Henry VIII. and his immediate successors, let us then fix our minds upon the arrival of the "Invincible Armada," and the subsequent destruction of the Spanish shipping at Cadiz by Howard and Essex, as representing a turning-point in our naval history. These did not, indeed, form the first chapter in the great struggle with Spain. ${ }^{2}$ They resulted chiefly from what Drake and his fellows had done in raiding the rich American possessions of the Spaniard, in assailing his commercial argosies afloat, and in "singeing his beard" at home. Let us not

1 "Expansion of England," vi.

2 Drake at Vigo, and in the West Indies, 1585 ; at Cadiz and Corunna, 1587 ; the Armada, 1588 . Subsequent expeditions of Drake, Hawkins, Frobisher, and Howard. Destruction of Spanish shipping by Howard and Essex at Cadiz, I 596. 
fail to note at this period, and in this connection, how the Navy, as we know it to-day, began with that commerce upon which it is still securely based. Commercial rivalry, the need of breaking monopolies, and maritime reprisal had, in fact, placed in the hands of Englishmen a new arm, and it was the Armada chiefly that taught us the use and value of it. Drake, with the prescience of a Nelson, had sought to cripple the Armada in the Spanish ports, and he stoutly urged, and was supported by Howard, that we should endeavour yet to destroy the Armada on its own shores. Twice in these times ( 1588 and 1596 ) were we saved from invasion by the fleet. Mark how the fact weighed with the seamen of that age. "Surely I hold," wrote Raleigh in his "History of the World," "that the best way is to keep our enemy from treading upon our ground, wherein, if we fail, we must seek to make him wish that he had stayed at his own home. . . . But, making the question general, the position, whether England, without the help of her fleet, be able to debar an enemy from landing, I hold that it is unable to do so, and therefore I think it most dangerous to make the adventure." Thus, too, wrote Sir William Monson: "The sequel of all these actions being duly considered, we may be confident that whilst we busy the Spaniards at home, they dare not think of invading England or Ireland, for by their absence their fleet from the Indies may be endangered, and in their attempts they have as little hope of prevailing." " And thus, too, wrote Bacon with great pregnancy: "Surely at this day with us of Europe, the vantage of strength at sea (which is one of the principal

1 "Naval Tracts" in Churchill's "Collection of Voyages." 
dowries of this lingdom of Great Britain) is great; both because most of the kingdoms of Europe are not merely inland, but girt with the sea most part of their compass; and because the wealth of both Indies seems in great part but an accessory to the command of the seas." We thus see that the Elizabethan thinkers already divined that against the foreigner maritime strength must be

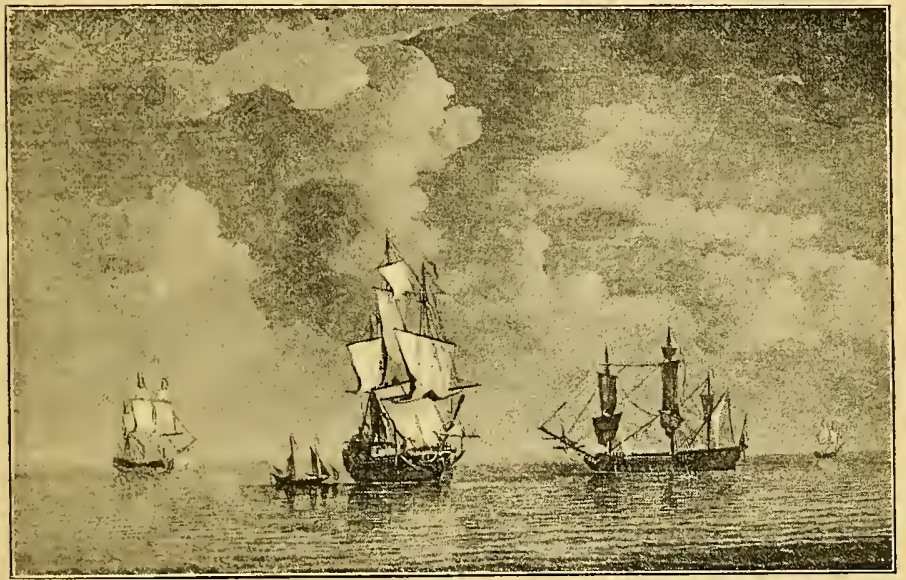

CAPTURE OF THE "NINFA" BY THE "ROYAL FAMILY" PRIVATEERS, FEBRUARY, I747.

(Charles Brooling.)

England's mainstay. But the full development of the strategic idea of command of the sea was reserved for a later day, and we shall see that even so much as had been learned was destined yet to be many times forgotten by Englishmen.

The Navy of Elizabeth.-The queen has been accused of parsimony in regard to naval affairs, but the "Navie 
Royall," forced onward by the circumstances of the time, grew stronger in Elizabeth's reign than ever it had been before, though it was not yet fully recognized as a national arm. It still, indeed, bore something of the character of a private speculation.

The merchant marine was encouraged by bounties, and chartered companies traded through the Sound to all the ports of the Baltic, as well as along the shores of the Levant and in the Archipelago, and opened up the resources of the countries neighbouring the Black Sea. ${ }^{1}$ In the year preceding the Armada, Drake's capture of the Portuguese carrack San Felipe, had revealed the profits of the Indian trade, and had given stimulus to enterprise in the East. The occupation of the gentleman buccaneer was recognized as respectable, and the Oglanders, Champernounes, Killigrews, Careys and others, who had begun by preying upon the property of the Spaniard and the Portuguese, gained official positions in the Royal Navy. The naval expenditure largely increased, and vast sums were expended in fitting out plundering expeditions, in which persons of all classes took shares. The queen was to have had a third of the plunder, for example, of the disastrous venture of I 595 , from which Drake and Hawkins never returned. Meanwhile, if the rough seafarers had shown the way to new possessions, in the persons of Sir Walter Raleigh and Sir Humphrey Gilbert, they had manifested the genius that colonizes, and had laid the first foundation of Greater Britain, with which the history of the Navy will ever be bound up. And let us not forget their magnificent

${ }^{1}$ For an article on "The English in the Levant," by Mr. J. Theodore Bent," see the "English Historical Review," October, ISgo. 
courage and hardihood, for among them were men such as Fenner, the hero of the Castle of Comfort; Grenville, who fought the famous fight of the Revenge; Willoughby, Davis, and the captains of the Muscovy Company, who carried the flag into Polar seas. We thus observe how the seaward vocation of Englishmen now manifested itsclf. ${ }^{1}$

The Nei'y of the Stuirts. - Naval history cannot be apportioned under reigns, but it must be noted that the Stuarts had a keen sense of the value of Sea Power. It is to the time of James I. that we trace the origin of many features which distinguish our Navy at the present day. He, too, secured the foundations of our Empire by signing the Charters of Virginia in I606, and of New England in I620, and those wonderful voyages to the East Indies, which had begun in the latter years of Elizabeth, continued in his reign, and grew fruitful more and more. Let us not fail to note that our Empire and our Sea Power were growing steadily together. Yet the

In the Easter term of I 893 , Professor Froude delivered a course of four lectures at Oxford on "English Seamen in the Sixteenth Century," which give a very picturesque account of seafaring at that period. (They will be found in "Longman's Magazine," JulyOctober, I893). But in seeking to show our Sea Power as the "legitimate child of the Reformation," the Professor forgets the larger consideration which explains our naval history from that age to this, viz., the struggle for the commercial dominion of the world. Religion was often the cloak, but it cannot be said, when-in the words of a contemporary authority quoted by Professor Froudeit became "the secret, determined policy of Spain to destroy the English fleet, pilots, masters, and sailors, by means of the Inquisition," that the blow was other than political. It was the non sufficit orbis of the Spaniards, and the nascent world-expansion of England that led to the quarrel. The same causes brought about the subsequent struggle with the Dutch and the French. 
Navy of James reaped the whirlwind the sea-rovers of Elizabeth had sown. The profitable privateering of her reign had attracted a multitude to the occupation. Dishonesty and peculation reigned in every department of the administration, and the strong hand was not there to control. It was said by an observer in I608, that "the Navy is for the greatest part manned with aged, impotent, vagrant, lewd, and disorderly companions: it is become a ragged regiment of common rogues." The effect upon commerce was disastrous; within a period of eight years, for example, the Newfoundland Company suffered loss to the extent of $£ 40,000$ from piracy, and even Sallee rovers invaded the Thames. ${ }^{1}$

We pass onward now, omitting much, in order to reach the period in which, as our chief enemy, the Dutchman had replaced the Spaniard. Three things, however, must first be taken note of. They are the growth among naval men of the idea of the command of the sea, an idea which had but dawned upon the seamen of Elizabeth; the greater distribution of sea-borne commerce, through the new expansion of our influence; and the more sea-worthy character of ships-conditions which greatly affected the character of naval war. As the discovery of the New World had led forethoughtful Englishmen to a knowledge of the value of Sea Power, so did the exercise of this power begin to teach them that naval supremacy might mean something more than a transitory exhibition of strength over a limited and

${ }^{1}$ For the condition of the Navy under Elizabeth and her successor, see articles, by Mr. M. Oppenheim, in the "English Historical Review," July, I89I, July, I892, and July, I893. These are most valuable and instructive. 
partial area. ${ }^{1}$ Charles I. understood better than his father the value of maritime power. He maintained, by the voice of Selden ("Mare Clausum"), our sovereignty of the seas against the Dutch; he placed larger fleets in the Channel, and it was largely for gaining the necessary supplies by means of ship-money that he forfeited his crown and ultimately his life. As Admiral Colomb says, "Little has been done towards elucidating the share which Charles's understanding of the naval conditions of the Kingdom, and the want of understanding on the part of his opposing subjects, may have had in producing the Civil War, but it seems to be certain that the chief part of the money question was a naval one, and that the superior classes of ships which Charles prepared and built had a most material effect on the course of the Dutch wars." Mr. Oppenheim remarks, in the same strain, that, but for the fleets Charles was enabled by ship-money to send to sea, thereby presenting a semblance of power, the strife with France and Holland might have been precipitated by nearly half a century. This is a matter which has escaped the notice of our historians; but we may see plainly that while Hampden, Pym, and Glanville were fighting for the constitutional principles of taxation, Charles, with a larger view, was seeking to establish, by maritime power, the security of the kingdom itself. On the other hand, it must be remarked-though this chapter does not deal with the personnel-that the vital question of manning and provisioning the fleet was wholly neglected under Charles I., and that no fleet manned as his was

${ }^{1}$ Admiral Colomb, in his "Naval Warfare," has exhibited with masterly hand the development of the idea of command of the sea, and the conditions attending the exercise of that command. 
manned could possibly be efficient. "Foul winter weather, naked bodies, and empty bellies," wrote Mervyn, who commanded in the narrow seas in 1629 , "make the men voice the king's service worse than a galley slavery."

The Maritime Power of Holland.-The rise of the Dutch sea power was rapid. Raleigh could remember the time when one of Elizabeth's ships "would have made forty Hollanders strike sail and come to an anchor." "They did not then dispute de Mari Libero, and acknowledged the English to be Domini Maris Britannici." Yet in the time of the Commonwealth Van Tromp, forcibly disputing this claim, rode the Channel with a broom at his mast-head. The sea strength of the Dutch was based, like that of the English, upon trade. From a race of herring-fishers their vocation had made them the ruling commercial community of the world. ${ }^{1}$ They had preceded us as oversea traders. They had held their own, too, against all the might of Spain, and, in the midst of the conflict, had founded a great colonial empire. They supplanted the Portuguese in the East. It was their raising the price of pepper, in 1599 , that led to the formation of the "Company of the Merchants of London trading into the East Indies." By the massacre at Amboyna, in 1623, they drove the British Company from the Eastern Archipelago to the Indian Continent. We therefore see that, by necessity, the wars with the Dutch were both naval

3 A Dutch merchant in some ways typical was that Louis de Geer who raised the fleet with which the Swedish Admiral Thijssen defeated the Danes, and wrung from Christian IV., by the mediation of the United Provinces, the humiliating Treaty of Bromsebro. 
and commercial. Their character was revealed by the famous Navigation Act of Cromwell, which prohibited the importation of goods into England except in English bottoms, or in the ships of the powers which produced them, and thus led directly to the war of 1652 .

First Dutch War, I652-54.-It is not within the scope of this book to deal with the circumstances of the wars

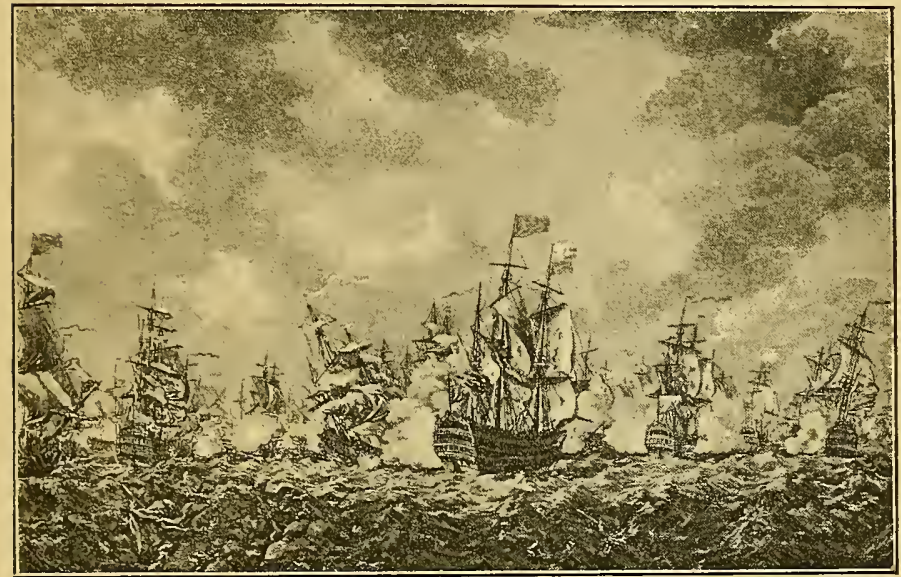

HAWKE'S DEFEAT OF CONFLANS IN QUIBERON BAY, NOVEMBER, I759. (R. Paton.)

with the Dutch. They have been described with singular lucidity, both in their tactical and strategical relations, by Admiral Colomb, in his "Naval Warfare," and, so far as the second and third wars are concerned, by Captain A. T. Mahan, U.S.N., in his masterly work "The Influence of Sea Power upon History" two books that are essential to an understanding of our history and of naval warfare. With these books 
Professor J. K. Laughton's "Studies in Naval History." must be named, as well as the same ivriter's lives of many seamen in the "Dictionary of National Biography." Professor Laughton has offered some valuable corrective criticism of Captain Mahan's work upon points of detail. In the terse words of that officer, "Cromwell's powerful fleets of ship-of-the-line in I652 shut the Dutch merchantmen in their ports and caused the grass to grow in the streets of Amsterdam." The war was condusted wholly afloat, an advance being thus made in the method of naval warfare. It began with the direct attack and defence of commerce, and ended with a series of conflicts between the rival fleets with the purpose of gaining the $11 \mathrm{ew}$-found advantage of command of the sea. In the end the Dutch were compelled to open free trade in the Scheldt, to admit that desperate blow at their carrying trade, the Navigation Act, and to salute the English flag. Hardly was the first Dutch war concluded when Cromwell found occasion to strike a sudden blow at the maritime power of Spain, claiming freedom of trade with Spanish South America, and his fleet was occupied in operating against the West India Islands, and in the capturing of Spanish plate ships. ${ }^{1}$

Second Dutch War, I665-67.- In the second Dutch war the Dutch were compelled to accept the inferior position. They had, however, grasped the essential conditions. They abandoned their trade in order to fight for command of the sea. The war included three notable battles-that off Lowestoft (June 3rd, I665), the

1. Capture of the Spanish Plate Fleet off Cadiz, September 8th, 1656. Destruction of the Spanish galleons by Blake at Santa Cruz, April 2oth, 1657. 
celebrated four days' battle in the Straits of Dover (June ist to $4^{\text {th }}, \mathrm{I} 666$ ), and that off the North Foreland (July 25th, I666). In the first and last of these the English were decidedly successful, but in the four days' battle they were not less decidedly the losers. This war is notable for a distinct alteration in naval tactics-the substitution of the close-hauled line-of-battle for the irregular methods of earlier warfare.

But here we note one of those circumstances which are the speaking lessons of naval history. Exhaustion and extravagance combined to make Charles II. and his advisers weary of the task of maintaining an effective fleet, and they counted too much upon the effect of the losses inflicted upon the Dutch. They forgot the very lessons that the war had taught, and were content, instead of making the enemy's shore the English frontier, to entrust the defence of the coast to fortifications, to lay up the ships in harbour, and to pursue the everfutile policy of preying, as an ulterior object, upon Dutch commerce. What was the result? In I667 De Ruyter was burning shipping in the Medway, and controlling the mouth of the Thames. Thus it was that England lost much of the fruit of her victories. Yet so great were by this time her maritime resources that the ultimate advantage remained with her, and she secured, as her most lasting gain, possessions in New Amsterdam, whereby her northern and southern American colonies were joined.

Third Dutch War, I672-74.--In the third Dutch war, taught anew by experience, England sought, with the help of France, utterly to destroy her commercial rival. The history of that war is the history of the dire straits of Holland, and of her deliverance, on this occasion, 
through her Sea Power in the hands of the great seaman De Ruyter, who, in the battle of Solebay (June 7 th, I672), showed his remarkable power, and who, at the great battle off the Texel (August 2 Ist, I673) saved his country, not by courage alone, but by equal forethought and skill. Yet Holland could not escape her doom. Driven into war with France, she was weakened by her very exertions,

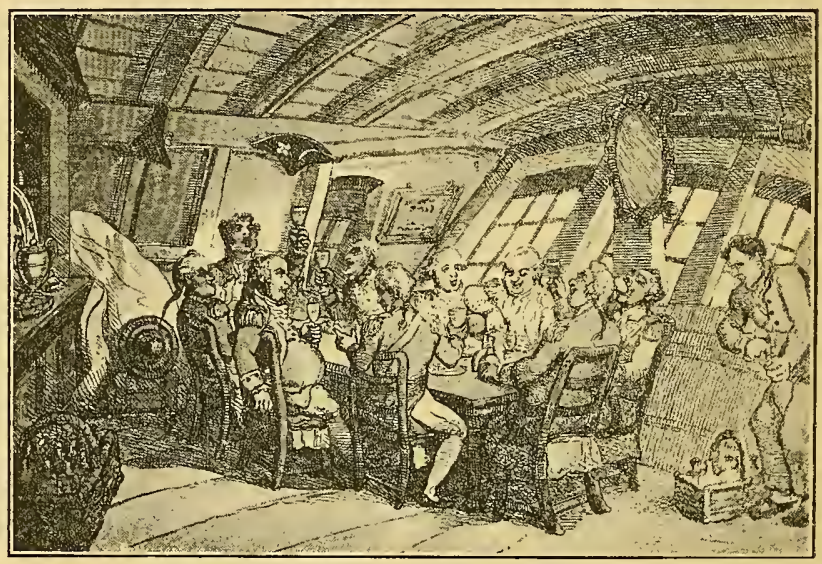

THE WARD-ROOM MESS, II.M.S. "HECTOR." CIRCA I 782.

(Rowlandson.)

and much of her trade passed to the neutral English flag, and, when England joined her as an ally-an alliance probably made possible only by the fact that England had already won in the maritime and commercial race-through her smaller size, poorer resources, and less advantageous situation, the process towards her final exhaustion, with many fluctuations, went on. And so, when England rose to a new struggle in the 
labour of her expansion, she found herself no longer confronted by the Dutch.

The Revolution of 1688.-The landing of William of Orange in 1688 is an event of political rather than of naval significance. We cannot read the history of the defection of Danby, Shrewsbury, Devonshire, Lumley, and the rest, from the cause of the Stuarts, and of the invitation to William which was carried to the Hague by so notable a seaman as Herbert, who commanded the fleet in which William sailed, without recognizing that the maritime arm of England was paralyzed. ${ }^{1}$ Yet James was not so careless of his naval defence as Macaulay has depicted him. On the contrary, he was active in fitting out a fleet for sea under Lord Dartmouth, and in making every preparation to resist the invasion. But the weapon thus prepared, which might have struck a heavy blow at the armament of William as it assembled in port, or was getting under weigh, itself contained the elements of disaffection, and William was allowed to land unopposed in Torbay. ${ }^{2}$ It is beyond the scope of this

${ }^{1}$ Admiral Arthur Herbert, Earl of Torrington, who, by his masterly strategy in "losing" the battle off Beachy Head (I690), saved the kingdom from the French, must not be.confused with Admiral George Byng, Viscount Torrington, the victor of Passaro. Arthur Herbert, being disaffected to the cause of James II., entered into communication with Dykvelt, the envoy of William of Orange, passed over on a mission to that prince, and, with the title of "Lieutenant Admiral General," commanded the Dutch fleet in which William reached Torbay.

2 Laughton's "Memoir of Torrington," and Granville Penn's "Life of Penn." Many interesting details of the maritime episodes of this period are set forth by Mr. J. R. Tanner, in an article entitled "Naval Preparations of James II.," in the "English Historical Review," April, I893. 
inquiry to dwell upon the cause of this impotence, but the lesson is plain. It is that a fleet, however efficient, may well be useless if ill or incompetently directed from on shore. Yet the same Herbert, Earl of Torrington, who brought over the Dutch prince, was shortly, in his action with Tourville, to give a lesson which was long unread, and which escaped the sagacity of Captain Mahan, that Sea Power well-handled afloat, even with the very semblance of defeat, may sometimes effect its purpose, in despite of feeble statecraft and corrupt administration. We shall see what was the full result when, in a later supreme moment of our history, England possessed a statesman who knew how to use her Navy ivell.

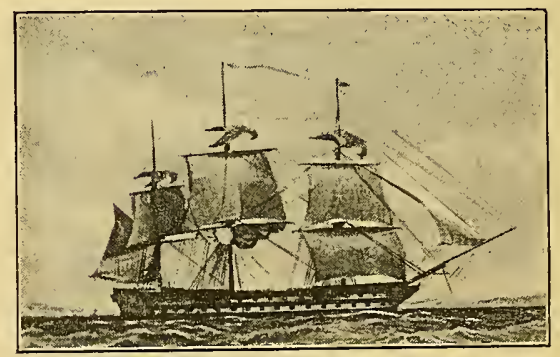

H.M. LINE-OF-BAT'LLE SHIP "RODNEY," 92 GUNS. CIRCA 1840. 


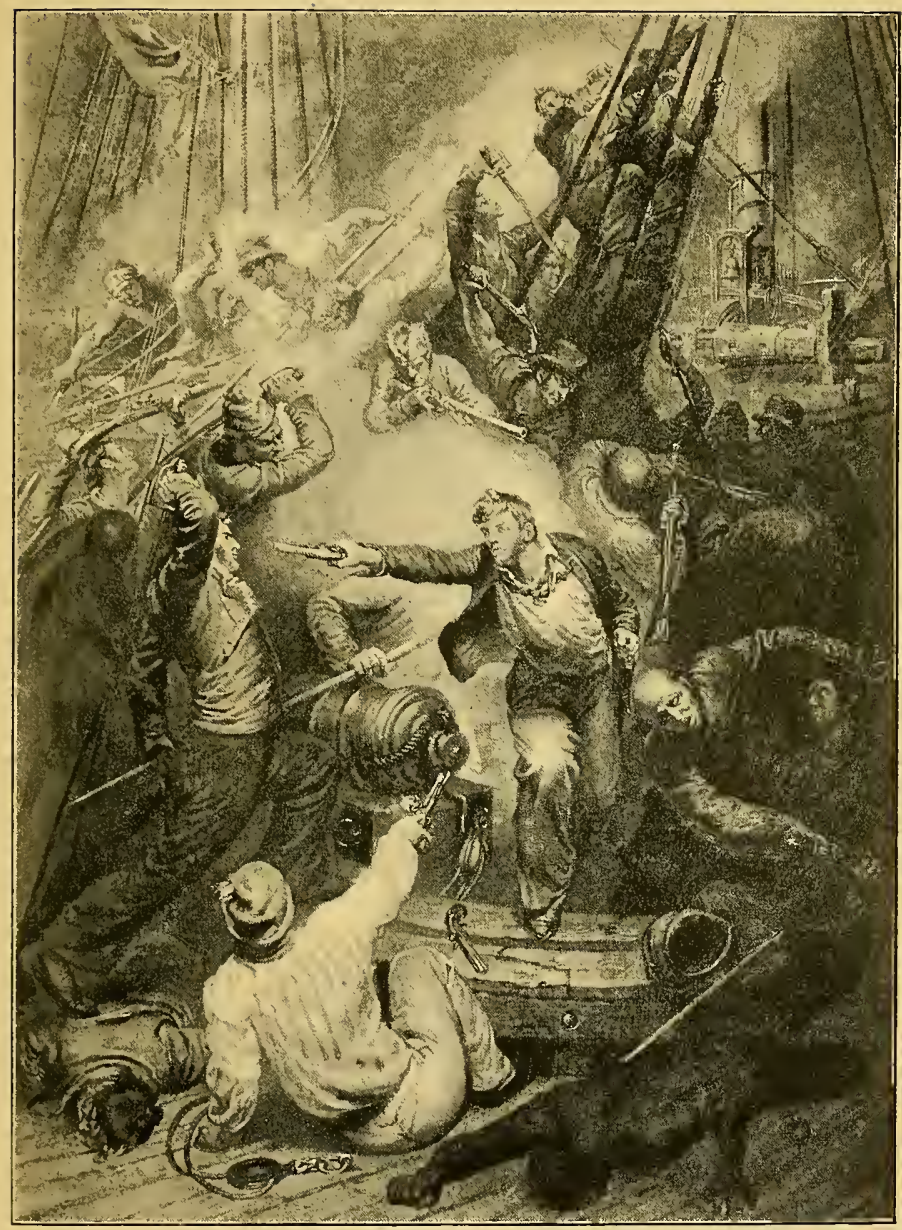

BOARIING A I'RIVATEER, ISO-.

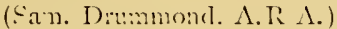





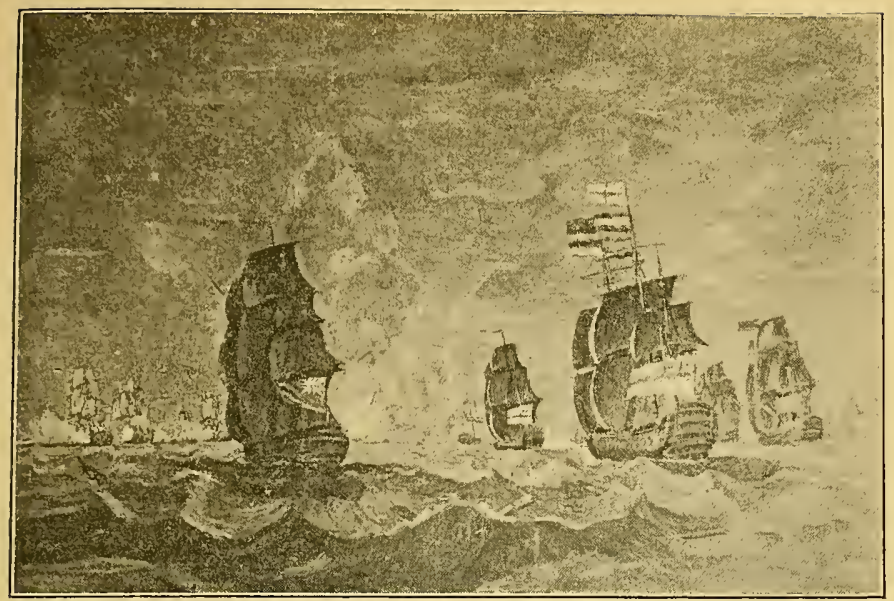

RODNEY'S DEFEAT OF DE LANGARA, OFF CAPE ST. VINCENT, JANUARY, I 7 SO.

(T. Luny.)

\section{CHAPTER III.}

THE SOVEREIGNTY OF THE SEAS.

THE Origin of our Later Wars with the French.The French were our rivals both in the New World and the Old. Jacques Cartier had preceded Drake and Frobisher. Samuel Champlain and his companions were establishing the settlements of Canada and Acadie, and La Salle was transporting his vessels from the great lakes of the north to the upper waters of the Mississippi, and descending by that mighty river-course to the Gulf of Mexico, when Englishmen were settling in colonies in the same continent. In the New World the French were, indeed, before us in the race. After the 
consolidating work of Richelieu and Mazarin, the rise of modern France and of the French Navy were alike due to the genius of Colbert. The wars of the eighteenth century may be traced to the rivalry that resulted from the conditions of the age, and we have to note how the English Navy protected us during the continuance of them, and in the end gave us the victory.

With the accession of William of Orange, England became by dynasty, as much as by commercial and territorial rivalry, the enemy of France, and if France had known how to use her new Navy well it would have gone hard with the English in the years following the Revolution of I688. As it was, only the great ability of Torrington, and Tourville's lack of vigour, rendered the French victory off Beachy Head (June $30 t h$, I690) incomplete. ${ }^{1}$ But the real want of the French for the right handling of their fleet was competent statecraft; and statesmen, in maritime affairs, may either make or mar.

The Navy of England, however, was equal to its duties. The famous battle of Barfleur (1692) defeated Louis' great project of invasion, and gave to the French Navy a blow that might well have been crushing. 'Thus England was once again saved by Sea Power. But neither the defeat, nor the greater disaster of the burning of shipping at La Hogue, sufficed to destroy the Navy of Colbert and Seignelay. It sank, as navies have many times sunk, under the withering influence of individual incapacity and incompetent statesmanship. Marshal Bellefonds, accompanied by the exiled King James, and

${ }^{1}$ For a picture of Torrington as "the great strategist who saved his country by the sacrifice of his own immediate reputation," see a masterly article on "Command of the Sea," in the "Quarterly Review," October, I893. 
with an army of 30,000 men, looked on at the burning of the French ships by a few English boat-parties. It was rumoured that the Marshal had allowed the ships to be run ashore in order to cover the clumsiness of his nephew, who had allowed the Terrible to get aground. But the mismanagement of the French Navy by statesmen was far more disastrous to its welfare. If it did not appear in the official papers of Bonrepaus, Intendant of the Navy, it would seem incredible that, in I69I Pontchartrain, Naval Secretary of State, with Louvois and Marshal de Feuillade, had actually proposed to do away with the French Navy altogether, on the ground that it was useless except for coast defence, and that even this duty could be accomplished more economically by means of additional troops. " These significant facts are well worth noting. From such incapacity to understand the conditions of the problem nothing but disaster could result. We need not wonder, therefore, that up to the Peace of Rysivick (September Ioth, I697) the English Navy cxercised a compressing force upon France, that it effectually prevented the success of the French operations against Spain, and that England and Holland, as sea-powers, gained from the struggle such commercial security and advantage as directly added to their maritime strength.

The War of the Spanish Succession, I702-I 3.-Such, moreover, was the subsequent exhaustion of France that during the War of the Spanish Succession her fighting fleets were withdrawn from the sea, and she

1 See the "Battle of Barfleur and Destruction of French ships at La Hogue, May igth to 24th, I692," "Quarterly Review," April, 1893, and an article by Professor J. K. Laughton, R.N., "Army and Navy Gazette," No. 1687, vol. xxiii. 
devoted herself to a guerre de course-the commercedestroying which had failed so completely in the hands of Charles II. It was the golden age of the great French privateers-Jean Bart, Duguay-Trouin, Du Casse, and many more-concerning whose destructive operations, and the ultimate futility of them, the writings of Laughton, Norman and Mahan may be consulted. ${ }^{1}$ At the close of the war England had proved herself a Sea Power in the true sense of the word. Though there liad been no great fleet actions--perhaps the most notable event of the war was the capture of Gibraltar (1704) by Sir George Rooke and Sir Cloudesley Shovell_-France was everywhere humiliated, and the Spanish possessions in America escaped only because, by William's support of the Austrian prince, his lleet was detained in the Mediterranean. England remained confirmed in the possession of Gibraltar, Minorca, Hudson's Bay, Nova Scotia and Newfoundland; and she secured the monopoly of the slave trade to the American colonies of Spain, and thereby for the first time became the great slave-trading power. From henceforth, save when it has been jeopardized by the incompetency of her rulers, the supremacy of England at sea has been admitted if not recognized.

"The noiseless, steady, exhausting pressure with which Sea Power acts," says Captain Mahan, speaking of the war ended by the Peace of Utrecht," "cutting off the resources of the enemy while maintaining its own, sup-

1 "The Influence of Sea Power upon History" (Captain A. T. Mahan, U.S.N.) ; "The Corsairs of France" (C. B. Norman); and "Studies in Naval History" (Professor J. K. Laughton, R.N.).

2 The Treaty of Utrecht, concluding the War of the Spanish Succession, March 3ist, I7I3. 
porting war in scenes where it does not appear itself, or appears only in the background, and striking open blows at rare intervals, though lost to most, is emphasized to the careful reader by the events of this war, and of the half century that followed. The overwhelning Sea Power of England was the determining factor in European history during the period mentioned; maintaining war abroad while keeping its own people in prosperity at home, and building the great Empire which is now seen, but, from its very greatness, its action, by escaping opposition, escapes attention. On the few occasions in which it is called to fight its superiority is so marked that the affairs can scarcely be called battles. With the possible exceptions of Byng's action at Minorca and Hawke's at Quiberon Bay (the latter one of the most brilliant pages in naval history), no decisive encounter between equal forces, possessing military interest, occurs between I700 and 1778 ." It is worth while to dwell upon this point a little: The undisputed supremacy of England dated from the War of the Spanish Succession. "Before that war England was one of the Sea Powers, after it she was the Sea Power, without any second." And this power rested firmly upon a great Navy and a vast commerce. Let us not fail to note, too, that this is the supreme period in which the British Empire grew.

But the incidents of this great history can be but glanced at here. The first point we have to notice is the fixity of purpose with which England smote at the power of Spain, rising afresh under the guidance of Alberoni. The destruction of the Spanish fleet by Sir George Byng (August IIth, I7I8) off Cape Passaro, when no war had actually been declared, may not commend itself to our moral sense, but, combined with the fatuous attack of 
the French in the following year upon the Spanish dockyards, it practically annihilated the Spanish Navy. Yet the struggle with Spain was not over. We shall not forget the story of Jenkins's ear, ${ }^{2}$ nor the barbarities of the Spaniards in prosecuting their right of search in Caribbean waters, where they were defending the West Indian monopoly which England was seeking to invade. That war thereupon broke out which began with the unsatisfactory expedition of Vernon to Porto Bello and Cartagena, and the adventurous cruise of Anson (1739-42). It included Mathews's action off Toulon (February, I 744) -one of those which Englishmen would like to forgetard the victories of Anson and Hawke off Finisterre (March 3rd and October I4th, I747), whereby the destruction of the French fighting fleet was completed-and ended with the Peace of Aix-la-Chapelle, which terminated the war of the Austrian succession. ${ }^{2}$ England gained little by the struggle. She failed to reap the fruit of her exertions partly because the fleet had shown, except towards the close, no fitness for its task, and was ill employed, but her command of the sea at least enabled her to make peace on equal terms

The truth is that English statesmen, forgetting the seaward vocation of their country, had plunged us into the vexations of a great continental war, wherein we had met disaster. Instead of devoting our resources to the strengthening of England's maritime power they had burdened us with huge debts by subsidizing foreign soldiers to fight for a cause which was but in part our own.

1 For a confirmation of the story of "Jenkins's ear," see a communication by Professor J. K. Laughton to the "English Historical Review," October, I889.

2 The Treaty of Aix-la-Chapelle, April I8th, I748. 
The essential question of maritime supremacy had in fact been realized neither by France nor by England, and the settlement of it was reserved for a later day. Yet, if France had possessed an efficient Navy, even if one inferior in strength to our own, she might at that juncture have gained her end.

In the Seven Years' War (1756-63) the circumstances were different. We had mastered the lesson. Our command of the sea gave us universal sway during that struggle, and made us indisputably first of the worldpowers. Effectually were we protected from the invasion planned by De Choiseul when Boscawen defeated and dispersed the Toulon fleet of De la Clue (August I 8th), and when Hawke annihilated the great armament of Conflans in the splendid action of Quiberon Bay (November 20th, I759). It was the fleet alone that rendered possible the taking of Louisburg, Quebec and Montreal, and put an end to the rule of the French in Canada. The same power brought about the downfall of French dominion in India, when Pocock was able, even without decisive victories over D'Aché, to cut the communications of the French at sea. ${ }^{1}$ And, when the French fleet was ruined by its exertions and its reverses, England was free to direct her maritime attack upon the distant possessions of Spain, and the Spanish colonial empire crumpled up like a leaf. England's influence and power were wherever her fleet could go. She reaped an immense increase of commerce, and, territorially though much was given up, she remained, after the Peace of Paris, with India secure, and with possessions in North America

1 See an article by Captain S. M. Eardley-Wilmot, R.N., entitled "India, the Gift of Sea Power," "United Service Magazine," New Series, vol. iii. 
which embraced the whole of the present United States as far west as the Mississippi, and Canada from Hudson's Bay; retaining moreover four islands in the West Indies, and wringing from Spain the concession of all the points in dispute.

War of American Independence, I775-83.-The towering supremacy thus gained by the exercise of Sea Power was, however, to suffer later a serious reverse through the insufficiency of the fleet, which had not grown in correspondence with our larger responsibilities. During the years following the peace the French, on the other hand, profited by experience, and the resurrection of the French Navy went on apace under the firm hand of De Choiseul, who united together the powers of the house of Bourbon both in France and Spain. Thus was constituted an effective maritime arm which, at the outbreak of the war with the American colonies, equalled, if it did not excel, our own. To the American colonies the French Navy, as Washington many times said, was all important. "Upon decisive naval superiority every hope of success," he wrote, "must ultimately depend." Without such superiority, the struggle was hopeless; with it, the colonies gained independence. But the maritime war was waged not alone on the coasts of North America, but in every part of the world. In European waters the allies accomplished little against us, in part because our fleet gave them sufficient occupation elsewhere; but their projected invasions failed mainly because of divided counsels and mismanagement among themselves. The French and Spaniards appeared, indeed, in the Channel in overwhelming force (August, I 779), but failed to take advantage of our weakness. The history of their abortive 
gatherings is very curious, and we may draw from them a lesson as to the inherent feebleness of maritime coalitions. England will be weak, indeed, when her interests are intrusted to an ally afloat. To the same period (February, I $782-J$ Jne, I $78_{3}$ ) belong the brilliant operations of Suffren against Sir Edward Hughes in East Indian waters, wherein the great Frenchman showed himself a consummate master of offensive naval war. If he had found ready instruments in his lieutenants it would have $g$, ne hard with the squadrons of Hughes, but the tenacity of the Englishman and his captains, though their force was generally inferior, maintained the struggle for control of the seas until peace was declared. On the American coast itself, Howe, off Rhode Island (August 9th, I778), had proved himself the superior of D'Estaing, and, when the scene of operations was transferred to West Indian waters, the Frenchman was again unequal to his task. In these waters Rodney was shortly to gain imperishable renown in his great actions against De Guichen (April I 7 th, I 780 ), and De Grasse (April I2th, I782); but, before his final triumph over the latter, we have to note the disastrous effect of insufficient Sea Power in the failure of Graves to relieve Curnwallis, from which the loss of our American colonies necessarily ensued. ${ }^{\prime} \quad$ It is not the purpose here to treat the many interesting circumstances attending the actions of Rodney, Hood, and others in West Indian waters. More important for us than Rodney's muchdiscussed tactical manœuvre of breaking the line, is to mark the fact that his decisive victory over De Grasse

1 Surrender of Cornwallis and his army at Yorktown, the last important act of the War of American Indeperdence, October Igth, I78I. 
off Dominica (April I2th, I782), though fought so far away, operated in saving us from overwhelming attack from the French in the narrow seas. ${ }^{1}$

What, however, it is essential to observe of the great war in which England was shorn of her American colonies is that their loss was assured when France threw her maritime power into the scale. ${ }^{2}$ The truth is that we were outmatched. To command the sea everywhere had become impossible. Great as our Navy was -and the thought is a profitable one at the present day-it was not equal to its task, for the Empire then, as now, lay in every region of the globe. "It is impossible," wrote the First Lord of the Admiralty to Rodney, "for us to have a superior fleet in every part, and unless our commanders-in-chief will take the great line as you do, and consider the King's whole dominions under their care, our enemies must find us unprepared somewhere, and carry their point against us." In truth, save in American waters, and there with no sufficient effect, England was driven to accept the defensive or inferior position, and to fight in nearly every case with smaller numbers. In the East, Hughes was confronted by the superior armaments and skill of Suffren; at home we were threatened with invasion; Gibraltar was closely beset; in the West Indies our possessions slipped from us one by one. Thus it was that the Peace of $1783^{3}$ found us shorn of the American colonies; giving up or

${ }^{1}$ See "Rodney," by D. Hannay, in the "English Men of Action" Series, and "Rodney and the Navy of the Eighteenth Century," “Quarterly Review," January, I892.

${ }^{2}$ Offensive and defensive alliance between France and the American colonies, February, 1778.

${ }_{3}$ Treaty of Versailles, September, 1783. 
restoring to France the islands of St. Pierre and Miqueinn, St. Lucia and Tobago, with Senegal, and many establishments in India; and ceding Florida and Minorca to Spain. Verily we have herein a speaking lesson of the disasters arising from the insufficiency of the factors constituting Sea Power.

The IVar of the French Revolution and Empire, I792I 8 I5.-But the British Navy was to prove equal to greater deeds than it had yet accomplished. Shaken by the combined attack of France, Spain and Holland in the last war, it gathered, shortly after the opening of the War of the French Revolution, strength sufficient to sustain its greater burden, and in Nelson and his compeers it produced seamen as great, and in some respects far greater, than England had known before. And what is even more important to be observed, England possessed at the same time in the younger Pitt-the promoter of the arts of peace and of internal reforma statesman who knew better than any of his predecessors how to shape the course of England as a maritime power." Let us note how different was the case with France. The French Navy during the War of American Independence, and in the years that followed it, under the ministry of the Marquis de Castries, had reached a height of glory it had never before attained. It had become an admirable instrument of power. But, when it fell under the influence of Jean Bon Saint-André and those who wielded the forces of the Revolution, men who had no "appreciation of the factors conditioning efficiency at sea," its splendid corps of officers withered under the blight, while the ships were wretchedly manned

1 Between the years 1792 and 1800 the fleet was increased by more than so per cent. 
with mutinous seamen, frenzied soldiers and sea-sick peasants, whom very little care was taken to train. ${ }^{1}$ An inevitable result followed from these diverse conditions of the two navies. The commerce of England grew prodigiously, and she became thenceforth the workshop and mart of the world, while, by the year I799, commerce had almost entirely forsaken the French flag, and the fleet of France soon thereafter scarcely sought to control the western seas. Our sea-girt land, protected by its fleets, made us free to pursue the means of onr internal prosperity, and by our maritime power we constituted ourselves the rulers of the commercial activities of the world. If we turn now to the effect of the Navy in crushing the Republic and shattering the projects of Napoleon, we find that it operated chiefly by exercising a deadly compressing power.

When the squadron of Villaret Joyeuse, "manned," says Captain Chevalier, "mostly with men who had neveir been to sea before," leaving Brest in order to meet the great convoy of food supplies from the United States, fell in with the British fleet under Howe, the great though incomplete victory of June Ist, I794, was gained by the British fleet. We cannot doubt that it would have been more complete if Howe had been a younger man. It was in 1795 that the French, finding their weakness, withdrew their ships from the sea, and began in earnest once again to pursue the gnerre de conrse, a circumstance in reiation to which Captain Mahan may be quoted. "Inferiority carried beyond a certain degree," he says, with obvious truth, "becomes impotence, nor will all the commerce-destroyers fancy

${ }^{1}$ Loir, "La Marine royale en 1789 " (I892). Chevalier, "Hist. de la Marine française sous la Première République" (I886). 
can picture restore the balance to the nation hopelessly weaker in ships of the line-of-battle." Under these conditions the attempt of Hoche to invade Ireland was made. His fleet stole out from Brest on December I6th, I796. It was a bold and rash adventure, made by men who knew little of the conditions of maritime warfare, and it failed, as Admiral Colomb has conclusively shown, mainly through the pressure of England's Sea Power. ${ }^{1} \quad$ The French, he tersely says, were not provided with the means of victory, "they were, like any other burglars, in fear of the police." Yet the weakness of the loose system of blockade adopted by Howe and Bridport was here conclusively shown, and the advantages of the method of Jervis soon became evident.

The naval inferiority of France was so far admitted only in the west. The maritime forces of England had been feebly wielded by Hotham in the Mediterranean, and, in presence of the superior armaments which the French and Spaniards had been allowed to assemble there, our fleet was withdrawn from that sea at the close of I796. At this critical juncture, however, the worthlessness of the Spanish fleet was made apparent by Jervis's notable victory off Cape St. Vincent (February I4th, I797), wherein Nelson and Collingwood showed their prowess. Bonaparte nevertheless believed his hour had now come, and regarded the Mediterranean as his pathway to the East. How fatally he had miscalculated his power was shown when Nelson, sweeping the land-locked sea, destroyed the French fleet in Aboukir Bay (August Ist, I798), and shattered for ever all Bonaparte's projects of Oriental dominion. The chief lesson to be drawn from the battle of the Nile, and the ' Journal of the Royal United Service Institution, January, I 892. 
events which led to it, is the futility of attempting oversea expeditions without first having secured the control of the intermediate water-way. It is a lesson which appears to have impressed itself upon Bonaparte, for he did not attempt to repeat such tactics when it was his aim to accomplish the invasion of England. The com-

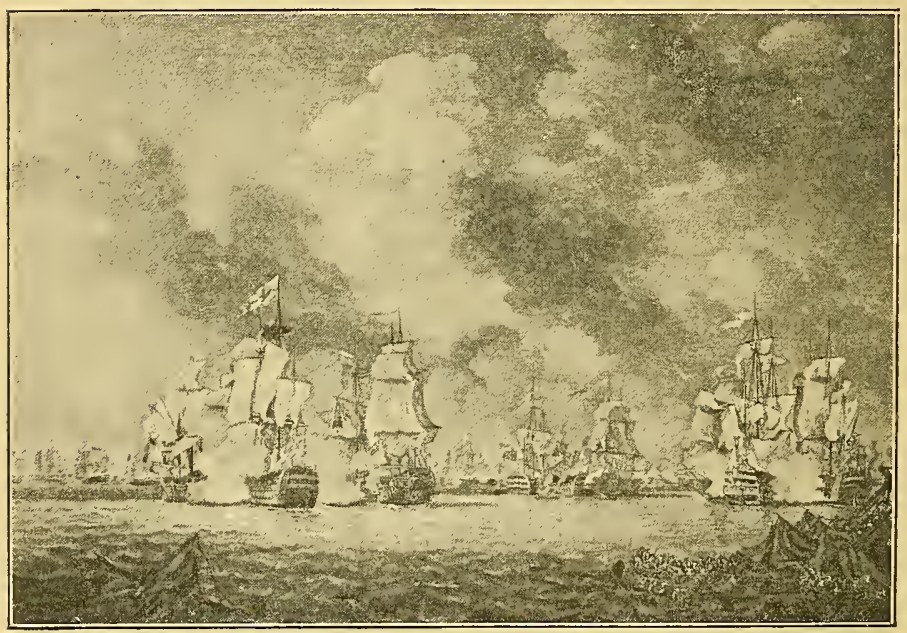

RODNEY'S DEFEAT OF DE GRASSE, OFF DOMINICA, APRIL, I782.

(R. Paton.)

mercial character of the war now brought England into conflict with the Northern Powers, whom Bonaparte was leaguing together against us, but the brilliant expedition to the Baltic broke up the new coalition, and the maritime pressure upon France went on. The final act of this great naval drama was the victory of Trafalgar (October 2 Ist, I SO5), whereby England was once again saved from fear of invasion, and the ultimate fall of the 
CHAP. III.] THE SOVEREIGNTY OF THE SEAS.

continental Dictator was assured. But it is worth while to note that neither the Admiralty nor naval officers generally shared the terror of the country. They knew that our fleet, as of old, made invasion impossible.

Henceforth, indeed, the fleets of France were wholly swept from the seas, though a futile attempt was made in I 807 to recover the dominion that had been lost; and Bonaparte was driven by the exercise of our Sea Power to those continental complications and wars wherein he perished. Meanwhile our ubiquitous Sea Power was securing our dominion and influence both in the Old World and the New. It formed the base and support, the essential means, of all our operations both in the Peninsula and in Belgium. We do not hear that the French fleets were alert to threaten our passage, or break our communications. As a French writer has said, by a bold and happy figure, "They were the ships of Nelson that were the victors at Waterloo." Captain Mahan tersely and ably demonstrates the nature of the power we exercised.

"Amid all the pomp and circumstance of the war which for ten years to come desolated the continent, amid all the tramping to and fro over Europe of the French armies and their auxiliary legions, there went on unceasingly that noiseless pressure upon the vitals of France, that compulsion, whose silence, when once noted, becomes to the observer the most striking and awful mark of the working of Sea Power."

Our subsequent naval history, though notable enough, need not detain us. ${ }^{1}$ Since I 8 I 5 our command

1 An excellent and impartial authority for the naval incidents of the American War of I 8 I2-I 5, is Mr. Theodore Roosevelt's "Naval War of 1812" (New York, 1882). This work in great measure 
of the sea has been so complete that we have scarcely been conscious of its existence. There was no enemy afloat to threaten our communications or bar our passage during the Russian War or the Indian Mutiny, nor has a maritime rival arisen during any of the other wars we have waged. Thus our ubiquitous Sea Power has placed in our hands the weapon we have effectively wielded. And, lastly, in relation to this ubiquity, it is worth while to note that there has never been a better example of it than in the suddenness with which the ships were recently brought together for the blockade of the slave coast of East Africa.

displaces J. F. Cooper's "History of the United States' Navy," and James's "Naval History," in regard to its special subject.

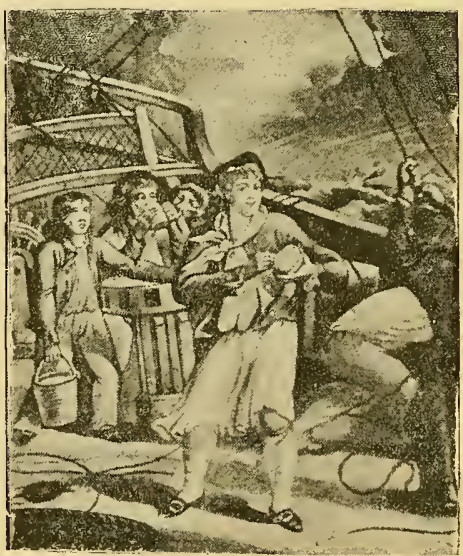

JACK'S QUID OF COMFORT IN A STORM

(Headpiece to Nautical Song, I795.) 


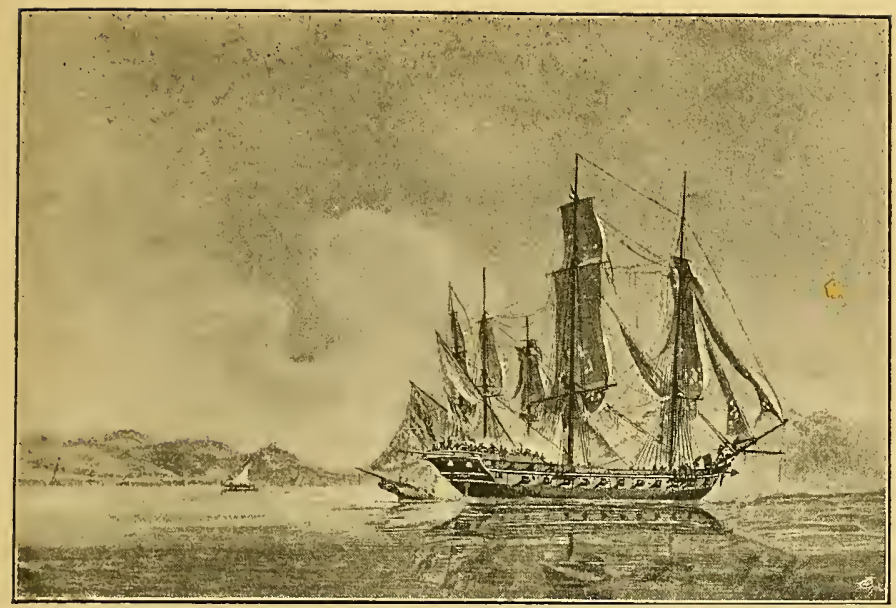

CAPTURE OF THE "GAMO" BY H.M.S. "SPEEDY," MAY, ISOI.

(J. Pocock.)

\section{CHAPTER IV.}

THE NAVY AND THE STATE.

FROM the naval history of which a broad view has been taken in the previous chapters very definite conclusions must surely be drawn. It is, at any rate, evident that we cannot regard the subject as merely curious or speculative. The matter must be vital to our welfare; for we saw how our state began and grew by possession of maritime strength; we observed that in the Middle Ages the unchanging laws which govern Sea Power, though their existence was then barely suspected, operated just as they operated later; how, with efficient fleets, the country was secure; and how, when the seas 
were uncontrolled, commerce suffered, and invasion became possible. Then we remarked that, after the great discoveries, our dominion, influence, and trade began to spread, by means of Sea Power, through new regions, and that the foundations of our existing Empire were thus laid. From this we saw how, in the march of our progress, we came into conflict, first with the Spaniard, the inheritor of the discoveries of Columbus and Vasco da Gama, whose monoplies we were resolved to invade, then with the Dutchman, who had become our commercial rival all over the world, and, lastly, with the Frenchman, whom, after a long-contested struggle, we subdued. And we saw how, in each of these great conflicts, the Navy was the instrument of our power, and the indispensable means to our end.

From these great features of our history we infer with certainty that the Navy must be a factor of quite determining importance for our present state. The operations of our maritime power have, in fact, originated with a set of particular conditions which are stable in their nature. They are conditions that exist now as they have always existed ; but this is to be noted-that, with every step in our territorial, naval, and commercial expansion, we have added, in a very marked degree, to the range and incidence of them. It follows that, at the present time, the Navy is of greater importance to us than ever it has been before. Now this matter needs to be investigated. The inquiry will lead us to the same conclusion to which our view of naval history has already brought us, and at the same time will show us what must be the future work of the Navy, and in what light we must regard this prime instrument of our power.

The first consideration which claims our attention 
depends upon the insularity of our country. We cannot be attacked without the employment of the maritime arm; we cannot ourselves conduct offensive operations without the exercise of Sea Power. Now this insularity has given us singular advantages. The map of Europe is dotted with the crossed swords which mark where, in the border-lands of the States, contending armies have striven for the mastery. There is graven deeply upon the memory of the peoples of the continent the recollection of slaughtered men, ravished women, children left parentless, villages wasted, crops not garnered, fields untilled. We may see at this present day the nations of Europe groaning beneath the burden of military establishments still, standing yet sullenly watching one another. But where within our island country has the Englishman done battle with the invading and uninvited foreigner? Our insularity, in short, made potential by our fleets, has given us freedom from the burdens that weigh upon others. Universal military service has never become necessary to us, and we need not count upon our army for the defence of our shores. We have been left free to exert the talents of our people in the pursuits that have made us great, and, when Europe was given up to the occupations of the sword, England became the workshop of the world.

We thus see that the advantages of insularity, which are secured by the possession of Sea Power, are precious to us in a high degree. Lord Wolseley has indeed said, speaking at Liverpool, in December, I887, that "Everybody whose intelligence is above the ordinary intelligence of a school-boy, must know this country is open to invasion. When the Channel is in possession of a foreign hostile navy, then, not only will it be possible, but most 
certainly this country will be invaded." We may take leave to differ from his lordship in regard to the policy of an enemy under such circumstances. His remarks, though they were presumably intended to lead to an opposite conclusion, serve admirably to enforce the supreme value of the Navy; for the same authority, in the House of Lords, has said that "if a hostile force of, say, I00,000 men were to land upon our shore, there is no reason why that force, properly led, should not take possession of London." The Duke of Wellington, in a letter to Sir John

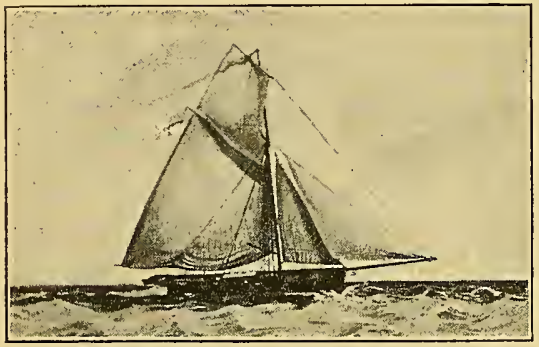

H. M. CUTTER "BRAMBLE," IO GUNS. (Circa I840.) Burgoyne, published in 1847 , had already said, as the country then stood-and if it were true that the exertions of the fleet alone were " not sufficient to provide for our defence"-that we were "not safe for a week after the declaration of war."

He therefore clinched the matter by saying, "We have no defence, or hope of defence, except in our fleet." To prevent so dire a catastrophe as the Duke of Wellington thought possible, in case of the insufficiency of the fleet, and as Lord Wolseley dreads, no sacrifice can be too great. Now, even with "the ordinary intelligence of a school-boy," we may plainly see that there is a degree of maritime strength so preponderating that invasion must become impossible. Even without taking into account the teachings of history, so much is obvious. 
We must not deceive ourselves. It is that degree of maritime strength at which we must aim, and nothing less.

But, in truth, before passing on, let us say that we may dismiss from serious consideration the pessimistic views of the expiring "invasion school." These not only ignore the teachings of history, but rest upon a series of baseless assumptions. The British. Navy is always the obstacle. The fleet must first have been "beaten off" (which is an event, if we keep it strong enough, that can never happen), or, more foolish still, must have been "decoyed away." It must have been utterly destroyed by the wonderful torpedo devised by Sir George Chesney in the "Battle of Dorking," or have been finally crushed, as is planned by the author of "Plus d'Angleterre," in the "Battle of Abervrac'h." By one means or another, the Channel, to use the words of Lord Wolseley, must first be "in the possession of a foreign hostile navy." In short, the invasion of England, as pictured by the alarmist, always rests upon the assumed insufficiency of the fleet for its duties.

But now, closcly connected with the question of invasion, another consideration forces itself upon us. I have suggested that we may venture to differ from Lord Wolseley's views as to the policy of a landing being made upon our shores. There is, indeed, excellent reason to believe that we could be vanquished by an enemy who had secured command of the sea, without a further blow being struck. As a writer in the "Quarterly Review" has tersely said, in an article upon "Naval Warfare and National Defence," which may be warmly commended as a sound exposition of the subject, "there is no arguing with an empty belly." "England has long 1 "Quarterly Review," April, I892. 
been unable to produce either the food-stuffs for her people or the raw material for her manufactures. Without supplies from abroad, we should certainly starve. We depend upon a vast fleet of cargo-vessels to bring us even the very necessaries of life. In the year i 890 our yield of wheat was $75,363,750$ bushels, and in I 892 it was $63,250,000$ bushels, whereas in the last-named year we imported I $76,000,000$ bushels. In I 892 our imports of foodstuffs alone reached the colossal value of $£ 188,462$, 107. During the first eight months of the year I 893 their value was $£$ I 6, r 95,98 I. These are facts of very weighty bearing upon our welfare. Let us not be deceived. It is sometimes asserted that we possess food-supplies which would suffice for three months, or six months; but a very little consideration will show us that, upon the outbreak of a war with France or the United States, such would be the rise in prices that, within a month, famine would stalk through the land. Thus it is true that a maritime power, capable of commanding the neighbouring seas for a certain period of time, could subdue us even without a man being landed upon our shores. In the absence of our fleet, not all the manhood of England could prevail. Such was the opinion forcibly expressed by the three distinguished admirals who reported upon the Naval Manœuvres of isS8. We have, moreover, before our eyes, in the Cotton Famine, the dire results which ensued from the stoppage of raw material by a war in the opposite hemisphere, in which we had ourselves no direct concern. What should we do, then, with our furnaces extinguished and our looms unemployed?

Free trade has given us the cheap loaf, but it cannot secure it to us. Cobden was well aware of the fact that 
free trade involves a dominant Navy. "I have said in the House of Commons," he told his constituents at Rochdale, "and I repeat it to you, if the French Government showed a sinister design to increase their navy to an equality with ours, then, after every explanation to prevent such an absurd waste, I should vote one hundred millions sterling rather than allow that navy to be increased to a level with ours." A concomitant of the immense advantages which Free Trade has conferred upon us, a means, indeed, by which they have been secured, has been the making us dependent upon distant countries for the food of our people.

So far we have seen, by a consideration of our national situation, that Sea Power is supremely important for our internal welfare. But now a wider range of responsibility presents itself to us. All that our Empire is it became by the exercise of Sea Power; and we ask ourselves, looking at our greater imperial necessities, Is the vast Empire, thus built up, to be maintained? It can be maintained only by possession of the power by which it was made. Sweep away the merchant marine, and the Navy which safeguards it, and our possessions will drop off like fruit from a blasted tree. They will fall into the lap of the maritime power by which we are undone. Without a sufficient fleet to keep open our communications, none of our colonies or dependencies could secure themselves from foreign dominion. ' It is indeed beginning at length to be understood that the necessities of Imperial Defence must constitute the strongest bond to hold the Empire together. There are some who have said that upon the outbreak of war between England and a Continental power, colonists would advocate a proclamation of political independence, and the protection 
of the colonies themselves by a declaration of neutrality. But, as Washington said in 1796 , "To secure respect to a neutral flag requires a naval force organized and ready to vindicate it from insult or aggression."

All our colonies are largely dependent upon over-sea trade. The total value of the exports of our Australasian possessions, in the year I $89 \mathrm{I}-92$, was $£ 73,056,948$, whereof the export to the mother country was of the value of $£ 32,629,37 \mathrm{I}$, the bulk of the balance being for exports to other members of the British Empire. In the same year the shipping entered and cleared at the ports of these Australasian possessions displaced I7,459,109 tons. So that we see, apart from imports and the necessities of coast-defence, how vast are the colonial interests which it falls to the imperial fleet to protect. In maintaining the Navy, the nation thus makes, and malies cheerfully, vast sacrifices for the benefit of the colonists. Colonists, it is true, are sometimes heard to say that the squadrons in colonial waters are insufficient to withstand powerful attack. But the fact cannot be too soon mastered that the battle which will save Australia and New Zealand, will probably not be fought in southern waters. Nowhere in that hemisphere does a strong maritime power exist, and thus the naval battles of the future, in which the outermost limits of the Empire will be defended, will, we may assume, be fought on the great strategic routes from Europe, or even in the English Channel. Let it never be forgotten that as soon as the members of the Empire are cut off from communication with its heart, they will fall a prey to the power that intervenes.

We may now consider what is the special relation of the Navy to the defence of India. That defence is very 
closely associated in our minds with the Quetta railway, with Kandaliar and the Helmund, Bannu and Ghazni, Peshawur and Kabul, Chitral and Badakshan. It is mainly for the protection of India that our standing army is maintained. Yet, how few people reflect that, without Sea Power, the defence of India is impossible? Our operations in Afghanistan are dependent upon a naval base: cut off from the sea, their failure will be foredoomed. Reflect for a moment what might have happened-and, in like case, may yet happen-if, during the Indian Mutiny, a strong maritime power had arisen to dispute with us, as the French and Spaniards disputed with us during the revolt of the American Colonies. Can we doubt that the conclusion-the loss of Indiawould have been foregone? Lord Roberts, speaking at the Mansion House on June I2th, I893, laid great stress upon the weighty fact that, though the troops in India are sufficient for their duties in peace time, "a very considerable reinforcement of British soldiers would be needed in the event of a serious struggle with a civilized power." With undeniable force he said, "This fact must be borne in mind, and the naval and military forces of the Crown ought to be so organized as to insure the requirements of India being met, should the necessity arise. To the Navy would fall the all-important duty of safeguarding the transport operations." It is, indeed, upon open communications with England that the defence of the Indian frontier, and the protection of the Indian coasts, must ultimately rest. In war time the Mediterranean route to the East may have to be abandoned, owing to the closure of the Suez Canal ; but that result will inevitably follow our inability to command the sea, and, with such inability, the ocean route will itself 
be menaced and become dangerously insecure. Thus it is that, in the defence of India, an all-important element is Sea Power.

Let us now turn to the work of the Navy in regard to the defence of commerce. This question might have been treated along with that of the protection of our food supplies, but since it affects the Colonies as well, it is more fitly considered with our Imperial responsibilities. The total imports of the Empire during the year I 89I-92 were returned at $£ 727,892,9$ I I, and the total exports at $£ 549,245$,008. The registered tonnage under the Imperial flag was $9,438,836$, and the aggregate tonnage entered and cleared at the ports of the Empire was 163,634,729. In the year I892 the gross imports of the United Kingdom alone were of the value of $£ 423,892,178$, while the exports were worth $£ 227,060,224$, the enormous total of $£ 650,952,402$ being thus reached. If we turn to the reports for the first eight months of the year I893, we find these respective sums represented by $£ 265,917,577$ (imports) and $£ \mathrm{I} 46,959,492$ (exports), making a total of $£ 4 \mathrm{I} 2,877,069$. It must not be overlooked, in considering these figures, that 70 per cent. of the carrying power of the world is in our hands. We may thus certainly say that the vast bulk of our imports and exports is carried in British bottoms.

In this chapter it will be impossible to deal, except by suggestion, with the complexities of the question of commerce-protection. The effect of war upon the commerce of those engaged, except to the belligerent possessing preponderating maritime power, is admitted to be disastrous. Nations are, in fact, nowhere more assailable than in their commercial life, and therefore 


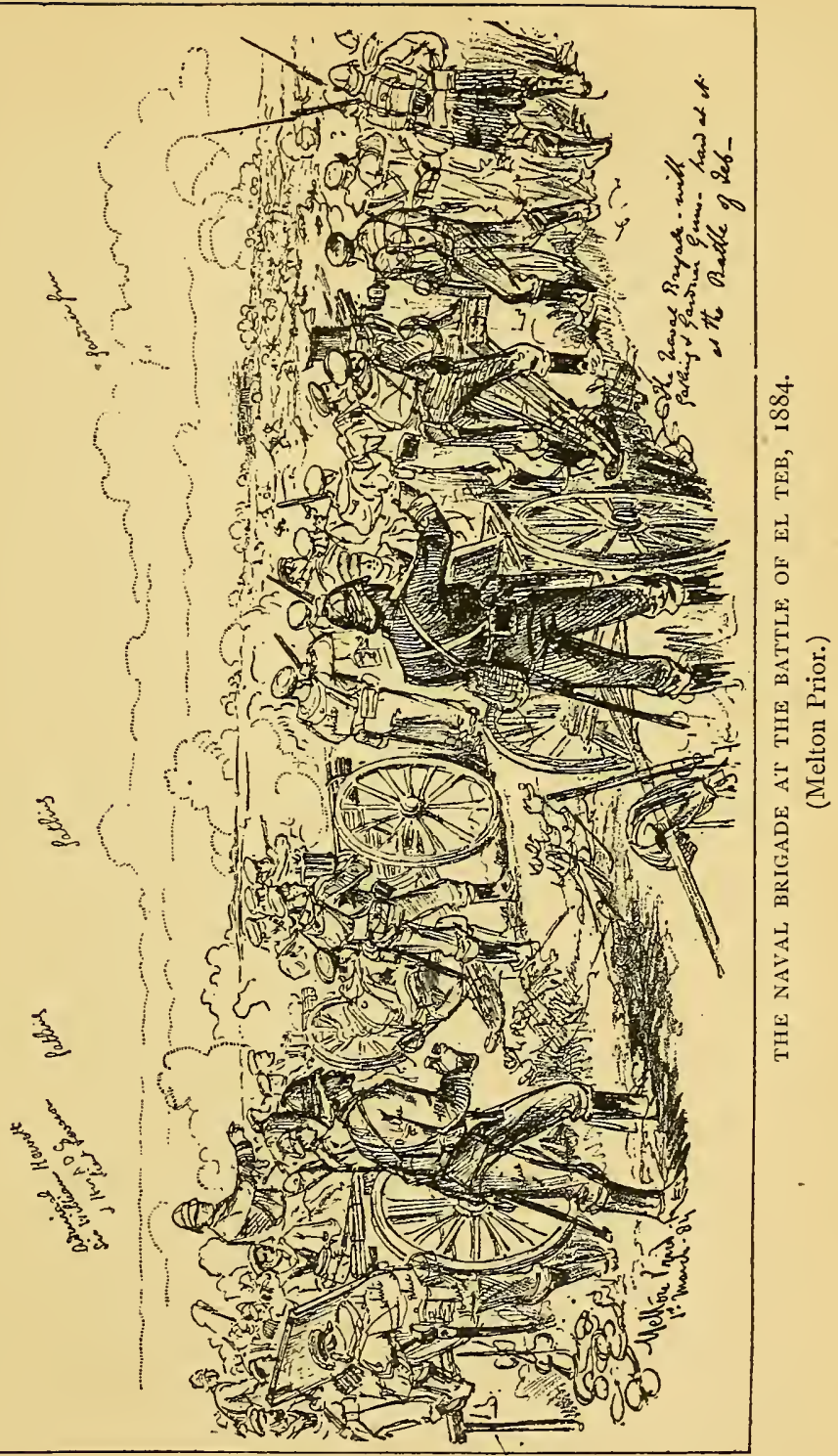


commerce must always be a chief object of attack. During the American Civil War, trade, thus preyed upon, forsook the national flag, and the United States have never retrieved the loss. The British Empire, it is obvious, being spread throughout the globe, and possessing a commerce far greater than that of any other nation, or, indeed, of many nations put together, is vulnerable in a high degree. The destruction of our floating commerce in a single war might, indeed, cripple us for generations. It would be a blow from which we might never recover.

Owing to the very vastness of our merchant marine, and to the suddenness with which modern wars are developed, we cannot expect that there will be any wholesale resort to the painful and dangerous expedient of transferring our trade to a neutral flag. Let us not be deceived by thinking that the Declaration of Paris can protect us. It is an instrument of the vaguest description, establishing mere principles without defining the application of them. No man can say what is "contraband of war," but the French may well choose to include food in that category. Our steam mercantile marine alone is valued at one hundred millions of money. How, at the sudden outbreak of war, can it be transferred to a foreign flag? What flag or flags can cover it? It is an express condition of the Declaration that "the captains and crews must be, if not entirely, almost entirely of that nationality whose flag flics at the peak." The crowning absurdity is that France, almost the only enemy we have to fear, expressly declares that she will not recognize the neutral flag unless the transfer of shipping to it shall have been accomplished before the declaration of var. In these circumstances the Declaration of Paris 
CHAP. IV.] THE NAVY AND THE STATE.

is a danger and not a safeguard. It lulls us into false security, and causes us to throw away our rights as belligerents. It imperatively needs to be revised. ${ }^{1}$ Here then, as elsewhere, the Navy is our all in all. Without it our over-sea commerce would perish; and, although Captain Mahan has conclusively demonstrated that the guerre de course cannot ultimately avail a State deficient in maritime power, we must remember that, under such circumstances, in the hands of the French, backed by a strong navy, it would prove a weighty instrument.

Peace is our best security. A Navy so powerful that none would venture to disturb our occupations, so strong that the advantages which resulted from the victory of Trafalgar, and the events that ensued, should, by its very static force, be maintained, would be our trustiest safeguard. But a security absolutely necessary for the defence of our commerce is a Navy at least of such strength that, upon the outbreak of war, it would be able to confine the enemy's fighting fleets to port, or to destroy them in action. Yet, though our merchant marine is vulnerable to attack, it nevertheless, as Lord Brassey well says in the "Naval Annual," is the main source of England's superiority as a naval power, for it gives us the "means of creating and improvising the force which must be called into existence whenever war

${ }^{1}$ Upon this subject see Mr. Douglas Owen's "Declaration of War." An admirable article by the Hon. T. A. Brassey on the principles of Imperial Defence, entitled "Great Britain as a Sea Power," in the "Nineteenth Century," July, 1893, throws a great deal of light upon commerce protection and the Declaration of Paris. A powerful address delivered by Lord Charles Beresford on July I 3 th, I893, to the London Chamber of Commerce, upon "The Protection of the Mercantile Marine during War," must not be overlooked. 
begins." It provides us, in short, with the essentials of that power of strenuous endurance which has more than once given us the victory.

The considerations which have been advanced above need not be laboured further, though the evidences that support them might be strengthened a hundred-fold. We have been brought to the same conclusion to which our historical inquiry directed us-namely, to the conclusion that Sea Power is to the British Empire its mainstay. The thought has forced itself upon us that the Navy is an arm for defence, a power that gives us security. We need it to protect us from the possibility of invasion, to make sure our supply of the necessities of life. to hold our Empire together, to avert paralysis from our industries, and to safeguard the vast commerce we have built up. In a word, we need it that we may be able in peace to develop, consolidate and maintain that which we have already secured. No sacrifice can therefore be too great for the upholding of our fleet. We see that the Navy is not merely our first line of defence, but our only line, for, with our Navy swept away, all would be lost. With the efficient protection of the fleet the life of our Empire will go on unimpeded; without that protection, the British Empire would cease to be, and England herself would emerge crippled from the struggle, and cut off from all the sources that gave her wealth, prosperity, and security.

If such be the decisive and vital importance of the Navy, some may say, how is it that so many of us are oblivious of that importance, and that in practice we relegate the Navy to a place secondary to that occupied by the Army. The explanation of this circumstance is certainly to be found in the fact that the operation of 
Sea Power is gained generally by static force, or, to use the word happily employed by Captain Mahan, that it is " noiseless," and further, that "excursions and alarums" are but the incidents of its sway. Sea Power, in short, if supremely dominant, may gain its purpose without the fighting of a battle or the discharge of a gun. Like the atmosphere we breathe, we become conscious of this power only by the consequences of its absence. Yet, probably, in I 8 I 5 no intelligent Englishman was ignorant of the causes which had led to the overthrow of

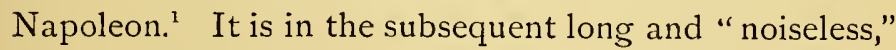
but markedly effective, influence exercised by the Navy, that we find the cause of our lamentable forgetfulness. We find it more especially in the circumstances of the Russian War. History presents us with no example so complete of the dominance of Sea Power. Yet, because the active operations were conducted ashore, the teaching of the war has been wholly misconceived and perverted. Admiral Colomb speaks with no uncertain note on this subject. "If," he says, "there had been in any part of the world a superior Russian naval force, it would have been impossible for success to have attended the expedition to the Crimea." The war, in fact, illustrates excellently well the respective rôles of the Navy and the

1 It is worth while to cast back our minds to a time when the value of the Navy was understood by the people. There was long a deeply rooted prejudice in England against the existence of a standing army, dating back to the time of Cromwell's majorgenerals, or earlier. The project of William III., to increase the army after the Peace of Ryswick, was one of the greatest causes of his unpopularity. The grants were stoutly opposed by Naval officers, and they had the ear of Parliament, for large Naval votes were made without division, while, after much discussion, the only men raised in the United Kingdom in 1698 were raised as Marines. 
Arny. The successes of the Army can be gained only as the result of the earlier victories of the ficet, be these victories "noiseless" or static, as in the case of the Crimea, or be they active and dynamic, as in the case of the victories of Nelson.

The result of this total misconception of the teaching of events has been to hand over to the military arm the great question of Imperial Defence. The "noiseless" action of Sea Power is lost in the visible presence and audible tramp of troops upon men the majority of whom have probably never set eyes on a warship. Yet, look at it how we may, the fleet is the right arm of our Empire, and every penny ill-spent or diverted from the Navy tends to the weakening of that right arm and mainstay. No liberality on the part of the nation, no exercise of technical skill on the part of officers, can compensate for the defects of a scheme fundamentally wrong. Right statesmanship is the only safeguard; sound and fixed policy is what we need. Happily there is now a better understanding of the problem of Imperial Defence, and we look back in amazement upon the fatuous policy we have pursued. The question is before all, and above all, a Naval one. Is it, then, rational that military officers should be chiefly consulted thereupon? What has been, in the past, the result of this policy? The Royal Commissioners of $1859-60$ founded upon the possibility of a visionary "catastrophe," or the absence of the fleet "from whatever cause," a plea for an expenditure of twelve millions upon fixed defences. But, notwithstanding the prodigious squandering of money upon the fortifications of Portsmouth and Plymouth, Colonel Schaw demanded, in December, I886, a further outlay of $£ 833,000$ upon the works at Plymouth, 
because they were held to be incomplete; and, in February, I 888, Sir C. Nugent expressed the firm belief that "if you beat to quarters at this moment you could not open fire over the whole sea-front of Portsmouth." Thus we see that, in the view of some military officers, the money has been spent ineffectually. The necessities of the problem of defence are indeed yet far from being perfectly grasped. Admiral Colomb, however, has done more than any man to define the relation of a moving Navy to fixed defences, and his "Essays on Naval Defence" may be commended to the inquirer. He has shown conclusively that without command of the seaunless communications can be cut-territory cannot be effectually attacked.

The truth is, that an all-powerful Navy is our only safeguard. Those who recognize the true significance of Sea Power for Imperial Defence will stoutly oppose extravagant outlay upon useless fixed defences, whereby the maintenance of an efficient fleet may well be precluded. Raleigh, who was in the midst of fighting, understood the problem better than Englishmen who have not fought a naval battle worth the name since. Trafalgar. Thus he says: "To entertain them that shall assail us with their own beef in their bellies, and before they eat of our Kentish capons" (i.e., to attack them afloat), "I take it to be the wisest way to which his Majesty, after God, will employ his good ships on the sea, and not trust in any entrenchment on shore." If it be desired to invade this country, command of the sea being first gained by the enemy, our great fortifications can be evaded, for there are a hundred places upon our shores where boats could readily be beached. To attack Portsmouth and Plymouth was no part of the plan of Napoleon 
in I 803-5. And, regarding our Imperial duties, though it may be wise to fortify coaling-stations and fixed points against raids, these have no value apart from the floating power they subserve.

These considerations bring us once again to the thought of the supreme importance to Great Britain and

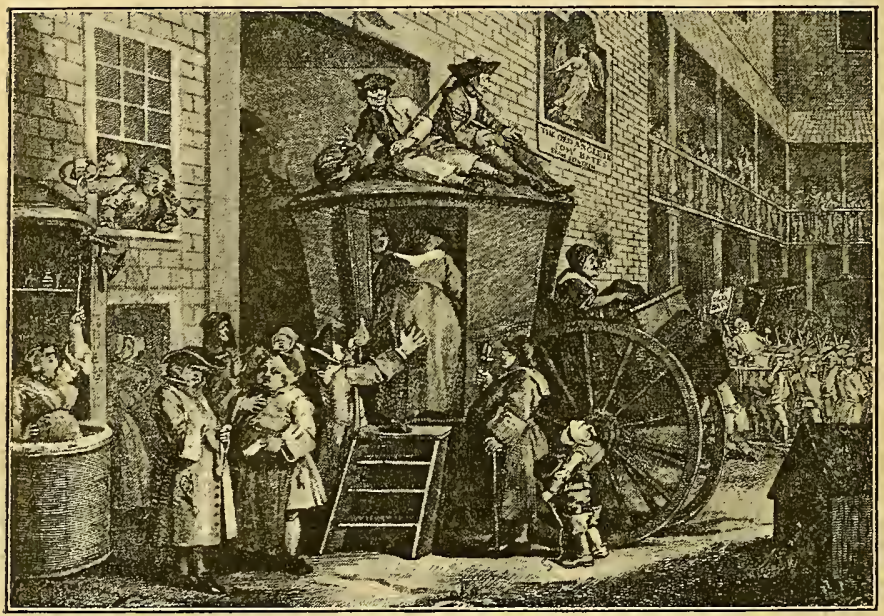

AN INN YARU, I747.

(Hogarth.)

[The sailor on top of the coach had been round the world in H.M.S. Centurion with Anson.]

the Empire of a powerful and efficient Navy. Such a Navy, however costly, is cheap; an inefficient Navy, however cheap, will be costly. It may cost our national and Imperial safety. There are some who would have the British Empire trust, for its dominant margin of strength, to alliance with a foreign power. But the history of such coalitions gives no warrant for confidence. 
We saw how little the French and Spaniards gained from their command of the Channel in $\mathrm{I} 78 \mathrm{r}$. The truth is that, apart from jealousies which have to be overcome, a foreign alliance can only be purchased at a price, and that price must be some object ulterior to our own, that may compel us to expend our strength where we should rather husband it. Moreover, a foreign alliance can never be ensured. We shall only be safe when we can stand alone. The Navy must not only be equal to our possible adversaries; it must have a commanding superiority. In this connection, let us not forget that the French Navy is in a state of vigorous developmentthat the annual expenditure upon it, which, in I88 I, was $195,600,000$ francs, has risen in the present year (1893) to $255,600,000$ francs; ${ }^{1}$ that the United States are creating a fleet, and that Russia and other powers are all adding largely to their maritime strength. Sir Geoffrey Hornby, who is admitted to be one of the first of our seamen, spoke thus to a representative gathering of merchants and bankers at the Cannon Street Hotel, on June 5th, I888: "I fancy some people will say- You a British admiral, and not content to meet your enemy on equal terms!' Yes, I am that admiral, and should never be content to meet an enemy in equal force, if by any possible efforts or prevision I could meet him in superior force. And for this reason, that to do so would be to infringe the first principles of warfare." Sir Geoffrey was but saying what Sir Cloudesley Shovell, who had been

1 The total outlay upon the French Navy sanctioned for the year 1894 is $267,371,528$ francs, being the largest sum ever voted ; but it is anticipated that in $\mathrm{r} \delta 97$ the expenditure may approximate to $300,000,000$ francs. The chief increase in the expenditure of I 894 will be upon new ships. 
fighting for thirty years, wrote to the Earl of Nottingham in I702. "The misfortune and vice of our country" he said, "is to believe ourselves better than other men, which I take to be the reason that generally we send too small a force to execute our designs. But experience has taught me that, where men are equally inured and disciplined in war, 'tis, without a miracle, number that gains the victory, for both in fleets, squadrons, and single ships, if near equal force, by that time one is beaten and ready to retreat, the other is also beaten, and glad the enemy has left him. To fight, beat, and chase an enemy I have sometimes seen, but have rarely seen at sea any victory worth boasting where the strength has been nearly equal."

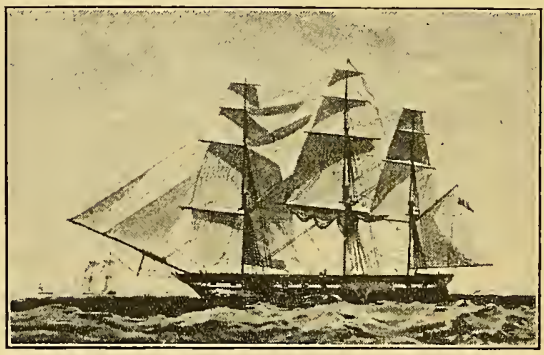

H.M. FRIGATE "PIQUE," 36 (iUNS.

(Circa I 840.) 


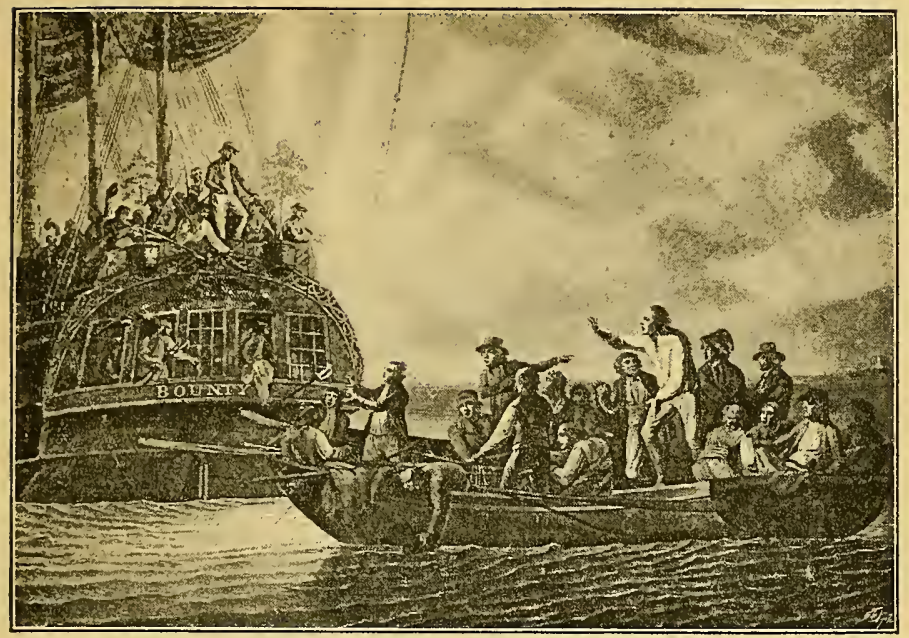

THE MUTINY ON BOARD H.M.S. "BOUNTY," APRIL, I789. (R. Dodd.)

\section{CHAPTER V.}

THE NAVY : ITS RELATION TO DISCOVERY AND TO THE PUBLIC SERVICE.

THE Navy and Exploration.-So far, we have regarded the Navy as the safeguard of our welfare and of our interests against aggression; but it has done, and will yet do, for us many things that are scarcely less valuable. It exercises functions in peace as well as in war. Let us first see what it has done in the work of exploration. There are few chapters more fascinating than this in the history of the world. The modern Navy began, as we have said, with the discoveries of the great navigators; 
and it continued the work which they had initiated. In these days, too, although the range of discovery is restricted, there yet remains, in the investigation and charting of the seas and their landward borders, and we may hope, perhaps, also in further Polar exploration, ample work of utility and interest for the Navy in time of peace. It is not easy to say precisely at what period our view of this subject should begin, for the early voyages, though they were undertaken chiefly by our fighting seamenby men like Raleigh, Frobisher, Drake, and their comrades-were mostly the outcome of private enterprise, at a time when the Navy was not fully recognized as the public service which it is to-day.

The stimulus to Discovory.-The main stimulus that fired the enthusiasm of the early explorers was furnished by a hundred marvellous stories which told of the riches and wonders of the Indies and Cathay. When the Renaissance breathed a new enthusiasm into the fifteenth century, the nations of Europe were thereby impelled to attempt the discovery of maritime routes to the mysterious East, and thus a new world was discovered, and even the icy barriers of the Pole were explored. The Spaniards dreamed of reaching the Indies by sailing due westward, and in this way the immortal discovery of Columbus was made, and European navigators first set sail on the Pacific. Among the Portuguese, who pursued the eastward way, by successive voyages the African coast was explored, until Bartholomew Diaz doubled the Cape of Storms, and Vasco da Gama, pushing across the unknown sea beyond, the first of Europeans, reached India by sea. With the same purpose did the Dutchmen (I 594-97) grapple the icy perils of the North-East Passage, where that intrepicl seaman Barents laid his bones. 
Englishmen, in the persons of Sir Hugh Willoughby, who perished on the coast of Lapland; Borough, who discovered the strait between Novaya Zemlya and the mainland ; Pet, who penetrated the Kara Sea, and Jackman, who never returned from his voyage, had preceded the Dutch in those waters ; but the work of our countrymen has lain mostly in seeking that North-West Passage which is associated in our minds with all that is enterprising and daring, and with the steady endurance and unfailing hardihood of British seamen.

The North-West Passage-Early Voyages.-P'ursuing this ideal, many Englishmen proceeded north-westward. John Cabot reached the coast of Labrador, and in 1497 touched the continent of America, a year even before Columbus. The three voyages of Martin Frobisher (1576-78) promised a revelation, and to that period also belongs the famous "Wiscourse" of Sir Humphrey Gilbert, Raleigh's half-brother, wherein he maintained the practicability of the North-West Passage. Another undaunted seaman of those times was John Davis, who, like Frobisher and Raleigh, fought against the Spaniards in I 588. In seeking the North-West Passage, Davis became the real father of Arctic Exploration. We remember him, too, as one who did much to advance the art of navigation. Davis claimed to have proved the existence of a passage by the north-west, "of God for us alone ordained," and, if his three northern voyages (I $585-87$ ) had not demonstrated this entirely, they at least had laid a sound foundation for future navigators. ${ }^{1}$ The

'See "A Life of John Davis the Navigator," by Clements R. Markham, in "The World's Great Explorers" Series. Davis proclaimed the practicability of the North-West Passage in his "Worlde's Hydrographical Description" (1598). 
celebrated Henry Hudson, who had already twice (in I 607 and I608) explored the seas eastward of Greenland, intent all the time on reaching India across the Pole, now passed the strait which worthily bears his name (in I6ro), explored the eastern coast of Hudson's Bay, and was cast adrift with the sick and loyal of his ship, to be heard of no more, by despicable and truculent mutineers, most of whom perished as they deserved. The work of Hudson was carried forward by Button (afterwards Admiral Sir Thomas Button), and by Fox, Bylot, and Baffin, and the last named sailed forward by a northerly course through Davis Strait into Baffin Bay.

From this time forward Arctic waters became better known through the frequent voyages of whaling captains and the operations of the Hudson's Bay Company; but it was not until towards the year I74I that the interest in the North-West Passage was revived. The matter was then forced upon the attention of the Government, and, even in the midst of the war with Spain, the Admiralty despatched Captain Middlețon, in the summer of that year, in command of two ships, with instructions to endeavour to make the passage and join Commodore Anson, who was then engaged upon his adventurous cruise in the Pacific. Middleton, proceeding to the northern end of Hudson's Bay, wintered in the ice, and upon his return reported that the route was impracticable. Many in England, however, were not convinced of this, and in I 745 a reward of $£ 20,000$ was offered, under sanction of an Act of Parliament, "to such person or persons who shall discover a north-west passage through Hudson's Strait to the western and southern oceans of America." 
CHAP. V.] THE NAVY IN TIME OF PEACE.

Southern Exploration.-But it is now time that we turn our attention to the exploration of the southern hemisphere, which had attracted the interest of many thinking people. Jacob le Maire, and Schouten, the master-mariner of Hoorn, had rounded Cape Horn in

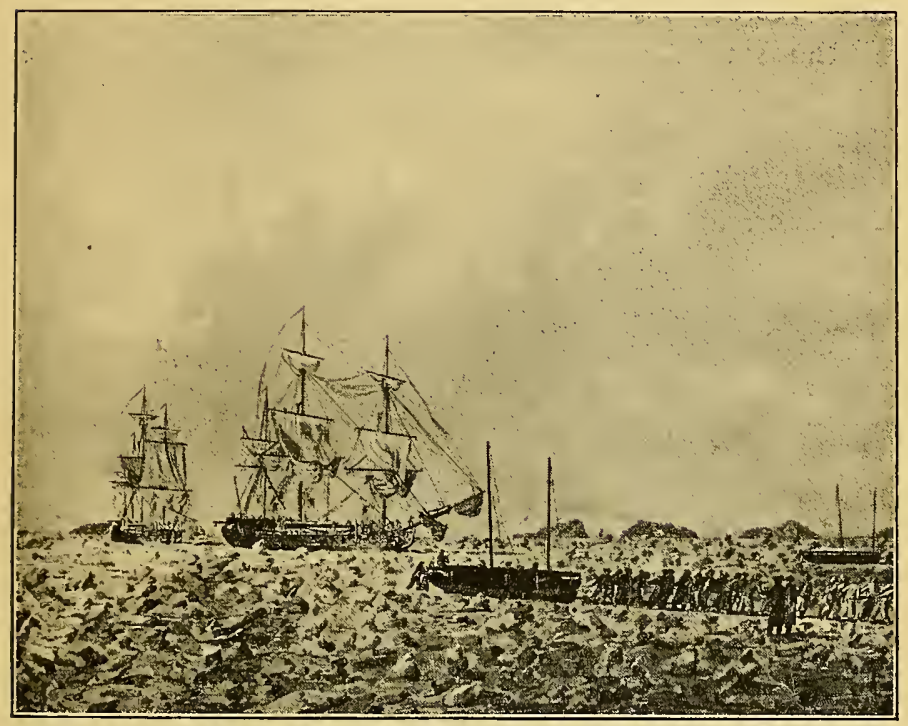

H.M. SHIPS "RACEHORSE" AND "CARCASS" IN THE ARCTIC SEA, I773. (J. Cleveley.)

[Nelson served on board H.M.S. Carcass in this expedition.]

I6I6; the Dutch were rich in the possession of Java; and Tasman had made his famous voyage from Batavia in 1642. Captain Narborough had charted the Straits of Magellan in 1670, and the cruises of Dampier, Woodes Rogers, Shelvocke, and many more, had spread 
abroad the rumour of rich islands in the southern seas. So it was that, at the close of the Seven Years' War, Commodore Byron, who had been in the Wager during Anson's voyage of twenty years before, and who fifteen years later was engaged with D'Estaing, set sail in I764 with the Dolphin, frigate, and the Tamar, sloop (Captain Mowat), with the purpose of exploring the Southern Pacific. He visited the coast of Patagonia and the Faikland Islands, passed through the Straits of Magellan, discovered several of the outlying Snciety Islands and other islets, on his way to the Ladrones, and returned home in I766. The Dolplin was at once refitted, and placed under the command of Captain Samuel Wallis, who, accompanied by the Swallow, sloop (Captain Carteret), and the Prince Frederick, store-ship, set sail on a quest similar to that of Byron. Wallis has left an excellent description of the Straits of Magellan. The ships parted company, for the Dolphin had a better pair of heels than the Swallow, and they did not meet again. Wallis, in the course of his cruise, discovered Tahiti-the Otaheite of Cook-but the honours of the voyage certainly remained with Carteret, who, in his small, old, and illfound craft, made known the Southern Society Islands, as well as the Santa Cruz or Queen Charlotte Islands, the Admiralty group, Pitcairn Island, and several other small places, and separated New Britain from New Ireland, showing a firmness, harclihood, and enterprise in the midst of difficulties that were worthy of Cook himself.

The famous voyages of the great navigator were thus prepared for. They cannot be dealt with here, and the enthralling story of them has been fully told. They 
should be known to every Englishman, and be familiar to every schoolboy. ${ }^{1}$

The investigations of Cook in Southern waters were continued, among British officers, by Vancouver (I79I), who explored the southern coasts of Australia for a distance of 500 miles, and by Captain Flinders and others. Flinders was an explorer comparable to Cook. Not less by his sterling services to his country in this great work than by the bravery with which he confronted disaster, crossed the sea in an open boat to bring succour to his shipwrecked companions, and the melancholy episode of his foul imprisonment by the French at Mauritius, is his name dear to Englishmen, and to the men of Greater Britain.

The North-West Passage and Polar ExplorationLater Voyages. -We left Arctic exploration with the

1 The account of the first voyage was compiled, with adornments, in a pedantic and ponderous fashion, by Dr. Hawkesworth ; but, happily, Captain IV. J. L. Wharton, R.N., F.R.S., Hydrographer to the Admiralty, has recently eclited, with notes, Cook's own Journal-a fine, direct, and vigorous narrative of the famous voyage. The Journal of the second voyage, in which, for the first time, Cook himself became known to the reading world, was edited by Dr. Douglas; and the scientific gentlemen who were with the expedition also published their records and observations. George Forster, one of the German naturalists, wrote indeed, in 1777 , a very readable narrative, which, however, was looked upon as a breach of confidence. The story of the third voyage, from which neither Cook himself nor Captain Clerke, who succeeded him in command, returned, was also edited by Dr. Douglas, the third volume being from the Journal of Clerke; but the book is in part a compilation from the writings of others. Of the biographies of Cook, the work of Dr. Kippis, written in 1788 , and a brief popular sketch by Mr. Walter Besant in the "Men of Action" Series, may be referred to. The series last named also includes lives of Drake and Dampier. 
voyage of Captain Middleton in I74I. Other voyages were made in subsequent years without much being added to the existing knowledge of the Arctic regions; and, in 1773, the Admiralty, at the suggestion of Mr. Daines Barrington, brother of Admiral Samuel Barrington, despatched Captain the Hon. Constantine Phipps, afterwards Lord Mulgrave, in the Racehorse, accompanied by the Carcass (which carried Horatio Nelson among her crew), to attempt the North Pole. The season was one of great severity, and Captain Phipps returned after battling with the ice north of Spitzbergen, without having added much to geographical knowledge. In the same direction was made the expedition of Buchan and Franklin in 1818 , during which the edge of the pack was examined, but little northward progress made. Buchan, who had already done excellent service in the exploration of Newfoundland, was in the Dorothea, and Franklin, as lieutenant, was in command of the Trent, both of them vessels built for the whale-fishery. It was during this adventurous voyage, beset several times by the moving pack, in the midst of extraordinary dangers and hardships, that Franklin, who had shared the perils of the South with Flinders, gained his first Arctic experience. We can do no more than refer to the expedition of Lieutenant (afterwards Sir John) Ross in 18 I 8 ; to Franklin's overland journeys in 1819 and 1827 ; to the voyage of Lieutenants Parry (subsequently Sir Edward Parry) and Liddon (which gained the reward of $£ 5,000$ offered by Parliament in I8I8), and to Parry's second and third voyages. In the last of these (1827) his sledge parties reached the then untouched latitude of $82^{\circ} 45^{\prime} \mathrm{N}$. Nor must we linger over the voyage of Sir 
CHAP. V.] THE NAVY IN TIME OF PEACE.

John Ross in the Victory, 1829-33, during which the Magnetic Pole was reached by a sledge party under James Ross, who had been with Parry in I827, and who subsequently commanded the Antarctic Expedition of I 839. Those who would learn what the Navy has done

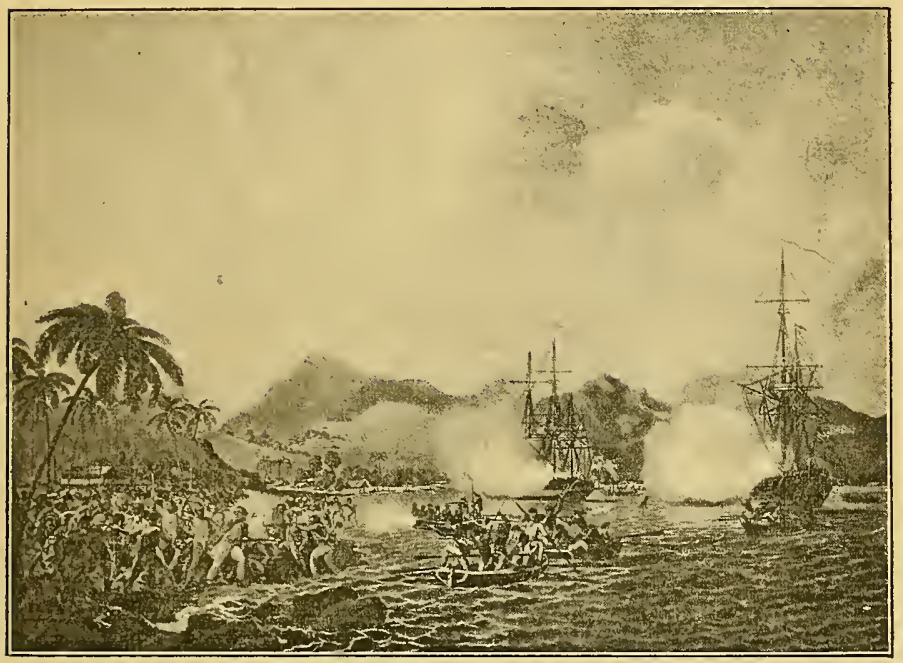

DEATII OF CAPTAIN COOK, IN KEALAKAKUA BAY, HAWAII, FEBRUARY, I779.

(J. Cleveley.)

in the work of Polar exploration, and would read the harrowing story of that last ill-fated expedition, with its three winters passed in the ice, wherein Franklin diedthings which cannot be related here-we commend to Captain (now Rear-Admiral) A. H. Markham's "Life of Sir John Franklin, and the North-West Passage"-a valuable record of Arctic journeyings. Neither can an 
account of the many Franklin relief and search parties find a place here, though they added much to our knowledge of the frozen borders of North America. Captain (afterwards Sir Robert) McClure, who passed in the Investigator through Behring Straits in 1850 , and spent two winters in the ice on the north of Banks Land, was discovered by a sledge party from the Resolutc. This was one of the ships under the command of Sir Edward Belcher, which had come westward through Lancaster Sound, and was wintering southward of Melville Island. McClure and his ship's company were carried to the Resolute, from which, after another winter, they were transferred to the Phonix, and so returned to England, being thus the first actually to make the North-West Passage. They received a fitting reward of $£ 10,000$ from the English Government. It was by the expedition of the Fox, under Captain (afterwards Sir Leopold) McClintock, R.N.-the fifth ship fitted out mainly at the charge of Lady Franklin -that the final record of the fate of Franklin and his companions was discovered, and the same expedition added the knowledge of some 800 miles to our charts.

The work of Arctic exploration, thus advanced by successive naval officers, has since been carried on by enterprising navigators of many nations. The last Arctic voyage in which ships of the British Navy were engaged was that of Sir George Nares, who, with the Alert and Discovery, in I875-76, attempted, by way of Smith Sound, to reach the Pole. Severe scurvy put an end to the work of the sledge parties; but, as Rear-Admiral A. H. Markham, who was with the expedition, says: "The north-west coast of Greenland was explored to lati- 
tude $S 2^{\circ} \mathrm{I} 8^{\prime}$ and $50^{\circ} 52^{\prime} \mathrm{W}$. longitude; the northern shore of Grinnell Land was thoroughly examined to the 85th meridian of longitude, while a position was obtained on the frozen sea on the $63 \mathrm{rd}$ meridian of longitude, in latitude $83^{\circ} 20^{\prime} 26^{\prime \prime}$, being just within 400 miles of the North Pole." We may re-echo Admiral Markham's hope that the British Navy may yet be enabled still further to extend the sphere of human knowledge in regard to the regions of the Pole.

Hydrography and Scientific Investigation.-But the peaceful work of the Navy has not lain solely in territorial discovery. It has long undertaken, and still energetically pursues, the useful labour of hydrography. Its surveying-ships are continually engaged in charting sea-borders and harbourages in every part of the world, in observing characteristics of tides and currents, and in otherwise extending the means and possibilities of safe navigation. It has lent its aid, moreover, to the scientific work of deep-sea sounding. The Lightning, for example, in I868, and the Porcupine in 1869 and 1870 , did notable work in this department; while the celebrated voyage of the Challenger (I87276) rendered splendid service to the cause of physical science.

Repression of the Slave Trade.-We may now turn to another branch of the peaceful work of the Navy, which, however, has often necessarily assumed the appearance of war. I mean the repression of the slave trade. It is peculiarly fitting that England should take upon herself this work of humanity, remembering the share John Hawkins had in originating the trade, what part English merchants took in it, and how a chief clause in the Treaty of Utrecht secured to England the Assiento, which gave 
her the monopoly of the supply of slaves to the Spanish possessions in America. We need not trace the rise of public feeling against the horrors of the trade, nor the circumstances that led to the abolition of it; but the horrors of the "middle passage" should not be forgotten. When first the Navy took part in the work of abolition, five or six ships, ill-selected and unsuitable, were ordered to cruise on the African coasts, and were withdrawn during several months of the year to avoid the rainy season. Our treaties with foreign powers at the same time restricted the work. But, mainly through the exertions of Lord Palmerston, there were grafted into the international code of Europe the enactments necessary for giving effect to the abstract resolutions of the Congress of Vienna. From that time forward the squadron upon the African coasts has been able to do no little in checking the trade; and a very brilliant chapter of naval history would recount the gallant deeds that have been done in this work. Yet there were some, about the year I 850 , who were stoutly opposed to the maintenance of the squadron, on the ground that its cost exceeded its worth, and that the African coasts were "the grave of British seamen." We may well feel glad, however, that the British Navy has never ceased its work in the repression of slavery, and has set an example to the world of energy and efficiency directed to the good of humanity. Both on the West Coast of Africa and on the East, as well as earlier on the American littoral, by the exercise of vigilance and determination, in circumstances involving no small risk to individuals, the maritime avenues of the nefarious traffic have been closed. For the encouragement of this arduous labour, a system of sufficient bounties has been wisely devised, and the recent blockade 
of the East Coast by Great Britain and the Powers, is yet fresh in our memories. It was an example of Sea Power well and swiftly used. Those who would have a stirring picture of the repression of the traffic on the East Coast, with some particulars of how it differs from the practice on the West, cannot do better than read

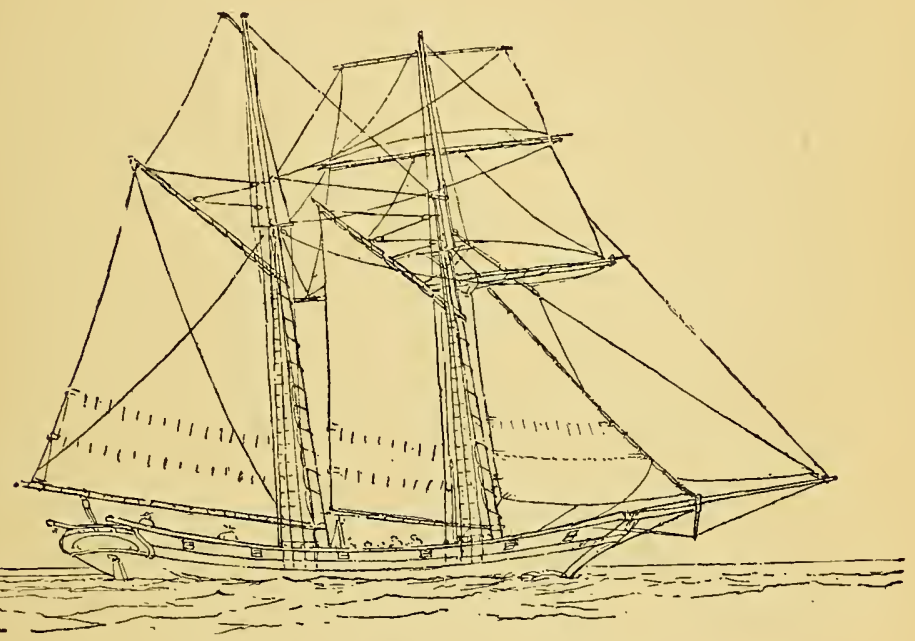

A SLAVER IN THE OLDEN TIME.

(West Coast of Africa.)

Admiral (then Captain) P. H. Colomb's "Slave-Catching in the Indian Ocean, a Record of Naval Experiences" (I873).

The Peace of the Seas.-And now there remains to be dealt with, briefly, yet another function of the Navy which is not warlike - the keeping of the peace of the seas by the repression of smuggling, piracy, and mutiny, 
three practices which form notable chapters in romance. How efficiently the Navy has checked the smuggling which once was rife, is very well known. The smuggling trade had grown so vast at the end of the last century, that, according to a pamphlet of I779, the greater part of $3,867,500$ gallons distilled annually at Schiedam was smuggled into England, while, by way of France, prodigious quantities of tea were surreptitiously introduced. But the smuggler found himself confronted by an efficient Coastguard service, and smuggling became and still remains an impossible trade. ${ }^{1}$ Piracy, too, is now practically extinct, and, so long as the Navy is efficient, will never again lift its head. Yet we saw, in an earlier chapter, that, during the Middle Ages, piracy was the scourge of commerce, which it. crushed as with an iron grip. We shall not forget the pirates of the Irisl Sea, nor how the Pickpocket of Dover captured Strafford's baggage, an immense store, when he went over to Ireland to assume his duties as Lord Deputy. But Strafford, stimulated probably by this personal incident, with the resolute determination which was his characteristic, put an end to piracy in those waters, and swept the freebooters from the sea; and thus, and only thus, did his firm government of Ireland become possible. Chapters might be filled with our naval dealings with the buccaneers and pirates of those days. Lord Exmouth's operations against the Algerine pirates (1816), and those of subsequent years (like Blake's earlier expedition to Algiers), took the form of hostilities against a pirate nation. These, as

${ }^{1}$ See "Smuggling Days and Smuggling Ways ; or, the Story of a Lost Art," by Lieutenant the Hon. Henry N. Shore, R.N. 
well as our repression of piracy in the eastern Mediterranean, and in the Straits of Malacca, the China seas, and other neighbouring waters, cannot be dealt with here. So efficiently has the maritime arm been wielded against the freebooters of the sea that navigation has been wholly relieved, and is kept free from the ancient scourge of piracy. Such is one of the debts that commerce owes to Sea Power. The Pax Britannica has replaced the anarchy of the seas. And so, too, in regard to mutiny in merchant ships, it is the Navy that maintains or restores order. In case of outbreak or violence the master of a merchant ship resorts to the senior naval officer accessible to him, who, in conjunction with the consular officers, is empowered to award punishment, and to see that justice is done.

Nor must the useful labours of the Coastguard ashore, apart from the repression of smuggling, be forgotten. It is the work of the excellent men of this service to patrol their guard by day or night, in fine weather or bad, to be constantly on the alert, to keep a sharp look-out for signals from light-ships, to render aid to vessels in distress, sometimes to man a lifeboat, to protect wrecked property, and to take charge of coast-signalling; and, at the same time, to be ready at any moment, as the first reserve of the Navy, to go afloat whenever the needs of mobilization may call.

And thus we recognize, as was said at the beginning of this chapter, that the Navy exercises functions in peace as well as in war. We cannot dispense with its services in the important work of charting coasts, estuaries, and harbours. We may yet employ it again in Arctic and Antarctic exploration, in which Englishmen, as 

of old, should be foremost. Neither can we lose the services of the Navy as a chief instrument in the repression of slavery, and in maintaining the peace of the seas.

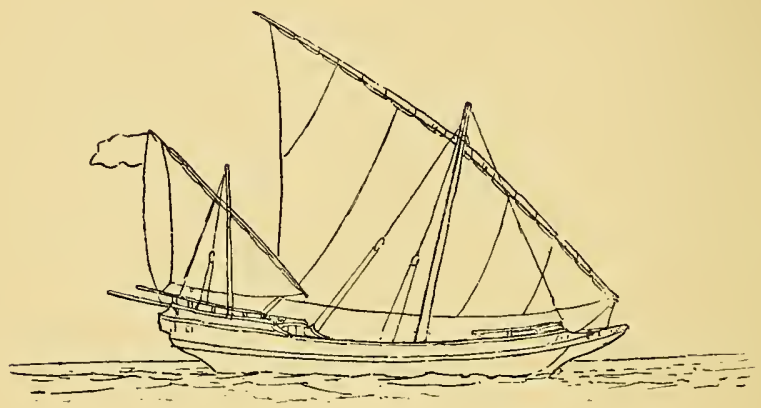

A SLAVER IN THE PRESENT DAY.

(East Coast of Africa.) 


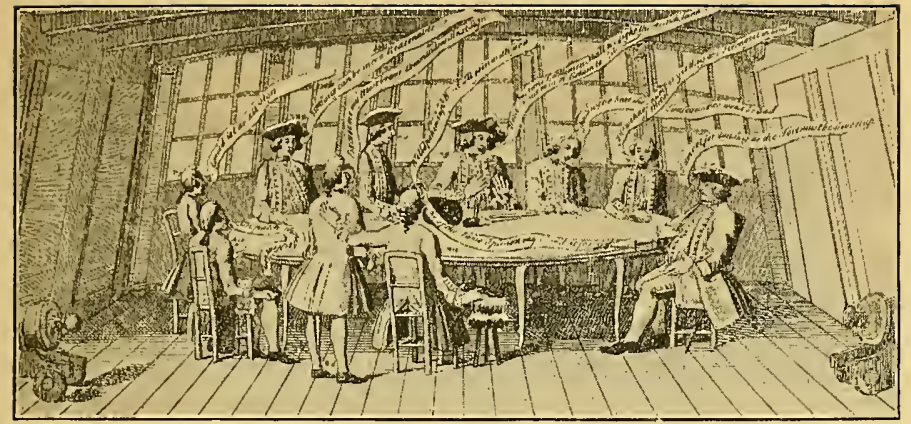

BYNG'S COUNCIL OF WAR ON BOARD H.M.S. "RAMILLIES," MAY, I756. (From a contemporary satirical print.)

\section{CHAPTER VI.}

FLAGS AND SIGNALS.

DiRECTLY connected with the growth, organization, and usage of the Navy is the subject of its flags, whether used as emblems of nationality, to denote rank and command, or for communicating intelligence. Moreover this is a subject about which a good deal of ignorance prevails, and therefore I have selected it for the final chapter of this section. The paintings of our naval battles are full of inaccuracy and anachronism in this respect. We can pardon the clergyman who hoists a white ensign, a purely naval flag, over his church, under the impression that it is a national emblem, when we find a Royal Academician like Sir William Allen giving the English ships at the battle off Cape St. Vincent ( 1797 ) the Union flag, which did not come into being until January Ist, I 8O I, and Admiral Beechey, who should certainly have known 
better, painting the English standard reversed, with the fly to the mast, in a picture representing the destruction of the Spanish Armada in 1588.

The three principal flags which we now connect with a ship of war are the ensign, the "Jack," and the pennant, the first-named being borne at the peak or on a staff in the stern of a vessel; the second in the bows; and the last at the masthead. It is immaterial to the flying of these three flags whether a ship has one mast or more, and as a matter of fact their prototypes were carried by the ships which had but one. Oddly enough, though, the ensign and the "Jack" have to a certain extent changed their significance, for whereas the former was purely a sign of nationality and the latter of ownership, the white ensign now denotes that the vessel is in the country's service, while the "Jack," which is common to both land and sea forces, has become the national emblem.

The pennant, on the other hand, has always denoted the rank of the commander of the vessel. In ancient times he was a soldier, and, in the smaller craft, a manat-arms bearing on his lance a single-tailed pennon which he transferred to the ship. In more important vessels he was a knight, who carried a swallow-tailed banner, or, as some say, a burgee, now the distinguishing flag of a commodore, or captain in command of a division. And then, on more important occasions, a knight-banneret went afloat, perhaps in charge of the expedition, and his square flag is now carried by our admirals. At first these flags, indicative of individuals, appear to have been the only ones flown, although in some cases a banner dedicated to the patron saint of the expedition would be prominently displayed. It is probable that the flag with a blue border and a cross of gold, 
which flew from the masthead of the ship which carried the fortunes of William the Conqueror across the Channel, was of this description, especially as it is said to have been given to him by the Pope. ${ }^{1}$ Any way, a cross was not the personal cognizance of the Dukes of Normandy, although it certainly was that of some of their followers.

Naturally, when the ships used for an expedition were hired, or belonged to a powerful confederation like the Cinque Ports, they would also display their own proper banners, and there is no question that the port flag was in common use for some time before that which denoted nationality. In those days allegiance to one's town was quite as much a living sentiment as allegiance to one's country, and we may be sure that if the portsman did not display his banner it was because he was engaged in business of which he had reason to be ashamed. It may be mentioned in this connection that it was a custom, well into the present century, for a merchant vessel to carry, in addition to the national ensign at the peak, a flag at the mizen painted with the arms of the city in which her owner lived, and another at the fore bearing those of the place or nation to which the person or company freighting the vessel belonged. In the present day the house flag has largely superseded the port flag in the merchant navy, just as the "Jack" took the place of the "three lions dimidiated with sterns of ships" when the Royal Navy of the Cinque Ports ceased to supply the bulk of the national bulwarks.

We have noted, then, the use of the personal flag, the flag of the patron saint, and that of the port or

1 Nicolas, vol. i., p. 6 I. 
community to which the ship belonged; and to these there was added very early in the thirteenth century the banner which is still the distinguishing mark of English nationality. The use of the St. George's cross for this purpose appears to have originated at the time of the Crusades, when it became desirable for several reasons, and not the least that of discipline, for the soldiers of each contingent of the Christian forces to bear some sign which, while it marked the common purpose, enabled those of one nation to be easily distinguished from the other. The cross was the emblem that every Crusader had assumed, but, while the French chose a white cross on a blue ground, the English adopted red on white; and these crosses were displayed, not only on the soldiers' surcoats and trappings, but also on the banners. When Richard Cour de Lion embarked in the English fleet which carried him from Messina to the Holy Land, there cannot be a doubt that the St. George's cross was hoisted by all the vessels, and it does not seem improbable that henceforth it became usual for English ships to fly it.

It is uncertain whether this device became the English flag of command at once, or whether the personal banner of the leader still continued to hold that significance. It is quite clear, however, that throughout the thirteenth century the flags carried by ships bore a greater import than they had done previously. Thus in I2I7 we are told that, when the Cinque Ports'fleet went out to meet, and so gloriously beat, the invading squadron under Eustace "the Monk," instructions were given to one of the Kentish sailors that, on engaging the enemy's flag-ship, he was to board her, climb the mast, and cut away the banner, in order that "the other vessels may be dispersed 
from the want of a leader." For, in I 250 , not only did the ship of the admiral of the fleet carry a flag of command by day, but by night she carried a lantern to indicate her position to the rest of the vessels. In I 297 an international agreement to carry colours in the ships was made between Edward I. and Guy, Count of Flanders, who arranged that their respective subjects should for the future "carry in their ensigns or flags the arms of their own ports, certifying their belonging to the said ports." While this convention was doubtless meant to facilitate the suppression of piracy and the like, it indirectly shows that the practice of carrying an ensign or national flag had now become common. About the same time we hear of the expedient of hoisting false colours with intent to deceive; some Spanish vessels when engaged in attacking English ships doing so under the Portuguese national flag instead of their own. This use of false colours is distinctly against the etiquette of the present day, which allows of their employment to entice an enemy within reach, but distinctly forbids the exercise of any hostile act under their shelter. In the illuminated pictures of vessels in the Middle Ages, the flag at the masthead is sometimes square, sometimes a swallow tail, but more often a pennon, and in English ships it is almost always charged with a cross; then in the bows, on the fore-stage or castle, is a standard with the royal arms, or those of a baron or other chief; and in the aft-castle is displayed that of the port or confederation to which the vessel belongs. There are exceptions to this rule, but they are few, and it is noteworthy that, in spite of the introduction of the other masts, the "Jack" and the ensign still continue to be carried on staves at the extremities of the vessel, as the banners 
of ownership and nationality were five hundred years ago. ${ }^{1}$

About the middle of the fourteenth century that which had been custom became law, and the red cross on the white ground which flew over the ships at Sluys was legalized as the badge of English nationality. In I 345 or I 346 more than one hundred and sixty "pennoncells, with the arms of St. George on them "were made for the fleet, showing that each vessel was to carry such a pennant. In smaller quantities banners, bearing the image of each ship's patron saint or an emblem having some association with his name, were supplied, as well as a few larger flags with the cross.

These latter were probably flags of command, as we are told that when Edward III. set forth on his expedition to invade France, he "declared himself admiral for that voyage; took the ensign (the flag of command, and not the standard) from the Earl of Warwick, and running ahead, led the fleet with a fair wind." It is worthy of remark, too, that there are several allusions in the old chronicles leading one to suppose that the display of extra flags, that is to say, flags in addition to that of the port, denoted the warlike purpose of the vessel

${ }^{1}$ The seals of the Lord High Admirals of England throw much light upon the flags flown in mediæval ships, and upon the heraldic character of sails, which cannot, in the early period, be dissociated from them. The square sail of the ship represented in the seal of Sir John Holland, Earl of Huntingdon (circa I 437), bears the lions of England within a bordure semée of fleurs-de-lys. The arms depicted on the sail in the seal of Richard, Duke of Gloucester (afterwards Richard III), are those of England and France quarterly, with a label of three points, and the same are displayed on a large square banner flying from a staff in the aft-castle. In other cases the cross of St. George flies in this position. 
carrying them, and that this was specially so of the display of the St. George's cross. It is almost beyond a doubt that the coats of livery, or " jacks" as they were called, which the soldiers wore at Crecy (I346) and Poictiers ( 1356$)$, bore this badge, for the old "Articles of War"drawn up by Edward III. or his gallant son, the Black Prince-ordained that "Every man, of what estate, condition or nation he be of, so that he be of our party, shall wear a sign of the arms of St. George, large, both before and behind; upon peril that if he be slain or wounded to death, he that hath done so to hin shall not be put to death, for default of the cross that he lacketh. And no enemy, whether prisoner or not, shall wear the said sign of St. George, upon pain of death." The sailors of the Cinque Ports also, in I5I3, if not long before, wore as their uniform "a cote of white cotyn with the red cross and the arms of the Ports underneath." And now onward until the accession of James I. the red cross on a white field was the English flag. It was under it, as Professor Laughton so eloquently says, "that the great seamen of Elizabeth's time traded, or explored, or fought; it was this flag that Drake and Cavendish bore round the world, that Lancaster carried to the East Indies, and Frobisher to the far North; that flew triumphant against the Spaniards off Gravelines on the 29th of July, I 588 , or, with less good fortune, though not with less glory, waved o'er the shot-torn wreck of the Revenge off Flores on the Ist September, I59I." 1

On April I2th, I606, it was ordered by King James, that, "Henceforth all our subjects of this isle and Kingdom of Great Britain and the members thereof, shall

1 "The Heraldry of the Sea :-Ensigns, Colours, and Flags. “Journal Roy. Unit. Serv. Inst.," vol. xxiii., p. I 16. 
wear in their maintop the red cross, commonly called St. George's cross, and the white cross, commonly called St. Andrew's cross, joined together according to a form made by our heralds, and sent by us to our admiral to be published to our said subjects." The "Union Jack" so introduced was the same as that we now use, except that the cross diagonal or saltier was pure white. At this time, however, the "Jack" was not put into the ensign, which remained white with a red cross for a few years longer, until the tactical necessities of large fleets brought about their subdivision and an alteration of the flag at the same time.

In or about 1627 , and probably at the time of the expedition against the Isle of Rhé, the fleet was divided into three squadrons, and each squadron was given a different ensign, the centre red, the van blue, and the rear white; each flag having in the upper corner, next to the staff, a white canton charged with the St. George's cross. At the same time the squadrons were subdivided into three, respectively commanded by an admiral, vice-admiral, and rear-admiral, carrying their distinctive flags on the main, fore and mizen masts. As, however, the admiral commanding in the centre was not only in command of the red division but of the whole fleet, he flew, instead of the red flag, the Union at the main, and thus it happened that there was no Admiral of the Red; nor was there any until November 9th, I 805, when, as a special compliment to the Navy after Trafalgar, this rank was instituted. The second in command flew a blue flag at the main and the Union at the fore ; the third, a white flag at the main and the Union at the mizen. The Lord High Admiral when afloat in command, and sometimes also other commanders-in-chief, flew, instead of the Union, 
the Royal Standard, and this the Duke of Buckingham did in this very expedition to the Isle of Rhé. At about this time the pennoncelles, or as they were now called pennants, were made of three colours for the whole of their length, and towards the end were left separate in two or three tails. This custom obtained all through

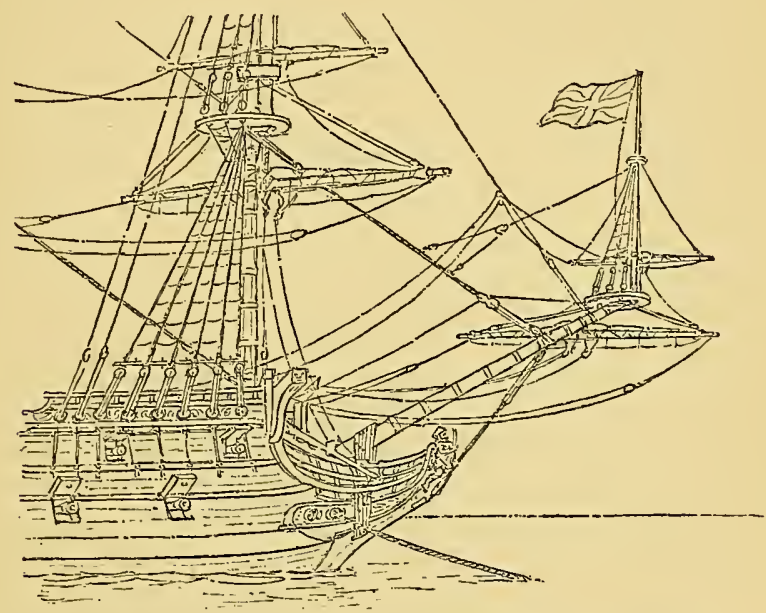

SPRI'T-TOPMAST, SIXTEENTH AND SEVENTEENTH CENTURY.

the eighteenth century and up to the end of the war in 1816.

The next change in "Jack" and ensign came about with the death of Charles I., when the Parliament, professing to represent England and Ireland only, prescribed, on March 5th, I649, as a substitute for the Union Jack, "the arms of England and Ireland in two escutcheons, on a red flag within a compartment, or." This flag would thus appear to liave been red, with two shields in 
a yellow diamond or oval, one bearing the St. George's cross, the other, the harp of Ireland. In the admirals' flags the compartment was encircled with a laurel wreath. At the same time it is pretty nearly certain that in what is technically called the "fly" of the ensign the Irish harp appeared, and that the "Jack" worn at the head of the spritsail-topmast reverted to the old St. George's flag. It has, however, been stated also that the "Jack" of this period bore the crosses of St. George and St. Andrew combined, with the Irish harp in the centre of the flag. ${ }^{2}$ The blue colour, being Scotch, was now made distinctive of the rear squadron instead of the van, changing places with the white. It was under these flags that Blake won his victories.

At the Restoration the Union flag was restored both as a "Jack" and as a flag of command; Pepys noting, under date May I3th, 1660, that a council of war was held "to acquaint them that the Harp must be taken out of all their flags, it being very offensive to the King." ${ }^{2}$ In Van der Velde's picture of the fleet bringing home Charles, the Naseby is shown with the standard at the main, the Admiralty flag at the fore, the Union at the mizen and at the sprit-topmast head, and a red ensign with the St. George's cross in the upper canton at the stern. As Van der Velde was there in person this is doubtless a correct presentment.

In May, I707, when constitutional union was made with Scotland, in the reign of Queen Anne, the "Jack" was for the first time placed in the upper corner of the

1 "The National Flags of the Commonwealth." "Journal Brit. Arch Assoc.," vol. xxxi. p. 54.

2 "The Diary of Samuel Pepys," Wheatley's edition, vol. i., p. I 38. (G. Bell and Sons.) 
ensigns, and the red cross displayed across the white ensign as it is now. At the same time the "Union Jack" ceased almost entirely to be worn as a flag of command. With the exception of Sir George Byng in I7 I8, and Sir John Norris in 1744, no admiral carried the "Jack" at the main from I704 until I794, when Lord Howe wore it in the campaign which culminated in the battle off Ushant on June Ist. When Ireland also became a portion of the United Kingdom, the "Jack" was once more altered, and what we know as the cross of St. Patrick was introduced by order, January Ist, ISo I, and thus we get the Union Flag of to-day, which is essentially the people's flag. Just as the Standard contains the personal emblems of the Crown, the regimental banners are distinctly military, and the red, white and blue ensigns are sea service flags, and have no kind of meaning when used by other than seafarers.

By Admiralty order of August 5th, I 864, it is ordered that "admirals, vice-admirals, and rear-admirals shall in future wear respectively the white flag with the red St. George's cross thereon at the main, fore, and mizen topgallant masthead. All Her Majesty's ships-of-war in commission shall bear a white ensign with a red St. George's cross and the 'Union Jack' in the upper canton" - the flag which all the ships had carried at the Nile and at Trafalgar. British ships and vessels employed in the public service, or when commanded by R.N.R. officers, and carrying a certain number of Reserve men, were authorized to fly the blue ensign. All other British ships, except a few like those of the Royal Yacht Squadron, having special authority to do otherwise, were ordered to fly the red ensign. This order is still in force.

In olden times before ensigns were carried at the 
mizen peak it was held a sign of victory to trail the enemy's flag over the taffrail in the water, and in pictures of the battle of the "Glorious Ist of June," I794, this method of illustrating defeat is shown. In later days it has been customary to hoist the flag of the beaten enemy underneath your own to convey the same information. To do this in time of peace is regarded as an insult, and if done by mistake, in dressing ships for example, an apology would be demanded. To reverse the ensign, that is to say, to hoist it upside down, is a signal of distress, and this is accentuated by making it into a "weft," which is done by knotting it in the middle. This method of showing distress by means of a "weft" is mentioned in naval works written in the reign of James I. The "Jack" is also used for other purposes than to denote the nationality of the ship and as a flag of command. When hoisted at the mizen peak and accompanied by a gun it is the sign of a court-martial ; when at the mizen topgallant masthead, it signifies that the ship flying it has the guard for the day; and when surrounded by a white border it is shown at the foretopgallant masthead it is the signal for a pilot, and in this shape it is known as a "Pilot jack." The "Jack" also occurs in all combinations of signal flags denoting a ship's name, and last, sad but honoured use, it is the pall of every soldier and sailor. Why, or dating from what period I cannot say, but it has long been customary when a man-of-war is ordered to pay out of commission, to hoist at her masthead an immensely long pennant, which has therefore become the sign of the homeward bound.

Signals are of great antiquity, and were very early in use among maritime nations. Flag signals were employed in the English service in the thirteenth century, 


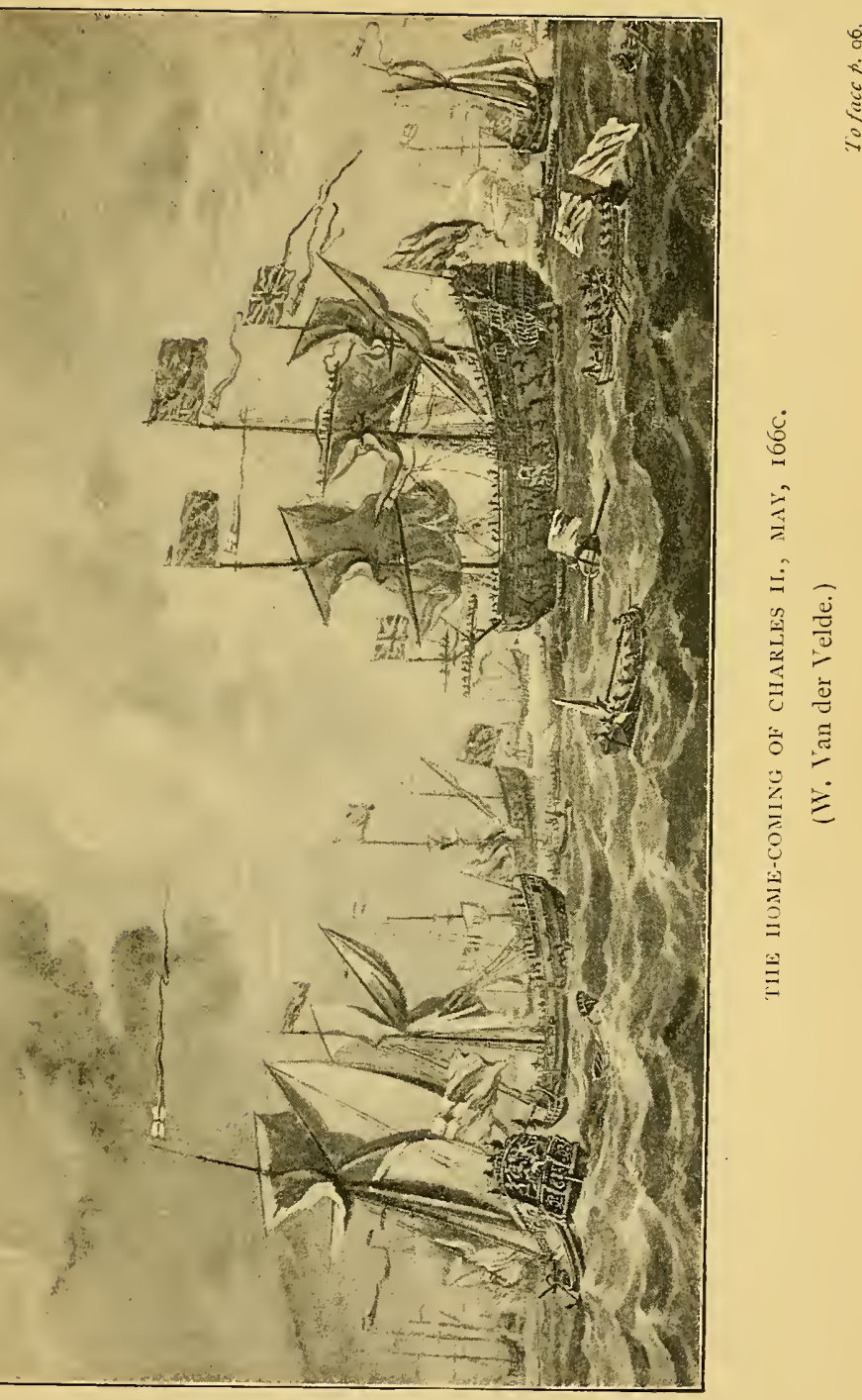



for in the laws of the period it is prescribed that a ship wanting to be towed or to pick up a pilot was to show a banner. In the naval instructions of 1350 , it is mentioned that if the admiral wishes to summon the captains and masters of the fleet, he is to do so by hoisting a "banner of council," and a flag was to be displayed on the discovery of a supposed enemy at sea. Towards the end of the sixteenth century some approach to a regular code seems to have been made, but it was not until Sir William Penn d:ew up what are known as "the Duke of York's Fighting Instructions," about 1655 , that we find signals incorporated in the regulations. Even then the only flags used, with one exception, are the ensigns, pennants, and red, white, and blue flags of command, in general use for other purposes. The exception is a flag striped red and white, which was used as a signal to chase, and which, by the way, it is quite possible was the origin of the United States ensign.

This code of James II. continued in use until the close of the American War, when a Mr. McArthur, secretary to Lord Hood in the IVest Indies, turned his attention to the subject. He devised a plan by which, instead of the complicated and unwieldy method of showing the flags in particular positions of the rigging, he proposed to simplify matters by using more flags and showing them in combination. His plan was not at once adopted, for Lord Howe had also drawn up a code, but when this was ordered to be tried experimentally by a squadron under the command of Lord Hood, McArthur suggested from his old code a number of additions and alterations, the value of which were demonstrated by the experience then gained. From a plan suggested by Admiral Kempenfelt, McArthur also compiled a code of 
night signals, and these two codes came into use in I 792-3 and are known as Lord Howe's signals. They were used up to the time of Trafalgar, when Sir Home Popham's code was substituted, and upon this is based the system now in use.

NoTE.-For the purpose of flag-signalling in the Navy, two sets of flags are used, distinct from those of the International Code, together with a set of pennants. The first set of flags represents the letters of the alphabet, and the second the numerals. The former set is used with the vocabulary signal-book, while the latter and the pennants are employed chiefly in reference to the evolutionary signal-book, or that used for tactical movements. It is the rule of this code that no signal is answered until it is fully understood, and that no signal is made executive (which is done by hauling it down), until every ship has replied. Many of the flags and pennants have also special significations. Thus the square yellow flag $(w)$ denotes that sickness is on board, while the square blue flag, with white square in the middle $(0)$ is also the "Blue Peter," which is hoisted to show that the ship is about to put to sea. The flags of both the Naval and International Codes are depicted in Alton's "Seamanhood" (Griffin, Portsea).

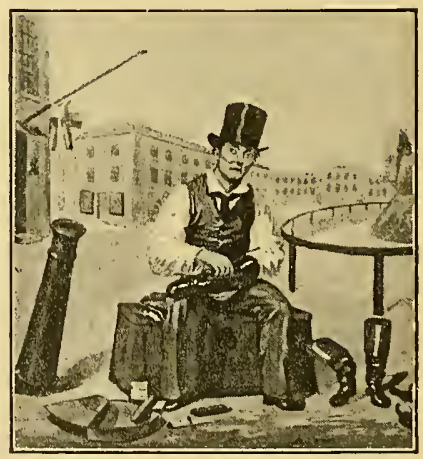

A IID. ON HALF-PAY, IS27.

(H. Heath.) 
PART II.-NAVAL ADMINISTRATION. 

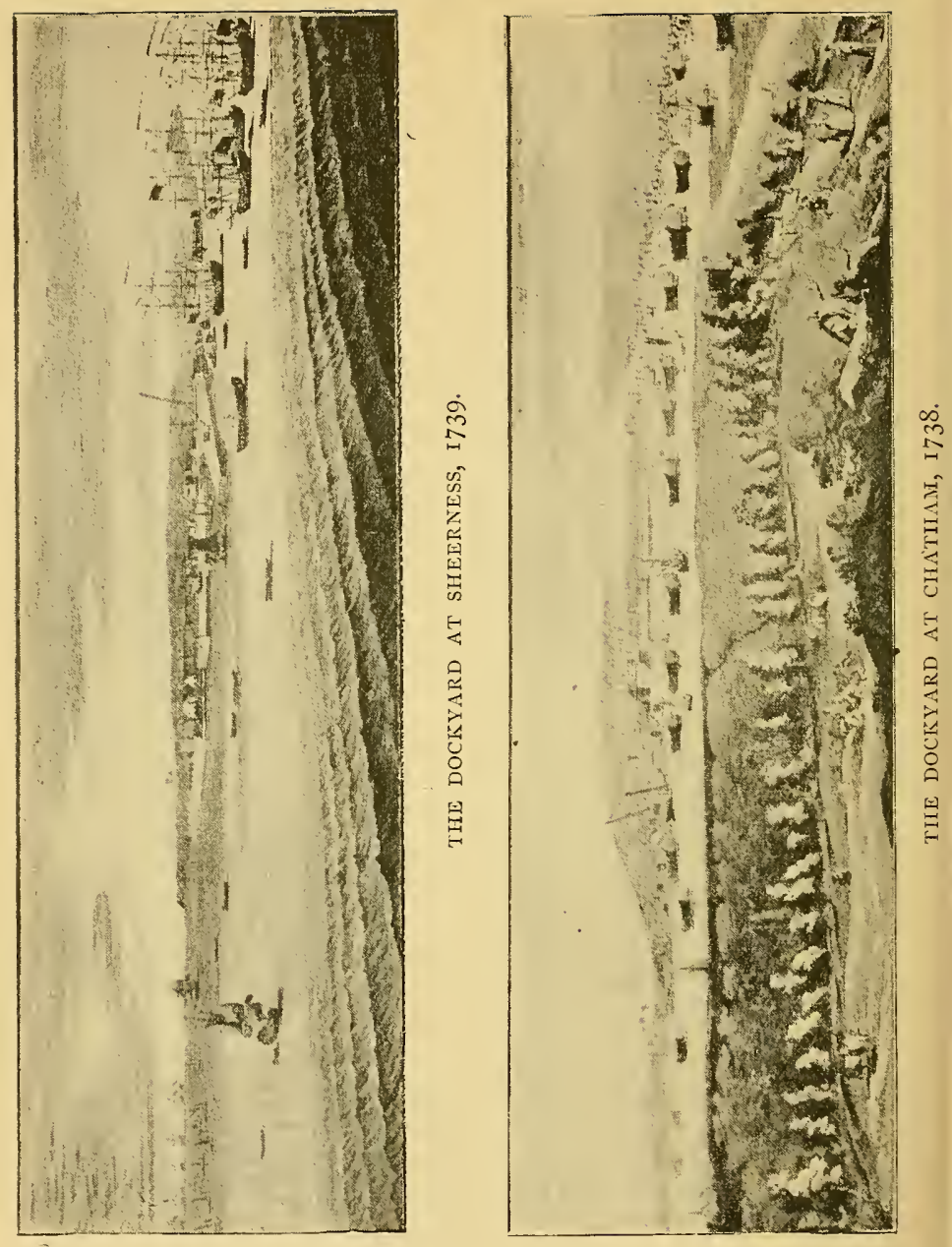


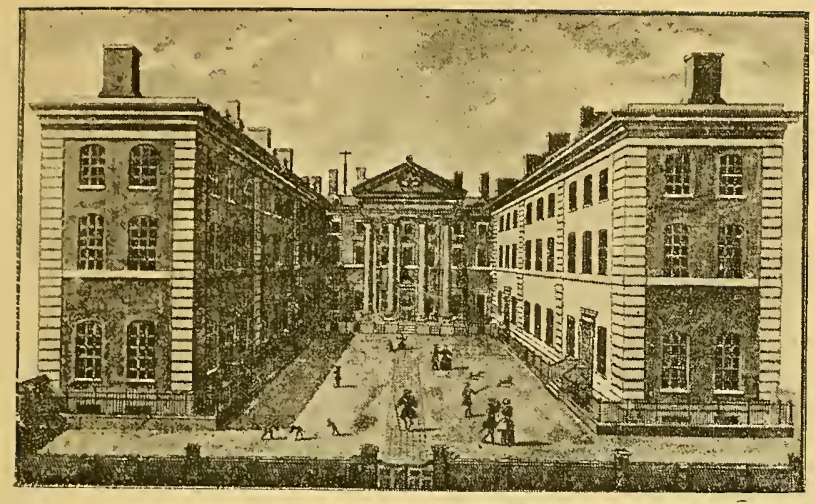

TIE ADMIRALTY OFFICE AT WHITHIIALL. I754.

(Engraved for Strype's edition of Stow's "Survey of London.")

\section{CHAPTER Y.}

THE LORD HIGH ADMIRAL AND TIIE BOARD OF ADMIRALTY.

IN the days when this island was under Roman rule one of the three officers entrusted with its administration was designated the Count of the Saxon Shore-so-called from its liability to the inroads of Saxon pirates-and it was this person's duty to attend to coast defence. With that object in view he provided ships, and soldiers trained to fight at sea (marines); he also constructed harbours to shelter, and castles to protect his naval forces. In the arrangements made by this official we find the germ of our system of naval administration.

There came a time, after the Romans had left, when 
the strategical value of the positions chosen by the Count of the Saxon Shore, made itself obvious to their successors who had effected settlements on the littoral, and this was the origin of the Cinque Ports-at first a congeries of trading communities linked together for mutual protection and closely connected with wealthy and powerful ecclesiastical bodies, and later the nucleus and support of a naval association capable of serving the State in war time.

As affairs became more settled the guardianship of the seas, and the control of the naval forces (at that period, and for long after, a composite fleet consisting partly of vessels the private property of the ruler, and partly of "people's ships,") became vested in the Crown, and their management devolved on the King and his Council, before whom competent persons were, from time to time, summoned to give advice upon maritime affairs. It is noteworthy in this connection that the earliest extant minutes of the proceedings of the King's Council relate to matters connected with the Navy, and are addressed to Sir John de Roos, one of the admirals of the northern fleet in $1337 .^{\prime}$

It was customary, however, to delegate this control, either partially or in full, to officers who were at first styled "Guardians of the Seas," and afterwards admirals. But, while the King's ships remained few in number, the duties of this official, or his court - which seems to have had an existence at least as early as the reign of Henry I. (I IOO)-chiefly related to civil and criminal causes connected with maritime affairs-duties which were similar to those afterwards exercised by the Lord High Admiral

${ }^{1}$ Sir H. Nicolas's "History of the Navy," vol. ii., p. 188. 
-i.e., a combination of the powers of the present Lords Commissioners, and of the High Court of Admiralty.

It was in the reign of John (I 199) that an approach was first made to a regular naval establishment, the principal management of the fleet being at that time entrusted to William of Wrotham, Archdeacon of Taunton, who was designated "Keeper of the King's Ships," and "Keeper of the Sea Ports." This functionary and his successors exercised executive power not only over the galleys which were actually the property of the King, but also over those which the Barons of the Cinque Ports were bound to provide by their charters. They are found assisting the King and his Council, and the admirals, in the management of such naval forces as existed up to the reign of Henry VIII.

At exactly what period the term "Admiral" first came into use is doubtful, but the great Hubert de Burgh, who, although not a sailor by profession, commanded the ships which repulsed the French attempt at invasion in 1217 , does not appear to have been so called. It is not indeed in any English record that the title appears until I300, when Gervase Alard, one of the bravest and most distinguished seamen of his time, is described in the Wardrobe Accounts as "Admiral of the Fleet of the Cinque Ports." Three years later Edward I. issued letters patent informing his subjects that Alard had been so appointed. In France, however, the term had been previously in use, and the fact that in a convention executed at Bruges in March, 1297, Sir William Leybourne is styled "Admiral of the Sea of the King of England," may be held proof that he was executing the duties, although his official designation was "Captain of the King's Sailors and Mariners." 
From this date onward, the title of admiral, presently crombined with that of captain, was held by two, and sometimes three, officers who were from time to time appointed to the command of fleets for the protection of the coasts. The same powers were exercised by these officers as had been previously exercised by the "Guardians of the Sea;" and they seem not only to have had executive administration, but to have held court and decided causes within the limits of their jurisdiction, either summarily or after investigation of the facts hy a jury of mariners.

The minutes of the Council in I337, referred to above, contain directions to the admiral to impress ships and men for the King's service, and summon men-at-arms, armed men, and archers, who are to be reviewed before embarkation. ${ }^{1}$ It is not stated for what expedition this mobilisation of the northern fleet was needed, but the ships were to assemble at the port of Orwell (Harwich), and the soldiers were to be victualled and embarked at Yarmouth. The admiral was instructed to personally superintend the equipment of ships and the choice of men for their crews, as well as to "hold Court according to maritime laws."

About the middle of the fourteenth century the

'It appears from the "Close Rolls of Edward II." that such administrative business as the levying of ships had been transacted earlier through the King's Chancery, without the intervention of the admiral. Thus, in 1308 , requisitions were addressed to Robert de Kendale, Constable of Dover Castle and Warden of the Cinque Ports, and to the "barons, bailiffs and men" of the ports, as well as to the mayors and bailiffs of the southern ports, to provide men and shipping for service against the Scots. It was

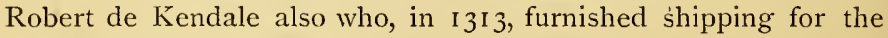
Kìng's journey over-sea. 
Commons began to complain about the maladministration and neglect of the Navy, but without much effect. The state of affairs, however, became intolerable in

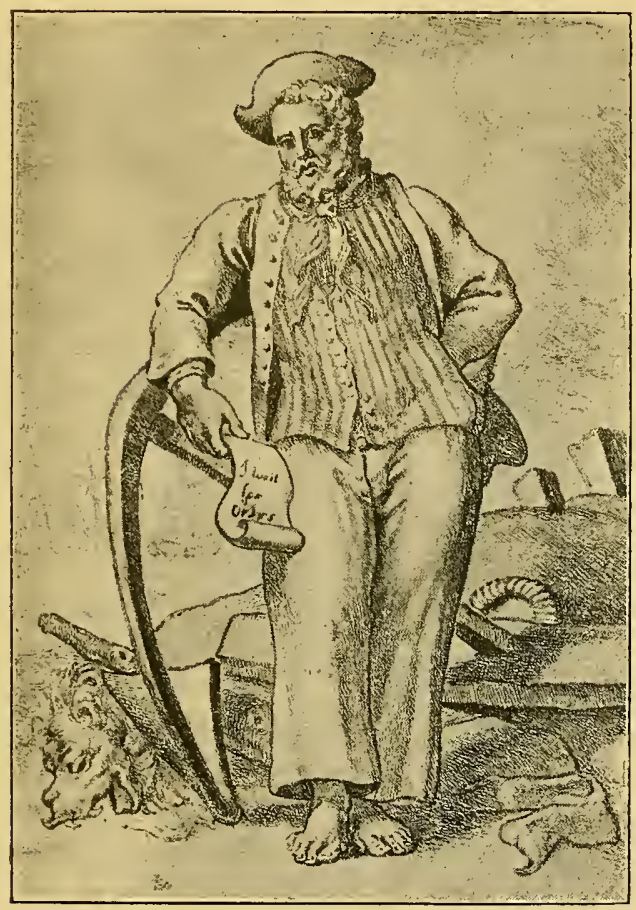

THE BRITISH HßRCULES, I737.

(From a contemporary satirical print.)

October, 1383, when the Earls of Northumberland and Devon, who were then the admirals, declared that they could not in the circumstances any longer undertake to secure the safety of the seas. In November, 
I 390 , therefore, a measure was adopted for the encouragement and protection of the Navy which was more fully carried out two centuries later by the celebrated "Navigation Laws." It was enacted that "all merchants of the realm of England shall freight in the said realm the ships of the said realm and not foreign ships, so that the owners of the said ships may take reasonably for the freight of the same." This law, probably because it was not properly enforced, did not afford much relief, and, in 1406 , the merchants offered to undertake the safeguard of the seas themselves, and in A pril they nominated their own admirals. The expedient was not found to work satisfactorily, and in the following December the commissions of these "mercantile admirals" were superseded by the appointment of the Earl of Somerset as "Admiral of England."

From that time forward until I628 the control of the Navy was delegated by letters patent to a succession of officers sometimes styled "Admirals of England, Ireland, Aquitaine and Picardy," and sometimes "Lord High Admirals." The badge of office was a gold whistle set in precious stones and suspended by a gold chain $;^{\mathbf{1}}$ and until the reign of Queen Anne the salary was 300 marks only, but there were other and very large enoluments arising from droits of various descriptions. These were resigned by Prince George of Denmark (Lord High Admiral I702-8) into the hands of the Crown, a fixed salary being attached to the office in lieu.

The administrative acts of the kings prior to Henry VIII. had, so far as the Navy is concerned, little

I See "The Naval Chronicle," vol. xxv., p. 474, I II I. 
continuity, except perhaps in the matter of the Cinque Ports' charters. Sometimes actuated by a love of display, and sometimes by the necessities of the moment, they built, or bought, ships of their own, or exercised the powers which enabled them to impress those of the merchants. The supply of stores and victuals was of a hand to mouth description, and, although sheds existed in which the vessels were laid up during the winter months, no regular provision of money was made for the maintenance and equipment of the Navy. It was not, indeed, until the time of the Commonwealth, when the affairs of the Navy were managed by a Committee of Parliament, that the system of Navy Estimates was introduced by Cromwell, the amount of the first vote being $£ 400,000$.

To the prescience of Henry VIII. is due the organization of the Admiralty as a great department with Dockyards, Victualling, Ordnance, and subsidiary branches, a large proportion of the necessary expenditure being borne by the spoil of the monasteries. He appears to have constituted the Admiralty Board to assist in carrying out the executive functions which had heretofore devolved upon the Lord High Admiral, and the Navy Board to undertake the civil administration which before had been connected with the office of the Keeper of the King's Ships. The interior work of the department was reorganized, and a Surveyor of Marine Causes, a Treasurer, and a Comptroller of the Navy appointed.

It was not until the reign of Edward VI. that the regulations made by these officials were turned into ordinances which formed the basis of all subsequent instructions drawn up for the guidance of those to 
whom the management of the civil affairs of the Navy had been committed.

An important development of the executive administration of the Navy took place in the reign of James I. by the appointment of a Council of men of rank, or of naval experience, to assist Buckingham, who had succeeded Nottingham as Lord High Admiral, in the management of naval affairs. This Council may be deemed the forerumner of the Board of Admiralty as now constituted, as it prepared the way for the further change which tookplace in 1628, when the office of Lord High Admiral was, for the first time, placed in Commission, the Commissioners being the great officers of State. During the Commonwealth both the Admiralty and Navy offices were managed by Committees of the House of Commons, the Commissioners receiving an allowance of $3 s$. per diem. ${ }^{1}$

At the Restoration Charles II. appointed the Duke of York Lord High Admiral, but the introduction of the Test Act in 1673 compelled the Duke to resign his office, which was then placed in Commission, the Commissioners, as before, being the great officers of State, with Prince Rupert at their head. King Charles took advantage of the change to reserve to the Crown the tenths of all prizes, and other droits of Admiralty. This Commission continued until May, I684, when King Charles assumed the government of the Navy personally, and retained it until his death. James II. on his accession, mindful of the jealousies that had arisen between the sovereign and himself when Lord High

'For many details of the above changes see Pepys's "Diary" and "Memoirs," and "The Eng. Hist. Reriew." 
Admiral, as to the exercise of the large powers of that office, declared himself, in Council, Lord High Admiral and Lord General, and personally managed the affairs of the Navy, through Secretary Pepys, until the Revolution.

In the first year of the reign of William and Mary (r689) the office was again held by a Commission, at the

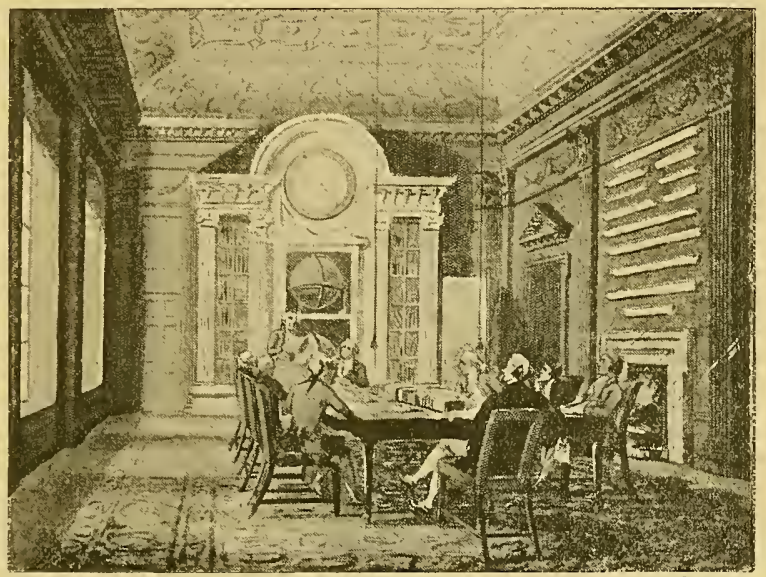

THE BOARD-ROOM AT THE ADMIRALTY, ISOS. (Rowlandson and Pugin.)

head of which was placed Admiral Arthur Herbert, who was created Lord Torrington. In I690 an Act was passed (2 Will. and Mary, Sess. 2, cap. 2) confirming the powers of the Lords Commissioners of the Admiralty, and two years later the following resolution was passed by the House of Commons :-

"Resolved, that it is the opinion of this Committee that, in pursuance of His Majesty's speech, the House 
be moved that His Majesty be humbly advised to constitute a Commission of Admiralty of such persons as are of known experience in maritime affairs: and for the future all orders for the management of the fleet do pass through the Admiralty that shall be so constituted."

It would seem that this Act was declaratory rather than creative; it recited and recognized the ancient power and privilege of the office, while it checked the influence of the Crown.

This resolution, and the statute above referred to, are the original authority for the constitution of the Board of Admiralty in its present form. One of the early acts of the Commissioners thus appointed was to double the pay of the officers of the fleet, though it was reduced again in 1700 . The reasons given for this liberal increase were somewhat curious :-First, the scale of pay was not equal to that of neighbouring nations; second, King James had established table money, and had led officers to expect they would receive it-an expectation which was not fulfilled; third, the great and general neglect and remissness of officers in discharge of their duty.

In I7OI King William III. dissolved the Commission and appointed the Earl of Pembroke Lord High Admiral, much against his will, "as he saw it would draw a heavy load upon him, and he was sensible that by his ignorance of sea affairs he might commit errors." The expectation was justified, and in the following year he was dismissed from office.

The charge of the Navy now devolved on H.R.H. Prince George of Denmark, who in I7O2 was appointed Lord High Admiral of Great Britain, with a Council to help him, and retained office until his death in 1708 . Of his administration Burnet says: "The making of 
Prince George our Lord High Admiral proved in many instances very unhappy for the nation; men of bad designs imposed upon him; he understood those matters very little, and they sheltered themselves under his name, to which a great submission was made, but the complaints rose the higher for that."

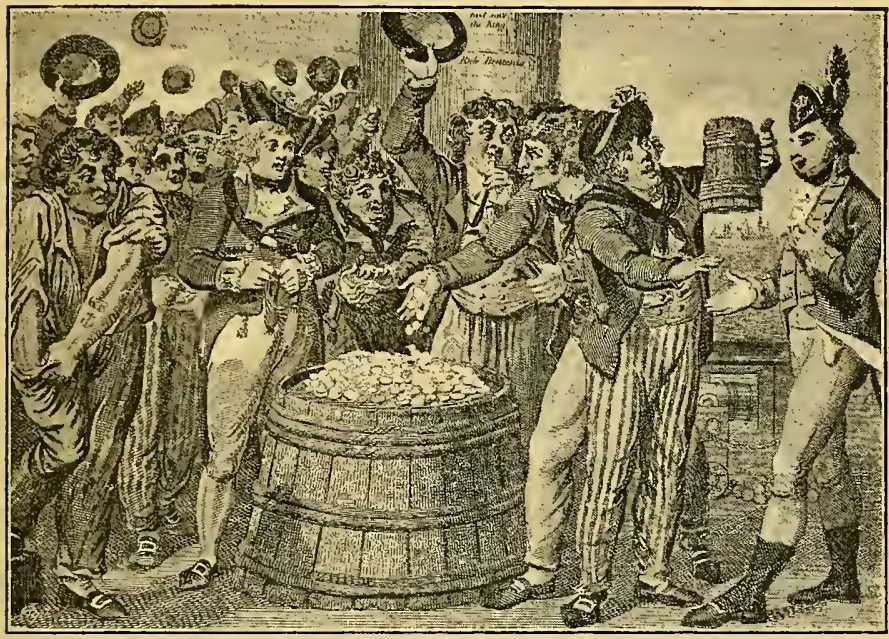

SEAMEN OF H.M.S. "ARGONAU'T," I789.

(From a contemporary print.)

Except on these occasions, and once again, when the Duke of Clarence (afterwards William IV.) was Lord High Admiral from May, 1827, until August, I 828), the office has been in Commission, and is likely to remain so. The number of Commissioners varied from five (I 828 to 1830 ) to six (from i 830 to I 868 ), but no organic changes (except those effected by Sir 
James Graham in $\mathrm{I}_{32}$, which are dealt with later on in connection with the Navy Board) took place in the constitution of the Admiralty until December, I868, when the office of Third Lord was merged with that of Controller, who then for the first time had a seat at the Board, while the office of Fourth Naval Lord was abolished.

The reason for giving the Controller a seat at the Board, and making him the superintending Lord for all business connected with the building and repair of ships, with guns and with naval stores, was the anomalous position he occupied by being placed under the supervision of the First Naval Lord-i.e., the officer specially coricerned with the strength and efficiency of the fleetso that, practically, the only member of the Board in a position to enforce economy in shipbuilding was the one who was most interested in increased expenditure.

By Order in Council of January I4th, I869, the First Lord was declared to be responsible to the Sovereign and to Parliament for all business of the Admiralty, the other members acting as assistants in the transaction of the duties, which were divided into Personnel, Material and Finance.

The Board thus constituted consisted of the First Lord, the First Naval Lord, the Third Lord, who was also Controller, the Junior Naval Lord, the Civil Lord, the Parliamentary Secretary and the Permanent Secretary. The Parliamentary Secretary became responsible to the First Lord for the finance of the department, in which duty he was assisted by the Civil Lord, the Permanent Secretary taking exclusive charge of the Secretariat under the First Lord.

By an Order in Council of March 19th, 1872, the 
Controller ceased to be a member, but remained responsible for material. A Second Naval Lord „was re-established, and the three Naval Lords were made responsible for the personnel of the Navy and the movement and condition of the fleet. A new office, that of Naval Secretary, was also created. In the same year (April I6th, I 872) certain alterations in the constitution of the patent of the Board of Admiralty were approved by the Law Officers of the Crown. The papers, which are of a confidential nature, are deposited in the Record Office of the Admiralty.

On November Ist, I877, the office of Permanent Secretary was abolished, the duties being merged with those of the Naval Secretary; but on May Sth, I882, the office of Naval Secretary was abolished in its turn, and that of Permanent Secretary revived. On April I 8 th, I882, the Board was once again reconstituted, the Controller resuming his seat, and a non-Parliamentary Civil Lord, possessing special mechanical and engineering knowledge, and also experience in the superintendence of large private establishments, being added to it for the purpose of assisting the Controller in business relating to the material of the Navy. This new appointment was, however, abolished in July, I885, since which time the constitution of the Board of Admiralty has remained unchanged.

The question as to whether the First Lord of the Aclmiralty should be a civilian or a naval officer has been often and keenly discussed. ${ }^{1} \quad$ The first constitution of the Board appears to indicate the latter, while on the other hand Parliamentary experience and training may

' See "Admiralty Administration : its Faults and its Defaults," by Admiral Denman, I86I. 
well be considered essential in the holding of a high political office. The advocates of one view may cite the facts that Lord Anson, a naval officer, was First Lord in Lord Chatham's administration, one of the most successful in English history, that Lord St. Vincent acted in the same capacity under Pitt, and that Lord Barham was in a similar position during Nelson's triumphs in I805; while their opponents may bring forward the opinion of Sir James. Graham, who, when questioned by the Select Committee of the House of Commons in I86I, replied, "If you ask me whether I think them [i.e., naval officers], the best administrators in their mixed capacity of Civil and Naval servants, I am not of that opinion."

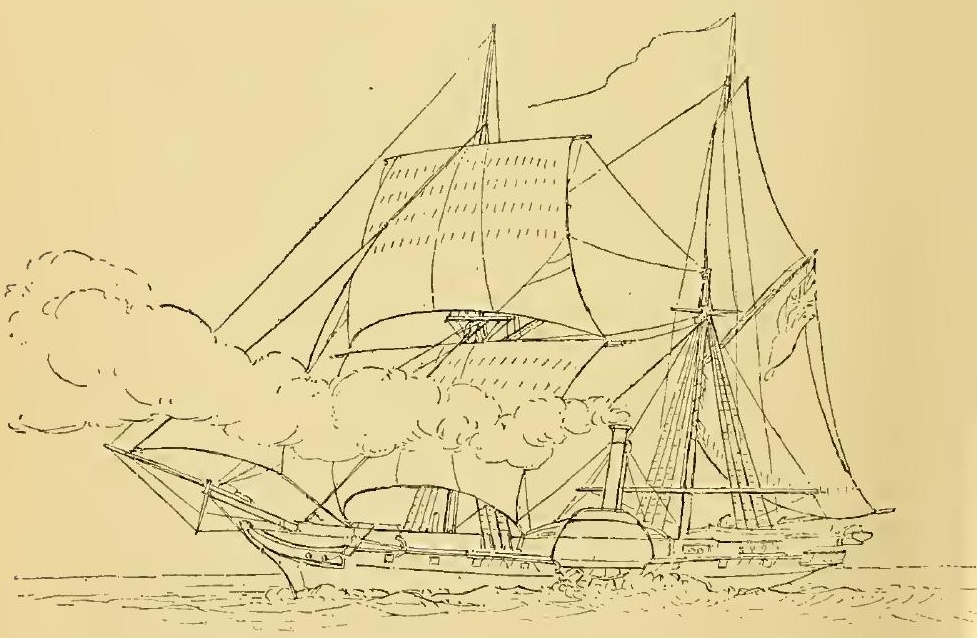

H.M. STEAM FRIGATE "FIREBRAND," 6 GUNS.

(Built at Portsmouth, I843. Broken up about 1867.) 


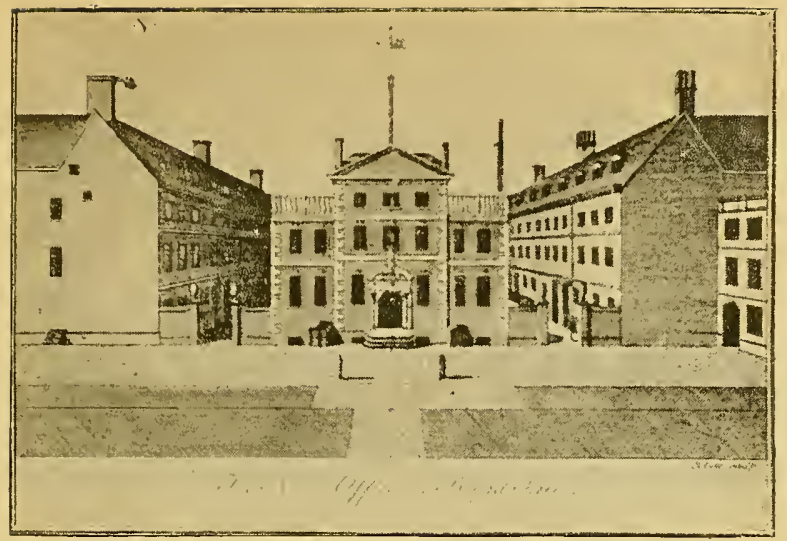

THE NAVY OFF1CE, CRUTCHED FR1ARS, 1750.

(Cole.)

\section{CHAPTER II.}

THE EQUIPMENT OF THE FLEET.

IT has been mentioned that Henry VIII. appointed the Navy Board. He also established the Trinity House, ${ }^{1}$

' The Guild of the Holy and Undividable Trinity and St. Clement, at Deptford Strond, more familiarly known as the Trinity House, was incorporated by Henry VIII. in 15I4, at the instance of Sir Thomas Spert, Comptroller of the Nary : to this body is intrusted the regulation and management of the buoys and lighthouses of the shores and rivers of England; they also appoint and license pilots. In 1854 the Cinque Ports' pilots were placed under the control of the Trinity House, which, at the same time, was given a general supervision over the Commissioners of Northern Lights and the Ballast Board of Dublin, the bodies intrusted respectively with the care of the lighthouses and buoys on the coasts of Scotland and Ireland. See "The Trinity House of Deptford Strond," by C. R. Barrett, I 893 . 
and appointed certain other officials charged with the administration of the various naval departments. Particular duties were assigned to each member, and they were ordered to meet at least once a week at the office on Tower Hill and to report their proceedings monthiy to the Lord High Admiral.

The morality of those times, especially in money matters, was notoriously lax, and it is not surprising, therefore, to find that charges of peculation against all the departmental officers and their subordinates were exceedingly rife. It is, however, doubtful if the greater part of these accusations of maladministration were well founded, and those who are interested in the matter may be referred to the articles of Professor Laughton, in the "Dictionary of National Biography," upon the naval officials of the time, and to Mr. Oppenheim's papers in the "English Historical Review." The subject of victualling I have deemed important enough to deal with separately.

Benjamin Gonson was Treasurer of the Navy in Henry VIII.'s reign, and in those of the two succeeding monarchs, but, in 1578 , he was succeeded by his son-inlaw, the famous Sir John Hawkins, who managed the Navy for seventeen years, and by common consent did more than any other man to organize victory for our fleets in 1588 . His duties included the superintendence of the administrative work at the dockyards ; of the construction and repair of ships; and generally of every executive detail connected with their equipment. To his judgment, knowledge of naval affairs, and effective supervision, it was largely due that our ships "were more handy, more weatherly, and more heavily armed than those of Spain, and, above all, that they were ready 
when they were wanted." It may or may not be true that he embezzled money supplied for the repair of ships, that he issued old cables, and oakum which was rotten, that he blackmailed the shipwrights and was guilty of many other malpractices of like nature, but of one thing we have proof positive, that, when the fate of England depended upon the condition of the fleet, it was found to be efficient for the work it was called upon to do.

In Elizabeth's reign the ordinary expenses of the Navy appear to have been about $£ 6,000$ a year, but special estimates were drawn up when a fleet was required for service, and the preparation for war largely increased the expenditure. In the year of the defeat of the Spanish Armada it is estimated that as much as $£ 88,000$ was paid to Hawkins, exclusive of charges for victualling, and of those borne by the ports which furnished contingents at their own cost. The amount of compensation paid to the owners of the eight vessels used as fire-ships at Calais was $£_{5}$, I I I IOs., which, on the whole, was not a bad investment. The average annual cost of the Navy for the six years following 1588 is given by Mr. Oppenheim as $£ 42,500$.

Speaking generally, it may be said that the organization of the Navy, in spite of many defects, was at this period equal to the calls made upon it, and that it was at least smoother in its working than that of any other of the departments of State. Naval men will want no better evidence of this than is to be found in Monson's statement that in 1599 a fleet was actually prepared for sea in twelve days; and the reason is unquestionably to be found in the fact that the men who filled the high offices of the Navy were experienced seamen, in whose 
patriotism and ability, whatever she thought of their honesty, the Queen had confidence.

That James I. paid as much attention to the Navy as he did, seems to have been duc, at least in part, to the Commons. But it has been claimed for him that his personal interest in it was even greater than that of Elizabeth, and it should be mentioned that he established the Shipwrights' Company, and placed at its head Mr. Phineas Pett, the designer of the Prince and the more noted Sovereign of the Seas.

The abuses of naval administration had, however, now become so great that in I6I 8 the Board of Principal Officers was dissolved and a Council of Commissioners appointed, responsible only to the Lord High Admiral, but with absolute charge under him, and powers to "manage, settle, and put the affairs of the Navy in a right course, and to take such measures as they might deem necessary to prevent the continuance of the great frauds which prevailed."

So long as Hawkins had been Treasurer of the Navy, and even so long as Elizabeth exercised a keen supervision over the affairs of the sea service, the fact that Nottingham as Lord High Admiral took little interest in the details of its administration was not of great consequence, but from about the time when Sir Robert Mansell was appointed Treasurer, in 1604, the system of control and the conduct of the Navy Office became utterly scandalous and corrupt. In 1608-9 an inquiry was held by Commissioners specially appointed, and their report, with the depositions on which it was based, is still in existence.' Among the abuses reported on,

1 S. P. Dom. Jas. I. xli. Cott. MSS. Julius F. iii. 
some unquestionably began about I 597-98, or shortly after Hawkins's death. Among these are enumerated delay in paying off ships, to the discontent of the men and extra expense of government; combinations between captains, pursers, and victuallcrs to return false musters; and the practice of selling appointments to inferior posts. But the chief officers later on became not merely indifferent to this style of thing, but ringleaders and participators in similar malpractices, until, as one writer put it, "To say truth, the whole body is so corrupted, as there is no sound part almost from the head to the foot; the great ones feed on the less, and enforce them to steal both for themselves and their commanders." ${ }^{1}$ No great benefit acciued from the report of I608, but ten years later Buckingham succeeded Nottingham, and the appointment of a Commission reduced the position of the principal officers to mere heads of departments "Immediate benefit was obtained from this reform : the fleet and dockyards were kept in repair, theft was checked, and two new ships a year were built for five consecutive years, all for less money than Mansell had squandered in doing nothing efficiently."

After the ill-fated expedition to the Isle of Rhé, the Commission was dissolved by Charles I. and the affairs of the Navy reverted to the Board of Principal Officers, which had been established by Edward VI. There is some reason to believe that the administration of the later Commissioners being found less competent and honest than had been that of their predecessors was the cause of this cliange.

During the Commonwealth the affairs of the Navy

1 Coke MSS., Cal. Hist. MSS. Com. Report xii., App. pt. i. p. 4. 2 "Eng. Hist. Review," vol. vii., July, 1892, p. 4So. 
were managed by a Committee of Parliament, but on the restoration of Charles II. the Duke of York, being appointed Lord High Admiral, at his suggestion the Navy Board was reconstituted, and three new Commissioners, Lord Berkeley, Sir William Penn, and Mr. Peter Pett, were appointed to act with Sir George Carteret, the Treasurer-Controller, Sir William Batten, Surveyor, and Mr. Samuel Pepys, Clerk of the Acts, as Principal Officers and Commissioners of the Navy. A set of instructions and standing orders for the guidance of the Principal Officers and Commissioners of the Navy, and the superior officers of the dockyards, was also drawn up, and proved to be of great value. These instructions were printed in I7I7, and in the preface, written by a naval officer for the published edition, as well as in Pepys's "Memoirs of the Navy," printed in I690, many interesting and instructive details of the naval administration of this period will be found.

In 5670 the whole business of the Navy, including the victualling and transport work, was conducted by the Navy Board, and had seemingly returned to the old groove. In that year "A Sailor" wrote to a member of the House of Commons:-

"When men are established Commissioners what is their business? If they have bought their place then they must make good their purchase money: they must get something to live at a great rate; they must provide something for their children's portions; they must lay by something to make their peace when they are found tardy; they must reserve something to live upon when they are old, and after all these somethings it is ten to one if the people have anything left besides taxes."

Perquisites abounded; each Commissioner had a 

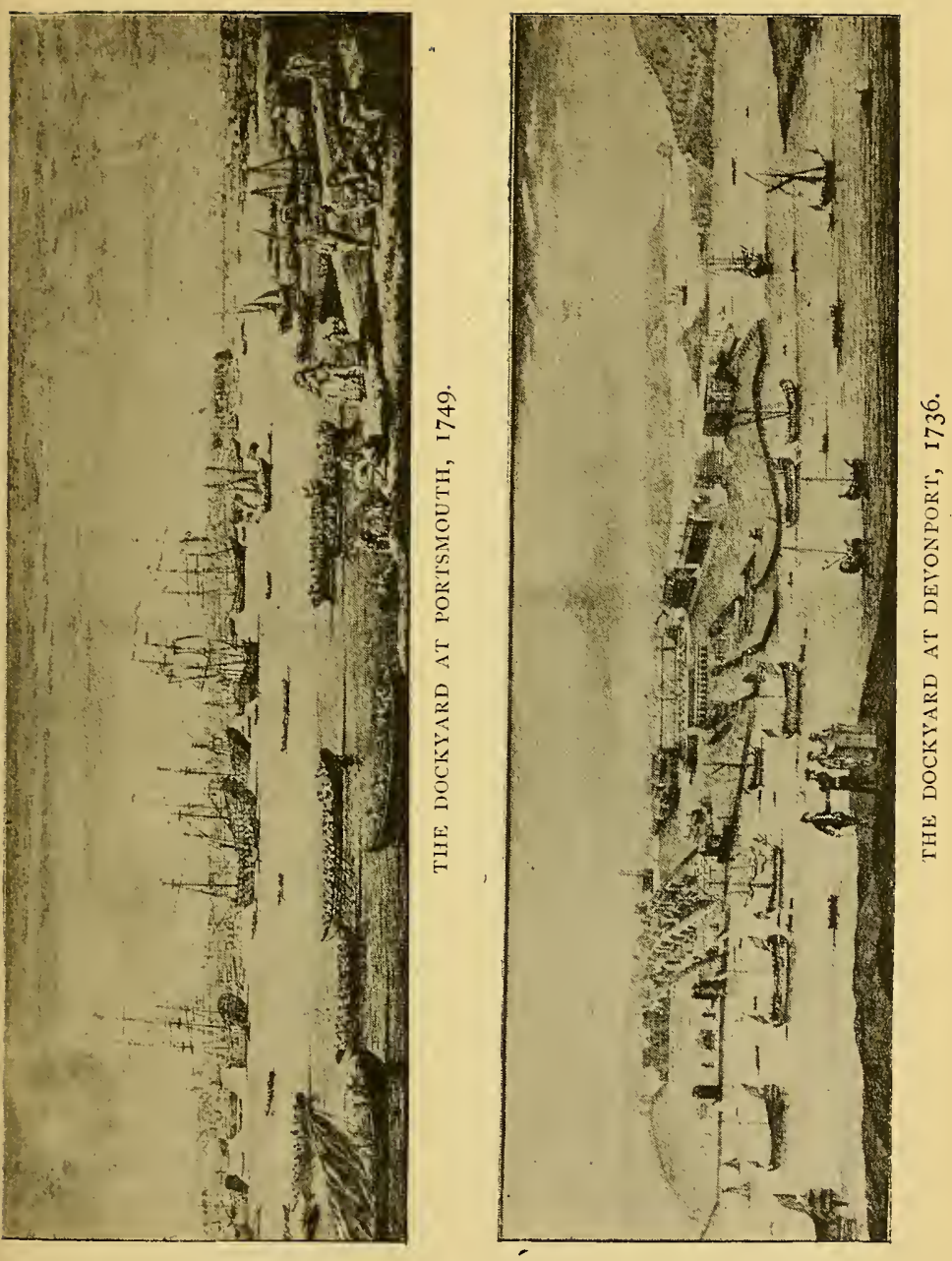
labourer allotted to him, whose duty it was to cut off board ends and carry them to him daily; then they had an allowance of tongues, beef, pork, and marrow-bones, the tails of the hogs and the kernels of the oxen going to the clerks, who were also allowed the privilege of cutting "beef and pork steaks from the flesh." Nor was this all. The same "Sailor" goes on to say that "the Commissioners and their friends, by making interest for their friends to sell in Provisions, have too often been the occasion of bad Provisions being brought into the stores; for when Goods are bought by favour and affection the Quality of the Commodity is not considered, but the gratuity to the officer is the principal Verb. By this means the Victualling was a long time supply'd with Bread made of undue mixtures, as Horse Beans, Pease, Rye, Barley, etc. Nay, damaged Pease have been bought out of the office, afterwards dry'd over the Baker's oven, ground into Flower, Bread made of it, and sold into the office at the same price as if made of all wheat."

All perquisites in connection with the victualling of the Navy were taken away in pursuance of an address of the House of Commons in I702, with the exception of "the antient custom of issuing out a Proportion of Tongues to the Commanders, which was ordered to be continued, in regard they are no charge to the Government, but given in by the Contractors."

At this time the whole of the business of the Navy, including the Victualling and Transport duties, was conducted by the Navy Board, but in 1683 the Board was relieved from the Victualling work, which was intrusted to four Commissioners, a number increased in 1689 to five, and in I794 to seven.

From a treatise on the "Dominion of the Seas," 
published in I705, and dedicated to Prince George of Denmark, we learn that he had for his council Sir David Mitchell, George Churchill, Admiral of the Blue, Richard Hill, Sir Cloudesley Shovell, rear-admiral of England and joint-admiral of H.M.'s fleet ; and for secretaries, George Clarke and Josiah Burchett (the auther of a naval history). The Lord High Admiral and his council were charged with the fitting out of ships, the supply of stores, and the general administration of the Navy. It was the duty of the Treasurer of the Navy, the Navy Board having stated the amount they needed, to obtain it from the Treasury. To the Comptroller of the Navy was confided the payment of wages and the examination and checking of accounts. The Surveyor of the Navy was to survey the magazines of reserve stores, to supervise the ships and the work in the yards, as well as to control the boatswain's and carpenter's stores. The duties of the Clerks of the Acts, Charles Sergison and Samuel Atkins, comprised the record of all orders, contracts, bills, warrants, and minutes of both Boards. In addition to the four last-named officials, the Comptroller of the Victualling accounts, the Comptroller of the Treasurer's accounts, the Comptroller of the Storekeeper's accounts, with an extra Commissioner, Sir Thomas Hopson, also had seats at the Navy Board. The Commissioners of the yards, which included as well as those at Deptford, Woolwich, Chatham, Portsmouth, Plymouth, two at Kinsale and Lisbon respectively, were, as a rule, naval officers.

The duties and responsibilities of these officials gradually increased with the growth of the Navy. The departments also increased in number, until, in 1782 , when Rodney was winning fame in the West Indies, and Keppel was First Lord, there were thirteen altogether. 
These were distinguished as follows:- The Navy Office, in Crutched Friars, was charged with the building, repairing, and fitting out of ships and with mustering their ships' companies. The Victualling Office, on Tower Hill, with a subsidiary establishment at Deptford, with victualling. The Ordnance Office, in the Tower, with the provision of warlike stores; this office had both a civil and military branch, and supplied the troops and garrisons as well as the Navy. The Pay Office, in Broad Street, had to do with the payment of wages, half-pay, and widows' pensions. The Sick and Hurt Office, in Tower Hill, with providing for the sick; this office had agents at the various ports, and in addition to the care of sick and wounded, provided for their use afloat such luxuries as sugar, sago, barley, spices, currants, and portable soup as well as medicines. The Trinity House in Water Lane, Tower Street, was charged with the examination of officers' qualifications. The Chest, at Chatham, provided gratuities to the wounded and maimed. The Royal Hospital, at Greenwich, received seamen when superannuated. The Receiver's Office, on Tower Hill, was charged with the receipt of sixpence a month deducted from each person's wages in the $\mathrm{Navy}$, and also from every seaman's in the merchant service, for the support of Greenwich Hospital. The Marine Office, at the Admiralty Office, administered the marine establishments. The Court of Admiralty, at Doctors' Commons, was charged with the trial of maritime offences. The Board of Longitude, with the discovery of the longitude. And the Royal Academy, at Portsmouth, with the instruction of youth for the Navy.

${ }^{1}$ See a curious little work called "The Neptune of Europe," published by John Bell, British Library, Strand, 1782. 
In I 788 , a Commission of Inquiry into the Civil Affairs of the Navy recommended that the clerks in the Admiralty, and other public officers, who along with other privileges had been allowed to cut beef and pork steaks from the flesh provided for the service, should receive fixed salaries, instead of being, as heretofore, paid by fees from individuals, a measure however which was not adopted until 1796.

The institution of a Transport Board dates from I689, when, in consequence of the efforts that were being made in Ireland by James II., with the assistance of the French, to regain the throne, orders were sent to the Navy Office, by the Admiralty, to provide shipping for 23,528 men and 4,384 horses. This task, however, the Navy Board represented their inability to perform, in addition to the other urgent business of their office, upon which the Lords of the Admiralty, by the direction of the King, appointed three captains as Commissioners to manage the business, with a Cashier, Secretary, and Clerk. The Assistant Surveyor of the Navy and a Purveyor from the Navy Office were associated with the Comnissioners. The total shipping taken up was 19,308 tons, and the rates varied from I I $s$. to I $4 s$. per ton per calendar month.

This arrangement did not, however, work satisfactorily, and so much difficulty was experienced in taking up and fitting out and provisioning vessels that on February 26th, 1690, an Order of Council was issued appointing a Commission, consisting of eight members, to execute the service of providing ships and necessaries for the transportation of the army to Ireland.

The Commissioners executed their duties for a short time at Trinity House, but afterwards had a separate 
office allotted to them. The Commission was reduced in I7I 7 and abolished altogether in I724, peace having reigned of some time: the work of providing transport for troops and army stores then devolved upon the Navy Board; the conveyance of provisions for the fleet upon the Victualling Commissioners; while the Ordnance (1)ffice engaged such freight as was required for that department.

- In consequence of prevailing abuses the Commission was revived in I794, the constitution consisting of two naval officers and a civilian: in January, 1796 , the business relating to the care and custody of prisoners of war, other than those who were sick, was transferred from the Commissioners of Sick and Wounded to the Transport Board, to which two members, one a naval officer and one a civilian, were added. In I 806 the whole of the business of the Sick and Hurt Office, hitherto intrusted to three Commissioners, two of whom were physicians, was also transferred to the Transport Board, the senior physician being added to the number of Commissioners. This arrangement lasted until I8I7, when the Commission was again abolished and its powers transferred to the Commissioners of the Navy and Victualling respectively.

With sundry unimportant changes the constitution of the Navy Board remained the same until 1832, when the Premier, Earl Grey, who had himself filled the office of First Lord of the Admiralty, directed Sir James Graham, then First Lord, to reform the system of administration, directing his attention more particularly to the construction of the Board of Admiralty, the Navy Board and the Victualling: Board. .' The main object of Lord Grey was the concentration of power, and with 
this view both the Navy and Victualling Boards were abolished, and the duties transferred to f five principal officers under the direct control of the Board of Admiralty, each department being placed under a superintending Lord, who represented it at the Board. The five principal officers were:- the Surveyor of the Navy; the Accountant-General; the Storekeeper-General ; the

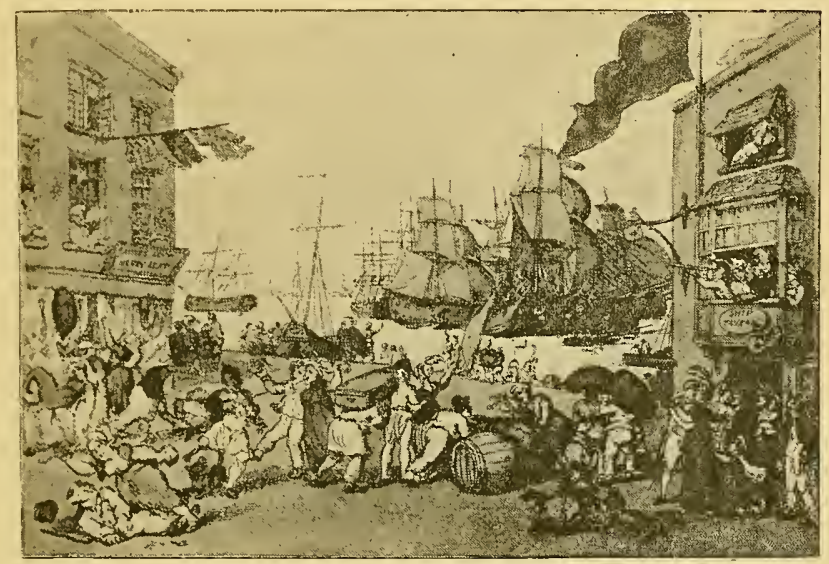

PORTSMOUTI POINT. CIRCA I799.

(kowlandson.)

Comptroller of Victualling and Transport Services; and the Physician-General of the Navy. This arrangement is practically the same as that now existing, except that the constructive duties formerly devolving upon the Surveyor, or as he was subsequently styled "the Controller," are now intrusted to an officer styled Assistant Controller and Director of Naval Construction, who is also the head of the Royal Corps of Naval Con- 
structors. The duties connected with the purchase of naval stores were also, in 1869 , detached from the Storekeeper-General and intrusted to a Contract and Purchase Department, now presided over by a Director of Navy Contracts, the title of Storekeeper-General itself being abolished and the modified duties taken over by a superintendent, now Director of Stores. In I869 the title of Comptroller of Victualling and Transport service - from whom the Transport duties had been detached in I 862-was altered to that of Superintendent of Victualling, which was, in its turn, changed to Director of Victualing in 1879; while, in 1841, the Physician-General of the Navy became known as Inspector of Naval Hospitals and Fleets, a title changed in I843 to that of Director-General of the Medical Department.

The Transport duties were detached from the Victualling Office in I 862, and placed under a Director of Transport, the salary being originally fixed at $£ \mathrm{I}, 000$ per annum, with a house, or $£ 200$ allowance in lieu thereof : in 1858 a salary of $£ \mathrm{I}, 300$ per annum was attached to the office, but the present emoluments are $£ \mathrm{I}, 200$ per annum, the holder of the appointment being a naval officer.

The pressure occasioned by the Russian war was met by the appointment in February, 1855, of Captain Craigie, R.N., Major Robertson and Mr. William Drew, with Mr. Giffard as Secretary, to be Directors of Transports and of Prisoners of War, an arrangement which lasted until March, I 857, Mr. Drew, only, retaining office until May, i 858 .

Another former member of the Navy Board-then known as "Civil Architect and Engineer"-is now represented by the Director of Works; the Hydro- 
grapher represents an office first established in I796, and the Admiral Superintendent of Naval Reserves dates from 1857 , at which time the control of the Coastguard, formerly entrusted to the Treasury, was transferred to the Admiralty. The other more important officers are the Deputy.Adjutant-General of Royal Marines, first appointed in July, I $\$ 25$, and the Director of Naval Ordnance, an office which in its present form dates from I 866 only, but which represents a very ancient office, formerly known as "Master of the Ordnance." The duties connected with naval ordnance were, hovever, in the last century, transferred to the Master-General of Ordnance, who had also the charge of army guns. This system, which remained in force until quite recently, has, happily for the naval service, been put an end to by the establishment of the Naval Ordnance Store Department, over which the Director of Naval Ordnance presides, assisted by a Storekeeper-General.

An ancient and honourable office, that of Treasurer of the Navy, has disappeared entirely, the duties having in I 836 been merged with those of the Paymaster-General ; the emoluments of this office were very considerable, and it was held by many distinguished men. The Director of Education has also disappeared; this office only existed from $\mathrm{I} 864$ to $\mathrm{I} 874$. The duties are now divided between a portion of the staff of the Royal Naval College, the Chaplain of the Fleet, and the Inspector of Naval Schools. In place of these, two new directorships have sprung up; one, that of the Director of Greenwich Hospital, an office created in I886, and the other, the Director of Naval Intelligence, who presides over a department first organized in I887. The establishment of this last-named department may in 
some ways be said to mark an epoch in our naval adminstration. It is looked upon by many naval officers as the greatest advance we have made in this generation towards insuring the readiness of our fleet for war. Its duties are twofold: the collection of information, and arranging for the speedy employment of all our maritime resources. There is therefore a Foreign Intelligence section whose functions are the collecting, classification, and indexing of all information relating to foreign navies, inventions, trials, experiments, and foreign maritime matters generally; and secondly, a Mobilization section, charged with the arrangement and organization of our resources in ships, officers and men, coal, stores, and other munitions of war, and framing strategic plans suitable for carrying on war with different Powers in various emergencies.

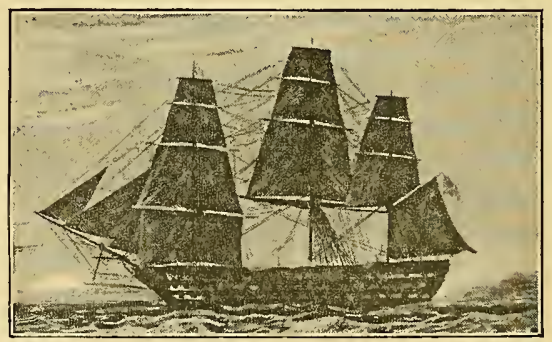

H.M. LINE-OF-BATTLE SHIP "QUEEN," IIO GUNS. CIRCA I84. 


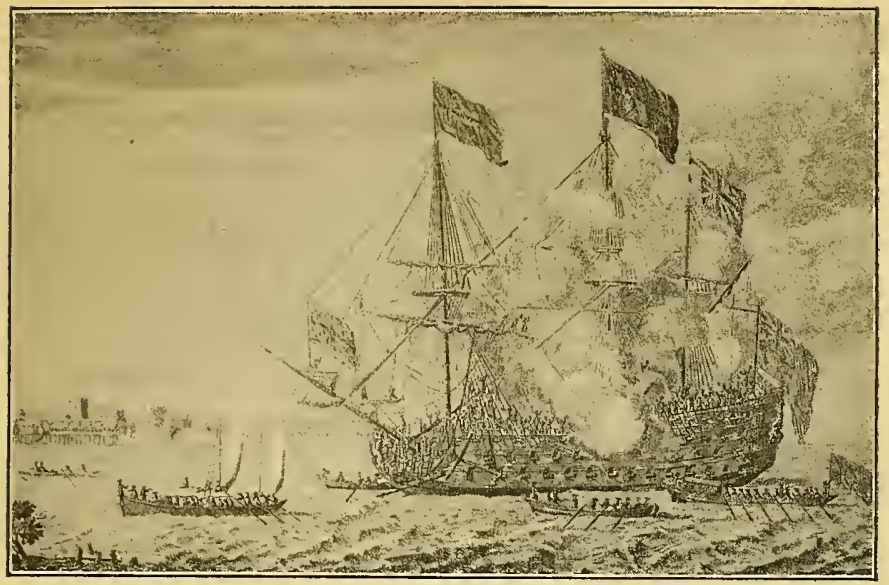

H.M.S. "BRITANNIA," IOO GUNS, OFF WOOLWICH, I72I.

(Thos. Bastion.)

\section{CHAPTER III.}

THE VICTUALLING OF THE FLEET.

DURING the reign of Elizabeth the business of victualling the fleet was conducted by contract under the special supervision of the Surveyor-General of the Victuals, who was a member of the Navy Board, and whose instructions were to maintain a sufficient stock to supply a thousand men at sea for one month at a fortnight's notice. If the victualling department became overstocked owners of merchant vessels were expected to buy the overplus. A letter of 1659 directs the Lord Mayor of London to forbid the city butchers to sell meat to ships until the Government stores of salt beef were sold out. Outward-bound traders were not 
allowed to pass down the river unless a certificate of such purchase was produced.

The scale of victualling at this time, for man or boy, was one gallon of beer, a pound and a half of bread or biscuit, and two pounds of fresh or salt meat per diem, except on fast days, when a pound and a half of salt fish were substituted. Half a pound of butter was allowed six times during a month of twenty-eight days and the same amount of cheese.

The quality of the regulation provisions appears to have been frequently very bad, for, says a seventeenth century writer, "In the late Queen's time many thousands did miscarry by the corruption as well of drink as of meat." Raleigh says that old oil and fish casks were used for the storage of beer, and Sir Richard Hawkins thought that in twenty years Io,ooo men died from scorbutic affections. The men certainly required good food and plenty of it, for their accommodation was of the worst, insufficient, and badly ventilated, and the smell from the ballast which all ships carried, and which was seldom changed, must have been poisonous. The introduction of hammocks in I 597 was doubtless a great improvement on the previous state of things, the misery of which is well depicted in Lord Howard's letters in I 588, after the Spaniards were beaten and the danger had passed. He writes :- " Sicknes and mortalitie begin wonderfullie to growe amongste us ..... the Elizabeth which hath don as well as eaver anie ship did in anie service hath had a great infectione in her from the beginning, soe as of the 500 men which she carried out, by the time she had bin in Plymouth three weeks or a month there were ded of them 200 and above, soe as I was driven to set all the rest of her men ashore, to take out 
the ballast and to make fires in her of sivet broom 3 or 4 daies together, and so hoped therebie to have cleansed her of her infectione, and thereuppon got new men, very tall and hable as eaver I sawe and put them into her; now the infection is broken out in greater extremity than eaver it did before, and they die and sicken faster than ever they did, soe as I am driven of force to send her to Chatham."

He also speaks of the men having so little shift of apparel and no money to buy it; reporting, too, that although the beer has been condemned as unfit for use, it is still served out to the men ; remarking that " nothing doth displease the seamen more than sour beer."

I do not know whether it was the custom with us as with the French to temporarily bury the dead, after an action, in the ballast, but if so it may not have been altogether the fault of the bad beer that the ships were infected. ${ }^{1}$

At this time the only storehouse of any importance was that on Tower Hill, though there were small establishments containing brewhouses, baliehouses, mills, etc., at Dover, Portsmouth, and Rochester; the practice was for ships to be supplied at such ports as they touched at with provisions provided by contractors, or purchased by the pursers.

In 1622 a contract for provisions states that " every man's allowance was one pound of biscuit, one gallon of beer, two pounds of beef with salt, four days in the week, or one pound of bacon or pork and one pint of peas, as heretofore hath been used and accustomed, and for the

1 Admiral Hosier's body was brought home from the West Indies in the ballast, but it is said to have been embalmed. For French custom see "La Marine royale." 
other three days in the week one quarter of stock fish, half a quarter of a pound of butter, and a quarter of a pound of cheese; saving for the Friday to have the quantity of fish, butter and cheese but for one meal, or else instead of stock fish such quantity of other fish or herrings as the time of the year shall allow."

The contractors were paid $7 \frac{1}{2} d$. per diem for every man's victuals in harbour, and $\delta d$. per diem when at sea. The compulsory fast days were the origin of the term "Banyan days," no meat being issued on Mondays, Wednesdays, and Fridays : this restriction was removed in $\mathrm{I} 824$.

In 1680 the Commissioners of the Navy took the victualling into their own hands, but put it out to contract again in the following year. Colonel Pride and others were the purveyors through the first Dutch War up to I655, when the Commissioners resumed control and deputed three of their number to manage matters. This arrangement lasted until the Restoration, when Mr. (afterwards Sir) Dennis Gauden was appointed "Surveyor-Generall of all ye victuals of his Majesty's Navy."

Mr. Gauden does not appear to have thought that he had got hold of a very good thing, or, at any rate, after a fashion not unknown to contractors nowadays, he thought it worth while to endeavour to convey that impression to other people. In 1663 he had a great dispute with the "best of the Commanders going against Argier about their fish and keeping of Lent, which Mr. Gauden so much insists upon to have it observed, as being the only thing that makes up the loss of his dear bargain all the rest of the year." 1

Notwithstanding his "dear bargain" he found means 1 Pepys's " Diary." 

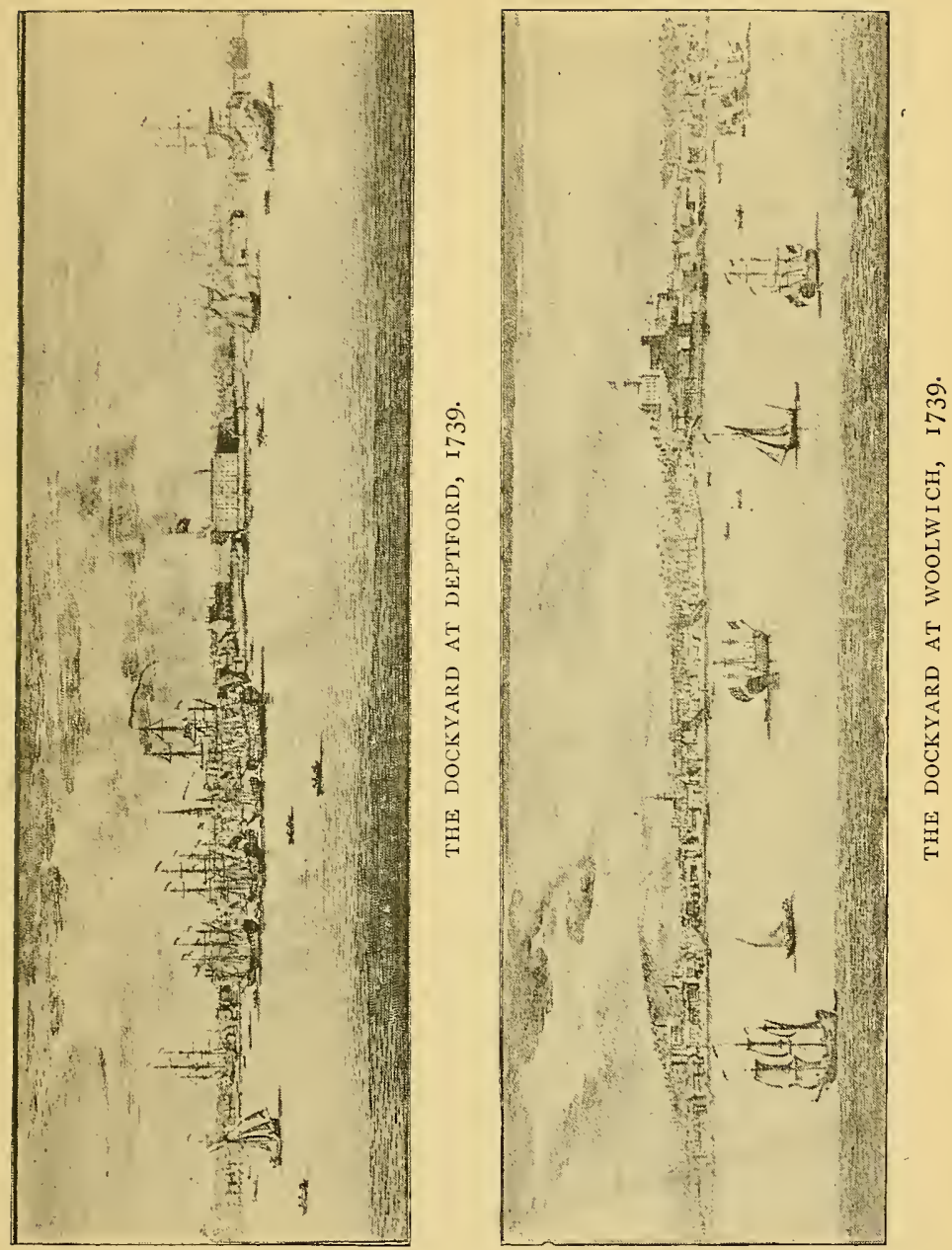
to present Pepys with two silver and gilt flagons in 1664 , and with the substantial douceur of $£ 500$ in the following year, possibly as a mark of gratitude for the "great tenderness" with which, as Pepys says, a little difficulty had been arranged in I 663 between Mr. Gauden and the Lord Treasurer as to the security to be given by the former for the customary advance of money on his annual declaration.

The scale of diet given by Sir W. Monson, in his "Naval Tracts," approximates closely to that specified in the contract above referred to, the description of fish to be served out to the men being given as "haberdine (i.e., dried salt cod), ling or cod in the proportion of a side of salt fish to every mess of four men." Stock fish or salt fish, bread and wine, had been the staple food of English seamen from the earliest times.

The ration of beer, one gallon per diem, served out to every man and boy appears large, but it must be remembered that at that time beer stood in the place of wine, tea, spirits, and, in the case of sailors, even water; for no means then existed by which it could be condensed, and it was not yet the practice to carry it in tanks.

The beer supplied by contract was for many years of infamous description, notwithstanding the fact that the contractor had to make oath that he had used the proper proportion of malt and hops; and there is abundant evidence that it was a prime cause of the disease which wasted our fleets on foreign stations to an almost incredible extent. "A hot country, stinking meat, maggoty bread, noisome and poisonous scent of the bilge-water, have made many a brave sailor food for crabs and sharks." And again, "where we had one 
man dyed by shot in the Navy we had ten dyed by means of bad provisions," says an indignant writer in a pamphlet ${ }^{1}$ addressed to the Houses of Parliament in 1703 . That this statement is scarcely exaggerated is proved by the fact that Admiral Hosier, while cruising in the West Indies with seven ships of the line for the protection of trade, but with strict orders not to act on the offensive, buried his ships' companies twice over, and eventually died himself, broken-hearted, reappearing, however, to Admiral Vernon after the victory of the latter over the Spaniards, in company with his 3,000 men "all in dreary hammocks shrouded, which for winding sheets they wore," as is recorded in Glover's most pathetic and veracious ballad entitled "Hosier's Ghost."

To remedy the evil as much as possible, in so far as the quality of the beer was concerned, the Navy Commissioners caused brewhouses to be established at the Government yards, but, although the quality of the beer improved, it was found impossible to stow more than a few weeks' consumption on board. This difficulty it was which led to an extension of a practice, which had then recently sprung up when the beer ran short, of issuing rum or wine instead, until at length, between 1832 and 1835 , the brewing of beer for use in the flect finally ceased.

At first the rum was served out undiluted, the ration being half a pint in two servings, but in 1740 Admiral Vernon, whose nickname was "Old Grog," on account of a grogram coat he used to wear in dirty weather, instituted the practice of watering it before issue. This circumstance, it need scarcely be added, gained for the mixture the name it still retains.

${ }^{1}$ Pamphlet, Radstock Coll., Royal United Service Institution. 
It will be convenient now to complete our notes upon the use of alcoholic beverages in the Navy. The ration of spirit was reduced from half a pint to one gill in I824, in which year tea was first issued, and the evening grog was abolished. The introduction of the imperial measure, however, in 1826 , in lieu of the wine measure hitherto used, added one-fifth to the ration, and the custom of serving evening grog recommenced. In 1850 , in consequence of repeated complaints by commanding officers, it was again decided to reduce the ration by one-half, the evening portion being then stopped for a full due. Both officers and men were at the same time granted an increase of pay proportionate to the savings price of the rum.

The ration of salt meat was also raised from threequarters of a pound to one pound per diem and the allowance of sugar increased ; mustard and pepper were now for the first time introduced, being issued in lieu of a portion of the oatmeal and vinegar hitherto allowed. The committee intrusted with this investigation further recommended that the issue of raw spirits should be entirely discontinued, that the allowance should be mixed with three parts of water, and that no spirit should be issued to midshipmen or boys except under special circumstances.

In I 88 I the issue of the spirit ration to officers, other than warrant officers, was discontinued, a small sum being paid in lieu to the respective messes. At the same time, in the case of the ship's company, the issue was limited to men over twenty years of age.

Returning to the seventeenth century, we find that Pepys, in his letter to Sir William Coventry concerning the victualling of the Navy, dated Greenwich, January Ist, 
I665, refers to the difficulties entailed upon the pursers by the scarcity of fish, which, however, he does not consider an unmitigated evil, because "the fish-rooms of few ships being placed otherwise than under the steward's room next the kelson it is odds but the bilge-water spoyles two if not three of the six months' fish by scenting it, and so rendering it useless." In the same letter he refers to the hardships inflicted upon the pursers by the extraordinary provisions they had to lay in at their own cost to secure the favour of the captain-not always with success, as he instances a case in which the purser "was beaten for once eating a fowle of his own buying because it hath stoode in the Captain's coopes."

From 1673 to 1692 the contract rate varied from $14 s$. to I $S s .3 d$. per man per month; it was found, however, that the contractor made enormous profits and that the service was subject to many inconveniences, so that the Admiralty once more took the management into their own hands.

The rations were probably not rendered more appetizing by the manner in which they were cooked. In I 704 the Lord High Admiral sent an order to the Navy Board directing them for the future to appoint cooks for Her Majesty's ships, but at the same time charging them "to give the preference to such cripples and maimed persons as are pensioners to the chest at Chatham." Before this time the appointment of cooks was vested in the admiral commanding the fleet, and was frequently given to very improper persons. Lord Nottingham, when Lord High Admiral, gave a patent to his own cook to appoint all the cooks in the Navy. The very name, "salt junk," given to the ration of salt meat is suggestive of the quality usually expected, "junk" 
being the bulrush of which ropes were formerly made, and, hence, a slang term for meat that is ropy and salt.

Another evil complained of was that certain captains or "Huntsman Commanders" as they were called, made a practice of keeping packs of hounds on board ship, a practice denounced ${ }^{2}$ as a dog's trick upon poor sailors, "who, instead of handling of sails and hauling the main tack aboard, were employed in that pretty diversion of looking after hounds." It was one man's business, at least, says this writer, to fling the bones overboard when the captain's dogs had dined. He goes on to speculate curiously as to where the dinner came from, since the dogs were not borne upon the purser's books, and "yet they had provisions when the poor sailors wanted theirs." Most of these evils he traces to the Secretary of the Admiralty, whom he describes as crouching behind his periwig, like a rat behind a butter firkin, on the look out for perquisites.

In 1690 one-fourth of the beef was ordered to be reduced and made good by flour and raisins, "not worse than Malaga," and about the same time efforts were made to obtain fresh water from salt by distillation, several patents being granted and experiments carried out. Among others, Captain Walcot submitted (I702) a proposal of this nature which was reported to be "very practicable," and sixty years later Dr. Lind showed the feasibility of the process. It was not, however, until many years later that the practice was generally adopted.

The practice of stowing water in tanks was only partially adopted prior to I815, after which date the system became general. The benefits derived from the

${ }^{1}$ Letter from "A Sailor to a Member of the House of Commons." Radstock Coll., Royal United Service Institution. 
change cannot be over-estimated, as water kept in casks became slightly foetid after a few days, owing to the disengagement of the hydrogen; and after two or three weeks so loathsome that it could only be swallowed with repugnance.

The anti-scorbutic properties of lime-juice appear to have been known early in the sixteenth century, but it

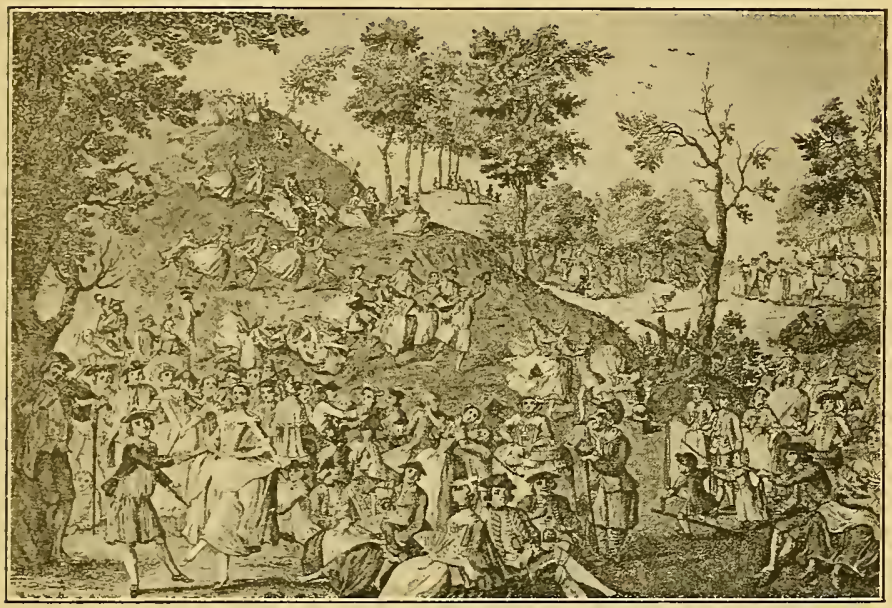

GREENWICH HILL, THE SAILORS' PARADISE, I756.

(From a contemporary print.)

did not become a regular article of issue until I 795 ; the introduction of it into the Navy was mainly due to the exertions of Dr. William Harness and Sir Gilbert Blane, and the result was immediately shown by a material diminution in the death rate. In order to preserve the juice from mildew, to which it is peculiarly liable, sperm oil was floated on the top, which it was necessary to 
remove by means of wool before use; but in I 869 the present practice of fortifying the juice with rum was resorted to.

Cocoa was introduced as a Navy ration in $\mathbf{I} 825$, the breakfast ration prior to that having been "burgoo," an unpopular mixture made by boiling oatmeal in water and sweetening it with molasses, when obtainable.

The practice of preserving meat commenced about ISI2. At first the issues were only used as a "medical comfort," but the success attending this use led to the general adoption of these preparations.

The practice of supplying libraries to Her Majesty's ships originated in the distribution of tracts and religious books through the agency of the chaplains, a custom of very early date, since it is referred to in a diary of I704.

In I 8 I6 the "Naval Chronicle" records the fact that Lieutenant Baker and Dr. Quarrier, officers of H.M.S. Leander, then fitting out at Woolwich, proposed the formation of a library on board that ship, and offered to contribute thereto their own libraries consisting of several hundred volumes. The introduction of the Seamen's Library in something like its present form was also partly due to the exertions of the philanthropist, Mrs. Fry, who first induced the Admiralty to supply libraries to naval hospitals and then to extend the practice to the Coastguard. These libraries consisted chiefly of religious books, and the Government grant in aid of the project was supplemented by various societies and by private contributions.

In July, I 838 , the supply of libraries to sea-going ships was sanctioned by the Board of Admiralty, large ships being provided with 276 , and small ones with I 56 volumes. These libraries also were to a large extent 
religious, but in I 862 an extensive revision took place, and the character of the books was then secularized, provision being made for the supply of religious books to chaplains independently. Subsequent periodical revisions took place, the most important being in 1889 , when the library was relieved of a considerable number of ponderous and inappropriate books, these being replaced by others of a more attractive character. A want of long-standing was met in 1892 by the establishment on board Her Majesty's ships of an Officers' Library containing valuable books of reference, and also of Station Libraries; these latter, being permanently attached to the various stations and not to any particular ship, the books circulate among the various ships of the squadron at the discretion of the Commander-in-Chief.

The principal home victualling yards are those at Deptford, Gosport, and Plymouth; there is also a small depôt, capable, in time of need, of considerable expansion, at Haulbowline (Queenstown); while abroad there are depôts at Gibraltar, Malta, Halifax, Bermuda, Jamaica, Cape of Good Hope, Trincomalee, Hong Kong, Esquimalt, and Sydney.

The largest yard is that at Deptford, which can also lay claim to the greatest antiquity; at this yard, as at Gosport and Plymouth, exists a bakery capable of turning out very large quantities of biscuit; also flourmills, oat-mills, a cooperage, and saw-mills. At Deptford also is manufactured the whole of the cocoa, mustard, pepper, etc., used in Her Majesty's Navy, while a considerable portion of the stores obtained under contracts, such as cloth, serge, flannel, tobacco, salt meat, rum, soap and candles, are delivered there for examination, prior to distribution to the other yards and the Fleet. 
For this latter purpose Deptford is especially well adapted, being situated in close vicinity to the docks. Deptford as a shipbuilding yard occupies a large space in Navy history, but its importance in bygone times can scarcely have been greater than now, when it is acknowledged that "the victualling is a business which requires not only indefatigable industry, but conscience also, since the lives of British sailors are dependent upon it, and the integrity of the Empire upon them." But Deptford has scen great changes, and many distinguished men. It was established as a building yard in I573, so it is one of the oldest yards, and had probably been a private yard long previously. In $1576 \mathrm{Sir}$ Martin Frobisher, one of the men who did "signal service in eighty-eight," " repaired his pinnace here before sailing on his first voyage in search of the North-West Passage. From its docks sailed Sir Francis Drake, in 1577 , to circumnavigate the world; and Sir Walter Raleigh made it his point of departure in 1589 . Frequent reference is made to it by the diarists Evelyn and Pepys, and the latter sent ten brass guns to defend it when the Dutch were in the Medway. Some guns, with the date I649 cast in the metal, are still preserved in the yard, and are believed to be these veritable pieces of ordnance. Captain Cook commissioned the Resolution at Deptford, in 1776 , for his last voyage; and so one could go on connecting it with the greatest names in our naval annals. Finally, it may be recorded that here Peter the Great learnt to put ships together. The yard was first used as a victualling yard for naval purposes in 1742 , as a subsidiary establishment to the storehouse on Tower Hill, 1 "Life of Sir Martin Frobisher," Rev. F. Jones, Longmans, I878. 


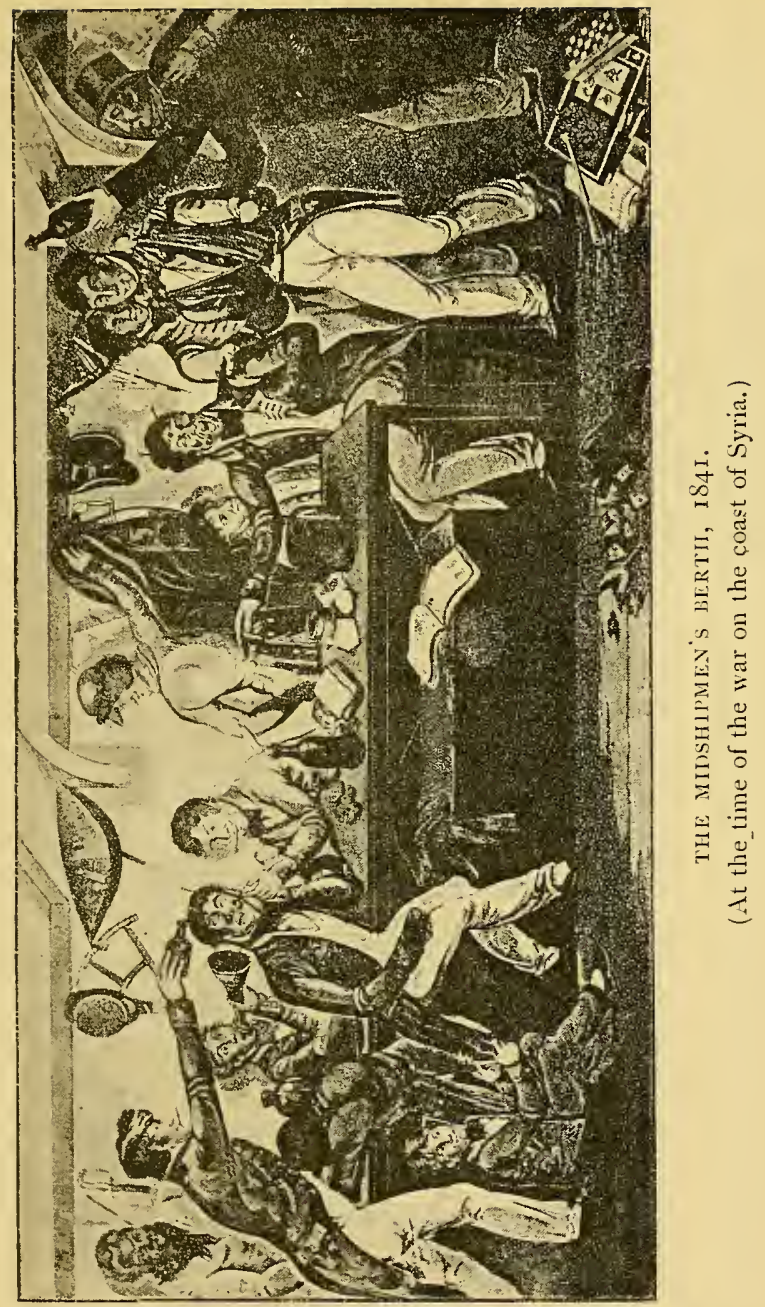


but prior to that date a portion of it had been used as a storehouse by the East India Company, and also as a place for embarking cavalry for foreign service; part of the site now occupied was formerly a porrion of the garden of the famous "Sylva" Evelyn. In 1869 shipbuilding ceased, and a portion of the yard was sold. Twice it has been burnt, in 1739 and 1761 , but its present buildings were erected by Sir Charles Middleton in $\mathrm{I} 7 \mathrm{SO}$.

A great many of the victualling stores supplied for the Navy come from private contractors, and by far the larger proportion pass through the Deptford yard to be tested. In the Navy clothing is not served out to the men ready made to anything like the same extent as it is in the Army; the practice being for the Paymaster to demand from the Victualling yard sufficient quantities of every description of material, even down to pins and needles, and these are issued to the sailor, on payment, as he requires them. The responsibility of making up the garment rests with the individual sailor, who can either do the work himself or intrust it to a contractor, but, in either case, the standard pattern has to be rigidly adhered to, and it is very necessary, therefore, that the serge, flannel, calico, etc., should be thoroughly tested as to quality, strain and dye. As a consequence of the care taken in these respects the sailor gets his food, rum and tobacco, absolutely unadulterated, and his clothing materials thoroughly sound, good, and comparatively cheap. The sailor is nothing if not a grumbler, and, as he can no longer find fault with the quality or the quantity of the provisions supplied to him, he has taken another tack, and growls, with perhaps some cause, about the hours at which he has to eat them. 


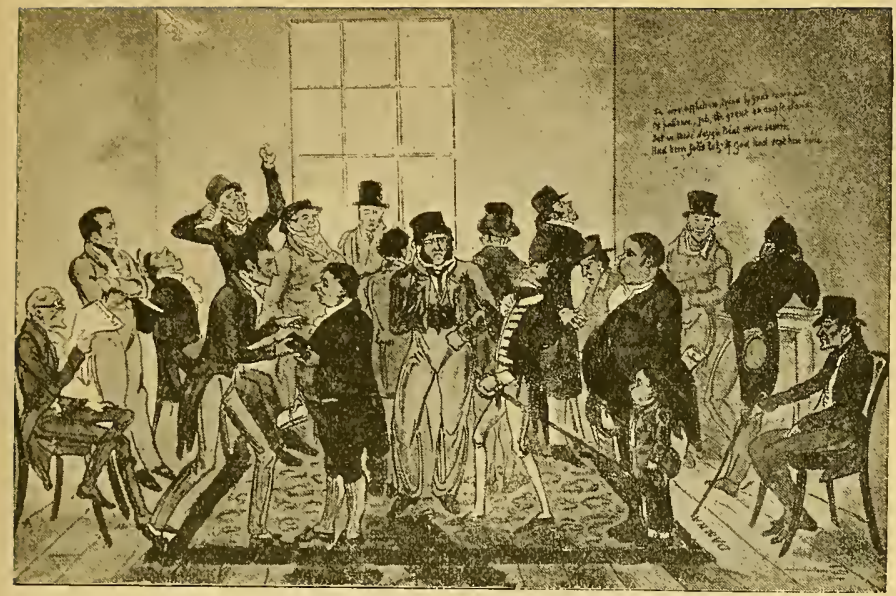

THE WAITING-ROON AT THE ADMIRALTY, I 820.

(G. Cruikshank, after Capt. Marryat, R.N.)

\section{CHAPTER IV.}

ADMIRALTY BUILDINGS.

THE Admiralty, Whitehall.-While the government of the Navy was intrusted to a Lord High Admiral, the Admiralty Office was merely the personal office of the Lord High Admiral, and, consequently, changed its locality from time to time, the business being conducted either at the residence of the Lord High Admiral or of his secretary.

It was by such a change that the site occupied by the present Admiralty Office became first connected with the Navy through the medium of George Villiers, Duke of Buckingham, who in 1626, being then Lord High 
Admiral, convened at his residence, Wallingford House, a new council "which highteth the Council of the Sea, consisting of divers privy counseliors and lords and knights." The house in which this council met had originally been built by William, Lord Knollys, afterwards Viscount Wallingford and first Earl of Banbury, from whom it passed into the possession of the duke, whose body was conveyed thither after his assassination by Felton in 1628 , and was taken thence by night for burial in Westminster Abbey.

After the death of Buckingham the office of Lord High Admiral was put into Commission with Edward (afterwards Sir Edward) Nicholas, the late duke's private secretary, as secretary, Juxon, Bishop of London, being one of the members. The meetings of these Commissioners continued to be held at Wallingford House until the execution of Charles I. in I649. It was on this occasion that, from the roof of Wallingford House, Archbishop Usher took his last look at the King on his way to the scaffold.

Wallingford House then passed into the hands of the Commonwealth, and the office for "granting passes to persons going abroad" was located there. At the Restoration it reverted to the Villicrs family and was occupied by George Villiers, the second and witty duke, whose birthplace it had been in 1627 .

Meanwhile the business of the Admiralty Office had been conducted in a variety of places: the Earl of Northumberland, when Lord High Admiral, dating his correspondence from his house in Queen Street, Covent Garden, and his successor, the Earl of Warwick, from Warwick House in Holborn.

In 1660 the office occupied a portion of the old Palace 
of Whitehall, whence it was removed in 1674 to Derby House, situated at the east end of Channel, now Cannon, Row, Westminster, a house purchased by Pepys, acting on behalf of the Admiralty, from the Duke of Ormond. In 1684 the Admiralty Office was once more transferred to the Palace of Whitehall, the business of the Navy being transacted sometimes at Lord Brouncker's house and sometimes at the Robes' Chamber of the Great Palace.

Four years later, when Pepys resumed office as Secretary of the Admiralty, he transacted business at his house in York Buildings, built upon a portion of the site of York House : the spot is marked by the water-gate at the foot of Buckingham Street, on which the arms of the family of the Villiers are still visible. Here the office remained until 1689 , when it was removed to a house in Duke Street, Westminster, previously (I685-8) occupied by the notorious Lord Jeffreys. A description of this house is given by Stow in his "Survey of London." In I695 it was determined to remove the office once more to its old quarters at Wallingford House, which, however, it was necessary to pull down and rebuild. So badly was the work executed that only twenty-five years later an Order in Council was obtained authorizing the erection of a new building at a cost of $£ 22,400$. The architect of the new building was Thomas Ripley.

\section{"See under Ripley rise a new Whitehall." 1}

The mahogany of the doors, etc., was brought from Jamaica by the Mermaid sloop of war, specially despatched to the West Indies for that purpose. Pending the completion of the new building, the business of the Admiralty was conducted at a house in St. James's

$$
1 \text { "Dunciad," book iii., p. } 327 .
$$


Square belonging to the Marquis of Halifax ; but, in I 725 , the office was removed to the present site. The building is described by Strype in the revised edition of Stow, published by him in 1754 ; the screen was added by Robert Adam in I760, with the view to mask the inordinate height of the Ionic columns supporting the portico, a fault for which the architect was not responsible, he having been compelled to carry them to a preposterous height in order that certain of the windows of the building might not be obstructed.

Ugly as it is, and inadequate for its purposes, the building is not devoid of interest. In the first room on the left of the passage as you pass towards the principal staircase, then known as the "Captains' Room," Nelson's body rested on the night of January 8th, I806. On the opposite side of the passage is the waiting-room on the walls of which Marryat wrote,

"In sore affliction, tried by God's command, Of patience, Job, the great example stands;

But in these days a trial more severe

Had been Job's lot, if God had sent him here."

The Board Room, the scene of the banquets presided over by Miss Reay, the beautiful but unlucky mistress of Lord Sandwich, otherwise "Jemmy Twitcher," is enriched by carvings of Grinling Gibbons. There are also distributed about the building several sea-pieces by Van der Velde ; a bird's-eye view of Venice by Francesco Guardi ; paintings by W. Hodges, R.A., from sketches taken by him during the second voyage of Captain Cook; others by J. Webber, R.A., painted under similar circumstances, representing places visited during the third and last voyage of the celebrated circumnavigator; and by W. Westall, R.A., who accompanied Captain Flinders in 
his survey of Australia. Besides these there are numerous portraits, the most notable being that of Sir William Beechey, and one of Nelson, painted by Leonardo Guzzardi for Sir W. Hamilton in I 799. In the central hall stands the original plaster cast of the statue of Nelson in Trafalgar Square, executed by E. H. Bailey, R.A., in I 844 , while a delightful twenty-four hours clock, presented by Queen Anne, is preserved in the Board Room, together with the badge of the Admiralty Barge Master, and the verge formerly borne in state before a newly-appointed member of the Board on his induction into office. There is also a large and valuable collection of manuscripts and books, but owing to want of space, and inadequate arrangements in other respects, they are disposed in a manner which materially reduces their value for purposes of reference.

The Novy Office.-The Navy Board in the reign of Elizabeth met at an office on Tower Hill, known as the "Queen's Consultation Room." This office was situated east of the Tower, on the site of a monastery founded by King Edward III. in I389, and suppressed in 1539 by Henry VIII., thereafter " being clean pulled down by Sir Arthur Darcie, Knight, and others, of late time, and in place thereof is built a large storehouse for Victual, and convenient ovens for baking of biscuits to serve her Majesty's ships." " The Board continued to neet here until I664, when they acquired a site in Seething Lane to which the Navy Office was transferred. The history of the site is given by Stow, and the Navy Office itself is described in "Noorthouck's London," published in 1773 .

The building was situated between Crutched Friars and Sidon (corruptly Seething) Lane, and had an entrance 'Stow's "Survey of London." 
from each thoroughfare: Pepys's house was actually in Sidon Lane, while that occupied by Sir William Penn was on the north side of the garden. This building, which no longer exists, was the scene of Pepys's labours, and it was here that he underwent the memorable siege by bailiffs from whom he escaped through the window after his faithful subordinates had exhausted their devices in keeping at bay his foes. Here, too, he acquired wealth with singular rapidity, which, however, may possibly be explained by a passage in a letter dated April 6th, I686. ${ }^{2}$ "Sure Pepys would value Ossory's recommendation at no mean rate, though Eure (i.e., W. Hewer, a Commissioner of the Navy, who had been Pepys's servant) and he together neglect all where money chink not." And again, in a subsequent letter, "I know the griping temper of both him and Eure and what rate every poor bo'sun pays for what he has purchased with his blood and many years' hardship."

During the prevalence of the plague in 1665 the business of the Admiralty and the Navy Board was removed to Greenwich, accommodation being provided in the "Manor House," otherwise known as the Old Palace, a building afterwards cleared away to provide a site for the erection of the present Queen Anne's quarters. Pepys did not think much of the change of locality as a security against infection, for he writes :- "To Greenwich to look after the lodgings appointed for us there for our office, which do by no means please me, they being in the heart of all the labourers and workmen, which makes it as unsafe as to be, I think, in London." Business was resumed in Seething Lane in the following year, that of

1 Ellis's "Orig. Lett.," vol. iv., 2nd series. 
the Great Fire, in which the office narrowly escaped destruction. Workmen were brought up from Deptford and Woolwich yards to pull down the adjacent houses, and the remedy proved effectual; but so near was the danger, that Pepys took the precaution of burying the

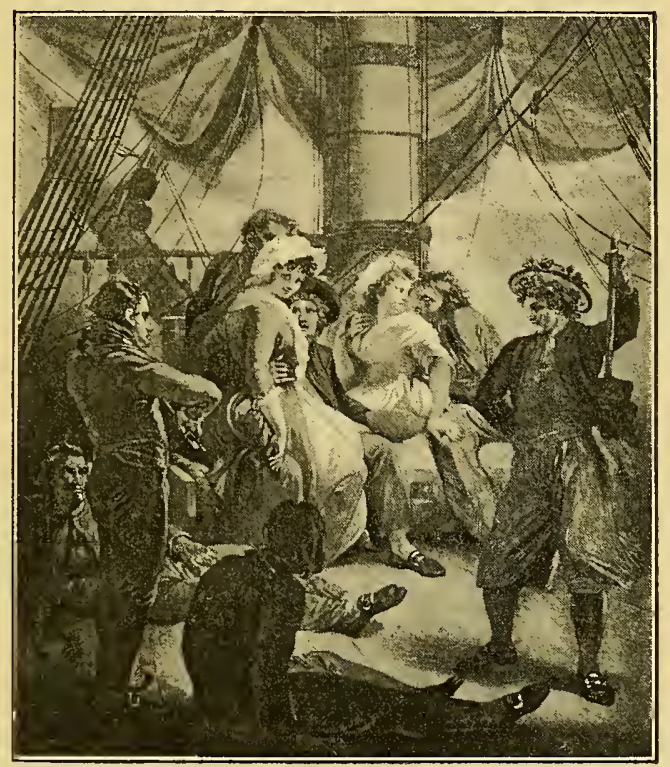

ON BOARI) H.M.S. "PRINCE GEORGE" IN I779.

(T. Stothard, R.A.)

office records in the garden, together with his "wine and Parmezan cheese." The rest of his private property he removed to Deptford by lighters.

The office in Seething Lane continued to be occupied by the Navy Board until about I780, when the Board removed to Somerset House. This building, erected in 
I775, occupies the site of a palace erected by Edward Seymour, first Duke of Somerset, uncle and Protector of Edward VI. On the transfer of the Navy Office the west side was appropriated to the Victualling, Navy Pay and Transport Branches, while on the west terrace were the official houses of the Treasurer and the Surveyor of the Navy, of three Commissioners of the Navy Board, and of the principal officers of the Victualling Department; the remainder of the building being occupied by the Royal Academy, which held its first exhibition there in 1780 . The department of the Surveyor of the Navy was removed to Whitehall in 1855 , and the work of centralization was completed in $1869-70$ by the transfer of the whole of the Admiralty departments to Whitehall and Spring Gardens.

Greenzeich Hospital.-The buildings formerly and still colloquially known as Greenwich Hospital, though appropriated since 1873 to the purposes of the Royal Naval College, occupy the site of an ancient royal palace called Greenwich House, which was a favourite royal residence so far back as the year $\mathbf{I} 300$, and was the birthplace of King Henry VIII., Queen Mary, and Queen Elizabeth. The building was enlarged by Edward IV. and Henry VIII., who re-named it Placentia. At the Restoration the old palace was pulled down and the west wing of the present building erected.

Large numbers of sick and disabled seamen were a natural consequence of constant hard fighting at sea, and provision for their maintenance had been matter for legislation from an early period.

In the twenty-third year of Queen Elizabeth an Act was passed whereby every parish was assessed at a weekly sum for the maintenance of disabled seamen and 
soldiers born and resident within the county. This was the origin of what was known as the Chatham Chest Fund, the resources of which were subsequently increased by the compulsory stoppage of sixpence per month from each seaman's wages; this stoppage was instituted by Sir Robert Mansell when Treasurer of the Navy, but it is probable that the immediate benefit to the Fund was not great, as it is recorded of him that "he falls presently into raging passions and pangs when they call for it." I

The original Chest, an iron box, is preserved in the Museum of the Royal Naval College, where it was deposited by the Admiralty in I 845 .

In the reign of Charles II., before there were any hospitals for decayed sailors and soldiers, the masters of all the hospitals in England were directed, at the conclusion of a war with Holland, to send notice to the Commissioners of the Sick and Wounded when any vacancy happened, so that such a vacancy might be filled by a soldier or a seaman, either of the same town and county, or as near thereto as possible, and all such alms places as were in the King's gift were ordered to be given to poor seamen. Evelyn was one of the Commissioners of the Sick and Hurt Office, and made many representations as to the want of provision for the maintenance of his charge. On September 30th, I665, he writes from Sayes Court, "I have here full five thousand sick, wounded, and prisoners perishing, who are not to be fed without your care; that reproach and the utmost confusion will be the event of your not providing for us. The prisoners dying for want of bread, our sick and wounded for want of harbour and refreshment. His

1 S. P. Dom. Jas. I., xli. f. 25. 
Majesty's subjects die in our sight and at our thresholds without our being able to relieve them, which with our barbarous exposure of the prisoners to the utmost of sufferings, must redound to His Majesty's great dishonour and to the consequences of losing the hearts of our own people who are ready to execrate and stone us as we pass." 1

In I674, at the conclusion of the Dutch War, the Navy Board were ordered to enter on board one of His Majesty's ships, for victuals and wages, crippled sailors who applied, in proportion of one cripple to every fifty of the complement. On November I2th, I694, King William III., in his speech to Parliament, ${ }^{2}$ said, "he would be glad if they would take into their consideration the preparing some bill for the encouragement of seamen," adding that "they could not but be sensible how much a law of this nature would tend to the advancement of trade and of the naval strength of the kingdom, which was the great interest of the public and ought to be their principal care."

Matters were brought to a climax by the number of wounded seamen landed after the victories of the English flcet under Russell. The scanty hospital accommodation was entirely inadequate to meet this fresh strain, and the palace at Greenwich, already partially rebuilt, together with eight acres of ground, was appropriated for the reception of the disabled seamen and the relief of widows and orphans. Two thousand pounds per annum were granted from public funds, but, in addition to this, private contributions came in handsomely. A body of Com-

1 "Domestic State MSS.," chap. ii., cxxxii.

2 Journal of the House of Commons, vol. xi., p. I7 I. 
missioners was appointed, and in 1696 the Register Act authorized the deduction of sixpence per month from the wages of all mariners, with certain specific exceptions, for the use of the hospital.

In 1673 the accommodation at the hospital being insufficient to relieve the great numbers of seamen worn out and become decrepit in the King's service in consequence of the war, "out pensions at the rate of $£ 7$ per annum were established."

Funds were drawn from many sources. In I699 the King allotted $£ I 9,500$, being the proceeds of certain fines levied on smugglers and others. A lottery called the "Charitable Adventure" was organized, but produced only $£ 600$, though the projectors obtained for it special exemption from the Act for the Suppression of Lotteries, on the ground that it would produce $£ \mathrm{I} 0,000$ per annum. In 1705 the effects of Kidd the pirate, valued at $£ 6,472$, were appropriated to the use of the hospital, to which also reverted the forfeited and unclaimed shares of prize and bounty money, and the Derwentwater Estates, of an annual yearly value exceeding $£ 20$,000.

Considerable abuses crept into the management of the hospital, Lord Sandwich especially making free use of the patronage for political purposes. Indeed, to such an extent were improper candidates introduced, that, as the result of an inquiry instituted by Sir C. Wager in I742, 800 of the inmates were discharged. Peculation was also rife as regards the supply of provisions ; stewards, purveyors, cooks, and bakers grew rich with a marvellous rapidity, though not always with impunity-one cook getting seven years' penal servitude from Sir John Fielding, coupled with an expression of regret that he could not hang the rascal at the hospital gates. 
In 1782 there were in the hospital and school 2,300 men, 140 women as nurses, 150 boys and 5 sick nurses. The pensioners were clothed in blue, and allowed clothes, linen, stockings, shoes, and one shilling a week for tobacco. The clothing consisted of a blue shirt, a hat, three pairs of blue yarn hose, three pairs of shoes, and four shirts every two years; in addition to which the pensioners were allowed neckcloths, nightcaps, and all necessaries for bedding, which were changed as worn out. The diet was on a liberal scale, including two quarts of beer per diem; and the surplus pea-soup was distributed at the gate to the pensioners' families. On holidays and naval anniversaries they were allowed a double allowance of beef and beer, the latter being also of stronger mettle. Some of the pensioners were distinguished as boatswains' mates, having a narrow gold edging on their hats and eighteenpence a week pocket money. To each ward was also allotted a boatswain, whose duty it was to keep order in the men's quarters and to report misdemeanours. He wore broad gold lace round his pockets, cuffs and hat, and was allowed half-acrown a week pocket money. The boys, all sons of sailors, were also dressed in blue, and were educated from the age of eleven until they were sixteen at a school specially instituted for the purpose.

This school in connection with the hospital was founded in I 72 for the education of the children of the pensioners, but there was also in existence a second school, entitled the Royal Naval Asylum, which provided for the education of 600 boys, and was under the management of Lloyd's Patriotic Fund. In I829, the funds of this latter establishment were handed over to the Greenwich Hospital School, which was then divided into an 
Upper and Lower School, each consisting of 400 boys, and a female side, where 200 girls were accommodated in what is styled the "Queen's House." The girls' school was abolished in $184 \mathrm{I}$.

The whole of the boys were under an obligation to go to sea, and, until the abolition of the Navigation Laws, which tended to reduce apprenticeship in the mercantile

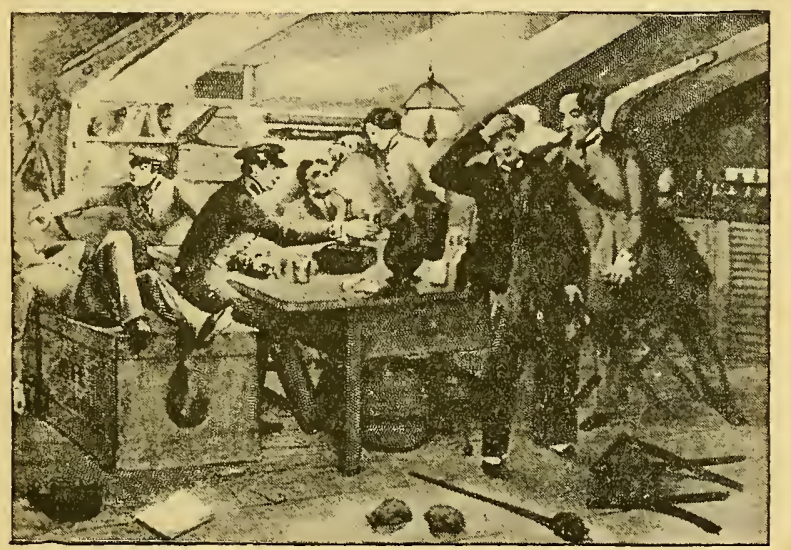

THE MIDSHIPMEN'S BERTH, I 854 .

(At the time of the war with Russia.)

marine, a considerable proportion of the Upper School boys were so apprenticed.

Eight of the leading boys were appointed annually masters' assistants in the Royal Navy, an outfit of the value of $£ 5$ o being given to each. Many others entered the Navy in a similar capacity at the expense of their friends, while the Engineer Department of the Royal Navy was for many years largely recruited from the Lower School, whence boys were transferred to the factories at the 
various dockyards to serve their apprenticeship before going to sea. The distinction between the Upper and Lower Schools was abolished in IS6I, the establishment being arranged mainly on the lines of the Lower School, and so it remains at the present day. The numbers are now fixed at $\mathbf{I}, 000$, in addition to which Ioo boys have, since I 889 , received their education at the School under an arrangement with Sir W. Boreman's Trust.

In the Painted Hall, or Picture Gallery of the hospital, Nelson's body lay in state, and was conveyed thence by water to Whitelia!l Stairs accompanied by an imposing procession of barges. In this Hall there is a most interesting collection of paintings, representing many of our most celebrated naval commanders and their actions. There is also in the establishment an excellent naval museum.

In I 865 an Act was passed empowering the Admiralty to grant pensions in lieu of food, etc., to such of the inmates as preferred, and in I859 another Act made such pensions compulsory. The hospital then remained unoccupied until I $\$ 73$, when it was appropriated to the purposes of the Royal Naval College, which was established with the object of providing for the higher education of naval officers in all branches of theoretical and scientific study bearing upon their profession.

The Naval Academy.-In the early days of the last century ships of war carried schoolmasters, who were ordered to employ their time "in teaching the volunteers writing, arithmetic and the study of navigation; also whatsoever may contribute to render them artists in that science." It is highly probable that the education afforded by these schoolmasters was of a very limited description, for even if some of their pupils became 


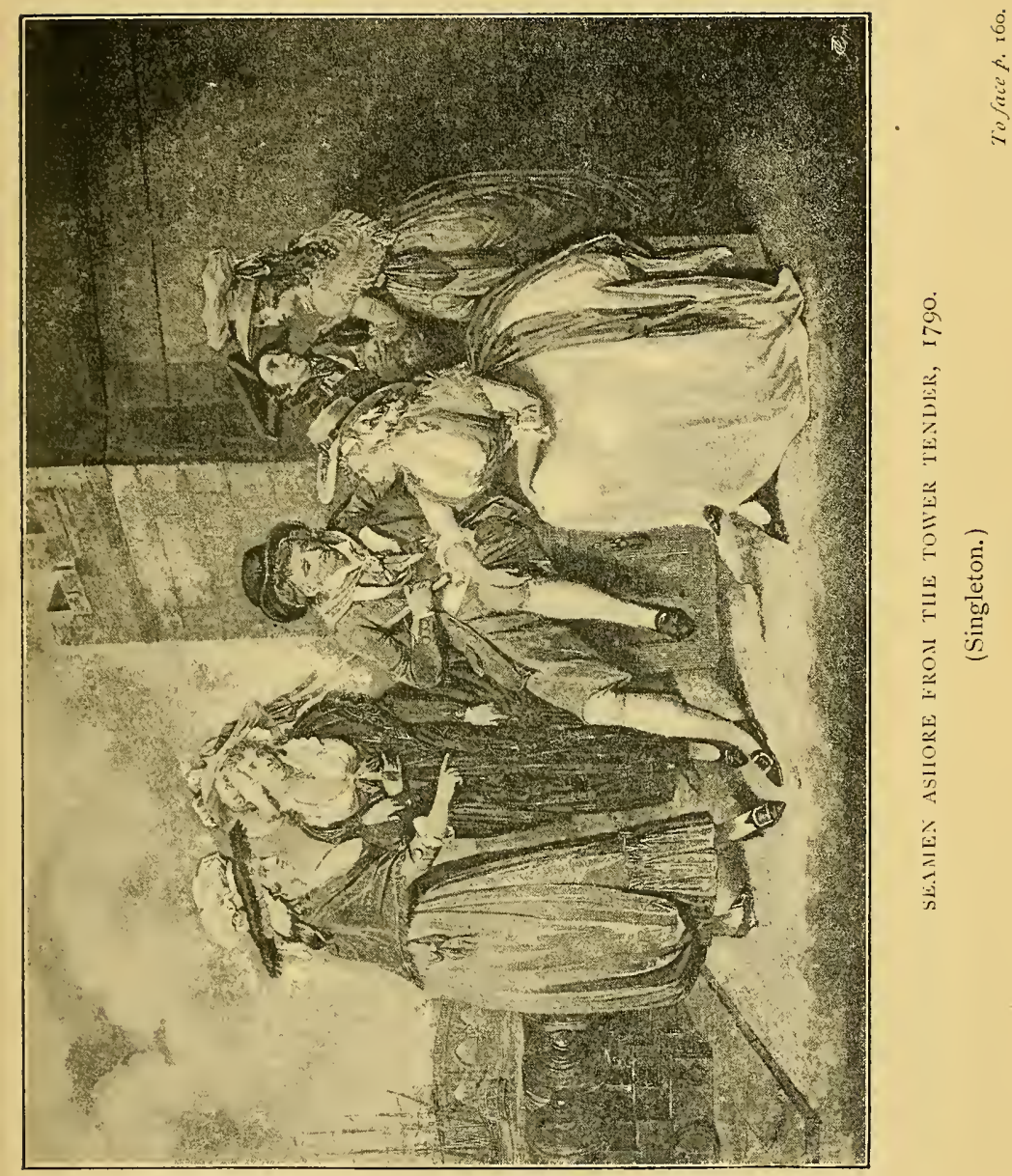



"artists" in the science of navigation, the majority of them remained but imperfectly acquainted with many other matters pertaining to their profession. So obvious did the want of some further means become at length, that, after much deliberation, a Naval Academy was opened at Portsmouth dockyard in I729, for the instruction in "maritime affairs" of forty young gentlemen between the ages of thirteen and sixteen. The cost of this establishment was $£_{5} 60$ per annum, the funds for its maintenance being obtained by appropriating the bounty given to young officers who entered the Navy with what was known as a King's letter. The subjects taught at the Academy included writing, arithmetic, drawing, navigation, marine surveying, gunnery, fortification, French and fencing, in addition to "the exercise of the firelock." After the first year the youngsters received, in addition, practical instruction from the Master Shipwright and Master Attendant of the dockyard and an experienced gunner gave practical lessons in gunnery. ${ }^{1}$

The Academy method does not appear to have been popular, and after passing through several vicissitudes the institution was remodelled in 1808 and placed under the educational control of Professor Inman, then recently returned from the surveying voyage of Flinders to Australia. The curriculum of study was extended, and even included dancing. In I 837 this system was abandoned upon the institution of Naval Instructors, a method of keeping up the education of young officers which appears to have been first proposed in a pamphlet written in 1799 by the Rev. Joshua Larwood.

1 "The Shipping World," November, 1888. 
In 1839 the College at Portsmouth was re-opened for the benefit of a limited number of senior officers and mates, and there also examinations were held for the entry of cadets. It is now chiefly used for the reception of acting sub-lieutenants who are passing their examination for lieutenant in the School of Gunnery at Whale Island.

The Dockyards.-The dockyards are popularly supposed to have been founded by Henry VIII., who also appointed a Keeper of the Royal Storehouses at Deptford and Erith. But long prior to this date there had been royal shipbuilding establishments. In the reign of $\mathrm{King}$ John, the Keeper of the King's Ships is found superintending the construction of buildings for naval purposes; and in May, I2 I2, the Sheriff of Southampton was commanded to cause the docks at Portsmouth to be enclosed in a strong wall, in the manner the Archdeacon of Taunton would point out, for the preservation of the King's ships and galleys. Storehouses were also constructed for the ships' stores and tackling. There must, therefore, have been some kind of a yard at Portsmouth at this time. There were probably dockyards or arsenals at Rye, Shoreham, and Winchelsea as well, in which the King's ships were built, and laid up when not required for service.

Derrick, without giving his authority, ${ }^{2}$ tells us that Woolwich, Deptford, and Portsmouth were established early in the reign of Henry VIII., and Camden calls the first named "the mother dock," but it is quite as likely as not that all three were then placed on a more perma-

1 Nicolas's "History of the Navy," vol. i., pp. 147, $22 \&$.

2 "Memoirs of the Navy," I 806. 
nent footing than had been the case previously. Both Woolwich and Deptford were closed as shipbuilding yards in I $869-70$, and the former is now appropriated to the Naval Ordnance Department, and so much of the

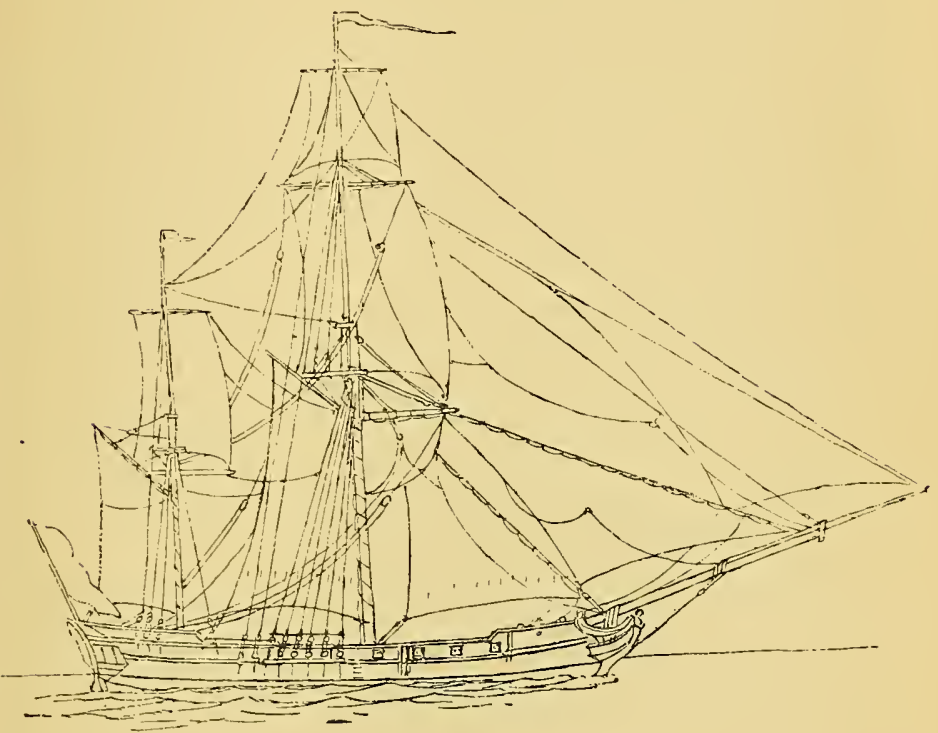

H.M. KETCH "ARROW," 6 GUNS.

(Built at Portsmouth, IS23. Broken up about I845.)

latter as was not then sold, to victualling purposes and a naval depôt.

Portsmouth did not possess a dry dock until after 1655 ; in 1764, when the Earl of Egmont was at the head of the Admiralty, "the Navy Board were directed to propose a plan of improvements for the dockyard here, and in consequence they formed a very noble one, 
which was laid before His Majesty in Council, approved, and ordered to be carried into execution. The original estimate of the first design amounted to $£ 352,240$, of which there was laid out at the end of the year I 773 the sum of $£ 299,917$ in the execution of the plans. Some variations have been found necessary in consequence of the fire." I In I 848 a steam basin and factory were constructed, and the little slip of land which Henry VIII. added to the yard has now been increased until its area is upwards of II 5 acres. When the improvements now in progress are completed, Portsmouth yard will contain five building slips and fifteen dry docks, besides the long locks between the basins, which can be used as dry docks if necessary.

Chatham yard was founded by Queen Elizabeth on the site of the present gun wharf, but was removed about the year 1622 somewhat further down the river. Upnor Castle and Gillinghaim Fort were built at the same time, to defend the approaches to it by water. In the succeeding reigns it was enlarged and improved, especially under Charles II., when it was the great naval arsenal, on account of the war with the Dutch and northern powers, it being nearest the enemy's coast. The yard then stood on sixty-eight acres, and had the largest water frontage of any Government yard. Lines were thrown up in 1756 to provide for the security of the dockyard, and also to serve as a kind of fortified camp for an army. Like Portsmouth it has been enormously increased, but a great deal of the land enclosed is not yet utilized.

Plymouth was first established in the year 1689 ; it

${ }^{1}$ King's MS., Brit. Mus. Supp. No. 44. 
was, however, some time before it was completed. Previous to that date a master shipwright and artificer had been borne on board a ship in the harbour purposely fitted for their reception. "The great advantages of a dockyard at this place having been experienced during the several wars since the year I689, many additions and improvements have therefore been continually making to it, but the most considerable were those in the execution of a plan formed by the Commissioners of the Navy pursuant to an order from the Admiralty when the Earl of Egmont presided thereat in the year 1764 . The original estimate of this plan was $£ 379,170 . "{ }^{1}$ It was not until I 824 that the name was altered to Devonport, and to this Keyham and its steam factory have since been added.

Sheerness was established as an adjunct to Chatham in the reign of Charles II., but the present yard dates only from I 822. Pembroke docks became a permanent establishment in ISI5. The Alexandra dock at Haulbowline (Queenstown) was opened in I 885 .

These are the only public dockyards at home now, but there were also yards at Harwich, Deal, and Kinsale at one time, and in the last century men-of-war were built in private yards at Shoreham, Blackwall, Wapping, Ratcliffe, Cowes, and Southampton, just as they are on the Tyne, the Mersey, the Clyde, and elsewhere now.

Naval establishments are at present maintained at Gibraltar, Malta, Bombay, Trincomalee, Hong Kong, Esquimalt, Sydney, Port Royal, Bermuda and Halifax; while in the old days there were English yards at Lisbon

${ }^{1}$ King's MS., Brit. Mus. Supp. No. 44. 
and New York, and truth to tell, the story of the Navy must be incomplete until the many interesting details connected with the rise and decline of these numerous establishments are brought to light.

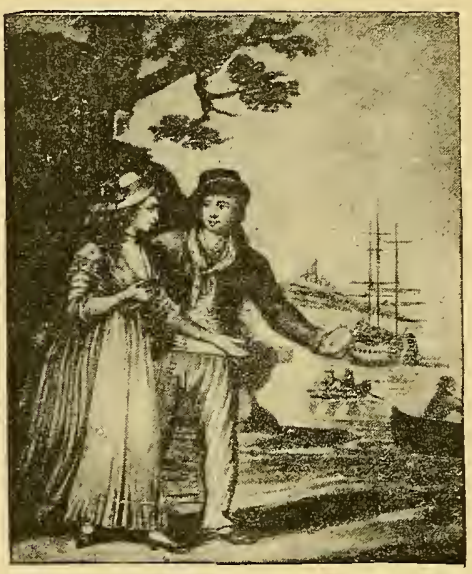

JACK'S KEEPSAKE FROM HIS LOVE. (Headpiece to Nautical Song, I795.) 


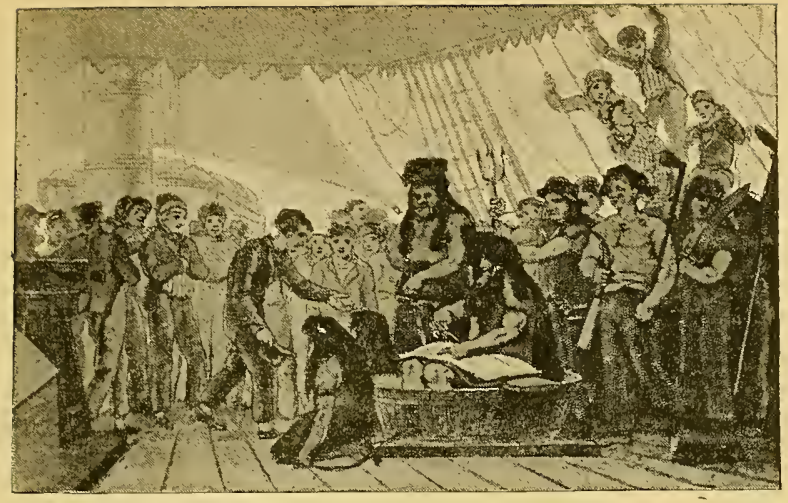

NEPTUNE'S REVELS. CROSSING THE 1.1NE, I S2O.

(IV. Daniell, A.R.A.)

\section{CHAPTER V.}

THE LAIVS AND CUSTOMS OF THE NAYY.

THE laws of the sea were defined by Sir John Barrow as " certain general laws acceded to by the common concert of nations by whom the maritime affairs of traders are regulated and all controversies adjusted, each nation having its own distinct Admiralty or tribunal for the trying and punishing offences."

Writing in $1664,{ }^{2}$ Dr. Exton, Judge of the High Court of Admiralty, describes an ancient authentic book as "having been from time to time kept in the Registry of

${ }^{1}$ See "The Maritime Dicæologie, or Sea Jurisdiction of England ; set forth in three several books." London, I664, fol. 
the Court for the use of the judges of the Admiralty successively, and as free from suspicion of being corrupted or falsified as the records of any Court whatsoever."

This book, he said, contains the "ancient statutes of the Admiralty to be observed both upon the ports and havens, the high seas and beyond the seas, which are engrossed upon vellum in the said book and written in an ancient hand in the ancient French language."

The "Black Book of the Admiralty," which is thus described, after being constantly referred to as the standard authority in the Admiralty Court until the end of the eighteenth century, suddenly disappeared, $\mathrm{Mr}$. A. Luders, who had occasion to consult it in 1808 , being informed by the officers of Doctors' Commons that "they had never seen such book and knew nothing of it."

In its absence an English MS. in the Library of the College of Advocates in Doctors' Commons, entitled "An Abstract of our Lawes of Oléron and of the Lawes in the antient Black Bcok of the Admiralty and of our Maritime Lawes amongst the Acts of Parliament, etc., comprised in an Alphabetical Tabie, with Translations of the said Lawes of Oléron and those in the Black Book," was made to do service for it; but in 1858 , in consequence of the dispersal of the College and the sale of its library, this source of information ceased to be available for public purposes.

There was, however, a modern transcript of the Black Book in the Library of the Admiralty, and various MSS. in the British Museum, by the collation of which it was possible to restore the text with reasonable accuracy, a task admirably performed by Sir Travers Twiss, Her 
Majesty's Advocate-General, in I87 I. Three years later the missing book was accidentally discovered at the bottom of a chest supposed to contain private papers belonging to a former Registrar of the Admiralty Court, which had been transferred from his private offices to the cellars of the Registry.

This discovery enabled it to be ascertained with tolerable certainty that while the Black Book of the Admiralty-compiled for the use of the Lord High Admiral or of his Lieutenant who sat as his judge in the High Court of Admiralty-contained ordinances drawn up antecedent to the reign of Edward III., no part of the writing, which was in various hands, was of a period earlier than the reign of Henry VI.

The statutes contained in the Black Book are largely based on the laws of Oléron. These laws, by which the seafaring nations of the west were governed, were a code adopted, according to tradition in Castile, by Alphonso X. in the thirteenth century, as a body of positive law for the settlement of disputes in maritime matters, and introduced into England by Richard I. In support of the tradition it may be stated that the island of Oléron furnished an important contingent to the great fleet which was sent forth in the second year of the reign of Richard I. for the relief of the Holy Land, and that amongst the five commanders of that fleet was William de Forz, of Oléron, whom the King appointed one of the justiciaries of his navy. This code was founded on certain ancient sea laws, formulated in the Republic of Rhodes, and received and confirmed by the Romans and all the neighbouring states bordering on the Mediterranean, in the same manner as the code promulgated at Wisby, a small Swedish town in the island of Gothland, was 
received and conformed to by the nations bordering on the Baltic and to the north of the Rhine.

As early as the reign of King John all causes of merchants and mariners happening on the main sea were tried by the Lord Admiral, who, in deciding such cases, was guided by the Sovereign's Orders in Council, the unwritten laws and customs prevailing in nautical matters at the time, the decisions of his predecessors in office, and the principles of justice acknowledged by himself.

Thus certain laws came into force in maritime affairs as the necessity for them arose; those applicable to the discipline on board ship would be practised by the captains and masters when at sea, and in these ways our naval law probably grew for centuries, some of the laws and customs running back, like the Common Law of England, to times beyond the memory of man, and thus gaining a similar authority. ${ }^{1}$

The jurisdiction of the admirals was defined in the time of Richard II., when it was enacted that "Admirals and their deputies should confine their jurisdiction to things done upon the sea, and in great ships being and hovering in the main stream of great rivers, yet only below the bridges of the same rivers nigh the sea." 2

The code of Oléron did not err on the side of leniency. " Know all men that We, with the aid of upright Counsellors, have laid down these ordinances: whoever shall commit murder aboard ship shall be tied to the corpse and thrown into the sea : if a murder be committed on land the murderer shall be tied to the corpse and buried alive: if any man be convicted of drawing a knife for

1 Admiral Shortland's "Laws which Govern the Navy."

2 I 5 Rich. II., c. ii. 
the purpose of stabbing another, or shall have stabbed another, so that blood shall flow, he shall lose a hand: if a man strike another with his hand he shall be ducked three times in the sea: if any man defame, vilify, or swear at his fellow he shall pay him as many ounces of silver as times he has reviled him. If a robber be convicted of theft, boiling pitch shall be poured over his head and a shower of feathers be shaken over to mark him, and he shall be cast ashore on the first land at which the fleet shall touch." One striking feature of this code of laws is that, while the authority of the captain is upheld and rigorous penalties are enacted for mutiny, it is specially enjoined that the opinion of the crew is to be taken under certain circumstances and the decision of the majority abided by.

For instance, in the event of a question arising as to the expediency or otherwise of setting sail, it is provided, "That if a ship is in haven and stays to await her time, and the time comes for departure, the master ought to take counsel with his companions, and say to them, 'Sirs, you have this weather.' There will be some who will say 'the weather is not good,' and some who will say the weather is 'fine and good.' The master is bound to agree with the greater part of his companions. And if he does otherwise the master is bound to replace the ship and the goods if they are lost, and this is the judgment in this case."

If mariners went ashore without leave, got drunk and made a disturbance and were injured, the master was at liberty to leave them behind and hire others instead. And if he had to pay the substitute higher wages he could charge the defaulter with the difference, that is to say "if he can find anything of theirs." If, however, a 
mariner fell sick and became incapable of work, the master was to put him ashore and seek a lodging for him; providing him, moreover, with a candle of tallow and one of the ship's boys to attend on him, or, failing that, a hired woman.

If contention arose between the mariners, the master, before turning one or all of them out of the ship, was bound to take away the table-cloth from before them three times, as a warning; and, as there was only one cooked meal a day, the practice was apparently equivalent to giving three days' notice.

In order that he might always be available for duty the mariner was forbidden to undress himself unless he was in a port for wintering, and the penalty for disobedience was that for each offence he was to be plunged into the sea with a rope from the yardarm three times, and after the third offence he was to forfeit his pay and any share he had in the freight of the ship. For sleeping when on the look-out in a hostile place, the penalty, in the case of a mariner of the forecastle, was to be "beat naked by all the crew, and to be plunged into the sea three times with a rope from the yardarm;" if a mariner of the poop (? petty officer), he was to lose his wine and all his food, except his bread, and have a pail of water thrown over his head downwards.

Every mariner was required to bring armour and weapons with him on board, and to be prepared to use them at all times in the service of the ship, and he was strictly forbidden to sell them before the completion of the voyage, under the penalty of being fined.

For centuries this code was the basis for the administration of justice in connection with maritime affairs, whether naval or mercantile. 
A permanent Court of Justice-the forerunner of the Court of Admiralty-was held under the authority of each Lord High Admiral ${ }^{1}$ for the trial of sea causes both for life and goods; but, so far as discipline afloat was concerned, it became the practice for each commander-in-chief, when an expedition was going out, to promulgate a code of instructions for the guidance of the several captains. These instructions were based upon those of more ancient date, the powers delegated to the captains being of the most summary character. IVe shall not forget the stern dealing of Drake with Doughty during the famous circumnavigating voyage, and it adds something to our conception of the relentless character of the procedure in those days to learn, from the letters of Mendoza, the Spanish Ambassador, that Drake's own hand wielded the headsman's axe.

Monson, Boteler and other writers of the Stuart period, criticize the severity of the punishments, but, from a code of instructions issued by Admiral the Earl of Lindsay in 1695, in which the summary punishments include ducking, fasting, keel-hauling, flogging at the capstan, hanging weights on offenders "till their heart or back be ready to break," or to "gagg or scrape their tongues for blasphemy or swearing," it is evident that no change had taken place up to the end of the seventeenth century.

The first approach to a uniform and modified procedure was the passing in 1645 , by the Long Parliament, of an ordinance and articles concerning martial law, for the guidance of the Navy.

This ordinance provides for the trial of captains and

${ }^{1}$ Nicolas, "History of the Navy," p. 197, chap. ii., I 350. 
commanders by general court-martial, and of subordinate officers and others by "ship court-martial," of which latter court the gunner and boatswain, officers of that period, were to be members. Written records of the proceedings were ordered to be made, and a power of. control over the more serious sentences was reserved to the Admiralty. Under the Act I 3 Car. II., c. 9, the Lord High Admiral again received power to issue commissions for holding courts-martial, a power which continues to be exercised by the Board of Admiralty, but the "ship court-martial" has fallen into disuse. In connection with these courts-martial it is curious to note that Pepys, although a civilian, received a temporary commission as a captain in the Navy to enable him to sit on one. Writing on March I 3 th, r669, he says :

"That which put me in good humour, both at noon and night, is the fancy that I am this day made a captain of one of the King's ships, Mr. Wren having this day sent me the Duke of York's commission to be captain of the Jerzy, in order to my being of a court-martial for examining the loss of the Defyance and other things."

Although in this instance he does not seem to have been an actual member of the court, he was associated with another, held to inquire into disputes between the captain of the Nonsuch and his lieutenant, "a drunken kind of silly business." But in this, also, the worthy secretary withdrew before the Court gave judgment, "it being feared that this precedent of our being made captains ... might be hereafter made of evil use, . . . to make packed courts, by captains made on purpose."

The first articles of war were formulated soon after 
the Restoration, the articles being drawn up by Admiral Montague and approved by Lord Chancellor Hyde, the House of Lords having called attention to the necessity of preparing some such code.

"The regulations already referred to had been limited to fleets under individual admirals. The powers of the Court of Chivalry, from which courts-martial are supposed to have originated, had fallen into almost entire disuse, the Petition of Rights had declared commissions for the trial of mariners according to the practice of martial law to be illegal, and the Common Law knows nothing of courts-martial."

The thirty-third article of Section I of Act I 3 Car. II. c. 9 is important, for it clcarly points to the principal source from which these regulations were drawn. It runs thus: "All other faults committed at sea shall be punished according to the customs used at sea."

This code forms the basis of the present "Articles of War." It enjoins the regular performance of public worship aboard ship, gives power to hold courts-martial, and to administer oaths, and confines jurisdiction to the limits prescribed in the Act of Richard II.

During the eighteenth century, under the auspices of Anson, the jurisdiction was greatly extended, and in I749 the Consolidation Act of George II., 22, altered and amended the previous Acts to suit the requirements

${ }^{1}$ The Court of Chivalry was a military court, established by Edward III., of which the Earl Marshal and Lord High Constable were joint judges. Having encroached on the Common Law, its jurisdiction was defined by I3 Rich. II., stat. I. An attempt was made to revive it in the reign of Queen Anne, but it is now in abeyance except as represented by the Earl Marshal's court.

2 Thring, "Criminal Law of the Navy." 
of the service of that day. Out of the thirty-six articles it contained, ten award punishment of death without qualification, and twelve death or such other punishment as the court-martial shall deem fit. The thirty-sixth article again referred to the source of all our naval regulations; it runs thus:

"All other crimes, not capital, not mentioned in this Act, shall be punished according to the laws and customs used at sea."

In practice this sanguinary code was found too severeit was under it that Byng suffered-so in the nineteenth year of the reign of George III. an Act was passed to amend it, permission being given to the court in certain cases to substitute another penalty.

The Act of Charles II. was, by order of the Lord High Admiral, periodically read to the crewrs of His Majesty's ships, and this practice has continued to the present day. George II.'s Act, amended by that of George III., continued in force for nearly seventy years, when, in I 847 , the general laws for the government of the Navy were reconstructed, and placed on a new footing, by the Naval Discipline Act (more familiarly known as the Articles of War), the preamble of which commences with the statement, now more than 500 years old, "It is the Navy whereon, under the good providence of God, the wealth, safety, and strength of the kingdom chiefly depend."

The Naval Discipline Act, which has been several times altered and amended, together with the Queen's Regulations and Printed Instructions, the Orders in Council, and the Admiralty Circulars which are from time to time issued, have brought the code of laws by which the Navy is governed, so far as is possible in a service in which the maintenance of strict discipline and 
unquestioning obedience is essential, into conformity with the more humane standard of modern legislation.

The Admiralty Instructions.-The special codes of instructions issued by commanders-in-chief with Admiralty sanction, have already been mentioned; in 1730 these orders, together with the regulations in force on ship-board at the time, were collected, altered, and added to by the Commissioners for executing the office of Lord High Admiral, and by Order in Council were printed and issued, for the guidance of the Navy, in I 73 I. This was the first edition of what is known as "The King's or Queen's Regulations and Admiralty Instructions."

Many subsequent editions have appeared, the latest only last year, a bulky volume of some hundreds of pages, but, except in so far that they have been brought into conformity with modern ideas and surroundings, the relation of the rules of 1730 is practically the same as those of I 893 .

The first edition was divided into five parts. Part I. related to flag-officers, courts-martial, rank and command, marks of ceremony and respect, colours, and the rules for the appointment of officers in ships abroad. Part II. related to the captain or commander, discipline, manning, sick or hurt seamen, provisions, payment in case of the men being placed on short allowance, slops, pilotage, convoys, salutes, and prizes. Part III. laid down the duties respectively of the lieutenants, master, boatswain, master sailmaker, gunner, gunsmith, carpenter, purser, surgeon, master-at-arms, corporal, schoolmaster, and cook. Part IV. related to hospital ships and the physician of the Navy. Part V. to wages, the number of officers, their servants, table-money, gratuities to the 
relatives of those slain in fight, gratuities to wounded, and pensions.

To attempt any detailed description of these or the present regulations is beyond the scope of this work, but before leaving this part of my subject it will not be without interest to refer briefly to what the old writers termed "The Usage of the Sea."

One of the most ancient of sea customs is associated with honours paid to, or claimed by, various personages as a mark of respect to themselves or to the country they represented. Kings Alfred and Edgar are said to have made the ships of other countries strike or lower their sails when passing the English war-vessels in the narrow seas. John Selden tells us that King John decreed that "If the governor or commander of the King's Navie, in his naval expeditions [which were all in that age upon the southern sea] shall meet any ship whatsoever by sea, either laden or empty, that shall refuse to strike their sails at the command of the King's governor or admiral or his lieutenant, but make resistance against them which belong to his fleet, that then they are to bee reputed enemies, and they may be taken, yea, and their ships and goods be confiscated as the goods of enemies." 1

Scores of instances occurred where this salute "in honour of the flag" was enforced by shot of gun, and up to the end of the last century the following instruction remained in the "King's Regulations:"

"When any of His Majesty's ships shall meet with any ship or ships belonging to any foreign Prince or State, within His Majesty's seas, which extend to Cape

1 "Mare Clausum." 
Finisterre, it is expected that the said foreign ships do strike their topsail, and take in their flag, in acknowledgment of His Majesty's sovereignty in those seas; and if any shall refuse, or offer to resist, it is enjoined to all flag-officers and commanders to use their utmost endeavours to compel them thereto, and not to suffer any dishonour to be done to His Majesty."

In the Regulations of the Trafalgar period this instruction disappears, but His Majesty's ships are enjoined not to strike their topsails, or take in their flags, unless the foreigners have already done so, or do so at the same time. If any of His Majesty's subjects shall so far forget their duty as to attempt to pass any of His Majesty's ships without striking their topsails, they are to be reported, "in order to their being proceeded against in the Admiralty Court."

To-day "dipping the flag" is an act of courtesy ; menof-war do not do it to one another, but if merchant ships "dip" their ensigns to them they reply in a similar manner. The custom of "striking" or lowering a sail has almost died out, although our little training brigs invariably do it when, in cruising about Spithead or the Sound, they pass a flag-ship. Only the other day, too, during the naval mancuvres, I saw the good old custom complied with, the ancient mariner in command of a Devon barque letting fly his topgallant halyards in salute to Admiral Fairfax in the Royal Sovereign.

Saluting with guns is as ancient as the guns themselves. The naval writers of the Stuart and Commonwealth period tell us of the huge waste of powder, and of ball too, which took place in consequence of the great prevalence of the practice. Pepys informs us how, when the news of King Charles's declaration came to the fleet 
in the Downs, "the General began to fire his guns, which he did all that he had in the ship, and so did the rest of the commanders, which was very gallant, and to hear the bullets go hissing over our heads as we were in the boat." 1

Dressing ship and manning yards in honour of some occasion is as old as the time of Queen Elizabeth, and a fleet in those days with all their flags abroad, silken pendants at the yardarms and on the stays, scarlet cloths round the waist and tops, yards and rigging "well hung with men," must have made as brave a sight as our ironclads do when Her Majesty reviews them at Spithead. The ceremony of receiving a royal personage on board, as described by Commander Nathaniel Boteler in the reign of Charles I., is almost exactly the same as that prescribed in the present year of grace.

The order of precedence for officers going aboard or departing from a ship, and the practice of hailing boats after nightfall, date from the last century. The junior always goes into a boat before his senior, but always leaves it after him. The starboard gangway and the starboard side of the quarter-deck are always used by commissioned officers, while the starboard side of the poop is generally sacred to the admiral. On coming on the quarter-deck, whether from below or from over the side, the symbol of authority is saluted, and in olden time every officer on deck acknowledged this salute. When the colours are hoisted at 8 a.m., or hauled down at sunset, they are saluted by everyone on deck, and if the ship has a band, it is in attendance to play the colours up.

' Pepys's "Diary," Wheatley's edition, vol. i., p. I26. 
After dark all boats approaching the ship are hailed, "Boat ahoy!" When a flag-officer is in the boat the reply is made, "Flag." When it contains the captain of a ship, the name of the ship is given in response to the hail. Commissioned officers, if they are coming on board, answer, "Aye, aye," but in every other case the reply is, "No, no," and this, whether the boat is bound for the ship or merely passing. That the custom was at one time slightly different will be seen by reference to an article in the "Naval Sketch Book."

When boats are passing one another, the junior salutes the senior, if the latter be royalty, or a flag-officer, by tossing oars, letting fly the sheet, or stopping the engines. Captains are saluted by laying on the oars (in other words ceasing to row), and other officers by merely touching the cap.

The regulations of $\mathrm{i} 808$ prescribe that ships when passing one another are to have a guard on deck to salute, and the practice is still in vogue, while on such occasions every officer and man comes to the salute with his hand to his cap. There are one or two customs in connection with courts-martial that have nothing to do, apparently, with law. While a court is sitting a Union Jack is hoisted at the peak, and a gun is fired as a signal of the court's assembling. All officers in port who are qualified to sit must attend. The prisoner's sword, if he have one, is placed across the table while the court is sitting, and when he comes in to hear sentence pronounced he knows whether it is favourable or not, according as the hilt or the point is placed towards him. "All who will" may be present at the trial. The youngest officer in the

${ }^{1}$ Ed. 1826, vol. i., p. 60. 
court has to give his vote first, and the determination of the court is settled by the majority of votes. As soon as it has been decided upon the sentence is to be pronounced in public.

Although all other salutes consist of an odd number of guns, those fired on the occasion of death are of an even number. When punishment, such as the death penalty, or flogging, is executed, all the ship's company are to be spectators, and the ceremonies on these occasions, as in that of the case of a funeral at sea, although now seldom or everwitnessed, are fully prescribed by custom, although they will not be found in any printed instructions.

Another very ancient custom is that of having public prayer on board each of Her Majesty's ships at least once a day. In the old days it was also the usage of the sea to sing hymns or psalms at the changing of the watch, and this was the practice in Blake's time. Nor was it by any means unusual at a much later date to have prayers before going into action.

All ships of war are furnished with fishing tackle, nets, hooks, and lines, while custom ordains a certain distribution of the fish caught. In the very first printed instructions issued there is an order that "where fish is to be had, the captain is to employ some of the company in fishing, and the fish which shall be caught shall be distributed daily to such persons as are sick, or upon recovery. And if there be any surplus the same shall be distributed by turns amongst the messes of the officers and seamen, without favour or partiality, and gratis, without any deduction of their allowance of provision on that account."

Admiralty Seals and Marks.-The Admiralty badge was for many years "a cressante with burning fyre," in 
other words, a crescent moon, horizontal, with a golden star between the horns. This badge, which dates back to crusading times, still forms the arms of Portsmouth. At some date in the late Tudor or early Stuart period its place was taken by the anchor, which was also used as a seal for many purposes, with a motto round it according to the fancy of the Lord High Admiral. When the Earl of Northumberland was in office, the anchor had a cable festooned about it in a wonderful manner. The Duke of York put this anchor into the Admiralty flag. About 1720 the foul anchor which had before been the badge of the Victualling Office was taken for the Admiralty and it was put into seal, badge, and flag. ${ }^{1}$ In I 8 I 5 the clear anchor was restored to the flag, but the foul anchor remains the badge at Whitehall.

There is an engraving of the Great Seal of the Admiralty (temp. 1585 ) in Hone's "Table Book," the device being " a ship of the period charged with the royal arms on the sail." No anchor appears in this device, which is copied from the Great Seal attached to the Commission granting the vice-admiralty of the Hundred of Milton to Sir Edward Hoby. ${ }^{2}$

The seal of the Navy Office was an anchor in pale between two small anchors erect within the beam or fluke, with this motto: "Sigillum officii Navalis." In I627 Charles I. ordered all muskets and other arms

1 See "The Naval Expositor," 1750.

2 The seals of the Lord High Admirals in mediæval and Tudor times form a most valuable and interesting series. They are masterpieces of the seal-cutter's art, and throw much light upon early shipbuilding. A description of the seal of Richard, Duke of Gloucester, will be found in a footnote on p. 90. See also "Archæologia," vol. xiv. 
before being issued for land service to be marked with the initials C. R., and those for sea service with C. R. and an anchor. ${ }^{1}$

The Broad Arrow used as the mark of Government stores was the cognizance of Lord de l'Isle, who was the First Commissioner of Ordnance in the reign of Queen Elizabeth.

It was suggested by Clode that the Broad Arrow was simply a corruption of the anchor; a conjecture, however, which is disposed of by a reference to Pepys, who, in his "Naval Minutes," writes, "One would have thought that had our Princes valued themselves so much in all ages upon their sea doings and sea power, they would have taken this publick brand, especially that which was to serve them in sea matters (as is just now observed), from something really relating to that element rather than to an arrow-head, a consideration that would easily have inclined one from the common figure of it to have drawn it to the signifying (tho' rudely), an anchor rather than an arrow-head, were it not that our very Laws, as I lately herein noted, have determined it for the latter."

Most of the public property used on board ship is marked with the Broad Arrow, but naval canvas is distinguished by a blue wavy line put on it after receipt at the dockyard. Cordage is marked with a coloured thread made up in the rope, the colour varying according to the yard in which it is made.

There are many other matters pertaining to the custom of the sea and the usage of the Navy, but to deal with them here would lead to such an extended treatment of the subject as limits of space do not warrant.

1 Rymer, "Fœdera," and Burke's "General Armoury."

2 "Military Forces of the Crown," vol. ii., p. 22. MS. in Pepys Library at Oxford. 


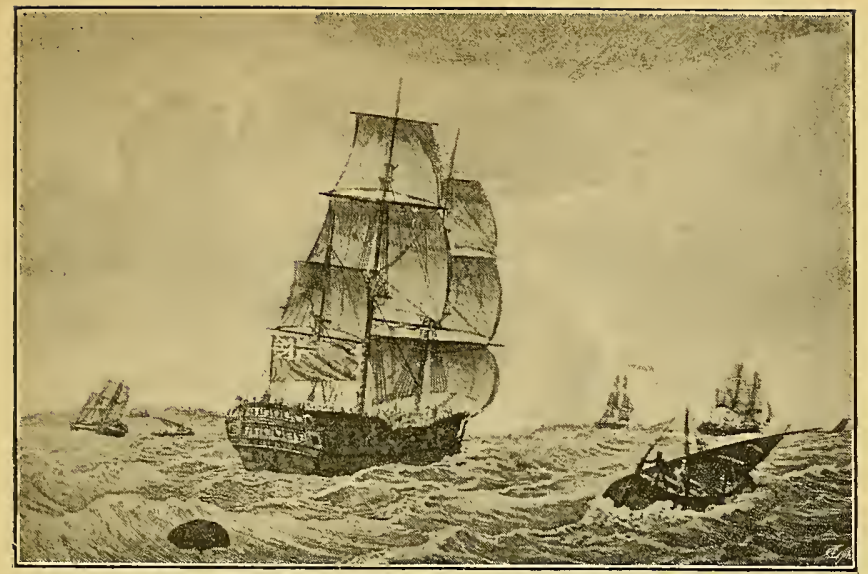

H.M.S. "PHENIX," OFF LISBON, I 78 I.

(A fourth-rate.)

\section{CHAPTER VI.}

CONCERNING THE NAMES OF OUR SHIPS.

THE whole story of the Royal Navy may be said to be garnered up in the names that many of our battle-ships and cruisers bear. Not only are these names in themselves "harvests of historic lore;" they form also in their inherited associations links with the past which make our war-ships of iron and steel kin with

"Those oaken giants of the ancient race That ruled all seas."

They aid to make the Royal Navy of to-day one with the Navy that under Drake and Blake struck down Spain and Holland in their might; the Navy that at La Hogue, 
at Quiberon and Dominica, and at Trafalgar, humbled to the dust the pride of France. So we at any rate like to think of the present Navy, in no small measure basing our hopes for the future on what has been achieved in the past.

There is, indeed, a vast store of historic memories in the man-of-war names of the Royal Navy-historic memories of widely varied and often highly curious interest, as a very slight and casual glance, running through a few of the names on the present list in the

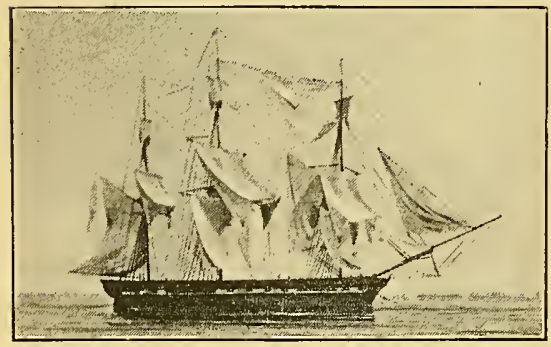

H.M. FRIGATE "VERNON," 50 GUNS. CIRCA I 840. order they originally came into the Navy, will serve to show.

Our new firstclass cruiser, $S t$. George, to lead off with what is undoubtedly the oldest man-of-war name in the service, not only bears a name originally bestowed as a naval compliment to the patron saint of England, but also serves through it --since she inherits that name through a long succession of predecessors, and traces it directly from the King's ship, George, or St. George, of Henry III.'s Navy-to connect the Navy of Queen Victoria with the old Navy of the Plantagenets. It further serves to commemorate in the Navy of to-day the once universal Catholic custom of mediæval times which gave to every English ship a patron saint of her own, whose image she carried and whose banner she flew. Our present Navy would only 
be doing honour to its old traditions were it to revive others of these saints' names, and restore to the list the names of some of the old consorts of our early $S t$. George, in memory of the splendid war-services of the Edward and Thomas and Christopher (so the names were familiarly known, dropping the prefix "Saint") war-ships of the fourteenth century English Navy that fought so well at Sluys, in the battle of Espagnolssur-mer, and in many another fight in the narrow seas.

Our Lion and Dragon and Antelopc, again, bear names that should not be without interest to us, as the survivors of a once large group of man-of-war names taken from the heraldic supporters and badges of the reigning house - the class of names that in historic sequence succeeded the saints' names for our English men-of-war, thus marking the fashion that came in about the period of the Reformation. The Elizabethan names, the group appearing on the Navy List next after the heraldic names, have also a tale of their own to tell. Victory and Triumph, Dreadnought and Revenge, Szviftsure and IVarspite-there is a manly ring about these names that fits well with the stir and turmoil of the fierce, hard-hitting times when they were first given to the fighting ships of Hawkins and of Drake. They are of a mould of their own, and differ from names before them and names after.

Quite a story is bound up with the name of Royal Sovereign in its earlier form of Sovereign of the Seas. For one thing, the "ship-money" levied for the building of the Sovereign was one of the prime causes of the great Civil War; for another, the name Sovercign of the Seas was specially bestowed by King Charles I. himself, 
as symbolic of the policy he set himself to carry out in reviving the old English claim to supremacy and "honour of the flag" within the four seas-within an area, that is, extending from a point half up the coast of Norway to Cape Finisterre on one side, and westward as far into the Atlantic as the meridian 23 west. The Dutch had recently officially protested against our claims in an elaborate State Paper formulated by their great jurist Grotius, and bestowing the name Sovereign of the Scas on the "crack" ship

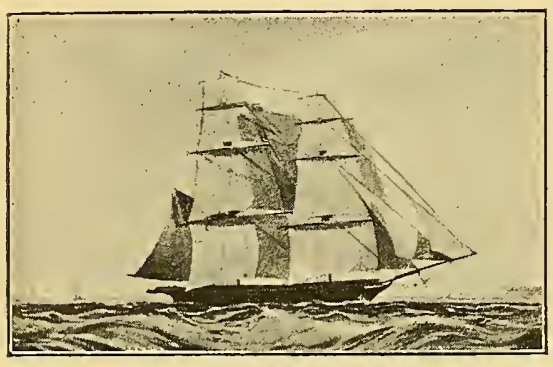

H.M. BRIG "PILOT," I6 GUNS. CIRCA I 840. of King Charles's Navy was designed as part of our reply and an authoritative reassertion of our claim.

In the name Worcester, again, borne by an old line-of-battle ship now employed on the Thames for the training of officers for the mercantile marine, we have a direct memento of the great Civil War; the first Worcester from which, through a line of other Worcesters, the present ship inherits the name, having been so named by Cromwell himself in honour of the "crowning mercy" of September 3rd, I65I. Cromwell gave similar commemorative names to other war-ships of the Navy, Marston Moor, for instance, and Naseby, but these did not survive the Restoration. By way of counter-irritant to the Worcester we have on the Navy List a Royal Oak, a name of closely-associated historic interest that was 
given to a man-of-war at the Restoration, and has been continued ever since in a series of successors down to its. present splendid representative.

The series of names commencing with "Royal" dates from the Stuart period-the idea taking shape in the first place with James I.'s Prince Royal. Our reigning monarchs' names had, of course, always had their place on the Navy List in one or other of the larger ships of the day; the Plantagenet Edwards, for example, had each his Edrvard Grace à Dieu, the Tudor Henrys each his Great Harry or Henri Grace à Dieu, and Queen Bess. her Elizabeth. But from now onward for a century and a half we find a regular series of "Royals," the example set with the Royal Charles being followed in the Roy'al James, Royal William, Royal Anne, and the various. Royal Georges. In the same spirit the names of royal residences, such as Nonsuch, Windsor Castle, Hampton Court, and Stirling Castle, were put on the list. There is though one excellent name we owe the Stuarts, Britannia, which dates from 1682.

An order of names in favour in the last century, the prototypes of our own "Admiral" class, dates from Pepys's time-the names given in honour of naval commanders and people of distinction connected with the Navy. Such names as Northumberland, Sandwich, Albenarle, Russell, commemorating chiefs of our seventeenth century Navy, and names like Nottingham, Penbroke, and Barham. Names of cities and towns, such as London, Edinburgh (the present Edinburgh is an exception, her name being conferred in honour of the Duke of Edinburgh), Glasgore, Liverpool, Dublin, Plymouth, Sheerness, and so on, are an old institution, and we might again follow Pepys's lead and restore some of them to. 
the Navy List. The class of names commemorating naval battles, as Barfleur and Solebay, and the later Belleisle, Camperdown, Nile, and Trafalgar, has had vogue for two centuries and is popular with seamen to an extent the commemorative names of land battles, such as Agincourt, Blenheim, Ramillies (as names, apart from the services of past ships so-called), Waterloo-and the lately introduced monstrosity, Marathon-can never hope to rival.

The name Edgar was originally given at the particular instance of James, Duke of York, whose memory, in gratitude for what he did for the Navy, our sea service should hold in respect. "The Duke fancied the name," we are told, "because Edgar was the first King that had the dominion of the seas which he went around about the kingdom every year with a thousand ships."

How the pseudo-classic tastes, prevalent towards the end of the last century, stamped their impress on the Navy we have evidence in many names which are still found on the list. It was thus that our Agamemnon, Bcllerophon, Orion, and the rest, were introduced by a First Lord of the Admiralty, a distinguished Etonian, who is said to have beer so devoted to the classics that he could hardly name a gun-brig without first turning up Lemprière's "Dictionary." Our Téméraire and Sans Pareil, Immortalité, Mutine, Volage, Magicienne, proclaim each its own origin, just as our Invincible, Superb, Magnificent, Majestic, Formidable, Monarch, Intrepid, Hero, Audacious, Melampus, and Active all conceal theirs. Nobody would guess that these last are really trophy names, with, attaching to them, many a stirring story. How their original foreign shape came to be transmuted is easily accounted for. Most of them came 
on to our Navy List, as a sort of revival, during the first half of George III.'s reign, years after the French ships that originally bore the names were captured into the service. The Admiralty, at this time, to find names for the crowd of new seventy-fours that they were adding to the Navy, turned to their old rolls of prizes taken in former wars, and, translating the names so found, added them in an English form to our own active list. Curious and replete with interest, too, are the tales of the origin of many other names-Black Prince and Union for instance, the "River" names, and the Boxer and Banterer classes.

A still higher interest, however, attaches to the war services that are commemorated in the names of our ships, if only, that is to say, people had any idea that these

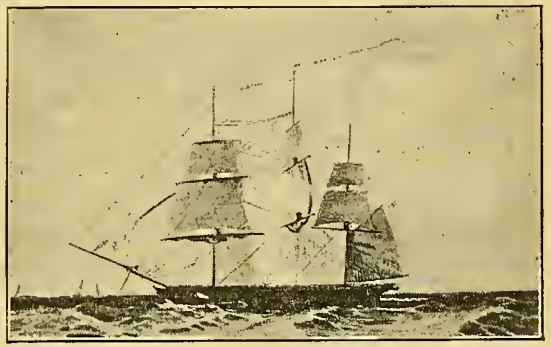

H.M. SLOOP "VESTA," I8 GUNS. CIRCA 1840.

possess associations at all. We all take proper pride in our old Victory, for example, but for most of us at any rate she is only the ship on board of which Nelson died at Trafalgar. Few trouble to think that there may be other memories attaching to our famed old heart of oak. There are though, and many of them. As a fact, the heroic service rendered by Nelson's famous flag-ship at Trafalgar is only one, and the last, of a number of other great services rendered by the same Victory, and by her predecessors, in previous days. From the Armada fight to Trafalgar, in unbroken series, 


\section{"Victory to Victory ever}

Hands the torch of glory on."

One Victory fought in the fore-front of every encounter with the Spaniards of the Armada. In another Blake flew his flag. On the quarter-deck of another as gallant a seaman as our Navy has ever had, Admiral Sir Christopher Myngs, fell in the heat of the battleexactly as Nelson fell at Trafalgar on the quarter-deck of our present Victory. Another saw service at La Hogue. With the memory of another is associated the story of one of the saddest catastrophes recorded in our naval history. Undying as is the renown of our Victory to-day, we should not forget those old ancestors from whom she inherits her name. And there are memories, too, deserving of recognition, of Keppel and Kempenfelt, of Howe and Hood and Jervis, all of whom in our present Victory, on the very same quarter-deck on which Nelson fell, commanded their fleets before the enemy. Is it too much to suggest that the Englishman of to-day ought to remember these things?

But the Victory's record is far from being the most distinguished in the Navy. Take, for instance, the story of another ship, one to which, for most people, no particular interest attaches, the Swiftsure. Did every British war-ship have a ship's colour or battle flag on which to record its war services, as every regiment has its regimental colour to bear an emblazoned record of the battles in which the regiment has taken part, our present Swiftsure's ensign would show not only more battle honours than any regimental colour of any Army can, but also bear more names than a Hohenzollern or Hapsburg shield bears heraldic quarterings. Omitting 


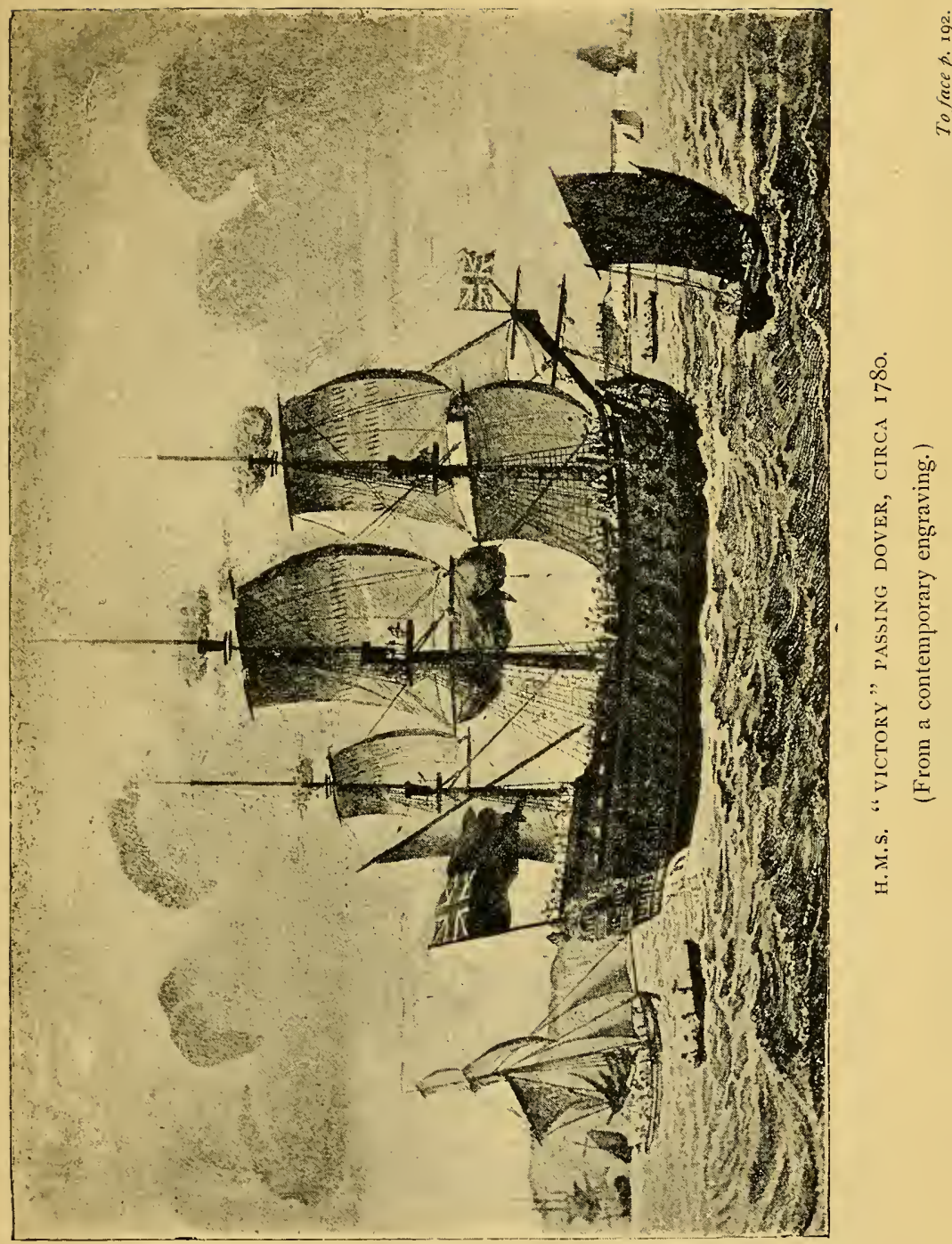



several minor actions, it would read something like this :

Defeat of the Spanish Armada, ${ }_{5} 88$.

Capture of Cadiz, 1596.

West Indies, I654 (Penn's flag-ship).

Santa Cruz, I656 (Blake's flag-ship).

Battle of Lowestoft, I665 (flag-ship).

Battle of June ist to 3 rd, I666.

Prince Rupert's three battles with De Ruyter, $\mathbf{x} 673$.

Victory over the French off La Hogue, I692.

Battle of Vigo Bay, 1702.

Capture of Gibraltar, I704.

Rooke's battle off Malaga, r704.

Boscawen's victory at Lagos, I759.

Hawke's victory in Quiberon Bay, I759.

Battle of the Nile, I798.

Calder's battle off Ferrol, 1805 .

Trafalgar, I805.

Surely the present bearer of a name with a range of service which practically covers the whole period of our modern naval history, should, and could, be granted some means of commemorating these heroic associations. And there is many another ship-name on the present Navy List that, for its story of - brilliant achievement, can run the Swiftsure close.

Our present Agamemnon derives her name directly from Nelson's favourite "old Agamemnon" and is the lineal successor of that same "Heart of Oak" on whose quarter-deck Nelson made his reputation as a captain. All imaginable difference in outward appearance that there may be between our great admiral's dashing twodecker of old and the grim mastodonte de mer that to-day 
bears the name of Agamemnon, is no outward symbol possible to keep in memory the association between the old heart of oak and the new heart of steel? Is the bond of sympathy that might thus be brought into being impossible? Was there nothing of the spirit of their common ancestor in the immediate predecessor of the present Agamemnon, the "superb Agamemnon" of Kinglake's "History," as she lay with stubborn courage facing and braving the hell-fire from the granite casemates of Sebastopol all through that live-long aftermoon, October I 7 th, I 854 ? Was there nothing of the "Nelson touch" in the heroic remonstrance of the blucjackets of that same Agamemnon on the night before the battle, when, hearing that the morrow's attack was to be headed by another ship, with one accord they made claim that it was their right to lead the line?

There are numerous ships in the Navy that bear names of ancestors which, in the battles of our old wars, singie-handed, made ships of the enemy lower their colours. The Monarch, for one, inherits the name of the old Monarch of the Nelson time, under whose broadsides three admirals of the enemy hauled down their flags in three several battles. The Superb, for another, is the successor of Keats's famous Superb, whose brilliant attack at the first-and forgottenbattle of Trafalgar, in I8OI, made one enemy strike her ensign, and two more blow themselves up; the sane Superb, moreover, that, in Admiral Duckworth's fight off San Domingo, in I806, shattered the biggest ships of the enemy right and left, triumphantly assailing them, as the gallant vessel swept forward along the French line, with Nelson's portrait swinging from 
the mizen-stay, and the band playing "Nelson of the Nile." There was an earlier Superb, too, whose fine performance in battle deserves some record surely, old Streynsham Master's Superb, which, in the action "Mediterranean Byng" (the elder Byng, who beat the enemy and was not shot,) won off Cape Passaro (in I7 I8), boarded and took single-handed the. Spanish commander-inchief's flag-ship - a feat unparalleled in naval annals.

The Amplion inherits the name of Sir William Hoste's "darling Amplicon, the ever memorable," that, at Lissa, fighting gun muzzle to gun muzzle with two enemies bigger and of heavier metal than herself, one on either side, closed the combat by bringing down the ensigns from

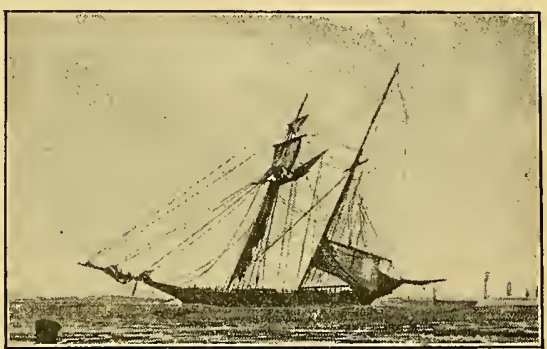

H.M. SCHOONER "SPIDER," 6 GUNS. CIRCA I 840 . the flag-staffs of both. Why might not our war-ships bearing historic names and names of long descent be dealt with, by official sanction, in some such manner, so that every man and boy on board could not fail to know the long roll of honours which his individual efforts are depended on to maintain? Surely we, of all nations, have reason to point with pride to the events of our Navy's resplendent past and to commemorate them-we, to whom that Navy has ever been England's strong right arm and sole defence, the cutting-edge, as it were, of England's sword- 
"TVe, sons and sires of Seamen,

Whose realm is all the Sea!"

It ought not to be hard to teach those who man our Dreadnought and Conqueror and Bellerophon, say in a form for all the world to see and honour, something of the heroic records attaching through their names to the ships they serve in-to make the heroism of the old British Navy thus live again in the names of the new, to lead our bluejackets, in Kinglake's stirring language, to "glory" in their ships' "ancient names, connecting each with its great traditions, and founding upon the cherished syllables that consciousness of power which is a condition of ascendancy in war."

Two stories, to conclude, will give a notion of the actual prevailing state of things. "I do not think I am exaggerating," remarked an officer who served on board our last Royal George in the Black Sea, "when I say, that, with the exception perhaps of our captain, the late Sir Henry Codrington, there was not an officer or man on board who had a clear idea of any one erent in our naval annals that attaches itself to the name of Royal George, or any idea at all beyond a hazy recollection of some child's story of a Royal George once capsizing at Spithead." The second incident, dating only a few months back, is quite comical in its ineptness. Our new first-class cruiser Gibraltar had just been launched on the Clyde, and "Success to the Ship" had been proposed as a toast at the déjeuner given by the shipbuilders in honour of the occasion. Our first Gibraltar, a ship of Queen Anne's Navy, received that name as a memento of the dashing capture of the fortress by Admiral Rooke; another took a distinguished part in the Seven Years' War with Hawke 
and Boscawen; and another, after being captured into the service as a Spanish prize in Rodney's daring battle that stormy January midnight of I 780 , among the reefs under Cape St. Vincent, served with Jervis off Cadiz, and with Nelson off Toulon, closing a distinguished career after an existence on the active list of over half a century. All that the Scottish marquis who returned

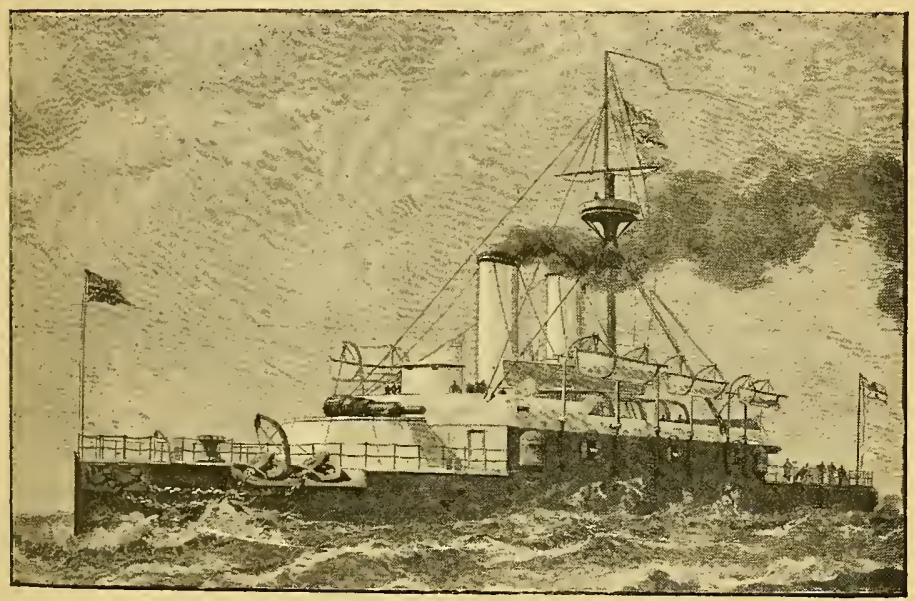

H. M.S. "COLLINGWOOD."

(9,500 tons displacement ; 9,570 horse-power. Completed I886.)

thanks on behalf of his wife, the lady who launched the Gibraltar, had to say, however, was "that he thought no more appropriate name than Gibraltar could have been chosen for the ship the marchioness had that day christened, because, only a few months before, her ladyship had happened to pass Gibraltar in a P. and O. liner, and had often said how pretty she thought the big 
rock looked by moonlight!" Not a word of what the name Gibraltar meant to England and the Royal Navy; no thought of any historic memories attaching to a once famous man-of-war name ; nothing of Rooke, or Rodney, or Nelson-only moonshine!

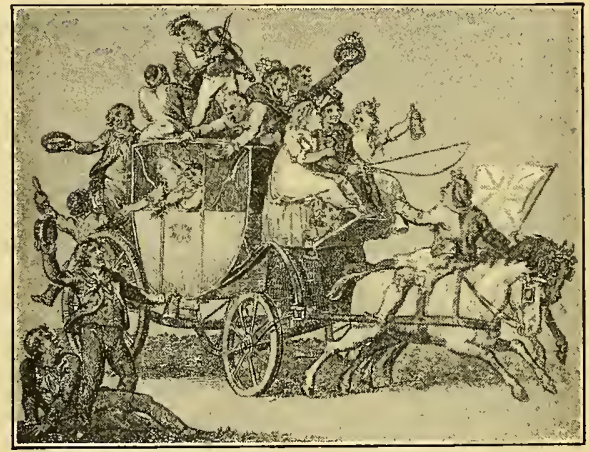

PAID OFF AT PORTSMOUTH, 1797.

(Isaac Cruikshank.) 
Part III.-NAVAL MATERIAL. 



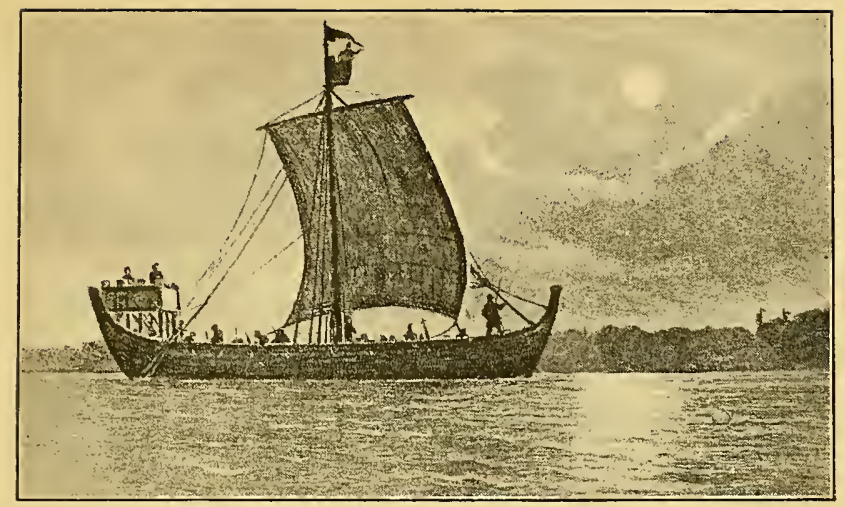

ENGLISH SHIP, THIRTEENTH CENTURY.

(Arenhold.)

THE EVOLUTION OF THE SHIP-OF-WAR.

NAVAL Architecture of the Britons and Romans in Britain (B.C. 56 to A.D. 450 ).- The ancient Britons were hardly without sea-going vessels. They had a regular trade with the continent, and could scarcely have left the oversea transport of their merchandise to strangers. Their coracles of wicker on a wooden frame, with a covering of hide, might serve for inland navigation, or even to cross the Channel on a summer's day, but something stouter was wanted to convey over the cattle and tin that the Britons exported. Their kinsfolk, the Brittany Gauls, had, Cæsar says, sea-going ships solidly built with oak timbers a foot thick and clamped with iron, with 
high bows and sterns, and fitted with leather sails and chain cables, and the southern Britons had probably similar ships. There is reason, indeed, for supposing that a contingent of British vessels of this type was present in the fleet of 220 vessels destroyed at Quiberon by Cæsar B.C. $56 .{ }^{2}$

A century later the Roman war-galley had become the fighting ship of Britain, supplemented by a new class of cruisers of native design and construction, the "pictae." These were light vessels rowing twenty oars a side, coated with wax below water, and, so as to be invisible at sea, furnished with grey-blue sails, and manned by oarsmen in grey-blue. ${ }^{2}$ With such ships the Counts of the Saxon Shore watched the coasts, and later Carausius and Allectus held the British seas against all comers.

The Ships of the Saxons and Dancs (A.D. 450 to I066). -The vessels of the Saxon raiders-called variously, "ships," "long ships," "ceols," "hulks," and "æscs"were large, undecked row-boats, built so as to be readily beached. They held fifty or sixty men, had high prows and sterns, and carried a single mast with square sail. The Saxon invaders were in turn attacked by the Danish rovers, who came in ships which, while mainly only a development of the same type as the earlier Saxon vessels, were larger and better sea-going vessels. Like their contemporaries, the Viking ships, they were either undecked, or else (in the larger ships) had light removable half-decks. The gunwales were widened with planks where the fighting men stood behind the

1 Froude's "Cæesar : a Sketch," pp. 288-29 I.

2 Sir H. Nicolas, "History of the Royal Navy," vol. i. 
"shield row" or range of overlapping bucklers along the sides. A typical Danish war-ship was uneartled a few years ago at Nydam in South Jutland-a vessel seventy-five feet long by ten and a half feet wide, and meant apparently for twenty-eight rowers. The sails in these vessels were secondary to the oars. The Saxons, on the defensive, originated a still more powerful ship. "King Alfred," says the "Saxon Chronicle," "commanded long ships to be built to oppose the (Danish)

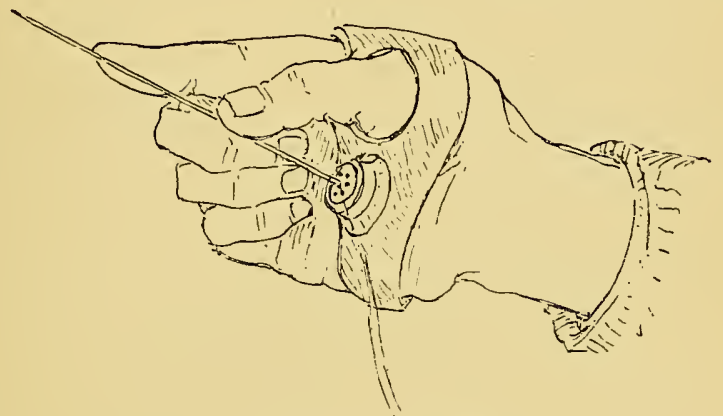

A SAILOR'S PALM AND NEEDLE.

æscs. They were full nigh twice as long as the others ; some had sixty oars and some had more. They were both swifter and steadier, and also lighter than the others. They were shapen neither like the Frisian nor the Danish, but so as it seemed to him that they would be most efficient." With these the enterprising monarch achieved many memorable successes. The institution of "King's ships," vessels which were the property of the king and designed primarily for fighting service, dates from these war-ships of King Alfred. In peace they were hired out as trading ships, and so paid for their keep. 
Canute and his successors introduced among us still larger war-ships than had been hitherto known. Canute's Dragon, is said to have been 200 feet long, and to have carricd seventy oarsmen, besides a crowd of soldiers. There were also "long serpents," which were vessels a little smaller. These big vessels, though, were exceptional; the fighting ship of the day being, as a rule, a vessel of a hundred feet long, or less, pulling fifteen to twenty oars a side.

The fashion of lavishly adorning ships was at this time universal in the North. Ships had prows shaped like dragon and serpent heads (whence the larger types of ships derived their names), or like the heads of lions, eagles, dolphins, or bulls, the sterns being wrought to resemble the corresponding tails. The warriors' shields were usually ranged along the sides, all brilliantly painted-red for the Danes, black and yellow for the Norsemen, white edged with red or blue for the Saxons. Carving and gilt work was distributed everywhere over the ship. Sails were commonly of bright colours, striped red, blue, or green and brown. The usual tactics of the time were to run down the enemy and sink him; failing that, to close and board, settling matters hand to hand with battle-axes and swords. ${ }^{1}$

The Ships of the Norman Kings (A.D. 1066 to I 199).English fighting ships in the Norman period, the eleventh and twelfth centuries, were mostly under fifty tons. They were partially-decked vessels carrying one square sail, with high bows and sterns on which, before action, were fitted fore and aft "castles" for the fighting men. These were square open box-like structures supported

${ }^{1}$ Sir H. Nicolas, "History of the Royal Navy," vol. i., passim. 
at the outer end by the frame of the ship itself, and inboard by temporary stanchions. ${ }^{1}$ The idea of these superstructures was, however, not original. They had been used in the old Roman war-galleys of classic times, and still existed among the Byzantines, the successors of the old Romans. The Bayeux tapestry and the seals of our seaports give an idea of what these gens de guerre (whence our term "man-of-war") were like. They were painted along the sides in bands of red and blue, yellow and brown, had "shield rows" at the gunwale, carved figure-heads, and sails striped in red and brown and yellow. The Crusades brought in sailing ships of yet larger build. Some of those employed in the Mediterranean, in the pilgrim traffic, were able to stow away, we are told, from 800 to I,000 people. King Richard's soldiers were mostly conveyed to the East in sailing craft- " busses," bluff-bowed, heavily-built vessels with bulging sides ; "vissiers," broad flat-bottomed craft; and "barges." The largest of these vessels were onemasted, and carried one small boat. To steer with they had a wide-bladed oar which was worked over the starboard (steer-board) quarter. They were supplied with spare steering oars, and also with grapnels for anchoring and for making fast to an enemy when about to board. Sweeps, or long pulling oars, and spare sets of sails and cordage, were also furnished to every vessel. Each ship had a master and fourteen men.

To close and board were the tactics in favour, and accordingly a crowd of soldiers were carried, a proportion being armed with cross-bows, which carne into

${ }^{1}$ Historic Towns, "The Cinque Ports," Prof. Montagu Burrows, pp. $86,87$. 
general use at the time of the Crusades. They manned the "shield row," the fore and aft castles, and "top" castle, a circular stage with breastwork, on the mast, in shape something like the fighting top of a modern armourclad. From these stones and darts were flung as the ships came together. Our English Crusaders brought back with them and introduced in our ships, among other novelties, catapults, mangonels, and scorpions-mechanical engines for hurling huge stones or heavy javelins and incendiary projectiles as the opposing vessels neared--which the Byzantine Greeks had kept up the use of from classic times, They also introduced Greek fire, with its apparatus of spouting tubes fixed at the ships' prows.

The battle-ships of the period, however, were great galleys with ram bows propelled by double banks of oars, such as King Richard's famous Trench-the-mer, and lighter "gallions" (also beaked vessels), besides "dromons" (a Byzantine naval term), which were long swift ships, and "snakes," light scouting craft. Galleys were swifter and handier to mancuvre than sailing vessels, of course, but, though ideal craft for the Mediterranean, their slender, narrow build and low freeboard (barely five feet) rendered them unfit for the heavy seas and rough weather of our northern waters. ${ }^{2}$

The Ships of the Plantagenets (A.D. 1200 to I485).The art of big ship building begins from now to move forward with appreciable strides. The ship of the thirteenth century was an advance in size and seaworthiness on its predecessors, though still only with one mast and sail. The larger vessels reached eighty tons, carry-

${ }^{1}$ Sir H. Nicolas, "History of the Royal Navy," vol. i.; and Prof. Montagu Burrows, "Cinque Ports." 
ing thirty seamen and as many cross-bowmen and soldiers. The average ship's company of a vessel of the Cinque Ports' Navy at this time was twenty-four, according to the Ports' Domesday Book:- a "rector" or master, "constable" or boatswain, twenty-one seamen, and a boy or "gromet." Galleys were masted, and carried from thirty-five to seventy men - rector, steersmen, galleymen and mariners. They were fitted for war

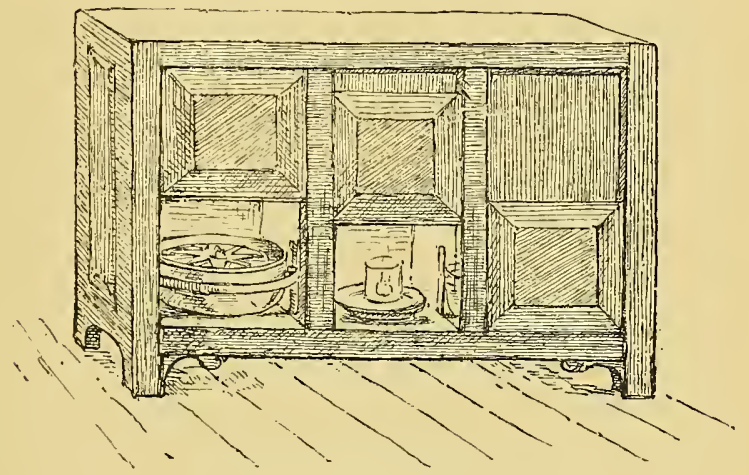

A SHIP'S BINNACLE, EIGHTEENTH CENTURY.

service with "fore" and "aft" and "top" castles as before, the "shield row" being retained as a shelter for the cross-bowmen.

In the king's war-ships we are told each sailor was given two spears long enough to spit a man with on the deck of a ship alongside. The seamen were warned not to throw these spears. Slings and javelins were used as before, and stones, with axes and bills to cut the enemy's rigging at close quarters. The king's fleet comprised "King's great ships" (sailing vessels), 
and "King's great galleys" (rowing vessels), with a fighting tail of smaller craft. To run alongside the enemy, under cover of the fire of the cross-bowmen and volleys of heavy stones, darts, and incendiary projectiles from the hurling engines, and then grapple and board, was the approved method of warfare at sea.

A larger ship came in about 1277, the "cog," hitherto a small vessel, but now recognized as the best for fighting purposes. The Cinque Ports' cogs of Edward I. carried one master, two constables, and thirtynine mariners. Several important changes and innovations date from this period. The large oar-propelled galley for purposes of war in English waters dropped out of use. The rudder hung to the stern-post replaced the old steering-paddle worked over the quarter. Cabins were regularly fitted up on board. ${ }^{1}$ National banners now began to be regularly worn at the masthead, being usually supplied to all ships before sailing on a war cruise, together with special streamers and pennants. The "bloody flag," a red streamer, seems to have been the usual battle flag. "These," we are told, "signify amongst all seamen death without quarter, and mortal war."

Another new idea was a special commander-in-chief's lantern in fleets. The sides of ships were greased, and their bottoms coated with a mixture of pitch, tar, oil, and resin, seams being caulked with "mosso," a compost of moss and hair. Iron rudder-chains came into use, the newly-introduced rudder being worked by a tiller.

1 They were not what we understand by the term, living rooms on board, but portions of the ship below boarded or screened off for store-rooms, the buttery, and where the provisions for knights and higher officers were kept. 
CHAP. I.] THE ANCIENT SHIP-OF-WAR.

" Ratlines," "polyves " (pulleys), "sheeves," “ swivels," "stays," and "backstays," "hawsers," " cables," "sheets," "yard ropes," "bowlines," "sounding lines," are all now first heard of.

Progress became still more marked during the reign of Edward III. The "cog," now a vessel of from I 80 to 240 tons, carrying 60 men per IOO tons-distributed at

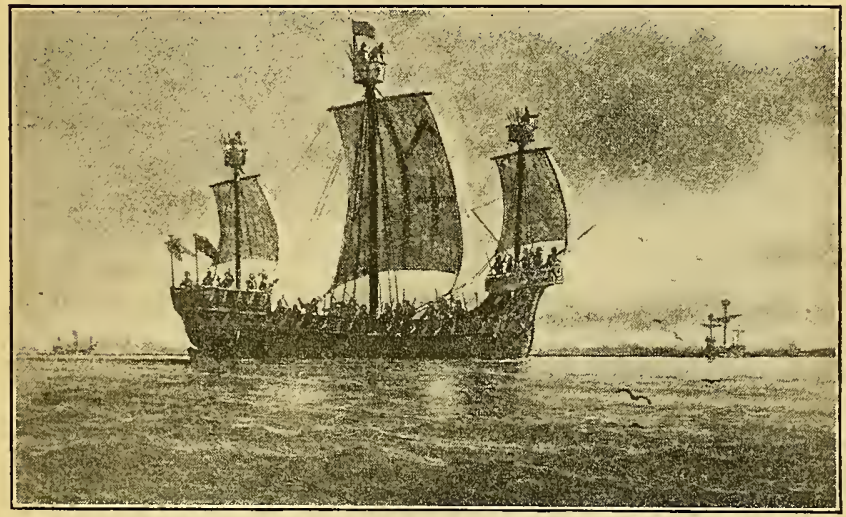

ENGLISH SHIP, FOURTEENTH CENTURY.

(Arenhold.)

the rate of 25 soldiers and 25 archers to Ioo seamennow became our ideal fighting ship. ${ }^{1}$ The lighter sailing ships were "barges," and " balingers," carrying 60 seamen, I 5 soldiers, and I 5 archers each; "pinnaces," carrying 35 men all told ; "shutes," and "fluves," shallow

1 Vessels of this kind were King Edward's famous cogs, Christopher, Edward, and Thomas, whose names have been preserved for us because of the distinction they acquired in battle. 
transport vessels, and "liques" and "lynes," small swift rowing galleys.

What large galleys still existed in northern waters were, for all purposes, parade craft ; such as the king's eighty-oared galley, La Philippa, a luxurious affair with red sails and a red awning. One mast was the rule, though two-masted vessels-the foremast raking forward right over the bows-were in existence.

The castles, "fore" and "aft," were only temporary structures, fitted in king's ships and others, for war service; as were also the "top" castles on the mast, whence missiles were flung on the enemy's decks. From the castles, sheltering behind their leather-covered wooden pavis shields, the English archers and their auxiliaries, the Genoese cross-bowmen, fired their arrows and bolts as they neared the foe, until the critical moment arrived to run alongside and board. ${ }^{2}$ Cannon now (1 346) began first to be used at sea, mounted on the castles of the larger cogs. They were poor things at first, made of hooped iron bars, of small bore, and firing stone balls. Of such small account were they that for another two centuries reliance was placed, in preference, on the springalds and mechanical hurling engines of the old style, with their crushing masses of stone and lead and iron bar projectiles. ${ }^{3}$

The half century from Edward III. to Henry V. saw the cog disappear, and a larger type of vessel come in.

So-named after the queen.

2 With ships so equipped and armed our ancestors fought at Sluys and Espagnols-sur-mer, and before that under Hubert de Burgh, off Dover, in Henry III.'s reign.

3 Sir Harris Nicolas, "History of the Royal Navy," vol. i. ; and Artillery," by E. W. Lloyd, R.N., and A. S. Hadcock, R.A. 
CHAP. I.] THE ANCIENT SHIP-OF-WAR.

This was the "ship" or "great ship," some 500 tons burden, two-masted, with 90 sailors, 130 archers, and 60 spearmen. They were copied from the Spanish and Genoese carracks that visited us to trade, and fought in our Frencl wars, either in the pay of the French, or, when on our side, as prizes from the enemy. These carracks were tall-sided vessels, so high out of the water, indeed, that the men of our cogs, when they met them first in the fight of Espagnols-sur-mer, in Edward III.'s time, could hardly, we are told, reach the enemy on deck with their spears. Barges and balingers continued the lighter war-ships of the period-low, long-built, onemasted vessels of about roo tons, with sails and sweeps, carrying each 50 mariners, 25 archers and 25 spearmen.

The tactics of the day were still to close and board, covered by volleys of stones and arrows. The cannon mounted on board ship being used for the effect of their noise and smoke on the enemy's nerves rather than their destructive powers. They were reckoned as supplemental to the hurling engines. Hand fire-arms were not yet invented, the long-bow and cross-bow being the principal arms of attack on sea and land. The king's ships of war at this period were profusely adorned. Some had purple sails embroidered in gold and emblazoned with bright colours, heraldic carving of badges and devices being bestowed about the hull everywhere. Sail was "made," or shortened, by lacing to the foot of the mainsail, or unlacing, "bonnets," or extra pieces of sailcloth-the old-time method, in fact, used by Sweyn and Canute's Norsemen. " We now hear first of "blocks," "rigging," "capstans," and "capstan bars." Ships were

${ }^{\prime}$ See "Old Sea Wings, Ways, and Words," by R. C. Leslie. 
"calfacted," or caulked, with tow and tallow. Lanterns for ship lights all through the fleet became universal.

From Henry V. to Henry VII. continuous progress was made in ship-building. In Edward IV.'s time ships of 900 and $\mathrm{I}, 000$ tons, with two masts, are stated to have been in existence. The fore and aftcastles of king's ships and vessels used in war were

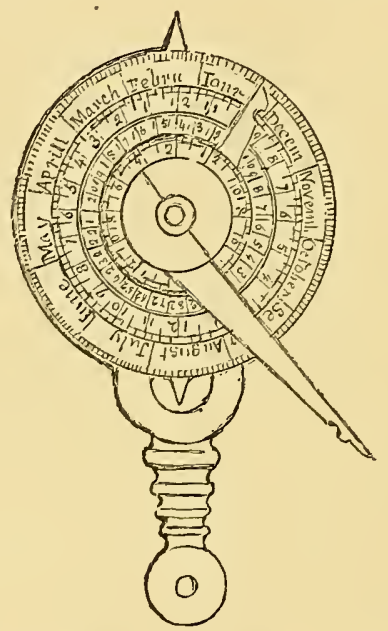

A Nocturnal, SIxteenth AND SEVEnTEenth CENTURy.

now becoming permanent structures, wrought strongly into the framework of the hull. The weight of the cannon that about this time began to be mounted on board ship in the castles, requiring stronger platforms than the earlier temporary constructions afforded. Heavy guns of cast-iron, and of larger calibre than before, firing increased charges and using stronger powder and iron shot, were also in use by this time, 
requiring stouter and better supported framework to bear them.

Next, above the new permanent aft-castle, to shelter the men who had to fire the guns from wind and weather and the missiles of the enemy in action, a light timber penthouse roof was erected. This being later made flat and given light bulwarks brought into being another deck, the poop. The space at the stern of the roofed-over aft-castle was then fitted up with stern windows. At the same time the bulwark shieldrow on the exterior of the waist, between the castles, was fitted up with loophole spaces for the archers and cross-bowmen to fire through. These spaces being gradually contracted became finally circular portholes from which light cannon were fired.

It was from these circular ports in the upper deck bulwarks that the later idea came of cutting larger ports on the lower deck through the side planking of the hull. An extant drawing of a ship of $\mathrm{I}_{4} \delta_{5}$, belonging to the Earl of Warwick, gives a good idea of how these transitions came about. ${ }^{1}$

There was but one square sail or course on the mainmast, the light aftermast in big ships being lateen rigged. The raking forward foremast was practically a bowsprit. The overhanging stern with the rudder head coming up through the deck-an idea, like that of three masts, taken from the Spaniards or Genoese -was another advance. Small arms, or "hand cannon," as they were called, were now in use, soon to develop into the matchlock or arquebus. They were employed side by side with the cross-bow and English long-bow,

1 Reproduced in Professor S. R. Gardiner's "Student's History of England," vol. i., p. 339. 
but subsidiary to these, owing to their comparative slowness of firing, inaccuracy, and shortness of range. The compass with card and box had replaced the primitive floating "sailing needles" and lodestones.

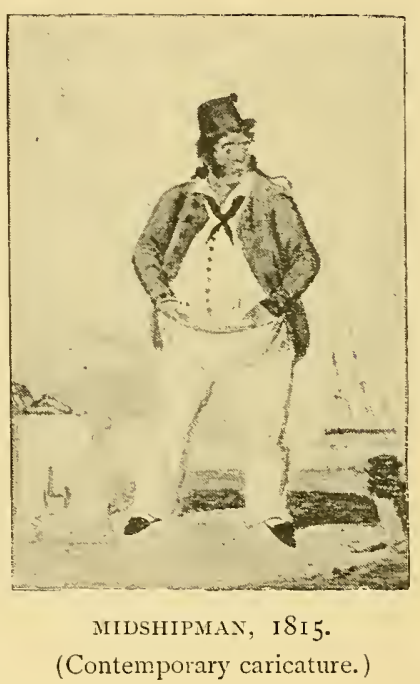




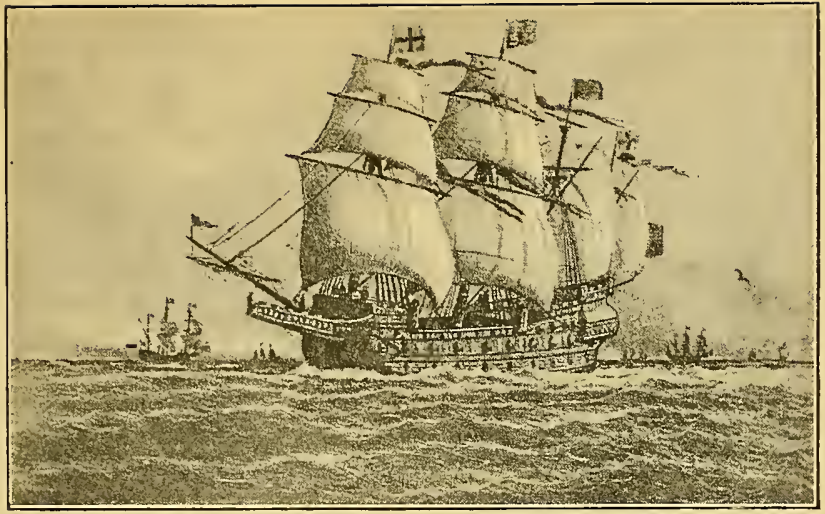

THE "HARRY GRACE À DIEU." LAUNCHED I5I5.

(Arenhold.)

\section{CHAPTER II.}

THE DEVELOPMENT OF THE SAILING BATTLE-SHIP.

IN Tudor Times (A.D. I488 to I604).-The art of shipbuilding in mediæval times culminates in the Great Harry, built in I 488 , at the cost of $£ \mathrm{I} 4,000$, by Henry VII. Her size was her special feature, as it was that of the Harry's Scottish contemporary, the Great Michael, a ship 240 feet long and 36 feet broad, mounting 8 great guns a side, besides lighter ordnance. Neither the Harry nor the Micliael, however, had portholes, which were only first invented in the year I 500, by Descharges, a shipwright of Brest.

The working out of Descharges' idea revolutionized sea warfare. He was able, with his portholes, to mount 
in his first ship, the Charente, besides the guns on the fore-castle and poop, a second battery deck giving a total broadside armament of 40 guns. Descharges next built the Cordeliere and the Caracon (80o tons), carrying from 80 to 100 guns, and then, in I5 I5, we sent afloat our Harry Grace à Dieu. She was a two-decker, with I4 heavy guns on the lower deck, I 2 on the main, I 8 lighter guns on the quarter-deck and poop, 18 on the forecastle, and Io for firing astern.

The early portholes were small, and did not admit of firing save in one direction. But, as from difficulties in loading it was unusual for ship guns in action to fire more than once or twice, cramped portholes did not so much matter. To clear the waist of boarders that had made good their footing-for to run alongside and board were the regular tactics of the time- "murdering pieces," short, wide-mouthed guns firing a hail of projectiles, were mounted on the afterpart of the fore-castle and forepart of the poop, pointing inboard.

As a further aid against boarders the overhanging. turrets we see in the pictures and models of the Harry, at the angles of the fore-castle and poop, were designed to give flanking defence to the ship's side. ${ }^{1} \quad$ Additional fire was obtained from the archers and slingers posted aloft in the top-casties that war-ships still carried.

The Harry Grace a Dieu had four masts and a bowsprit, all square-rigged. The sails were a course and topsail on the "foer" and "mayne," and a lateen on the "mayne mizzen" and "bonaventure" masts. ${ }^{2}$

The guns were arranged-the heavier pieces-cannon

${ }^{1}$ See the model at the Naval Museum, Greenwich Hospital.

${ }^{2}$ At this time the Trinity House Brethren formed our school of 
(60-pounders), demi-cannon (32-pounders), cannon-petronel (24-pounders), and culverins (I 8-pounders)-on the lower deck, with demi-culverins (9-pounders) on the main. Sakers (5-pounders) and minions (4-pounders) were mounted on skids, or grooved blocks, on the quarterdeck, fore-castle and poop, with falcons (2-pounders), and falconets on swivels, "murdering pieces," "fowlers," "top-pieces," and "hailshot pieces." Some of the guns were of brass, but most of iron, and the smaller pieces were breech-loaders.

The size of the Harry is put in one list at $\mathrm{I}, \mathrm{OoO}$ tons, in another at I,500-owing to the loose methods of measurement in vogue. The unit of ship measurement, both in England and on the continent, at the time, was, as heretofore, the tun cask of wine, and the stated tons or tuns burthen of a ship meant the number of tuns or butts of wine she could carry. War-ships' tonnage was estimated by roughly comparing their bulk with merchant-ships of known carrying capacity.

The Harry Grace à Dieu may be taken as typical of the war-ship of the first half of the sixteenth century. King Henry's other large ships were only copies of her on smaller lines. The Royal Navy at this. time was roughly classified into "ships" and "galliasses" (huge galleys propelled by sweeps), and, for smaller craft, "roo-barges" and "pinnaces." Among general improvements introduced between Henry VIII. and Queen Elizabeth were the gradual lowering of the fore-castles,

naval design and construction, training master-shipwrights for the Royal dockyards, and drawing up the plans for proposed ships. They finally supplemented the imported Italian craftsmen whom King Henry brought over from abroad to build the earlier consorts of the Harry Grace à Dieu. 
and the sheathing the keels of ships with lead, an idea adopted from the Spaniards. ${ }^{1}$

There was a distinct move forward in Elizabeth's time. If the limits for larger ships were kept within I,000 tons these were built on longer keels, with lowered superstructures and finer lines than heretofore. This made them better sea boats than ships of the Harry Grace à Dieu type, swifter and capable of carrying more sail.

Such improvements, though, were not made without opposition. "Old salts" used to the ships of King Henry's time scoffed and shook their heads, and foretold disaster. "The new ships would be too crank to carry sail, and only fit for smooth water, and would inevitably founder in the heavy seas of the Atlantic."

Raleigh took up the cudgels for the new school. "The high charging of ships," he says, "makes them extreme leeward, makes them sink deep into the water, and makes them overset. Men may not expect the ease of many cabins and safety at once in the Sea Service. Two decks and a half is sufficient to yield shelter and lodging for men and mariners and no more charging at all higher, but one low cabin for the master."

Raleigh's "Discourse of the First Invention of Ships and the several parts thereof" details the progress made. "It is not long since the striking of the topmast (a wonderful ease to great ships both at sea and in harbour) hath been devised, together with the chain pump, which takes up twice as much water as the ordinary did. We have lately added the Bonnet and the Drabler"-extra

1 After being now tried, this experiment with lead was revived some eighty years later, in Pepys's time, with considerable success, for many ships continued to be so sheathed down to the introduction of copper. 
pieces laced to the foot of the courses, the "bonnet" first, and below it the "drabler." " "To the course," continues Raleigh, "we have devised studding-sails, topgrallant sails, spritsails, topsails." The weighing of anchors by the capstone is also new. We have fallen into the consideration of the length of cables, and by it we resist the malice of the greatest winds that blow. . . . We carry. our ordnance better than we were wont, because our nether overloop [the after orlop or lowest deck] is raised commonly from the water, to wit, between the lower port and the sea. We have also raised our second decks, and given more vent thereby to our ordnance lying on our nether loop. We have added cross pillars in our royal ships to strengthen them, which be fastened from the keelson to the beam of the second deck. . . . We have given longer floors to our ships than in the elder times, and better bearing under water."

Sir John Hawkins's plan for sheathing ships against the teredo worm must be added-by nailing to the ship's planking, below water, boards coated on the inner side with "tarre, halffe a finger thicke, and upon the tarre another halffe thicke haire. . . . The worm passing the sheathing, and seeking a way through, the haire and tar so involve that hee is choked therewith." Outside, the sheathing was coated with tallow, soap, and brim-

2 This must mean that the old method of making additional sail by these means had been suffered to fall into abeyance, for, as we have seen, the "bonnet" and "drabler" were old devices, in use among the Norsemen of six centuries before. Chaucer refers to the use of the bonnet, see "The Merchant's Second Tale."

2 Raleigh's "studding-sails" also. were different to what was at a later time meant by the term. 
stone, or train-oil, resin and brimstone boiled together, 'to preserve her caulking, and make her glib and slippery to passe the water." ' The large ships continued, as before, to be four-masted, with upright bowsprit and with circular ports. Top castles were still used for archers and arquebusiers to shoot down from.

The armament was the same as in Henry VIII.'s reign. "Great ordnance," cannon royal, I 2 feet long, and of $8 \frac{x}{2}$ inch bore, with a point-blank range of 185 paces, and extreme range ("long random shooting"), about a mile, cannon-serpentine, -bastard, -petro, and demi-cannon; culverins, basilisks, and demi and bastard culverins, sakers, minions, falcons, falconets, and rabonets. 'To work these the gunner had "ladles," a separate size for each kind of piece, to spoon the charges (ten per gun being the allowance) from the powder barrels into the guns. Also "priming horns," "irons" and "linstocks." "Sprights," or heavy arrows, as well as round shot, were fired from the smaller ordnance. The larger ships mounted from 40 to 60 "great ordnance," firing a broadside of some 400 pounds weight. For the small-arm men 200 arquebuses and 40 long-bows, with 80 sheaves of arrows per ship, were the usual equipment.

Tactics had now made a great advance. "Sea fights in these days," we are told, "come seldom to boarding or to great execution of bows and arrows, small shot, and the sword, but are chiefly performed by the great artillery breaking down masts and yards, tearing, raking, and bilging the ships."

The science of navigation, too, had made strides.

1 This device was generally adopted, and remained practically the favourite method down to the middle of the eighteenth century. 
In addition to a practicable compass in use before Henry VIII.'s reign, there were the "astrolabe" and the "cross" or "fore" staff. The astrolabe, for taking the altitude of the sun and stars, was a graduated circle with a movable diameter carrying light vanes, which was used

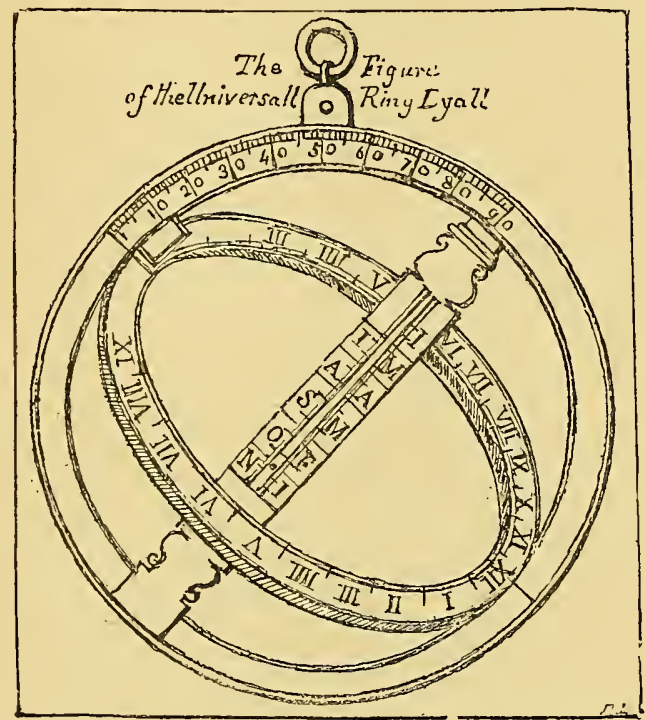

AN ASTROLABE, SIXTEENTH OR SEVENTEENTH CENTURY.

suspended by a ring representing the zenith. The angle required was obtained by moving the diameter until directly in line with the sun and the observer's eye. The cross-staff was a square graduated rod with two wooden cross-pieces, or "transversaries," that slid on it. After taking the bearing of the sun with the compass, the end of the staff was held against the observer's eye 
while an assistant moved the transversary until one end centred the sun and the other coincided with the horizon. In Elizabeth's Navy an improved cross-staff, called the "back-staff," or "Davis's quadrant," from the name of its inventor, the navigator, John Davis, came into use, as did the log-line, invented about the middle of the century by one Humphrey Cole.

Under the Stuarts (A.D. I604 to I7 I4).-Under King James I. a step forward in naval construction was made by the building of a larger ship-of-war than any since the Harry Grace à Dien. The Prince, or Prince Royal, designed by Phineas Pett, ${ }^{1}$ was a two-decker of 64 guns, I,200 tons burden, keel I I 4 feet, and 44 feet beam. She was four-masted, with the usual upright bowsprit mast. According to the official list of 16i 2 the Royal Navy at this time was classified under "shipps Royall" and "great shipps," ranging from I,200 to 800 tons; "middling shipps," ranging between 800 and 600 tons; "small shipps," ranging between 600 and 300 tons ; and "pinnaces" below 300 tons. King James's Prince was ere long, however, outdone by King Charles's Sovercign of the Seas, our first three-decker, "built to the great glory of the English nation, and not to be paralleled in the whole Christian world."

Thomas Heywood, who executed the carved work, described her in an elaborate treatise. "She has three

1 The Petts were a distinguished family of naval architects and shipwrights who first came into notice in Queen Elizabeth's time. Phineas Pett and his son Peter Pett the elder, in particular, who built all our men-of-war of note during the first half of the seventeenth century, were men of the highes repute for skill and attainments. There is a splendid model of the Sovereign in the Museum at Greenwich Hospital. 
flushe decks and a forecastle," he tells us, a "halfe-deck, a quarter-deck, and a round house. Her lower tyre hath thirty ports, which are furnished with demi-cannon and whole cannon throughout. Her middle tyre hath also thirty ports, for demi-culvern and whole culvern. Her third tyre hath 26 ports for other ordnance. Her forecastle hath I 2 ports and her halfe-decke I4 ports. She hath 13 or I 4 ports more within board for murdering pieces .... besides a great many loopholes out of the cabins for musket shot. She carries, moreover, Io pieces of chase-ordnance right forward, and ro right aft."

Heywood dilates on the gorgeous decorations of the ship. Her sides, he tells us, were "carved with trophies of artillery and types of honour, as well belonging to sea as land, with symbols appertaining to navigation, also their two sacred Majesties' badges of honour, arms with several angels holding their letters in compartments, all which works are gilded over and no other colour but gold and black. Upon the beak-head sitteth King Edgar on horseback, trampling on seven Kings," there being also at the bows "a Cupid bridling a lion," with allegorical figures, and at the stern a carved Victory "in the midst of a frontispiece," with other startling devices. From the keel to the poop lanterns - of which she had five, the largest of them so roomy that "ten people could stand upright in it"-the Sovereign measured 75 feet. $^{1}$

${ }^{1}$ Mr. Oppenheim gives the following details of the Sovereign of the Seas, which do not appear to have been known to Heywood. She is first mentioned in August, I634, when the Masters of the Trinity House volunteered the opinion that she was an impossible dream; that a three-decker was a thing "beyond the art or wit of man to construct." In January, 1635 , an estimate was called for for 
The Sovereign was, in Blake's time, cut down a deck, to a 90-gun ship, and had her fourth mast removed. In I684, on being renovated throughout, she was re-named Royal Sovereign.

The ordinary "capital" ships of King Charles's Navy as a rule mounted from 70 to 36 guns, and were of more manageable size; under 800 tons. Thus, in the list of I642, the James is set down as of 875 tons and 50 guns; the Victory of 793 and 46 guns; the Vanguard of $75 \mathrm{I}$ and 42 guns; the Reformation of $73 \mathrm{I}$ and 42 guns; the Rainbow of $72 \mathrm{I}$ and 42 guns. All

a vessel of 1,500 tons- "the king with his own hand hath set down the burden"-and in March Phineas Pett was ordered to prepare a model of "the ship royal." A month later he, Pennington, Mansell, and Wells met and agreed on the dimensions afterwards substantially adopted: gross tonnage, by depth, I,466 tons; by draught, I,66I tons; and by beam, I, $\$_{3} 6$ tons-no explanation given of method of arriving at the figures. Pett's estimate of cost, $£ \mathbf{r} 3,680$ -actual cost, $£ 40,8338 s$. I $\frac{1}{2} d$., exclusive of guns. Keel laid at Woolwich, in presence of Charles, on January I6th, 1636 ; launched October, 1637. Pett had recommended that she should not be launched until the spring, as she would grow foul lying in the river through the winter, but Charles had annotated "I am not of your opinion." It was intended to give her 90 guns, but here again we read : "His majesty has since altered his resolution, both in respect of the number and nature of pieces." In the end, 102 brass guns were required, at an estimated cost of $£ 24,7538 s$. $8 d$., thus divided: lower tier, 20 cannon drakes and 8 demi-cannon drakes; middle tier, 24 culverin drakes and 6 culverins; upper tier, 24 demi-culverin drakes and 2 demi-culverins; fore-castle, $\delta$ demiculverin drakes; half-deck, 6 ditto ; quarter-deck, 2 ditto ; bulkhead abaft the fore-castle, 2 culverin drakes. The guns were engraved, at a cost of $£ 3$ each, with the rose and crown, sceptre and trident, and anchor and cable, and the motto, "Carolus Edgari sceptrum stabilivit aquamm" - "being a scutcheon and motto appointed by his majesty." 


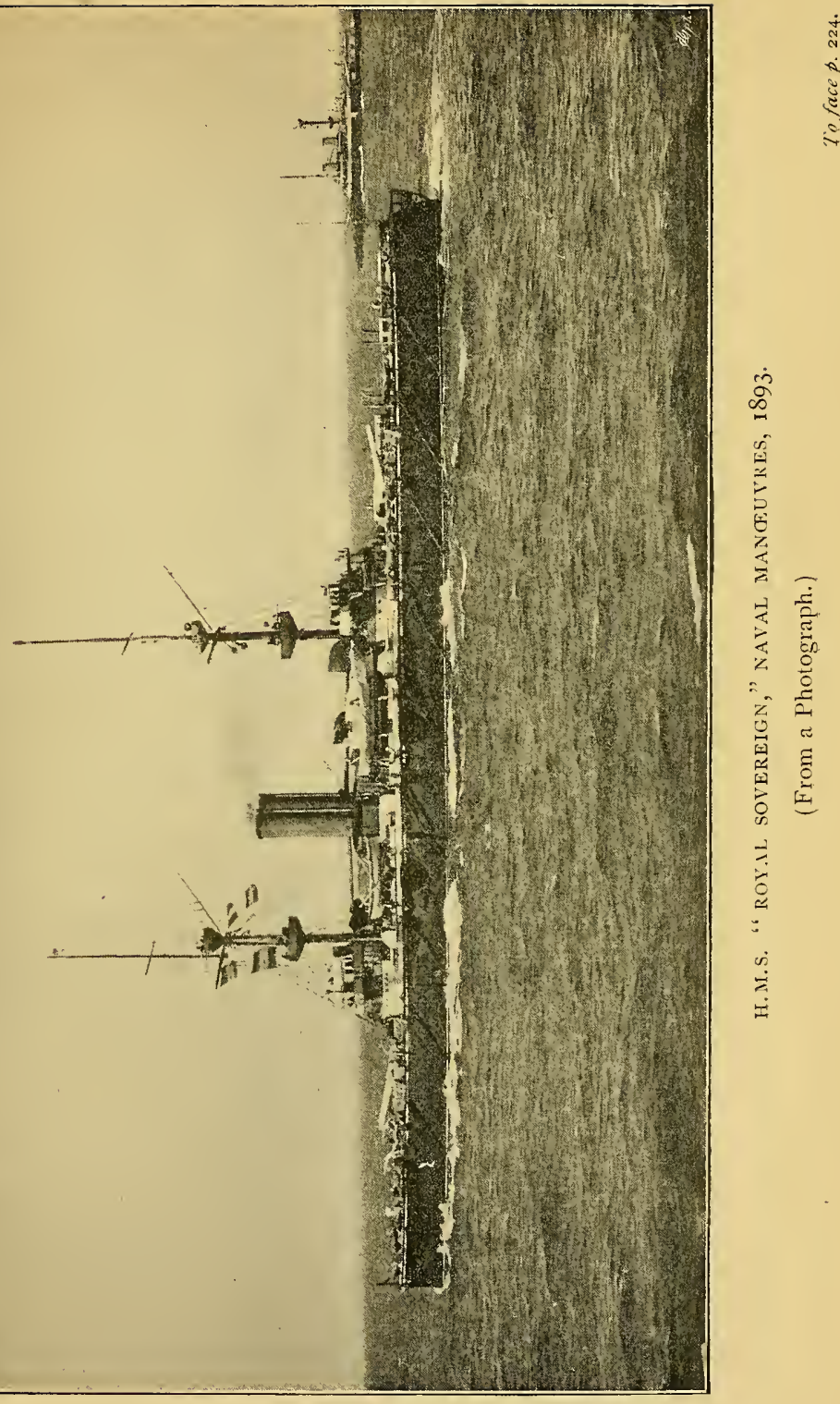



were well built, embodying every improvement up to date.

The old system of classifying ships by their size, as "great," "middling," "less" ships, was now altered in favour of regular "rates," which were at first classified according to the numbers of crew assigned to each. Somewhat later, in Cromwell's time, the rating of ships according to the number of guns carried became the regulation, a system rendered feasible by Pett's shipbuilding designs, which enabled ships to bring half their entire armament into action on one broadside.

Other notable reforms initiated under Cromwell were the reduction of masts to three, fore, main, and mizen, abolishing the "bonaventure" mast, the weeding out of the confused assortment of "cannons-royal," "culverins," "sakers," "demi," and "bastard" pieces, and so forth, hitherto used, in favour of pieces of not more than three or four distinct types. This last change, however, was only effected gradually.

As to what the men-of-war of the time were like. The stern towered up, broad at the water-line and narrow above, with right aft a narrow strip of deck from side to side. Below this another deck with a slight downward slope ran forward and ended at the mizen-the poop. The deck below the poop ended at the mainmast-the quarter-deck. Below the quarter-deck was the upper deck, "so called because it is the highest of all which runs the whole length of the vessel." Below this was the maindeck, where the heaviest guns were carried. The fore-castle was what its name implies-" a solid square fort rising from the level of the upper deck, rather higher than the poop, carrying guns, and capable of being held 
even if the rest of the ship is in the enemy's power." Above the fore-castle, by the linightheads, was sometimes erected a light deck, the topgallant fore-castle. The sails on the fore and mainmasts were courses, topsails and topgallant sails, with a lateen on the mizen. The bowsprit rose steeply from the square fore-castle and carried at the outer end a small mast with its "sprit topsail." As before, our men-of-war continued to be elaborately decorated with much extravagant carving and gilding over all.

Besides the broadside ordnance, swivel guns (patararoes) were mounted on quarter-deck and poop. In action there was still much reckless use of "fireworks" "arrows trimmed with wildfire to stick in the sails or ships' sides, hot and burning pikes of wildfire to strike burning into a ship's side to fire her," also "granadoes of divers kinds - hollow brass balls and earthen pots covered with quarter bullets stuck in pitch, and filled with good powder which, in a crowd of people, will make an incredible slaughter," "crossbar," "langrel," and "chain" shot. Old ships of smaller classes were made use of for fre-ships, now a tactical unit in all fleets, "besmeared with wildfire, brimstone, pitch, and resin, and all their ordnance charged with bullets and stones."

From Henry VIII.'s time onwards it was usual to attach ships of a small class and light build to each fleet as look-out ships or cruisers for scouting duty. They were called "pinnaces" and "fly-boats," and were vessels of about fifty tons burthen. From their small size, however, they were seldom used for independent cruising, their services being confined, as a rule, to attendance on fleets when at sea. For a hundred years and more, in fact, until Charles I.'s time, such small craft 
answered our needs, until the yearly depredations of the Dunkirk and Moorish pirates in the Channel began to come prominently under public notice, about the year I625. The master-shipwrights of the dockyards were now called on for designs of ships specially adapted for chasing privateers. They first proposed a cruiser whose length was to be nearly four-and-a-half times her beam. This was not accepted, however, and they next came forvard with "a nimble and forcible ship of 339 tons." But the Treasury could not stand the cost even of this, and finally a class of smaller craft, each of I 85 tons, was decided on. They were called "whelps," and were vessels built for sweeps as well as sails, threemasted and square-rigged, carrying Io guns (four culverins, four demi-culverins, and two sakers) on two decks.

For some twenty years the whelp class served all the purposes of the Navy, and then we hear of a decided step forward, which introduced a type of vessel that still more nearly approximates to the frigate classes of modern times. The idea originated with one of the Petts, whose Constant Warroick, built in I649, on the lines of a French man-of-war that visited the Thames, as a privateer for the Earl of Warwick, was sold to the government when the Dutch war broke out. The IVarreick, says Evelyn, was built "for a trial of making a vessel that would sail swiftly. She was built with low decks, the guns lying neare the water, and was so light and swift of sailing that she had ere the Dutch war was ended taken as much money from privateers as would have laden her; more such being built in a yeare or two did scour the Channel from those of Dunkirk and others which had exceedingly infested it." Upwards of sixty cruisers, in fact, 
were built on the lines of the Waraick after she proved such "an incomparable sayler." If the type of ship was new, however, the name "frigate" was not.

This term was originally used to denote a class of sailing galley used in the Mediterranean, and had also been the term for English merchant-ships for a century before the Warvick was thought of. Among the merchant-men serving against the Armada in Drake's squadron was a frigate Elizabeth Fownes, and before that Sir Humphrey Gilbert sailed to his doom in the little frigate, the Squirrel, of ten tons. King Charles, too, had a Swan frigate and a Nicodemus frigate, Admiralty yachts designed to attend the king on occasions of State. ${ }^{1}$

The Constant Waraick type of frigate, it must be noted, was essentially different from the frigate of later times. It was quite a century later that our first real frigate-a ship built to carry more than 24 guns on a single deck, with a quarter-deck and fore-castle-was built.

The largest Commonwealth man-of-war was the Ncseby, of I 556 ; of 96 brass guns and I,O00 tons, a ship the size of the Sovereign of the Seas cut down. Re-named Royal Charles at the Restoration, ${ }^{2}$ she was the ship the Dutch captured in the Medway and carried off.

The Royal Charles of 1668 that replaced her was still larger, and carried I Io brass guns. Next came the

1 They were Dunkirk prizes added in 1636 , and Pennington advised that the Swan should be taken as a model by the English builders. The Nicodemus was said to run away from everything "as a greyhound does from a little dog."

${ }^{2}$ In honour of being the ressel that brought the king over to England in 1660. 
Royal James ${ }^{1}$ of 1675 , constructed by Sir Anthony Deane, and embodying new ideas suggested by a French ship Sir Anthony inspected at Spithead. A still larger ship was built in I682, the Britannia, ${ }^{2}$ of 1,703 tons, 146 feet in length, with $47 \frac{\mathrm{r}}{2}$ feet beam and 22, feet draught. Unfortunately the prevailing tendency to "over-gun" our ships seriously affected their efficiency: "they sailed

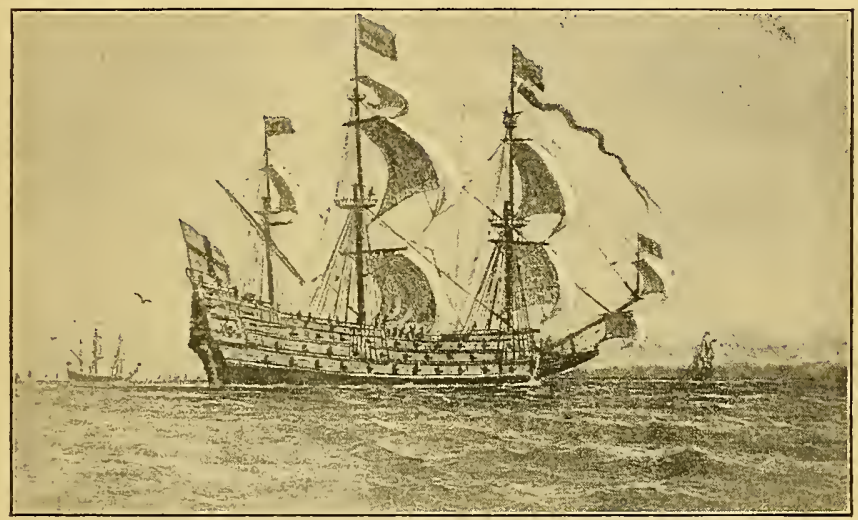

H.M.S. "ROYAL SOVEREIGN." LAUNCHED 1637.

(Arenhold.)

and worked heavily, while in rough or blowing weather the lower batteries could not often be used."

The Navy prospered under James II., and in I688 our position at sea was decidedly strong. Taking the Britannia of 1682 as the type of first-rate of the period,

' Became after 1690 the Victory, Admiral Allen's flag-ship in the battle of Barfleur or La Hogue in $\mathbf{1 6 9 2 .}$ There is a model of her at Greenwich.

2 Russell's flag-ship in the battle of Barfleur or La Hogue. 
the armament of this class consisted of twenty-eight 78 pounders, twenty-six 5I-pounders, twenty-eight 38pounders, fourteen 9-pounders, and four 6-pounders, a total of 100 guns. The Britamia cost, with rigging and equipment, $£ 33,390$. Second-rates were of 1,460 tons with a length of I 24 feet, 40 feet beam and I 8 feet draught, mounting twenty-six 63-pounders, twenty-six 4I-pounders, twenty-six 20-pounders, ten 9-pounders, and cost $£ 25,000$. Third-rates were $\mathrm{I} 20$ feet long with 36 feet beam, of I,O00 tons, and cost $£$ I 5,000 . Fourthrates, I0 5 feet long by 32 feet beam, of 532 tons, costing $£ 9,000$. The first and second-rates were three-deckers; third and fourth-rates, two-deckers; fifth-rates had all their guns on one whole deck and the quarter-deck; sixthrates on one deck only. In fleets, together with fire-ships, bomb-vessels were employed, these carrying one or two heavy mortars with a few light guns for self-defence.

The square sails were courses, topsails, and topgallant sails, with steering sails on the fore and mainmasts, spritsail and sprit topsail on the spritmast stepped on the bowsprit cap. Staysails and topmast staysails were in use, but jibs were not yet known. Cables were roo fathoms long, of $2 \mathrm{I}$-inch hemp, anchors being for first-rates, 430, I 5O, and 74 pounds weight; for second-rates, 3 I5, I IO, and 72 pounds; for third-rates, 173,96 , and 68 pounds. Besides the great guns, there were for the small-arm men muskets with match and snaphaunces, musketoons, blunderbusses, pistols, pikes, halberts, hatchets, swords, and hangers.

For navigation the back-staff or Davis's quadrant, was in use, with the log line, Gunter's scale and Briggs's logarithms.

About Charles II.'s time the old system of guessing the 
tonnage of ships by rough comparison with cargo-ships of like size gave way to a more scientific method of arriving at the result by multiplying the length of the keel by the extreme breadth and the depth of the hold, dividing the sum by Ioo. An ever-vexed question was the best method of sheathing, and all sorts of experiments, with lead and lacquer in particular, were tried, the authorities at length adopting a system, which lasted over a century, of studding or " filling" ships' bottoms with broad-headed nails hammered in close together, on which was paid a compost of tallow and resin.

The ornamentation of ships now reached its extreme pitch-the most elaborate carving and gilding being bestowed everywhere within and without, in the form of the arms and emblems of royalty, badges, wreaths, caryatides, tritons, dolphins, grotesque monsters, and so forth. ${ }^{1}$

By I6S5 the old-time guns, cannon, demi-cannon, culverins and sakers, had quite gone out in favour of guns classed by the weight of shot fired. The distribution of these was constantly simplified, and armaments definitely classified, in 90-gun, So-gun, 70-gun, 6o-gun, and 50-gun ships.

The establishment for first and second-rates in Queen Anne's time was 32-pounders on the lower deck (42pounders being permissible in larger first-rates), I 8 pounders on the middle, and 9-pounders on the main and

1 There are one or two very instructive models relating to this period at Greenwich Naval Museum. Henry Maydman, writing

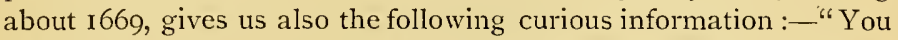
may modestly compute the charge of carving and painting, that is needless unto the Navy, at the twentieth part of the charge of the hulls of the ships of the Navy." Maydman also notes the danger to the ships themselves of all this garniture from its so readily catching fire. 
upper decks ; for So-gun ships, 24-pounders on the lower, I 2 -pounders on the middle, and 9-pounders on the upper deck; for 70 and 6o-gun ships, 24-pounders and $I S-$ pounders on the lower deck, and 9-pounders on the upper; for 50-gun ships, I2-pounders below, and 6 pounders on the upper decks.

This re-arrangement tended greatly to improve our lineof-battle ships and enabled tliem to keep the sea each

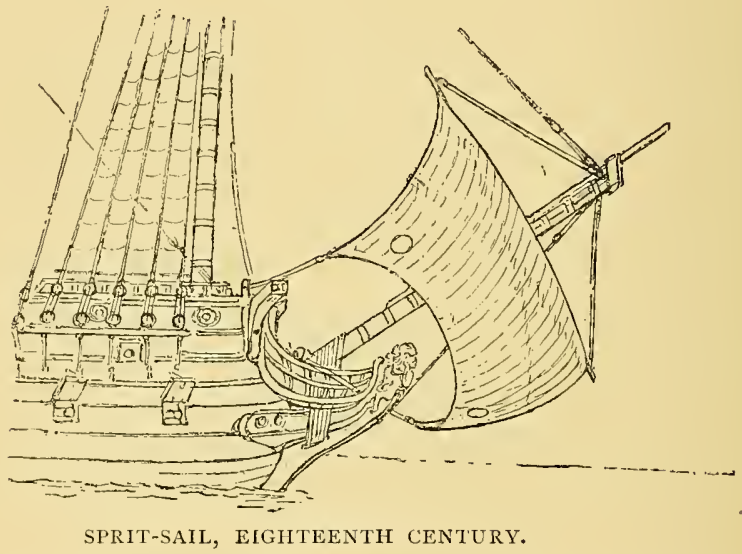

season longer than before, though there were still limitations. “An admiral," according to Sir Cloudesley Shovell, "would deserve to be broke who kept the great ships out after the end of September, and to be shot if he kept them out after October."

It was during the Restoration period that the hitherto closed-in sterns began to be built more open, with double. or treble tiers of ornate stern walk balconies, magnificently carved and gilded, thrown out from the light glass windows that filled up the entire afterpart of the ship. 
The prominent overhanging beak-an adaptation of the mediæval form of galley prow-so noticeable a feature in all men-of-war, from the Great Harry to the Sovereign of the Seas, and Royal Charles, now too disappeared, leaving nothing before the cutwater or stem. On this stem the figure-head was set as we still have it in sailing ships. It was, in first-rates, generally a carved wood equestrian statue of the ruling monarch, elaborately wrought with trophies and allegorical devices and emblems. For other rates, a lion rampant with open jaws and threatening aspect was the favourite cognizance, a type of figure-head which remained the special badge for British war-ships for over a century.

Inboard, the ship and her fittings were painted a dull red, in order, the tradition goes, to prevent blood-stains being too much en évidence in battle. It was also at the Restoration epoch that the regular wooden ship-gun carriage (painted red like the rest of the ship), with its four trucks, came into use. ${ }^{1}$ The old style of circular port had for some time gone out of use in favour of the square port, except on the upper and quarter-decks, where the circular ports, each surrounded by a gilt wreath, continued customary to the end of Queen Anne's time. The abolition of the circular ports throughout the ship for all decks was only recent though, as may be seen from a medal struck to commemorate James, Duke of York's victory over the Dutch on June 3rd, I665, where the ships shown on the reverse one and all have round ports. The exterior painting of the hulls of shipsof-war of the period was-for the upper works, above the

${ }^{1}$ A rudimentary form of carriage, also with trucks, had been in use since about the year 1600 ; it should be noted. 
line of the upper decks-dark blue encrusted with gilt ornamentation work; for the ship's side below this, down to the lower deck ports, yellow, with a broad band of black extending fore and aft at the water-line. Ships' bottoms were white, the colour of the "graving" mixture used.

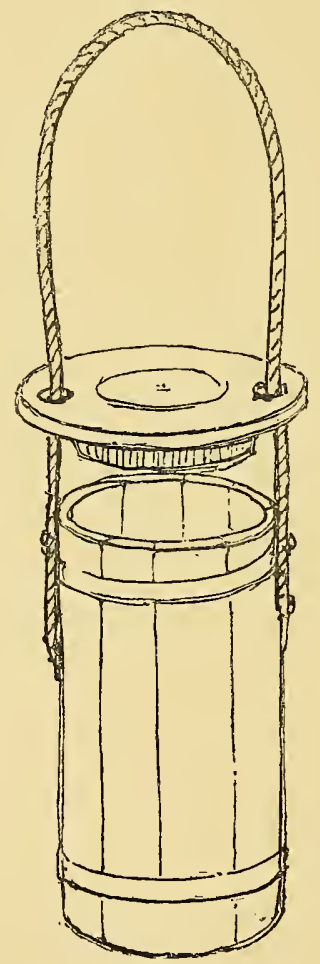

CARTRIDGE CASE. 


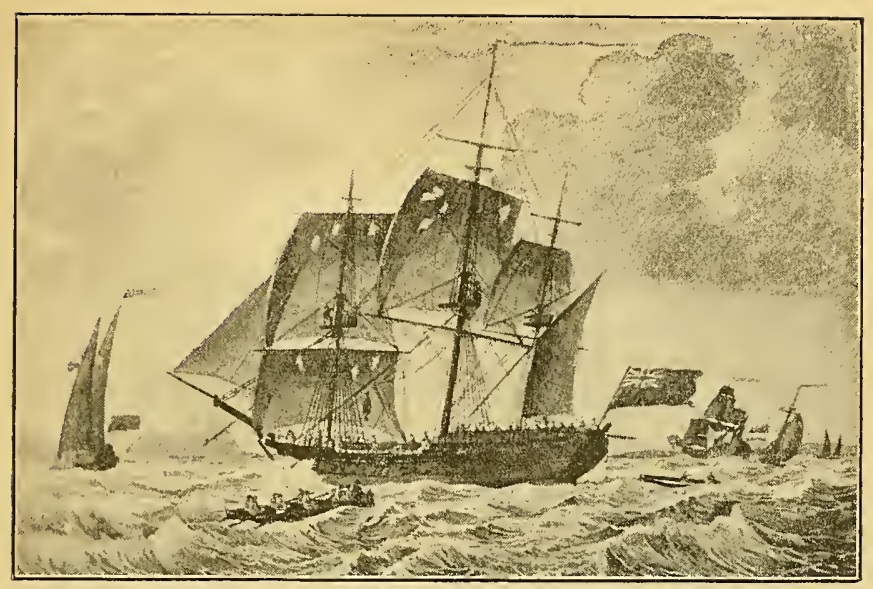

H.M.S. " ALARM," OFF GIBRALTAR, I7 8 I.

(A fifth-rate. Built circa I755.)

\section{CHAPTER III.}

'THE TRANSCENDENCE OF WOOD, CANVAS, AND HEMP IN NARINE ARCHITECTURE.

I 700 to I 860.- The line-of-battle ship classification of I690 into 90, 80, 70, 60, and 50-gun vessels lasted until after the Seven Years' War. For the first half of this period there was a gradual increase in dimensions. It ranged from $I, I O 0$ tons to $I, 550$ in the 90-gun class, the lower classes being correspondingly raised, with a tonnage difference between each class of some 200 tons.

Then came the establishment of the Navy Board scale of dimensions, of I7 I9, which officially fixed that 
existing tonnage dimensions in each class were to be considered as the limits. Much harm to efficiency resulted, for our shipwrights were practically compelled to stand still, regardless of the advances other nations made, notably the French and Spaniards. Even before I7I9 the French had been building superior vessels, class for class, to any we had. In I704, in fact, the Navy complained that the French 50-gun ships (to take one class only) were larger than our sixties, of better shape for speed, and better able to hold the wind.

Matters got much worse after the ordinance of 17 ig, with the result that in $\mathrm{I} 745$, when we were at war with the French, we had Admiral Knowles writing to Anson at the Admiralty: "Our 70-gun ships are little superior to their 52-gun ships." Our 80-gun ships, indeed, a Spanish officer described as "three-deckers on the dimensions of two-deckers."

Bitter complaints were repeatedly made of the crankness of our ships. In blowing weather, when our slower sailing fleets had their only chance of coming up with the enemy, while the batteries of the enemy's ships were "always open," we were unable, because of the crankness of the ships, to open the lower deck ports, or use our heavier guns at all. The weak scantling of our ships, less vital perhaps when navies retired every year bodily into port between October and April, was a serious defect now ships kept the sea all the year through. Another vital defect was the light metal of our ships, under the existing system, compared with the enemy's heavy broadside armaments.

The British man-of-war of the time was in every way an inferior craft-narrow in beam, lean bowed, and so deficient forward in bearing that pitching and rolling 
in rough weather imperilled the masts. The Ioo-gun ship of I 745 had a gun-deck of only I 78 feet, compared with the 165 feet gun-deck in the Ioo-gun ship of Charles II.'s time. There was this to be said for our ships: when we chased the French, if their fleets contained ships originally taken from us, the slowness of these invariably insured their lagging behind and consequent recapture. Our quondam French prizes at the same time always led in chase, and were practically the ships we relied on to catch the enemy with.

So seriolis did the situation become, that, though we were at war, a committee of flag-officers and Commissioners of the Navy had to be convened to consider the matter. New designs and suggestions for ships of all rates were called for from the dockyard master-shipwrights, but with poor results, for, as a fact, no one seemed capable of improving on the I7I9 scale. Fortunately a man like Anson was in authority, and at his instance the captured ships that we had at our disposal were turned to for models.

The French and Spanish battle-ships of the day were seventy-fours and sixty-fours - vessels designed with dimensions proportioned to their armaments. Taking these two classes for exemplars, to save time and expense a number of 9o-gun three-deckers were first cut down to two decks and a half, and given 74 guns. And then we set to work to build seventy-fours and sixtyfours of our own. The building of sixties and seventies, except those already advanced on the stocks, was at the same time stopped, and the inefficient So-gun threedeckers were abolished. How the Navy profited, those who served in the War of the Austrian Succession, and later in the Seven Years' War, discovered. 
With the Seven Years' War came in first the frigate class of the orthodox type; a vessel, that is, carrying her armament on one deck and built for independent cruising at a high speed. Hitherto, since the Constant Warwick, there had been nothing between the cramped, heavy sailing 44-gun two-decker of 850 tons, and the weakling 20-gun ship, a pigmy with popgun armament. The new, swift 28 and 32 -gun frigates (60I and 706 tons respectively) supplied a real need, and these " eyes of a fleet" from now on find a place in the British Navy. A larger class, the 36 -gun frigate (728 tons), was at the same time experimentally introduced, but only three of these were built.

As with our seventy-fours, we took our frigate models from the thirty-sixes and thirty-twos captured in the war. After the Peace of Paris, for economical reasons, sixty-fours came into favour, though seventy-fours continued to be built. Their average tonnage was-the sixty-fours, 1,436 tons; the seventy-fours, 1,790 ; a marked advance on the old seventies and sixties of fifteen years before, of which some were still among the ships in ordinary. Even the discarded So-gun three-decker had been of no more than $1,6 \mathrm{r} 5$ tons.

The day of the sixty-fours was not to last long. When the American War broke out they were numerous, especially in our over-sea squadrons; but the Navy condemned their small size, and we turned our attention exclusively to seventy-fours. Henceforward for fifteen years the seventy-four was the ideal fighting ship for the line of battle.

To fill the gap between the 74 and the three-decker 90 and roo-gun ships, after the disappearance of the old eighties-the new eighties on two decks did not 
come in till I793-the 98-gun class was created; at first by the expedient of adding eight quarter-deck guns to existing 9o-gun three-deckers, of whose light broadside complaint had been made. Later, after 1788 , a class of ninety-eights larger than the converted nineties was built, which lasted until after I 8 I $_{5}$. But the 98 was never a success, and was looked upon as an illegitimate sort of three-decker, introduced as a cheap substitute for regular three-deckers, such as the IO4 and the IIO-gun ship.

By this time (I795) our pioneer I Io-gun first-rate (I00 guns for a century and a half had been the limit in armament) had been launched, the Ville de Paris, named after Rodney's famous prize. Nine years later came a second, the Hibemia, and four years after that we sent afloat our first I20-gun ship, the Caledonia. It was, however, against our policy to build monster craft of such overpowering armament, though they were to be found in other navies of the time. We preferred, taught by ex. perience, a numerical preponderance of ships of medium dimensions-the 74-gun ship class, to wit. In fact, I 20 guns remained our limit in armament for first-rates down to 1850 .

The gradual increase of dimensions since the day of the Royal William, of ninety years before, is noteworthy. The Royal Willian, by the way, was I,9is tons, as compared with the two typical first-rates of the preceding century, Sovereign of the Seas, I, 547 tons, and Britannia, I,7O3 tons.

Then came in the Navy Board rules of I7I9. Compare, for example, the Royal William (of the year I 7 I9) with the IOO-gun ship Victory of 1737 (lost in the Channel, I744), of I,92 I tons (I74 $\frac{3}{4}$ feet length, $50 \frac{1}{2}$ 
feet beam, with $2 \mathrm{O}_{2}$ feet depth). Little more is the difference between the Victory and the Royal George of 1756 (Kempenfelt's ill-fated ship), of 2,04I tons (length 178 feet, beam $5 \mathrm{I} \frac{3}{4}$ feet, depth $2 \mathrm{I} \frac{\mathrm{r}}{2} \mathrm{feet}$ ); and not much more between the Royal George and the next big first-rate, the Victory of I 765 (Nelson's famous flagship), of $2, \mathrm{I} \sigma_{4}$ tons (I $86 \frac{1}{2}$ feet length, 52 feet beam, $2 \mathrm{I} \frac{\mathrm{r}}{2}$ feet depth).

The old trammels in dimensions still held in the roogun Royal George of I 790 (built to replace Kempenfelt's), of 2,286 tons-an increase on the Royal William of seventy-one years before of only 365 tons. The I Io-gun first-rate Ville de Paris, of 2,35 I tons, for her increase in armament, was little-larger. Then came the I20-gun ship, Caledonia, of 2,616 tons (length 205 feet, breadth $54 \frac{r}{2}$ feet, depth $23 \div$ feet), in which a tendency to advance first appears. The proportion of length to breadth observed in the first-rates during the century and three-quarters between the Sovereign of the Seas and the Caledonia was, taking extreme limits, in the Sovereign 3.46 to $\mathrm{I}$, in the Caledonia 3.82 to $\mathrm{I}^{2}$

Resuming from the period of the Great War onwards. In I793, just as the old nineties had been converted into seventy-fours some of the still existing old sixty-fours were cut down a deck, or "razeed" (a term that now came into use) into forty-fours. With the 50-gun twodeckers, of which we still had a number, these fortyfours formed a class of heavy cruiser, by themselves, a link between the line-of-battle ship and the frigate, that was useful for convoy and general service in distant seas,

${ }^{1}$ For a detailed narrative of our progress in shipbuilding during the seventeenth and eighteenth centuries, the reader is referred to Charnock's " Naval Architecture." 
The war with France saw marked changes in our frigates. The 36-gun class, re-introduced successfully about 1780 , became, with the old thirty-twos, the favourite cruisers of the day until ousted by the larger thirtyeights and forties (of 900 and 1,000 tons), which came in after I793. By capture we acquired, in addition, some very smart 44-gun frigates, the crack class in the French

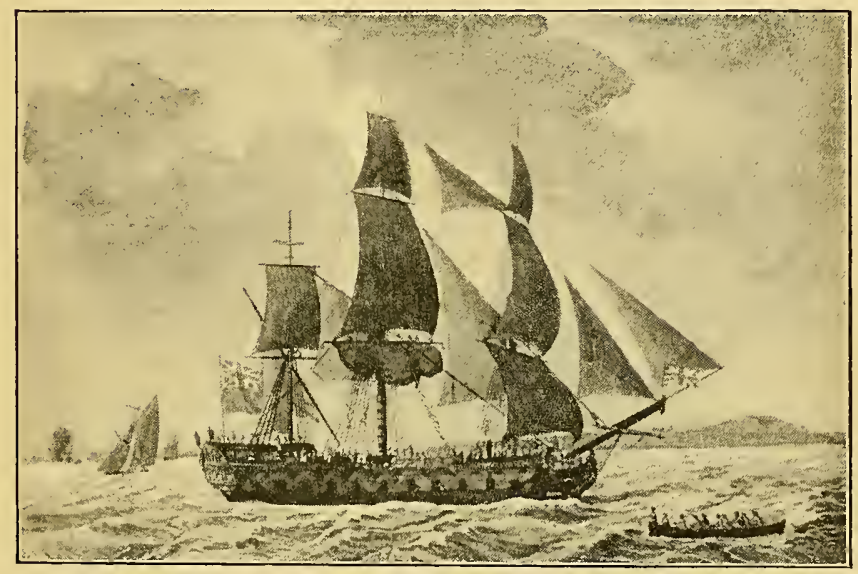

H.M.S. "MARLBOROUGH," OFF BEACHY HEAD, I 7 I.

(Third-rate, launched I767.)

navy, which proved ideal craft. The limit in frigates was reached in the 50 -gun frigates of 1,572 tons, of the year 1813 , that were specially built-in addition to the 50 -gun cruisers converted for the occasion from "razeed" seventy-fours-to cope with the American so-called "frigates."

It was really only in the Great War that we first began to proportion dimension to armaments, and that but $\mathrm{R}$ 
tentatively, learning the lesson at last after scientifically comparing ships we had captured with our own of the same rate. It was startling to find, taking the case of one class only, that French eighties were bigger and better than our ninety-eights or, indeed, than some of our first-rates.

The Canopus, So, taken at the Nile, for instance, was 2,257 tons; the Guillaume Tell, taken in I800, 2,265 tons; our own Neptnne, 98 (built in I796, the year the Canopus was built), only 2, I Io tons, our own Foudroyant, 80 (launched just six months before the battle of the Nile), a poor 2,062 tons. Still more striking was the case of the Commerce de Marseilles, of 120 guns, taken at Toulon in I793, whose tonnage of 2,747 was far above anything we built until the present reign.

Certainly, as has been said, the superiority of foreign models had been acknowledged long before, even earlier than Anson's time; but, tied down by the bonds of the Navy Board restrictions, they had proved practically useless to our shipwrights. Some improvement, though, had followed-the ships in the fleets of Keppel, Rodney, and Howe were certainly the better for suggestions gleaned from our old prizes of the Seven Years' War and before-notably, the three masterpieces, the French Invincible and Courageux, and the Spanish Glorioso, and, for the frigates, the French Hébe (taken in the war of I778)-but meanwhile foreign dockyards had gone still further ahead.

As with line-of-battle ships so with frigates; the prizes the fortune of war and better seamanship gave us after I793 (such as the famous Forte, 40, of I,400 tons) were revelations to our shipwrights. The lesson, if, perhaps, to some extent lost, owing to the restrictions in dimen- 
CHAP. III.] THE DAYS OF OAK AND HEMP.

sions still enforced, was now sufficiently taken to heart to allow of our having seventy-fours of our own, such as the Superb, of I,927 tons, and the Kent, of 1,964; and frigates such as the 40-gun Acasta and Cambrian of I, I42 tons.

The average cost of men-of-war in Nelson's timecoppered, masted, and rigged, but excluding armaments -is worth noting: Ioo-gun ships, each, $£ 67,600 ; 98$ gun ships, $£_{57, \mathrm{I} 20 ;}$ So-gun ships, $£_{53}, \mathrm{I} 20 ; 74$-gun ships, $£_{43}, 820 ; 64$-gun ships, $£_{35}, 920 ; 50$-gun ships, $£ 25,720 ; 44$-gun ships, $£_{21} 1,400 ; 38$-gun ships, $£ 20,830$;

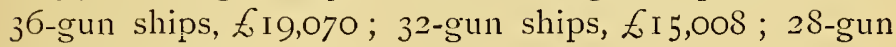
ships, f $\mathrm{I} 2,48 \mathrm{So}$.

The rates of the period were:-first-rates, above 100 guns ; second-rates, ninety-eights and nineties (the remnant "in ordinary"); third-rates, eighties, seventy-fours, and sixty-fours ; fourth-rates, fifties; fifth-rates (frigates), forty-fours, forties, thirty-eights, thirty-sixes, thirty-twos ; sixth-rates (frigates ana corvettes), twenty-eights, twentyfours, and twenties; below these came sloops, brigs-ofwar, cutters, and small craft. Intermediate classes in each rate, such as the II2-gun and 56-gun ships, were prizes from the enemy left with their original armaments. ${ }^{1}$

Our system of rating however was radically false, for the official ratings took no count of the carronade armament that every British ship carried in addition to her broadside guns, although these pieces, at the close quarters at which we fought, were every bit as destructive as the long guns. For instance, our 32-gun frigates, if they officially carried 32 long guns, mounted

1 See Fincham's " Naval Architecture." 
6 carronades as well, making $3^{S}$ pieces in all ; our nominal 38 -gun frigates actually carried 46 pieces; our 40 -gun and 44 -gun frigates actually 48 and 50 pieces. And the same with line-of-battle ships, though here the proportion of carronades to broadside armament was less marked.

It was only in $I S I 7$ that, by an Order in Council, carronades were first reckoned in a ship's armament, and a ship's nominal force brought into accord with her real fighting strength. The result was that new ratings had to be established with a new distribution of armaments in each class. First-rates henceforward comprised the larger three-deckers, mounting IO4 guns and over, up to I 20 guns; all smaller three-deckers (including the last of the ninety-eights) being classed second-rates. Thirdrates included the entire two-decker class, ranging from 92 guns to 58 ; the one-decked classes comprising ships mounting from 52 to 20 guns, which were all rated broadly as frigates. Corvettes, and sloops, brigs, and so forth, were under 20 guns.

This general re-arrangement was simplified by degrees by eliminating intermediate armaments, which, in the course of the next few years disappeared as the older ships passed away. So the old hundred-and-fours, ninetyeights, and seventy-fours of Nelson's time vanished, giving place to the hundred-and-twenties, hundred-andtens, ninety-ones, and eighties of the later years of our sailing Navy, with no intermediate classifications at all, and so on with the classes below, the old sixty-fours and two-decked fifties, which were similarly improved out of existence.

As a curiosity it may be noted that our last commissioned fire-ship disappeared just after Trafalgar 
CHAP. III.] THE DAYS OF OAK AND HEMP.

(there were seven in commission in 1800 ), and the last bomb (we had seven in commission in I8I5) after I $S_{3} 6$.

The old Navy attained its extreme development after I 832, when, on the appointment of Captain Symonds, a naval officer of high attainments, as Surveyor of the Navy, all restrictions as to dimensions and armament

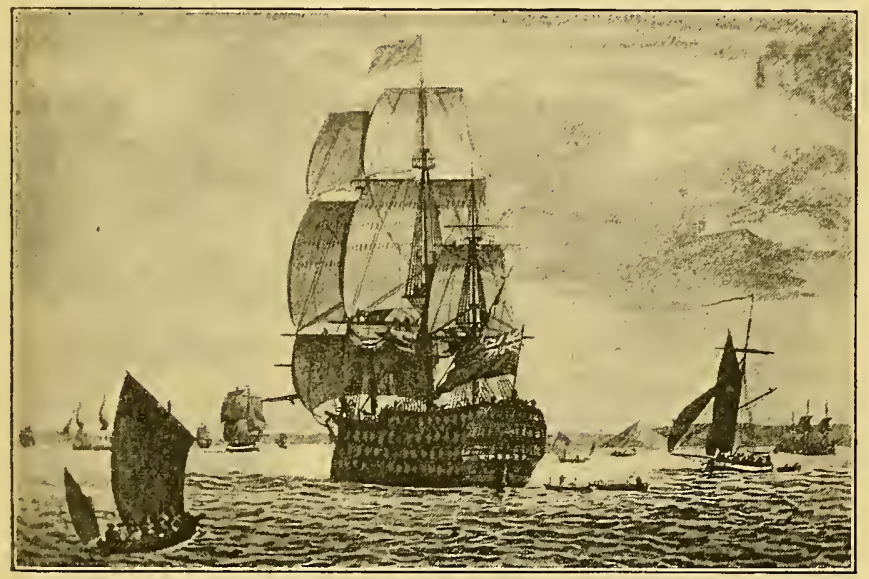

H.M.S. "LONDON," OFF PLYMOUTH SOUND, I78I.

(A second-rate, launched 1763 .)

were at last removed. Complete discretionary power was now given the Surveyor, with the result that our ships soon became the embodiment of efficient construction, each class exactly suited to its work.

The institution of a system of experimental trials with ships of various classes of the new types greatly furthered the advance made. This was the era of the magnificent I IO-gun ship Queen, of 4,476 tons displacement (3, IO4 
tons burden, old measurement), launched in 1839 , and the 8o-gun ship Vanguard, of 3,542 tons displacement, launched in 1835 . The special features of the new ships were increased speed and stability, greater breadth, loftier 'tween decks, and more roomy batteries. In the Vernon type of 50-gun frigate $(2,388$ tons displacement), launched in 1832, the British Navy found its ideal sailing cruiser. Between 1850 and 1860 came the final advance in dimensions for the large first-rates, vessels such as the grand I 3 -gun ship Duke of Wellington, and the later and still larger I 2 I-gun ships MIarlboroug $/ 2$ and Howe (note the reduction in armament), with which the sailing Navy of England reached its climax and its close.

Between 1700 and 1860 , notable accessory developments came into existence, by gradual modification and the suggestions of experience. The introduction of copper sheathing in place of the old "hobnail" bottom was of vital importance. Experimentally tried after I76I in one or two frigates the new idea proved successful, but trouble was caused for some time by the oxidizing of the iron fastenings used. Later, however, mixed metal fastenings were adopted, and then it was found practicable to use copper generally in the Navy. By 1783 every British man-of-war on service was copper sheathed.

Next the usage of building ships under cover, suggested by the Venetian practice, was instituted (after I792), with the practical result that our ships lasted twice as long as before. Towards the close of the Napoleonic war improvements of vital importance in the framing and strengthening of the hull were introduced by Sir Robert Seppings, one of the most eminent of 
constructors. These were the filling in of the openings between the timbers of the frame; the trussed frame and diagonal rider; the permanent fastenings of the beams to the sides by shelf-pieces; thick water-ways and side binding-strakes; and the laying of decks diagonally.

To Sir Robert Seppings we owe the device known as "scarphing," by which the "compass" or crooked timber for the knees and curved parts of the ship's frame could be artificially made with pieces of straight timber joined into the required shape, which ended the old state of things whereby ships, otherwise fit for launching, often remained on the stocks for months, until a few indispensable pieces of naturally bent timber could be obtained. We owe to Sir R. Seppings, further, the rounded bow (introduced after $I S I I$ ), such as we see in the wooden men-of-war still left us, in place of the hitherto existing weak beak head; ${ }^{1}$ and the abolition of the old flat stern for the round stern-an alteration which appears in ships built after ${ }^{-} \$ 20$.

The circular stern yielded after I 832 to the elliptical stern of Sir William Symonds-the form found in our existing wooden war-ships. Sir William Symonds' surveyorship is, moreover, specially notable for the radical

${ }^{1}$ A three-decker, the Namur, had, previous to I805, on the occasion of her being cut down, had her fore-castle removed and a circular bow built all the way up, but what particularly attracted attention to Mr. (as he then was) Seppings' proposals, was the shattered condition in which the Victory's weak beak head was found when she was overhauled at Chatham after Trafalgar. Below, where the Victory's bows were round, hardly a shot had penetrated; above, where the beak head was, the forepart of the vessel was matchwood. 
change in the lines below water of the hull that he effected in the ships he designed; the so-called "pegtop" bottom, which he substituted for the heavier full bottom, with many advantages.

The complete decking over of the deep waist between the quarter-deck and fore-castle, noticeable in old ships, was only accomplished in the period after the Great War. Half a century before, to get rid of the inconvenience of descending into the waist to pass from quarter-deck to fore-castle, narrow gangways, level with the top of the bulwarks, had come into use. These narrow gangways, after being at first supported by shelfpieces and brackets attached to the ship's side inboard of the waist, were gradually made wider, supporting beams being laid at intervals across the waist from bulwark to bulwark. To shelter those using the gangways in action and the small-arm men, a double canvas breastwork, stowed with hammocks as a protection from bullets, was run along the outer side of each gangway-the arrangement in vogue in the Trafalgar period. Later, after the war, the athwartship beams were decked over, with or without strips of grating amidships to let air below, and thus the "spar-deck" with a solid bulwark along the sides came into existence.

In matters of external and internal colour and ornamentation a notable change was made early in the nineteenth century. From I700 to about i 80 I blue upper works and canary yellow sides, with wide black strakes at the water-line, were usual for the exterior of ships, and blood-red for inboard surfaces. Lord Nelson, for reasons of his own, introduced in his fleet the chequered side, black and yellow - the exterior of the hull black all over, with a yellow strake along each tier of ports, the 
CHAP. III.] THE DAYS OF OAK AND HEMP.

exterior of the port lids also being black; and after Trafalgar the "Nelson mode," as it was called, was adopted throughout the service, white being later substituted for yellow. At the same time green (occasionally in a few ships buff or a pale brown colour was preferred) began to be adopted for the inboard colour, as a substitute for red. The inner sides of the portholes, however, continued until quite recently to be red. Later, early in her present Majesty's reign, white came into favour in place of green, and still remains so.'

The tendency throughout the eighteenth century was to cast off, both within and without, the elaborate decorations hitherto in fashion on ship-board. The Admiralty order of I 703 led the way, by directing the excessive bow ornamentation of scrolls and emblematic devices to be confined to plain figure-head with moulded trail-board, doing away at the same time with the heavy gilt-work brackets encrusting the stern-lights. The gilt wreaths round the upper deck ports and the carvings in relief, till now universal, went at the same time; also the hitherto customary gilt mouldings within board, for which was substituted a plain deal lining devoid of ornament. Canvas screen bulkheads, too, were now substituted for the carved wooden frame bulkheads which had been usual. The upper works above the quarter-deck tier continued, during the century, to be gaily adorned with royal cyphers and emblematic devices, painted at first on a band or ground of bright red or blue, and later on dull blue; but gradually the devices became less and less ornate, leaving only a plain band of blue along the

1. A visit to, the naval models at South Kensington Museum and the United Service Institution will show many examples of colouring during the transition period. 
upper works, which, in turn, vanished when the black hull of the "Nelson mode" came in."

During the eightecnth century heavily built stern galleries were universal, a triple tier in first-rates, a double tier in $9 S$ and 9o-gun ships, a single tier in seventy-fours and sixty-fours. These galleries began to be discarded at the beginning of the present century in third-rates-and soon after in all ships under 98 gunsfor closed glassed-in stern-lights. The stern galleries grew more simple in first-rates, until, finally, only a single plain stern-walk aft of the upper deck cabin is found in the largest ships of later types.

The well-known lion figure-head which during the sixteenth and seventeenth centuries adorned the prows and beak heads of English war-ships, was, by the order of 1703 , made our official man-of-ivar badge (except in cases of first-rates, which were given a highly-adorned equestrian effigy of the reigning monarch). This red or gilded lion remained our typical man-of-war figurehead till near the end of the eighteenth century, when it began to be replaced by brightly-coloured full-length effigies emblematic of the ships' names; a style that in its turn yielded, when the round bow and "Nelson mode" of painting came in, to the plain white bust or three-quarter length figure-head of our own times.

The old round top on the masts went out at the beginning of the eighteenth century. It disappeared on the bowsprit end with the spritmast (which left the jackstaff as a memento of itself) and the sprit-topsail. The

1 The gradual abandonment of ornamentation, and the tendency to substitute more and more sober-hued colours, can be traced in the admirably arranged series of models at the Naval Museum, Greenwich. 
CHAP. III.] THE DAYS OF OAK AND HEMP.

spritsail beneath the bowsprit remained till nearly the end of the eighteenth century, when it disappeared, its naked yard, after a time, being replaced by spritsail-gaffs. As the bowsprit decreased from a mast (its original form) to a spar, the masts proper were gradually lengthened, while, above the topmast, the topgallant mast came to be

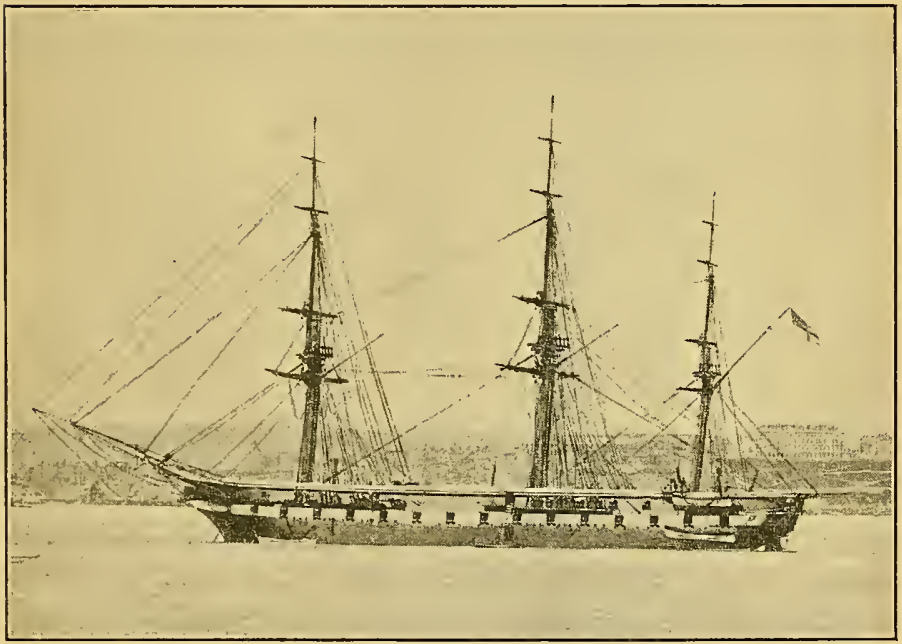

H. M.S. "LIVERPOOL," I 863 .

$(2,656$ tons, old measurement ; 600 nominal horse-power. $)$

added. The old lateen mizen yard and sail existed to the last decade of the last century, when the spankergaff and boom came in. This latter spar, as it extended over the taffrail more and more, eventually forced the ensign-staff out. Staysails were in use in Queen Anne's time ; royals, or as they were called, "topgallant royals," 
came in, with studding sails, ${ }^{1}$ in the latter half of the eighteenth century, also the flying jib.

Chain cables, first used after I 8 I I, proved an immense boon, saving space below and being cleaner and easier to handle: iron tanks for fresh water in place of the old foul, unhealthy wooden casks ; and iron ballast, instead of the old stone and shingle ballast, came in a little later; copper powder cases in place of the old wooden kegs came in about I 812 ; hide-thong tiller ropes in 1807 ; and after that leather storm sails, and "bull's eyes" for portlids to give light in rough weather.

In gunnery, meanwhile, notable improvements were made. The old 58-pounder "cannon-royal," and 32pounder "demi-cannon," with the 24-pounder, I2pounder, 5-pounder, "sakers," and $2 \frac{x}{2}$-pounder "faucon," were the naval guns of the later Stuarts. They did not go out until George I., when the 42-pounder and 32-pounder, so designated, were introduced, with the 6-pounder, in place of the "saker" and "faucon," which now disappeared. The armament of a Georgian first-rate with the new guns was:-lower deck, 42pounders ; middle, 24-pounders ; upper, I2-pounders, with 6-pounders on quarter-deck and fore-castle. This arrangement was modified in George III.'s reign, when I 2-pounders replaced the 6-pounders. Towards the middle of the reign there was a further modification, and 32 -pounders began to replace the 42 -pounders in certain of the first-rates.

The 32-pounder had, meanwhile, been the heaviest gun for line-of-battle ships below first-rates. Naval officers considered this to carry a sufficiently heavy

${ }^{1}$ Referred to two hundred years before by Raleigh as a new idea in his time; but another sail was meant. 
projectile, and such guns were more easily worked pieces than the bigger 42-pounders. Also the heavier ordnance was condemned as straining the frame of a ship in rough weather. For these reasons 42-pounders were withdrawn in favour of 32 -pounders in all firstrates. For thirty years and more, after Trafalgar, the 32-pounder remained our heaviest service weapon, Stronger ships, however, were then in the Navy, and the discarded 42-pounders ( 8 -inch calibre) began to be replaced. The 68-pounder was at the same time introduced. These last were the heaviest pieces used in the old Navy. Calibres below the 24-pounder were now done away with, and a little later all below the 32 pounder, effecting a great gain in simplicity of armaments. Thus in the first-rate of the last period, such as, for instance, the I 2 I-gun ship $M$ arlborough, we find only the three pieces-68-pounder 8 -inch, 48-pounder, and 32-pounder.

The two chief gunnery inventions between I700 and I 860 were the carronade and the shell gun. The carronade, so called from the place it was first founded at, Carron, near Falkirk, was introduced in I779. Its characteristics were, that while shorter than the 4-pounder, and lighter than the 12-pounder, its calibre enabled it to throw a shot equal to a 32-pounder. A still larger calibre was introduced later, the 68-pounder, and the Carron Iron Works Company proposed Ioo and I 30pounders. These pieces were considered unnecessarily heavy, and were declined by the Admiralty.

At first, objections to the carronade were raised in the Navy :-it quickly became too hot to work continuously in action; it was clumsy; its recoil was liable to carry away the breechings; its range was too limited; its 
shortness endangered the sides of the ports it fired through. But the practical advantages of the weapon gradually asserted themselves, and, after being satisfactorily tested in frigates, it was, in 1797 , ordered for all line-of-battle ships, in place of the fore-castle and quarter-deck 9-pounders. Nevertheless, as has been remarked, carronades were not counted in the ship's nominal armament. Still more revolutionary in its effect - for it eventually wrought the doom of the wooden ship-was the introduction of shell guns for sea warfare, due to the initiative of a French officer, Colonel Paixhans, in 1827 .

Numerous progressive developments in gumnery appliances took place during the eighteenth century. Gunlocks and tin firing-tubes were introduced, in place of the old powder-horn and linstock, in some ships towards the close of the Seven Years' War. But objection was raised that the tubes were mischievous, and caused accidents in the 'tween-deck batteries, and they were practically given up and the old match tub returned to.

It was not till after 1780 that the gun (flint) lock with an improved tube was finally adopted, match tubs being employed at the same time, in case of the locks failing. The detonating lock and percussion tube came in I 842, and a few years later flannel (which, like the old flintlock had previously been tried and given up) replaced paper for cartridges.

The old truck gun-carriage, introduced in the seventeenth century, remained in use till 1865 , in fact, after the wooden ship itself had been condemned. The marked quoin, with its roughly-cut scale of elevation, which had been in use from early times, only went out in 1825 when the elevating screw came in. Rockets 
first formed part of ships' equipment in 1833 , and three years later, field gun-carriages for landing parties were for the first time supplied to the Navy.

Among the scientific inventions of the eighteenth century of particular benefit to the Sea Service, the most notable were Hadley's invention of the sextant for determining latitudes, in I73I, and Harrison's invention of the chronometer for determining longitudes, in I762. No less important was the publication of the "Nautical Almanac" by Dr. Neville Maskelyne, the Astronomer Royal, begun in 1767 .

In I762 a proposal made to Anson for supplying lightning-conductors to the Royal Navy, was adopted, and conductors made of jointed lengths of copper rod were supplied, packed in boxes, from which they were to be taken out and erected before a storm. This type of conductor, supplied to Captain Cook, proved its value over and over again. Among naval officers generally, however, it was looked on as a mere scientific toy, and therefore seldom used, the rods being left in the boxes they came in; a course that cost the country in the Great War, when our ships covered every sea, many lives, and a money loss in damage to ships of over $£ \mathrm{I} 00,000$. It was, indeed, only in I 844 that lightningconductors were definitely established in the service.

A regular system of ventilation, on the plan of a Dr. Hales, by air-pumps and miniature wind-mills was introduced in 1753 . It remained in use nearly fifty years, and proved of high benefit, both to the health of our crews and the preservation of our ships. Experiments were first made with distilling apparatus on board ship in 1702 , but certain practical difficulties were not surmounted till early in the present century. The steering 
wheel, it may be added, first came into general use early in the eighteenth century taking the place of the old whip-staff.

A complete alteration in the system of reckoning marine tonnage was enacted by I 3 th Geo. III., cap. 74, which did away with the old method of measurement by multiplying together length, beam, and depth of hold. The elaborate formula,

length (cutwater to stern-post) $\times$ extreme beam $\times \frac{\text { extreme beam }}{2}$

$$
94
$$

which took its place, remained the official system of measurement down to the introduction of the modern system of computation by displacement.

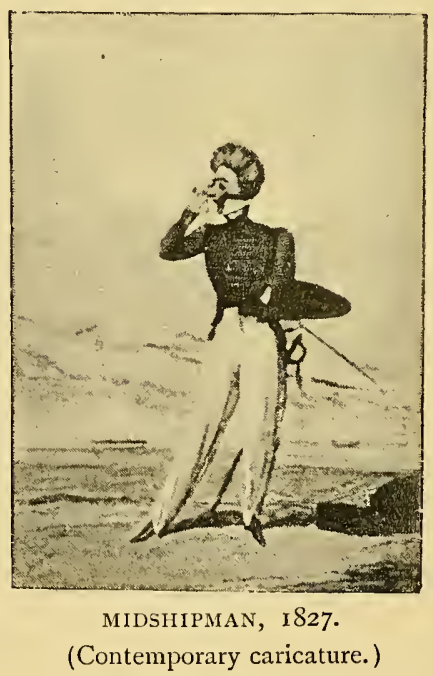




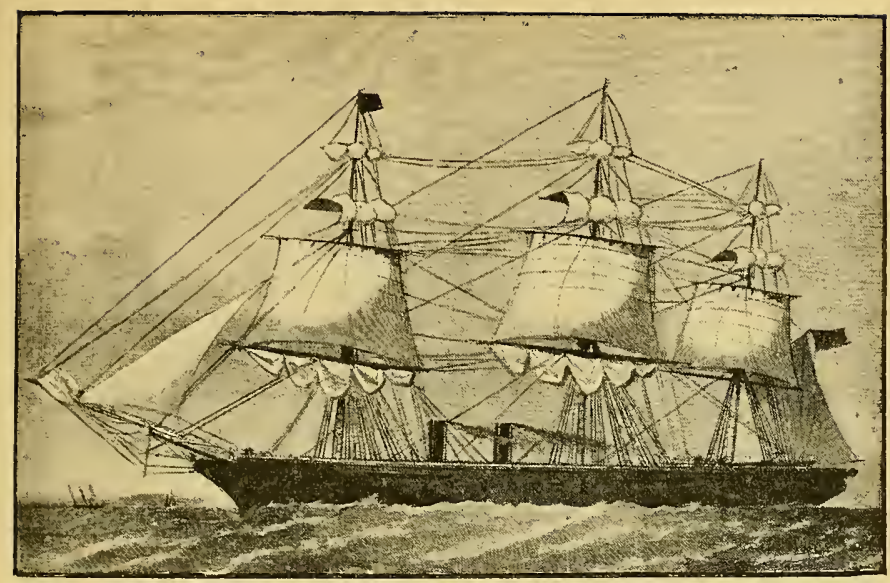

H.M.S. "WARRIOR," I 863.

(Laid down at Blackwall, May 25th, IS59. Completed I86I.)

\section{CHAPTER IV.}

THE ROYAL NAVY OF TO-DAY.

OUR modern Royal Navy is practically the creation of the past thirty years. It dates, in fact, from the introduction of armour and rifled ordnance, the appearance of which on the scene condemned the older Navy to vanish off the face of the sea. The history of the development of the Royal Navy of to-day is, in a sense, writ large in the types of the fighting ships of which it is comprised. In their wide variety our battle-ships and cruisers furnish evidence which shows by what gradual 
steps the art of modern naval construction has been evolved. Each type of ship in turn has been introduced, as an experiment, as an improvement on its predecessor; the new types, as each appeared, taking precedence of, and thrusting back into a secondary position, the type that went before, and so on. ${ }^{1}$

Dealing first with battle-ships. Our earliest series of types are for the most part comprehended in what we now officially designate as the "third-class," though some of the earliest ships of all, such as our older broadside ironclads, of the Warrior, Aclilles and Minotaur groups, are now placed outside the battle-ship category altogether and classified as cruisers. As at present constituted this "third-class" comprises existing battle-ships of 6,000 tons and upwards, built between $\mathrm{I} 866$ and I872, and capable of II knots speed at least. In this class are included the ships of the belt and battery type which succeeded the broadside ironclads: the Belleroplion, Hercules and Sultan, the Invincible, Audacious and Iron Duke, the Swiftsure and Triumph; together with our earliest surviving turret-ship, the Monarch, ${ }^{2}$ and the small modern battle-ships Conqueror and Hero, built ten years ago as second-class battle-ships.

The present second-class comprehends the former firstclass battle-ships of the period between I 873 and I 885 ,

1 The term "battle-ship" is the modern adaptation (officially adopted in the re-classification of I892) of the older form of "lineof-battle ship," or "ships fit to lie in a line," in battles between fleets, in troduced under James I. to distinguish these from vessels intended for independent cruising. As in time past, so in the future, battle-ships alone can decide the fate of a war.

2 Our first turret ironclad proper was the converted three-decker Royal Sovereign of I864; our second, the ill-fated Captain, lost in 1870. 
vessels of 8,500 tons and upwards, capable (like those of the third-class) of a minimum sea speed of I I knots. In the list are found the turret sea-going monitors Devastation, Thunderer and Dreadnonght, the turret-ship Neptune, the later belt and battery ships Alexandra, Superb, and the belt and barbette ship Téméraire, to-

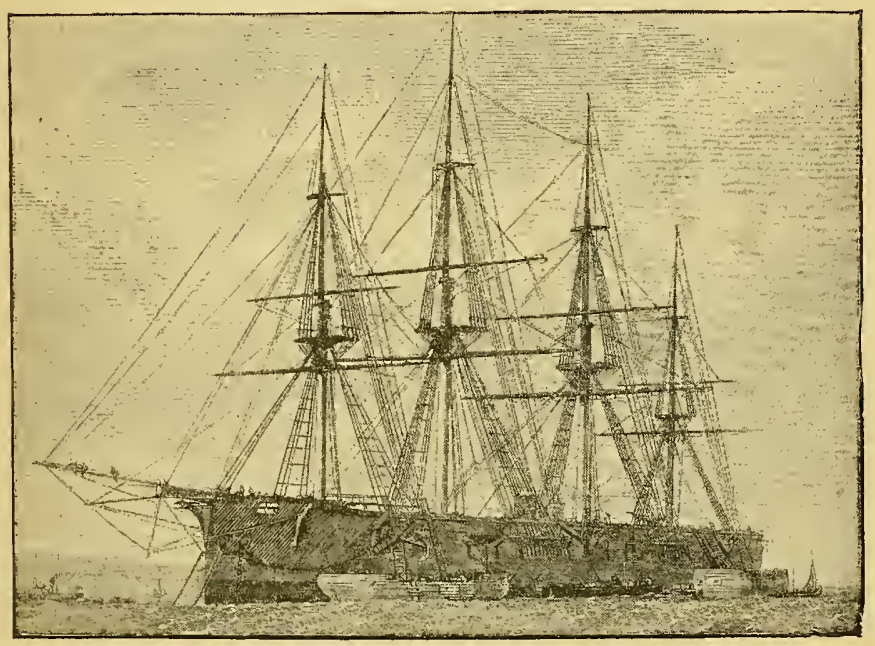

H.M.S. "ACHILLES," I 868 .

(9,820 tons displacement ; 5,000 horse-power. Completed I864.)

gether with the "citadel" turret-ships Inflexible, Ajax, Agamemmon, Colossus and Edinburgh.

Our first-class counts in all the new turret and barbette battle-ships built since I $\$ 86$, vessels of 9,500 tons and upwards, of not less than I 3 knots sea speed, and mounting guns of a minimum calibre of Io inches. In the roll are included the so-called "Admirals," the barbette ships 
Anson, Benbow, Camperdoren, Collingrwood, Howe and Rodney, the turret-ship Sans Pareil (sister to the ill-fated Victoria), the turret-ships Trafalgar and Nile, the Naval Defence Act turret-ship Hood, and barbette ships Royal Sovereign, Empress of India, Ramillies, Repulse, Resolution, Royal Oak, Revenge, with the smaller Barfleur and Centurion, the Renown, and the battle-ships of the Spencer programme under construction, the Majestic and Magnificent, and their congeners.

Two of the older ironclads, the Orion and Bellcisle, have dropped into the fourth or coast defence class, and now rank with the flotilla of small but powerful vessels of the Rupert, Hotspur and Cyclops group. In the same class the older ironclads Prince Albert and Penelope, built between 1860 and 1870 , also are now included. ${ }^{1}$

One specially-designed vessel, the torpedo ram Polyphem and machine) guns that she mounts are designed solely to keep off small craft while she performs her allotted work of employing her peculiar offensive weapon as an auxiliary to a battle-ship fleet in action. She has been too costly to be deemed a success.

As with the battle-ships, our cruisers are divided into three groups or classes, and in these the existing types are as various as are the battle-ship types. In like manner they represent a gradual development. High speed, with no armour at all or other protection, was

1 What Great Britain really wants with such craft--except as perhaps station ships in certain places, and for use in that capacity their speed is too slow-is doubtful. In time of war our real coasts are the enemy's own shores, controlling the sea to within gunshot of the enemy's land defences. Practically coast defence ships are useless to us, and ought to be left out of all reckoning. 
aimed at in our earlier cruisers, represented in the Navy to-day by the Inconstant, Active, and Volage. The corvette class, smaller vessels of medium steaming ability but full sail power, next came into favour. Then we took up with the armoured heavy cruiser, fully masted and rigged, represented by the Nclson, Northampton, and Shannon.

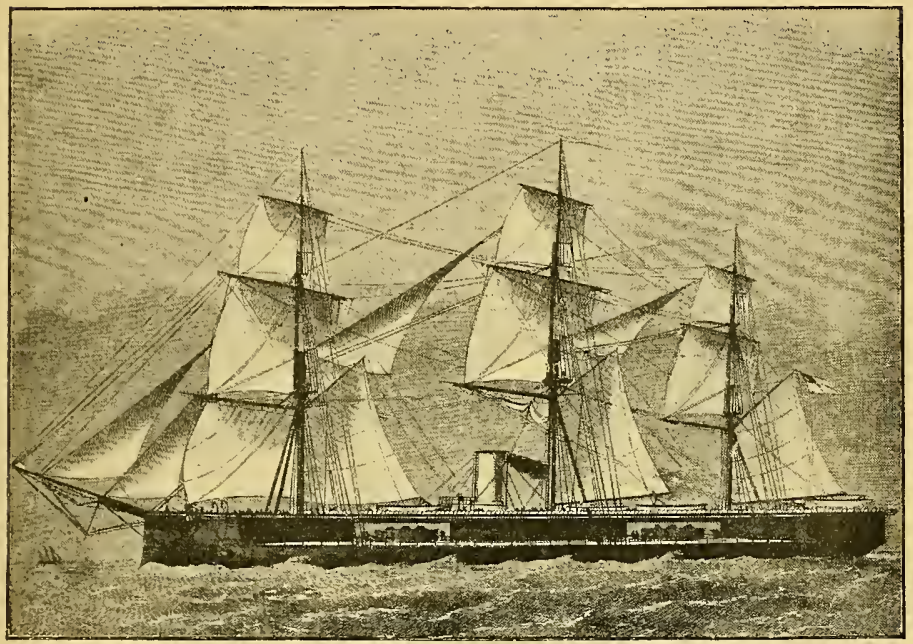

H.M.S. " CAPTAIN."

(Launched at Birkenhead, March 29th, 1869. Capsized in the Bay of Biscay, September 6th, 187o.)

After that, proceeding by degrees through the swift despatch-boats Iris, Mercury, and the Calliope unarmoured cruiser class, we arrived at the mastless, swift, armour-belted cruiser type, of which the Warspite and Impérieuse and Orlando classes are examples, passing later to the accepted modern type of cruiser, which, 
while carrying no side armour, is protected by means of a horizontal steel deck over the vitals. Such as these last are the Blake and Blenheim, the Edgar and Talbot, the Powerful and Terrible, and other cruisers of the Hamilton and Spencer programmes.

In consequence of the existence of this variety of types we have included in the three regulation cruiser groups, under the present official classification, many different sorts of vessels. In the first-class count old broadside ironclads of the Warrior, Achilles, and Minotanr classes (re-boilered and partially re-armed with quick-firing guns) and the heavy cruisers Shannon of I 875 (a type by itself), and Nelson and Northampton of I876. Also the completely belted, powerful barbette cruisers Impériense and Warspite, and the Orlando type, comprising, besides the Orlando herself, the Aurora, Anstralia, Galatea, Immortalité, Narcissus, and Undannted. The Warrior, Black Prince, Achilles, Agincourt, Northumberland, and Minotanr, like the Shannon, Nelson, and Northampton, are old and slow (I4 knots) vessels, though capable enough for convoy and commerce protection in time of war. The others are swift and powerful vessels - the Impériense and her sister ship-of 8,400 tons and 10,000 horse-power ( $16 \frac{\mathrm{I}}{2}$ knots), mounting four 22-ton guns, with a subsidiary armament; and the Orlando class of 5,600 tons and 8,500 horse-power ( $18 \frac{1}{2}$ knots), mounting two 22-ton guns, with subsidiary armament.

The newer first-class cruisers are steel-deck protected vessels, of high speed and coal capacity. They comprise the Blake and Blenheim, ships of 9,000 tons and 2 I knots speed, mounting 22-ton guns for main armament, the Royal Arthur and Edgar group (nine vessels), ships of 7,350 tons and 20 knots speed, with similar armament, 
and the Powerful and Torrible of 14,200 tons and 22 knots speed.

In the second-class are the twenty-nine cruisers of the Apollo and Astrea types, of the Naval Defence Act, ships of 3,400 tons and 20 knots speed ; and the "protected" steel-deck cruisers of the Mersey class, ships of 4,050 tons, I 8 knots speed (Forth, Serern, and Thames). The Leander

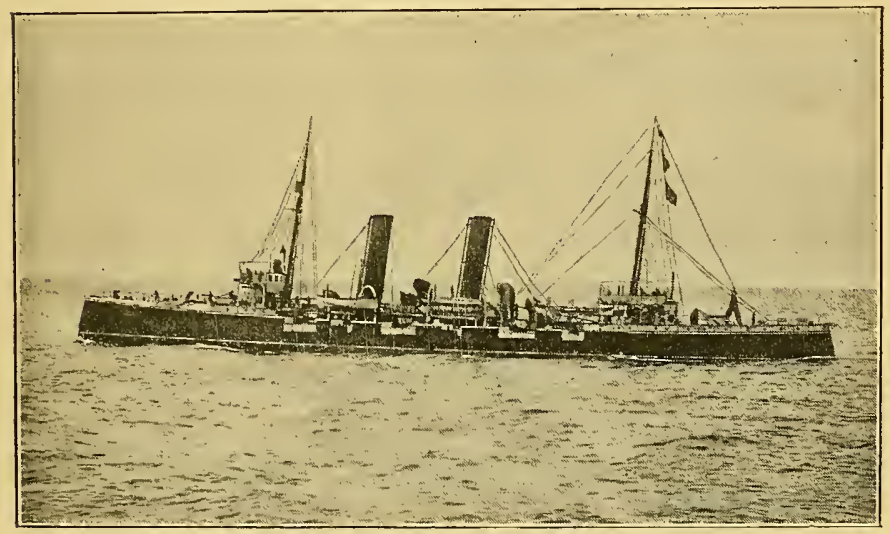

H.M.S. "MELAMPUS."

(3,400 tons displacement; 9,000 horse-power. Completed I89o. Built by the Naval Construction and Armaments Co., Barrow.)

type of cruiser(Leander, Amphion, Arethusa, and Phaeton), ships of 4,300 tons and 17 knots speed, also count in the second-class. In this category also are included the despatch cruisers Iris and Mercury (protected by the arrangement of their coal bunkers), of 3,730 tons and i 8 knots speed, and some of our older cruisers-such as the Inconstant, Active, and Volage, built about i869, the 
Raleigh, built in 1873, and the Bacchante and Boadicea, built about i $\$ 76 .{ }^{1}$

The third-class is similarly formed of cruisers of various types and ages. It includes vessels ranging in size from the cruisers of the so-called " $M$ " class (five ships), of 2,950 tons and 19.75 knots speed (Magicienne, Marathon, etc.), down to the small vessels of the Tartar and Archer class, of $I, 770$ tons and $I 7_{2}^{\frac{1}{2}}$ knots speed. In the thirdclass also are the Pandora group, to which the five cruisers provided by the Australian Colonies belong, ships of 2,575 tons and I9 knots speed, the Barham and Bellona, of I,830 tons and 19.5 knots speed, the Barrosa, Barraconta, Blanche and Blonde, of 1,580 tons and $16 \frac{1}{2}$ knots speed; the eight ships of the "C" class (Canada, Champion, Carysfort, etc.), vessels of 2,380 tons and 12 to I 4 knots speed, the Heroine and her sisters, the Hyacinth, Pylades, Rapid, Royalist and Satellite, ships of I,420 tons and I 3 knots speed; and the four old vessels of the "Gem" class, ships of 2,120 tons and I 3 knots speed (the Emerald, Garnct, etc.).

Below the cruisers come various groups of smaller craft: sloops, such as the Espiègle, Icamis, Nymphe, and Swallow, averaging I,000 tons; gunboats, such as the Curlew, and smaller fry like the Goldfuch, Thrush, and Redbreast, of 700 or 800 tons ; torpedo gunboats of various types, iike the Rattlesuake ( 550 tons and 19 knots speed), Grasshopper (525 tons and 19 knots speed), Sharpshooter (735 tons and 2 I knots speed), Alarm and Speedy (800 to I,000 tons and 19 to 20 knots speed), and

${ }^{1}$ On the speed and sea-keeping capabilities of the first and secondclass cruisers, acting as what Nelson called the "eyes of a fleet," our squadrons will in wars of the future have to rely for information, and the performance of scouting duties before the enemy. 
the flotilla of torpedo boats, of various sizes between 90 and 150 feet long, added to the Navy since 1877 , when the torpedo boat was first adopted into the service.

Between the Spcedy class and the torpedo boats proper comes the new "Destroyer" class, in which the Havock, Daring and Homet, twin-screw vessels of 220 tons and

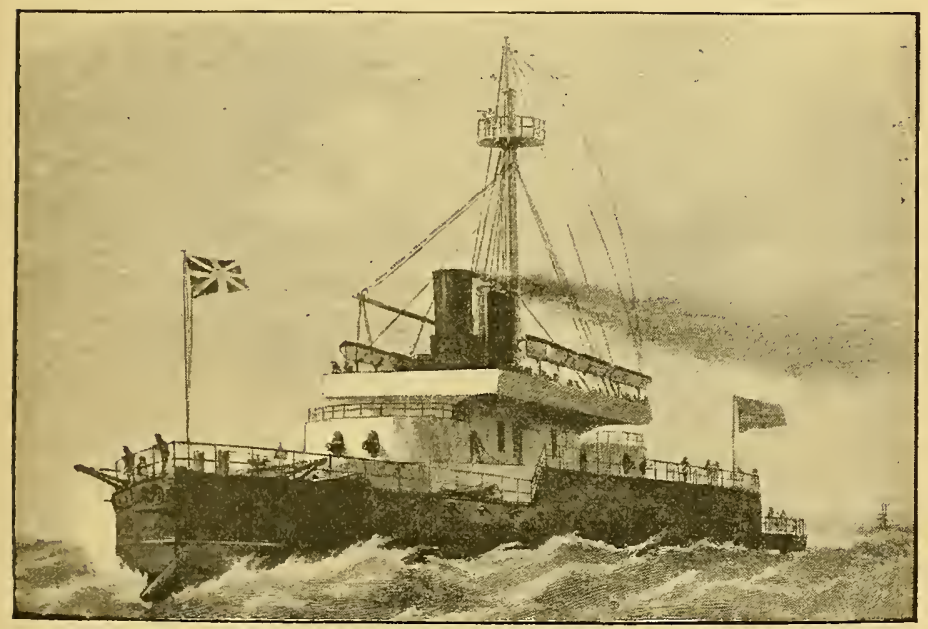

H. M.S. "THUNDERER."

(9,330 tons displacement; 7,000 horse-power. Completed I877.)

27 knots speed, lead the way. As their name, "torpedo boat destroyer," implies, they are specially designed to act against and keep down hostile torpedo boats, whose action, especially in home waters and at night, might in time of war inconvenience our larger ships.

As a supplement to the cruiser strength of the Royal Navy the authorities have within the past ten years been forming an auxiliary fleet comprising the swiftest 
ocean mail steamers of the day, vessels constructed with under-water subdivisions and fitted to receive on emergency an armament of quick-firing guns.

This brief statement is, of course, little more than a summary of the progress and development of the Royal Navy since its reconstruction in I860. ${ }^{1}$ Read as an introduction to, and in connection with, the following chapters on the development of guns, armour, and steam propulsion, a fairly comprehensive general view of our present material for fighting on the sea may, it is hoped, be gained.

1 For fuller particulars see "The British Navy," by Sir Thomas Brassey, K.C.B. Longmans, I882 ; "The Naval Annual,". I886I894; and "A Manual of Naval Architecture," by Mr. W. H. White, C.B., Assistant-Controller and Director of Naval Construction. Murray, I 894 .

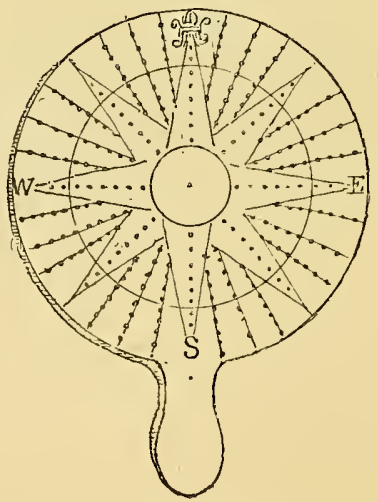

A TRAVERSE BOARD. 


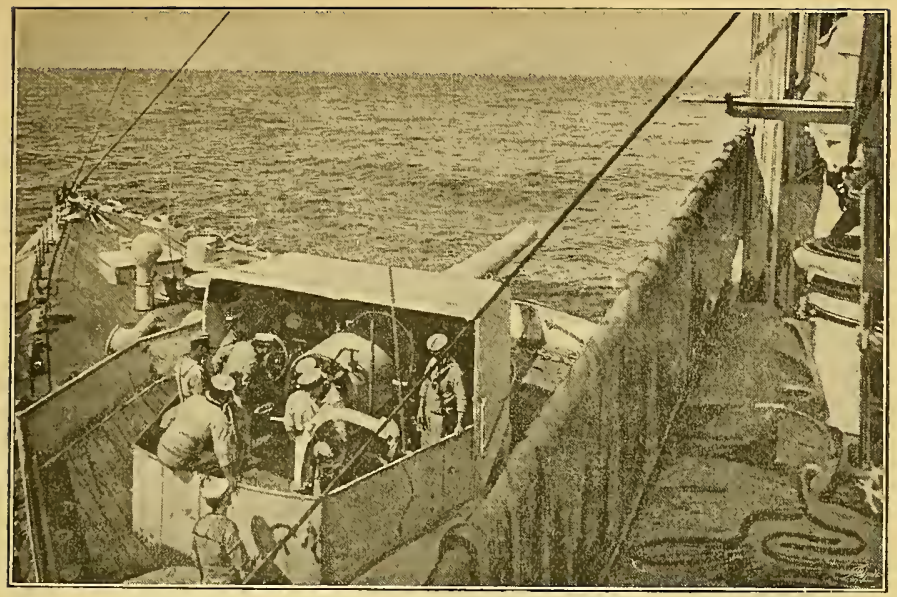

9'2" 22-TON BREECH-LOADING GUN AS MOUNTED IN BOW OF H.MI.S. "BLENHEIM."

CHAPTER V.

THE DEVELOPMENT OF OFFENSIVE POWER.

THE Gun.-It was just before the outbreak of the Russian War that attention began to be directed to the deficiencies of the heavy ordnance of the day. The general introduction into the land service of a rifled small arm first set artillerists thinking, and led them to consider the shortcomings of their own weapon. Nothing more powerful than the 68-pounder existed, a cast-iron smooth-bore piece of practically the same type as the ordnance of Queen Elizabeth's time, nearly three centuries before. The question was brought to a direct issue a little later, when armour became generally adopted 
for war-ships. Against the new defensive methods the smooth-bore big gun was proving itself helpless. But our artillerists and inventors declined to be baffled, and set to work, Mr. Armstrong and Mr. Whitworth leading the way, to bring out a weapon that should prove able to pierce armour. Mr. Armstrong had already (in 1855 , at the time of the Russian War) experimentally produced a small rifled gun, a "built-up" weapon, as it was termed, constructed on the principle of a rifled inner tube strengthened by outer coils of wrought-iron. This proved so successful that the method of its construction was officially accepted as a guide for the future. At the same time the old type of gun, made of cast-iron, and of one piece, was also experimented with : in order, for one thing, to utilize the large supply of these weapons that we had on hand. It was expected that a fairly efficient weapon might be obtained by rifling the bore and strengthening the gun externally by shrinking on a wrought-iron jacket over the cast-iron barrel. But failure was invariably the result. After strengthening some of the cast-iron guns internally, by inserting a tube of steel or wrought-iron, better results were arrived at, but these methods were recognized as at best only makeshifts. The cast-iron heavy gun, however tinkered up and doctored, was essentially incapable of standing the strain and shock of firing under the new conditions.

The Armstrong system of gun construction, with modifications suggested from time to time by experience, has been that followed by us from the first. A steel inner tube, reinforced with outer layers of coils of wrought-iron, was employed by Lord (then Mr.) Armstrong, in our earlier heavy guns. It was replaced by a wrought-iron tube, but, in later types, an improved 
knowledge of the qualities of steel led to its re-introduction. Next the wrought-iron coils superimposed upon the tube went. These were replaced by hoops or cylinders of wrought-iron, shrunk on over the tube, forming the bore of the gun, one above another in varying thicknesses. ${ }^{1}$ More recently (since 1882 ) steel has

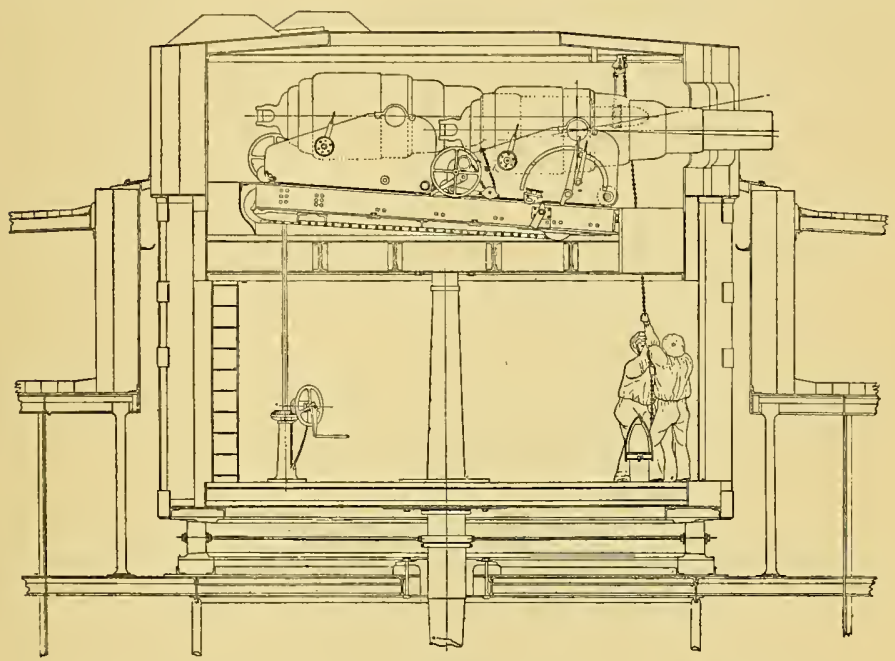

I2-TON 9" MUZZ1,E-LOADING ARMSTRONG GUN AS MOUNTED IN

A TURRET.

(Most of the older ironclads carry these guns.)

entirely replaced wrought-iron for great guns, and heavy

1 This was the modification adopted on the proposal of Mr. Fraser, of Woolwich, "who advocated the use of a few large hoops (instead of several small ones) by forming two thick coils, one upon the other, without separate welding or machining. The mass thus formed was welded together. .... This modification departed from the theory of building guns up, but, being more economical, it found favour at Woolwich until steel entirely superseded wrought-iron." "Artillery," by E. W'. Lloyd and A. R. Hadcock, p. 40. 
ordnance are now constructed of steel throughout. The hoops or "jackets" also have been replaced by coils of wire or steel tape wound closely in layers round the tube, the system known as the "ribbon construction."

With all this an enormous increase in the size and weight of guns has taken place, Up to 1865 the 68pounder held the field. Then came the $6 \frac{1}{2}$-ton gun of $7 \frac{\mathrm{I}}{2}$-inch calibre, firing a projectile of I I 5 lbs. weight, and capable of piercing 7 inches of iron at I,OoO yards. This was followed by the 9-ton gun, the 12-ton gun, and the I 8-ton gun, this last firing a $400 \mathrm{lb}$. projectile designed to pierce 9-inch armour. After that, at a stride, the I2inch 25-ton gun was produced, and then the 35-ton gun, a weapon of the same calibre, but longer and more powerful. A new form of propellent, slow-burning powder, had begun to come into favour with artillerists, and to give facilities for the cartridge charge to develop its full energy before the shot left the muzzle, a considerably longer gun was introduced, the $12 \frac{1}{2}$-inch 38 -ton gun, throwing an Soo lb. shot. To work so heavy a weapon, machinery had to be relied on, to the total exclusion of hand-power, which, with guns up to the 25 -ton gun, had hitherto been partially employed. Then the ease with which the hydraulic mechanism employed did its work led to another step forward. We brought out an 8o-ton gun, with a bore of 16 inches and firing a $1,700 \mathrm{lb}$. projectile. This was to meet the heavy armour, upwards of 24 inches thick, which foreign navies were adopting. The So-ton gun is mounted, however, in only one of our ships, the Inflexible, for, at this point, finality in muzzle-loading ordnance was reached.

The superior advantages of breech-loading ordnance (which, between $\mathrm{I} 860$ and I865, we had adopted and 
then discarded by reason of the complexity of the loading mechanism employed) were finally admitted beyond gainsaying. For one thing, experience had introduced a simpler and more trustworthy method of breech-loading than the original Armstrong system. For another, the vast increase in length of heavy guns, which the improved slow-burning ("cocoa" or brown) powder, that had replaced the old black powder, necessitated, compelled the old system of loading to be done away with in favour of one better accommodated to limited

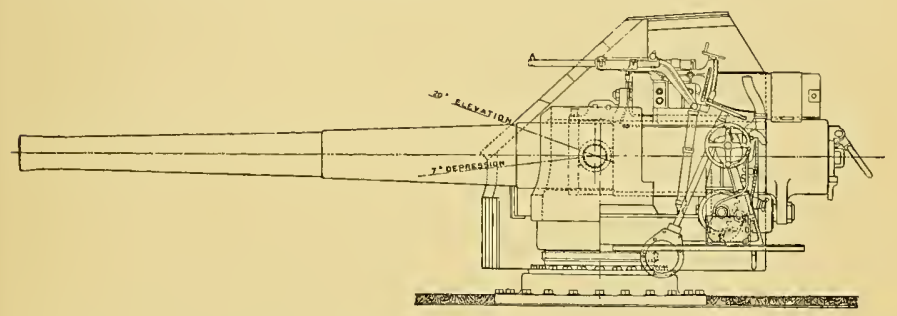

6" QUICK-FIRING GUN ON CENTRE PIVOT PEDESTAL, UPPER DECK MOUNTING.

(Designed and made at EIswick.)

space on board ship. The breech-loading system was adopted after I8SO, and then guns of varying sizes were introduced in rapid succession, just as had happened in the case of the old muzzle-loader.

First, the I4-ton gun appeared, then in succession the $22,29,43$, and 67 -ton guns, these pieces coming into use gradually, as the muzzle-loaders of corresponding power were withdrawn. From the 67 -ton gun we next passed at a bound to the monster I Io-ton guns, mounted in the Benbow, Sans Pareil, and in the ill-fated Victoria.

Originally brought in to match similar weapons with 
which the Italian Government was arming some of its ships, this giant weapon has now, on account of its want of endurance, structural weakness, and excessive cost, come under a ban with the authorities. For all practical purposes, indeed, it is claimed by naval men that a gun half the weight would answer all purposes, and be preferable. Under all but extraordinary circumstances, it is maintained, a yet lighter weapon, of about 30 tons, would suffice. Such a gun, it is contended, would be capable of being "man-handled," or worked entirely by its crew, should, as might well happen in action, the main hydraulic machinery be damaged. In accordance with these views weapons of this size (the 29-ton gun) now constitute the primary armament in the newer battle-ships, such as the Centurion and the Barfleur, and in some of the renovated battle-ships of older types, such as the Devastation and the Thunderer.

The 43-ton gun is carried in the Colossus and Edinburgh, the first battle-ships to be armed with breechloaders, in the Hero and Conqueror, and in the Collingzeood and Howe of the "Admiral" class. The 67-ton gun is mounted in the other "Admirals" (except the Benbow), as well as in the eight first-class battle-ships of the Royal Sovereign class built under the Naval Defence Act.

Side by side, practically, with the breech-loading heavy gun came in the quick-firing gun. About 1880 the need of a light, handy weapon, suitable for keeping up a rapid, continuous fire on swiftly-moving objects, such as torpedo boats, then prominently coming into notice, began to be felt. The ordinary light, breechloading guns of the day fired too slowly. Time was lost in loading and training between each discharge, which, in the case of an attack on battle-ships by torpedo boats, 

miglit enable these to run in with impunity within discharging range. There were already in use machine guns of rifle calibre-Gatlings, Gardners, and Nordenfelts, which were loaded and fired mechanically, but something more destructive was wanted. In response

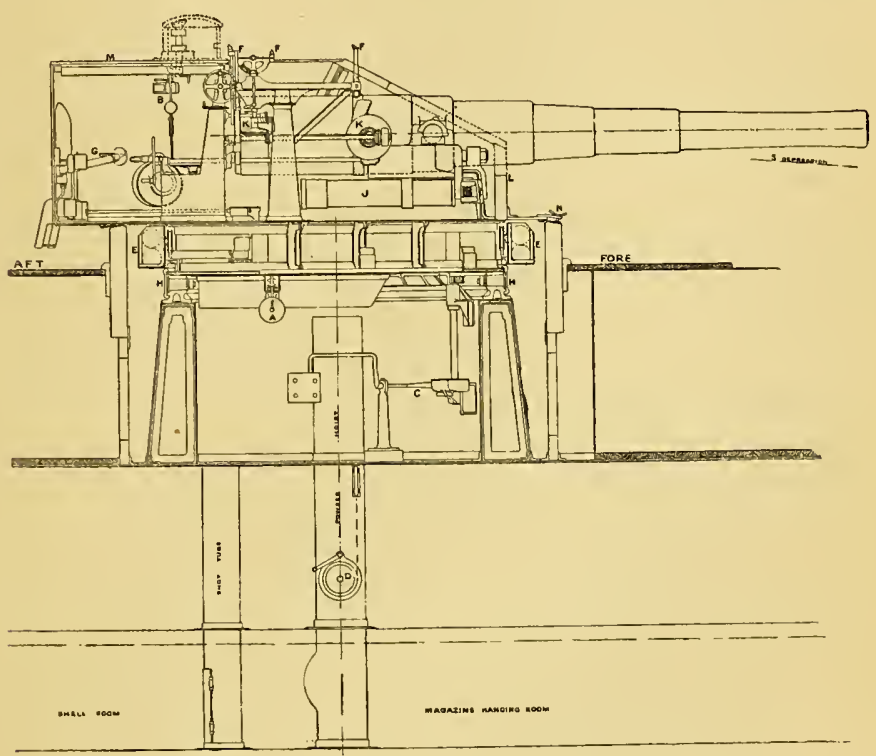

9.2" 22-TON BREECH-LOADING GUN ON ELSWICK AUTOMATIC MOUNTING.

(Specially designed for high angle fire.)

to the demand, first of all, 3-pounder and 6-pounder guns (Hotchkiss and Nordenfelt) were devised, rapidity of action being obtained partly by a peculiar breech mechanism, partly by employing cartridges constructed to contain the charge and shot in one, which enabled the operations of loading to be performed at a single 
motion. The gun, in fact, could practically be fired as fast as a man could slip projectiles into the breech, the mechanism, moreover, working automatically, down to ejecting the fired cases-all by a single movement of a lever. Elswick then produced 'a heavier piece, the 30pounder, which proved itself capable of being as quickly fired as the original 3-pounder and 6-pounder. This weapon, after exhaustive experiments at Portsmouth, developed into the 45-pounder of 47 -inch calibre. Lord Armstrong's firm also introduced a non-recoil system of mounting which added enormously to the efficiency of the quick-firing gun. Matched with the ordinary 5-inch breech-loading service gun the 4.7-inch quick firer proved capable of discharging Io rounds in 47 seconds, the same number of rounds being fired by the 5 -inch in 5 minutes and 7 seconds. Smaller sizes of the Elswick quick-firing gun, the 25-pounder, the r2pounder and ro-pounder, were subsequently adopted for use in the smaller classes of vessels, such as torpedo gunboats. Progress in the other direction has meanwhile resulted in the production of a quick-firing weapon still larger than the 45-pounder, the 6-inch roo-pounder (also from Elswick) which has proved so efficient that it has been adopted for the secondary armament in firstclass battle-ships and cruisers, and the heaviest guns in second-class cruisers.

Besides their secondary armaments of quick-firing guns, all modern vessels of war carry in addition a numerous equipment of machine guns of rifle calibre, Gatlings and Nordenfelts, which are given positions on the upper decks and in the military tops wherever space can be found for them.

Ammunition: powder.-Of the first importance are 
the developments in ammunition, which have accompanied the developments in ordnance. At first, with the old 68-pounder gun, we used ordinary fine grain black powder. Then, to produce slower combustion, and reduce the strain to the gun caused by the violence of the sudden explosion of such enormous charges as had come into use, we used coarse grain powder. Next, the charge was made up of powder worked into small lumps or "pebbles," and, after that, in small blocks or "prisms," with the design of causing the charge to burn itself out less suddenly than it did as one mass of small grains. The practical outcome of "slow combustion" is "that the powder charge continues burning and throwing off gas all the time the projectile is travelling through the bore, and thus imparts to the shot a much higher velocity than could be obtained with the old quick-burning and violent powder, the whole force of which was expended before the shot had travelled many feet." And, further, the gun itself is less strained. The adoption of a still slower-burning propellent, "cocoa" powder, so-called from its brown colour, was the next step, the powder used in the charges being (as before with common black powder), to induce yet more gradual combustion, shaped in hexagonal prisms, with a hole pierced through each prism to let the charge ignite throughout readily and equably. From "cocoa" powder we have passed to "cordite," a smokeless explosive of still greater power. A I 7-lbs. charge of "cordite" produces results equal to those produced by a 50-lbs. charge of "cocoa" powder. "Cordite" is so-called from its external resemblance to long pieces of thin black or grey cord, and is more particularly used in quick-firing guns.

Ammmition: shot.-With regard to the projectiles, 
the old spherical shot and shell became useless when rifling was introduced, and we use now only shot of cylindrical form with pointed head. There are four kincls of these. First, steel armour-piercing shot designed to penetrate the thickest steel armour. Second, the Palliser chilled shot of cast-iron. In this the head is specially prepared by undergoing a process of " chilling:' in other words, it is cast in a metal mould, by which the fore part of the projectile is rendered excessively hard through the rapidity with which it cools, compared with the after part, formed in a sand mould. Palliser projectiles are used against iron and thin steel armour. The third species of projectile is "Common Shell," made of cast-iron, and containing a large bursting charge of powder. The fourth, "Shrapnel Shell," in which bullets, to be burst over or among masses of men, are crammed. Quick-firing guns use small, pointed, solid steel shot and shell. The system of rifling for breechloading ordnance differs essentially from that for muzzleloading ordnance. In muzzle-loaders the projectile bears studs which fit mechanically into and follow deep grooves in the bore: in breech-loaders the grooves are shallow and grip the projectile by means of the copper jacket that cases it. The casing of the projectile, with that intention, is made of slightly larger diameter than the bore through which the projectile is propelled, the copper case moulding itself into the grooves as the shot is forced out of the gun, taking the twist of the rifling in its course. To enable the gun to be loaded, the chamber at the breech in which the shot is placed with its powder charge is constructed of larger diameter than the bore of the gun.

Gun-carriages.-In the mounting of naval ordnance the ingenuity of inventors has kept pace with the pro- 
gress made in the construction of ordnance. To the old style of wooden gun-carriage on trucks, only done away with in 1864 , succeeded iron carriages with slides and traversing platforms on the system designed by Captain (now Admiral) Scott, which is still in use. Then came the "Elswick compressor brake," an arrangement fitted to the gun-carriages of this type to absorb the recoil

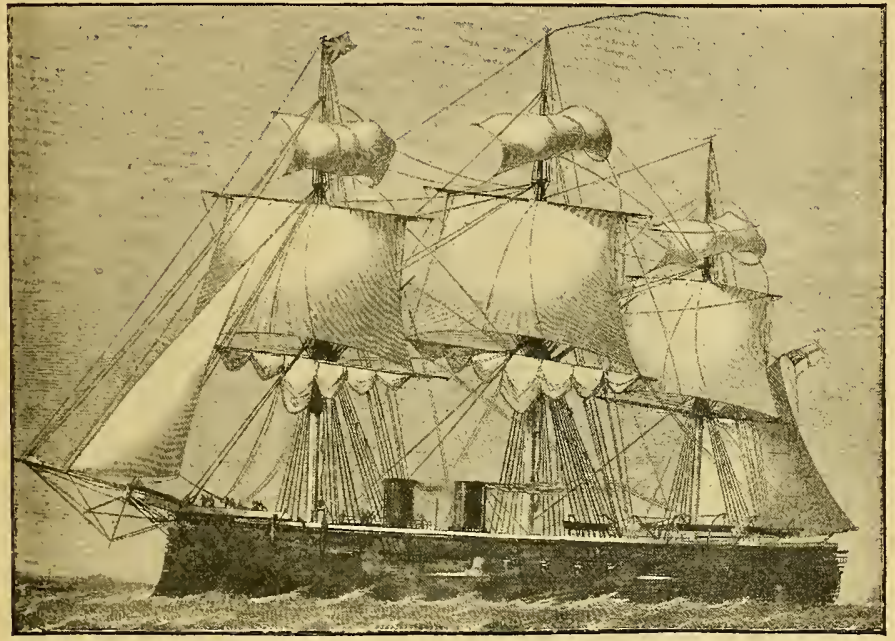

H.M.S. " HERCULES."

( 8,680 tons displacement ; 8,500 horse-power. Completed I868.)

previously regulated by friction between the carriageslide. The "compressor brake" saw the muzzle-loading gun out. It was followed by a hydraulic brake mechanical system, introduced in the Téméraire of 1876 and the Inflexible. This served until I882, when the Vavasseur hydraulic gun-mounting, which, while elevating and training the gun, admits also of being worked 
up to the moment of firing, was devised specially to meet the high recoil energies of breech-loading ordnance. More recently a tendency to do away, as far as possible, with machinery in working naval guns, in favour of a simpler manual system, has been gaining ground, though in practice man-power can only be employed in guns of less than 30 tons weight. Above that weight, for all purposes, hydraulic power has hitherto been found indispensable, and the Vavasseur system is accordingly relied on with our present heavy guns.

The Ram.-The ram and its possibilities were apparently not appreciated by the designers of our earlier battle-ship types. It first appears, in anything like the shape of the weapon we know, in the Bellerophon of I866, developing two years later into the form seen in the Hercules. The Warrior and Defence classes had plain up and down cutwaters, and the Valiant, Repulse and Agincourt classes the same, though with these last the cutwater takes a recurved and somewhat protruding form, suggesting, in the light of later developments, that the authorities were still half decided on the necessity of providing a ram. But, since I 870, the ram has formed as much an offensive feature of all our battle-ships as their guns. Of its tremendous powers of destruction, the sinking of the Italian flagship by an Austrian vessel at the battle of Lissa, and the sinking of the Vanguard by the ram of the Iron Duke, gave proof positive. Since then we have had further evidence of its fearful capabilities in the disaster to the German ironclad Grosser Kurfiirst in the Straits of Dover, and the appalling catastrophe which, in a breath, as it were, deprived England of the great flagship Victoria with so many officers and men. 
The Torpedo.- While the term torpedo is now only used for mobile torpedoes, in its earliest form the torpedo was a submarine mine enclosed in a metal case and intended to be exploded by mechanism under a ship's bottom. ${ }^{1}$ It was used thus in the Baltic by the Russians, and by the Confederates in the American War of Secession to block the approaches to their own ports. The

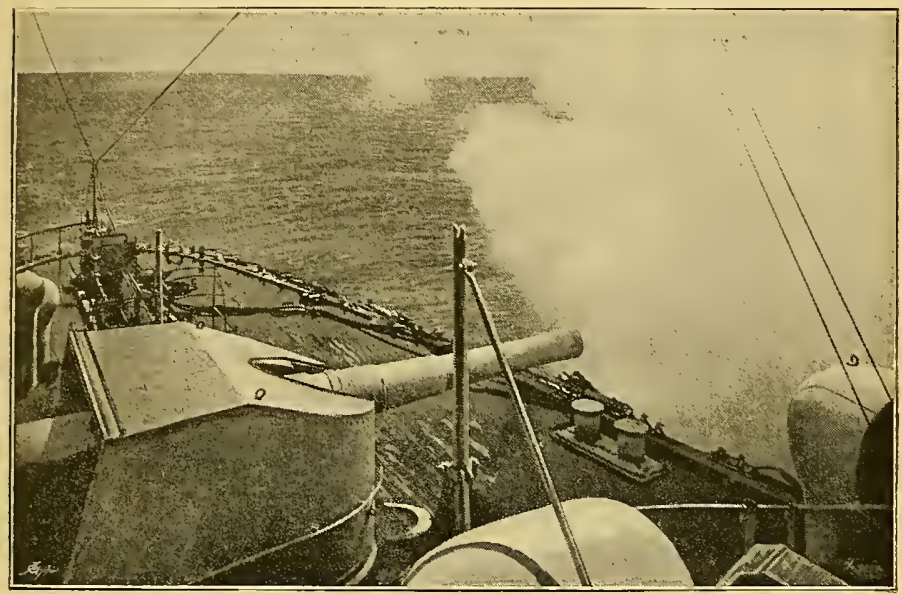

FIRING THE AFTER 22-TON GUN, H.Mr.S. "BLENHEIM." (Naval Manourres, I893.)

mines were stationary, being moored in the channels by which the hostile ships were expected to approach, with a view to their exploding on being run down. This type of torpedo had, however, the defect of being uncertain and too passive in its operation. Something more direct and active, better fitted for offensive warfare, was required.

${ }^{1}$ See "Torpedoes and Torpedo Warfare," by Lieut. Sleeman, R.N. Griffin, I882. 
The spar torpedo was thereupon devised-the converse of what had gone before. Instead of the ship being left to come by chance on the mine and explode it herself, the mine was now taken to the ship and fired alongside of her or underneath. In the spar torpedo the explosive charge was carried at the end of a long pole at the bows of a launch, to be fired when touching the side of the attacked ship. An electric wire led from within the boat to the charge, along the pole, which was dipped on reaching the ship attacked so as to explode the torpedo under water. But the risks to the attacking launch, as it ran alongside the enemy with its torpedo, were enormous, 'and experts then cast about for a less perilous method of managing the business. A sort of surface torpedo, shaped like a boat and propelled and steered by internal mechanism of its own, was then proposed. It was to be discharged at some distance from the enemy's ships and left to find its own way. This was the original idea from which was evolved the Whitehead and Woolwich torpedoes of to-day.

While the scheme of the Whitehead torpedo was being worked out by its inventor, the towing torpedo, was proposed by Captain Harvey, R.N. Here a submarine mine was attached by a towing-rope to large ships, to be hauled across the bows of an enemy in action and exploded while in contact. The Harvey torpedo was little more than an experiment, however, and its day lasted only until the fish torpedo appeared in I868.

In that year Mr. Whitehead, an English engineer, resi-

1 Witness the fate of the steam launch in which the gallant Lieutenant Cushing, of the Federal Navy, blew up with a spar torpedo the Confederate war-ship Albemarle. The explosion of the torpedo, while it wrecked the Albemarle, destroyed the launch, and Cushing only escaped after a long swim. 
dent in Austria, brought out the terrible engine that bears his name, in the form of a torpedo capable of being easily directed, and travelling under water for a considerable distance and at a high rate of speed with certainty of direction. It was of steel, cigar shaped, and was driven by a small engine worked by compressed air, with a screw propeller, the mechanism being contained in the after portion of the torpedo itself. Horizontal rudders, adapted to the pressures of water at different depths, regulated at

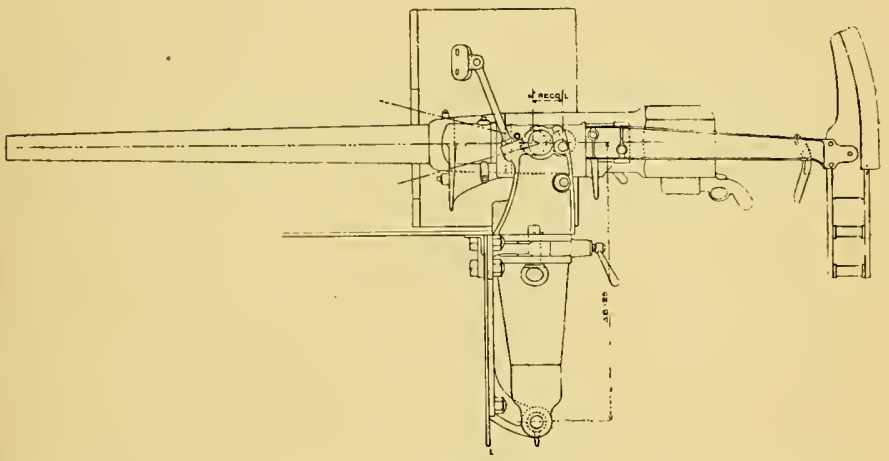

6-POUNDER QUICK-IIRING HOTCHKISS GLN ON HYIRAULIC RECOHL MOUNTING.

(Designed and manufactured at Elswick.)

will the distance below the surface the torpedo was to act. The explosive (at first gunpowder and later gun-cotton) was packed in the fore part of the torpedo, the firing of the charge being effected on impact by means of a striker and detonating cap. The capabilities of the original Whitehead torpedo were 8 knots an hour with an extreme range of a quarter of a rnile. The capabilities of the latest pattern are nearly half a mile range and 30 knots speed. The diameter of the later Whiteheads also has been gradually increased until it is now is 8 inches, with a 
charge of gun-cotton which has also been increased to 200 lbs. This charge is considered more than efficient to blow in the bottom of the strongest ship built. ${ }^{1}$

The Whitehead torpedo brought into existence the swift-steaming torpedo boat, designed to dash in within effective range of an enemy, discharge the torpedo, and then sheer off out of reach of hostile fire. As the torpedo itself has become more and more efficient and formidable, so the boats have grown larger and swifter. At first a boat 80 or 100 feet long, of 18 or 19 knots speed, to operate from a war-ship or off a seaport, was held to answer all requirements ; now we have sea-going torpedo boats upwards of 150 feet long, with a speed of 27 to 30 knots, and capable of raiding across the Channel in a few hours. In the methods of launching torpedoes similar progress in the direction of increased efficiency has been attained by the introduction of the submerged launching-tube system as a substitute for the original "above water" tube system, which necessarily exposed the torpedo to the risk of being hit by a shot, and exploded on board its own ship disastrously before being fired.

It is hoped to obtain protection against the torpedo by means of a net or "crinoline" extended on booms round the ship attacked; these are, however, of doubtful value at all times, and ships under weigh would find great difficulty in using them. Protection against the torpedo boat when on its way to launch its deadly missile is partially obtained by means of the quick-firing gun, but the best plan of all is to destroy the torpedo boat in daytime, when it is at the mercy of a faster vessel. The Havock class is intended for this purpose.

${ }^{1}$ A single Whitehead sunk the Chilian war-ship Blanco Encalada in the recent civil war, blowing in the ship's side under water and sinking her, with great loss of life, in six minutes. 


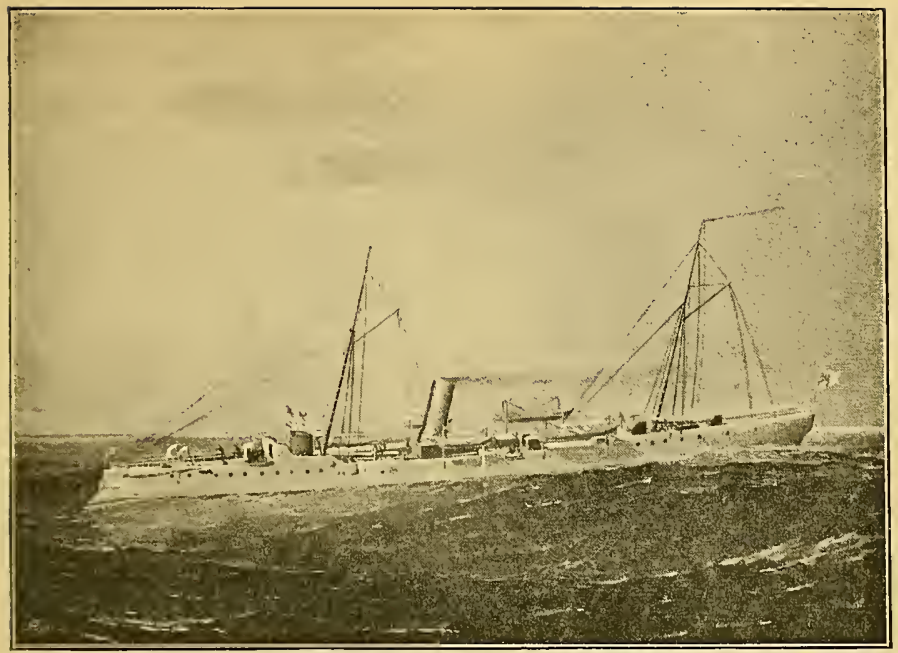

H.M.S. "RATTLESNAKE."

(Torpedo gunboat, built by Messrs. Laird of Birkenhead.

Completed r856.)

\section{CHAPTER VI.}

THE DEVELOPMENT OF DEFENSIVE POWER.

ARMOUR.-The question of the capability of iron as a material for building war-ships was raised in 1834 , when it was brought before the Admiralty by Admiral Sir George Cockburn. There were-already in the mercantile marine sea-going iron ships, and iron steam-packets were generally employed on our rivers and coasts. The official target experiments that were made to test the shotresisting powers of iron, however, resulted unfavourably. The comparatively thin iron plates tested were easily 
penetrated, and the jagged rents made by the shot seemed of a nature impracticable to deal with on board ship with the appliances in use. The projectiles employed, the ordinary round shot of the day, were also invariably found to break up and scatter in irregularly shaped fragments, an effect certain to be disastrous on board ship. The employment of iron in war-ships was on these results condemned, and the question shelved.

Abroad similar proposals met meanwhile with no better results. The same Colonel Paixhans who had brought forward the naval shell gun in $\mathrm{I} 84 \mathrm{I}$, proposed, in addition to an iron skin and frame for the hulls of the war-ships, thick side plates to keep out the shells he had been instrumental in introducing. The French naval authorities of the day, however, rejected Paixhans' plans, and four years later they again-on the score that the weight of the iron plating would not allow ships' batteries to be efficiently armoured-rejected proposals that a naval architect M. Dupuy de Lôme, put forward for an iron protected ship, having at the water-line a belt 8 feet wide and $6 \frac{1}{2}$ inches thick along her whole length.

In England, however, a change with regard to the application of iron for war-ships had now come over the mind of the naval authorities. The British Admiralty had to some extent begun to reconsider their position, and were sanctioning the construction of iron frigates. Of these the largest and most notable were the 6-gun paddle frigate Birkenhead, of 1,400 tons, eventually lost at sea under tragic circumstances, and the I8-gun screw frigate Simoom, of I,979 tons. But, as the later conversion of these vessels into troop-ships showed, the authorities ere long went back to their first opinion antagonistic to iron. 
The incapability of the wooden ship to withstand shell, was indeed only first accepted after the world had been startled and appalled by the fearful devastation of the Russian shell fire at Sinope; the only possible remedy being pointed out by the later event of the bombardment of Kinburn in 1855, where the shell gun was held at defiance by iron armour on the roughly-cased hulks known as the "floating batteries." Even after

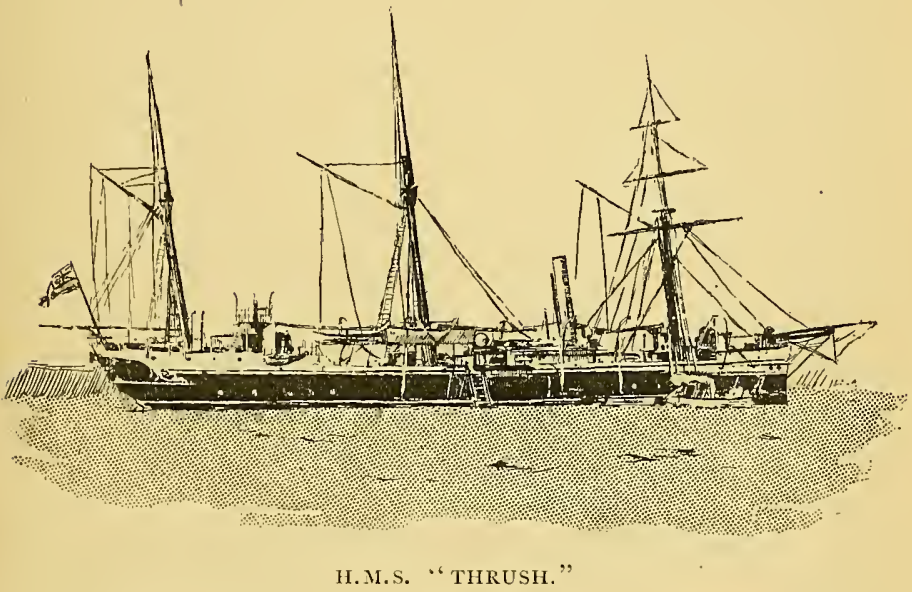

(Gunboat built by Messrs. Scott and Co., Greenock. Completed I889.)

Kinburn, however, the British Admiralty hung back for a while, at least as far as concerned sea-going war-ships, with the result that they were forestalled by the French, who, in 1859 , brought out their epoch-making armourclad war-ship the Gloire, which sealed the fate of the unarmoured wooden vessel.

How unlooked for was the advent of an armour-clad seagoing man-of-war, as anything more than an experiment, 
by the authorities on our side of the Channel, may be judged by the fact that in I 860 the Admiralty-though our first ironclad, the Warrior, was under construction -not only ordered the laying down of several wooden three and two-deckers, but also demanded from Parliament, and got, close on a million sterling for replenishing the dockyard timber sheds. The result was that in 1863 , when the great sweep was made of the wooden ships that were literally blocking up our harbours, scores of brand new men-of-war, which had never been commissioned and had never left port, were sold in batches, practically at the price of firewood, simply to get rid of them.

The French Gloire was answered by us with the Warrior. We improved, however, on the Gloire by framing the hull of the IVarrior and her sister entirely of iron, with the result that, while they remain capable of service to this day, the French earlier ships, which were for economy framed of wood and plated over with iron have long since been broken up.

Our special and unrivalled natural supplies of iron, and the facilities at the disposal of England for building iron ships at less cost than could be done abroad, gave us a great advantage over the other nations at the outset. In fact, with the-resources we had at command, the introduction of iron war-ships was all in our favour, making England for the time being, at any rate, independent of outside supplies, an exactly contrary position to that she had held in the later days of wooden ships, when the lack of ship timber at home often compelled us to rely to a dangerous extent on the supplies our agents abroad could purchase.

The ironclad war-ship being established, at once 
rivalry was set up between the resisting power of the armour carried and the guns that artillerists began designing to pierce it. Against the guns of the Warrior's day, $4 \frac{1}{2}$ inches of iron with is inches of teak backing and half an inch interior iron skin, were proof. As guns grew more powerful, $5 \frac{\mathrm{r}}{2}$-inch armour, such as is carried by our Agincourt class, came in. In the Bellerophon of i 866, armour 6 inches thick appears, increasing, to meet the increasing powers of penetration of the gun, to 9 inches (at the thickest part) in the Hercules of I 868, to 12 inches in the Devastation of 1873 , and the Alexandre of 1875 , and to I4 inches in the Dreadnought of 1876 . The armour on all these ships is of wrought-iron.

In is8o came the Inflexible (launched in I876, completed in 18SO) with 24 inches of "compound" armour, (iron faced with steel) a new departure, in which twothirds of the thickness of the plate is of wrought-iron and one-third of steel.

The idea of "compound" armour is that the hard steel surface on the face of the plate would resist penetration and compel projectiles to glance off, the necessary toughness and resistance against cracking or breaking up, on account of the brittle nature of steel, being imparted over the entire plate by its wrought-iron back. All our battle-ships from i 880 to I890, have compound armour-plating. Plates entirely of steel have come into favour now, the natural resisting powers that steel possesses being found capable of improvement in the direction of toughness by a process invented by an American named Harvey.

In the Inflexible, armour would seem to have reached its maximum thickness, 24 inches, for since then from I 6 to 20 inches has been considered adequate for all 
practical purposes. This thickness is found as the maximum in the armour of our battle-ships of later date.

The gradual increase in weight and thickness of armour plates led to the introduction of the various and widely differing types of war-ships to be found in the Royal Navy. Taling these in order of sequence, the general difference noticeable between them is the gradual development of the tendency to thicken or strengthen the armour protection on the central body of the hull, shielding the gun, the machinery, and "vitais" of the vessel at the expense of the rest of the ship, the increased weight arising from the thicker armour being compensated by lightening, or depriving entirely of armour, the ends and less "vital" portions.

In the first types, to protect the battery was all that was considered needful. Then the whole side of the ship was cased. After that armour was taken off the sides, except on the battery and along the water-line. Next armour was taken from the water-line entirely and concentrated in the form of a "citadel" round the battery. Again, only portions of the battery (the turret orbarbette) were protected and partial protection given to the waterline. Now the entire battery is strongly protected with armour of varying thickness, thick armour also protecting two-thirds of the water-line.

The "broadside ships" of the Warrior and Aginconrt classes represent the earliest type. In them the sides of the ship are protected by armour, distributed at first (as in the Warrior) partially, as a "patch" of armour shielding the centre of the ship while leaving the ends exposed; later (as in the Agincourt), by extending the armour over the whole length and height above water of the hull from stem to stern. The "central battery 
ships"-Bellerophon, Herculcs, Alexandra classes-came next. In these the armour while being concentrated on the centre of the ship extends also in a narrow strip as a complete belt along the water-line. The armour is at the same time made thicker than in the Agincourt class.

While the central battery type was being developed, the turret system, devised on an entirely new principle, came in, producing the "breastwork monitors" of which the Dcvastation, Thunderer and Dreadnought are earlier examples. In these ships the battery or primary offensive armament is reduced to one or at most two pairs of heavy guns, which are enclosed, each pair, within a circular thickly-armoured turret, raised clear of the body of the ship and revolving so as to admit of a fire in all directions. The body of the ship at the same time is armoured immediately beneath the base of the turrets with a narrow belt continuously at the waterline from stem to stern. Such is the case in turret ships completed before 1876 , when a modification amounting to a new departure was initiated in the Inflexible.

In the Inflexible the turrets are placed in échelon and close together, the hull below and between them being extremely heavily-armoured and closed in by transverse armoured bulkheads to form a "citadel" reaching down to the water-line. To allow for the immense weight of armour on this "citadel " the rest of the ship's side, fore and aft, is left entirely without armour. To afford compensating protection, a light steel deck arches over and covers in the unarmoured portions of the hull below the water-line, extending fore and aft from the armoured "citadel" to the ends of the ship.

This general idea, more or less improved on, has been followed in later battle-ships. In these the base of the 
central armoured area or "citadel" varies considerably in length at the water-line, the tendency ever being to extend it fore and aft to gain additional water-line protection. For example, the Inflcxible of $1876-80$, with a length over all of 320 feet, has only i io feet of that length armoured; the Anson of I885, with a length over all of 320 feet, has 150 feet of that length armoured; the Trafalgar of 1887 , with a length over all of 345 feet, has 320 feet of that length armoured; the Royal Sovereign of $\mathrm{I} 892$, with a length over all of 380 feet, has 252 feet of that length armoured. In the still newer ships a kind of half barbette, half turret is used, and all the larger guns of the secondary battery are in casemates, the remainder being protected by shields.

The modification of the turret system of mounting ships' heavy armament known as the barbette system, which has come into such favour with us, affects to some extent the distribution of armour on board ship. In the barbette system the closed-in revolving turret with embrasures for the guns to fire through, is replaced by a low fixed breastwork, over which the guns act entirely in the open, exposed from muzzle to breech. The resultant saving of weight is utilized to further the fore and aft extension of the water-line armour.

The diminution of the breadth of armour protection at the water-line in our battle-ships built between I 880 and 1890 is noteworthy. In the older ships up to the Dreadnought and Alexandra, the breadth of water-line side armour extends from 6 or $6 \frac{\mathrm{r}}{2}$ feet below water to 8 or 10 feet above. In the "Admirals" it is only 5 or $5 \frac{\mathrm{r}}{2}$ feet below water to 3 feet above.

Closely associated with armour protection is the modern method of safeguarding the ship by means of a 
double skin, or bottom, combined with a system of water-tight compartments, or, as it is called, cellular subdivision. While in earlier war-ship types, the doublebottom arrangement is rudimentary, being practically confined to a strip on each side of the keel, the entire length and breadth of the vessel below the armour belt and from stem to stern under water is now protected in

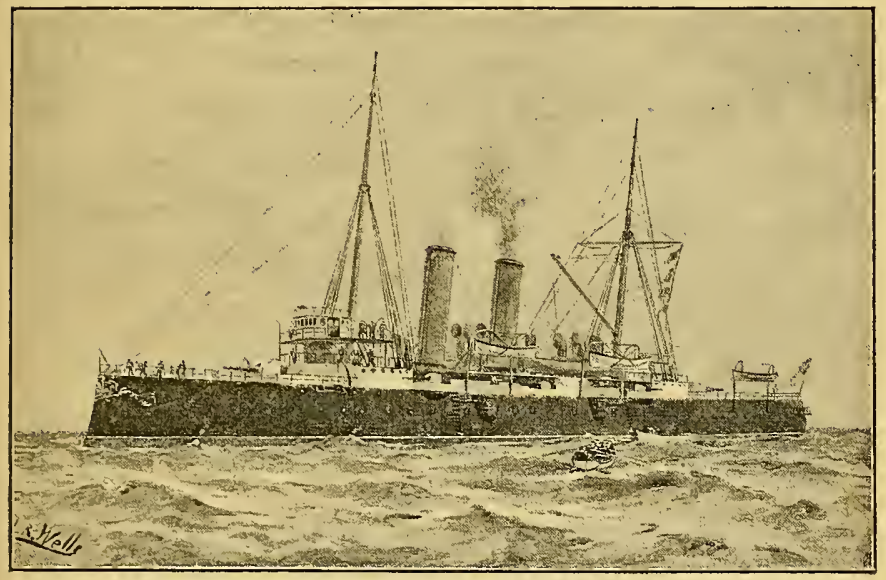

H.M.S. "EDGAR."

(7,350 tons displacement ; I2,500 horse-power. Completed I 890.$)$

this way. The double bottom comprises two separate thin iron or steel skins, the space between which is fitted with a partition framework arranged lengthwise and crosswise. The protection thus gained is devised as a safeguard against a ship sinking suddenly when struck by a torpedo or being penetrated by a rock. Additional protection is sought by the subdivision of the hull beneath the water-line inside the double bottom into separate water-tight compartments by longitudinal and 
transverse bulkheads. This expedient, also specially designed against the ram and the torpedo, is practically non-existent in earlier war-ship types.

The under-water horizontal deck system (introduced between 1876 and $\mathrm{I} 880)^{1}{ }^{1}$ is the very latest devised form of protection, subordinate to, and distinct from, the side armour protection. It may be termed indirect protection, the curved steel deck being liable to be struck only indirectly or in a glancing manner. Thus a much less thickness of steel than would be necessary to resist the smashing effect of direct hits can be made to suffice. As a fact, practically, from 2 to 6 inches thickness of horizontal armour, according to liability to exposure, is all that is considered requisite. The armoured ends in battle-ships, as has been said, are so protected fore and aft from where the heavy side armour leaves off.

It is particularly in cruisers which cannot be hampered with side armour that the horizontal and curved armoured deck system finds its use. All our modern cruisers at present completed, from the Blake and Blenheim, and the Edgar and Royal Arthur class, to the third-class cruisers of the " $M$ " class, so obtain all their protection. Those also of the Spencer programme, the Powerful and Terrible, and the Talbot class are so protected. Possibly the armoured underwater deck may yet have to give way in the cruiser of the future to the entire plating of the sides above water with light steel side armour, thick enough everywhere to keep out all but the heaviest projectiles, as has been attempted in some of the most recent French and Russian types; but this will probably necessitate increased dimensions.

${ }^{1}$ At the suggestion, in the first place, of Admiral Robert Scott. 


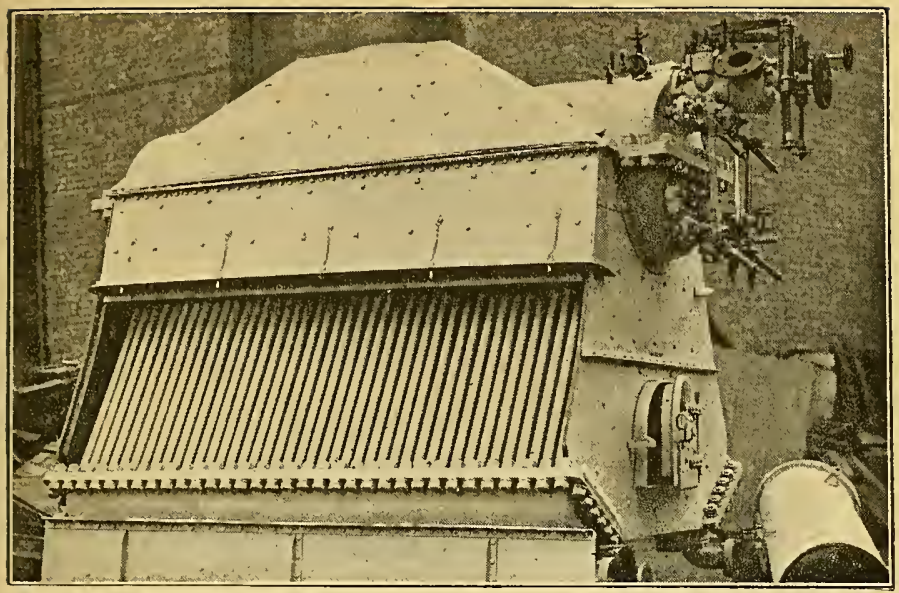

WATER-TUBE BOILER.

(Yarrow system.)

\section{CHAPTER VII.}

STEAM ON BOARD SHIP.

AtTEntron began to be turned to the capabilities of steam in naval warfare shortly after I 8 I5. Small steam vessels were already in use as canal tugs and packets on the Thames and Clyde, and similar vessels had made short coasting voyages, and even crossed the North Sea; but the subject from a naval point of view was not taken up until the elder Brunel first urged on the Admiralty the probable advantages of the new motive power. Brunel's proposals were in part favourably received. The Admiralty expressed themselves prepared to agree 
that steam might possibly be useful-in small vessels for towing ships-of-war out of harbour against contrary winds. They "deemed it unnecessary," however, "to enter into the question as to how far the power of the steam-engine might be made applicable to the general purposes of navigation."

Having defined their position, after further deliberation the Admiralty ordered a wooden paddle-steamer, the Comet, of 238 tons and 80 horse-power, and also purchased into the service another, the Monkey, of 212 tons and 80 horse-power.

Thus, in 1822 , the start was made. Following on, other similar small vessels were added, designed to act either as tugs, general service vessels, or packets. Of these, in I827, we had fourteen. A larger type of steamer then began to come in; the Rhadamanthus and the Salamander, of 8 I 3 tons and 220 horse-power, and the Black Eagle yacht, of 240 tons and 260 horse-power, built between 1827 and I 829 , leading the way. All these vessels were contract built, the construction of steamers only coming under the Surveyor of the Navy in 1832 .

Then the question of steam war vessels arose. The idea took six years more to develop, resulting after that time in the construction of some steam sloops of war, of which the most notable was the Cyclops, of I, I95 tons burden ( 1,862 tons displacement) and 320 horse-power.

Another step forward, in 1842 , produced the steam frigate Firebrand of 1, 190 tons burden and 400 horsepower. In I 843 was built the first steam-propelled royal yacht, Victoric and Albert, of I, 442 tons displacement and 400 horse-power; a 46-gun sailing frigate, the Penelope, being in the same year cut in two and 
lengthened 65 feet to receive 650 horse-power engines. The steam frigate, Retribution, I,64 I tons and 800 horsepower, of the following year, marked further progress, and then came, in 1845 , the Terrible, steam frigate, of $\mathrm{I}, 850$ tons and 800 horse-power.

This year is memorable for the first placing of the engines below the water line (suggested by Admiral Sir Charles Napier), though the side wheels and their huge paddle-boxes remained of necessity still exposed-the main objectionable feature of the paddle-wheel system. Another acknowledged evil was the space that the wheels and their boxes took up, limiting a ship's armament practically to her bow and stern guns. For this reason, indeed, many officers contended that small paddle vessels would serve all purposes, as increased size brought little gain in offensive power. At this juncture it was that the screw propeller came in, and set the matter at rest.

For more than twenty years the authorities had been aware, for the reasons just given, that a system of propulsion other than the side wheel was desirable, and to meet their known views numerous projects for underwater propellers had from time to time been put forward. Unsuccessfully, however, until, in I 836, a form of screw was proposed by Mr. F. Pettit Smith. Experiments proved Mr. Smith's screw to have advantages in power over the side wheel, but though we had at length got what we wanted, its application in sea-going ships was met with objections both by engineers in general and by the Navy, headed by Sir.W. Symonds himself, in particular. For one thing, it was confidently declared, it would be impossible to steer with a screw propeller. Even a satisfactory official trial in the presence of several 
eminent Admiralty officials could not overcome prevailing prejudices.

The screw, however, continued to be unofficially tried in packets and other small vessels, with such persistent success, that in the end the Admiralty gave way. In I 842 , as an experiment on their own account, they ordered the Rattler of 777 tons and 200 horse-power to be fitted with a screw. The Rattler did so well that official trials were instituted between her and a paddle vessel of equal horse-power, the Alecto. The complete defeat of the paddler was the result. When as a final test the two ships were lashed stern to stern and each driven ahead full speed, the Rattler simply dragged the Alecto after her in tow at three knots an hour. A later trial, between the Niger screw and the Basilisk paddler, ended similarly. The Niger easily hauled the Basilisk after her, despite every effort of the paddler. This was conclusive, and the screw was next experimentally fitted in two line-of-battle ships, the Ajax and Blenheim. A speed of over 7 knots was attained, whereupon the Admiralty set about constructing regular screw frigates and corvettes.

The Dauntless, Encounter and Arrogant, led the way. In the Arrogant the proportion between horse-power and tonnage was I horse-power to 5.17 tons, with an average speed of $S_{\frac{1}{4}}$ knots. The Ajax and Blenheim experiments were also followed up in other line-of-battle ships. At first, certain existing two and three-deckers were converted-by being cut in two, lengthened, and fitted with the screw. Then new ships were specially designed. These vessels formed the backbone of our fleets in the Russian War, though no inconsiderable proportion of our Black Sea and Baltic squadrons, at 


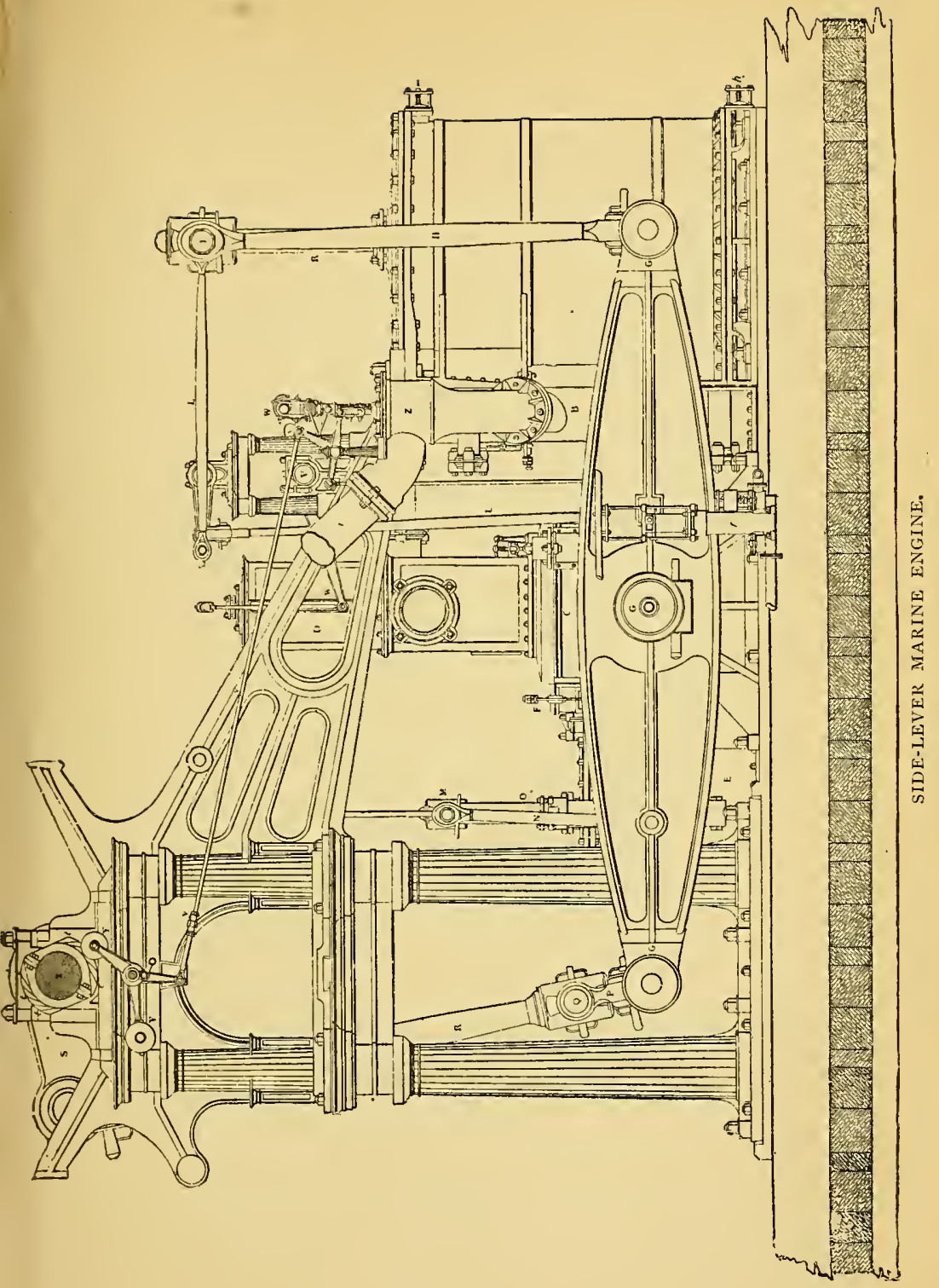


least in I 854, were sailing ships. In the next year, however, we replaced sailing men-of-war entirely with steamships in both squadrons.

After the Russian War steam reduced sails entirely to secondary and auxiliary rank. "Sailing ships," ran the official declaration promulgated in I859, "are unfit for active service." But the change was not carried out in all squadrons till i 862 , when the ironclad steamer was definitely established.

In I 868 , up to which year the single propeller had been universal, twin screws (first proposed in I 860) with separate engines, one to each propeller, were first fitted in a British ironclad, the Penelope. The twin screw met with such success that the system was henceforward exclusively adopted in the Navy. In I874 our first mastless ironclad, the Devastation, was commissioned in the Channel Fleet, and sails became practically obsolete some nine years later. The replacing of the rigged masts originally designed in the Warspite and Imperrieuse, by pole-masts with military tops, marks the final stage of the transition.

The progress and development in ship machinery since the first introduction of steam ought really to rank as one of the wonders of the age. The sidelever engine, with its long solid connecting-rod and lever system joining piston-head and crank, was the parent type, an adaptation to marine purposes of Watt's wellknown beam-engine in general use on land. By forming a crank on the wheel-shaft equal to half the piston stroke, and joining the crank-pin by a connecting-rod with the end of the beam oscillating on its centre, Watt had first showed how to make the shaft revolve continuously. In the land engine, however, the beam was 
CHAP. VII.] STEAM ON BOARD SHIP.

placed high over both piston and crank-shaft, a form which took up too much space for board-ship conditions.

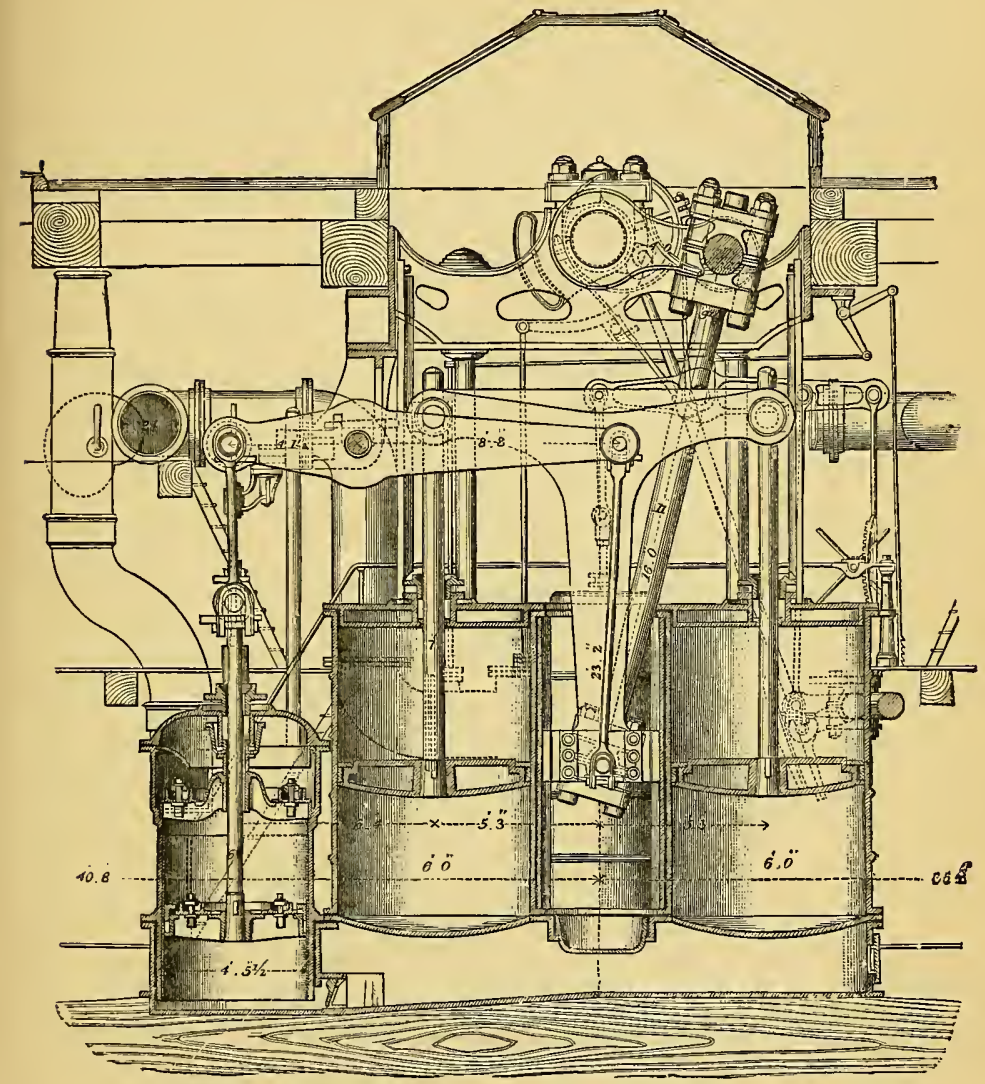

MAUDSLAY'S PADDLE ENGINE, I 827 .

To obviate that difficulty the beam was placed low down, near the foundation plate, and below the driving 
machinery, with which, in its altered position, instead of acting directly, as before, it had to be connected by a system of levers' at the side of the machinery. From the cross head of the piston-rod, two connecting-rods, one each side of the cylinder, led down, attached at their lower ends to one end of the beam, the other end of the beam being joined to and working the crank on the wheel-shaft directly above it, by means of another and longer connecting-rod.

All marine engines were so fitted up to between I 837 and 1843 , when the new direct-acting engine with oscillating cylinders did away with side levers by connecting the head of the piston-rod directly to the crank. The new system dispensed with the beam and connecting-rod, and, at the same time, enabled the steam cylinders to be placed where the connecting-rod had been, directly under the crank-shaft. To enable the piston-rod to adapt itself to the movements of the crank, the cylinder was mounted to swing or oscillate, two short arms or trunnions, projecting on opposite sides about the middle of the cylinder, being provided. These were also made hollow, with shut-off valves, one trunnion for steam to enter the cylinder by, the other for exhaust steam to pass to the condenser.

At this time it was that the horizontal direct-acting engines were first fitted in a British war-ship, the Amphion frigate, a type that came afterwards widely into favour. In the Amplizon's engines the pistons had two rods each-one above the level of the crankshaft, the other below-connected on the further side of the shaft by a cross head and return connecting-rod back to the crank.

About I 850 the tubular boiler replaced the old flue- 
boiler, with its intricate system of internal flat-sided flues winding up and down with various convolutions, which had been in use from early times. The tubular marine boiler (patented in $\mathrm{I} 848$ by Lord Dundonald) substituted for the flat convoluted flues and simple furnace a combustion chamber at the back of the furnace, with a nest of straight tubes that conducted the hot air and flame through the length of the boiler to the front up-take chamber and funnels, a system that gave a far greater heating surface and was much less complicated than the old.

The general acceptance of the screw propeller led early to another radical change in machinery. This was the replacing of the geared engine originally designed for the side wheel (and used in the Rattler and our earliest screw ships), with its oscillating mechanism working a triple spur-wheel geared into a cogged pinion on the screw-shaft, by a system which coupled the propeller shaft directly to the engines without any cogs at all. Thus the rotatory speed of the shaft was quadrupled, allowing the propeller to revolve as fast as the engines worked.

The trunk engine, also originally invented for paddlewheel machinery but not at first favourably received, was at this time revived as a screw engine by Messrs. Penn, by whom it was fitted in most of our early broadside ironclads. In the trunk engine the piston-rod is dispensed with and space saved, the connecting-rod being directly attached to the piston, and passing through the cylinder cover enclosed in a tube or "trunk" attached to the piston, and of a diameter to permit of the lateral vibration of the rod within as the "trunk" alternately entered into and emerged from the cylinder. 
In I 866 came the introduction into the Navy of the compound engine, duuble-expansion system-first made practicable for sea-going ships by Randolph and Elder, of Glasgow, in 1856 -which was tested successfully by Messrs. Humphreys and Tennant in the first British ironclad so fitted, the Pallas. In the double-expansion engine, two cylinders, one small and the other four times larger, were employed, steam being admitted first to the smaller at high pressure (6o lbs. to the inch in those days), and then into the larger. Thus greater power was obtained with reduced fuel consumption.

The compound engine compelled the disuse of salt water for feeding the boilers, hitherto universal in marine systems, and the introduction of surface condensers for providing fresh. In like manner, the increasing steam pressures that were gradually being attained, led to the introduction of the circular boiler, of stouter build than the old box-shaped boiler heretofore in general use. With sea-water, steam of higher pressure than $35 \mathrm{lbs}$. to the square inch could not be got, owing to the incrustation deposits in the boilers, while, at the same time, the box type of boiler with its flat surfaces, stayed together internally from side to side for strength, was found unable to safely bear pressure above $40 \mathrm{lbs}$. to the inch.

The compound engines, though in every way highly satisfactory, were, however, only gradually introduced, and did not generally supersede simple engines till I872. Compound horizontal cylinder engines with three cylinders, one high-pressure and two low, are also to be found in a few ships of this period, fitted with return or direct connecting-rods as space permits.

Between I875 and I880, hollow, compressed steel shafting, greatly reducing weight in the machinery, was 
CHAP. VII.] STEAM ON BOARD SHIP.

introduced; also the arrangement of "tandem" engines (with high and low-pressure cylinders in line), set one before the other, instead of side by side, which effected a most valuable gain in space below.

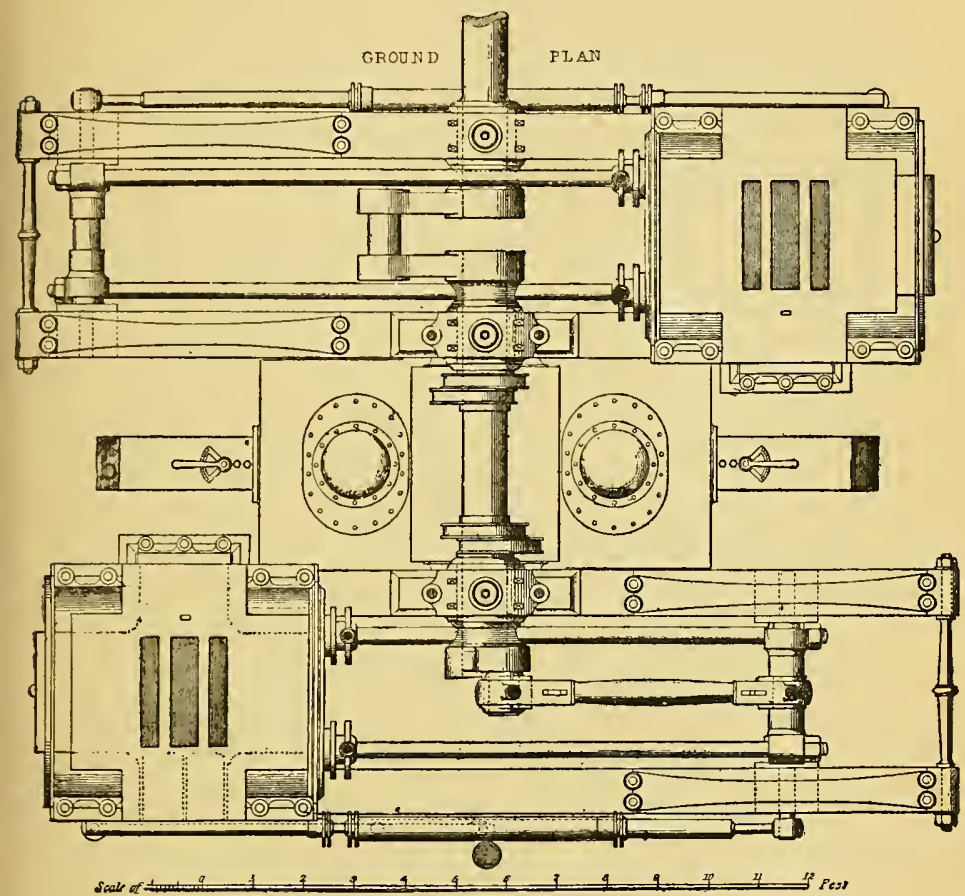

SCREW ENGINES OF H.M.S. "AMPHION," I 844 .

The inverted cylinder or " steam-hammer" engine, so called from the mode in which the cylinders are placed above the crank-much as the cylinder of a steamhammer stands above the anvil-now also came into general use in the Navy, enabling the older horizontal 
engine-a form with many disadvantages-to be dispensed with.

The great advance in the manufacture of "mild" steel, about I 878 , by enabling steel to be applied to the construction of marine boilers, and the simultaneous invention of the corrugated furnace as a substitute for the simple cylinder-shaped furnace hitherto used, led to the introduction of triple expansion, by which it became feasible to obtain a greatly increased pressure of steam with a much diminished expenditure in fuel.

In the triple-expansion system the increasing difference of temperatures found to exist between the two cylinders of the compound system-a difference that becomes more and more marked the higher the pressure employed-is divided between three cylinders of progressively increasing capacity, the steam expanding from one into the other, till practically every ounce of power has been got out of it.

The practical gain by triple expansion has been:immensely increased steam pressure (a rise of from 90 lbs. under the compound engine system to I 50 lbs.), increased power in engines, and increased speed, with a saving in fuel that gives war-ships an immensely increased radius of steaming.

The Rattlesnake, prototype of the Sharpsliooter class of torpedo-catchers, whose marked success in past Naval Manouvres is well known, was one of our first vessels fitted with triple-expansion engines. Her propelling machinery consists of two sets of vertical triple-expansion three-crank engines, having cylinders of $18 \frac{1}{2}, 27$, and 42 -inch diameter respectively, capable of exerting 2,700 horse-power at about 3 Io revolutions. The four boilers, fitted in two separate stokeholds, are of loco- 


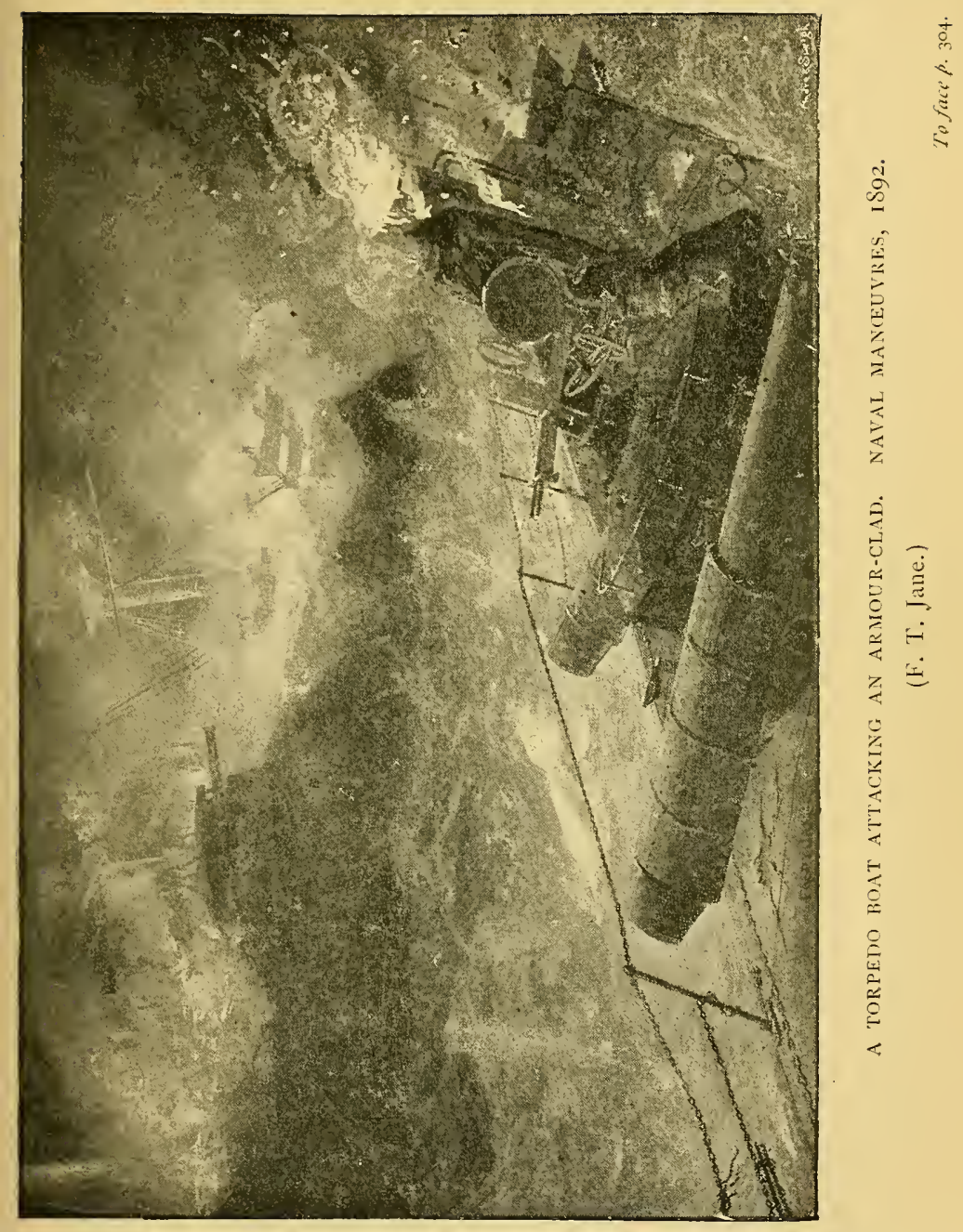



motive type. The working pressure is 140 lbs., heating surface, 4,640 feet, area of the firegrate, 122 feet. For forced draught the stokehold is fitted with four fans.

Higher efficiency still has been obtained by the further development of the system in the Bellona and Barham, and the engines of the first-class oceankeeping cruisers Blake and Blenheim. In the Bellona and Barham the engines are a double set of vertical triple-expansion engines with cylinders 27,40 , and 60 inches diameter, capable of 6,000 horse-power and $19 \frac{1}{2}$ knots an hour speed.

In the Blake and Blenheim the engines are four sets, triple-expansion, with inverted vertical cylinders, designed to give 13,000 horse-power, with 20 knots maximum speed, at natural draught, and 20,000 horse-power, with 22 knots at forced draught. The engines of the Blake and Blenileim are arranged, two sets to each propeller, in four compartments, each pair of engines being coupled. Each engine has a high-pressure cylinder of 36-inch diameter; intermediate cylinder, 52-inch; and low-pressure cylinder, 8o-inch. Six double-ended boilers supply the steam, having four furnaces apiece at each end and one combustion chamber per boiler.

To give some notion of the colossal scale on which the arrangements of the Blake and Blenheim are carried out, it may be remarked that the engines and boilers fill some two-thirds of the entire length of each ship.

In the Blake and Blenheim the marine engine is at its extreme development up to date, and identically the same system has been, and is being, applied throughout the Navy in the engines of the battle-ships and cruisers constructed under the Naval Defence Act of I889, and in the new constructions of Lord Spencer's programme, 
as well as in the new engines that are being placed in armour-clads of older types as these are converted.

The battle-ships of the Royal Sovereign class each have triple-expansion vertical engines of 13,000 horsepower maximum, high-pressure cylinder, 40-inch diameter; intermediate, 59-inch; low-pressure, 88-inch, supplied by eight single-ended boilers working up to I 50 lbs. steam pressure. The engines of the "Admiral" class, and of the Trafalgar and Nile (12,000 horsepower nominal), and Sans Pareil, are similar in general arrangement, as are the 10,000 horse-power engines of the Renown, Barfleur, and Centurion.

The engines of the first-class cruiser class (Edgar type) are also triple-expansion, inverted, ${ }^{1}$ with cylinders of 40-inch, 59-inch, and 80-inch diameter, capable of I 50 lbs. steam pressure, with four double-ended boilers ( 6 feet by I 8 feet), capable of 12,000 (nominal) forced draught horse-power, and 10,000 natural draught. The engines of the second-class cruisers, also vertical tripleexpansion, are in two sets, with five boilers, two singleended and three double, working up to $1 \sigma_{5} \mathrm{lbs}$. pressure ; and similarly with the third-class cruiser engines, which are in two sets per ship, of 7,500 horse-power (forced draught maximum) capable of 19 knots, with four double-ended boilers.

Still more noteworthy even are the results that have been achieved in the trials of the torpedo-gunboat Speedy"

${ }^{1}$ The term inverted vertical cylinder denotes the relative position of the piston and cylinder ; the piston being placed beneath the cylinder and entering it from below, with an upward thrust, instead of, as in ordinary land engines, working from above down through the top of the cylinder. A great saving of room is one advantage gained. 
CHAP. VII.] STEAM ON BOARD SHIP.

and of the torpedo-boat destroyers Havock, Ferret, Hornet, and Daring. In the two first-named vessels, with ordinary

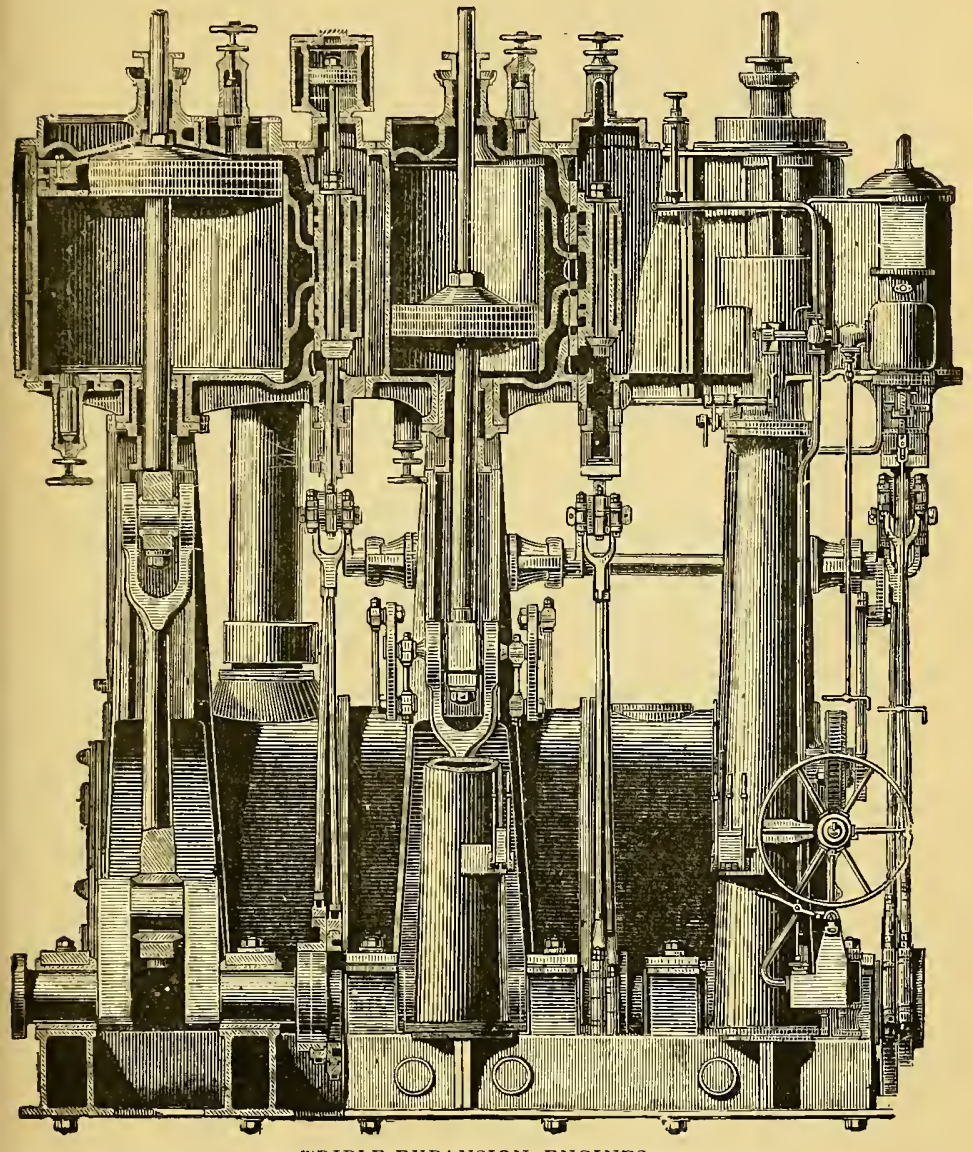

TRIPLE-EXPANSION ENGINES.

locomotive boilers and triple-expansion engines, speeds of 26.5 and 28.4 knots an hour respectively have been 
attained. The Hornet, with Yarrow's water-tube boilers, has achieved $27.8 \mathrm{knots}$, and the Daring, fitted with water-tube boilers on the Thornycroft system, ran at the still more remarkable rate of 29.2 knots an hour.

Contemporaneously with the introduction of the triple-expansion engine and double-ended boiler is that of forced draught, a method for increasing the air supply to the furnaces by closing all the ordinary apertures into the stokehold, and by means of fans through special ventilators creating an extraordinary draught of air on the fires. It was designed as an expedient for pressing the engines at the highest possible speed by artificially intensifying the air draught into the stokeholds, and causing the fires to burn with abnormal fierceness, the increased heat raising vastly more steam-power than could be obtained naturally. The intention was estimable, but unfortunately its effect on the boilers themselves was ruinous-tubes giving way and crippling ship after ship as fast as they were tried.

The situation became so serious that the placing of double-ended boilers in new ships was suspended, and it was even feared that the immense sums spent on the boiler supply of the Navy had been practically thrown away. This was little over two years ago.

A remedy-stop-gap perhaps in nature, but, for all that, sufficiently effective-has, however, been devised at the eleventh hour, the device of a "tube ferrule." The ferrule, briefly described, consists of a short, bell-mouthed tube, which is inserted into the mouth of each boiler tube with the object of carrying the heat past the tubejoint to a part of the tube higher up, better capable of absorbing it without injuriously overheating the metal. 
CHAP. VII.] STEAM ON BOARD SHIP.

The ferrule also protects the tube-plates, at the point of juncture, from direct impact of the flame. After being tested in several ships which had hitherto regularly

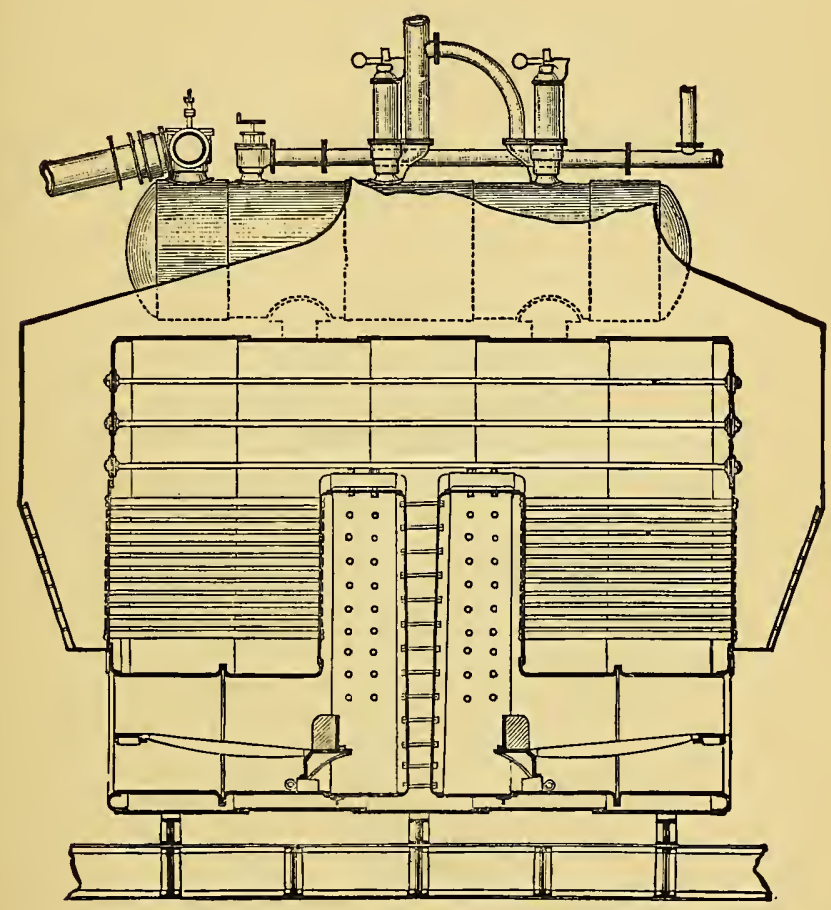

LONGITUDINAL SECTION OF DOUBLE-ENDED CIRCULAR HIGHPRESSURE BOILER.

broken down under forced draught, the ferrule is now fitted in all double-ended boilers throughout the service, with various modifications suggested by further experience, such as the copper sleeve to enhance the dura- 
bility of the ferrule and render the process of sweeping ferruled tubes easier.

Hardly less marked than the marvellous progressive development in marine engineering as applied to ship propulsion, is the development in the application of steam machinery for general purposes on board ships. While in our earlier ironclads steam was used only for the ship's main propelling engines, it has now practically ousted manual gear on board ship entirely; to an extent that in our first-class battle-ships the auxiliary engines number some seventy, of varied and diverse mechanism worked some by steam, others by hydraulic power. Machinery weighs the anchor; steers the ship; rotates the turrets; loads, elevates, runs out the heavy guns; brings up ammunition; produces the electricity for all needs; ventilates the ship; hoists in and out the boats; works the pumps and fire-engines; distils the water used on board; closes the water-tight doors; and so on, performing all the ordinary duties of everyday life on board ship.

Among latest developments in marine engineering one of the most important is the tubulous boiler, a system, that is, practically the converse of the ordinary. The furnace in the tubulous system is itself surrounded by a nest of water tubes which are led through the fires, instead of the heat, as in the ordinary boiler, passing through the boiler in tubes led through the water. The tubulous boiler has been tested, with the highest success, in the new gunboat, Specdy, which has eight of these boilers, constructed on Thornycroft's curvilinear tube system; also in a first-class torpedo boat, constructed by Yarrow on the straight tube system; and in the Homet and Daring, previously mentioned. In the torpedo boat the quadruple-expansion system of engines (four 
cylinders of gradually increasing diameter) is also being tested. The boilers of the cruisers Powerful and Terrible, of 14,200 tons displacement, will be on the tubulous or water-tube system, of a French type. The engines of these vessels, with natural draught in the stokeholds, are designed to give 25,000 horse-power.

The triple screw has not yet been adopted in the British service, although several foreign powers have

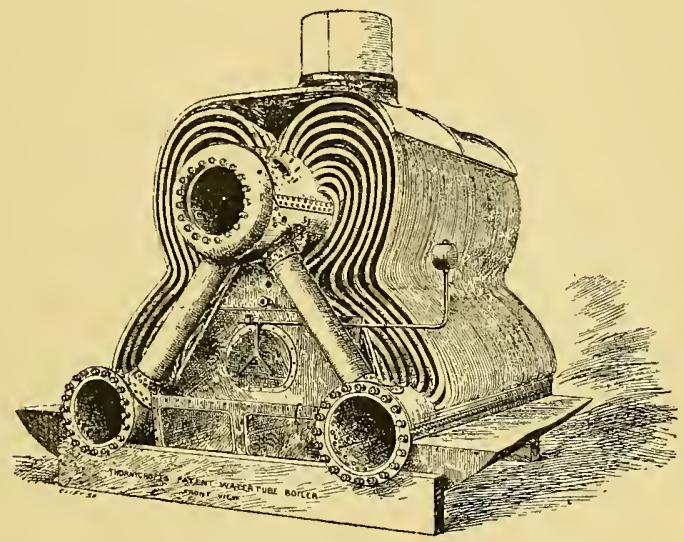

BOILER OF H.M.S. "SPEEDY," I893.

(Thornycroft.)

already employed it in new ships. The experiment was first tried in I886, in the Italian torpedo-catcher, Tripoli, a vessel of 750 tons, and in three other Italian vessels of the same class. The result was unfavourable, owing, it would seem, to the small size of the ship, which compelled the three screws to be placed so closely together that the centre propeller had no "solid" water to act on. Later experiments with larger vessels have been more favourable, notably in the case of the American 
triple-screw "commerce" destroyer, Columbia, of 7,500 tons, tried with success in the autumn of 1893 . At the trials of the Columbia a speed of nearly 23 knots (with forced draught) was attained, the centre screw during the runs apparently adding considerably to the driving power of the two side screws. Two of the new Frencli battle-ships, the Bouvet and the Masséna, vessels of I I,800 and I 2,200 tons, are designed to take the triple screw, which has already been applied in the armoured cruiser Dupuy de Lôme.

Another new idea in marine engineering is the possible substitution of "induced draught " for "forced draught," the distinction between the two systems being, that in "forced draught" the air is driven into the front of the boiler by fans, while in "induced draught" it is sucked in (also by fans) at the base of the funnel,

There is also a tendency in some directions to employ petroleum as a substitute for coal, several experts contending that the use of liquid fuel will greatly facilitate the work of stoking, as well as give other advantages. A system invented by an engineer named Cuniberti is in use in the Italian and German navies, while in France and in Russia experiments to the same end are reported to have given excellent results.

Electricity, is being experimented with, especially abroad, in a very important direction-with a view to its taking the place of hydraulic force as a semi-primary power, such as in the mechanism for turning the turrets and for working and laying the heavy guns.'

1 For fuller particulars see "Marine Engines and Boilers," by G. C. V. Holmes, Chapman and Hall, 1889 ; and "Steam Machinery," by Messrs. Langmaid and Gaisford, Macmillan, 1893. Several papers recently read before the Society of Naval Architects should also be consulted on the latest inventions and innovations. 


\section{Part IV.-THE PERSONNEL OF THE NAVY.}





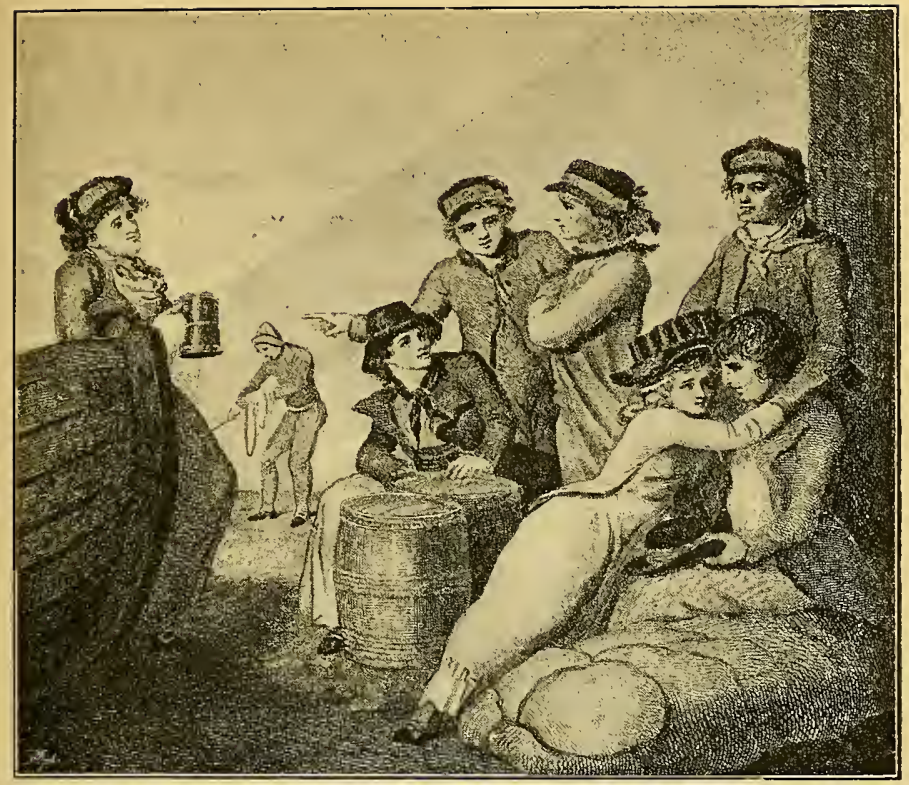

SEAMEN OF H.M.S. "EDGAR," PORTSMOUTH, I 785 . (Bunbury.)

\section{CHAPTER I.}

THE SEAMEN AND MARINERS OF ENGLAND.

HAVING dealt with the material of the Navy and its administration and duties, there remains to deal witl what is, after all, its most important part, the personnel --the body of men, that is, who themselves constitute the Navy; those who handle and fight our ships. As it happens, this is a subject about which perhaps less has 
been written than upon any other in the whole range of naval affairs.

To quote the words of the preliminary circular issued by the recently founded Navy Records Society: "Everyone who has paid any attention to the subject, knows how curiously ignorant we are as to the social life or social status of our forefathers in the Navy. We do not know," this document continues, "where or how they lived, messed or dressed." The result is that the most ridiculous fallacies have had, and have still, the widest vogue even with people otherwise well-informed and well-read. For instance, we may note in passing how "the fact that a large proportion of our officers entered the service as 'captains' servants' has been over and over again put forward as a proof that they were for the most part of low origin." Nothing, as will be seen in the course of these chapters, is further from the fact. Or, again, if we take the press-gang system, few people have an idea to what extent it was a regularly authorized and constitutional practice for manning our Navy, nor how many centuries it goes back for its origin; nor are they aware that the laws relating to its enforcement are yet upon the statute book.

In fine, the whole story of the personnel of our Navy is one of continuous growth and steady development, authorized at every stage by the law of the land, but each advance growing out of experience and trial, and thus made, after full consideration, by those responsible for the safety of the Realm. As the child, in natural course, in the sequence of years, becomes the man, so our naval personnel of to-day has come to the vigorous prime in which we see it, by steady and natural formation, out of and from the naval personnel of the English 
sea service which, no matter in what rudimentary form, came into being and shape first under the Plantagenets and the Tudors; indeed, even before their time, and before ever Norman William set foot on the shingle beach of Pevensey Bay.

To begin then. The English man-of-war's man, using the term as generic for the force of men specially maintained to fight in the king's ships against the king's enemies, is an institution at least nine centuries old. Tracing back his origin to the Anglo-Saxon Buscarles, or Butsecarles, he connects, through the Cinque Ports' Navy, directly with the Royal Navy of later days, and so to our own time.

The Buscarles, as far as can be made out, were a naval fighting force more or less corresponding with the Huscarles, or Royal body-guard of landsmen who stood round Canute, Godwin, and Harold, alike on the steps of the throne and on the field of battle. Apparently they were a mercenary or paid force, a body of picked men enrolled and regularly maintained to sail and fight the king's ships, which comprised the larger types of vessels of the day, and those which bore the brunt of the fighting. Whilst a detachment of them was employed ordinarily to serve constantly on shore, side by side with the Huscarles at the king's court, the main body was usually quartered near the mouth of the Thames, and at various ports along the south coast of England, ready at a moment's notice to embark in and take charge of whatever ships the king might order to be embargoed for war service.

The ships they would serve in were, of course, for the most part the private traders of peace time, mer-. chantmen hastily armed for the emergency, and were 
quite distinct from the few regular "king's war-ships" that existed as a permanent force, and were manned by the Buscarles at all times. In peace time, as a rule, those of the Buscarles who were not on actual service with the Royal body-guard, sailed the king's ships either as sea-police or in the king's private vessels on his majesty's private affairs.

This sea force was kept up as a fighting body for the king's ships under our first three Norman rulers, until Henry I.'s reign, when, as Professor Burrows has reason to believe, they were "amalgamated with the Cinque Ports' force, from which they were clearly distinct in earlier days."

Of the internal organization of the Buscarles, we learn from Sir Harris Nicolas that in the eleventh century the ships were each under a "batsuen" (boat's swain or husband), who commanded her crew in action, and acted at all times as master, pilot, or steersman, being paid ten marks for his services. ${ }^{1}$ The rowers, who took their orders from him, were paid eight marks a man; provisions and clothing-of coarse rough woollen cloth dyed blue-being provided with the pay for all ratings. With this permanent force ready mobilized, and at

${ }^{1}$ Edward the Confessor's principal ship carried a rector or captain, as well as a boatswain or steersman, and the names of both officers have been handed down to us. That the seafaring profession was to a great extent hereditary is shown by the interesting facts, that Stephen Fitz Erard or "Stefanus Stirman," the rector of William the Conqueror's ship, was the grandfather of Thomas Fitz Stephen, who fifty-four years later steered to her destruction the ill-fated Blanche, in the wreck of which vessel the young Prince William and his sister were drowned; while Alan, of Cœur-deLion's vessel, the Trenchmer, or, as we might say, the Sheerwater, was also the son and grandson of sailors of note. 
hand, the king was able, on the outbreak of hostilities, to find the ships, by simply "arresting" for war service what ordinary traders he chose. The law gave him power to do this both with ships and men, and also to forbid-until the king had chosen what he wantedall vessels leaving port at such a time without a special permit.

As I have said, the Buscarles were eventually absorbed into and incorporated with the Cinque Ports' forces. These forces, as is told elsewhere, were a more or less national organization, and had co-existed with the Buscarles, though distinct from them, and as an independent body, for a hundred years already. This body had passed from its earlier shape as an allied group of trading communities lying along the south-east coast of England, banded together for self-defence and finding its own men for that purpose, into a military organization, wearing a distinctive dress and a badge of arms of the respective ports, with its own officers and seamen, and under stress of circumstances had thus grown into the national warmarine as "The Royal Navy of the Cinque Ports."

Edward the Confessor, failing in his attempts to raise the money necessary to support a standing Navy, seems to have given the first impetus and encouragement to the scheme which led to the organization of the Cinque Ports' naval force, thus providing his kingdom, as the Historian of the Cinque Ports ${ }^{1}$ remarks, with a cheap defence, for the Crown paid nothing towards the support of the ships or their men - these latter being also available for the king's ships when wanted for actual war service.

'Captain Montagu Burrows, R.N., Chichele Professor of Modern History at Oxford. 
Not only was the country thus economically provided with a Navy, but the franchises and privileges accorded to the Cinque Ports at the same time attached the Ports' men permanently to the Throne. The complements of the fifty-two ships, which in return they undertook to supply for fifteen days in cases of emergency, were twenty-four men per ship (I 205).

From portions of the "Ports' Domesday Book" (drawn up in the reign of Henry III., and still in existence) we learn how a little later these Cinque Ports' ships were manned. Each ship at this time carried twenty-one seamen and one boy (the gromet or groom), with a rector or master, and a constable or boatswain. Their duties were, however, confined to managing the ship, and not-as had been the case with the Buscarles, and in earlier days with the Cinque Ports' seamen themselves-to sailing and fighting her.

For fighting the ship it had by now become customary to put on board a body of men-at-arms, cross-bowmen, and spearmen, under a knight, who took supreme command of the ship. The tactics of the time were to run alongside the enemy, board, grapple, and fight it out hand-to-hand as on shore, and the knight, as commanding-in-chief, directed the master and seamen where he wanted to go, and alongside what enemy he wished to be laid. ${ }^{1}$ It was the same with the king's ships proper, whose seamen crews merely navigated the vessels they

${ }^{1}$ Edward III., at the battle of "L'Espagnols sur mer," fought on Sunday, August 29th, I350, is reported to have said to the helmsman or master of his ship, in words which have a strange similarity to those used by a British admiral four hundred years later, "Lay me against that Spaniard who is coming this way, for I wish to joust with him." 
were in, so as best to suit the convenience of the soldiers they carried, and to whom alone the fighting was intrusted. There were, however, frequent occasions when seamanship told, and soldier officers-like Blake in later times -profited by experience at sea, as we see from the brilliant battle off Dover, in which the Justiciary, Hubert de Burgh, with forty ships, met, outmanœuvred, and overpowered, by his naval tactics, a French fleet of between ninety and a hundred sail (I2I7).

Under Edward I. and his son the ships grew larger than heretofore and more men were employed afloat, the larger "cogs" of the day being manned by thirtynine mariners each, with one master in charge and two constables, his assistants. Smaller vessels had one inaster (the term "rector" was going out of use) and one constable only. As ships continued to increase in size, complements were naturally increased also. The relative position of and distinction between the master and his seamen, who sailed the ships, and the knight or military chief and his soldiers-Genoese cross-bowmen (now universally employed in English war-ships), archers, slingers, and men to work the arbalists, or stone-hurling engines- who fought her, remained as before, practically until the beginning of the sixteenth century.

The military required their own departmental officers on board, such as the "fletcher," to keep the arrows of the archers trimmed, and the "armourer," who had care of the armour of the knight and his mail-clad officers, riveting it before battle, and so forth, besides looking after the leather helmets and jerkins of the soldiery. These, by the way, were usually supplied either on loan for the expedition, or bought for the king at a valuation, after being taken over compulsorily by royal warrant. 
Both the ships and their companies required for the king's service were obtained compulsorily, the orders to the officers engaged on the duty being to "arrest and seize" the vessels required, and to "select" to sail them the best and stoutest men-described officially as "sailors and mariners," i.e., those who were used to distant voyages in large ships and men brought up in smaller coasting and fishing vessels. This had been the legal procedure from the days of the Anglo-Saxons, and had been enforced by every Norman king; an enactment of Henry II., forbidding ships to be sold out of England, or seamen to go abroad. ${ }^{\text {" The regular stores }}$ and provisions laid in by our ships before going on service comprised, among other things, wine, bread or biscuit, and stock-fish, with torches, tallow candles, cressets, and lanthorns.

Cabins for the accommodation of the higher officers serving on board came into use early in the thirteenth century, the idea being taken probably from the arrangement in the large Venetian merchantmen which periodically visited England. They were generally constructed at the bows and stern. ${ }^{2}$

The rank and title of "admiral" now appears for the first time. It gradually ousted the various titles by which those in charge of the king's fleets had been hitherto known, as "leaders and governors," "justices,"

2 As early as I206, we learn that, though the king's galleys or ships were usually manned by impressment, seamen were sometimes enlisted, and voluntary service was not unknown. The penalty for disobedience to the impress laws was harsh: "Know for certain that if you act contrary to this, we will cause you and the masters of your vessels to be hanged and all your goods seized for our use."

2 Harris Nicolas's "History of the Navy," vol. ii. pp. 173 and 443. 
"leaders and constables," "keepers of the sea coast," "captains and keepers of the sea." Gervase Alard, who was in charge of the Cinque Ports' flotilla in Edward I.'s expedition to Scotland in 1300 , was the first to officially bear the title, which henceforward is constantly met with, either by itself or joined with "captain" as "captain and admiral," or, less frequently, "admiral and captain."

The title "admiral" was at first personal to the official in supreme command of our naval force, but it very soon was enlarged in scope, and became general for all commanders of fleets and squadrons, as early as I 3 I I, in fact. These commissions, which were "during the king's pleasure," and dependent on the loyalty, ability, and good conduct of the officer, gave power (including that of impressment) ${ }^{2}$ within the coastwise limits of the admiral's jurisdiction duly defined, over the sailors and mariners of all ports, and all men-at-arms and men fit to serve as such, as well also over all soldiers embarked.

The admiral and his deputies were also authorized to keep a record of seamen and material within their jurisdiction; with power, on occasion, to seize ships, barges, boats, and provisions, armour, and other necessaries, and press men as they might need.

The pay of the post of admiral at this time-unless the holder of the office was already a baron or an earl, when he received $6 s$. $8 d$. or $6 s$. $4 d$. according to rank, with allowances for his retinue-was that of a knight or banneret serving in the field, $2 s$. or $4 s$. Afloat, in token of

I Power was given in 1294 to Sir John Leybourne to impress seamen, and in I 3 I 5 to Sir John de Botetourt; and doubtless all the other admirals received similar power. 
chief command, he hoisted his ensign on his own shipbecoming the exact counterpart of the modern "flagofficer" in this particular.

Contemporaneously with the rank of "admiral" the rank of "captain" came into general use-about I 300 . The captains, though what their precise duties were is uncertain, were of higher consideration than the masters who sailed the individual ships. Each, probably, commanded a division of the fleet, under the admiral. Their pay was half the admiral's, and twice that of the masterIs. a day, the same as an esquire received.

Of the other officers, there was the master, as before, to sail the ship under its military chief; and the constable, the master's right-hand man, whose powers were not dissimilar to those of a boatswain of the last century, and who, like that worthy, carried a rattan. There was also one chaplain to each fleet, whose duties extended to every ship. The master, constable, and chaplain were paid each $6 d$. a day.

The seamen of the period received $3 d$. a day (later $3 \frac{1}{2} d$.), being a penny more than the common foot-soldier. The ship's boys got $\mathrm{I}_{2} d$. a day. The seamen's working dress was a loose, coarse, frieze blouse, falling to the knee, and gathered in at the waist, with sleeves to the elbow; they carried a knife slung under one arm by a lanyard round the neck, and for the Cinque Ports' men the livery and badge of their port as before. ${ }^{1}$ For arms, each sailor had to provide himself with two spears, one long and one short, which he was directed to be careful not to lose by throwing. The officers of the Cinque

${ }^{1}$ See Chaucer's description of the lodesman and shipman in the "Canterbury Tales." 
Ports' ships, as well as the captains and masters of the king's ships, seem, further, to have had allowances made them before going on war service, and on other occasions, to purchase distinctive robes.

Voluntary service and impressment both helped to man the Navy at this period, and, as when men were pressed, "special instructions were given that only the "fittest" were to be selected, we may assume that there was no lack of mariners. At the same time this process of selection appears to have operated adversely to the interests of the merchants, and complaints were frequently made in the Commons about the impress of skilful masters and the ablest seamen. On the other hand, as early as 1315 we find clauses in the safe-conduct granted to merchant ships specially exempting the crew from impressment unless the master was willing to spare a few hands. The punishment for
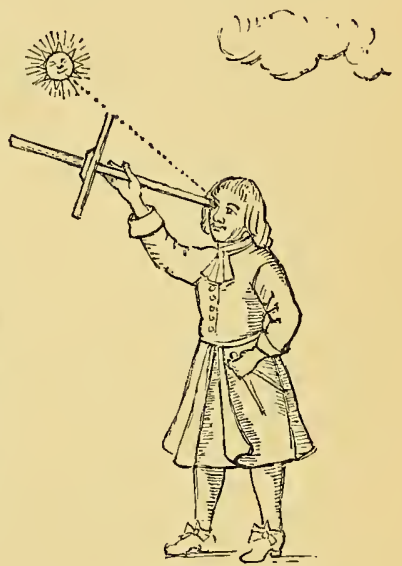

SEAMAN USING A CROSS-

STAFF, FIFTEENTH

CENTURY. evading the impress was now less severe; one year's imprisonment for a first offence, and, for a second, two years' and forfeiture of goods. It is curious, as an example of superstitious fancies in the Navy, to find, in I377, the failure of an expedition ascribed by some writers to the fact of women having gone to sea in some of the ships.

To encourage the officers and men during war service, 
a system of "prize-money" distribution began to be gradually instituted from this period, the value of all captures made being divided, a fourth to the king, a fourth to the owners of the hired ships, and the rest between all who were present and within sight at the time of the capture, in the proportion of one double share to the admiral and a single share to every other man engaged. This was in addition to the sixpence a week "reward" which the king might allow as a gratuity to all seamen serving him afloat.

All power of punishment was vested in the admiral, before whom all transgressors were to be brought "to receive such punishment as the law of the sea provided." The penalties which the admiral by virtue of his commission had power to allot ranged from death and mutilation to fines (flogging, curiously, is nowhere mentioned), the admiral's deputies being empowered to act for him, except in those cases that involved the death penalty. The procedure was for the offenders to be arrested and imprisoned in the ship by the master, who could call on all under him to assist, until the case had been brought before the admiral. There is record, however, of special authority being given through the admiral to the masters of certain of the larger ships "to chastise and punish all mariners and other men in those ships as often as they should happen to offend, according to the custom of mariners."

New ship's officers-the "Clerk," described in contemporary documents as the "burser," whence, by an easy transition, is derived the name "purser," and the "Carpenter"-appear during the fourteenth century. The clerk was the paymaster of the crew, engaged the armourer and the ship's workmen, and had charge of 
the stores and provisions, which he, further, sometimes provided. His pay was $6 d$. a day. ${ }^{1}$

Sixpence a day was also the pay of each of the carpenters, of whom there were sometimes, in the larger ships, two. Among the ship's company was included a "lodeman" or pilot; one of the mariners already on board, with the necessary local knowledge, was selected for the post as a rule, to whom extra pay was given for his services as these were required, from point to point.

During the fifteenth century the officers and ships' companies comprised, as before, the master, constable, clerk, and carpenter, sailors and boys. The status of the master gradually improved as his charge became more important-with the advance of navigation and the art of shipbuilding. The ships had now begun to carry cannon and had become in themselves tactical engines of war, and quite different from the early style of vessel, used solely as a vehicle for bringing the soldiery on board into action.

The advance in the responsibilities of the master's duties was certainly recognized by Henry V., and led to a radical change in the organization of the personnel of the fleet. In I4I7 the king led an expedition into Normandy, the naval preparations for which were extensive. A numerous fleet, of which one hundred and thirty ships were supplied by England, was equipped and collected at Southampton. To obtain the command of the seas necessary to the safe passage of troops and reinforcements, the principal ships of the Royal Navy

1 The accounts of the purser, or clerk, of the Christopher in 1338 , and of the Thomas in 1340-42, are in the Rolls from Carlton Ride (J.P.R. I25, 41 I-426). Harris Nicolas's "History of the Navy." 
were despatched, under the Earl of Huntingdon, to clear the Channel, and on July $25^{\text {th }}$ met and defeated the enemy's sea forces. Then the king sailed, and without further opposition landed at Touque, near Honfleur, on August Ist.- Twelve days later, by an order to the Chancellor, his majesty granted annuities to the masters of each of his ships, carrakes, barges, and balingers. From this time, too, it is stated that the appellation "Captain" was occasionally given to the masters of the king's ships.

Here, then, we have the genesis of a permanent corps of naval officers. Sir Harris Nicolas, who gives, in his "History of the Navy," the text of the king's letter, seems scarcely to have recognized its importance, but to my mind it marks a most noteworthy epoch in the life of the sea service, for it demonstrates practically how the value of his Navy impressed the king, while it gives the key to many problems which have puzzled students of naval history. From this time forth there was a small body of professional men, experienced in the needs of the service, in permanent pay, and ever ready with suggestions and advice for its improvement and welfare. The names of these Fathers of the Royal Navy and of their ships I have deemed of sufficient consequence to add in a note. ${ }^{1}$

${ }^{1}$ John William of the Jesus, Stephen Thomas of the Trinity Royal, Jordan Brownyng of the Holy Ghost, John Gerard of the Peter, William Payne of the Paul, John Thornyng of the Andrew, - Pendrell of the Christopher, Wiiliam Richeman of the Marie, William Hethe of the Marie II., John Mersh of the George, William Robynson of the Nicholas, John Kyngeston of the Katherine, Ric. Walsh of the Marie III., Thomas Martyn of the Forward, William Cheke of the Marie IV., William Yalton of the Christopher II., John Piers of the Petite Trinity, Rauf Hoskard of the Anne, Robert Shad of the Nicholas II., Edward Hooper of the George II., 
Changes were made at this time in the appointments of the admirals and commanders of the fleet at sea. After I406, while there was always one "Admiral of England "- -a nobleman of rank-as titular head of the Navy, special subordinate admirals were appointed to take personal charge of the conduct of the king's squadron and fleets on active service. These were variously styled "Admirals," "Captains," "Leaders of men-at-arms and archers on the sea," or "the King's Lieutenants on the sea," and they exercised under the king's commission full powers over those serving under them.

The sixteenth century caine, and with it grew up a spirit of over-sea adventure and exploration which brought English sailors into rivalry and hostile contact with the naval adventurers of other lands. Our newborn interests thus created required the existence of a permanent sea fighting force to safeguard them, and so our naval affairs had to be definitely organized on a wider and more national basis than had sufficed in earlier times. To take charge of the large war-ships we were now sending afloat, officers and men were wanted in larger numbers and of a higher training than could be provided under the comparatively haphazard system of the past. The large ships' companies that were now embarked, with their vastly increased duties, required additional subordinate officers to control them.

At the head of these came in the Boatswain ${ }^{1}$ (taking

Stephen Welles of the Cracker, Andrewe Godfrey of the Gabriel John Bull of the Little John, Janyn Cossard of the James, - Rowe of the Swan, and Janyn Dene of the Katherine 11 .

${ }^{1}$ It is probable that the term had all along been in use afloat, but was not employed as an official designation. 
the place of the "constable" of former days) with his assistants or "mates," and the "quarter-masters." The numerous heavy guns that were now mounted, not, as hitherto, on the upper deck alone, but all over the ship below, almost wherever a port-hole could be cut, needed special men to look after them, and thus were brought in the Gunner and his mates. The old practice of intrusting the fighting of the ship to soldiers was still continued, however, but with constant modifications. It had become gradually evident that there was no room for both on board, and that the seamen could be more easily and naturally trained to the use of arms, than soldiers to the working of ships. But that consummation was not yet. Throughout the century, in addition to the seamen, a large contingent of musketeers (portable small arms having come into general use), with a fighting tail of archers, continued to be regularly allotted to each ship as part of her crew, under their own officers. Thus in our first big man-ofwar, the Great Harry of I512, we find the ship's company told off as-soldiers 349, mariners 30I, gunners 50. As the Great Harry' carried at least 72 guns of large size, possibly the gunners in action attended only to the larger pieces, leaving the smaller to the men to manage. Raleigh, at a later date, speaks of some of the ships of his time having 40 guns and only 20 gunners in charge of them, in which case we may suppose that they acted as captains of guns and that only one broadside was manned at a time.

The result of the century's experience in regard to the relative complements of soldiers and sailors on board is shown by a comparison of the company of the Great Harry with that, for example, of the Victory of 1558 , in 
which latter, out of a total of 400 all told, the mariners numbered 268 to Ioo soldiers. The gunners were in about the same proportion-32 to 42 guns.

Forty years later the contingent of soldiers was done away with entirely, and the sailors were left to fight and sail their vessels for themselves. A "station list" of a ship of this latter period (1624), the Speedzuell, of 30 guns, shows how the new system of duties worked :- I 8 gunners and 48 men for the battery, 50 small-arm men (with arquebuses, and bows and arrows), 50 to work the ship and man the tops, and 4 in the powder-room.

As to officers and noncombatants. The "captain" of the Great Harry period was, as a rule, very little more of a seaman than the knight embarked to command the "king's ships" of the past had been. He, no doubt, had more to do with the ship's duty than the oldtime knight had, but he was

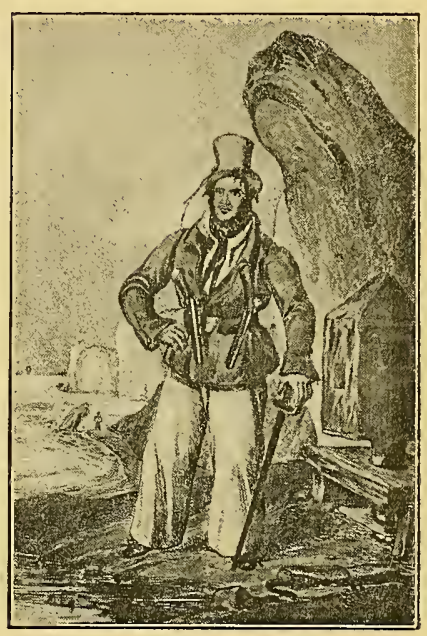

PREVENTIVE SERVice Man, i829. (Heath.) more of an amateur than a professional seaman. Sir Thomas Knyvett, for example, who was a captain of the Great Harry herself, was also the king's Master of the Horse, and a soldier bred. As before, the actual handling and care of the ship herself rested particularly with the master. It is not, indeed, until we come to the Elizabethan period that we find seamen-captains 
proper, such as Drake, Hawkins, and Frobisher, commanding the fighting ships of the Royal Navy.

To mark, as it were, the transition stage in the evolution of the naval officers between the amateur and the professional (a stage which lasted as nearly as possible one hundred years), there are found holding commands in the same fleet with the above-mentioned seamen, Lord Howard of Effingham, Lord Thomas Howard, Lord Harry Seymour, Lord Sheffield and Sir Richard Grenville. The Royal Navy, it must be remembered, was not yet-nor for some years to come-a profession with the higher officers. Men like Drake and Hawkins were, indeed, only found side by side with the others because they had made such a name for themselves that they could not be passed by with safety in time of peril; their prowess as maritime adventurers made them indispensable. The commands, too, were only temporary, for the special service in hand, after which the ships engaged were put out of commission, and both gentlemen and seamen-captains relegated to private life once more, just as the ships' crews at this time were no part of any standing national force, but were engaged and paid by the week or month, or for some particular expedition, after which they were discharged and turned adrift. At the same time, a small permanent force of officers and men existed as ship-keepers, having charge of the vessels when laid up in harbour. After the Armada fighting, however, the amateur naval officer began to be replaced by the trained seaman; although the process was very gradual.

Here it is that we once more meet with the masters of the king's ships, and are able to note the effect of this body upon the progress of the Navy. The exact date 
at which the Guild or Fraternity of Pilots, Seamen, and Mariners was first founded, at Deptford Strond in the county of Kent, is unknown, but it existed in the fifteenth century and presumably mustered among its members those masters and captains who had been granted annuities, in I4I7, as permanent servants of the Crown. The first document, now extant, which concerns the guild, is dated the fourth year of the reign of Henry VIII., and is addressed to "the Masters, Rulers and Mariners of the King's Navy in the Thames." Two years later, at the instance of Sir Thomas Spert, who had been the master of the Mary Rose and of the Henry Grace à Dieu, the king granted a charter of incorporation to the guild, and made this same officer first Master of the Trinity House. Among the powers given by their charter we find authority for making laws, ordinances and statutes for the relief, augmentation and increase of the shipping of the realm, as well as for the conservation and improvement of the science and art of mariners.

'Thus, when, in I 520 , the Admiralty and Navy Boards projected by Henry VII. were established, the Incorporated Masters of the Navy were the professional men consulted, and we find the seamen who held offices in connection therewith, to be for the most part Brethren of the Trinity House. Later, in the days of Queen Elizabeth, the corporation is styled "a company of the cheefest and most expert governors of ships, charged with the conduction of the Queen's Majesty's Navy Royal, bound to foresee the good increase and maintenance of ships, and of all kinds of men, traded and brought up to water-craft, most meet for Her Majesty's Marine Service." Its mission was therefore clearly not merely to exercise a general supervision of the material, 
but to reform the personnel, "lately decayed by the admission of young men without experience," and this mission it fulfilled, so far, at least, as one class of officers was concerned, to quite a recent date.

It was at this time ( 1580 ) that the lieutenant first appears as the holder of a naval rank, the post being introduced with the double intention of providing the captain with an assistant combatant officer who should be qualified to take his place on occasion, and also with the idea of forming a body of trained sea officers from whom the captains of the Royal Navy might be drawn as the older captains died off. One lieutenant to each ship, and no more, was the establishment at first. The appointment of the lieutenant, who was an officer of social position, rested with the captain, who generally made his choice from among his personal friends. The masters, on the other hand, were appointed by the Admiralty, who selected them from the masters' mates, young men in the first place recommended to the Admiralty by the Trinity House Corporation.

Monson, writing later, tells us that the captain, while he could displace any other inferior officer, could not displace the master, being able only to stop his wages till the Admiralty or special officers appointed by the Lord High Admiral had heard the complaint. Most of Elizabeth's sailor-captains were also masters, but the system did not long obtain, much to the disgust of the old salts. Monson, speaking of the great discouragement there was to men bred to the sea, in "the preferring of young, needy, and unexperienced gentlemen captains over them in their own ships."

To what extent the cadres of the Navy were complete by 1588 we know from the State Papers of the time, 
which give the various grades on the establishment, with the pay of each rank and rating:-lord admiral, $£ 36 s .8 d$; vice-admiral, $£^{2}$; rear-admiral, I $5 s$. ; captain, $2 s .6 d$. all per day. Everyone else was paid by the month :lieutenant, $£_{3}$; preacher, $£_{2}$ to $£_{3}$; secretary, $£_{2}$; corporal, $£$ I $7 s .6 d$. ; master, $£$ I to $£ 32 s$. $6 d$.; master's mate, $17 s .6 d$. to $£$ I IOs.; quartermaster, I $7 s$. $6 d$. to $£$ I 5 s.; pilot, $£ 7$ to $£ 7$ IOs.; boatswain, I $3 s$. $9 d$. to $£ \mathrm{I}$ Ios. ; master carpenter, I $7 s .6 d$. to $£ \mathrm{I} 5 s . ;$ master gunner, I $3 s$. $4 d$. to I $5 s$.; purser, I $3 s$. $4 d$. to $£ \mathrm{r}$; surgeon, $£ \mathrm{I} ;$ cook, I $3 s .9 d$. to I $7 s .6 d . ;$ drummer, I $5 s$.; yeoman of sheets, I $7 s .6 d$; yeoman of powder, i is. $3 d$; steward, I $7 s .6 d$; trumpeter, £I; piper, I5s. ; armourer, I $8 s$. $8 d$. ; sailor, Ios. (raised to I $5 s$. by Charles I.) ; gromet, $7 s .6 d$.

The duties regularly allotted to these officers to perform, show to what a pitch of organization the

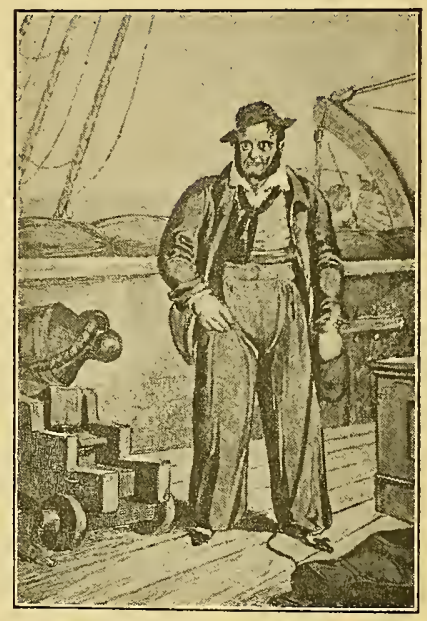

SEAMAN OF REVENUE

CRUISER, I 829.

(Heath.) Navy had attained. The captain and lieutenant, as has been said, were the chief executive officers, with general authority over everybody. The master and his mates navigated the ship. The pilot was an official provided by the Trinity House Corporation for service afloat in home waters. The corporal, who first appears towards the end of the sixteenth century, looked after the small 
arms and the musketeers' equipment, and exercised the small-arm men. The master gunner and his mates kept the guns in order and saw to their tackle, besides looking after the powder-room or magazine, and the gunroom where the small-arm ammunition was stored. The master carpenter and his mates looked after the repairs and general state of the hull, seeing to the plugging of the shot holes in action, the pumps and caulking, and the masts and yards. Attached to the carpenter in the larger ships in James I.'s time was the "joyner" who attended to the internal fittings, the mess-tables, scuttles, lockers, chests and the carved work in the great cabin. The boatswain and his mates had charge of the ropes, rigging, cables, anchors, sails, and flags, superintended the men at their stations, and saw to the setting of the watches, besides superintending, if not carrying out, punishments-" at the capstan, by the bilboes, or with ducking at the main yardarm "-and on occasion taking charge of the long-boat. The "cockswain"1 (who with the master and the boatswain carried a whistle) had charge of the captain's barge. The purser kept the nominal roll of the crew, the pay-sheet, and received the stores and provisions from the victuallers, transferring them to the immediate custody of the steward, who served the provisions, beer, and bread to the cook. The quartermasters, whose numbers on board varied according to the size of the ship, had charge of the hold and its stowing, conned the ship under the master and his mates, and assisted the steward to give out the provisions, beer. and bread. Last of all was a most useful officer known

${ }^{1}$ This was a very old title derived from the cog, originally a ship, but afterwards a boat, of which this man had charge. 


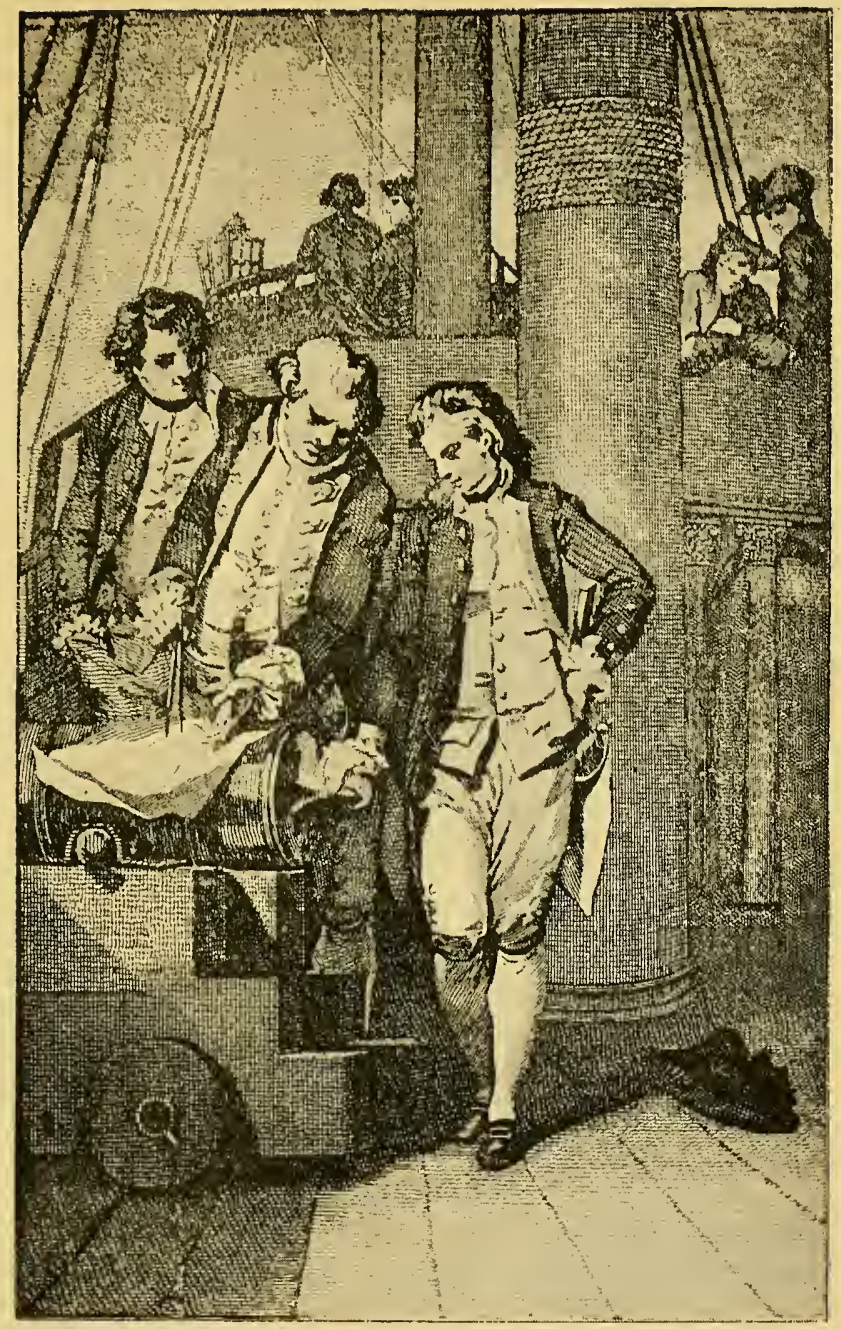

PRINCE WILLIAM AS A MIISHIPMAN OF THE "PRINCE GEORGE," JUNE, I 779 .

(Thomas Stotharcl.) 

as "the swabber," who saw to the ship being cleaned within and without above water, and was answerable for the men keeping their persons clean.

Prayers were said by the preachers twice a day, and there was, besides, the singing of a psalm at watchsetting, a very old custom in the English sea service. Preachers, however, were not regularly allotted to every ship till 1626, in which year we find the Duke of Buckingham announcing the fact as a new custom to the University of Cambridge :- "His Majesty having given order for preachers to goe in every of his ships to sea." As to the chaplain's pay, sums of a groat and twopence were deducted monthly from each man's pay for the preachers and the chirurgeons on board. In action the chirurgeon and his mates were posted in the hold to attend to the wounded, and the minister was also to be in the hold "to comfort and exhort the hurt."

With all this organization, discipline in the Navy throughout the century was by no means all it should have been. Take, for example, the case of the crew of the Mary Rose, of Henry VIII.'s Navy, which capsized at Spithead. On the word of their own commander, Sir Peter Carew, they were "a sorte of knaves whom he could not rule." They "soe maligned and disdayned one the other," we are further told, "that refusing to doe that which they should doe they were careless to doe that they oughte to doe, and so contendinge in spite, perished in frowardnesse." The Elizabethan captains kept a better hold of their men, but at the end of the century things were as bad as before, if not worse. The ships were manned by a "loose rable" and a "vagrant, lewd and disorderly"-a "ragged regiment of common 
rogucs" was one of the descriptions of the crews of his majesty's ships. Not that it was otherwise than might have been expected, for no care was taken of the men, either to pay them regularly, or to supply them with eatable provisions, and clothing, or to look after them when sick; while they were punished for every offence with remorseless savagery-by flogging, keelhauling, tongue scraping, hanging up with weights round the neck "till heart and back were ready to break," and so on.

One can well believe Raleigh when he tells us, "they go with as great a grudging to serve in His Majesty's ships as if it were to be slaves in the galleys," a dislike that often took the practical form described by the Naval Commissioners of 1625 - "the pressed men run away as fast as we send them down."

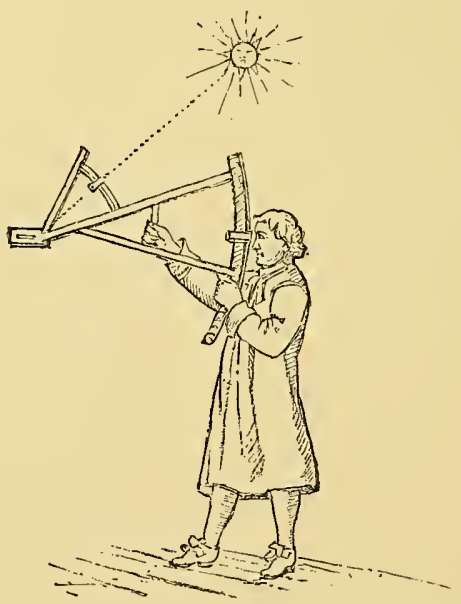

SEAMAN USING DAVIS'S QUADRANT, SIXTEENTH CENTURY. 


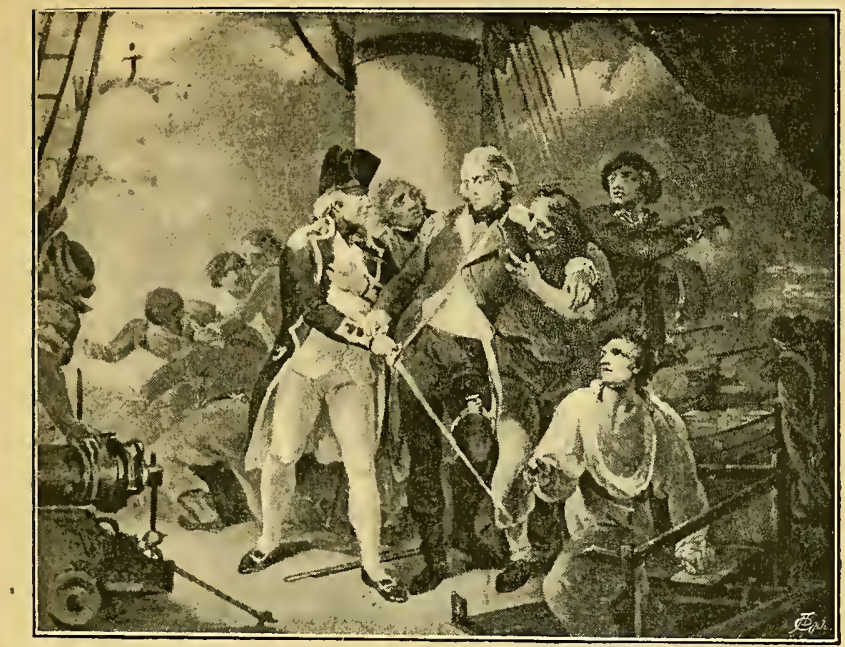

CAPTAIN HENRY L. STRANGWAYS, OF THE MARINES, MOR'TAILY WOUNDED IN THE ACTION BETWEEN THE "GLATTON," 56 GUNS, CAPTAIN HENRY TROLLOPE, AND A FRENCH SQUADRON CONSISTING OF FOUR FRIGATES, THREE CORVETTES, AND A CUTTER.

(Singleton.)

\section{CHAPTER II.}

SEA OFFICERS FROM BLAKE'S DAY TO NELSON'S.

In the preceding chapter we have briefly traced the changes which took place in the personnel of the Navy used for fighting purposes from the Saxon times to the days of the Stuarts. It has been shown how the improvements and modifications in the means and methods of navigating and equipping ships, the developments of the ships themselves, the introduction of new material of war, and the larger needs of an augmented national 
fleet, had all operated and assisted to bring about an alteration in the composition of the complements of the vessels. We have noticed also how by degrees a desire, and indeed a need, for an amelioration of the conditions of sea-life aboard ship, in the changed circumstances, appeared to be having its natural effect, although but slightly, along with other causes, upon the mode of housing and berthing the ships' companies and attending to their well-being. How, too, the necessity for a more numerous, a permanent, and a differently qualified force had begun to affect the rate of wages, while other factors, such as the competition and rivalry with the merchant marine, having tended to diminish the supply, the arrangements for raising and maintaining a sufficient number of officers and men were in process of being recast and systematized.

The fact which comes out most plainly in connection with every change or modification is its spontaneity. In a sense it is evolved by force of circumstances, and the demand is from within, from the sea service itself, which had already voluntarily tested the proposed plan and found it beneficial.

This is, by the way, the most obvious characteristic of that most conservative institution, the Navy, and yet it is one that has been frequently lost sight of by writers. It is worth keeping in mind, for it explains so much that would otherwise be inexplicable. The administration of the Navy, its regulations, its procedure, and its methods are, with very few exceptions, the fruit of spontaneous growth. When they are not so they are not the better for it. There are particular periods when we can point to the recognition by law, and the organization on a firmer foundation, of existing customs and 
practices which had stood the test of time and trial; but it is almost impossible, certainly until we come right down to the present era, to put one's finger on a man, or a body of men, and to say that he or they established this department or function upon entirely new principles.

At this stage of our story, it is expedient and desirable, in describing the advancement and development of the personnel of the fleet, to make a fresh start; not that it is possible to say here the old ended and the new began, but merely because it will cnable us to place the facts in a clearer light if we deal with the different classes of officers and men separately. As regards the former, however, we find in the early days of the Stuarts that the distinction between the various grades of officers, executive, civil, and petty, afterwards sanctioned by law, was very loosely drawn. The broad line of demarcation, indeed, which now exists between the foremastman and the quarter-deck officer, is a matter of the last half century, for although very few captains and flag-officers came in at the hawseholes, it was common enough in the first quarter of this century to find lieutenants who had learnt their trade on the forecastle. In Tudor and Stuart times every man, almost, who was intrusted with responsibility was described as an officer, and more particularly if, as was the case with many of those in the lower grades, these filled some permanent post, when, in the vessels laid up "behind the chain " in the winter months, they remained on board as ship-keepers.

For example, Boteler, a naval commander, who wrote in Charles I.'s time, includes in his list of officers the swabber, a most useful functionary doubtless, since his 
duties were chiefly to attend to the cleanliness and sweetness of the ship, "by the burning of pitch, and such other wholesome perfumes between decks." But neither from his pay nor his position, could he be properly classed as an officer in the modern sense of the word. Before the century expired this became recognized, and, after a brief existence as a petty officer, he disappeared among the men on the lower deck.

About the same period, Admiral Sir William Monson classifies as an officer the master trumpeter, also an inportant personage, for he it was, that could with his "noise" mortally affront an enemy and put him to shame. ${ }^{1}$ We lose sight of him, along with many similar picturesque excrescences in the second decade of the eighteenth century.

The higher warrant officers, as the master, purser, and surgeon, were in a different position from the other officers, by reason of the power intrusted to them and their connection with guilds or departments on shore. The masters were ali Trinity House men, the surgeons were nominated by the governing body representing their profession, and the pursers were, in a sense, the representatives afloat of the Navy Commissioners, to whom they gave bond for the proper performance of their duties. These higher warrant officers formed, in a measure, an advisory board to the captain, who was enjoined to consult with them in circumstances of doubt or danger. Socially speaking, it was exceptional to find the captain of a different class from the officers mentioned above, but the master fluctuated between the Royal and

${ }^{1}$ For some amusing instances, see Clark Russell's "Betwixt the Forelands." 
Mercantile Services, and the purser, like the gunner, boatswain, and carpenter, was a standing officer ; whereas the commissioned officer merely joined for the cruise, and by virtue of his commission represented the Government.

The captains of men-of-war in the sixteenth and seventeenth centuries may be divided into two categories: those who were bred seamen, chiefly serving their apprenticeship in the merchant navy, and usually in ships owned or commanded by relatives, and those who entered the Royal Navy by influence or interest, and generally with little or no previous knowledge of the sea.

In the first class, only to cite well-known names, we have Drake, Monson, and Penn, while in the second, Grenville, Blake, and Monk are notable examples. The two classes are found serving side by side for I 50 years, a gradual change taking place, on the principle of the survival of the fittest, in favour of the men who had been brought up as youngsters to a seaman's life.

More often than not, these officers, whichever way they entered the king's service, were of what it was the fashion to call "good family"; they belonged, as we should say, to the middle class, but they were poor. They chose, in fact, the sword wherewith to cut themselves a portion in life. Nevertheless, there were exceptions, and scions of the aristocracy, like Edward Montagu, Earl of Sandwich, were to be found cheek by jowl with Sir Christopher Myngs, who is said to have boasted that he was a shoemaker's son.

In this connection it must not be forgotten that an old Commonwealth man may well have deemed it an honour to proclaim himself a son of the people. That the fact of being a tradesman by no means argued an obscure 
origin is shown by Pepys' parentage and relationship. Apart from this, however, in the troublous times of the Civil War, seamanship and merit did give the best claim to command and promotion, and men of whatever station, by reason of natural ability or prominent talent, came to the front. Nevertheless, taking the officers as a whole, we do not find grounds for the sweeping statements of Clarendon, Campbell, Charnock, and Macaulay on this subject. The Navy was in the main then, as it is still, a democratic service, but ignorance of sea manners and customs caused these writers, as well as many who have followed them, to fall into error when referring to the Navy and its commanders.

Penn's career is fairly typical of that of the majority of the sea officers of the pre-Revolution period who attained to commissioned rank. He came of good family, and was educated for the profession of the sea, serving with his father in various mercantile voyages. Presently, by interest with a friend, he was made a lieutenant in the Royal Navy. That friend, who was a naval officer and afterwards Sir William Batten, was probably influenced quite as much by the fact that his protégé was already accustomed to a sea life as by more personal considerations, but such a qualification was not held to be necesary by all the men who had the power or the privileges of appointment. Afterwards Penn rose by his talents and his trustworthiness. Yet we find it cast in his teeth, as in the case of others, that because he had been a "cabin-boy," therefore he was of "low origin."

The assumption is devoid of reason, and the "cabin boy" argument only rests upon the fact that he went to sea in some such capacity with his father for the purpose of learning his business. More than a hundred 
years later Nelson sailed in the Carcase as a "captain's servant," but we do not argue from that circumstance that his social position was "obscure." Nor should we be ready to assume that because in the seventeenth century an admiral had at some period of his career been described as a ship's boy, therefore he could not have been originally intended to adorn the quarterdeck. Many a lad rose in the Navy as Penn did, both before and after his day, while exactly the same thing occurred in the Army and other professions. Young gentlemen served their apprenticeship, as it were, as page to some man of note or position, and worked their way up, partly by influence and partly by talent, to the higher grades of their chosen professions. Page-boy or cabin-boy, it was a similar method of beginning a career under the most promising auspices, and was followed by rich and poor alike, provided only that the essential patronage was forthcoming.

Pepys, under date June 4, I66I, says, "Thence to my Lord Crew's, to dinner with him, and had very good discourse about having of young noblemen and gentlemen to think of going to sea, as being as honourable service as the land war. And among other things, he told us how, in Queen Elizabeth's time, one young nobleman would wait with a trencher at the back of another, till he came of age himself. And witnessed in my young Lord of Kent, that then was, who waited upon my Lord Bedford at table, when a letter came to ny Lord Bedford that the Earldom of Kent was fallen to his servant, the young Lord, and how he rose from table, and made him sit down in his place, and took a lower himself, for so he was by place to sit."

That which was good enough for the nobility, was in 
those days good enough for commoners, and thus it is easy to understand why it was not considered derogatory for well-born lads to act as cabin-boys or servants to their patrons.

On the other hand, some men went afloat at an age when it was beneath their dignity to occupy these positions, and they were styled gentlemen-volunteers. Sometimes they learnt in time to be good seamen, provided their hearts were in their work, and it suited their stomachs-but far oftener their only qualification was courage, which, without experience or discretion, led them into trouble.

That a good deal of jealousy should be created by this practice of having two classes of officers is not surprising, and probably the most scathing indictment of the system was penned by a Mr. Gibson, whose remarks are quoted by Charnock in his "Naval Architecture."

This writer begins by comparing the conduct of Drake, Hawkins, Burroughs, Frobisher, and Monson, whom he styles "tarr-pawling commanders," with that of Lord Effingham, the Earls of Southampton and Cumberland, Lord Thomas Howard, Sir Richard Lewisham, Sir Richard Grenville, and other "gentlemen-captains," who commanded fleets or ships from I 585 to 1603 . He draws therefrom the conclusion that whereas disaster most frequently attended the latter, success was invariably achieved when the expeditions were in the hands of "a captaine experienced in the well navigateing his shipp joyned with courage and timely care upon emergency."

This view of the matter, if somewhat exaggerated, was not without foundation, but it had far more truth in the case of the gentlemen-volunteers of a later date than in those of Elizabeth's time. Raleigh, Seymour, Howard, 
and Grenville, although they had less technical training than Drake and his brother tarpaulins, were still, as Professor Laughton points out, "capable seamen and experienced officers;" but later on it was the needy hangers-on of the Court who contrived to get many of the sea appointments.

Money was to be made in several ways by the captain of a man-of-war and his friends. If they had stomach for fighting there were prizes to be taken from the Algerines. If not, then by carrying treasure or mercliandise, a practice permitted until $\mathrm{I} 686$; or a more questionable course, by conniving with the purser in stealing from the ship's provisions and stores.

In 1608, a Commission to inquire into the Navy reported that "the captains, being for the most part poor gentlemen, did mend their fortunes by combining with the Pursers," and "the instances," says Pepys, writing seventy years later, "of captains giving up their whole care to profit themselves, and not the King's service, are infinite." Which goes to show that, under Stuart management, both before and after the Commonwealth, the Navy was in a very bad state indeed.

Under Oliver's rule, a different condition of affairs arose. Men were appointed from the shore as commissioners with the rank of "generals at sea," just as happened in the French Navy at the time of the Revolution in I794, but with this difference, that the choice of the Protector was seldom at fault.

The step was apparently taken lest the sailors might feel tenderly towards the king's person, and there is evidence that until after his death a strong sentiment of loyalty did exist. The appointment of land officers also created a feeling of jealousy and dislike to the army 
faction, which afterwards was to operate strongly in bringing about the Restoration. But directly the Dutch wars began, the seamen had no time to trouble about politics; their time was fully occupied in "keeping foreigners from fooling us."

Moreover, the minor appointments were still filled by seamen, and when it was ordered, in 1646 , that all commissions to flag-officers, captains, and lieutenants, should be made in the name of the Parliament only, the generals of the fleet were also ordered to prepare a list of the names of captains for appointment, and there can be no question that Blake, and probably Deane and Popham also, relied in great measure upon the advice of the seaofficers, both in this matter and also in the manner of fighting.

Penn was selected for a command because he showed himself to be an experienced and skilful seaman; and Jordan, although he was one of the captains who had carried his ship over to the enemy in 1648 , was in the following year reinstated and his valuable services retained to the country. In fact, under the Commonwealth, the best claim to promotion was fitness for the vacant post, and this fact accounts as much as any other for the victories of those days.

As a rule, the Navy received good treatment under the Commonwealth, in spite of much bickering with the soldiers who had the upper hand on shore. Officers and men were paid regularly, there was constant employment for almost, if not all, the seafarers in the country by the working of the Navigation Laws, and good service received prompt recognition. Nevertheless, the jealousy aroused between the land and sea servicescaused by the attempts of the former to subordinate 
the latter-had a direct effect upon affairs throughout the stormy period which followed upon the death of Cromwell and the return of Charles II.

The institution of the rank of lieutenant has already been mentioned in a previous chapter. The letters of Lieutenant Richard Tomson of the Armada days, show him to have had the graphic touch needed for a modern war correspondent. Felton, who stabbed Buckingham also held this rank. For some unexplained reason the grade almost died out, and on its re-establishment in the middle of the seventeenth century, its purpose is plainly set forth as "to breed young gentlemen for the sea service, . . . the reason why there are not now so many able sea captains as there is use of, is because there hath not been formerly allowance for lieutenants, whereby gentlemen of worth and quality might be encouraged to go to sea."

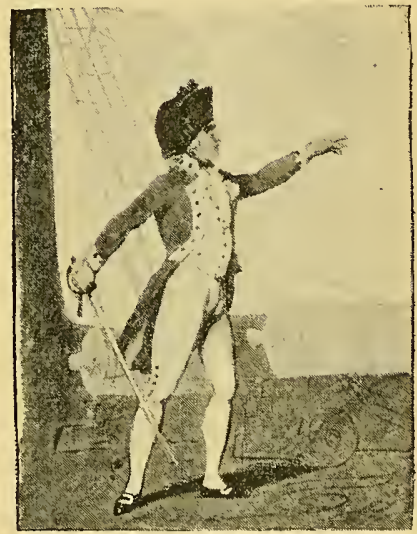

LIEUTENANT, R.N. CIRCA

I 787-97.

(Rowlandson.)

This view of the lieutenant's position was not universally held, for many men were appointed to the rank who had not been brought up afloat as youngsters. The sea officers, however, are in no doubt as to the qualifications and duties of a licutenant. Monson says: "A captain is to make choice of his lieutenant, and it is as necessary that he be a man of experience as himself; and though no such officer be allowed in His Majesty's. 
ships, but of late, and that the master repines to have a lieutenant above him, yet do I hold it fit to have a lieutenant, and he to have entertainment from the King, as well as his allowed shares in a private ship-of-war, for these reasons: a lieutenant is an employment for a gentleman well bred, who knows how to entertain ambassadors, gentlemen, and strangers when they come aboard, either in the presence or absence of the captain." And he offers a great many more arguments to the same effect. Boteler also says: "A lieutenant's place at sea is as the lieutenant's place ashore; for, in the captain's absence, he is to command in chief. Only he is to be admonished that he be not too fierce in his way at the first (which is a humour whereto young men are much addicted), but to carry himself with moderation and respect to the master, gunner, boatswain, and other officers, that so he may not be despised, but beloved and obeyed; and when experience hath taught him somewhat more fully to understand his place, he may grow to a higher strain, and at last attain to his affected post, a captainship."

It is obvious that when these officers wrote they had no idea of the lieutenant fulfilling the purpose of the present naval cadet. It was felt that the lieutenant must have had previous experience afloat, and we find Boteler suggesting that the corporals should be "gentlemen born," so that this office "may lead on in a fit way to the finding out of a lieutenant."

There were many disadvantages in taking commissioned officers straight out of the merchant service, as was sometimes the custom when their ships were hired or pressed for the public work. Penn mentions one in a report he was ordered to make in 1652 on the qualifi- 
cations of the officers of the fleet. He recommended that commanders of merchantmen should be superseded when they were part-owners, because they were far too careful of their vessels in action.

So we come now to the interesting development by which the midshipman, from being a foremast hand, rose to the dignity of a quarter-deck officer, and thus solved the problem of how "to breed up officers and gentlemen, who should be also seamen, skilled to manage a ship and maintain a sea-fight judiciously, of discretion and courage, and able to speak to the seamen in their own language."

A means already existed in the system which permitted every officer to take to sea with him a retinue or following. There was, however, no obligation upon an officer to use this privilege for the benefit of the Navy, and, moreover, the choice of youngsters was in the hands of the officers and not in those of the king and his ministers.

This system is said to have originated, but more probably it first received official sanction, in Elizabeth's reign, when each captain of a man-of-war was allowed two "servants" for every fifty of his crew, and if he was a knight, double that proportion. Whether he took this number to sea with him, mattered not; he drew their pay and rations, and therefore he could utilize the permission to increase his pay, or could in this manner find employment for his relations, friends, or followers.

"Gentlemen volunteers" went to sea in this way; but a writer in the reign of James I., says they usually returned knowing as little as when they sailed, since "the professional seamen hated them and would give them no instruction." 
Later on, however, the "cabin-boys" who had been taken to sea by the sailor captains came to the front and drew attention to the advantages of the practice. These captains, that they might as they grew up keep their protégés under their own eyes, had put them to work with the midshipmen, and some of the more far-sighted had even endeavoured to regulate this arrangement by special orders. Thus we find Penn, in his instructions to commanders, notifying "that he shall not make any a midshipman that hath not served seven years at sea, and unless he be able to navigate the ship he belongs to -unless by special warrant." The midshipmen made by "special warrant" were the protégés of the captain, who were thus able by his influence to attain the rating with less sea service than the others. ${ }^{1}$

Here it is necessary to explain the way in which the seamen were distributed and stationed for working the ship. The oldest and most experienced among the prime seamen were denominated "forecastlemen," and looked after that part of the ship furthest from the captain. The smartest and most agile were "topmen," working on their respective masts. The remainder, mostly landsmen or those newly raised, worked in the waist under the gunner and his mates, while between the main and mizen masts, or amidships in a four-master (from whence the appellation), the "midshipmen" formed the "after guard," a name which eventually became a term of reproach, and was lost in that of "quarter-deckmen."

But the quarter-deckmen of that period were the

' It will be remembered that when Pepys went to sea as Montagu's clerk in the Naseby, he was rated and received pay as a midshipman, by "special warrant." 
midshipmen, who might, as Penn's instructions intimate, be promoted from among the seaman class, if they had qualified by service and training, or might be the young friends or followers of the captain or admiral. In either case, whether they were gentlemen born or not, depended entirely upon the will and fancy of their patron. They learnt their work under the supervision of the mates and quartermasters, many of whom had been midshipmen themselves. Even when the rank of midshipman conferred upon its bearer the right to be classed as a gentleman, which happened when the uniform was given in 1748 , it by no means followed that he was so by birth: there were always exceptions to the rule, and, moreover, he might live to a good old age, retire on "half-pay." and never rise a step higher. ${ }^{1}$

It was King Charles II. who, upon the old system, by the advice of his naval officers, grafted a modification which prepared the way for further improvements. In 1676 certain regulations for the entry of volunteers were promulgated. The preamble runs: "Whereas out of our Royal desire of giving encouragement to the families

1 Professor Laughton mentions the case of a midshipman hanged in 1779 , for murdering his mother, who had come on board his ship at Spithead, and had tried to make interest with the first lieutenant to be allowed to attend the ship as bumboat woman. When her son remonstrated with her on her taking such a step, as calculated to lower him in the estimation of the officers, she seated herself on a chest outside the berth and poured forth on him and his wife all the abuse she could compass with a very foul tongue. The poor man, driven almost mad, made a push at her with a hanger that he caught up, more to frighten her than anything else, but it killed her and he was found guilty of murder. "Naval Promotion," a lecture delivered at the Royal United Service Institution, June 25 th, I 880 . 
of better quality among our subjects to breed up their younger sons to the art and practice of navigation, in order to the fitting them for further employment in our service, we have for some time past been graciously pleased at our extraordinary charge to admit of the bearing of several young gentlemen to the end aforesaid, on board our ships in the quality of volunteers." Each rate of vessel was allowed to carry a certain number of these "volunteers by order," or as they were more generally called, "king's letter boys." Their pay was fixed at $£ 24$ per annum, and the age at entry was not to exceed i 6 years.

Following his regulations for the entry of volunteers in 1676 , the king in the following year established rules "for the qualification of persons to enable them to become lieutenants." The principal conditions were three years' sea service, including one as midshipman; that candidates should not be under 20 years of age; that they should produce certificates of sobriety, diligence, and ability; and that they should pass an examination before a commander of the Royal Navy and two other officers, or three principal officers in a fleet or squadron. It may be here mentioned that the qualifying sea service was increased to six years in $\mathrm{I}_{70}$, and that the examination was transferred to the Navy Board in 1728, when the king's letter was abolished, and the Naval Academyat Portsmouth instituted. The youngsters who passed into the service from the academy or college were allowed to count a certain amount of time as sea service for their period of study, and this continued to be the case until the training-ship Illustrious in 1843 took the place of the college closed in 1837 . It was not until the early years of this century that permission was given 
for the midshipmen to be examined at the naval ports instead of in London.

In these regulations of Charles II., founded as they were on existing institutions and practice, we have the principles governing entry and qualification for the executive branch of officers which obtain to-day. From that time no person could become a captain until he had passed for lieutenant, while one of the qualifications for that rank was previous service in the Royal Navy in a lower grade. If there was any exception to this rule, which I doubt, it was only in cases where it was obvious that the qualifications for lieutenant existed, and to hold an examination in the circumstances would have been absurd. To those, however, who have read Marryat, it will not be news that the examination for lieutenant was frequently quite perfunctory, while Dundonald's "Autobiography of a Seaman" will explain how it was possible for a boy to put in his years of sea service while yet in the nursery.

The new regulations were thoroughly elastic, and admitted of at least three methods of entering the commissioned ranks-methods differing in detail, but conforming in principle to the established rules.

Some officers entered with the king's letter, and directly at the public expense; these were generally sent to serve under some distinguished naval officer or Court favourite. Thus the Duke of Grafton went to sea with Sir J. Berry; and Lord Aylmer under Sir Robert Robinson; and in the Duke of York's Memoirs may be seen a letter recommending a son of Lord Darcy to the care of Sir Richard Stayner. Byng, the hero of Passaro, afterwards Lord Torrington, joined in 1678 in this way, 
and he it was who, when at the Admiralty, substituted for this system that of the college.

But the "servant" system still existed and remained in force until I 794 . Youngsters went to sea with a friend or neighbour of their fathers', and were either rated on the ship's books as a servant of the admiral, captain, lieutenant, purser, or some other officer, even of the gunner and boatswain, or as A.B., ordinary, or landsman, the last-named rating existing up to a date somewhat later than the Russian war. Among the earlier cases of officers who entered in this fashion, may be mentioned Sir Cloudesley Shovell, Sir Edward Whitaker, and the Earl of Peterborough. In later times, anyone who looks through O'Byrne's “Naval Biography," published in I 845 , will find scores of examples of flag-officers, captains, and lieutenants who were still alive at that date. The late Admiral of the Fleet, Sir Provo Parry Wallis, was one of the few men who, entering in this way, survived to the present decade.

It mattered not, however, whether they entered as king's letter boys, through the academy, or with these bogus ratings, all served their apprenticeship in the same way on the quarter-deck and were intended for officers. Most of them passed for lieutenant, and then whether they obtained a commission and rose any higher, depended something on merit, but a great deal more on interest.

It is to be noticed that no one who entered by these methods could be said to have risen from the ranks, or, as the phrase in the Navy has it, have "entered at the hawseholes," meaning to come in as the cables do, through the lower deck. The custom described above of rating the lads as "officer's servants" or as "seamen," has given 
rise to this belief, and its expression by Macaulay, who spoke of Shovell as a "cabin-boy," appears to have led some high authorities adrift on this point.

Nevertheless it was possible to enter the commissioned ranks through the hawse-holes, although it was very far from common for those who did so to rise beyond the rank of lieutenant. In this case apprenticeship in the merchant marine was a sine quà non. Dampier and Benbow are early examples; Sir David Mitchell and Captain Cook are other instances; Captain Campbell, who told the king to knight his wife, is another, and in the "Biography" of I $\$ 45$ which has already been referred to, those who are interested in the subject will find perhaps half-a-dozen cases proving that the practice still existed up to the end of the Great War.

The system may be exemplified by Benbow's career. He had been apprenticed in the merchant service, probably to a relative, for at an early age we find him in command of a ship, which is, in a way, evidence of wellto-do friends. Then his bravery commended him to the Admiralty. Herbert of Torrington, apparently at Shovell's suggestion, made him master of his flag-ship, from which we may conclude that he had satisfied the Trinity House of his qualifications as a navigator. Then we have him commanding such ships as lieutenants were usually given, and having thus by merit and influence attained to executive rank he is promoted to captain and admiral. That such an exception from the rule was unusual is shown by the jealousy it created, which had such a disgraceful result in the West Indies.

Sir David Mitchell is said to have been pressed into the service; there is nothing unlikely in this. He was master of a merchantman, and masters were not exempt 
from the press, as we know from Maydman and other writcrs. But he was already a seaman and an accomplished scholar to boot. After a period of probation in a subordinate grade, his captain gave him an acting commission as a lieutenant. When he returned home, he got this commission confirmed by interest ; then he rose by that and merit combined, to be an admiral.

One more example, because it is certainly among those of the latest date. James Clephan, after having served his time as an apprentice in the merchant service, was pressed into the Navy in July, I794, as an A.B. on board the Sibyl; a year later, having been of service to the master, he, by the interest of that officer, was rated master's mate of the Doris. In a boat of this ship he took part in the cutting out of the Cheorette on the night of July 2 Ist, ISoI, and, for his distinguished gallantry on this memorable occasion, he was promoted to lieutenant. In the Spartiate he was present at Trafalgar, saw a good deal of further service, was made commander, and died a captain in 1854 , the year the war with Russia broke out.

Having described the various methods of entering the executive ranks, we may now hark back to the seventeenth century for a few remarks in elucidation of those interesting subjects, Pay, Half-pay, and Promotion.

Prior to the reign of Charles II. no provision existed for the maintenance of commissioned officers of the Navy while unemployed. Admirals, captains, and lieutenants were discharged to the shore as soon as their ships paid off. At the same time various practices were resorted to by those who possessed sufficient influence with the authorities, to keep their places and pay even when the ships were not properly in commission. There was, 
however, no permanent force of commissioned officers, and many men like Herbert, Lord Torrington, fluctuated between the land and sea services. ${ }^{1}$

In September, I667, it was directed that " the Captains of Ist and 2nd rate shipps should be kept on half pay to the very day the peace was proclaimed." About the same time the practice was authorized of bearing in time of peace all commanders and lieutenants "who might deserve it," on the books of one of His Majesty's ships, as "extra midshipmen," but it was soon found necessary to limit the number. In 1672 it was directed that commanders of first and second rates and second captains of flagships should have half-pay "while on shoar this winter season," and in 1674 , the privilege was extended to them "so long as they are unprovided for."

With the issue of these orders we have the beginning of a permanent force of commissioned officers, although the standing force of warranted officers and ship-keepers, which included the purser, had, as I have shown, existed long previously.

The next important step, proposed and formulated in. orders dated July, I686, is known as King James's Establishment. Its purpose was to prohibit the carriage of freight and merchandise in men-of-war, a privilege which had been grossly abused; and, as a substitute for the

${ }^{1}$ Naval officers frequently held commissions in the Marines. The appointment of Captain Francis Digby to the admiral's regiment in $167 \mathrm{I}$ is the first instance, but the practice did not become common until the raising of the two Marine regiments in 1690 , from which date onwards numbers of naval officers held commissions in the corps, and performed the regimental duties of their ranks. See the "Historical Records of the Royal Marines," by Major L. Edye, R.M.L.I. 
profits arising therefrom, a "table money," ranging from $£ 250$ per annum in a first-rate, to $£ 83$ in a sixth-rate, was granted. The prohibition was to be enforced under serious pains and penalties, but it is doubtful whether the table money was paid.

At the same time captains were ordered at the conclusion of a voyage to transmit to the Secretary of the Admiralty a journal of the proceedings of the ship, upon the proper receipt of which the final adjustment of his pay and allowances would depend. Of course, journals had been liept before this time, as the pages of Purchas, Hakluyt, and others show, but it was now made obligatory in ships of war.

That the flight of James interfered with the carrying out of some of his plans for naval reform is certain, but the Lords Commissioners of the Admiralty appointed by his successor took the matter up warmly, and the result appeared in what is known as King William's First Establishment, dated February, I693. Six reasons which appeared to render a revision of pay necessary are therein set forth. They appear to have been partly based upon some petition or statement of grievances, for the first three are of this nature, and are to the effect that English naval officers were not paid as well as French, that table money had been promised but not paid, and that it was invidious to give some officers half-pay and not others. The other three reasons dealt with benefits that might accrue to the service by the change, such as by giving more pay the number of "servants" could be reduced, convoy money might be stopped to advantage, and since discipline is incompatible with discontent, the removal of the latter would tend to improve the former. 
The new establishment doubled the sea-pay of flagofficers, commanders, lieutenants, and masters. Halfpay was allowed "during their being ashoar in times of peace" to all flag-officers, captains of first, second, third, fourth and fifth rates, and all first lieutenants and masters who had served one year in such rates, or had been in a general engagement with the enemy. Lastly, the number of "servants" was considerably reduced, in the case of some of the admirals from fifty to fifteen.

The advantages were more to the lower than to the higher grades; and, consequently, in I699-1700, the captains having raised an outcry, a new establishment was issued, which is signed by "J. Bridgwater, G. Rook, D. Mitchell, and G. Churchill." The sea-pay was retrenched, from one to two-thirds of the recent increase being stopped, and at the same time the allowance of servants was restored

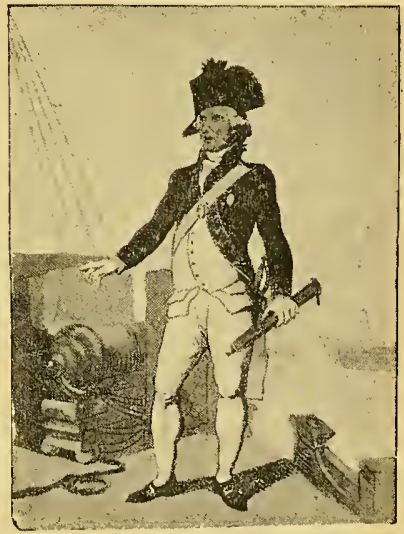

ADHIRAL. CIRCA I797-I8I2. (Rowlandson.) to nearly its former footing. The persons who suffered were the commanders, lieutenants, and masters.

However, the system of half-pay, which had originally been intended merely to apply in time of peace, was now made permanent. But it was found necessary to limit the numbers, and the privilege was allowed to Io flagofficers at rates varying from i $7 s$. $6 d$. to $£ 2$ Ios. per day; 50 captains at Ios. and $8 s$.; 100 lieutenants at $2 s .6 d$. and 
$2 s$; and 30 masters at $2 s .6 d$. and $2 s$. Power was reserved to the Admiralty to compel officers on half-pay to reside near his majesty's yards and perform such dutics as might be required of them. - The scale of pay allowed at this period to officers varied according to the rate of the ship in which they served. A "commander and master," who acted as captain in a sixth-rate, received $£$ I4 per month, while the captain of a first-rate received $£ 42$ per month. A lieutenant's pay varied from $£ 7$ to $£ 88$ s. per month; a master received about the same as a lieutenant; surgeons had $£ 5$ per month; purser, $£_{2}$ to $£ 4$ per month with perquisites ; gunners, boatswains, and carpenters, about the same amount; midshipmen, from $£$ I IOs. to $£ 25$ s. per mensem. ${ }^{1}$

Surgeons were first admitted to the privilege of halfpay in 1729 ; the number of masters was increased in I749; while in I75 I officers were for the first time allowed to go abroad, with the permission of the Admiralty, without forfeiting their half-pay.

In I 7 I 8 it was ordered that admirals should be promoted by seniority if duly qualified; and in 1747 the superannuation of captains being authorized with promotion to flag-rank, gave rise to the term "yellow admirals." So many captains were passed over in I788 that those who considered themselves aggrieved brought the matter to the notice of Parliament, and a two days' discussion ensued. In the end the Government prevailed, but shortly afterwards (I790) there was a very large promotion, and some, at least, of those whose

${ }^{1}$ It may be noted that there were two classes of midshipmen, receiving different rates of pay. The higher class receiving as much as the captain's clerk, the lower or "midshipman ordinary" only the same rate as an able seaman. 
names had been omitted in the previous batch were now included. All promotions to the captain's and flag lists are now ( 1894 ) by seniority, but subject to certain restrictions governed by age.

In I749 an attempt was made to make officers on half-pay subject to naval discipline, but three admirals and forty-seven captains having signed a petition, the matter was brought before the House of Commons, and the project failed. The student of naval history cannot fail to be struck with the circumstance that every increase of pay or privilege was brought about by petitions such as the one just mentioned, or that which Lord Howe presented in 1773 on behalf of the captains of the Navy. But to pursue the subject here would occupy more space than we have at our disposal.'

An Order in Council of April, I794, effected a great alteration in the mode of entry of officers, for it swept away nearly all the "servants," and substituted for them "boys" of three grades or classes. At this time the flag-officers' retinue varied in numbers from fifteen to fifty; captains were allowed four "servants" for every hundred men of their ship's complement; and the lieutenants, master, second master, purser, surgeon, chaplain, and cook were each allowed one "servant;" boatswains, gunners, and carpenters might have two. No "servant" was to be under I 3 years of age unless "the son of an officer," and then not under I I years." The servants to

2 See the paper read by Professor Laughton before the Royal United Service Institution, June 25 th, I 880 , and an article, "How Naval Reform has been Won," United Service Magazine, November, I 893 .

"This rule was constantly violated by having the boy's name entered on the ship's book long before he went to sea. 
the "standing officers" were to be apprentices bound for at least five years.

By the new rules, only flag-officers were allowed servants, and these were to be bona-fide "domestics." Of the boys who took the place of the remainder, one-fifth were to be young gentlemen volunteers, intended for officers, who were not to be entered under I I years of age; three-fourths were to be between the ages of 15 and $I 7$, and were to keep watch and watch with the seamen; the rest were to be between 13 and 15 years of age, and were intended as bona fide servants of the other officers.

A further distinction was made subsequently between first and second-class volunteers, those in the former being intended for executive officers, the latter to rise in the master and paymaster lines. As a matter of fact, there was nothing to prevent second-class volunteers from passing for lieutenant, and they did sometimes rise to be captains and admirals. And it was not impossible for a second-class volunteer to become a clerk and then a midshipman or master's mate, and therefrom to pass to the cxccutive line. The title "naval cadet" was substituted for that of volunteer in 1844 .

The custom followed by flag-officers and captains of carrying a certain number of persons with them from ship to ship was regulated in I806; it is now prohibited. Before leaving this subject of "servants" and "followers"-which had such an important bearing on the internal economy of the Navy-two quotations from writers who lived so far apart as the reigns of Queen Anne and Queen Victoria, will not be out of place. Says the former:-

"A gentleman is put in command of (suppose) a fourth- 
rate shipp, complement 200 men; he shall bring neere 20 landmen into the shipp, as his footman, taylor, barber, fiddlers, decayed kindred, voluntier gentlemen or acquaintance, as companions, etc. These shall have the accomodation of a master's mate, midshipman, quartermaster, master trumpeter, coxswaine, etc., and too oft their pay, while others do the duty for that of an able seaman, or such as deserve it not. Next he covetts to have all the rest of his complement, able seamen, to the denying an officer the privilidg of a servant, which custom was given him with a seaman-captaine. If he presses masters, or master gunners, boatswaines or carpenters of bigg merchant shipps, they shall fare noe better in their accomodation and wages than others before the mast."

And Captain Sinclair, R.N., writing in I 858 upon the customs and usages of the service as he remembered it from ISI 5, says:- "There is one word that used to convey a very strong professional meaning, but which has latterly fallen into disuse. A 'follower' was a person following an adniral or captain from ship to ship, sharing his prosperity or adversity, treading in his footsteps, upholding his name and system above all others, standing by each other at all times and seasons, through good report and bad report, and in many instances ending happily for both parties. An admiral was sometimes enabled to give his future son-in-law a freight, his haulingdown vacancy, and his daughter." :

The conveyance of freight under new regulations is still possible, as the recent trouble about Balmaceda's bullion

1 Flag-officers were first allowed captains under them in 1677. Naval aides-de-camp were first appointed in $I_{1} I_{5}$, the proportion being four flag-officers and six captains. 
shows. Admirals were also, until quite recently, allowed the privilege of nominating one lieutenant for promotion to commander when they hauled down their flags.

Of the social life of the Navy in the seventeenth and eighteenth centuries not a great deal is known; we get a few glimpses of shipboard scenes from the diarists, and a few pictures of seamen from the playwriters and novelists. If the indications there to be found are trustworthy, they tell us that while the sea did breed a peculiar class of men whose characteristics found quaint expression in their manners, language, and costume, there were also quite as many variations of character as were to be found ashore during the same periods. There were brutes afloat like Smollett's "Captain Oakum," and there were dandies like Shadwcll's "Captain Mizen," but the bulk of them, whether they hailed from the quarter-deck or the forecastle, were honest, hardworking fellows who strove each in his own way to do his duty in the state to which God had called him.

For officers and men alike, it was a hard, wearing life; they had to get along as best they might without any of the comforts which existed even then for the dwellers on shore in their own station. Pay was scanty enough, but it only came at long intervals and then with large deductions; the food was of the worst, the ships were often ill-found, and the insufficient accommodation generally quite devoid of sanitary method. It could not be wondered at if the seamen had been a rough lot, callous of life, brutal of bearing, and incapable of sentiment. But this does not appear to have been the case if the journals (both official and private) of the officers can be admitted as evidence ; on the contrary they afford the strongest proof of humane feeling, patriotic devotion, 
and a lively trust in Providence. I wish I had space to quote from these journals, but it is to be hoped that when the Navy Records Society gets fully to work some of them will see the light of day.

The position of the commissioned officers was superior in every way, except perhaps in the matter of pay, to that of those who were merely warranted. Sometimes they were also their superiors in the social world, but this was no more the rule then than it is now.

It was the autocratic power of the captain that placed this officer far above all the rest of his officers. This is the exaggerated picture which a scurrilous pamphleteer of the early part of the eighteenth century draws of the relation between that officer and his subordinates:"Once a moon perhaps, he invites some Marine Lieutenant to taste of his bounty; but the poor gentleman finds his dinner bestowed rather as a charity than an honourable entertainment, for upon his entry he finds him aforehand seated at the Table with as stiff an air as if he expected your coming to kiss his toe, for no Pope on Earth can look greater. Down you sit along with this dumb God, who shows you what you are to do next by first helping himself : if you won't follow you may fast, for by Neptune, he won't assist you. Thus you sit as mute as a Fish ... till his worship has finished, and then he rises first-you may stay or follow him if you please, but not into the Cabbin but upon deck, and then you may walk and Digest both your meal and your reception."

The lieutenants were incleed at the mercy of the captain, and, according to his whim, his slaves or. his associates. As for the warrant officers he could beat them, and did on occasion, or Mạdman, who was a purser 
himself, does not speak truth. Good or bad, the captain's power was supreme, to use as he thought best, and doubtless there were tyrants and bullies then as there were in after times, or we should not have to deplore the loss of the Hermione, and rejoice at the winning of the Retribution.

The lieutenants also formed a distinct class, and from their higher altitude looked down upon the other officers or patronized them at their will. But here again if there was any difference in social rank it was exceptional: from the days of Pepys to those of Hannay, we read of blood relations between captains and lieutenants and masters and pursers; the same influence that obtained for one man the commission and the higher rank, obtaining for his brother the warrant and the better pay.

The distinction of ward-room and gun-room officers is comparatively modern; indeed, until the middle of the eighteenth century, there is no mention of the former place, which was, in the wooden ships, the big cabin in the after part of the ship under the captain's apartments, the gun-room on the deck below being appropriated to the gunner and his mates, and also used as the armoury of the ship.

About 1600 the officers were given cabins; the master in the round-house under the poop, the captain in the great cabin below the round-house, and the others elsewhere below, the partitions being, as a rule, of canvas; for of those built of wood it was said, "they are but sluttish dens, that breed sickness in peace, serving to cover stealths, and in fight are dangerous to the men with their splinters."

In the time of Pepys the officers appear to have had no general mess, each living apart in his own cabin.' $\mathrm{He}$ 


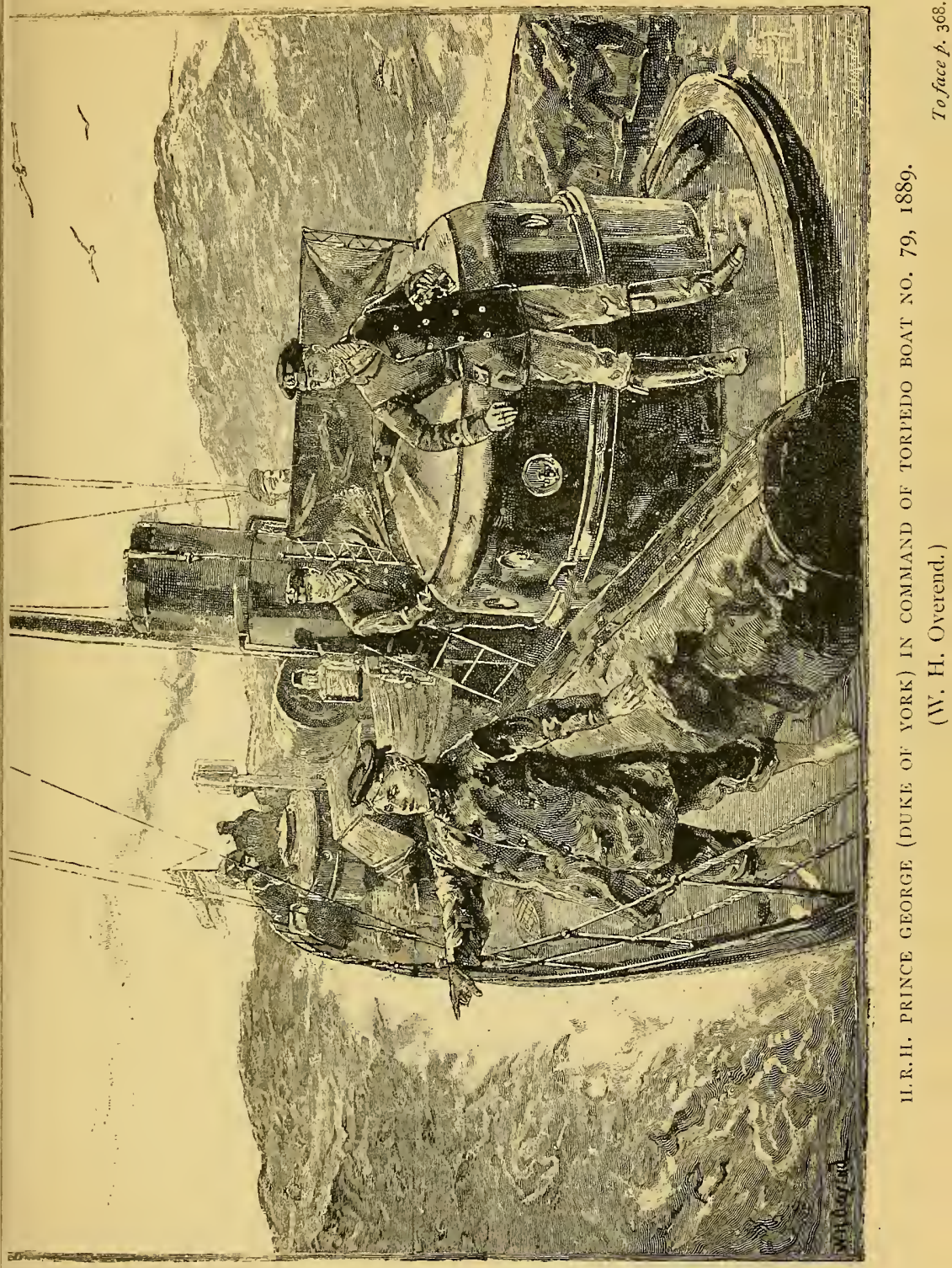



speaks of supping in the master's cabin and in the lieutenant's cabin, dining in the coach, or cabin forward of the captain's sleeping apartment, and in the purser's cabin ; but not a word about any mess-room common to them all. Yet Teonge, who was chaplain of the Assistance, Bristol, and Royal Oak in the Mediterranean from 1675 to 1679 , speaks of the living in the "state room," although he says nothing about paying mess money, or how the mess was catered for. Apparently everybody lived on the ship's provisions, the ration being common to seamen and officer alike. Nevertheless, as early as the reign of Charles I. we hear of stock being bought for the use of the officers in harbour, but whether at their own expense or not is nowhere stated.

About 1673 the allocation of cabins to the various officers was regulated afresh, presumably in consequence of complaints from some that they had been deprived of them; these were, however, held on precarious terms for long afterwards, as Maydman assures us. Falconer ${ }^{1}$ in his Dictionary, published in I 769 , defines the wardroom as the place where the lieutenants mess and sleep; and in 1758 we learn from the well-known "Petition" that they could turn the chaplain out of it if they objected to his company.

As the lieutenant seldom had private means, he lived

1 Falconer went to sea in the Navy as "purser's servant," and was rated midshipman in 1757 . Like many another, he then served in the mercantile marine, and his experiences are recorded in "The Shipwreck." He returned to the Royal Navy, but as he had not completed the time necessary to qualify for lieutenant, and being now thirty-three years of age, he accepted an appointment as purser, and was serving in this capacity when he was lost in the Aurora, i 769 . 
hard and fared badly. His pay was small, but what made it worse was the difficulty he found in getting it. Up to 1745 the lieutenants were not allowed to draw pay at all until the ship was paid off, and at this date permission to receive it yearly was only granted after a very strong remonstrance.

They said in their petition, that in time of war, it was almost impossible to get credit or borrow money except at a most ruinous interest, amounting sometimes to cent. per cent., "inasmuch that they cannot live or appear with decency and like gentlemen;" that the changing of ships, and the fitting for the different voyages, by "obliging them to equip themselves in a different manner," is a continual source of expense; "that as they attend to all duties, execute all orders, and upon all occasions are the immediate messengers of dispatch and trust, they are liable to many hardships and great expenses in the execution of the services on which they are sent, which services almost always require them to be dressed like officers of His Majesty, and to have money in their pockets to defray the many contingencies that happen ; to supply which, they are compelled to take up money at exorbitant interest."

This, it may be recalled, was before the introduction of uniform, and about the time that Smollett describes Lieutenant Bowling. In the flag-ships the sons of persons of influence fared somewhat differently, because, if they were of no higher social standing, at least their pockets were better lined.

The style of living has always differed more or less in the different classes of ships according to their size and accommodation. The ration of officers and men was and is exactly the same, and in the olden days the 
officers, at all events at sea, appear to have lived on it, although where their means permitted it was doubtless supplemented by a few luxuries. It is reported that when Prince Eugene visited the flag-ship of Sir Cloudesley Shovell, to confer with the admiral respecting the projected siege of Toulon, that he was amazed at the magnificence of the reception and entertainment offered to him. Yet we know that Sir Cloudesley Shovell was a man of simple habits, and must conclude therefore that the show and parade of this occasion was intended to impress the visitor and was successful. Captain Edward Thomson, R.N., who re-wrote "The Fair Quaker of Deal," and transferred its locale to Portsmouth, describes the cabin of Captain Mizen, in I755, much as Smollett has done that of Captain Whiffle, in I748, as a most luxurious abode, furnished with

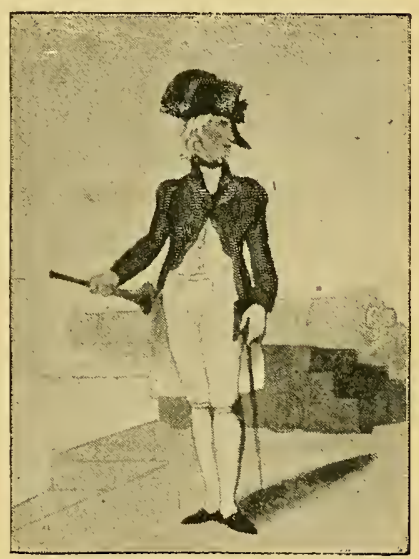

CAPTAIN, R.N. CIRCA I797-I8I2. (Rowlandson.) couches and even a piano. These, however, must have been exceptions, and Captain Sinclair, R.N., tells us that, in I8 I 5 , "live stock at sea was a thing nearly unheard of. The lockers round the inside of the berth were filled with potatoes, and a bag or two went under the table, in addition to which we carried as much tea, coffee, and spices as the spare room could hold and our own finances warrant. . . No stock of wines or spirits was ever allowed. It was never thought of." The 
same authority gives a different picture of dining with the captain to that drawn by Mr. Edward Ward, and described on a preceding page. He says, "the captain's dinner hour is about three o'clock, at which time a procession is formed of the three or four invited guests. As the bell strikes six, the drummer beats the tune of the 'Roast Beef of Old England,' and you walk into the cabin and take your places according to seniority. In most cases it really is the festive board, and the whole affair passes off agreeably enough. The great man himself unbends. The first lieutenant, at the foot of the table, is jocular with the youngsters, whose spirits, elated by a few glasses of military port, and what they had not enjoyed for some time-a good tuck out-are inclined to look at the bright side of things in general ; and when, after taking a cup of coffee, which is the signal that all is over, the party disperses, there is a sort of feeling that they would not have minded shaking hands with the first Luff, for, after all, he was not such a bad fellow."

According to Burney, whose edition of Falconer's Dictionary appeared in 1830 , the midshipmen messed in the gun-room in line-of-battle ships, and the gunner looked after their clothes and acted as their caterer. According to Marryat and others, one of the old passed clerks sometimes performed this office, and his wife attended to the state of their linen. In an amusing volume of nautical sketches by Hamilton Moore, junior, there is a capital story of how some midshipmen pay a visit to the boatswain and his wife in the fore cockpit to take afternoon tea. When they were more than fifteen years of age the midshipmen joined the mess of the masters' mates, surgeon's assistants, and passed clerks in what then, as now, was called "the midshipmen's berth." 


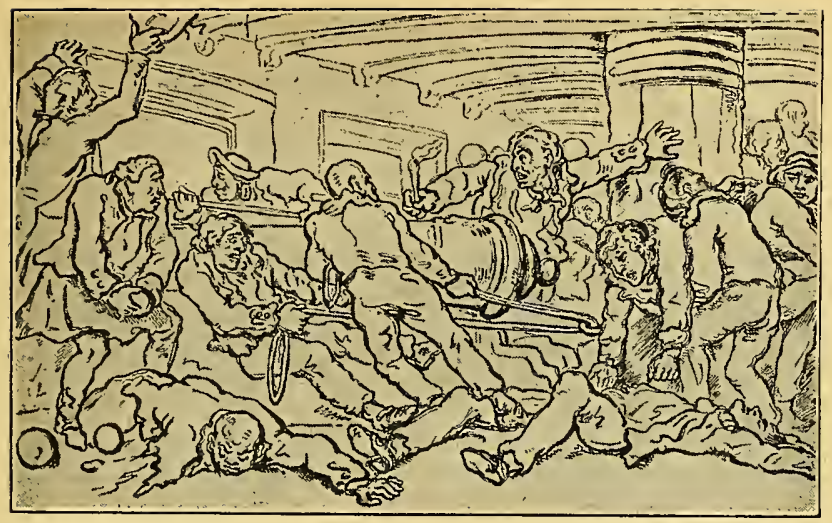

FIGHTING A GUN IN ACTION. CIRCA I782.

(Rowlandson.)

\section{CHAPTER III.}

WARRANT AND INFERIOR OFFICERS, SEVENTEENTH AND EIGHTEENTH CENTURIES.

TURNING now from a consideration of the superior and commissioned officers, their methods of entry, etc., to the lower and subordinate grades, a similar examination will show how by a gradual process of development, in conformity with the needs of the service under varying conditions, some classes became improved and raised, while others disappeared. This chapter also contains a brief exposition of the methods for raising and paying the seamen or bluejackets, as at length they came to be called. 
The masters and masters' mates were looked after by the Trinity House, part of whose duty it was to supply these officers and petty officers for ships of war, and to see that they were properly qualified. Usually the Trinity House, of which many of the Elder Brethren were masters themselves, had no difficulty in this respect, certainly not after the institution of half-pay. At other times we read of their resorting to the press, and masters were forcibly taken out of merchantmen and obliged to serve the Crown.

The appointment of a certain number of " masters of the king's ships" appears to have lapsed about the time of the Commonwealth, but shortly afterwards we learn that all the Younger Brethren of the Trinity House were liable to be called upon to serve as masters in the Navy. And three were actually deposed for refusing to do so.

Two years later, in 1675 , the Trinity House officials held their first examination of Bluecoat boys with a view to obtaining clever lads to be apprenticed to a seafaring life, and for long afterwards Christ's Hospital supplied midshipmen and mates who rose to be among the best masters in the Navy.

By reason of their unique position the masters received consideration above that bestowed on the other warrant officers. Up to the middle of this century it was possible for a captain to shift the blame for the loss of his ship on to this officer's shoulders. Anyone could be made master who was a member of Trinity House, and candidates who had received acting warrants while serving abroad were obliged to get a certificate from its officials before their warrants were confirmed.

Second masters in the eighteenth century, although they were classed and rated as petty officers, were men 
who had qualified for masters of lower rates, and until I 8 I. 4 a master was required to pass a separate examination for each rate of ship.

Masters' mates were frequently lower-deck sailors, who, having exhibited ability, either as seamen or navigators, or for gallantry, were rated petty officers of quarter-deck rank. Almost invariably, if a man passed from the lower to the quarter-deck he passed through this grade, but it was not essential that the master's mate should have come in at the hawseholes. Far from it, very many volunteers and midshipmen took the rate for the sake of the additional pay and prizemoney it carried. But, taking it, they gave up hope, unless by what was almost a miracle, of passing to the rank of lieutenant and the higher grades.

It is to be noted, however, that the masters' mates with Anson, Vancouver, and the other circumnavigators, almost always got lieutenants' commissions, and sometimes rose to still higher positions.

About the beginning of this century many a passed midshipman, without much interest, while waiting for his promotion, took the rate of master's mate. Then the grade of master's assistant was created as the complement in this branch to that of midshipman in the executive line, and while midshipmen rose to be " mates" without the prefix, the master's assistant became a "second master." New entries to this line ceased in 1867.

The title sub-lieutenant was originally created by Lord St. Vincent in I 802 as a temporary relief to very many deserving officers who had served their time and passed for lieutenants. In I 830 it had nearly died out, but in I 864 it was substituted for the rank of "mate" as intermediate between midshipman and lieutenant. 
All the early naval writers refer to the "Standing Officers." These were the purser, boatswain, carpenter, gunner, and cook. These officers received their warrants from the Admiralty, instead of, as was the case with the master, the surgeon, and the "inferior officers,"-among whom, in addition to the surgeon's mates, and second masters, were included the gunsmith, armourer, masterat-arms, sailmaker, etc.-from the Navy Office. It was not, indeed, counted a disparagement to any officer that he had in his time served before the mast, and many instances occurred in which, after having held a warrant, men reverted to the lower deck on impressment, or through other causes. In times of peace, the majority who were not in the standing force took employment in the merchant marine if they could get it, and to quite a recent date many an officer in the sailing Navy, if he aspired to be a complete seaman, would endeavour to render himself proficient as well as add to his income in this way.

Among the standing officers, the purser generally came from a different social class to the others. To start with, he was bound to have some capital, or moneyed friends, while another reason will appear later on. The boatswain, gunner, or carpenter, on the other hand, merely rose by his talents from the lower grades in which he had served his apprenticeship. How the cooks were chosen has been referred to in the chapter on Victualling.

All the standing officers had charge of the ship when in ordinary, that is after she had paid off, which in early times was an annual occurrence, for the vessels did not go to sea in the winter months. Each officer had his own department to look after, and his own little 
gang of servants and followers, ${ }^{1}$ from among whom in time there might be chosen his successor, while all together formed the nucleus of the sea-going crew of the ship. The captains sometimes complained bitterly of these little family parties, whose allegiance was not so much to the officer temporarily holding the king's commission, as to their immediate chief.

By the regulations of $173 \mathrm{I}$ these arrangements, which possibly originated in mediæval times, received, in a modified form, official recognition. The employment of the above five classes of warranted officers being "constant" they only became entitled to ask for superannuation after fifteen years' service, whereas the masters and surgeons, in consideration of not being employed constantly, could apply for pensions after eight years' sea service. The gangs of followers were broken up, a limited allowance of "servants" or apprentices to each officer being substituted, and the bulk of the standing crew supplied from the dockyards. This system was at first a fruitful source of contention between the officers in charge of the ships and those in charge of the yards. ${ }^{2}$ The privilege of servants was, as

${ }^{1}$ Pepys tells us, under date March 8th, 1659-60, "This noon I met at the Dog tavern Captain Philip Holland, with whom I advised how to make some advantage of my Lord's going to sea, which he told me might be by having of 5 or 6 servants entered on board, and I to give them what wages I pleased, and so their pay to be mine."

2 The difficulty does not appear to have been entirely surmounted until $178_{3}$, when the Admiralty appointed twenty-four masters from the half-pay list, for the sole purpose of superintending the ships in ordinary. At the same time, in addition to the warrant officers and their servants, a proportion of able seamen, ranging from thirty-six for a Ioo-gun ship to four for a cutter, were allowed for each vessel 
has been shown elsewhere, afterwards utilized for the purpose of evading the orders about youngsters qualifying for higher positions by sea service.

In such of the ships as were in "ordinary," or as we should now say in " reserve," the purser, boatswain, and carpenter kept harbour watch, thus showing that, in a certain restricted sense, even the officers of the civil (and now non-combatant) branch, who were not necessarily sailors, were expected, and obliged to perform executive functions. The gunners did not stand a watch but rowed guard in boats at night to see that the watchkeepers were on the alert.

Maydman, himself a purser, writing in the reign of William III., thinks that these duties might very well have been entrusted to the lieutenants, who for the most part being turned adrift when the ships came into port, would be glad to get the job. At the same time he is very clear on the point that the work of the standing officers was anything but light, and far from being adequately remunerated.

It was a period of development, when the ancient powers and privileges of the warrant officers were being gradually curtailed, and when, instead of being the captain's advisers in emergency, and responsible with him for the well-being of the ship, they were, upon any small offence, liable to be "caned, bilboed, and despitefully treated."

We learn something more of the nature of this change from the letters of a sailor who had served under Blake and Deane, and who, writing in the reign of Queen

as a dockyard complement (Schomberg's "Naval Chronology," vol. ii. p. 133). 
Anne, regretfully recalls the conditions of the service when the great Commonwealth victories were won. He says:- "We had then no double lieutenants to the nation's clarge, but one on board a ship, and he the captain's companion. The warrant officers were the lieutenant's companions, but especially the master, who had then the sole power of sailing and working the ship, without depending, as now, on the lieutenant's orders. Our masters, their mates, boatswains, gunners, and carpenters, had then as much command over the seamen, and were better obeyed than the lieutenants are now, and indeed they deserved it, for most of our warrant officers then were fit to command, and very often did so, with great reputation, when their superior officers were killed or disabled in a fight." 1

After instancing several cases in support of his argument, he goes on: "To convince you fully of the mischievous practice of depriving the master and other warrant officers on board our men-of-war of their former authority, and particularly that of taking from the master the power of navigating the ship, and conferring it on the lieutenants; if you please to inquire into the number of ships lost and damaged at sea for want of due care within these hundred years last, you will find our loss of men-of-war, since the lieutenants assumed the power of navigating to themselves, to be three times greater than when it was entrusted to the masters, who were then the ablest seamen in the nation, and made navigation their constant business; whereas too many of our lieutenants spend most of their time in a riotous

1 "An Inquiry into the Causes of our Naval Miscarriages, with some thoughts on the interest of this Nation as to a Naval War, and the only true way of Manning the Fleet, 1707." 
manner on shore, and cannot forbear their customary excesses when they go on board."

It would appear from this extract, that at this time it was in contemplation to abolish the masters and hand the navigation of men-of-war over to the lieutenants. If such was the intention, it never came to anything, and of the two lieutenants then carried in most ships, the senior was the organizer and administrator in chief of the internal economy of the vessel; the junior, the ostensible gunnery and musketry instructor. As it became the custom to carry more lieuteriants they merely fell in between these two, and performed the duties of watch officers and officers in charge of divisions of seamen and guns. The master and his mates were the sole navigating officers, and up to quite the end of the great war it was held no disgrace to an executive officer, providing he was a good sailor-man, to be neither navigator nor gunner.

The purser throughout the seventeenth and eighteenth centuries, was not the paymaster of the officers and men, for they were seldom paid in cash, and then not by him, but by special pay clerks from the ticket office. He accounted to the naval authorities for disbursements made for the ship, the expenses of which he defrayed either from a sum placed in his hands, or by bills. He had also the charge of, and to account for, the slops and provisions placed on board the ship for issue, the greater portion of his wages consisting of percentages on the value of the articles passing through his books. In addition to the stores of various kinds with which he was supplied, there were some which he was authorized to supply himself, such as coals, candles, lanterns, and the like, and thus he was not only the public controller, 
CHAP. III.] WARRANT AND INFERIOR OFFICERS. $38 \mathbf{I}$

but a private purveyor as well. It is not at all surprising, therefore, that at times when public and private interests clashed, the former suffered. ${ }^{1}$

He gave bond for a proper performance of his duties in the shape of two suretics for an amount governed by the rate of the ship in which he was serving. Latterly the bond was very high, being as much as $£ \mathrm{I}, 200$ in first-rates. Very often the purser was at the mercy of his sureties who used him as a middleman for the sale of their goods. Nowadays, by arrangement with the guarantee companies, the payment of a small annual sum relieves the accountant officer from trouble in this respect, and his position in the ship is on an altogether different basis.

That the captains and pursers of men-of-war under the Stuarts combined for the purpose of making illegal gains has already been mentioned, but that he should have to share the plunder was not to the taste of the former. In the reign of Charles II., therefore, a proposal was brought forward at the instigation of the captains, that the pursers should be abolished and their duties transferred to the former officers. The king, however, did not see the matter in the same light as those who made the suggestion, and asked, "when the men suffer, unto whom should they complain for justice?" When told that the captains would be just, he burst into laughter, and assured the petitioners that although they appeared to have a very good opinion of his captains, this opinion was not generally shared by the sailors, and on the whole he preferred to allow things remain as they were.

1 "Regulations relating to the Service at Sea," and "The News. Reader's Pocket Book, i739." 
But what they could not obtain in one way they did in another, and not long afterwards a new post, that of "captain's clerk," was instituted, with the pay of extra midshipman. This appointment was used at first by the commanders as a means of gratifying their friends and followers, but it led in time to an alteration in the method of entering the pursers' ranks. It was made a rule that service in this grade of clerk should be compulsory, and then the appointments fell into the captain's hands, at least so far as recommendation went. The independence of the purser was thereby sapped, and his powers and privileges were diminished, so that the responsibility for many of the malpractices with which the class had been charged rests quite as much with their superior officers, who shared the profits but not always the opprobrium.

The captain was answerable at the conclusion of the voyage by stoppage of his pay, until he had passed his accounts, handed in his journals, and the muster and cheque books kept by his clerk, with a certificate from each of the standing officers to the effect that he had not ordered anything to be done during the cruise which was irregular. This certificate was the last surviving relic of the old powers of the warrant officer, but it was found that the captains could easily overawe those under them into signing the certificate, and eventually the practice fell into disuse. In an extremely modified form a trace of this old custom is to be found to-day.

Maydman animadverts strongly upon the appointment of the captains' clerks, the gravamen of his charge being, that whereas they were the servants of the captain, the purser was the servant of the State. It was certainly the case in scores of instances, from the early part of the 
eighteenth century onwards, that the pursers were either relatives, connections, or friends of the captains. In numerous cases they were brothers; one serving his country ostensibly for honour, but finding his reward perhaps in prize money, the other filling the place of profit in which he was able to recoup the family for its patriotism.

It was by no means uncommon for the purser to buy his warrant, as much as $£ 60$ or $£ 70$ being the price in the reign of James I. Pepys records in his diary, on more than one occasion, receiving sums of money for this purpose, and his price seems to have been $£ \mathrm{IO}$. Later on it may be inferred from what the pursers say themselves, that either the Admiralty officials or the captains of ships made those who wished for the appointment bleed for the privilege in one way or another. Not until I8I3 was any examination deemed necessary, although from the very complicated system of accounts then kept, some previous experience was probably essential. Falconer, the sailor-poet, was, nevertheless, given a purser's warrant in $17 \sigma_{3}$, although his service in the Royal Navy had hitherto been almost entirely in the executive line as midshipman. He may indeed have gained sonre knowledge of the system of accounts when a youngster with Campbell; who was a purser, and under whose patronage he first went to sea. ${ }^{1}$

The chief duty of the purser in a sea-going ship was to keep a muster-book of the ship's company from which everyone on board was to be mustered every ten days, the entry, discharge, and attendance of every man

1 "Life of William Falconer," author of "The Shipwreck," a poem, 1762, "A Marine Dictionary," 1769 , and other works. He was lost in the Aurora in I769-70. 
being noted, and also desertions, death, or absences without leave. It was from this book that the tickets were made out and signed by himself, the captain, master, and boatswain, on the presentation of which to the proper officers, wages were paid. The only stoppage allowed on the ticket was for clothes supplied from the store of slop clothing on board. No supernumeraries were allowed to be entered without special order, and a distinction was to be made in the muster-book between pressed men and volunteers.

Among the various tricks by which the pursers and their accomplices made gains in addition to the benefits derived from men being allowed to leave the ship and not at once checking them as absent, the following may be mentioned :-keeping men's names on the books after they were dead, run, or discharged; buying the short allowance money ${ }^{1}$ of the men at half its value; giving the men "beverage" for good wine, or shrunken and perished victuals instead of prime when on foreign voyages; making out tickets for men who were dead or run, and then giving these men or their attorneys and executors some small consideration and drawing the full pay. Probably the most iniquitous proceeding of all was the first-named-the man being tricked into leaving the ship, either to go on shore, or by being passed or lent to another vessel, when the unfortunate fellow lost the whole of the wages due to him, the purser drawing them with a forged ticket.

1 Short allowance money was the account credited to the men when on short allowance, owing to the scarcity of provisions. Orders were given in the reign of Queen Anne that short allowance credits were always to be paid to the men themselves, but the order seems to have been frequently evaded. 


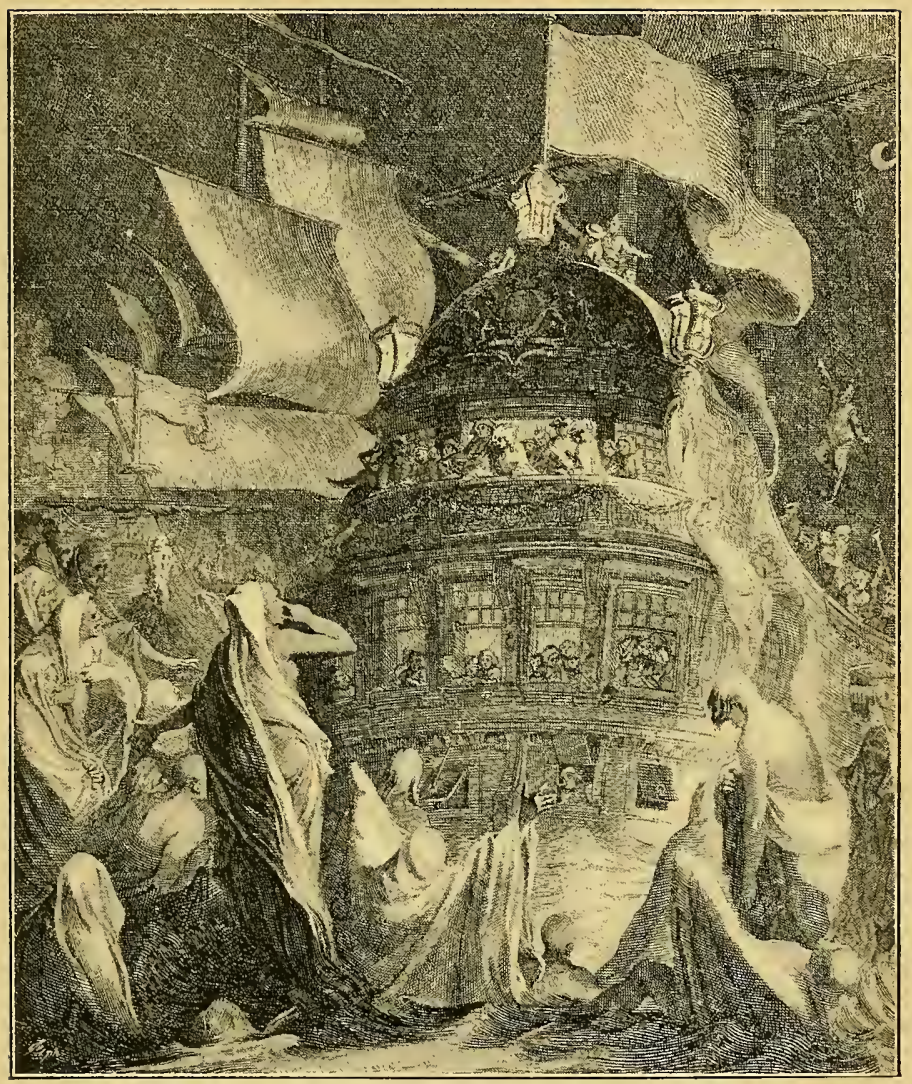

THE GHOSTS OF ADMIRAL HOSIER AND HIS MEN APPEARING TO ADMIRAL VERNON, I 740.

Satirical print published contemporaneously with Glover's ballad. (C. Mosley.) 

CHAP. III.] IVARRANT AND INFERIOR OFFICFRS. 385

The slops were provided by a contractor known as the slop-seller, and he was bound by the instructions to allow the purser a shilling in the pound on all sales. By overcharging both the living and the dead, the purser added to his commission and also to the overplus of stock, which would become his at the end of the voyage. But the profit did not all go to himself. He was very much in the slop-seller's hands, for if the two did not agree the captain was authorized to appoint someone else to receive and vend the slops. It could hardly have suited him that this should happen, and so, as Maydman tells us, if the slops did not come up to sample, it was generally to the interest of captain and purser to shut their eyes to the swindle. The purser was also allowed a shilling in the pound on sums realized from the sale of dead men's effects. Tobacco was not supplied by the Victualling Board until I798,

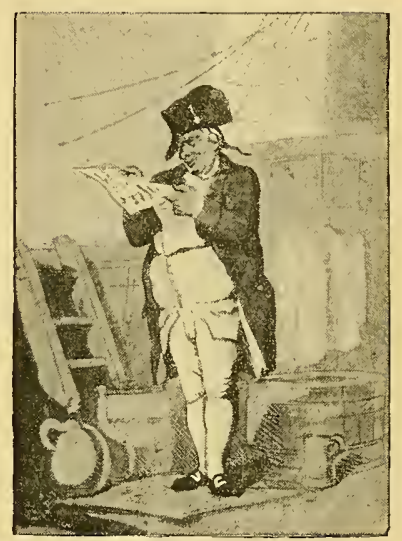

PURSER. CIRCA I787-ISI2. (Rowlandson.) and on this article also pursers had an allowance for depreciation, while the expression to "make dead men chew" has passed into a proverb. Altogether, until the beginning of the present century, the purser was practically, through his steward or some other agent, the purveyor of all necessaries not provided by the regulations as well as of all those which were so provided; if therefore the captain. liked to connive, or C C 
to be blind, the gains, legal and illegal, might be considerable.

It would be altogether unjust, however, to assume that because such things were common, therefore all, or even a great number of the captains and pursers were rogues or devoid of moral principles. The system was in fault. The State was looked upon as a milch cow; it was necessary to bribe, in some way or other, to obtain a good post, and, having obtained it, he was held a fool who did not get the most out of it.

The method of paying the ships' companies may be further explained here. All through the seventeenth and eighteenth centuries it was the rule not to pay anybody until the end of the commission, and to a certain degree the practice obtained until some fifty years ago. The superior officers drew bills; everyone else was given tickets as explained above, but the cash could often only be obtained at the Pay Office, where tumults were so frequent, owing to delays and difficulties in getting the money, that it was found necessary to transfer it to Tower Hill, so that help could be quickly summoned from the garrison at the Tower.

Doubtless the officers, if they had private means or well-to-do friends, and latterly through agents, were able to get advances, but the junior officers and men could only realize by selling or pawning the bits of paper which represented their long overdue wages. The sailor who commanded a Parliament ship, and whom I have already quoted, contrasts the system in vogue in those days and in later times. He says there was then "due care taken of their pay, which was the life of the Cause, for as soon as any ship came to be laid up or refit, the Books were made up, and money was ready at the 
port to pay off the men as soon as the ship was moored. ... The seamen's short allowance money being paid at the same time to a farthing. Nor had they any difficulty in receiving their Tun and Gun money (the same now called Prize money) and if they had been on any extraordinary service, there was a crown or ten shillings a man given them to drink the Government's health. . . . I cannot express the satisfaction I have had to see with what cheerful and lively countenances our men would come to the pay table, and as they swept the money into their hats, they would pray for the prosperity of the Government, and for the health of their captains and other officers. ${ }^{1}$ So that they parted with mutual Love and Respect, and when their commanders told them that they hoped they would be ready to serve the Government again upon the first notice given them, they would promise it with great cheerfulness, and be as good as their word."

At the Restoration all this was changed, and it is nothing to marvel at that, as Pepys tells us, our prime seamen by hundreds left the country and offered their services to the Dutch. Later on the same thing happened, not, perhaps, so much because pay was withheld, or because of the taut discipline and barbarous methods of punishment in vogue at the time, but owing rather to restrictions in the matter of leave and liberty to go ashore. $^{2}$

1 This custom of the men sweeping the money off the pay table into their hats or caps continues to the present day, and, with the exception that the paymaster of the ship takes the place of the pay clerk, and a lieutenant that of the captain, what may be called the ceremony of pay day is observed as it was in the Commonwealth times.

2 Admiral Patton in his "Natural Defence of an Insular 
The abuses in the matter of pay in the first half of the eighteenth century may be briefly summarized. The practice of placing the letter $Q$ for query against a man's name if he was sent on shore sick and did not return within a month, whereby he forfeited all his pay; the use of the letter $\mathrm{R}$ to denote that a man had run in the same way on the smallest pretence (in this case also all wages due were forfeited); the deferring or nonpayment of wages due to men who had died on service, although sufficient power had been given to executors to receive the same; the irregularity of payment, some ships' companies having three, four, and five years' pay due; the practice of transferring men from ship to ship, or lending them, with the consequent result that they lost their wages for the ship from which they were transferred; the non-recognition by the pay clerks, unless first bribed, of powers of attorney, whether given by officers or men; the difficulty of obtaining bounty for widows and orphans of men slain in the country's service; the non-payment of the wages of men who had died in the service without making wills or executing powers of attorney.

Empire," referring to the seamen discharged at the Peace of Amiens in 1802 , says, "It was found that many of them had upon being paid off from the ships, on signing the definitive treaty, actually embarked for foreign countries, without setting their foot in their own." Captain A. J. Griffiths, R.N., the author of "The Claims of the Navy," published in 1813 , mentions that Sir Thomas Troubridge told him that shortly after the troubles in 1797 , many of our seamen went over to Brest and assisted to fit out the French fleet.

1 See the "Sailor's Advocate," I 728 ; "A Letter from one bred to the Land Service on a more Easy Manning of the Fleet," 1747 ; and other pamphlets on the subject in the British Museum. 
CHAP. III.] WARRANT AND INFERIOR OFFICERS.

It may be doubted whether the sailors themselves would have formulated their grievances in this way. Probably they would have been content to ask for more pay, better food, and some liberty to go ashore. But the Sailor's Advocate, at least in some instances, had a direct interest in the sailor's ticket, and it was the difficulties in the way of realizing this piece of paper that loomed largest to him.

A furious controversy raged around the question of the propriety and expediency of the sailor being allowed to sell or transfer his ticket. One party urged that the system should be legalized, as offering the least of two evils. "Every man that serves the king for wages,". wrote a pamphleteer, "hath a right thereto, as good as any man hath to receive rent for a house or land, thereforc he further hath a right to buy and sell thereupon and engage the same for payment, which engagement should be satisfied at the payment of the ship or the tickets redeemed at sight." "The other party maintained that if this permission were granted, the seamen would be robbed by the ticket buyers who falsely claimed to have supported the men's wives and children during their absence from home.

As a matter of fact, there was an extensive illicit traffic in the tickets, and what between "ye Gent" behind the Curtaine," in other words the clerks at the Pay Office, the pawnbrokers or ticket buyers at the seaports, and the purser on board ship, the unhappy sailor, especially if he were a niarried man, fared badly, and received but a very small proportion of his wages.

Mr. Maydman was a strong advocate for allowing tickets to be sold openly and is supposed to have been in the trade himself. He declares that the seamen had 
no resource but to sell to the ticket buyers, or else he must "find his way behind the curtain at a cruel loss." Captain St. Lo, R.N., who wrote about the same time, was an equally stroug opponent of the whole pernicious system of payment, and this ticket-selling feature of it in particular. In his pamphlet he suggested, along with a system of registering seamen, reforms for many of the abuses mentioned above and also a plan to enable the seamen to allot a part of their wages. ${ }^{1}$

An Act of Parliament was passed in 1758 establishing a more regular method for the punctual and frequent payment of the men, and also to enable them to remit money for the support of their wives and families. In theory these methods were a great advance, especially the latter. by which any seaman wishing to remit could receive a ticket for such part of his pay as he did not wish to take in cash, which ticket he could send to his friends, who, as it was made payable on demand, were supposed to bc able to cash it by presenting it to any collector of customs or excise. In practice, it did not answer, partly, it would appear, owing to the improvidence of the bluejackets, whe sold their tickets at a large discount in order to obtain ready money, and partly because of the difficulties raised by the cashiers or paymasters, difficulties only to be re-

${ }^{1}$ Captain George St. Lo (or Loe), when in command of the Portsmoith, in 1690 , was taken by the enemy after a desperate engagement, in which he was severely wounded. During his detention in France he wrote several pamphlets comparing the nlanagement of the French and British. Navies, making. many useful suggestions. The best known of these is entitled "England's Safety, or a Bridle to the French King," proposing a new method for encouraging navigation, and raising qualified seamen, etc., I693. The frontispiece of this work contains an illustration of some seamen of the period, which is reproduced on p. 493 . 
moved by bribes. The sailors must not be altogether blamed, for their pay was small, and they did not receive it regularly, while their provisions were inferior in quality and often almost uneatable. Owing to this last-named cause the men were often obliged to buy other food at extortionate rates from the pursers afloat, or from the storekeepers, whose agents thronged off to the ships as soon as they came into port.

At this period it was that the fictitious "widow's men" came into being. By the Act of Parliament a sum equal to the pay and cost of victuals of a certain number of able seamen was to be set aside for the relief of poor widows of commissioned and warrant officers. The number was set at one man for every hundred, or if the personnel consisted of more than 20,000, two men for every hundred voted by the House of Commons. In order, apparently, that this sum should be estimated in the most complicated and extravagant manner, each captain of a ship was instructed to enter on his books so many fictitious names of men, proportionate in number, according to that of his crew, and to order the purser to check these so-called "widow's men" for pay and victuals. A clumsier expedient, or one more calculated to produce a plentiful crop of irregularities, it is difficult to conceive. ${ }^{1}$

It was not until after the mutiny at Spithead in 1797 that the grievances of the men were dealt with on a fair and equitable basis, and the authorities were forced to comply with demands which would never have been

1 It is but right to say, however, that this is not the universal opinion, for Admiral Sir A. Phillimore, in his "Life of Sir William Parker," says, "The system had its merits and produced a very good resurt" 
made had the reasonable and respectful petitions of the seamen for redress received just and proper consideration.

Among the concessions wrung from Parliament at this time was an increase of pay $;^{1}$ that of able seamen being raised to a shilling a day, clear of deductions, while the wages of ordinary seamen and landsmen, the latter a newly-introduced rate, were proportionally increased. Deductions from the allowance of provisions for leakage or waste, which had previously fallen on the sailor, were abolished. Wounded men who after six weeks ashore had been discharged, were now entitled to receive full pay until their wounds were healed, or if reported incurable, they were entitled to pension or admission to Greenwich. Other concessions were connected with a reduced charge for postage of their letters ; an increase of liberty to go ashore; the issue of fresh vegetables and new flour when in port; an improvement in the quality of the provisions generally; an altered dietary and better accommodation and treatment of the sick, including a more liberal suipply of medical comforts. Many of these matters did not require Parliamentary sanction, but one section of the Act passed at this time amended all previous legislation on the subject of allotments, and made it possible for the men to remit an allowance nearly equal to half the increased pay.

It had become customary to send cashiers to the home ports to pay the ships' companies an advance on commissioning, and their wages to date on paying off, but in ships on home service six months' pay was always kept in hand as a precaution and preventive against desertion, while those on foreign stations were still kept out of all

1 This was the first time the pay had been increased since the days of Charles II. 
CHAP. III.] WARRANT AND INFERIOR OFFICERS. 393

their money. Although, therefore, it was not until a much later period that the grievances in this respect were removed, it may be said that the actual reformation dates from what the sailors called "the Breeze at Spithead."

That the complaints of the men were well grounded was proved by their prompt redress upon compulsion, and it is marvellous testimony to their patience and patriotism that, while the powers they wielded were enormous, their demands were, on the whole, most moderate. But then the Spithead mutiny was, as we should say now, "run" by the seamen, which was not the case with that at the Nore and other mutinies of the period; and as one of the ringleaders in "the Breeze" said afterwards, "it was never forgotten that it was more in character with seamen to be under than over the mark." If they made a mistake at all, it was, perhaps, in not demanding a more regular payment of wages, for then and afterwards ships were away on foreign service as long, in some cases, as ten years, and not a man touched a penny of his pay until he returned to England. What a contrast is this to the present system, when the men are paid weekly and they can, if they prefer to do so, put their wages into a savings' bank on board and receive interest on it. And this in addition to being entitled to allot a portion of their pay, which is paid regularly, and never stopped without good and substantial cause. ${ }^{2}$

1 See "Tales of a Tar," London, I 830.

2 Lord Dundonald, in "The Autobiography of a Seaman," mentions that naval officers were compelled to draw bills for their pay on foreign stations, and had frequently to sell their bills at a discount amounting to thirty-five and forty per cent. He also, quoting from a speech made in the House of Commons, gives the length of time some vessels had been on the East Indies station 
One of the grievances of the men in I 797 referred to the insufficient attention paid to the care and requirements of the sick. This does not appear to have been attributed to the low standard of professional ability among the surgeons, but to want of proper accommodation and an adequate provision of what then, as now, were styled "medical comforts." It was by no means the first time that attention had been called to these needs, but "sanitation" and "hygiene" were words which for another half century were not to be found in the naval vocabulary.

In previous chapters the fearful mortality which raged on board the ships of Queen Elizabeth has been mentioned, and it was quite equalled by that which ravaged the fleets of James I. and Charles I. ${ }^{1}$ Pennington, in the reign of the last-named, complains that there are "no stores, no surgeons, no drugs, and the hammocks are infected and loathsome, and the men stink as they go, and the poor rags they have are rotten and ready to fall off." About the same period another officer writes, "there are few surgeons, and these few haunt the taverns every day."

Under the Commonwealth the picture changes, and we learn that "there was particular care to have our provisions good and in plenty. We had few complaints in these days of stinking meat, or bad drink aboard our fleet. ... We were also very careful to keep them [the

without receiving any pay :--Centurion, eleven years ; Rattlesnake, fourteen years; Fox, fifteen years ; Sceptre, eight years; Albatross, twelve years ; Willhelmina, ten years ; Russell, seven years ; Drake, six years (chap. xxix., p. 321).

' See Mr. Oppenheim's papers in the "English Historical Review," already referred to. 
CHAP. III.] WARRANT AND INFERIOR OFFICERS. 395

men] sweet and clean; and such as were sick or wounded had everything necessary provided for them and were carefully looked after. ... I cannot omit to tell you what I have frequently heard our great and good Admiral Blake say amidst his ship's company, that the meanest among them were freeborn Englishmen as well as himself, and that officers and mariners were all fellowservants to the government of their country."

This considerate and prudent conduct towards the men ceased at the Restoration, when surgeons' warrants could be bought, and when Pepys gives us an idea of the treatment of the wounded when he tells us how he met a man coming back from a fight with the Dutch with a plug of oakum thrust into the socket from which he had lost an eye. The appointment of Surgeon-General of the Fleet in 1664 appears to have had few beneficial results, either for his professional brethren, or for the service itself. Probably it was a step not entirely taken for the public advantage, but, like another change made ten years later, a bit of jobbery characteristic of this dissolute and venal age.

In June, I703, an order was issued that all medicines, drugs, instruments, etc., supplied for the use of her majesty's ships were, previously to being placed on board, to be reviewed at Apothecaries' Hall. Surgeons of ships in commission were to pack up and seal their chests and bring them up to the same place for examination. In the same order surgeons were first instructed to keep journals and records of cases.

The naval doctors were terribly disgusted, and presently fired off a rattling broadside at the "fumbling old miserly curmudgeons" of the Hall, who they declared had merely obtained the issue of these instructions in order 
to have a monopoly of the supply of medicines for the fleet. $^{.}$

In a pamphlet issued by them they bring a series of accusations against the governing body of Apothecaries' Hall and their servants, alleging on the evidence of several naval surgeons, supported by affidavits, that the medicines and drugs supplied from Apothecaries' Hall were dearer than, and of inferior quality to, those which could be purchased outside. From which it seems that up to the date of this order the surgeons had supplied their own medicines, or possibly these were purchased by the pursers. However, it was now a grievance that the drugs were to be obtained from Apothecaries' Hall, and further ground for complaint was found in the "unreasonable exactions of your mercenary, saucie and imperious clerk," a gentleman who, if the surgeon of the Oxford is to be believed, "sweated" the unfortunate medical officers cruelly.

The doctors further declared that they were put to much expense to bring their chests to town for examination, that the fees for examination were absurdly high, and that unless the examiners were bribed, they took occasion to find all manner of frivolous pretexts for delaying the grant of a satisfactory certificate, for all of which reasons they demanded reform. Apparently the surgeons did not obtain redress, for more than a quarter of a century later we find that Smollett's experiences are very much of the nature of those of which his predecessors complained.

It was about 1740 that Smollett was endeavouring to obtain a surgeon's mate's warrant; and, if "Roderick

1 See the "Navy Surgeons' Memorial to the Managing Apothecaries at Blackfriars, 1708." 
CHAP. III.] WARRANT AND INFERIOR OFFICERS.

Random" may be regarded as to some extent autobiographical, by the following procedure. First he had to obtain from the Board of Commissioners at the Navy Office, a recommendation to Surgeons' Hall for examination; this cost him a fee of $2 s .6 d$. to the clerk to the Secretary of the Board. This letter, which took two days to obtain, had to be left with the clerk at Surgeons' Hall with a fee of $\mathrm{I} s$. to quicken its way to the examiners. Then the examination took place and the examining surgeons, if satisfied, handed over a certificate to that effect on receipt of $5 s$. ; the beadle of the Hall required $3 s$. $6 d$., and "the old woman who swept the Hall," twelvepence, so that up to this point the expense was I 3 s.

But here the whole process of obtaining a warrant by interest, influence, and bribes commenced, and, as Random's friend told him, to obtain a place as surgeon's second-mate on board a 7o-gun ship cost him exactly $£ 3$ I2s., which he had every reason to believe was shared between the Secretary of the Navy and some of the Commissioners. The actual fee for the warrant, over and above the bribe, was I3s. The embryo naval surgeon had therefore to pay a sum of $£ 4$ I $8 s$. for a post the pay of which was $£ \mathrm{I}$ IOs. a month, that is, if he received his wages in full; but Roderick Random relates how this friend, to find the money to satisfy the harpies at the Navy Office and Surgeons' Hall, had given to a money-lender a power of attorney to "lift" his pay and deduct a commission of fifty per cent. Random also tells us how, when he turned over from one ship to another in the West Indies, he sold his ticket to a Port Royal Jew at forty per cent. discount.

It will be remembered, however, that Roderick himself did not get his warrant by bribery; he was pressed 
with much unnecessary violence, carried aboard the tender, and then sent to a ship in which by the influence of the surgeon he was first of all made "loblolly boy," or as we might now say, "sick berth attendant," and then, by the same interest, obtained a warrant as surgeon's mate. Doubtless Smollett wished to show that there were more ways than one of getting into the service; and, as a further example of the careless, lax methods in vogue at the Navy Office, he makes his friend William Thomson, the second surgeon's mate, obtain his warrant by a mistake, it having been intended for another man of the same name.

But, although it is most likely that Smollett in describing these various modes of entry relates among them his own experiences, it will not do to accept, without large deductions, his pictures of sea life. Captains Oakum and Whiffle, and Surgeons Macshane and Simper, are not types, but merely caricatures of persons whom Smollett had either come across or had heard about. It is the same with his episodes, as, for example, the way in which Oakum cleared the sick list. They were either events personally known to him and grossly exaggerated, with a heightening of all that is brutal, thoroughly characteristic of Smollett, or they were galley yarns, based more or less on fact, and traditional in the Navy.

In those days the surgeon's mate was a very "inferior" officer. His mess place in a line-of-battle ship was a square of six feet in the cockpit screened off with canvas and shut in by chests, dark as a dungeon, and smelling intolerably of putrified cheese and rancid butter. His food was the ship's rations eked out with a few onions, or some similar delicacy, purchased during the infrequent 
visits of the vessel to port. In a smaller vessel he might on occasion be permitted, as Random was, to mess with a master's mate and the gunner, and it was in any case as much as his skin was worth to appear on the quarterdeck without an order to that effect. Smollett's opportunities for lnowing what was transpiring, even in his own ship, compare but unfavourably with those of an intelligent bluejacket in the present day; for, as he says himself, "with the lieutenants I have no concern; and as for the captain, he is too much of a gentleman to know a surgeon's mate even by sight."

At some time in the eighteenth century, but, so far as I have been able to discover, not officially until the issue of the regulations of 1808 , masters, surgeons, and pursers received the title of "warrant officers of wardroom rank," and were thus differentiated from the boatswain, gunner, and carpenter. Naval instructors and engineers are comparatively modern classes, dating only from the year I 837. All these five classes of officers now receive commissions instead of warrants. Of the other inferior officers, the second master or master's mate alone rose to the dignity of the quarter-deck before he was finally abolished, the majority of those who were then on the same level with himself, and frequently his messmates, being now known as first-class petty officers.

The surgeon and the chaplain, until towards the end of the last century, occupied ill-defined positions in the social economy of the man-of-war. When a general mess for the higher officers first became the rule is uncertain, but when it did it was the mess of the licutenants. The master was generally admitted a member, and possibly the surgeon, but the chaplain not always, and the purser even less frequently. The captain, or the 
admiral, in a flag-ship, appears to have kept a table long before the other officers began to mess together, and to have thereat entertained the volunteers or letter boys intrusted to his charge, as well as those of the officers who were his particular followers. In I67 I it was ordered "that the marine officers should eat on board at the table of the captain, who was to be paid for the captain (of marines) double the allowance, and for the lieutenant and ensign, the same allowance as for a volunteer. ${ }^{1}$ There is also evidence that the chaplain, when one was carried, sometimes messed at the captain's table.

1 liat a chaplain was not invariably appointed to every ship may be inferred from Gibson, who says that the clergymen in the expeditions which seamen commanded took pains to write journals, but that the gentlemencaptains, to prevent having any such "true relations of their voyages," omit to carry chaplains to sea with them. Of these journals several are in existence; that by Teonge has been referred to; another, better authenticated, is published as an appendix to the memoirs relating to the Lord Torrington. The writer was the Rev. Thomas Pocock, M.A., chaplain of the Oxford, I698, the Ranelagh, I704, and the Union, I7Ir. The journal principally relates to the cruise of the Ranelagth off the Spanish coast, the capture of Gibraltar, and the battle of Malaga. Mr. Pocock mentions, under one date, “I removed into Mr. Master's cabbin, opposite to mine, which was enlarged for Mr. Vanbrugg," but the former officer was a midshipman and the latter a lieutenant. Later on he notes, "I removed out of the admiral's

${ }^{2}$ Corbett's "Collection of MSS., Admiralty Library," vol. xvi. fol. I, 2, quoted in Major Edye's "History of the Marines." 


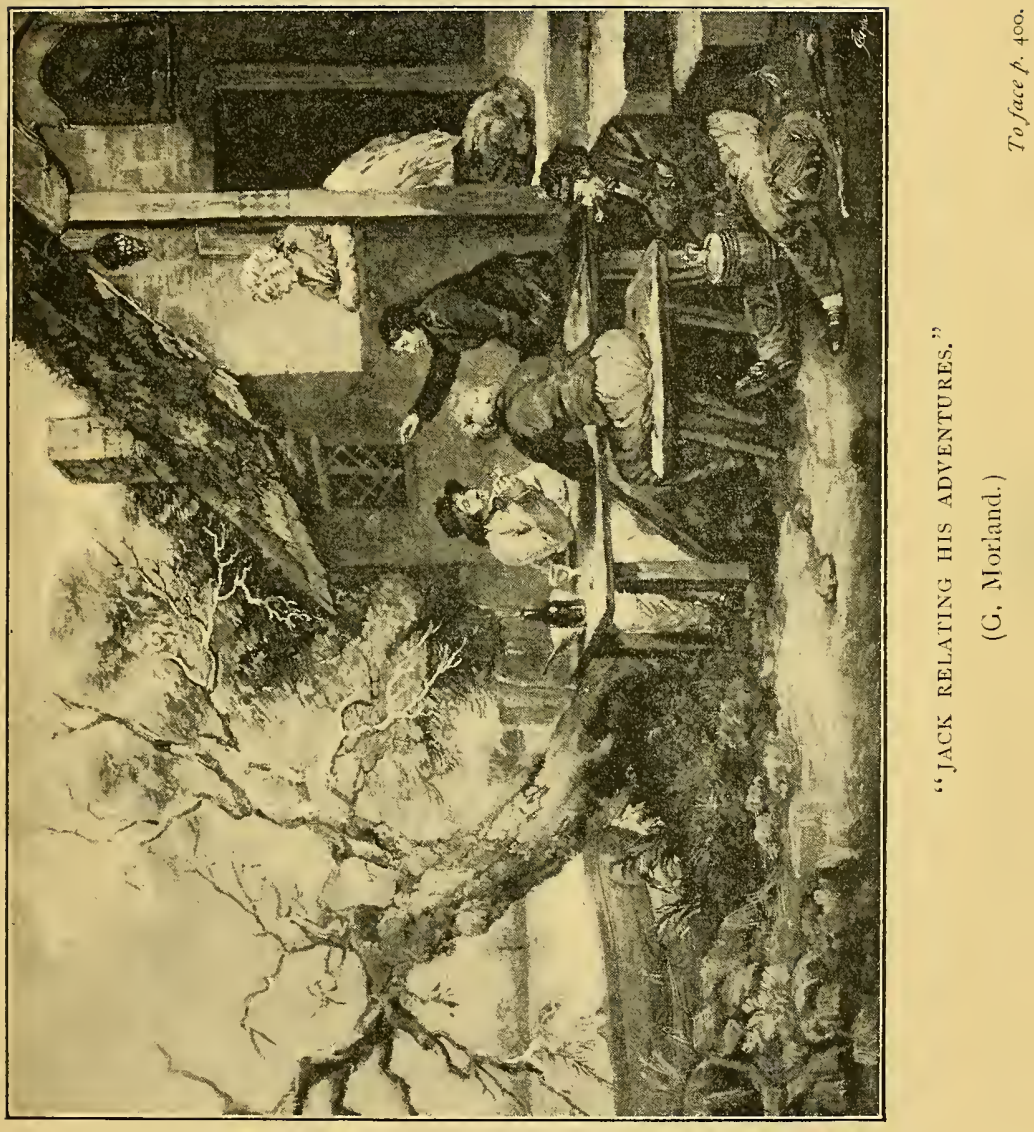



CHAP. III.] WARRANT AND INFERIOR OFFICERS. 4OI

cabbin and hung up an hammock in the lieutenant's." As he had not previously said anything about getting into the admiral's cabin, it seems possible that the "cabbins" referred to in the first note were subdivisions of this part of the ship, and that he afterwards went below into what would now be called the ward-room. His duties are thus referred to: "I preached this morning on the quarter-deck: read prayers about 4. I catechized first the volunteers and then the officers' boys, and I distributed about 500 books among the ship's crew. . . . I gave six young gentlemen $6 d$. a piece for learning the 6 first Psalms." Mr. Nathaniel Taubmann, another chaplain, published his journal, so far as it related to the movements of the British fleet and squadrons in the Mediterranean in I708-9, but he does not directly refer to the duties and position held by the chaplain. In that scandalous little book, "The Wooden World Dissected" (I744), we are told that "a sea-chaplain is one that in his junior days was brought up in fear of the Lord; but the University reasoned him out of it at last, and he has ofttimes thanked his good stars for it. ... There's as great a difference betwixt him and a reverend divine as betwixt a quack doctor and a learned physician; and he will never show it more than when you offer to tell him so, for he'll be readier to confute ye with his fists than any other proofs whatever. ... He drinks and prays with much the like fervour, and to show his abundant humility he will sometimes drink flip with the midshipmen; and, to prevent the fall of a weak brother, he will oft be so charitable as to drink for him. . . . He wears his prunella gown as chearily as he does his honesty; there's something in the wind to be sure when he puts on either. The captain, when he has got a super-ordinary 
dinner, sends for him to give the Benediction, but he makes no long-winded Grace, for he loves to keep his breath to cool his pottage. He's the captain's trusty camarade at a game or so, on a Sunday evening, but they play not so deep as they drink for a hearty Bout prevents the spiritual food of the day from lying heavy on the stomach, there being no better digester of good doctrine than good liquor."

It is significant that Captain Glasscock, R.N., although he states that all line-of-battle ships and frigates have chaplains allowed them, yet when describing the members of the gun-room mess of a frigate in I 800 never mentions the chaplain as one of them. He does, however, tell a story about the chaplain of the Meander, who, when the ship was in distress and making seven feet of water an hour, stripped and took his turn at the pump for the purpose of encouraging the men. His action had the desired effect, for whenever he grasped the handle the seamen on it greeted him with a cheer and a shout, "Now then, lads, all together, let's sweat the parson!" Many stories are told of the pluck and gallantry of naval "parsons" in action, but their station is distinctly laid down in the regulations as being in the cockpit with the surgeon to minister to the wounded and dying. Convivial souls as they not infrequently were, and, like Mr. Teonge, fond of good living and punch, there were among them plenty of staunch Christians and good fellows, while doubtless there were those also who furnished substantial excuse for the scurrilous wit of Mr. Ward and other pamphleteers.

The first definition of "petty officers" was given in the regulations of $\mathrm{I} 808$, wherein the captain is told that he is not to discharge or disrate any commission or 
CHAP. III.] WARRANT AND INFERIOR OFFICERS. 403 warrant officer of the ship he commands, except "the master-at-arms, sailmaker, caulker, ropemaker, armourer, armourer's mate, and ship's cook, who, though appointed by warrants, are to be considered as petty officers," and any of whom he may disrate to such situation as he considers them qualified for, or may appoint in their

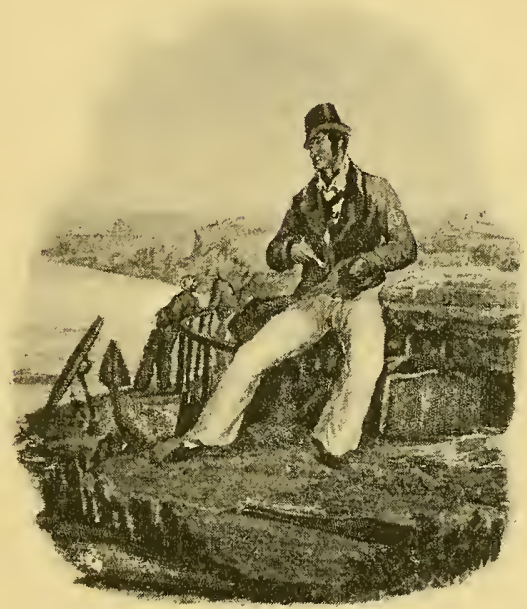

PETTY OFEICER. CIRCA IS28-33.

(Goni.)

stead any other properly qualified persons pending confirmation by the Admiralty.

The master-at-arms, as an officer, we first hear about just at the time when the master trumpeter with his "noise" disappears. He was originally, as his name denotes, the instructor in small arms, and was ordered daily to exercise such of the ship's company as the captain should appoint. This duty!he carried out under 
the junior lieutenant, who is sometimes described as "the lieutenant-at-arms." Subordinate to the masterat-arms were the corporals, fallen from that high estate in which Boteler expected to find lieutenants among them, but still performing similar duties. Gradually, however, the master-at-arms and the corporals had less to do with small-arm exercise and more with the preservation of discipline, until to-day they are the police of the ship. It is noteworthy that the master-at-arms was the only one of these inferior officers who received his warrant from the Admiralty.

Chief among the inferior or petty officers immediately under the boatswain was the master sailmaker, who, like that functionary, was appointed by warrant from the Navy Board. Towards the middle of the eighteenth century the ropemaker too, although presumably his trade was plied on board ship long before this period, appears among the subordinate petty officers directly connected with the boatswain. He also was warranted by the Navy Board. These officers had each their proportion of "mates" and "crew," including a certain number of "yeomen of the store-rooms." In a measure they formed a little group in each vessel, bound together by mutual interests, and having charge between them of everything pertaining to the motive equipment of the ship, rigging, sails, spars, and stores, including the ground tackle, or anchors and cables.

The immediate head of this department was the master, whose "mates" and "quartermasters," with their "gang," attended to the steering apparatus, compasses, wheels, relieving tackle, and so on. The art of navigating was in a sense extraneous to this business of superintending and maintaining the equipment con- 
nected with the motive and guiding powers; and, regarding the matter from a modern point of view, we should say that more good sailors, in the most comprehensive sense of the word, were to be found holding masters' warrants, than scientific navigators. ${ }^{1}$

Here we may briefly summarize the change and development in this particular group of officers. We saw first, when the navigation was chiefly confined to the coast, the "batsuen" in charge of ship and sailors. Then, as the needs of navigation increased, the magister, or master, a man of superior attainments, fills this place, and the boatswain is merely a storekeeper chosen from the older sailors. Then, with the growth of a permanent force and the need for standing officers for larger vessels, the boatswain again rises in importance, he and the

I Until the discovery of longitude, all navigation was more or less guess-work. An amusing, if spiteful, caricature of a master in the early part of the seventeenth century is thus drawn by the author of "The Wooden World Dissected:" "The Master is 'a seaman every bit of him'-his very conversation is so salt that he cannot have a Tooth drawn ashore without carrying his Interpreter. 'It's the aftmost Grinder aloft on the Starboard Quarter,' will he cry to the all-wondering operator. When he has to make a trip by land, "Ilp he hoists himself a Trip upon his Jig of a Horse and sticks as close to him with his Thighs as if he was got cross a Yardarm.' Being thus got priddy, with the Reins reived through both hands, he streight hawls them aft like Main Sheets, upon which the steed makes stern way, to his no small admiration. But resolving to try the Jade by and large, he trims all sharp, hawls aft upon one Rein only, and cuns with his Legs and Heels all weather, but, instead of running ahead, about ship goes the Beast and tosses my gentleman overboard. But up he ships upon his legs, as manfully as a Tailor upon a shopboard, and, finding that a Horse will neither answer the Helm nor his expectations, he e'en orders him back to his moorings and streight takes a berth in the Stage Coach, which always makes her way as good as she looks." 
newly introduced gumner being, next to the captain and master, the chicf fighting officers of the ship. The introduction and establishment of lieutenants diminishes his executive and watch-keeping functions, but his position is still most responsible, for he is, as it were, the chief engineer of the sailing craft, and with his assistant artificers, the sail and ropemakers, must maintain the motive machinery, repairing or replacing it if damaged.

Then came steam, superseding wind for motive purposes, and to-day the captain does not direct his sailors, but trusts to his stokers instead to carry him to the place where he can fight his ship. At the same time one cannot fail to see the close analogy between the present position of the engineer and that of the boatswain in the last century.

To the master, or navigating officer as he is now styled, the art of guiding and directing the course of the ship still pertains, but of the boatswain's ancient business almost all that still exists is connected with the boats and the ground tackle. This part, however, with the extended use of steel and iron, has greatly altered, and to it a great deal that is entirely new has been added. Moreover, owing to the scarcity of lieutenants, there is every reason to suppose that the boatswain will be again called on to perform many of those executive duties which fell to the lot of his predecessors.

Almost equal in antiquity to the title of "boatswain" is that of "cockswain," or, as it was originally written, cog-swain, the man in charge of the cog, or cock-boat. To-day every vessel, whether merchant-ship or man-ofwar, carries a large number of boats, but for a very long period ships seldom or ever carried more than one or two, and even at the beginning of the present century it 
was only just becoming customary to have them hanging outside the ship.' The cock-boat became the long-boat and the barge was added thereto, but the term cockswain remained, and while the boatswain had charge of the larger boat, that of the latter was given to the cockswain, these two officers, along with the master, being allowed to carry whistles. As the number of boats increased so has the number of cockswains, while the dignity of the title, if not the responsibility of its holder, has diminished. There is no longer a rating of cockswain in the Navy, the term being used merely to denote the person in temporary charge of a boat, whether that boat be an admiral's barge or a dingy, while the only cockswain that receives extra pay as such is the cockswain of a torpedo boat.

The gunner, although for a long time he held second place among the three principal warrant officers, has now become first. His duties and position, however, at all times placed him on a different footing from his colleagues, the boatswain and carpenter. He lived aft while they lived forward, for his armoury lay below the officers' quarters, while their store-rooms were down under the forecastle. The gun-room, of which he had special charge, was the living room of the junior officers, who, to some extent, were in his care, and in the first printed regulations we find that "he is to keep good order in the gun-room, and suffer none to lie there, but such as have a right thereto by their places, or whom the captain shall direct. He is to cause a careful man of his crew to watch there every night with a candle in a

1 Even in Burney's edition of Falconer's Dictionary, published in $18 I_{5}$, there is no mention of davits for hanging boats outside the ship. 
lanthorn." This watchman, whose duty it was also to keep the place clean, was known as "the lady of the gunroom," and the gunner's store-room, also in his charge, was known as "the lady's hole."

The chief assistants to the gunner were the armourer and gunsmith, who were warranted, not by the Admiralty or Navy Board, but by the Board of Ordnance. Their station was in the gun-room, to keep the small arms clean and in good repair. These officers also had their "mates" and "yeomen"; the yeoman of the powder room having at one time been amongst the officers."

The schoolmaster also messed in the gun-room. He received his warrant after passing an examination before the master, wardens, and assistants of Trinity House, for the purpose of obtaining a certificate of his "being skilled in the theory and practice of the art of navigation, and qualified to teach youth therein." He was ordered to teach the volunteers and other youths on board the ship, and to report such "as are idle or averse to learning."

The term "carpenter" is said to have applied in mediæval times to shipbuilders only, workers in wood on shore being denominated smiths; however this may be, there is no question that the carpenters in the Navy were shipwrights and caulkers. In very large ships, from early in the seventeenth century, a "joyner" was sometimes carried, and later on we find on the books blacksmiths, tinsniths, painters, and coopers, the lastnamed being attached to the ship's steward's gang, with the lamp-trimmer.

' See Pepys, who hears from his brother-in-law Balty that the latter is learning navigation from the "Yeoman of the Powder Room." 
CHAP. III.] WARRANT AND INFERIOR OFFICERS. 409

No carpenter could obtain a dvarrant unless he had served apprenticeship to a shipwright, and had given proof that he understood caulking a ship, how to fish masts and yards, and to cut them from rough spars. At the present time a carpenter must know much more than this, and be in fact a skilled artisan in iron as well as wood. He has to pass examinations before the dockyard officers and satisfy them that he understands the construction of iron and steel armour-plated ships, and knows all about the fitting and working of water-tight doors, double bottoms, hatches, and sluices, and the methods of flooding the magazines, and ventilating the ship, as well as the pumping arrangements.

Like the other warrants the carpenters had their gang, mates, etc., and these were, and are, classed among the "idlers," a name given to all those men who, from being liable to constant day duty, need not keep the night watches. This class is again divided into "working" and "excused" idlers, the former being those who are bound to drop their special tasks and attend to the summons for "all hands," the latter including the stewards and cooks who are only required to attend such calls as for "fire stations" and " general quarters."

After the lieutenants, the warrant officers took command of a ship successively in the order of their respective ranks according to seniority: masters, second masters, masters' mates, gunners, boatswains, and carpenters. The civilians, or non-combatants, were officially excluded from command, although, as our naval annals show, they were generally ready to take a hand in the game, and frequently not only in the ships, but on boat service and cutting-out expeditions, performed most gallant actions and exploits. 
The petty officers of the combatant branches would also be detailed for command, midshipmen and masters' assistants, until after the first quarter of this century, being so rated. The middies, with naval cadets, are now designated "subordinate officers;" the master's assistants have disappeared.

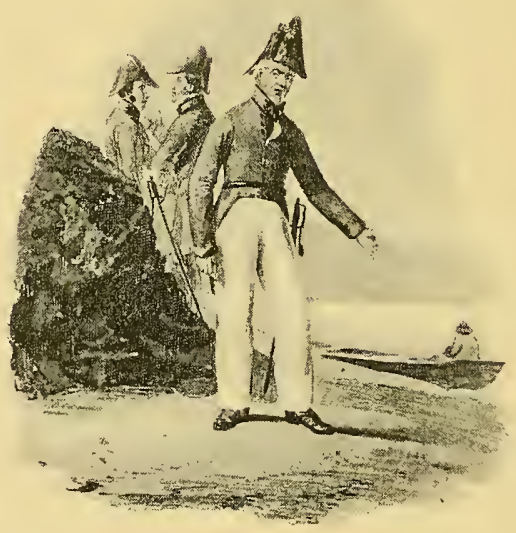

PURSER. CIRCA I828-33.

(Goni.) 


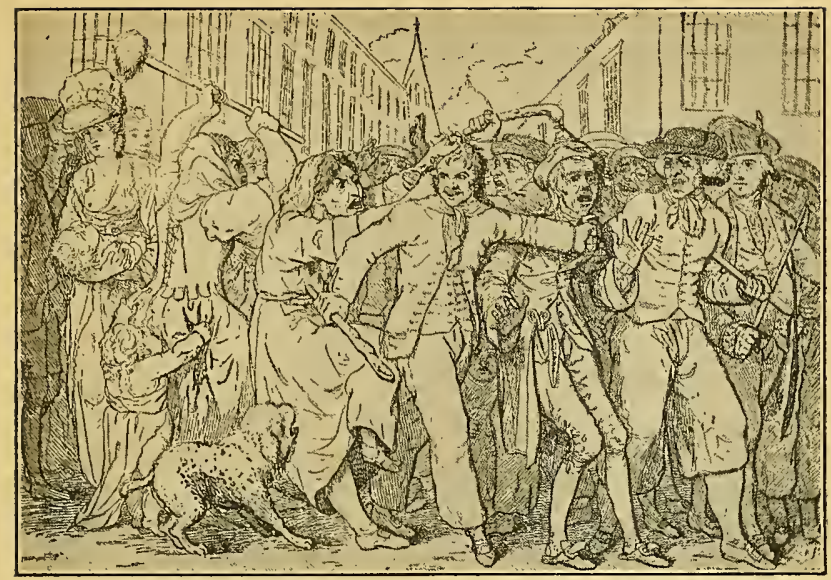

A PRESS-FANG AT WURK, I779.

(James Gilray.)

\section{CHAPTER IV.}

THE TARS IVHO MADE THE EMPIRE.

IT has already been told how under the Saxon monarchs it was the duty of the members of the Cinque Ports to supply ships and men for the king's service, just as the inland towns were bound in other ways to aid when called upon. It must not be supposed, however, that this duty fell on the Kentish corporation alone, the whole seafaring population of the island being liable for service if required. There came a time, however, when, owing to the increase of commerce and similar causes, the merchant trade and fishing industries offered greater 
inducements to the mariners than service with the king, and it was therefore with difficulty that his levies were obtained. Then it was that the system, sanctioned by custom as far back as our records carry us, became by law established. The first commission for the impressment of seamen for the king's service which is now extant bears date 29 Edward III., I 355.

The practice, according to Lord Mansfield, was "deduced from that trite maxim of the constitutional law of England, 'that private mischief had better be submitted to than that public detriment and inconvenience should ensue." Land service was also due and could be enforced by law, but those who were liable for work afloat were exempt from the land press. In I6 5 , for example, we find the Commissioners of Muster reporting to the Council that the Trinity House men, the ship carpenters, Thames watermen and Mint men, claimed exemption from all land service on the ground that "this privilege has been theirs in common with all seamen from time immemorial." At one time the military service demanded ashore appears to have been considered quite as much a hardship, if not more so than the service required afloat.

The days of Queen Elizabeth witnessed a great change in the character of the seamen, the bulk of whom, instead of being, as hitherto, drawn from coasting craft, or the fishermen and boatmen classes, were then really deep-sea sailors. The lists of those times give $\mathrm{I}, 500$ seamen, 2,300 fishermen, and 500 wherrymen as liable to be called upon to serve.

All merchant-ships then went armed for their own protection; consequently there was not a wide difference between the duties required of the crew of a war vessel 
and a merchant-man-especially as the latter frequently combined the professions of privateer or pirate-and the training was essentially the same. The deep-sea sailor was therefore a fighting man, and as a rule his ship could do some fighting at a pinch. The officers in the hired merchant-ships employed against the Armada claimed that their vessels did quite a fair share of the work. At this time, in spite of the bad treatment of the crews, there does not appear to have been any scarcity of men, and the "Press," as it is commonly understood, does not appear to have been in vogue.

It may be explained here, that the "Press" does not derive its name from the violence used by the "Pressgang," but from the "prest " or "imprest" money paid to the man on entry as an earnest of his wages on enlisting in the king's service. In addition to the "prest" money, which in amount was similar to that paid the military recruit, conduct money was paid, and thus the system might be, and was at times, most expensive and wasteful. In 1624 an estimate was drawn up of the expenses for fitting out a fleet of twelve men-of-war ; 3,000 men were required, of which number the river (Thames) was to supply 800 at "prest and conduct money" of $2 s$. $6 d$. per man, the remaining 2,200 being obtained from "remote places" at a cost of $8 s$. per man. When again discharged at the termination of the commission, the river men were to receive I $s$. each, and those from the country districts Is. "conduct money" to carry them home again.

But although in Elizabeth's reign there was no great difficulty experienced in obtaining men when wanted by "prest warrants," or warrants for paying "prest " money, it was very different in the time of James I., when we are told that the men "go with as great a grudging to serve 
in his majesty's ships as if it were to be slaves in the galleys;" and in the next reign, "they run away as fast as we send them down." In several ways this change is to be accounted for, but primarily it was undoubtedly caused by the dearth of seamen, owing to the decrease of commerce, the decay of the fishing industry, and the lack of mercantile enterprise.

Towards the end of the reign of James I. the merchantships dare scarcely sail because of the freebooters in the Channel, and Algerine rovers were actually known to raid ships in the Thames. Such seamen as there were, found employment under the pirates, privateers, and adventurers of the time, in whose service they probably experienced treatment very little better than that of the "Navy Royall;" indeed, the living may have been in some respects worse, but this was quite compensated for in their eyes by the liberty to plunder. ${ }^{1}$

The nature of the change is shown by the regulations and usage as to the employment of soldiers afloat. It had been customary to carry these in the proportion of one-third of the complement, but, in I6I9, in the report of a commission, we find it stated: "till the year 's soldiers and mariners were thus usually divided, but later experience hath taught us, instead of fresh-water soldiers (as they call them) to employ only seamen." But the dearth of mariners did not allow of this practice long, for in 1625 , at the time of the Cadiz expedition, soldiers were again embarked as part complement of the ships. ${ }^{2}$

1 See Boteler and Manwaring.

2 The miserable story of neglect and mismanagement at this period may be read in Mr. Oppenheim's papers in the "English Historical Review." I cannot do more than refer to it here. 
Pay was at this date increased from IOS. to I4s. per month, and then to I 5 s., subject to a deduction of $6 d$. for the Chatham Chest, $4 d$. for the preacher, and $2 d$. for the barber-chirurgeon. But this was merely nominal pay, and the scarcity of provisions was so great that the men were reduced to stealing the soldiers' arms and selling them for bread.

Át the same time the merchants were paying 30 s. a month, so that it is not surprising if they got the pick of the trained seamen. In 1627 , when the fleet was preparing for the disastrous expedition to the Isle of Rhé, a body of seamen marched to London to ask for food and pay, and the "prest" men at Plymouth seized the Guildhall, and there prepared to stand a siege. A letter from Sir Ferdinand Gorges to the Duke of Buckingham gives details of the grievances of the seamen:-

"They say they are used like dogs, forced to keep aboard without being suffered to come ashore to refresh themselves. They have not means to put clothes on their backs to defend themselves from cold, nor to keep them in health, much less to relieve their poor wives and children. When they fall sick they have not any allowance of fresh victuals to comfort them, or medicines to help recover them. That some of their sick fellows being put ashore in houses erected for them are suffered to perish for want of being looked unto, their toes and feet rotting from their bodies, and so smelling that none are able to come into the rooms where they are. That some provisions put aboard them are neither fit nor wholesome for men to live on. That therefore they had as lief be hanged as dealt with as they are."

At this time the principal business of raising men rested with the Trinity House, and the officers of the 
Corporation were hard pressed for expedients by which to get together sufficient. They had already, and with some success, petitioned for an increase of pay to the men, but in 1628 , when ordered to find 300 men and twelve masters, they resorted to a curious method. All owners of ships were ordered to furnish a list of the names of the seamen in their vessels to the Master of the Trinity House, and then the names were entered in a book. The next day a drum was beaten at a rendezvous on Tower Hill, and here all the seamen were expected to resort, when such as were chosen received "prest and conduct money" and were shipped off to the fleet.

The system appears to have been successful, in a measure, but its result was to be seen shortly afterwards, when Io,000 tons of shipping were lying idle in the river, and the scarcity of men was worse than ever. The seamen naturally betook themselves to the service of foreigners, and a writer of the time laments that English mariners, formerly renowned for patience and endurance, were now physically weak, impatient, and mutinous.

With the advent of Cromwell came better times. The sailor of the Commonwealth received good victuals, his wages were raised to I9s. a month, and they were counted from the date of joining, instead of the date of sailing. The "prest" warrants were still needed, but we read also of much voluntary enlistment. Of course the seamen were on the side of such liberal paymasters, and throughout the time of the Commonwealth there was but one mutiny, and that was not caused by a difference about pay or provisions. It was an officers' mutiny, and was due to a disagreement between the naval men and the soldiers, who they considered were being improperly placed over them. A number of ships 
went over from the Parliament side to that of the king, but no sooner did their crews find out what a difference it made to their pockets than most of them came back again and brought the vessels with them.

The difficulties in providing men at this time have a very simple explanation; they were due to the inelastic nature of the marine force, and its insufficiency to provide a reserve adequate to the expansion of the fighting Navy from a peace to a war footing. In 1628 the roll call showed that the entire resources of the countrywere about 16,000 men all told; the drain after this was continuous, and therefore when, in 1653 , the numbers required for the fleet were more than 16,000 , it was only to be expected that trouble would be found in raising them. Added to which the Navigation Acts had just been passed, and while not yet bearing due fruit, had increased the advantages presented by service with the merchants. The Trinity House did its utmost, pressing at one time thirty ships with full crews into the service, and at another supplying 600 men, when the "prest" men raised by the Watermen's Company ran away and hid themselves. When also the mutiny occurred in 1648 the Trinity House reported upon it, and eighty "well affected "s seamen offered their services to Parliament to reduce the revolted ships.

The part the seamen played in the troublous times previous to the execution of Charles I. is very interesting and instructive, but it can hardly be dealt with at adequate length here. ${ }^{1}$ I may, however, refer to that curious document, "The Seamen's Protestation."

In the winter of $\mathrm{I}_{4} \mathrm{I}-42$, after the king had entered

'See Mr. Oppenheim's papers already referred to, and Granville Penn's "Life of Sir William Penn," vol. i., pp. 259, 26I, 267, 273. 
the House of Commons and endeavoured to arrest certain of its members on a charge of high treason, a number of the sea captains and mariners went by river to Westminster to offer their services, and some of them were called into the House and thanked for their offer. Afterwards it appeared to them that their conduct was open to misconstruction, and they thereupon set forth their views in a document which was printed and made public. They explain that they came "above bridge" in order to protest against the act of the king, which they understood to mean that the House was to be dissolved, and remembering the words of Archbishop Cranmer, "Wo be to England when there is no more Parliament," they desired to enter their protest. Then they go on to say, "We, who are always abroad, can best tell, no government upon earth is comparable to it ; especially for keeping a crown upon a king's head; for the procuration of the subjects' loyaltie, and unfeigned fidelity to their monarch ; for the flourishing of traffique and merchandizing (this kingdom's right hand): the continuation of all which is, was, and must necessarily be by parliaments. . . . In vain it is for us to keep the narrow seas, if some go the way to lose the land. ... Be pleased to understand; although we have no churches, we say our prayers as well as you: and the same God you have at shore is ours at sea: whom we will serve, although not so decentlie as we would, being for the most part of our daies restrained from a church, to dwell upon the seas for your better securitie. For, be it well known, your safety consists in ours; your churches, aye and your houses too, would quickly fall and be in the dust, should we let pass those who long to prey upon your lives and fortunes. But, for our 
religion, king, and country, we do, and will, advance our colours against the world. And for confirmation to you all of our true hearts, we have all protested in this manner. ' $\mathrm{I}$, - do protest before Almighty God, to maintain, with my dearest life and blood, the protestant religion as it was established in the days of Queen Elizabeth: to acknowledge Charles, by the grace of God, King of England, Scotland, and Ireland : to stand - for the privileges of parliament : utterly from my heart to abhor all poperie, and popish innovation. So help me God." "'

So far as I understand it, these were the principles that guided the sailors throughout that great juncture in our nation's history, and that they reflect the greatest honour on the seafaring population is not to be gainsaid. Once more the sailors spoke out, when in 1648 they sent a petition to Parliament, praying that "all monopolies and restraint of trade may be removed; and some way taken to prevent shipping of goods in foreign bottoms; to the end that trade again may be restored, and the glory of the nation preserved." This was followed by the passing of the famous Navigation Laws of $165 \mathrm{I}$, which were not repealed for 200 years.

The Act passed in $165 \mathrm{I}$ was amended twice in the reign of Charles II. and once in the reign of George III. but the principle was not altered. The object to be attained was the increase of English shipping, and sea-

1 In the concluding words of this protestation, of which only a part is printed above, there occurs a passage which probably was known to the late Poet Laureate. "Now what remains, but that on our knees we send up our prayers to that great PILoT of heaven and earth, who steers the world with his finger, that he would protect and defend her, to his own glory and our comfort." 
men, and with this end in view it was ordered that no commodities, colonial or of any other description, could be imported into England, unless in vessels solely owned, and commanded, and chiefly manned by English subjects. There were some exceptions made to this rule, as, for instance, that goods produced in a European state might be imported, thence into England by ships owned, commanded, and manned by subjects of that state. In nearly every case, however, the exceptions were coupled with heavy duties and restrictions.

The first result of the law was war with the Dutch, who were deprived of the carrying trade with our colonies, and of the important advantages derived from the importation of fish into this country. What, however, is more to the point in this connection is, that the nursery of British seamen was thereby increased, and never afterwards failed, in spite of the enormous demands which, as I shall show, were made upon it. By the second Navigation Act of the reign of Charles II. British ships and British seamen were defined, the latter being "such as are natural born subjects of the Empire, or naturalized by Act of Parliament, or made denizens, or become subjects by conquest." By the Act of George III. this was extended so as to include "foreign seamen, who shall serve three years in the British Navy, during the time of war, if they have not taken the oath of allegiance to a foreign state."

When the Navigation Acts were repealed in $185 \mathrm{I}$, it was at first thought that a death-blow had been struck at the sources from which we had been in the habit of drawing our supplies of seamen. It is however to be remembered that the conditions have materially altered; then the merchant sailor was also a gunner, and the 
principal difference between the two services was to be found in their discipline; now the man-of-war's man must be highly trained to be efficient, and the mercantile marine can only supply the rough material to be worked into shape. This experience and training must be given in peace time, and therefore it is that Admiral of the Fleet Sir Geoffrey Hornby and other naval officers have suggested reversing the old order of things, and making the Navy the nursery for the merchant service by passing a great number of its officers and men through a war-ship training. The policy and system of the Royal Naval Reserve is in this direction, but as yet only tentatively and on a small scale.

I trust that the above digression will be pardoned, but it appeared naturally to find a place here, and I will now return to the seventeenth century.

Directly after the Restoration, when all the old evils returned in full force, the trouble about men recurred, mainly because, as a consequence of their treatment, the seamen took service abroad under more favourable conditions.

Pepys, under date March 27th, I662, notes: "We settled to pay the Guernsey, a-small ship, but come to a great deal of money, it having been unpaid ever since before the King came in; by which means not only the King pays wages while the ship has lain still, but the poor men have, most of them, been forced to borrow all the money due for their wages before they receive it, and that at a dear rate, God knows, so that many of them had very little to receive at the table, which grieved me to see it."

It is characteristic of the period that his grief should not be of long duration, for the very next entry in the 
diary is, "to dinner, very merry." The "imprest warrants" were out now all over the country, and in the Fleming papers are appeals from the magistrates of Cumberland and Westmoreland, to be allowed to impress "other able persons" so as not to denude the former county of all its seamen and so ruin its sea traffic.

The number of seamen to be carried by each vessel was now established on an authoritative basis, this having previously varied, sometimes being graduated on the tonnage of the ship, and at others being fixed apparently by the admiral or captain acting in conjunction with the authorities. In I666 the complements were increased somewhat for the higher rates; and in the following year the custom already obtaining of fining men for absence during the time the ship was fitting out, was made law. Two shillings and sixpence was to be deducted from their pay for each day's absence, and these fines were to be distributed among those who remained at their duty.

From the reign of Charles II. onward the complements of ships were formed of seamen, landsmen (although the rate was not authorized), and marines or land soldiers serving as marines. In 1664, an Order in Council authorized the raising of 1,200 soldiers to be formed into a regiment for service aboard the fleet, and this was the commencement of the Marine Corps. ${ }^{1}$ In 1672, the year of the battle of Solebay, we are told that "many poor prisoners [for debt] in London have petitioned lis Majesty, considering what they lie for is small and inconsiderable, to allow them to spend

'See Major Edye's "History of the Marine Forces, I664-I7or." Harrison, London, I893. 
the rest of their lives in his service at sea." As the request was granted we are justified in believing that the services of sturdy landsmen were not refused when they were to be obtained, and that most probably the authorities charged with the execution of the "prest warrants" had ceased to be particular about the previous sea experience of those they "arrested" for the king's service.

At this period the prest money was a shilling, and conduct money one penny a mile. A bounty appears to have been offered for the first time in 1672 ; six weeks' pay to all entering as volunteers in first or second-rates, and one month's pay to those joining third-rates. A news-letter speaks of many volunteers coming forward in consequence, eighty in Hull alone. It is interesting to note here that the number of men required for the Navy, which we saw in 1653 to be I6,000 men, had increased in 1658 to be 21,910 , and now, in 1688 , to be 42,000 . That the men did not always go willingly is demonstrated by the announcement in a news-letter of October I9th, I682: "Fifty pressed men being sent down the river in a hoy, under charge of a file of musketeers, threw them overboard and escaped."

The system of the "imprest" service was now in full working, and continued with very little alteration up to the end of the great war. Every mariner was liable to serve when called out ; if he came forward at once, well and good, if he did not, then he could be "arrested" and forced aboard the ships. The persons warranted to press, generally a "gang" of seamen under the command of a commissioned officer, although pressgangs were frequently in charge of masters' mates, boatswains, and even midshipmen, were distinctly ordered 
only to press seamen, but they were not very particular, and as a rule all were fish that came into the net.

They were also charged not to take money for exemption or exchanges, but this was another regulation which does not appear to have been very strictly followed. Landsmen or those properly exempt, if pressed against their inclination, had their remedy at common law, and in later times sometimes obtained damages, but it was not often that the poor man could take this course. However, from this cause there arose in the Navy a class of men the origin of whose designation has puzzled many writers. These were the "state-the-case" men, those who believed that they had been pressed illegally, and on the outside of whose letters of complaint was marked "State the case." With the majority of them it is probable that this is as far as the matter ever went.

A letter from Admirals Killigrew, Delaval, and Shovell, relating to the working of the press, may be mentioned here. It is dated on board the Royal Sovereign, at Blackstakes, in the Medway, January, I693, and addressed to Colonel Thomas Hopson, on board the St. Michael, acquainting that officer, "That all seafaring men are liable to be prest; and those that actually belong to any ships in the fleet are to be returned to those ships. They are to be ticketed, and not entered to remain with the officer that pressed them. That all officers who send men to the press shall give them tickets, No. I to I5, expressing in their tickets what press-gang they belong to. That all men belonging to any ships of their majesties that are pressed or detained on board other ships, be immediately returned to their proper ships, and if found on board merchant- 
men to be taken out of such merchant-men and returned to their proper ships. That no tickets-of-leave be given after the 5 th of February, except to the press-gang. That all captains give their officers, that go pressing, orders to receive all volunteers, or any other men that

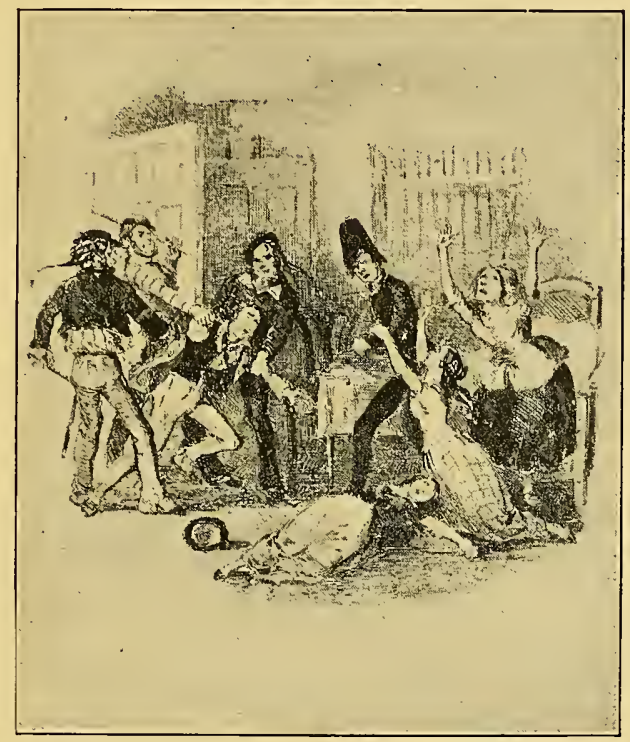

A PRESS-GANG AT WORK. CIRCA I8I4.

(H. K. Browne.)

are willing to enter the service, and give them a passage on board to the ship they enter or design for. That all sick men who have been put ashore since the igth of May, do return to the ships they then belonged to."

In 1696 an Act was passed establishing a register for 30,000 seamen, to be in readiness at all times for 
supplying the Royal Navy ; they were to have a bounty or retaining fee of $40 s$. yearly. This does not appear to have worked, and a similar bill brought in, in 1748 , was defeated by the shipowners, who feared that it would interfere with manning their ships.

In 1705 the vote was for 40,000 men, including marines, and in the same year several Acts were passed, having for their purpose the better manning of the fleet. Justices of the peace and other civil magistrates were empowered to search after seamen, and when found deliver them up to the press-gangs; penalties were laid for concealment of seamen, rewards to those who would discover and help to arrest them, including the miembers of the press-gangs themselves, who thus had now a direct interest in ferreting out and seizing those whom it is not wide of the mark to call their prey. Conduct money was allowed as before, and the entry of landsmen was authorized.

It was in this year that an Act was passed to allow seamen turned over from one ship to another to receive the wages due on a former ship. This law gave rise to a disgraceful state of things; for although the men received their tickets, they were not allowed to go on shore to spend the money. Instead of that, so long as the ship was in harbour, the men's "wives" were allowed to come on board, accompanied by traffickers in every kind of commodity which might be supposed to possess an attraction to the poor fellows in their enforced confinement. With them also came the "Jews," who made advances on the sailors' tickets at exorbitant rates of discount. The women were searched to prevent their smuggling liquor on board, but it found its way between decks nevertheless; and thus, while in port, the ship 
presented more often than not a continual scene of riot and disorder, drunkenness and debauchery. ${ }^{1}$

From I7I3, when the Treaty of Utrecht was signed, until I734, when war with Spain again threatened, the number of seamen voted for the service of the Navy stood, as a rule, at from 8,000 to 10,000 , an increase of only 3,000 being made in I7I8, when Sir George Byng was operating in the Mediterranean. In I733-34 the number jumped from 7,000 to 20,000 , and extraordinary measures became necessary to obtain the increase. A proclamation was issued, recalling all British seamen from the service of foreign powers, and offering a bounty of 20 s. for able seamen, and I5s. for landsmen. Press warrants were also issued, and these measures appear to have had the desired effect, for formidable fleets were despatched to sea. The next year Parliament voted 30,000 men with further

1 See a pamphlet entitled "Statement of certain Immoral Practices prevailing in His Majesty's Navy, 1822." The custom of carrying a certain number of the seamen's wives to sea appears to have prevailed all through the eighteenth century. See for example "Captain Opie's appeal against the illegal proceedings of ViceAdmiral Mathews," published 1745. There are also many well authenticated cases of women going to sea dressed as men. St. Vincent and the captains trained under him were the first to set their faces against the custom of carrying women to sea, and Nelson and Collingwood would not have them in their ships. But according to Marryat, Barker, Chamier, and others, the practice continued to exist, more or less, until the peace in 1817 . Until at some date subsequent to the Russian war captains often took their wives to sea with them (see Dr. Moore's "Post Captain, or Wooden Walls well Manned"), and even after the order was issued prohibiting the practice, it was not unusual for officers to evade it by getting another captain to give their wives a passage. This was done as late as I869. 
gradual increases in the ensuing years, until, in I74I, the number stood at 40,000.

However, that some difficulty was experienced about this time is evident, for several steps were taken which were evidently intended to aid in raising men. Merchant seamen, maimed, wounded, or disabled, while fighting in the king's service, were granted admission to Greenwich Hospital in 1735 ; an embargo was laid on all shipping in Great Britain and Ireland in I739, the year Vernon captured Porto Bello; and in 1740 several Acts were passed for the better supply of seamen, including one which exempted from impress seamen over fifty, or under eighteen, sea-apprentices for the first three years, and persons of any age for the first two years of being at sea.

In I742, a bounty of $£ 5$ was offered to able seamen, and $£ 3$ to ordinary seamen, while the widows of men killed in the service were promised a year's pay of their deceased husbands. At this time, also, pay in the merchant service was regulated at $E_{\mathrm{I}} \mathrm{I}_{5} \mathrm{~s}$. a month. This was striking at one of the chief causes which hindered the obtaining of men. Captain St. Lo, who has already been quoted, had pointed out years before, that while the man-of-war's man only received $£$ I $3 s$. a month, the merchant-man was earning $£ 2$ IOs. or $£_{3}$ a month, and in some trades even more. It was true that the merchant seaman, when returning from a voyage was liable to be "prest " just as he got into port, or even before he arrived there, but the pressing officer had power to make the master of the ship pay these men their wages, and as a rule the merchant seaman was more sure of his pay than the man-of-war's man. To limit the pay of the men in the merchant service seemed to be 
a clever, if hardly a justifiable move, but I have been nowhere able to find whether it worked as was wished and intended.

In I 755 , the vote was for I 2,000 seamen, but the next year, in consequence of the imminence of war with France, it sprang from this number to 50,000 , including 9, I 38 marines, this corps being now organized on a permanent footing. In 1757 it was increased to 55,000 men, in $1758-59$ to 60,000 , and in 1760 to 70,000 .

These enormous increases in the number of seamen required for the service of the fleet, although small in comparison to what was to come, could not be accomplished without strenuous exertions. The bounty no doubt attracted some men, but not as many as were wanted, and recourse was had, as usual, to the press. The method was to send to every important seaport town a "regulating officer, generally a post-captain, who chose certain rendezvous, usually a public-house, which he made his headquarters. From this place he despatched his gangs, under subordinate officers, to ransack the neighbouring country for seamen. The men raised or arrested received their shilling, and the gang got their "head" money. As it was to the interest of the latter to make as much as they could, they frequently pressed men who were not seamen, but at the same time there is no question that the proportion of the latter class was largely in excess of the other. It was reserved for a later date to man the fleet with the scum of the population.

Mr. Hannay ${ }^{1}$ tells how Rodney, when captain of the Prince George, in 1755 , went to work. One of his officers,

1 "Rodney," Men of Action series. 
" a Lieutenant Allon, was sent to London to set up a rendezvous, under the direction of the regulating captain, probably in the neighbourhood of Limehouse or Wapping. From this centre of activity the lieutenant went to work, recruiting men freely when he could, or laying hands on them in the fashion described in 'Roderick Random.' Lieutenant Allon's requests for more 'imprest' money were frequent, and were regularly answered with remittances. When he had secured a haul of men he sent them round by tenders to Portsmouth." Mr. Hannay notices that in this way it came about that Captain Cook was secured for the Navy, for in order to escape the "hot press on the river" the long-headed Yorkshireman decided that he had better go quietly, get the bounty, and likewise secure a chance of promotion.

But it was not only on shore that the press was at work, as may be seen by the following order, quoted by Mr. Hannay, and addressed by Rodney to Lieutenant Richard Bickerton: "You are hereby required and directed to proceed on board the Frederick and William tender, taking with you forty men from His Majesty's ship under my command, and immediately proceed to the eastward of the Island of Wight, and cruise for eight days between that island and Beachy Head, using your best endeavours to impress and otherwise procure all such seamen as you possibly can for His Majesty's service."

One hundred years previously Blake had issued an order that no more men were to be impressed from outward-bound merchant-men, "such a practice being of very much prejudice to the trade and shipping of the kingdom." But this was no time to think about lesser evils of the kind, and both outward and home- 
ward-bound ships were placed under contribution when men were wanted for the fleets of Boscawen and Byng.

Sometimes the homeward-bounders did not like it at all, and in one case reported by Rodney to Sir Edward Hawke, the crew of a merchant-ship, the Britannia, refused to lay to at the summons, and actually fired into her majesty's tender, whereupon the press-gang boarded the Britannia, and in the scrimmage three of her crew were killed. Rodney asks for instructions, and gets for answer:-Lose no time in putting on board the Britannia sufficient men to navigate her in safety to her moorings in the Thames, "directing them as soon as they get without St. Helens, to throw the dead bodies overboard. For which this shall be your order."

Here was evidently no very uncommon occurrence; it would have been better, no doubt, to have three more men living to serve the king; as it was, heave them overboard, and there was an end of it. That the business was demoralizing there is no question, but it was the law of necessity, and the naval officer had to do his duty. This is how it was regarded both by the hunter and the hunted, and it does not appear that any bad blood was bred.

In I 763 peace was proclaimed, and then the accounts for the war were made up, from which it appeared that out of a total of $183,893,1,5 \mathrm{I} 2$ had been killed in action or by accident, and 133,708 had died by sickness or were missing, leaving a balance of 49,673, of whom all but $\mathrm{I} 6,000$ were paid off. That item, " died by sickness or missing," is a curious one, and some light is thrown on it by a petition presented to the king this year by some hundreds of sailors, requesting to have their R's taken off. The desertions during the war were 
enormous. However, his majesty was pleased to grant the request to all those men who should appear by the books at the Navy Office to have entered the service again subsequently to their running.

From 1765 to 1770 , the number remained stationary, and then, on account of anticipated war with Spain in reference to the Falkland Islands, it rose from I 6,000 to 40,000 . Press warrants were issued and rendezvous opened, while in addition to a bounty of $£ 2$ offered by the king, the following cities and towns voluntarily offered to pay :-London, $£_{2}$; Bristol, $£ \mathrm{I}$; Montrose and Edinburgh, $£_{2} 2 s$. to able, and $£$ I Is. to ordinary seamen; Aberdeen, $£ \mathrm{I}$ I $s$. to able, and I $5 s$. to ordinary seamen; and Lynn offered $£ \mathrm{I}$ I $s$. to able seamen.

In the following year the questions at issue were supposed to be settled, and reduction took place, but in I773 a similar scare occurred, only to have a similar result. In 1775, when affairs began to wear a serious aspect in America, an increase of the fleet became necessary, and from 20,000 in that year, the number of men voted annually until the peace, was as follows :I 776, 28,000 ; I 777, 45,000 ; I 778, 60,000 ; I 779, 70,000 ; I $780,85,000 ;$ I $78 \mathrm{I}, 90,000 ;$ I 782 , I00,000 ; I 783 , I IO,OOO.

It is obvious that as the proportion of seamen to landsmen carried by the ships was large, the greater part of the men raised at this time must have come from the merchant navy, or at least have had some previous experience at sea. This view is, in a sense, corroborated by the literature of the period we are dealing with. 'There are many references to the hasty, harsh, and even brutal methods of the press-gang, but it is seldom that complaint is made against the system of impressment, 



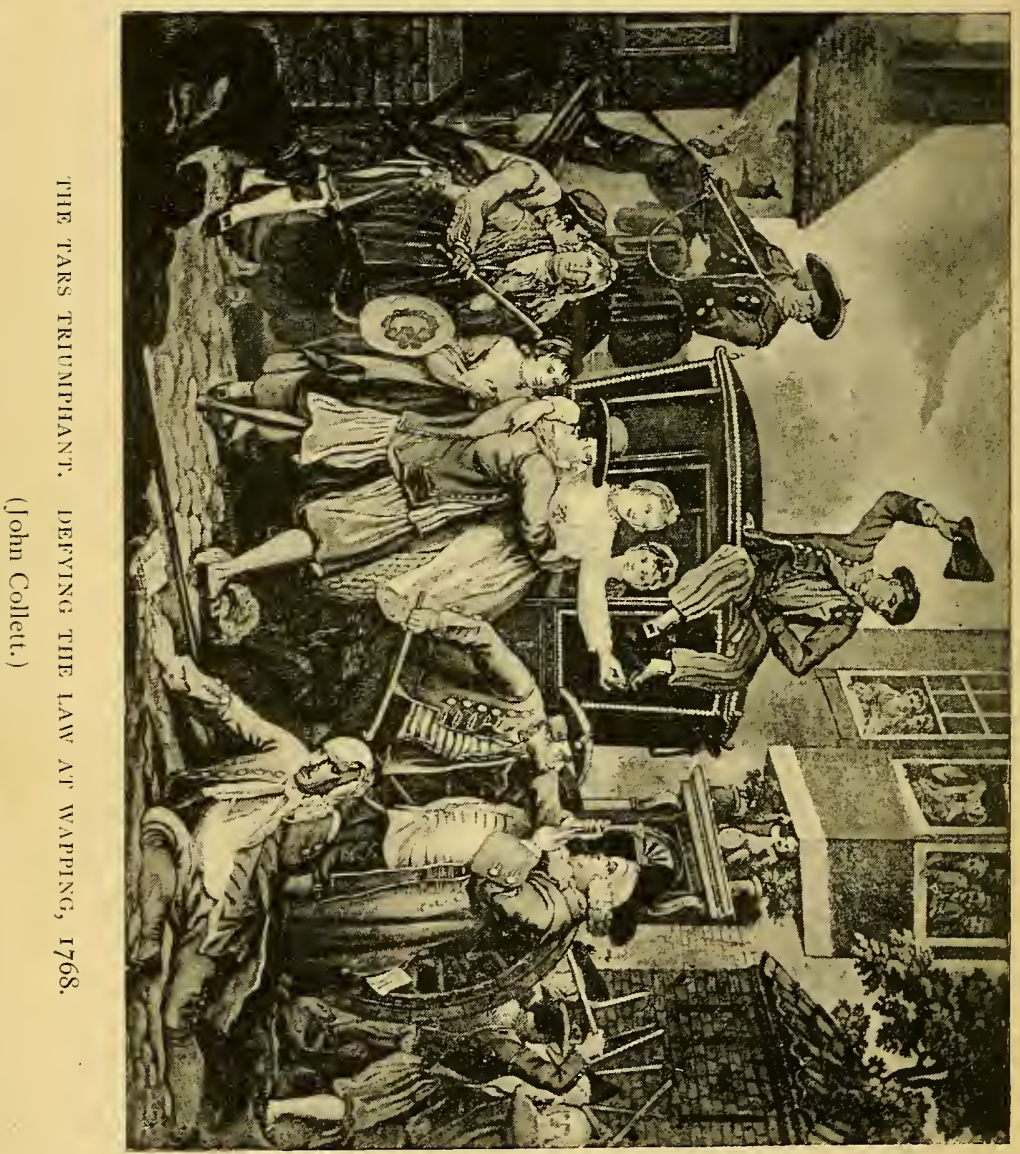


nor is it even a subject of grievance that persons were often illegally pressed.

Those who, like a writer in the "Oxford Magazine" in I 770, advocated the substitution of an enlarged bounty for the impress, appear neither to have studied Jack himself, nor the subject thoroughly. There is evidence that the seaman, as a rule, was not to be allured by any bounty, however large-which, it must be remembered, he would not get the chance to spend ashore-and that the alternative, liberty, so long as he possessed a dollar, and could evade his pursuers, was much more to his choice. Up to the end of this war the fleet had been manned almost entirely by impressment; and, while there is never a word in history to show that the men thus raised did not do their duty well in the face of an enemy, there is no record of such incidents as, in the Hermione, Renommée, and other ships of later days, make black pages in our annals. That the system, carried out as it was in a rough and ready way, bore with many hardships on the individual, there is no question, but at the time it was recognized as a necessary evil, and assuredly the newer methods of manning the fleet invented to supplement it were not improvements, if they were more humane. Douglas Jerrold, in his story of "Jack Runnymede," most graphically explains how his hero, from having a holy horror of the system, experiences its hardships in his own person, and thus in the service get a better insight into the causes which had called it into existence. Returning home, "Pray, sir," said he to a Parliamentary candidate who solicited his support, "what are your views on impressment?" "I am opposed, most assuredly, to the infamous and inhuman system of pressing," was the reply. 
"My service to you, sir," replied Jack Runnymede, "you don't have my vote. What! sweep us from the world as a naval power, by doing away with impressment? No, sir, not while I can lift my voice, will I consent to this. By losing this I should cease to be grateful, as I am, for my country-should no longer bless my stars that I am a Briton-no longer thank God that I am an Englishman."

At the termination of the war there was a little trouble at Spithead, with the crews of some of the ships about the port at which they should be paid off. Portsmouth ships were ordered to Chatham, and in these the crews became very riotous. The men of the Raisonnable, indeed, refused to weigh anchor, until the ringleaders were seized by the officers, and three seamen afterwards suffered death for this affair. There was, however, no combination on this occasion, and the only grievance appears to have been in the matter of the port of paying off.

The number of men voted in I 784 was only 26,000 , so that more than 80,000 men were paid off and sent adrift at this time. The number was still further reduced in the following year, and did not rise again until 1790 , as a consequence of what is called the Spanish armament. The next year came the Russian armament, when bounties were offered, but, before a fleet could be assembled, the differences between the courts were adjusted, and the numbers reduced again.

In 1792 the vote was for 16,000 men, but towards the end of the same year, when the vote was taken for 1793 , the number was raised to 45,000 . In February the National Convention of France declared war, and for I794, the year of Lord Howe's victory, the number was 
85,000 . Then it continued to rise until when the treaty of peace was signed in 1802 it stood at 135,000 , higher than it had ever been before.

The difficulty in the way of raising seamen had now been increased by the fact that the Americans owned a mercantile navy. This fleet, as well as our own mercantile marine, entered into the competition for the services of the men. Moreover, the discipline of the Navy had undergone a change, and not for the better. During the extraordinary efforts made to bring together great fleets towards the end of the American War of Independence there had not been much time to select and choose the most suitable officers, and many masters and mates of merchant-ships were given lieutenants' commissions. These men were often without education, unaccustomed to the exercise of power, unfitted to command themselves or others, and to their harsh and cruel behaviour we may attribute, at least in some measure, certain of the mutinies which occurred in the last decade of the eighteenth century, Secondly, during the ten years of peace which followed. there was a relaxation of discipline, and under the more stringent conditions necessitated by war and an influx of curious characters, all the men felt the curb and were ripe subjects for evil counsel. But it was to the entirely novel class of men now entered that the troubles owed their development, perhaps not even excepting that which we have spoken of as "the Breeze at Spithead."

It was well understood in 1793 that the demand for men would be great, and that the supply had for the reasons above-named become more restricted and capricious, so that we find the City of London at once offer- 
ing encouragement to the entry of volunteers. This was in addition to the bounty offered by the king, which, as usual, accompanied the issue of the press warrants. But enlistment was a slow and uncertain method, impressment a speedy and sure one, so a receiving ship, the Tower tender, was once again stationed in the river, and by the Navy List we find that in I 794 three flag officers, twenty-nine captains, and fifty-four lieutenants were engaged in the impress service. This year, too, it became apparent that the inducements held out to volunteers were insufficient to tempt them, and London raised its bounty for able seamen from $£ 2$ to $£$ IO Ios., for ordinaries from $£ \mathrm{I}$ to $£ 88 s$., landsmen were offered $£ 66 s$., and boys, now first entered as a rating, from $£$ I Is. to $£ 22 s$.

But impressment and bounty together were not enough to get together the men that were required, and in March, 1795, an Act was passed for raising a certain number of men in each county for the service of the Navy. The number was roughly proportioned to the population, Yorkshire having to provide $\mathrm{I}, 08 \mathrm{I}$, Lancashire 589, London I98, down to Radnor with 26, and Rutland with 23. In April this Act was supplemented by another, by which each port had to supply its "quota" of men, Newcastle finding I,240, Bristol 666, London 5,704, Liverpool I,7II, Mulhaven 700, and so on, some places having to find no more than Io. At the same time an embargo was placed upon all shipping, and every effort made to induce men to come forward, some of the counties offering as much as $£ 30$ a man to such as would voluntarily enter.

In the above Acts we have the origin of the "quotamen," the riff-raff of the counties and ne'er-do-weels of 
every class attracted by the high bounties. "These," says a writer in "Blackwood," "were landsmen, volunteers furnished by the several counties, and lured by enormous bounties-they were mostly better educated, too, than the regular hands, pen-and-ink gentry, unaccustomed to labour and restraint, and consequently prepared to find everything wrong. The celebrated chief, Parker, was a fellow of this stamp; contributed, we may add, by our 'gude town.' We are acquainted with a gentleman, still residing here, who was accidentally present when he was first brought before the sitting magistrate, charged with an intention to fly the country to defraud his landlady, to whom he owed about $£ \mathrm{I} O$. His address was so good, and pretensions so high, the magistrate at first scrupled to issue the warrant to detain him, although he had no bail to offer. But at length he was committed, accepted the high bounty to obtain his release, and just eighteen months afterwards hoisted his rebel flag at the Nore." On the same subject Captain Brenton, R.N., may be made to bear witness :- "The quota-bounty given in I795, I796, and $\mathrm{I} 797$, we conceive to have been the most ill-advised and fatal measure ever adopted by the Government for manning the fleet. The seamen who voluntarily entered in 1793 , and fought some of the most glorious of our battles, received the comparatively small bounty of $£ 5$. These brave fellows saw men, totally ignorant of the profession, the very refuse and outcasts of society, flying from justice and the vengeance of the law, come on board with bounty to the amount of $£ 70$. One of these objects, on coming on board a ship of war with $£ 70$ bounty, was seized by a boatswain's mate, who, holding him up with one hand by the waistband of his trousers, 
humorously exclaimed, 'Here's a fellow that cost a guinea a pound." "

A sailor thus describes the quota-men :-" Them were the chaps as played hell with the fleet; every grasscombing beggar as chose to bear up for the bounty had nothing to do but to dock the tails of his togs and take to the tender. They used to ship in shoals; they were drafted by forties and fifties to each ship in the fleet; they were hardly up the side, hardly mustered abaft, before there was, send for the barber, shave their pates, and send them for'ard to the head to be scrubbed and sluished from clue to earing, afore you could venture to berth 'em below. Then stand clear o' their shore-going rigs-every finger was fairly a fish-hook; neither chest, nor bed, nor blanket, nor bag, escaped their sleight-o'-hand thievery; they pluck you, aye, as clean as a poulterer, and bone your very eyebrows whilst staring you full in the face."

The manner in which criminals, sentenced in some cases to long terms of imprisonment, were almost invariably allowed as an alternative to volunteer for the Navy has often been described. As it was tersely put the other day :- " To country magistrates the arrival of a ship-of-war was often a great piece of luck. All the bad characters of the neighbourhood, loafers, poachers, footpads, possible murderers, men suspected of any crime, but against whom there was not sufficient evidence, were arrested and sent on board, with a note to the captain begging him to take measures to prevent their return; which, as such men were commonly stoutbuilt fellows enough, he was no ways loath to do. The gaol-birds from the town were unquestionably worse; worse physically, worse morally, and, perhaps, worse 
hygienically; they were not infrequently infected with gaol fever, and brought the infection to the fleet; they were largely the cause of the severe, even brutal discipline that ruled in the Navy towards the end of last century; and-added to the excessive amount of grog then established as the daily ration-gave rise to much trouble, crime, and mutiny.'

To the firmness and sagacity of Sir John Jervis, afterwards Lord St. Vincent, the restoration of discipline and the obedient spirit, so sadly shaken in 1797 , was due, in so far as the grand fleets were concerned. In the single ships and on foreign stations the mischief still existed, and every now and again broke out in succeeding years. But the usage of the time was unbendingly severe, and probably with crews which, although they comprised a large infusion of skilful seamen and reliable marines, were for the most part formed of only half-trained ordinaries or wholly untrained landsmen, this was necessary. Flogging was the remedy for all disorders with the majority of captains, not because they were unwilling to try any other, but because none other had proved effective, and it was not a time for experiments. Where the officers were skilful and energetic, and, above all, gentlemen, as they were in the vast majority of cases, they managed to get good results, even though the material they had to work upon was of the most unlikely, and the means to be employed not the best possible. That the efficiency of the Navy was at a high standard was due to the fact that, as Defoe says, "good officers presently made a good army," and when the exception is found to prove the rule, instead of attributing the fact to the troublesome element in the crew alone, it is as well to remember the Scotch 
proverb which says, "A bad shearer never has a good hook."

In I852 the system of continuous service was established, and when the war with Russia occurred, the value of this judicious step was felt. Seven thousand men had entered for the continuous service, and with volunteers and pensioners no trouble was experienced in obtaining the needed numbers, so that for the first time in our annals a war began without resource to bounty or impressment. Yet, curiously enough, the old feeling of the seamen still existed, for when those of Sunderland and Shields were asked to volunteer, some of the older ones replied: "We know we must go if really wanted. The unmarried ought to go at oncebut we, who are married, naturally wait for the impressment; and we know that always has been, and always will be, preceded by the proclamation of bounty." ${ }^{1}$

The war with Russia was not a naval war and the necessity for large fleets did not arise, so that the need was not severe, but here again, not taught in the least by experience, the authorities blundered. No sooner was peace proclaimed than 3,000 of the continuous service men were allowed to cancel their engagements, with this consequence, that when in 1857 it was announced that a convention had been arranged between the Russian and French emperors, the Admiralty were at their wits' end for men. Then resource was had to the old plan, and a bounty of $£ \mathrm{IO}$ was offered to able seamen and $£_{5}$ to ordinaries, and the natural grievance of the continuous service men had to be assuaged by giving them half these sums.

2 "The Life of Sir W. Parker." 


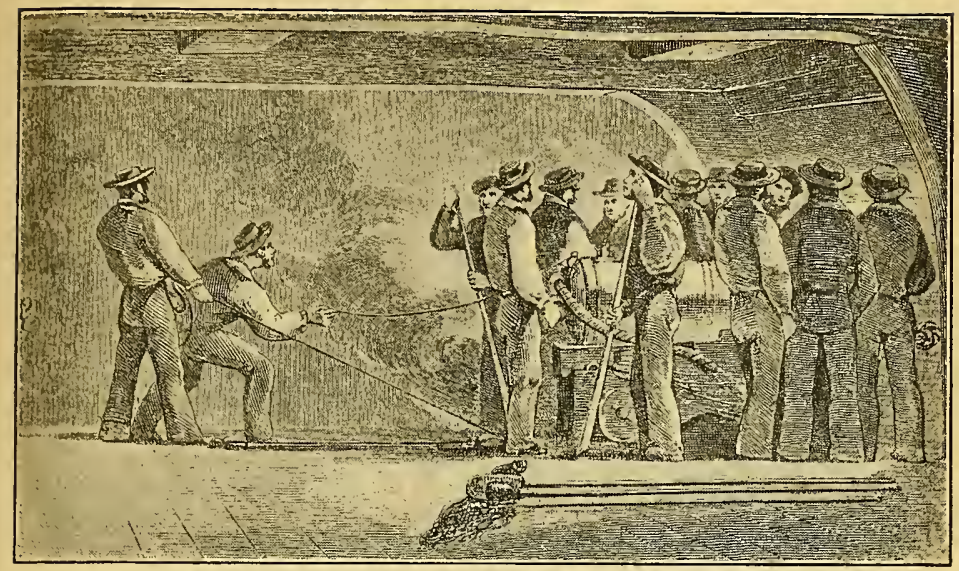

DRILL_ON BOARD THE GUNNERY SCHOOL, H.M.S. "EXCELLENT," PORTSMOUTH. CIRCA I860.

\section{CHAPTER V.}

OUR OFFICERS TO-DAY.

THE high qualities which would have sufficed to make an efficient naval officer in Nelson's time would no longer be sufficient, at supreme moments, in these days. Every step in mechanical invention as applied to ships of war, every new complexity, every added means of attack or power of defence, has added, little by little, to the burden borne by naval men, until, at length, to those placed in full command, the charge might well appear insupportable. "Have you ever stood within a conning tower?" asks Mr. H. O. Arnold-Forster in his 
graphic sketch of a naval engagement." "No; then you have never set foot in a spot where the spirit of man has borne the fiercest and direst stress to which the fell ingenuity of the modern world has learnt to subject it. You have not seen the place where the individual wages a twofold contest with the power of the tempest and the violence of the enemy; where, controlling with a touch and guiding with his will the gigantic forces of Nature, he stands alone in the presence of death, and asserts, amidst the awful crash of the mental and physical battle, the splendid majesty of the spirit of man."

Such is the ordeal that awaits the commander of every ship going into action against the enemy, and it is for this ordeal, for the stress of this supreme moment, that every individual executive officer in the British Navy strives to fit himself. Higher and more varied qualifications are therefore now demanded from each officer afloat than have ever been called for before. An inevitable result has followed. Much as, from some points of view, it may be regretted, specialism, which has been adopted in every branch of professional life, owing to the vastly greater field of knowledge that has been opened up, has necessarily been more widely introduced into the work of naval officers than was formerly the case, and we now find officers specially detailed for gunnery and torpedo, as well as for navigation duties. This, however, is but one of the many changes caused by the transformation of the material of naval war. The introduction of steam for the propulsion of war-ships added the engine-room complements to the personnel of the Navy, and, with the ever greater calls upon their

1 "In a Conning Tower, or how I took H.M.S. Majestic into Action." By H. O. Arnold-Forster. 
services, the superior grades of the engineering branch have won their way, through no little opposition, from a position of tolerance to commissioned rank and honourable recognition.

The lives of naval officers-like those of men on the lower deck-are now, in some respects, easier than they were of yore. There has been a general, if inadequate, increase of pay. Long periods of enforced inactivity are a thing of the past. Ships are more habitable, and it is possible to enjoy afloat many of the comforts of the shore. On the other hand, naval officers suffer under many difficuities, not the least of which is the stagnation in promotion. The number of lieutenants who see no chance of reaching the rank of commander on the active list is about one-half, and something certainly needs to be done to meet their case, and to remove a chief cause of discontent. There are grievances also in regard to long commissions of ships on foreign stations, without compensation to the officers when these are unhealthy; and the very inadequate allowance of leave is another active cause of dissatisfaction.

The duties of naval officers, in peace time, in drilling and training their crews to make use of the means at their disposal, and in navigating, handling and maintaining in efficiency the ships in which they serve, are many and complex. The naval officer is never idle. Constant supervision of the men under his charge, drill, gunnery practice, fleet manœuvring, the practical study of naval tactics-these are the things that principally occupy him. He may be engaged in the difficult work of hydrography, and may be sent away for long periods upon boat service. The command of various classes of vessels successively falls to him, and, with every step, 
his responsibilities grow. Rapid observation, swift mastery of circumstances, quickness of decision, initiative, readiness to act, the power of handling men, and of wielding complex matériel, willingness to accept responsibility, and yet unfailing obedience-these must be the executive officer's powers. The engineer officer, again, is responsible for huge and complicated machinery working at high pressure, for a crowd of auxiliary engines and electrical appliances for the distribution of power, and for the vital working of the ship. In him, therefore, must exist wide special knowledge, technical skill, unfailing endurance, and sustained power of work; else how should we be assured against mishaps and failures that would entail swift and inevitable disaster?

It may be asked if the British Navy is well provided with efficient officers. In relation to the vastness of its duties this can scarcely be said to be the case. During the Naval Mancuvres of I 893, for example, a number of torpedo-boats, which were lieutenant's commands, were sent to sea in the charge of sub-lieutenants. The dearth of lieutenants is, indeed, the crying example of the under-officering of our ships; but the whole question is too difficult and complex to be entered upon here. The development of the Royal Naval Reserve certainly constitutes a valuable step towards the officering and manning of the fleet, and there are now serving in many of Her Majesty's ships smart and capable officers of this service. But the training of the Reserve has not yet become wholly satisfactory, and it may be hoped, as I have said, that means will yet be found to make it more thorough and effective.

We may now consider, briefly. the channels through which the various superior branches of the service are 
now reached, the regulations in force in regard to them, the emoluments they offer, the pensions associated with them, and other like matters of practical interest to the service.

Executive Officers.-Appointments to naval cadetships are made by limited competition, with the exception of a few which are given to colonial gentlemen's sons, and to sons of naval and military officers. The examination takes place in June and December, physically at the Admiralty, and educationally by the Civil Service examiners, details of which will be found in the quarterly Navy List, or by application to the Secretary of the Admiralty. Good health and freedom from any physical defect is, of course, imperative, and the age is from $I_{3}$ to I4 years. The educational examination is divided into two parts, the "test" and "competitive."

The successful cadets are sent to the Britannia, the training establishment at Dartmouth, which consists of two wooden line-of-battle ships, which have been converted into comfortable quarters, with studies, model rooms, dormitories, etc.; and in close proximity on shore is a large cricket field and recreation ground, fives courts, tennis grounds, etc., where every sort of healthy recreation may be indulged in. In addition to this there is every description of rowing and sailing boat, into the art of handling which the cadets are practically and theoretically initiated. A boy's outfit for the Britannia may be put down at about $£ 40$.

During the two years' probation in the Britannia, naval cadets, in addition to their ordinary studies, are instructed in the first principles of seamanship, navigation and nautical astronomy. No pay is allowed to cadets in the Britannia, and during that period parents 
or guardians are required to pay $£ 75$ for each boy, and also such expenses for washing, repairing clothes and boots, hair cutting, pocket money, etc., as are incurred. Cadets are examined at the end of each term, and at the final examination are classified according to merit and conduct, when, in addition to valuable prizes, "time" may be gained, which reduces the period to be served before passing for midshipman by that amount, which varies from three to twelve months. On being drafted to sea-going ships naval cadets and midshipmen are detailed for minor duties under the commander and officer of the watch, such as charge of boats, mustering of "watch," heaving "log" at sea, etc., at the same time proceeding with their studies under the naval instructor in mathematics, trigonometry, mechanics, French ; in seamanship, gunnery and torpedo under a lieutenant; and in steam under the chief engineer. Examinations are held annually, and the boy's position, according to merit, is fixed.

Of course, midshipmen's duties are not of a very responsible nature, although, when in charge of men or boats, the lads' tact and presence of mind may be tried to a considerable extent, but when on board, their duties are carried out more or less under the officer of the watch or commander.

Naval cadets and midshipmen on leaving the Britannia become entitled to pay, the former at is. a day, the latter at $\mathrm{I} s .9 \mathrm{~d}$. a day, and the parents or guardians of boys are required to pay (half-yearly) in advance $£ 50$ per annum, which, with his pay, the boy receives monthly, and with it has to defray all his expenses for messing, servant, washing, etc.

Midshipmen having served four and a half years, and 
being 19 years of age, may pass for sub-lieutenants. This examination, the last required to be passed, is divided into five parts-seamanship, navigation, torpedo, gunnery and pilotage. In seamanship the examination is viv $\hat{a}$ voce, and is conducted by naval officers afloat, and, having passed, the midshipman buds into an acting sublieutenant and proceeds to the Naval College, Greenwich, where, after a period of training, he has to pass in navigation and pilotage. He then puts in about three months in the gunnery and torpedo establishment at Portsmouth, and, having passed, is confirmed as sublieutenant. A studious boy may now reap his reward, for promotion to lieutenant is awarded by the class of certificates obtained at these examinations; so that five first-class certificates promotes the sub-lieutenant after six months from the date of seniority in that grade, and so on down to twenty-seven months as sub-lieutenant, after which promotion is only by seniority. The pay of sub-lieutenants is $5 s$. a day.

The duties of a lieutenant are many and various. He has to be conversant with the general routine of the ship and drills, and all that may be comprised under the heads of seamanship, gunnery, small arms, torpedo, field gun, etc. In nearly all ships, except gunboats, lieutenants have charge of the watches, of a division of men, drill their quarters at the guns, and with rifles and cutlasses. A certain number are allowed to take up a subject as a specialty, such as gunnery, torpedo or navigation, and such officers as pass are generally appointed to ships for that particular duty. The pay of lieutenants commences at iOs. a day, and reaches I4s., but with allowances may be as much as $24 s$.

Lieutenants are promoted to commanders by selection 
twice a year, forty being promoted annually until the commanders' list reaches 270. After that number is reached promotion is governed by vacancies in the senior list. There are now 860 lieutenants, of whom about 40 are employed in the Coastguard, and, consequently, forego their chances of promotion, so that the proportion which may expect to reach the senior list is not large. The Coastguard offers a retreat for senior lieutenants, who get a more or less comfortable appointment on shore, in charge of a station and division of seamen who elect to finish their career in the Preventive Service. Lieutenants are also appointed in command of gunboats and small vessels; their pay in this case ranges from I $4 s .9 d$. to I $8 s .9 d$. a day. Lieutenants are compulsorily retired at the age of 45 , with a maximum of $£ 300$ a year.

Commanders are promoted from the lieutenants' list by the Lords Commissioners of the Admiralty, by selection. They are employed in command of sloops, and as second in command of our battle-ships and larger cruisers. In the first case the commander performs the ordinary duties and functions of a captain; in the second case he is responsible to the captain for the proper working of the routine, duties, and internal economy and cleanliness of the ship, and general supervision of the officers subordinate to him. Two years' service as commander is necessary to qualify a commander for the rank of captain, but the average length of service is five to six years. Commanders qualified in navigation are appointed to the larger ships as navigating officers. The pay is 20 s. a day, and there are various allowances for special duties.

Captains, as a rule, are unemployed for about three 
years after promotion, when they usually take the opportunity of going through a course of study at Greenwich, and of gunnery and torpedo at the respective establishments. From the time a captain is appointed to the command of a ship, until she is paid off, he is responsible that the Queen's Regulations and Admiralty Instructions are carried out in the various departments as therein laid down. A captain serves in that rank about sixteen years, but this may vary, as promotion to rearadmiral depends on vacancies occurring in the senior list. The full pay of a captain varies from $22 s .6 d$. a day, on promotion, to $45 s$., which is reached when within the first fifty on the list. Allowances, when in

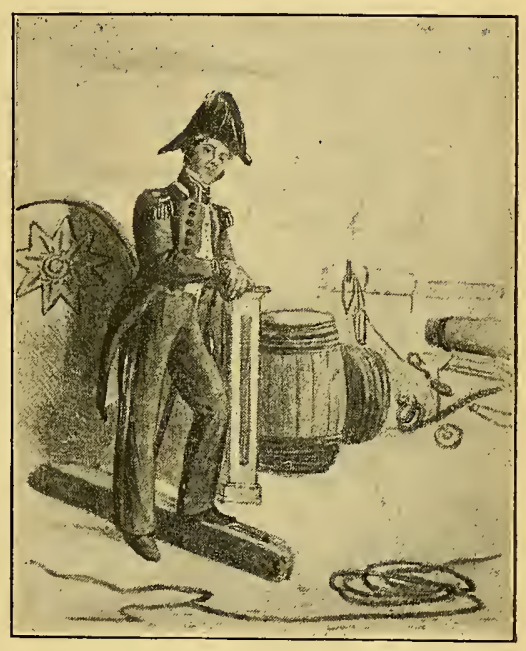

REAR-ADMIRAL, CIRCA I828-33. (Goni.) command of Her Majesty's ships, of from $7 s$. to I $8 s$. a day are given. Captains have the option of retiring at the age of 50 , but this is compulsory at the age of 55 . The retirement is $£ 600$ a year, depending on age and service.

The active list of flag-officers is composed of 35 rear* admirals, 20 vice-admirals, Io admirals, and 3 admirals of the fleet. The commands of our naval stations at 
home, and the commands of our flects at home and abroad, are intrusted to flag-officers, who are also appointed as superintendents of 'dockyards at home and abroad. The office of Lord High Admiral of the Fleet is executed by a Board of Commissioners, who are, as a rule with only two exceptions, flag-officers. The pay of flag-officers varies, according to appointment, from $£ 3$ to $£ 9$ Ios. a day, with retirement of from $£ 600$ to $£ 850$ a year. Rear-admirals rise to vice-admirals and admirals by seniority, but to admirals of the fleet by selection.

For an appointment as chaplain in the Royal Navy, the candidate must have been ordained a deacon and priest in the Church of England, or admitted into the same holy orders by the lawful authority of one of the churches within the realm of Great Britain and Ireland which are in communion with the Church of England; must not exceed the age of 35 years, nor hold any benefice with a cure of souls; must produce testimonials from the bishop of the diocese in which he was last licensed, and must be examined as directed by the Lords Commissioners of the Admiralty. The full pay is $22 \mathrm{~s}$. a day according to service, and retirement is optional at 55 years but compulsory at 60 years of age.

His duties are to conduct morning prayer daily, and on Sunday to perform Divine Service according to the liturgy of the Church of England; to administer the Holy Communion regularly; and to instruct in the principles of the Church of England all the boys in the ship and such young officers as the captain shall direct; to be assiduous in visiting the sick, and to give religious instruction to such men and boys as may voluntarily attend; and to supervise the naval schoolmaster in his duties. 
Naval instructors are entered between the ages of 20 and 35 years, and must pass an examination which will be found detailed in the quarterly Navy List. Candidates who have obtained a University distinction equivalent, at least, to a Senior Optime at Cambridge, a Second Class in the final Mathematical School at Oxford, or Junior Moderator in pure or mixed mathematics at Dublin, may be exempted from further examination except in Latin and French. Being found qualified the candidate then goes to the Royal Naval College, Greenwich, for six months' study, receiving $6 s$. a day during that period. $\mathrm{He}$ is then examined in navigation, nautical astronomy, nautical surveying, etc., etc., and if qualified is appointed a naval instructor. A chaplain on passing the necessary examination may combine the office of chaplain with naval instructor, receiving half the pay of naval instructor in addition to his own as chaplain. The duties of the naval instructor are confined to imparting instruction to the naval cadets and midshipmen placed under him, and preparing them for their various examinations and superintending their conduct while under instruction.

Engineer Officers.-For this branch of the service it is necessary to enter between the ages of 14 and 17 years, principally by means of competitive examination, a few nominations being the gift of the Admiralty. The examination is held simultaneously at some eight or nine principal towns in Great Britain by the Civil Service Commissioners in the month of April. Stammering or any imperfection of utterance is a decided disqualification at the physical examination, which in this case is held after the educational. Successful candidates are entered as engineer students on July Ist in each year, and go through 
a training for four or five years at the Royal Naval Engineers' College at Keyham.

During this training $£ 40$ a year has to be paid halfyearly, in advance, by the parents or guardians of each boy, and, as with naval cadets, their uniform and other clothing, etc., must be provided by their friends. Board, lodging and medical attendance are provided by the Admiralty. They are paid from $2 s$. to $8 s$. a week pocketmoney, and are allowed six weeks' leave on full pay annually, provided their conduct and progress have been satisfactory. Students are under the supervision of the admiral superintendent and a staff of officers specially appointed for the duty. As with naval cadets, a spacious cricket and recreation ground is provided, as well as boats of all descriptions, and sports and games of every kind are encouraged.

Whilst in the College, students receive practical instruction in the engineering workshops and drawing office, and in iron shipbuilding at Her Majesty's dockyards at Devonport and Keyham. Means are also afforded them of acquiring the groundwork of the knowledge required by naval engineers in the working of marine engines and boilers, and such repairs as are possible to be carried out on board ship; the practical use of the various instruments used in the engine-room; and also the construction and working of the electric light, torpedo and gun machinery. An examination is held annually, and at the end of the second term should a candidate fail to pass without satisfactory reason he is discharged. At the final examination 60 per cent. of marks entitle the student to go to the Royal Naval College, Greenwich, for further study, where additional advantages, in a lengthened course, are given to the two. 
boys who take the highest place at the examination at the end of the first course. The increase of pay from $6 s$. a day to $7 s .6 d$. a day is gained in a shorter period by the students who obtain higher-class certificates, and these also attain the rank of engineer sooner. The students who do not go to Greenwich are appointed to the depôt ship at Devonport as probationary assistant engineers, but remain in the Reserve until appointed to ships as their services are required. Probationary assistant engineers are confirmed at the end of twelve months if their conduct and qualifications are satisfactory.

Assistant engineers may pass for engineers after three years' service, and are eligible for promotion after five years' service. Engineers are appointed to small ships in charge, and as senior in large ships under the fleet, staff, or chief engineer. The full pay of an engineer is I2s. a day, according to service. Promotion to chief engineer is by seniority to fill vacancies. At present it takes about nine years to become a chief engineer, but this will be reduced slıortly. The senior rank is divided into chief, staff, and fleet engineers, four years in each of the first two ranks being the only qualification necessary for promotion. The full pay of these grades commences at I $2 s$. a day, and rises to $22 s$. a day, and retired pay up to $£ 400$ a year, according to service, is granted. Promotion to inspector of machinery is by selection, and to chief inspector of machinery by seniority. Inspectors of machinery and chief inspectors of machinery are appointed in charge of the different reserves at home and abroad. They are obliged to retire at the age of 60 with a pension of $£ 500$ a year. All ranks of this branch of the service are entitled to allowances for charge of machinery of Her Majesty's ships, when in commission; 
varying from $I s$. to $9 s$. a day. Half these rates are allowed when the ship is not in commission.

Accountant Officers.-For the Accountant Branch it is necessary to enter as an assistant clerk between the ages of 16 and 18 . The Civil Service Commissioners conduct the examinations half-yearly, first by test, and then by competition. Application to be put on the list of candidates should be made to the private secretary of the First Lord of the Admiralty. For full information respecting the examination, reference should be made to the latest quarterly Navy List. On passing the necessary examinations the candidate is appointed an assistant clerk, with the pay of $2 s$. $6 d$., and, while holding this rank, his parents or guardians must pay half-yearly, in advance, to the Accountant-General $£ 20$ per annum. At the end of twelve months, if he passes the required examination, he is rated clerk with the pay of $4 s$. a day. Assistant clerks are employed in the, ship's office, making themselves acquainted with the various ship's books which are required to be kept, and in studying the Queen's Regulations and Admiralty Instructions. The examination for clerk is principally to inquire into the knowledge of ship's work the boy has acquired during the preceding year. The clerk takes a minor part in the duties of the ship's office, but is not a responsible officer. At the age of $2 \mathrm{I}$ he is examined for paymaster, and, if passed, is appointed an assistant paymaster. The examination is conducted afloat by three paymasters in the presence of a captain or commander, and is almost entirely confined to ships' books and accounts, exchange, foreign weights and measures, and coins.

An assistant paymaster is a responsible officer, and is in many cases appointed in charge of sloops, despatch 
vessels, and gunboats, and in larger ships is in charge of the office, under the paymaster. His promotion to paymaster is by seniority, which at present is about eleven years, but is decreasing. The full pay is from $5 \mathrm{~s}$. to I I $s .6 d$. a day. There is no regular half pay for junior officers of any branch, but $2 s$. $6 d$. a day is in some cases granted in sickness; $2 s$. $6 d$. a day is given to officers appointed in charge.

The senior officers are divided into three classes, paymasters, staff-paymasters, and fleet-paymasters, six years' seniority being the qualification for promotion in each case. The pay is not affected by rank, but is, according to service, from I 4 s. to $33 s$. a day. Retirement $£ 450$ per annum, according to service and age: optional at 55 years, but compulsory at 60 .

Paymasters, staff or fleet, have the direction of the office staff, and are responsible for all pay accounts, ship's books, naval savings banks, public money, and all victualling and clothing stores in the ship for the crew. They make all payments and are responsible for them, and for all calculations respecting pay, provisions, and clothing on board; and, under the captain, for the correct and punctual rendering of the numerous and various returns and accounts called for by the Queen's Regulations.

Paymasters retired with twenty years' service, including four years as assistant paymaster, are allowed to assume the title of paymaster-in-chief.

Assistant paymasters, and paymasters of either grade, are appointed as secretaries to flag-officers and commodores. The selection rests with the flag-officer or commodore, and the appointment is only for so long as he remains in command of the station or district, on 
vacating which his secretary reverts to the rank of paymaster.

Medical Officers.-The candidate for entry as medical officer in the Royal Navy must be registered under the Medical Acts in force as qualified to practise medicine and surgery, and be between the ages of 2 I and 28 years. $\mathrm{He}$ is physically examined by a board of medical officers at the Admiralty, in medicine, surgery, anatomy, physiology, chemistry, and materia medica, and practical knowledge of drugs ; and, in addition, there are various voluntary subjects, including languages. On application to the Admiralty full particulars of the examination may be obtained, or by reference to the quarterly Navy List. The successful candidates immediately receive commissions as surgeons in the Royal Navy, and undergo a course of practical instruction at Haslar Hospitil. The pay of surgeons commencc.s at i is. $\sigma d$. a day, and rises to I $5 s .6 d$. after eight years' service. Surscons are appointed to smaller ships in medical charge and to lirge ones under the fleet-surgeon. A certain number are always $\mathrm{cm}$ ployed in the naval hospitals at home and abroad. In the largest ships there are, as a rule, three medical officers.

After twelve years' full-pay service, surgeons are advanced to the rank of staff-surgeons, with full pay of 2 I $s$. a day, rising to $24 s$. a day ; and fleet-surgeons' rank is gained after twenty years' service, with full pay of $27 \mathrm{~s}$. a day to 33 s. a day.

Surgeons and staff-surgeons after eight years' full-pay service are allowed to withdraw from the Navy with a gratuity of $£ \mathrm{I}, 000$; after twelve years' service with $£ \mathrm{I}, 500$; and fleet-surgeons with sixteen years' combined full-pay service are entitled to a gratuity of $£ 2,250$. 
The retirement is 30 s. a day, according to length of service.

A deputy inspector-general is selected from the fleetsurgeons' list. He is generally appointed to a hospital abroad at first, and subsequently at home, and after three years' foreign service, or five years' home service, is qualified for promotion to inspector-general of hospitals and fleets. He receives full pay at the rate of $42 s$. a day, and retired pay of 35 s a day. The inspectorgeneral of hospitals and fleets is selected from the deputy inspectors, and receives full pay of $55 \mathrm{~s}$., and $40 \mathrm{O}$. a day retired pay.

Officers, Royal Naval Reserve. - The Royal Naval Reserve is composed of officers and others of the mercantile marine. The officers, $I, 270$ in number, are divided into five classes:-lieutenants, sub-lieutenants, senior engineers and engineers, assistant engineers, and midshipmen. In addition to this active list there is a list of retired and honorary officers of the Reserve, but these are not required to undergo drill, nor are they liable to be called out for active service. Officers on the active list of the Royal Naval Reserve rank with officers of the Royal Navy of the same rank, but after them. To enter the Royal Naval Reserve, application should be made to the Lords Commissioners of the Admiralty through the Board of Trade. The necessary service and qualifications for appointment are published in the quarterly Navy Lists. Lieutenants, sub-lieutenants and midshipmen who undergo twelve months' training in the Royal Navy become entitled to an annual retaining fee of $£ 25$, $£ 20$, or $£ \mathrm{IO}$, according to rank. Officers on the active list are required to drill on board one of the Royal Naval Reserve drill-ships for twenty-eight days each calendar 
year, but if an officer is reported as being able to drill Royal Naval Reserve men, he will only be required to undergo seven days' test drill.

Officers of the Royal Naval Reserve, when called out by royal proclamation, receive the same pay as officers of corresponding rank in the Royal Navy, with these exceptions :

Midshipmen under three years receive $3 s$. a day.

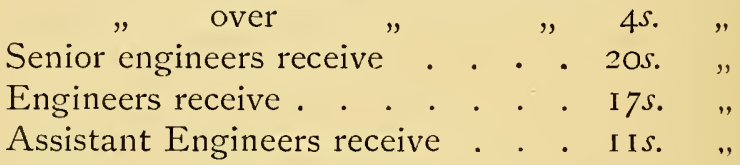

They are all granted equipment allowances of $£ 40$ for the senior officers, and $£ 30$ for the juniors : midshipmen receive $£ 20$. Officers undergoing voluntary service or training receive the same rates of pay and allowances as if called out. Officers who have qualified for navigating duties receive :-lieutenants, $4 s$. a day, sub-lieutenants, $2 s$. $6 d$. a day, when employed as such; and an allowance of $2 s$. a day to officers of ward-room rank, and I $s$. a day to officers of gun-room rank, is given as a contribution to mess expenses.

While attending drill on board a district drill-ship the officers of the Royal Naval Reserve live on shore and receive an allowance for board and lodging : lieutenants, IOs. a day; sub-lieutenants, $7 s$. a day; midshipmen, $5 s$. a day. Officers of the Royal Naval Reserve are compulsorily retired at 55 and 50 years of age, according to rank, and are placed on a retired list.

Ships of the mercantile marine commanded by an officer holding a commission in the Royal Naval Reserve, and in which ro per cent. of the crew are Royal Naval 
Reserve men are granted warrants entitling them to fly the blue ensign.

Pensions.-All claims for pensions for wounds, or disability to serve in Her Majesty's Navy, caused by service, are reserved for consideration by Her Majesty the Queen, except those to warrant and subordinate officers, which are considered by the Lords Commissioners of the Admiralty. The maximum pension for the loss of an eye or a limb, or an injury equivalent thereto, varies from $£ 350$ to $£ 50$, according to rank and circumstance; and for a warrant or subordinate officer from $£ 70$ to $£ 25$. An officer wounded in action may be granted a gratuity of one year's full pay of the rank he held at the time he received the wound, and the expense of his cure, if it has not been performed at Her Majesty's expense.

Officers injured on duty, but whose injuries do not

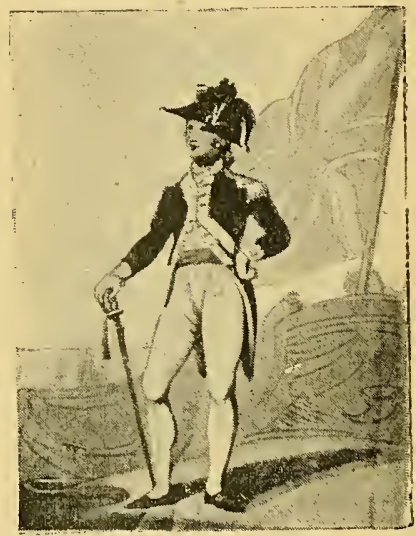

CAPTAIN OF MARINES. CIRCA I $7 \delta 7-97$.

(Rowlandson.) amount to the loss of an eye or limb, or loss of the use of a limb, or equivalent thereto, may be granted a gratuity of less than one year's full pay.

Good service pensions for distinguished services at sea are granted to flag-officers, captains, and medical officers in the Royal Navy, and to general officers, colonels and lieutenant-colonels Royal Marines, and are worth, for flag-officers, $£ 300$; general officers, $£ 200$; captains 
Royal Navy and colonels Royal Marines, £I50; and medical officers, $£$ IoO per annum.

One hundred and forty-two Greenwich Hospital pensions (and eighty-three naval pensions for executive officers only) are conferred on retired officers, under certain conditions of service, to afford some relief to them. They vary from $£$ I 50 for flag-officers to $£ 25$ per annum for warrant officers, and may be held in addition to retirement and pensions for wounds, or pensions granted with the Victoria Cross.

Royal Marines.-Under this head are included the corps of Royal Marine Artillery and Royal Marine Light Infantry, the former with their headquarters at Eastney, Southsea; and the latter divided into three divisions, at Chatham, Portsmouth and Plymouth. To enter the Royal Marine Artillery a lad must be between I6 and I 8 years of age, and be 5 feet 5 inches in height. Permission must be obtained from the Military Secretary, Horse Guards, to attend the examinations, which are by open competition, for admission to the Royal Military Academy at Woolwich, and take place half-yearly, and are conducted by the Civil Service Commissioners, and appointments to the Royal Marine Artillery will be offered to the candidates in order of merit, according to the number of marks obtained, and the vacancies. On passing, candidates are appointed as second lieutenants, and proceed to the Royal Naval College, Greenwich, for a course of study. Those who pass a satisfactory examination at the end of the first session will remain for another session, and on again passing satisfactorily will proceed to the Gunnery Establishment at Portsmouth for a course of gunnery and torpedo, when, if they qualify, they proceed to headquarters for further 
instruction in drill and military duties for service ashore and afloat. When not appointed to ships, officers of the Royal Marine Artillery remain at headquarters, where they perform the ordinary regimental duties under their own commandant. Officers of the Royal Marine Artillery are promoted by seniority in their own corps.

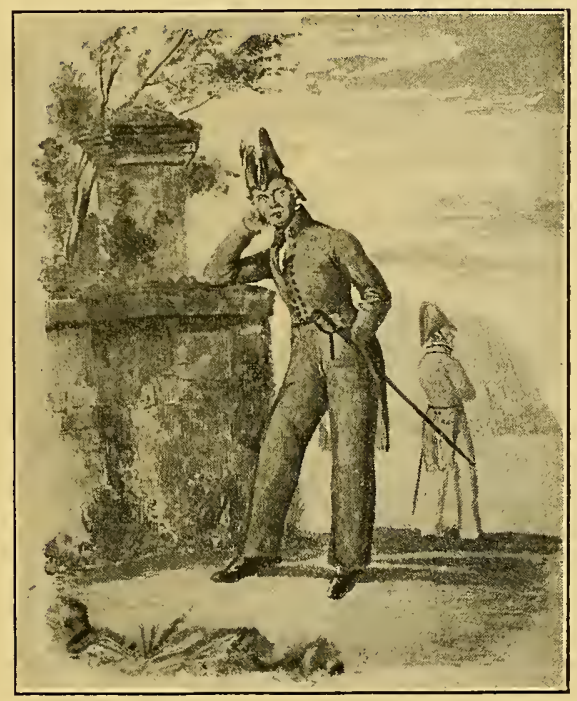

MASTER. CIRCA IS28-33. (Goni.)

For the Royal Marine Light Infantry the conditions of entry differ somewhat from the Royal Marine Artillery, in that the age of the candidate must be from I7 to I9, and for University men, under certain conditions, up to 23 years. The examination is the same as for the Marine Artillery, and on appointment as second 
lieutenant the officer proceeds to the Royal Naval College, Greenwich, for one session, at the end of which, on passing a satisfactory examination, he is advanced to lieutenant, from the date of passing, and then joins one of the divisional headquarters for instruction in military duties, etc. The strength of the Royal Marine Artillery, and the three divisions of Royal Marine Light Infantry, is over I3,000, of which about one-half are serving on board ships.

The marine officer on board ship commands all the marines on board in all duties relating to their distinct duties as marines, but he never assumes naval command or authority whatever, unless ordered to do so by the senior naval officer, and in all matters is under the command of the executive officer of the ship. The full pay of royal marines is:-lieutenants, $5 s .7 d$. to $7 s$. $10 d$.; captains, I $2 s$. $\mathrm{I} d$. to $\mathrm{I} 4 s$. I $d$.; majors, I $4 s$. I $d$. to I $6 s$.; lieutenant-colonels, I $8 s$.; colonel-commandants, 40s. Retired pay from $£ 225$ per annum to $£ 600$, according to service. ${ }^{\mathrm{I}}$

${ }^{1}$ For fuller details on the subject of the qualifications for entry, pay, and emoluments, and duties of officers of the Royal Navy and Royal Marines see the Admiralty Instructions and the Quarterly Navy Lists (price $3 s$. ): official publications to be obtained through any bookseller. 


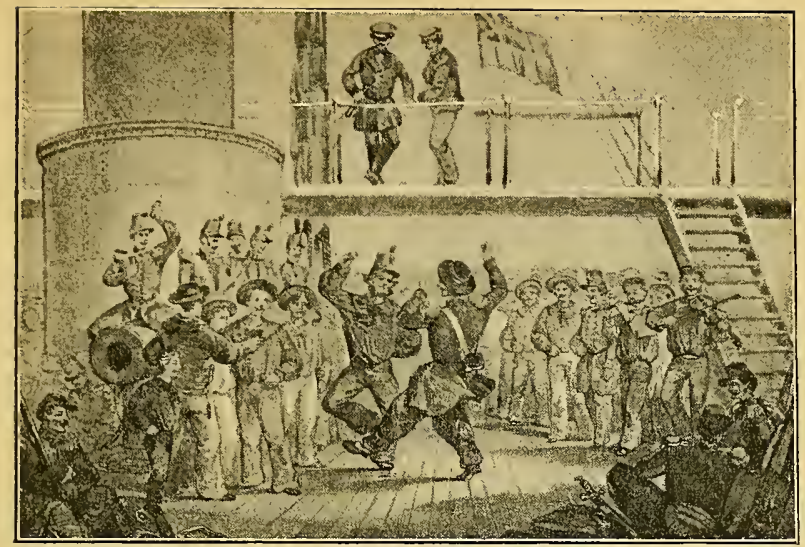

FRENCH SOLDIERS AND BRITISH SAILORS FRATERNIZING ON BOARD H.M.S. "VULTURE," AUGUST 7TH, I 854 .

(T. Dolby.)

IT matters not how excellent a fighting engine a ship may be, however powerful her armament, however good her defence; it cannot avail that she is capably and well handled by her officers, if she be not manned by soundhearted and sound-limbed men, by men thoroughly efficient in their work, who can be depended upon to do their duty in all circumstances that may arise, and however terrible the nature of these may be. It was no meaningless signal-that of Nelson's on the day of Trafalgar-"England expects that every man will do 
his duty." This doing of their duty by our seamen gained us the victory on that day as on every other great day in our annals. The supreme qualities that British seamen have exhibited have brought us all our triumphs. These men have never known when they were beaten. What commander of a fleet, what captain of a ship, could go into action unless inspired with full confidence in his men? History teems with examples of how, with this confidence and these qualities, in many a critical hour we have snatched victory even from defeat.

We can less than ever dispense with the fine qualities of British seamen in these days. The introduction of steam, and the wider application of machinery, have revolutionized life on board our ships. If the new complexity of appliances necessitates, in certain directions, greater technical skill, we may be sure that the vastly increased power of guns, and the use of high explosives, with the far heavier losses that cannot but be entailed, must call for moral qualities of firmness and true courage in a measure that has never been demanded before. In action, the decks of our ships will now be swept by a deadly hail of projectiles from quick-firers and machineguns, and their superstructures, at least, be shattered by the crashing of explosive shells ; and we have to remember, too, that, in the next naval engagement, in addition to the men on deck, there will be hundreds whose duty it will be, not to fight the enemy with their hands, but to fight him by remaining below, tending the steam machinery without which nothing can avail. We see, then, that these men also must possess the high qualities of moral and physical courage in such degree that they may stand calm and ready in the presence of 


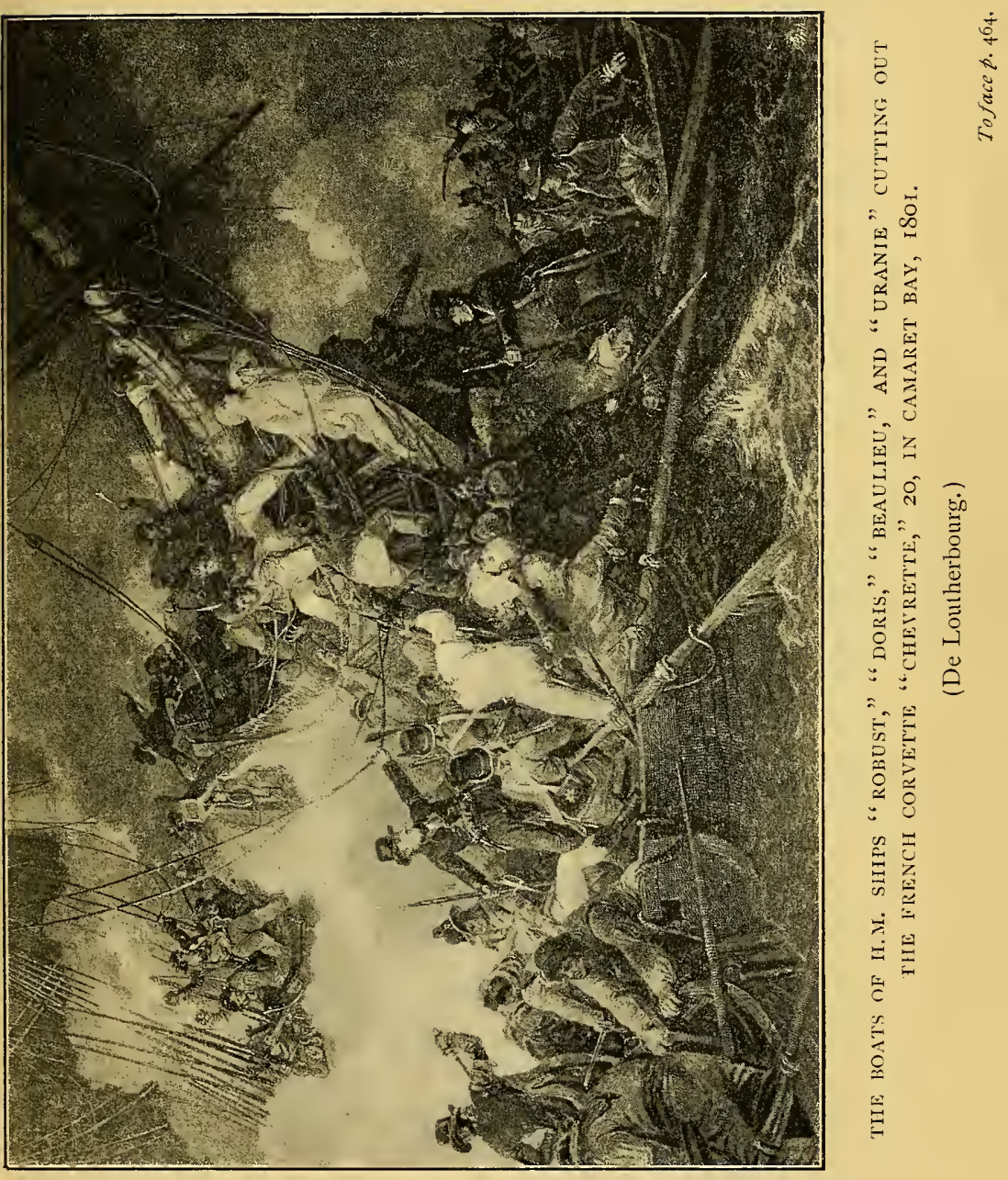



dangers they can neither measure nor wholly understand.

Not only has steam brought the engine-room complements into our ships, but it has caused us to discard sail-power for the propulsion of them, and thus the work of those who formerly handled the sails aloft has been very greatly changed. There are those who hold very plausibly that, insomuch as we no longer depend upon sails, it is needless, or even wasted labour, to instruct our seamen in the handling of them. Most of our naval officers, however, and those whose opinion is of the greatest value, maintain that the best qualities of a seaman, in bravery, hardihood, quickness of eye, alertness, and in all the characteristics of a "sailor-man," can only be developed by a course of training under sails.

This is a discussion into which we need not enter further. It is enough to make it plain that the formation of our seamen's characters, and the development of their powers, are matters of very great moment, demanding the closest attention and care. If the nature of work on ship-board has in some respects changed, certainly the special training must be at least as thorough as heretofore. But a seaman's moral qualities cannot be improvised. It is recognized by our most competent naval officers that his training must be begun while he is yet a boy, in the formative period of life, when the sense of duty and discipline may be awakened in him, and the moral qualities of will and courage be developed, whereby he will be fitted for responsibility, and be nerved for danger, as well as for the exercise of all his powers in action against our enemies. Not so much care, it may be remarked, is taken in forming the characters of the men who make up our engine-room complements, but 
these have the example of the seamen before them, and, in the recent memorable disaster of the loss of the Victoria have shown that they can rise to heights of calmness, courage, and discipline that have awakened, it is not too much to say, the admiration of the world. With these preliminary remarks we may proceed to inquire how the manning of the British fleet is provided for.

Seaman Class.-The seaman class in the Navy is kept up to its strength by the entry of boys who are thoroughly trained for a life at sea in training-ships established at various ports in Great Britain. They are entered at the age of $\mathrm{I} 5$ and up to $\mathrm{I} 6 \frac{\mathrm{I}}{2}$ years; must be of robust frame and of perfectly sound and healthy constitution, particular attention being paid to their teeth, as, without a good set, a blue-jacket would fare badly at sea, when no fresh bread can be had, but only ship's biscuit. The test represents such requirements that some 40 per cent. of the applicants are rejected. The candidate must be of the regulation height and girth of chest; he must not only have sound teeth, but be free from malformations and stiffness of joints; his hearing, sight, and sense of colour are tested; he is put to a considerable trial of physical strength by gymnastic exercises, and precautions are taken to insure that he is not epileptic.

Boys are recruited from all over the country, and if passed are drafted to the nearest training-ship for entry. Being in every respect fit, the first thing a lad has to do is to sign an agreement to serve continuously in Her Majesty's Navy for twelve years, from the age of $\mathbf{1} 8$. He then becomes a boy, second-class, and commences training. The scheme of instruction is framed to point to 
the amount of seamanlike knowledge to which an intelligent lad may approximate in the course of the twelve months allotted to his training for boy, first-class. This course includes instruction in bag and hammock, boatpulling, knots and splices, sails, masts and yards, flags, and the use of the lead and compass, steering, etc.

Once in work, the boy's life is very healthy and enjoyable. He is allowed plenty of leave to see his friends-sixteen days severallyat Easter and Michaelmas, and three weeks at Christmas-and he may gain special facilities at such times on the railway. The training-ships are the St. Vincent, at Portsmouth; the Boscawen, at Portland; the Lion and Impregnable, at Devonport; the Ganges, at Falmouth; and the Caledonia, at Queensferry. The boy has a free kit, and his work goes on regularly and progressively, his ordinary

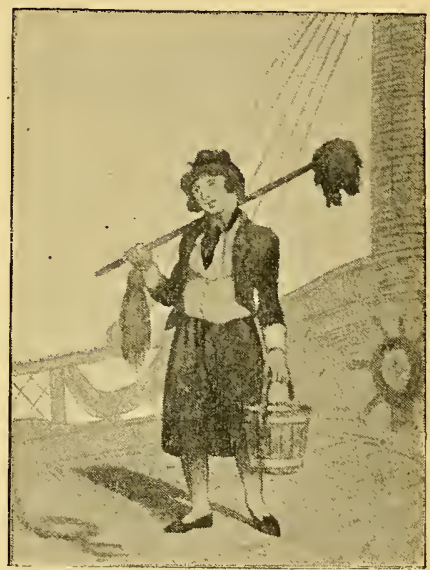

SHIP'S BOY. CIRCA ISOO.

(Rowlandson.) school work, including reading, writing, dictation, geography and arithmetic, being carried forward with his elementary seamanship. For his diversion ample opportunity is afforded for cricket, football, and other outdoor occupations, as well as for gymnastic exercises, and for bagatelle, chess, draughts, and various games; and he has access to a library, so that time never hangs on his hands. The diet, at the same time, is good and 
plentiful. In short, no better life for a boy can be desired.

Having become a boy, first-class, the youngster is now taught how to repair his clothes, signalling, sailmaking, fitting rigging, sail drill aloft, boat-pulling and sailing, swimming, etc., and the rifle and cutlass exercise, having passed in which subjects he goes for a six weeks' cruise in one of the training-brigs. This course in the trainingbrig gives the boy his first taste of real seamanship. He is put through rope drill, tacking and wearing in slow and quick time; he learns how to bend sails and weigh anchor, he is exercised in shifting sails, as well as masts and yards; he begins to handle studding-sails, and his drills become more complicated. His course also includes gun, rifle and cutlass drill. Meanwhile, he is having a good time afloat, with bathing, swimming, and other healthful exercises.

The boy is next sent to the depôt ship to wait draft to the sea-going training-ship for six months. In the training-ship his work in seamanship and gunnery is carried forward, he is thoroughly drilled, and falls into the routine of the ship. "General quarters," "fire stations," and "man and arm boats" are often piped for his benefit, and he returns in many ways efficient, having seen a good deal of the world, and having had many opportunities of improving himself.

At the age of $\mathrm{I} 8$ he is rated ordinary seaman, and as soon as he has had sufficient experience at sea and of a seaman's duties, and is a good helmsman and leadsman, etc., with a fair knowledge of gunnery, he is rated able seaman, with pay of Is. $7 d$. per day. A steady, sharp lad may soon pick up sufficient knowledge to pass for trained man, and for leading seaman, with a rise of pay 
to $I s .9 d$., and from this point up to chief petty officer no further examination is necessary, good character, intelligence, and smartness being the requirements to advance a man when a vacancy occurs for petty officer, second-class. Petty officers, first-class, are rated from second-class petty officers, when there is a vacancy, and in the same way with chief petty officers.

Before this time, however, the blue-jacket will have passed through his course of training in one of the gunnery establishments, where all that can be done to make a man lay a gun well will have been done for him. Already, indeed, before joining the gunnery ship, he would be possessed of a good knowledge of rifle, pistol, and cutlass exercise, and must have known a good deal about the armament, gunnery, and torpedo stores of his ship. His course at the gunnery establishment includes instruction in the handling of heavy guns, and technical teaching in regard to ammunition, projectiles, gun and rifle cartridges, rockets, boat's magazines and stores, fuses, tubes, and a host of other matters. He is drilled in the management of turrets and barbettes, both handworked and with hydraulics; and he is regularly put through cutlass and pistol exercise, as well as singlestick play, and ashore goes through squad and company drill with guns and rifle exercise. He also devotes a great deal of attention to machine and quick-firing guns. He will leave the gunnery ship with a certificate as first or second-class seaman-gunner. A man with a firstclass certificate may be further trained, and qualify as a gunnery instructor; or he may volunteer for a torpedo course on board one of the torpedo school ships, Vernon or Defiance. His training is thus going efficiently forward, and any improved grade adds something to his pay. 
There may come a time when the petty officer, having been a good deal afloat, perluaps desiring to get "settled in life," may think it desirable to join the Coastguard, a service which, in pleasant places, is pleasant enough. It may, however, take those who enter it to wild, outlandish regions, and the Coastguardsman, moreover, forfeits his rating, with his gunnery and torpedo pay, and returns to the rank of A.B. with the title of "Boatman." There are some other disadvantages besides, and the Coastguardsman's pension is not so good as that of his brother afloat.

A man having served seven years at sea, one year of which as petty officer, and being between the ages of $2 \mathrm{I}$ and 35 years, is eligible to pass for warrant officer of the fleet. The examining officers must satisfy themselves that the candidate is in every respect a practical seaman, and competent to take charge of a watch, and is acquainted with the rules and regulations for preventing collisions at sea ; a knowledge of working and manœuvring ships, signalling, and the effect of the helm ; and must understand perfectly the rigging of ships; how to secure and stow anchor; to erect secure sheers; and be able to write well and understand the four rules of arithmetic. The examining officers are a navigating officer and three gunners or boatswains, in the presence of a captain. Having passed the examination, the petty officer's name is put on a roster, and, as vacancies occur, these men are promoted to gunner or boatswain, and pass from the lower deck to a warrant officer. Warrant officers are, as a rule, in charge of stores, gunner's or boatswain's, according to their rank, but the juniors are usually appointed for quarter-deck duties to ships which do not carry midshipmen. 
Any warrant officer is eligible for promotion to chief boatswain or chief gunner, the selection resting with the Lords Commissioners of the Admiralty. Chief and other boatswains and gunners who may distinguish themselves by acts of gallantry and daring in $\mathrm{Her}$ Majesty's service, are considered eligible for promotion

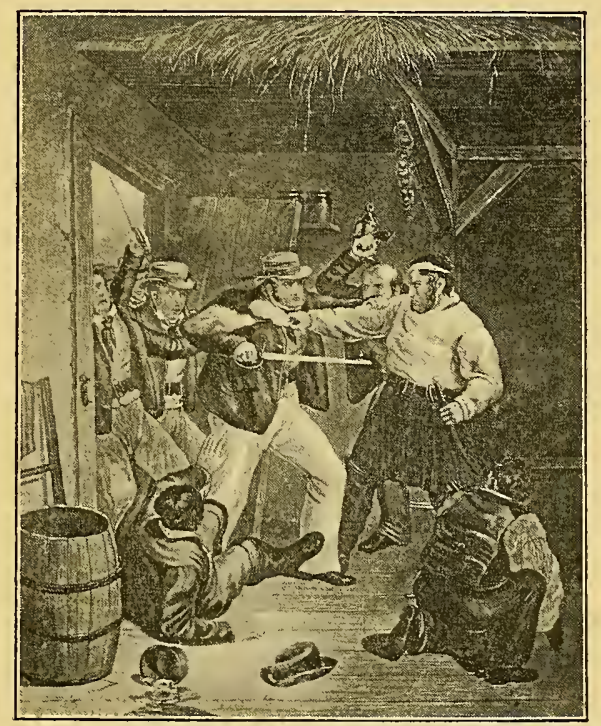

AN AFFRAY WITH SMUGGLERS, I 440 .

(G. Jones.)

to lieutenant (if under the age of 45 years), or such other rank or position as the Admiralty may deem fit. The pay of warrant officers commences at $£$ roo a year, and rises to $£ \mathrm{I} 50$, an additional $6 d$. a day being given when in charge of stores. A chief gunner's or boatswain's pay is $9 s$. a day, and $6 d$. a day for charge of 
stores. In the boatswain's charge are placed masts, sails, rigging, anchors and cables. He must make everything ship-shape, take charge of the holds and boats, and generally see to the cleanliness of the ship. In the same way the gunner has charge of ordnance stores, and must keep a careful account of them. It is his work to arrange for re-provision from the gun-wharves and powder magazines when the ship reaches port. $\mathrm{He}$ often keeps a watch, and not seldom is placed in command of a torpedo boat. Not only are warrant officers thorough seamen, but they hold very responsible positions on board our ships. They wear uniform, and have cabins and a separate mess. An admirable set of men, they still have a grievance; it is that more commissions are not given to them.

Lastly, in regard to the seaman class, it has to be noted that a number of boys in the training-ships are selected for the signal staff, and on being drafted to seagoing ships are rated signal boys, and instead of rising to A. B.'s, etc., as with other boys, become qualified signalmen, yeomen of signals, etc, up to chief yeoman of signals. They are employed entirely in signalling. As a signal boy the pay is $7 d$. a day, and a chief yeoman of signals receives $3 s .5 d$. a day.

Engine-room Staff, etc.-Next in importance to the seamen comes the engine-room complement. Stokers, second-class, are entered from the shore, the only qualifications necessary being that they are more than 19 years of age, over 5 feet 3 inches in height, and strong, healthy subjects; if with previous experience of steam-ship as fireman, they may be entered as stokers, with pay of $2 s$. a day. By steady conduct, good character and smartness these men can rise quickly to leading stoker, second- 
class, and leading stoker, first-class, with pay of $2 s .6 d$. a day, badges, etc. Ten years' service in these ratings is necessary for promotion to chief stoker, with pay of $2 s$. I $d$. to $3 s .5 d$. a day. Like the seaman, the stoker is put through a course of physical drill and gymnastics, as well as through cutlass, rifle, and pistol exercise; but there is this difference, that, while the seaman is never allowed to grow rusty, the men of the engine-room ratings, when once they leave the drill-class, are apt to find not much time for anything but the actual work of the stokehold. After joining a dockyard working-party, and serving some time in the reserve, stokers are drafted to sea-going ships, and fall into regular routine. They are placed in three watches, and so, nominally, get four hours on duty and eight hours off, but, in practice, much less of the last, for they have to take their turn in the ship's work, do a good deal of scrubbing, and attend certain drills and fire quarters, and be otherwise fitted for emergencies. Promotion to leading stoker, a firstclass petty officer's rating, brings new duties, including the keeping accounts of, and issuing engineer's stores, and the handling of hydraulic machinery, and the machinery of small boats, as well as the charge of water-tight doors, sluice-valves, double bottoms and other matters. More responsible duties, again, devolve upon the chief stoker, who ranks as a chief petty officer.

Engine-room artificers are principally entered from the shore or dockyards; the age must be between $2 \mathrm{I}$ and 28 years, and the candidates must be enginefitters, boilermakers, smiths, or coppersmiths, and present themselves for entry at a naval port. They are divided into four classes; on entry they are rated fourth-class, and rise up to first-class after twelve years' service. After 
ten years' service an engine-room artificer is eligible for advancement to chief engine-room artificer, provided his conduct has been very good, and he re-engages to complete twenty-two years' service from date of entry. . The pay of this class varies from $5 s .6 d$. to $7 s$. $6 d$. a day, according to service.

Under the head of artificers are classed carpenters, shipwrights, armourers, plumbers, painters, blacksmiths, and coopers. These ratings are filled by men entered from the shore with a knowledge of their trade, and advanced to the higher positions in their several branches by service, good conduct, and knowledge of their craft. The pay of all classes is good, and varies from $2 s$. to 6s. $6 d$. a day.

The ships' police branch of the service is recruited from seamen and marines, three years' service at sea with very good character being necessary to qualify for the junior grade (ship's corporal, second-class); but a petty officer of two years' high character can be entered as ship's corporal, first-class. Master-at-arms is the highest grade in the police, and may be attained after a year's service as ship's corporal, first-class; but to do so, a man must be fully conversant with the duties of the ship's police. A master-at-arms with a staff of ship's corporals is allowed in the larger ships, a senior ship's corporal doing the duty of master-at-arms in smaller ships. Pay commences at $2 s$. a day, and rises to $6 s$. after twelve years' service as master-at-arms. "If I were asked," says a recent writer in regard to the occupations of this official, "which post on board ship I would sooner see filled by anyone else than by myself, I should unhesitatingly reply that of the master-at-arms, or chief of the police. It is a thankless billet at the 
best, for though a man be even-tempered, tactful, estimable and exemplary in character and conduct, just in his dealings with the ship's company, and, as they say afloat, 'ready to act jonnic all round,' his efforts are seldom appreciated at their true value, and he cannot help incurring a certain amount of odium." The masterat-arms has, indeed, very varied and difficult work, in his function of preventing and detecting crime, keeping a defaulters' book, taking charge of prisoners, seeing that punishments are properly carried out, and generally of maintaining the good order of the ship's company.

Other Ratings. Stewards and cooks for officers' messes are entered from the shore, and only for such period as the officers

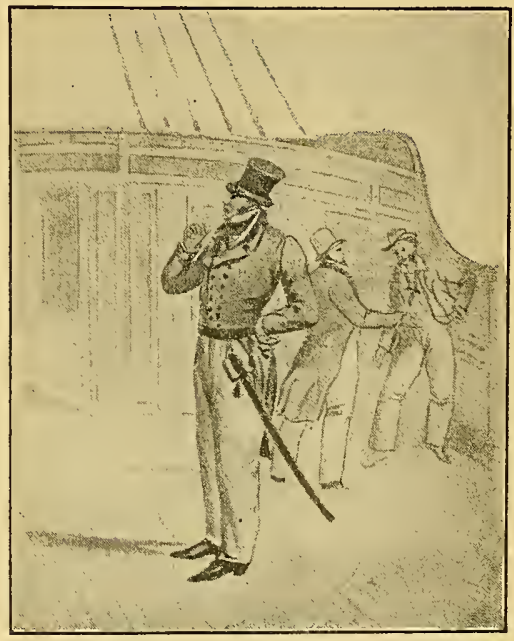

BOATSWAIN. CIRCA I828-33.

(Goni.) are satisfied with them. They are not a weil-paid class, in all cases the service pay having to be supplemented by the officers, up to double the amount, if a good and experienced man is desired. Their engagement always closes with the commission. The pay is I $s$. I $d$. to I $s .7 d$. a day. Ships' stewards are entered from Greenwich School, commencing as ships' stewards' boys and rising, through ships' stewards' assistants, to ships' stewards. 
These men are employed entirely under the paymaster, for charge and issue of ship's provisions, etc. Pay, as boy $7 d$. a day, increases to $8 s$. $6 d$. a day for ship's steward.

A certain number of boys are trained for the band in the training ships, but the backbone of the band is usually formed by the entry of musicians from the shore ; Malta and Sicily supplying the greater number for ships in the Mediterranean.

The sick berth staff are entered from the shore at Portsmouth, and put through a special training at Haslar Hospital. Age for entry must be between 18 and 35 years. On entry they are rated sick berth attendant; after three years' service, second sick berth steward ; and after three years' more service, sick berth steward. Chief sick berth steward may be reached after fourteen years' service. The pay on entry is $i s .4 d$. a day, and of a chief sick berth steward $4 s .6 d$. a day.

Having now given an account of the work and duties of the several ratings in the Navy, it will be useful to show how, in accordance with a recent Admiralty circular (September, I893), all petty officers and men are henceforth to be appropriated to the three home ports. This has long been felt to be desirable, both in regard to port duties and to the manning of ships. Men paying off, or returning to a depôt, will, therefore, now be required to declare to which port they desire to be attached, and they will subsequently be transferred only for very sufficient reasons. In the same way, men entered from the shore will be attached to the ports for which they are recruited, the cases of Sheerness and Chatham being specially considered in regard to armourer and any other ratings that are not entered there. In like manner, 
too, boys completing their course of instruction will be assigned, in particular proportions, to the several ports. These port division numbers will be subjected to an annual scrutiny, so that changes in the port requirements may be met.

The Royal Naval Reserve is an auxiliary element of strength upon which the Empire will count in case of war. As the Royal Commission on Manning the Navy said, Her Majesty "possesses in the merchant service elements of naval power such as no other government in the world enjoys." It was to bring together these elements that the Reserve was formed. I cannot do better than quote the late Mr. Thomas Gray, C.B., on this subject. "There is one institution," he says, in his admirable guide to the merchant service, "that every well-conducted and competent merchant seaman should join, and that is the Naval Reserve. Landsmen who may get to sea under the disguise of seamen are unfit, and are therefore not eligible for this creditable and highly respectable and patriotic institution. It is composed of the very best of good British seamen only. It is the cream of the merchant service. To join it is therefore one of the most honourable as well as one of the most useful things a sailor can do." 1

A Reserve man enrolled in the first-class has an annual retainer of $£ 6$, with a free kit, and in the second-class of $£_{3} 5$ s. with a free suit in the first and third years of service, and during drill receives the regular pay of a seaman of the same rating, besides being lodged

1 "Under the Red Ensign," by Thomas Gray, C.B., edited by Lieut. John B. White, R.N.R., chap. viii. 
and fed, or otherwise being paid an equivalent. He is, moreover, entitled to pension and to berths in the Coastguard under conditions. The uniform is that of the Royal Navy, with the distinguishing badge of R.N.R.

We have now surveyed the component elements of the seaman class and the engine-room complements of our fleet, and have glanced at the Reserve, but no picture of life in the British service would be complete without an account of that gallant and useful fellow the Royal Marine. Some notes upon the qualifications of marine officers have already been given. Time was when the "Jollies" were the butts of their comrades afloat, but they have a very distinguished history, and exercise very useful functions. No doubt the idea of a military force established for sea service-the corps was first raised by Charles II. in I664-presents at first sight a certain incongruity, though there was a very sufficient reason for it, but, as Major Edye remarks in his very valuable "History of the Royal Marines," the force "such as it was, such has it, in spite of many vicissitudes and heart-burnings, remained, ever loyal, not only to its sovereign and country, but also to its parent stem-the Royal Navy."

At the present time the red-coated marine may be seen all over the world sharing the work, the privileges, and the pleasures of his blue-frocked brother. There are two branches of the service-the Royal Marine Artillery ${ }^{1}$ and the Royal Marine Light Infantry-and it is to be noticed that the men in the ranks of both are of a much superior class to those found in many regiments of the Army. The enlistment is for twelve years, with

${ }^{1}$ See an article on "The Royal Marine Artillery," by Lieut. J. M. Rose, R.M.A., "United Service Magazine," August, I893. 
an additional two years if on foreign service, and men of good conduct may extend the period to twenty-one years, then retiring-it may be at the age of 39-with a ycarly pension of $£ 22 \mathrm{I} 6 s$. $3 d$, even if they have never risen from the ranks, but otherwise, with almost any sum up to about $£ 82$ a year.

The newly-enlisted recruit is sent to the depot at Walmer, where setting-up drill and gymnastics do much for him. He passes from the awlkward squad to conpany drill, with manual, firing, and bayonet exercise, and, after about eight months' work, made a new man, he is sent to headquarters. He may volunteer for the artillery branch, in which the pay is better, and may be transferred to it if he fulfil the conditions, but upon his proficiency in great-gun exercise will depend his remaining there. The recruit now becomes a regular soldier, takes his turn in guard, picket, and other duties, and enters upon more advanced drill. He goes, moreover, through a course of naval gunnery, and this whether he is attached to the artillery or infantry branch. While ashore he is comfortably housed, and has plenty of opportunity of entering into amusements and healthful sports, every facility being afforded for these; and he may be put into one of the workshops, and be enabled to add many shillings a week to his pay by doing blacksmith's, mason's, carpenter's, painter's, tailor's, and other work.

The time comes when he reaches the head of the roster for foreign service, and he then joins some ship, and is told off to a watch and a mess. Here his life is assimilated in many ways to the seaman's in regard to food and privileges. His work is chiefly on deck. He performs certain military duties, is quartered at the 
guns, has his station at fire-quarters, acts as small-arms man in landing parties, takes his turn as sentry, perhaps is an officer's servant, and does the work he knows best as tailor, shoemaker, or barber, and is, besides, the ship's postman. At length he returns hoine after a healthy and instructive time at sea, and once more his name is inscribed at the bottom of the roster, and he remains for another spell ashore. Good pay and pension, with little hard service, are his reward, and if he has a grievance at all, it is that promotion is a little slow, and that few warrants are issued to his branch of the service.

The training of the men of the British Navy-and the remark applies equally well to the officers-is a war training, and is intended to fit them for the hour of mobilization ; and to mobilize the personnel of the Navy is to bring every man to the ship and the duties for which he is appointed with the utmost celerity possible. Finis coronat opus. Mobilization is the point to which everything naval tends. Celerity in this matter, it should be noted, has grown more and more important with the increased rapidity with which attack may be developed. Our immense resources in shipbuilding, which have served us well on many an occasion, have certainly lost something of their value owing to this cause.

We hear a great deal of mobilization upon the recurrence of the naval manœuvres each year, but this mobilization is, in truth, but partial, for the complete operation would dislocate our seafaring life too much to be justified by any reason save war. We do not, for example, ordinarily call out either our auxiliary cruisers from the merchant marine, or the pensioners, and the men of the Royal Naval Reserve. These, however, know their 


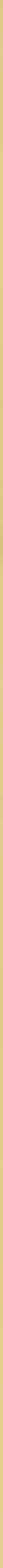



obligations well, and the last are now taken afloat in sea-going ships at certain periods, so that they are familiar with life on board men-of-war, and all have their allotted stations and work.

The central authority which sets the operations of mobilization afoot is the Admiralty, but the actual work is carried forward under the direct superintendence of the Naval Commanders-in-Chief at Portsmouth, Sheerness, and Devonport, and of the Superintendent of Naval Reserves at Spring Gardens. These high and important functionaries are collectively as the brain of the maritime body, in direct communication through various active sub-centres with its outermost limbs. From them emanate the instructions which give effect to the order to mobilize.

Already, of course, in the ships in commission are the men on active service; and to these, immediately upon the order to mobilize being given, come their old comrades of the Coastguard, who make up the complements of such ships as are but partially manned. The same order throws open the gangways and doors of the training establishments, depôts, barracks, and harbour-ships ; and from these, according to the carefully-planned paper scheme, issue-each provided with a card indicating his station and duties-the scamen, gunners, torpedo-men, signalmen, stokers and others who have been undergoing special instruction; the boys from the training-ships and their instructors ; the artificers who have had charge of the machinery of ships in reserve; the ship-keepers-in short, all the effective men belonging to the ports. This fine body of fellows is detailed to man the ships in the First Division of the Fleet Reserve, that is, the ships lying complete in every respect at the dockyards, and awaiting 
only their crews, officers, stores, and ammunition. The complements are made up by the embarkation of noncontinuous-service men, such as cooks and stewards, and the ships are ready for sea.

So far, the operation is complete, and so far, and sometimes a little beyond, we have often mobilized. But it is at this point that the work of the Superintendent of Naval Reserves will become effective in wartime. It will be for him to supply successive batches or waves of reserve men to the naval ports to take the place of those who are sent afloat. $\mathrm{He}$ will already have warned the headquarters of the Coastguard divisions at Harwich, Hull, Queensferry, Greenock, Kingstown, Limerick, Holyhead, Portland and Southampton, and the men there brought together will have departed to their appointed ports, and have gone to sea in the ships commissioned at the beginning of the mobilization.

The Coastguard ships, however, will have transferred their staffs for mobilizing purposes to the nearest drillship or barracks, to which will now converge the pensioners and all the men of the Royal Naval Reserve. These, having been embodied, will be sent in batches to the particular naval ports to which the recruiting stations owe their tribute of men. In this way the work of assembly will proceed, and thus the manning of ships in other classes of the Reserve, as well as of the auxiliary merchant craft, will be provided for. It is impossible to say where, in a great national crisis, the mobilizing of men would end; for all the seafaring manhood of our islands, all our artizan population-boilermakers, enginefitters, electricians, engineers, carpenters, and a host of others-would render their best in the Empire's need. 
Such, then, is a sketch of the mobilizing of the personnel, and all that has been said on this head applies, mutatis mutandis, as much to officers as to men. Much has necessarily been omitted, for a hundred considerations will occupy those who carry out the work, such as the provision of efficient men for the signal and look-out stations of the coasts, the passing of men through the special training-ships to facilitate the making up of ships' complements, and a host of others. But we are now able to see, in some measure, what means will be taken to bring the men whose training has been described, to the duties and work for which that training was designed.

Pensions.-Beforc we leave the subject of the personnel, some notes may be added of the pensions to which various classes and ratings become entitled. Every person belonging to a ship is entitled to a pension after twenty-two years' service, excluding boy's time, commencing at $10 d$. a day. This may be increased in several ways; for instance, a very good character throughout' a man's service gives him an extra penny a day; if discharged to pension with three badges, he receives another penny a day; and discharged as a petty officer after ten years' continuous service, his time as petty officer counts double for pension, so that it is possible for a man to become entitled to a pension for life of $£ 45$ I $2 s .6 d$. a year at the age of 40 .

At the age of 55 a seaman or marine may, at the discretion of the Admiralty, be granted an age pension of fivepence a day in addition to any naval pension he may be drawing, and at the age of 65 it may be increased to $9 d$. a day for life. Greenwich special pensions are awarded under the Greenwich Hospital Act, I 869, under 
which seamen and marines are admitted to the "benefits of Greenwich Hospital," by which term is meant the grant of special pensions from the funds of Greenwich Hospital to seamen and marines of good character who are infirm or helpless, or permanently or temporarily unable to maintain themselves, or their admission, if necessary, into naval hospitals or infirmaries. All pensions are granted during good behaviour, and may be forfeited by misconduct on the part of the pensioner, to be judged of by the Admiralty.

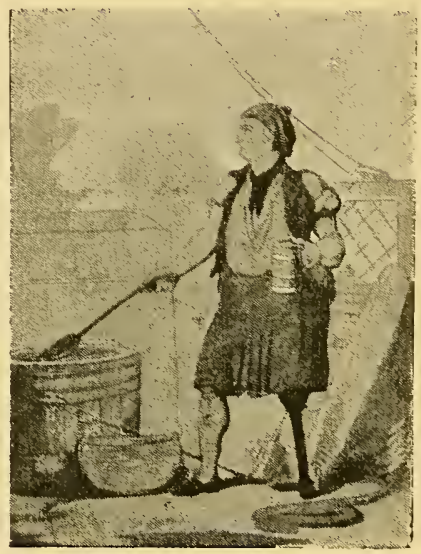

THE SHIP'S COOK. CIRCA ISOO.

(Rowlandson.) 


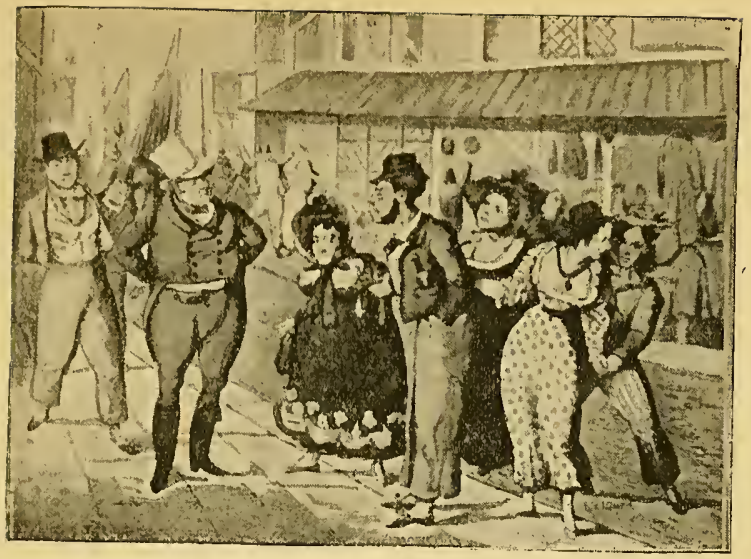

JACK'S WEDDING-DAY.

"Do you know who I am, fellow? I am the Deputy Port Admiral."

"Are you, by gosh! Then all I can tell you is you have a d-d good berth."

(IV. Alken, I 826.)

\section{CHAPTER VII. \\ NAVAL, COSTUME.}

THE dress worn at various periods of our history by the officers and seamen of the Navy has received little attention at the hands of writers on costume; nor has the matter been very fully treated elsewhere. A couple of short papers were contributed in 1830 and 1846 by Mr. E. H. Locker and Mr. John Barrow to the Society of Antiquaries and the Archæological Society; there is a chapter in the "Nautical Magazine" of I 846 , and a semi-official memorandum was compiled by Mr. F. H. Miller in I884. These are the only contributions to the subject that I have been able to trace, and they treat 
more particularly of naval uniform as prescribed for officers in I748. Yet it will be generally admitted that something more than mere curiosity would be satisfied by a knowledge of the appearance presented by the sailors whose efforts have so materially contributed to the glory, the maintenance and the expansion of this great Empire. ${ }^{1}$

The earliest reference made to uniformity in the dress of British sailors occurs soon after the Roman invasion, when we read that fleets were supplied with speedy long-boats smeared with wax to lessen the friction of the waves, and having their sails dyed a light blue colour to resemble the sea, while, still further to lessen the chance of being seen, the crews wore clothing of the same hue. It is reasonable, therefore, to claim for the colour of our naval uniform extreme antiquity, without going so far afloat for evidence as Captain Limeburner in Miss Porter's "Life of Sir Edward Seaward," where that worthy is made to say: "Our uniform was worn by Admiral Noah-aye, and before his time. Old Ocean himself wore it time out of mind. You have noted his blue jacket, I suppose, and seen his white lapelles, when he puts on his full dress, and he always wears that, d'ye see, in a gale of wind."

Throughout the Middle Ages it was customary for soldiers to wear a distinctive dress, or to exhibit on their apparel the national or party badge, and the mariners of the king's ships, or of ships hired for the public service, appear to have conformed to the same rule. The Wardrobe Accounts prove clearly that from a very

1 The greater part of this chapter originally appeared in papers written for the "Illustrated London News" (May I6th, I89I), and the "Graphic" (September Ioth, I 892). 
early period clothing of a special kind, or money to buy it, was provided to officers and men, both of the Royal and Cinque Ports fleets. In 1226 the master of Henry III.'s "Great Ship" received sixteen shillings to purchase proper robes. In 1277 , the Cinque Ports having to supply a fleet, the captains and rectors of the vessels received money to furnish themselves and their men with robes for the occasion. A little later and we find the master of the king's barge and the master of Prince Edward's barge receiving money to purchase their livery. Many more extracts to the same effect could be quoted, and in I 5 I3, Captain Montagu Burrows tells us, Henry VIII. reassigned to the seamen of the Cinque Ports, as their uniform, "a cote of white cotyn with a red crosse and the armes of the Portis underneathe."

Some idea of the dress worn by naval officers in the Tudor period may be obtained from a warrant dated April 6th, I604, by which James I. renewed Elizabeth's grant of "Livery Suits" to the six principal masters of his ships. This warrant is addressed to the Keeper of the King's Wardrobe, and directs him to deliver to the six officers named "the p'cells. following for their Lyurie coat, that is to saie, to euery of them two yards of fyne red cloth at I $3 s .4 d$. a yarde. Item, to euery of them two yards of velvet for gardinge the same coats at $20 s$. the yarde. To euery of them ten ounces of silk;" and so on, each material, its amount and cost, being mentioned. The coats were to be embroidered with ships, roses, crowns and other devices, and the grant was to be renewed annually, at Easter, to each of the officers specified, during his lifetime. The grant appears to have ceased about the time of the Commonwealth.

It is almost incredible that the mariners who first 
rowed, and afterwards handled the sails of war-vessels, could have performed their work if clad in mail. There is, indeed, no evidence that the seamen wore armour, although Sir Richard Hawkins, in I593, urges them to do so, and in Harrison's "Elizabethan England " mention is made of breastplates, and morions, as well as liveries and caps for the gunners, supplied in the equipment of the ships serving against the Spanish Armada. As to the cut and colour of sailors' dress in Tudor times, in Hakluyt's account of Sir Hugh Willoughby's expedition to the North Seas, in I553, Captain Richard Chancellor explicitly states that all the mariners of the squadron were "apparelled in Watchett or skie coloured cloth," Watchett being a place in Somersetshire noted then for its manufacture of sky-blue cloth as Kendal for its green. There nust also have been something distinctive in the garments worn, for one writer mentions how, meeting another vessel in the Pacific, "we knew her to be English because the seamen wore breeches." Chaucer's description in the fourteenth century of the shipman, "all in a gowne of falding to the knee," tells us of the antiquity of the petticoat, which as late as Marryat's time still formed a portion of the sailor's kit, but that 300 years ago trousers should have been characteristic of the English alone among seafarers is very curious.

From the reign of Charles I. to that of George II. naval officers were habited, at all events when they had their portraits painted, in the costume of the age they lived in. A letter which Mr. Locker wrote to the secretary of the Society of Antiquaries in I 830 amusingly illustrates this fact. He writes :-

"In the naval gallery of this institution (Greenwich Hospital) I can show you every variety of cut and complexion of dress- 
Nottingham, Raleigh and Torrington expand their dignity in courtly costume; Lawson, Harman and Monk frown in buff belts and jerkins; Sandwich, Munden and Benbow shine forth in armour ; while Rooke, Russell and Shovell, the heroes of a softer age, are clothed in crimson and Lincoln green, surmounted with the flowing wig, which then distinguished alike the men of the robe and of the sword. A portrait of one of my naval ancestors (Commodore Brown, who with Vernon took Porto Bello in 1739) exhibits him in a full suit of russet brown. Every man then dressed as seemed good in his own eyes. My late gallant father, who went to sea in 1745 , used to tell us that Captain Wyndham and all the officers of the $K^{\prime}$ ent, of 70 guns, in which he embarked, wore grey and silver, faced with scarlet. Such foppery, however, at that period, was not unfrequently combined with checked shirts and petticoat trousers."

The portraits referred to are still in the Painted Hall at Greenwich, and demonstrate clearly the absence of uniformity in those days. Nevertheless, there appears to have been a decided preference shown for scarlet faced with blue, or blue faced with scarlet, and in a print engraved by Weigel, in the reign of William III., an "Englischer Admiral zur See" is represented clothed in a long square-cut scarlet coat laced with gold, a longflapped blue waistcoat, cocked hat edged with feathers, black stockings drawn up to the knees, laced neckcloths, ruffles, etc.

Smollett makes Commodore Hawser Trunnion express a wish to be buried in "the red jacket which I wore when I boarded the Renummy." The Renommez was captured September I3th, I747, by the Dover, Captain W. Shirley, who afterwards became Earl Ferrers, and it is possible that Fitzroy Lee, who is supposed to have been the prototype of Trunnion, may have been on board her. In any case, it is fairly certain that Smollett had seen red jackets worn on board ship 
by naval officers at that date. Smollett also gives us the dress of Captain Whipple, R.N., the dandy in pink silk coat, white satin waistcoat, crimson breeches, and shoes of "blue meroquin," and, as a contrast, Lieutenant Bowling's holiday get-up, which consisted of "a soldier's coat altered for him by the ship's tailor, a striped flannel jacket, a pair of red breeches japanned with pitch, clean grey worsted stockings, large silver buckles that covered three-quarters of his shoes, a silver-laced hat whose crown overlooked the brims about an inch and a half, a black bobwig, a check shirt, a silk neck-kerchief, a hanger with a brass handle, girded to his thigh by a tarnished laced belt, and a good oak plant under his arm."

These two pictures are caricatures, or, at least, very much overdrawn, and it would be monstrous to suppose either that all the naval captains dressed like Whipple, or all naval lieutenants like Bowling. As bearing on this point, it may be mentioned that a Major Rennell, writing considerably later in the century, says he was told that "before Anson's time" the lieutenants of the Navy were in the habit of purchasing soldiers' coats at Gibraltar and Mahon, and, after trimming them with black, wearing them as uniform; while, from the diary of Colonel Fortescue, of a somewhat earlier date, we learn that it was the custom, when a naval man died abroad and his effects were sold, for military men to attend the auction for the express purpose of buying the uniforms, these being of more fashionable cut than anything that could be procured on shore. Gilbert Langley, writing about $\mathrm{I} 740$, says that when he was at Barbados some of the officers of H.M.S. Gosport visited his quarters, when one of them asked him "if he was not 
the commander of a vessel, for so he judged me by my apparel, which was scarlet trimmed with silver." Keppel, however, in 1747 mentions grey faced with red as usual colours, and these were the colours of the slop clothing issued to the men.

The Seaman's Dress: I 600 to i $800 .-F r o m$ an early date, and probably growing out of the older plan of providing clothes as well as arms, it has been the practice for the naval authorities to obtain supplies of clothing and retail them to the sailors. The earliest reference to the matter I have discovered is in Commander Boteler's “Dialogues," written about I630. Speaking of various measures that had been taken with a view to remove the grievances of the seamen, he mentions "that late addition also, of providing some convenient cloaths for them beforehand, hath been very well thought upon, for these people when they are left to themselves are generally found to make more of their Bellies than of their Backs."

Instructions on the subject were issued by the Duke of York (afterwards James II.) in March, 1663, when he was Lord High Admiral. By these it is laid down that the only slops permitted to be sold on board his majesty's ships are "red caps, Monmouth caps, yarn stockings, Irish stockings, blue shirts, white shirts, cotton waistcoats, cotton drawers, neats' leather, flatheeled shoes, blue neckcloths, canvas suits and rugs." It is somewhat strange that neither jackets nor breeches should be included in this list, especially as the seamen of the time are generally supposed to have worn red breeches. Henry Teonge, the chaplain of H.M.S. Assistance, from 1675 to 1676 , writes in his diary, under date July 22nd, 1675 : "This day we have a fayre 
on our quarter-deck-viz., our purser opens his packe, and sells to the value of 30 pounds or more, shirts, drawers, wascots, neck-clouts, stockings, shoes." And again, on June $\mathrm{I} I \mathrm{th}, \mathrm{I} 678$, in describing a similar sale, he omits all reference to jackets and breeches, which appear then to have been either supplied gratis or purchased ashore. ${ }^{2}$

Many regulations respecting the quality of slop clothing are preserved in the Record Office, but only two of these documents describe the colour. By an order issued August 24th, I706, by Prince George of Denmark, then Lord High Admiral, the various articles of clothing are to be furnished, under contract, by Mr. Richard Harnage, of London, and by Mr. Will. Francklin, "of Wappen, Stepney." Patterns of the "cloaths" are to be lodged with the storekeepers at Deptford, Woolwich, Chatham, Sheerness, Harwich, Deal, Portsmouth, Plymouth, Kinsale and Lisbon, and commanding officers are admonished to be careful and see that "the cloaths do in all respects agree with the patterns" before issuing them to the ships' companies. The clothing comprised :-

"Shrunk grey kersey jackets, lined with red cotton, with fifteen brass buttons and two pockets of linen, the button-holes stitched with gold-colour thread, at Ios. $6 a$. each; waistcoats of Welsh red, plain, unlined, with eighteen brass buttons, the holes stitched with gold-colour thread, at $5 s .6 \%$. each ; red kersey breeches, lined with

1 Two scarce prints show the sailor's dress of this period. From one of these, which formed the frontispiece to a pamphlet written by Captain George St. Lo, R.N., and published in I693, the seamen are reproduced on p. 493. In the other, a Dutch engraving, dated 1693, the costume only differs in the headgear, a cloth or canvas hat, cocked at the right side, being worn instead of a hairy cap. 
linen, with three leather pockets, and thirteen white tin buttons, the button-holes stitched with white thread, at the rate of $5 \mathrm{~s} .6 \mathrm{~d}$. each; red-flowered shag breeches, lined with linen, with three leather pockets and fourteen brass buttons, the button-holes stitched with gold-colour thread, at the rate of i $s .6 d$. each; striped shag breeches, lined with linen, with three leather pockets, and fourteen white tin buttons, the button-holes stitched with white thread, at the rate of $10 s$. $6 d$. each. Blue and white checked shirts and drawers, grey woollen stockings and gloves, shoes with round toes and brass buckles, with iron tongues and leather caps, faced with red cotton and lined with white linen, also figure in the list."

Whether the grey jackets, striped waistcoats, red breeches and red caps thus supplied were worn previous to the issue of this order of 1706 is uncertain, but that they formed the ordinary dress of the seamen from that date until some time between I740 and I 750 is quite certain. ${ }^{1}$ The next change was one of shape, colour and ma-

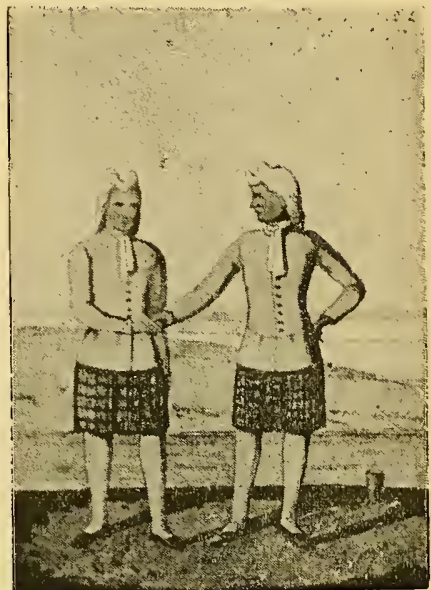

ENGLISH SEAMEN. CIRCA I693. (From a contemporary woodcut.) terial, but when it took place can only be guessed at approximately from a letter of the Navy Board, dated August 22nd, I740, acknowledging directions from the Admiralty to contract for providing seamen with green

1 Two prints show this red and grey costume, one dated 1737 is reproduced on p. 105 ; while the other, entitled "Next Skulls at the Admiralty," was published in 1744 , and can be seen in the Print Room of the British Museum. 
and blue baize frocks and trousers. The dress of the tar at the middle of the eighteenth century has been thus described:- " A little low cocked hat, a pea-jacket (a sort of cumbrous Dutch-cut coat), a pair of petticoattrousers, not unlike a Scotch kilt, tight stockings and shoes with pinchbeck buckles." " The general accuracy of this description will be seen from a number of prints reproduced in these pages, and at the same time the

1 The sailor's dress at end of reign of George II., temp. Seven Years' War, $1756-63$, is shown in two models of ships' boats landing soldiers, A (in the Rotunda, Woolwich); B (in Greenwich Museum, Anson ward). There were several combined expeditions at this time, and the soldiers shown seated in the boats (being rowed ashore), are in the army uniform, cloth grenadier caps, etc., in vogue up to the general order of I768. The naval officer in charge wears a plain blue coat with buttons, unfaced with white, white waistcoat and small-clothes of the earliest type. No dates are affixed to the models in either case, nor is any label or historical information. A.-The men (eight oars a side) wear shiny black hats, with brims turned up all round (something like a clergyman's soft hat), blue coats, size of modern pilot jacket, with split sleeves at cuffs, short white pants, tightish fitting, with blue stockings and buckle shoes. They wear the jackets open, exposing long-bodied waistcoats, some striped, some spotted red or blue on white. Shirt collars or neckerchiefs, apparently of the same material as the waistcoats, are pulled out at the back of the jacket and hang down to a point. The men wear their hair long and thick, not queued. All are dressed alike, with the exception of their waistcoats. B.-These men wear black hats of three kinds, one or two are cocked (the small apple-pasty shape), one or two are caps with tufts, like Tam o'Shanters, but the majority are hats as described in A. All wear blue coats, which are only different from those of the men in the other boat in that cuffs are not split open. The waistcoats and neckerchiefs are as before, but all wear voluminous spreading out white petticoats to the knee, with white stockings beneath; no breeches or drawers are visible. The naval officer and the soldiers are dressed as in $\mathrm{A}$. 
gradual change which took place during the next fifty years. The headgear, for example, made of canvas and tarred, with the brim cocked or flapped, had, in the time of Pepys, earned for their wearers the name of tarpaulins. In 1762 from the "London Chronicle" we learn of a new fashion the sailors had of wearing the brims uniformly tacked to the crown of the hat, in a way which made them look as if they carried a triangular apple-pasty on their heads. In the "Oxford Magazine" of 1777 there is an illustration of the press-gang, in which the hats of the men-of-war's men are depicted some tacked up and others not so. Cocked hats for the men went out of use altogether about 1780 , fur or woollen caps and soft hats taking their place, as shown in the pictures of Rowlandson, Cruikshank and Bunbury. Towards the end of the century waistcoats, shirts and trousers were of red or blue striped cotton, in appearance something like the stuff of which children's "Galatea" suits are now made; jackets were of blue baize or yellow nankeen, while the canvas or stuff petticoat, falling to the knees, protected their trousers from wet when sitting in the boats, or from chafe when lying across the yards reefing or furling sails. ${ }^{1}$

A practice as old as the Navy itself almost, and in vogue down to nearly the end of this century, was the wearing by the barge's crew, and sometimes others of the ship's company, of the colours or badges of their captains. Thus Anson, in I743, had his boat's crew clothed in a dress resembling that of the Thames water-

1 On pp. 497-515 will be found reproductions of some curious engravings of men-of-war's men, dated I779, from which it will be seen that petticoats and trousers were both in common wear at that date. 
men-scarlet jackets, blue silk vests, and silver badges on their arms. ${ }^{1}$

Uniform for Executive Officers. -In I 748 a uniform was first established for all naval officers of executive rank, the earliest dress being little different from the costume worn at the period on shore, but having a distinctive colour, buttons and marks of rank. We learn from the minute-book of a club of sea officers, which met every Sunday evening at Willis's coffee-house, in Scotland Yard, for the professed purpose of watching over their rights and privileges, that a resolution was passed at a meeting in 1745 that a uniform dress is useful and necessary for the commissioned officers as well as agreeable to the practice of other nations, and it is resolved, therefore, "that a committee be appointed to wait upon the Duke of Bedford and the Admiralty, and if their Lordships approved, that they will be pleased to introduce it to his Majesty."

Although the result of this memorial to the Admiralty is unrecorded, it appears to have been favourable, from

1 A badge of this kind, worn by one of the boat's crew of Admiral Sir Sam. F. Drake, about 1780 , was in the Naval Exhibition at Chelsea.

2 Sea officers' clubs are of great antiquity. In a sketch of the rise and progress of the Royal Naval Club of 1765 (a dining-club now amalgamated with the Navy Club of 1785 ), the rules of a similar club established about the year 1674 are quoted. The preamble to the rules runs:- "IVhereas the Commanders and Officers in his Maty Royall Navy hereto subscribing, have thought it convenient (for the improvement of a mutuall society and an encrease of Love and Kindness amongst them) to meete by way of Clubb one's in every weeke. It is now agreed," \&c. This club met every Tuesday at the Mitre, in Cornhill, the first Steward was Sir John Kempthorne, and among its other members were Sir John Holmes, Sir William Jennings, Sir John Berry, and Sir John Ashby. 


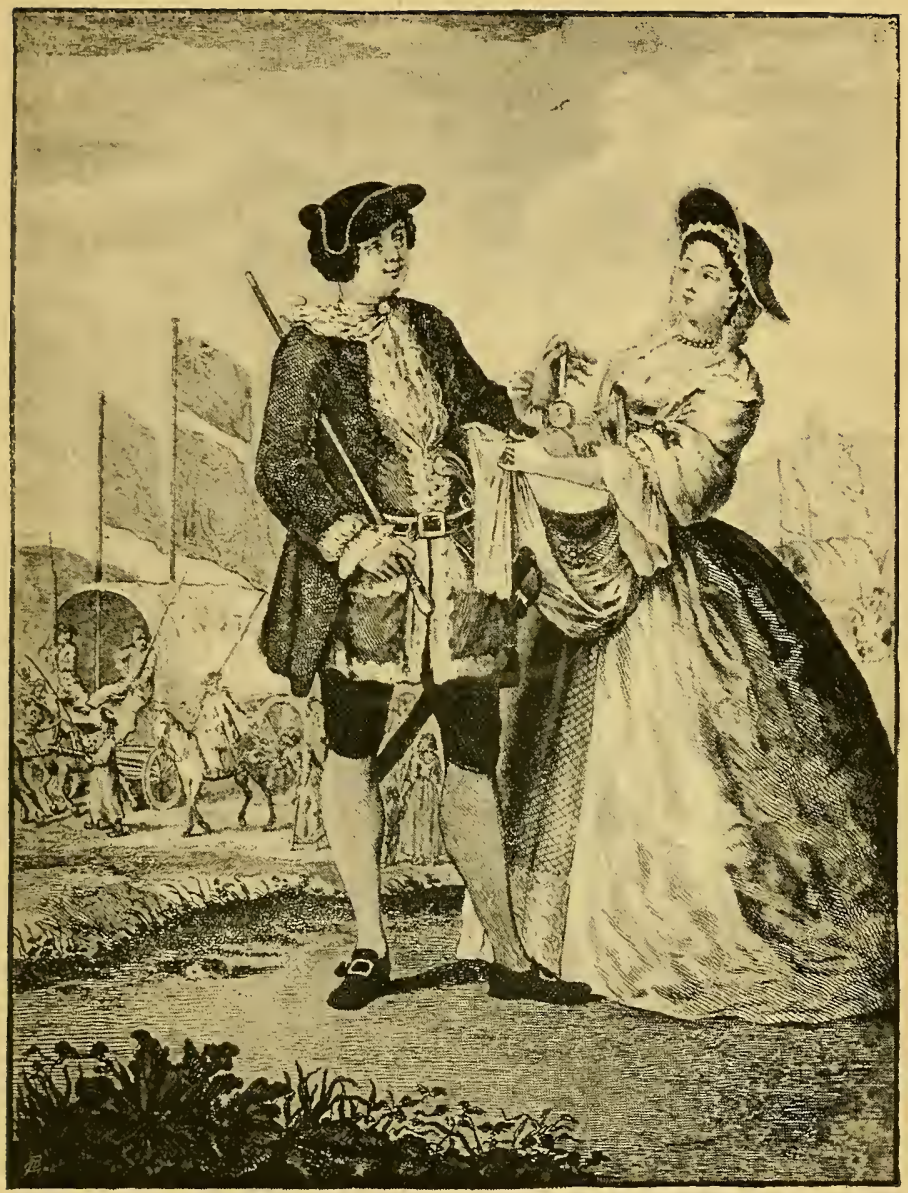

"THE SAILOK'S RETURN."

Contemporary print representing one of Anson's officers on his return from the cruise round the world in H.M.S. Centurion,

Sept. I740-June 1744 .

(Boitard.) 

the following passage in a letter which Captain Keppel wrote to Captain P. Saumarez, under date London, August 25th, 1746: "Tim Brett tells me you have made a uniform coat, etc., after your own fancy; my Lord Anson is desirous that many of us should make coats after our own taste, and then that a choice should be made of one to be general, and if you will appear in it here, he says, he will be answerable your taste will not appear among the worse." Sir Peter Warren also appears to have had something to do with the proposal, for in a letter from him to Lord Anson, dated Plymouth, August 3rd, I747, the following paragraph appears: "I cannot conceive what reasonable objection can be made by our service to the uniformity of dress and rank proposed in the instrumental I sent you, if it is approved of in that form by his Grace [the Duke of

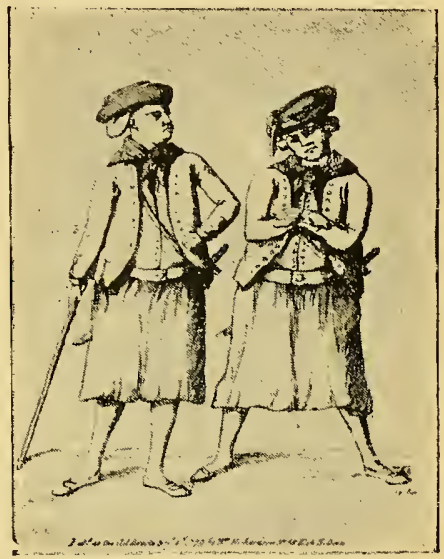

BRITISH SEAMEN. CIRCA I779. (From a contemporary woodcut.) Bedford], and, I pray you, let me know, and I will immediately be answerable for the carrying it through with many of our junior flags, and, I believe, with all the captains in general."

The choice of colours, however, was made finally by George II. himself, as appears by a statement received by Mr. Locker, from the lips of Admiral of the Fleet, the Hon. John Forbes, the gallant officer who resigned 
his seat at the Admiralty in 1757 rather than sign the death-warrant of the unfortunate Admiral Byng :-

"Adverting to the establishment of the naval uniform, the Admiral said he was summoned on that occasion to attend the Duke of Bedford, and being introduced into an apartment surrounded with various dresses, his opinion was asked as to the most appropriate; the Admiral said red and blue, or blue and red, as these were our national colours. 'No,' replied his Grace, 'the King has determined otherwise, for, having seen my Duchess riding in the park a few days ago in a habit of blue faced with white, the dress took the fancy of his Majesty, who has appointed it for the uniform of the Royal Navy." "

The adoption of this uniform was notified to the naval service by the following order, dated April I 3 th, I748. and addressed to twenty-one admirals, vice-admirals and rear-admirals, and one hundred and thirty-two officers in command of ships and vessels :-

"Whereas we judge it necessary, in order the better to distinguish the rank of sea officers, to establish a military clothing for admirals, captains, commanders and lieutenants, and judging it also necessary that persons acting as midshipmen should likewise have an uniform clothing, in order to their carrying the appearance which is necessary to distinguish their class to be in the rank of gentlemen, and give them better credit and figure in executing the commands of their superior officers, you are hereby required and directed to conform yourself to the said establishment, by wearing clothing accordingly at all proper times, and to take care that such of the aforesaid officers and midshipmen, who may be from time to time under your command, do the like. And it is our direction that no commission officer or midshipman do presume to wear any other uniform than that which properly belongs to his rank, etc., etc."

The instructions do not appear to have been sanctioned by an Order in Council or promulgated in the "Gazette ;" but, under the heading of "Domestic News," 
a paragraph was inserted in the "Jacobites' Journal " of March 5th, I 748, announcing their issue, and stating that "patterns for dress-coats and frocks" for each grade of officer had been lodged at the Navy Office and the several dockyards for inspection. No regulations were issued prescribing the dress, and no patterns were sent abroad. So we find Admiral Boscawen writing on February I3th, I749: "The order for establishing the uniform inclosed in your letter of April I 3 th cannot be complied with, as I am entirely at a loss with respect to patterns." Sir John Barrow, in his "Life of Anson," also states that good reasons existed for believing that the general adoption of the uniform was confined, or nearly so, for some time to flag-officers and captains. As no uniform was mentioned for warrant officers, one can quite believe Major Rennell when he says that in I759 he saw a master of a man-of-war dressed in a red coat trimmed with black.

The patterns for the garments worn by admirals and midshipmen have not been preserved, but a few coats, waistcoats, breeches and hats for captains and lieutenants were found at Plymouth in I846, and, being sent to the Admiralty, are now in the United Service Institution. The hats are three-cornered in shape, one is trimmed with silver or tarnished gold lace, and both bear the silk cockades instituted by George I. Lace and frills being then worn, there are no collars to the coats : they are made of thick blue cloth, the lappels which button back are blue, but the cuffs of the captains' coats are white, and the sleeves of all are purposely made short to allow the laced sleeves of the white kerseymere waistcoats to show beyond. There are two kinds of button-one flat, bearing a rose, the other round and plain. Although we 
have not the patterns, pictures of the dress of the admirals and midshipmen have come down to us, the embroidery and lace on those of the flag-officers being most elaborate.

On July 18 th, I 757 , the above regulations were superseded by an Order in Council which stated that the embroidered uniform clothing of flag-officers, and the full-dress uniform of captains, commanders and lieutenants was to be discontinued, and that the "frock uniform clothing" was to be altered. Admirals' frocks were to have narrow lappels down to the waist, small "boot" cuffs, and single instead of treble plain lace of mousquetaire pattern down to the side skirts. The lappels on the captains' and commanders' frocks were also to go down to the waist, and lieutenants the same, but with slash cuffs and lappels like the commanders, and without lace. The cuffs and lappels of the lieutenants' coats were ordered, in the following year, to be white instead of blue. ${ }^{2}$

In July, I774, this "frock" uniform was made full dress, and some slight alterations were made in the arrangement of the lace on the coats; flat buttons with an anchor and cable engraved thereon were substituted for the rose buttons; the waistcoats were to be plain and the breeches white instead of blue. At the same time an "undress" uniform was prescribed-the term does not appear to have been used before; the collar, cuffs, and lappels of this undress were made blue, and

: Stothard's picture at p. 336 shows Prince William Henry (afterwards William IV.) as a midshipman in blue coat, with a white patch on his collar, white waistcoat and knee-breeches. Admiral Digby is shown in the undress uniform of 1767 .

${ }^{2}$ Schomberg's "Naval Chronology," vol. i., p. 479. 
on the last named the rank was shown. Captains who had taken post three years and upwards were to wear twelve buttons by threes on the lappels, captains under three years' standing twelve buttons by twos, and nasters and commanders twelve buttons placed regularly.

In January, 1783 , the flag-officers got back their embroidery on the full dress, "the pattern to be the same as worn by corresponding ranks in the Army." Marks of distinction on the white cuffs were now introduced, admirals having three rows of embroidery, viceadmirals two, and rear-admirals one. Commodores having captains under them, and the captain to the admiral of the fleet wearing rear-admiral's uniform. In the undress, which was a blue cloth frock with blue cuffs and lappels, the grade was shown by the button-holes, those of admirals arranged at equal distances apart, those of vice-admirals by threes, those of rear-admirals by twos. Four years later ( 1787 ) considerable alterations were made in the existing clothing, while uniform was now established for warrant-officers and masters' mates. Lace was substituted for embroidery on the flag-officers' white cuffs, the collar of the coat was made to stand up, and adorned with a laced button-hole on each side. They also received a new button, gilt, with a small anchor in the centre surrounded by a laurel. The full dress of captains, post of three years, was a blue coat with white lappels, white cuffs laced with gold in two laces, stand-up collar, double laced and white lining; white waistcoat and breeches. A new button for commissioned officers under the rank of admiral had "the anchor in an oval." The full dress of captains under three years was similar, except that there was only one lace round the pockets and cuffs. Officers of the rank of master and commander 
had blue lappels and cuffs, but in other respects their full dress was that of the captain under three years. The lieutenant's full dress was but slightly altered, the coat had white lappels and cuffs without any lace on them. The undress or frock uniform was as follows :-for captain of three years post, blue coat, white lined, blue lappels and cuffs, fall-down collar, gold-laced button-holes, square at both ends, arranged regularly on the lappels. For captain under three years the same, except that the nine buttonholes were arranged on the lappels in threes. For master and commander the same, except that ten button-holes were arranged by twos. The lieutenant's undress coat only differed from his full dress in that instead of white lappels and cuffs it had a white edging or piping.

The warrant officers, which rank included masters, surgeons, pursers, gunners, boatswains, and carpenters, were given for their first uniform dress a blue cloth coat with blue lappels and blue round cuffs, a fall-down collar, three buttons on the pocket-flaps and three on the cuffs. The coats to be lined, but not edged with white. The button was with an anchor, "same as the captain's former one." The masters' mates, like the warrants, had no full dress, and their undress was the same as the lieutenants', but without lappels, with the collar falling down instead of standing up, and with warrant officers' buttons. The midshipman's uniform was slightly altered, it was now described as a blue cloth coat with no lappels, blue round cuffs, buttons on cuffs and pocket-flaps, stand-up collar with small white turnback "as before," white lining but not edged.

White cloth waistcoats and breeches were prescribed with all these dresses, but the rule was not strictly enforced. No rules as to hats or swords or boots were issued. 
All officers wore three-cornered cocked hats, lieutenants and officers below them in rank carried their swords (hangers) in a broad leather belt slung over the shoulder, until I 805 , when patterns of uniform swords were sent to the naval ports; and Hessian boots coming to the knee are said to have been introduced by Rodney, worn with white pantaloons. These were certainly optional in I SO5, for at Trafalgar Collingwood was asked by one of his officers whether he would not wear them, but replied, that, in case of being hit in the leg, silk stockings would be found less in the way of the doctor.

In several portraits of naval officers from I 7 So onwards I find epaulettes worn, but they were not made uniform until June, I795. They appear to have been uniform in the French and Spanish navies before this time, and, according to Mr. Popham Lethbridge, were introduced into our Navy by an incident

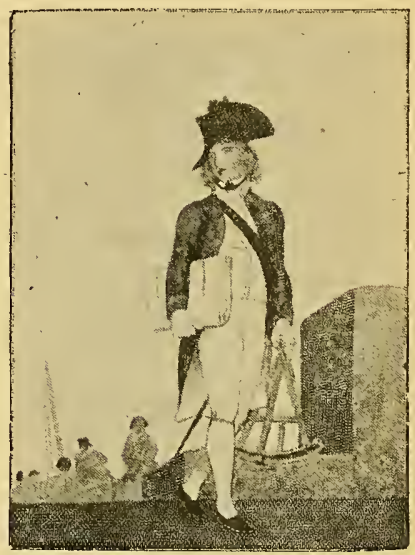

MIUSHIPMAN. CIRCA I787-ISI2. (Rowlandson.) which occurred when some English officers visited France during the peace. These officers found that the sentries did not carry arms to them, while they did so to the officers of marines, who, at that date, wore silver epaulettes; two of them therefore adopted gold epaulettes as part of their uniform, and when ane of these officers became a Lord of the Admiralty, he got the regulations altered. The white lappels and cuffs, except in 
the shape of piping to the lieutenant's coat and the patch on the middy's collar, disappeared at about the same time. $^{1}$

By the new instructions rank was to be distinguished by the gold epaulettes. Admirals wore two, with one, two, or three silver stars on each, to denote rear, vice, and full admirals respectively. Captains over three years' standing, the plain gold epaulettes; captains under that seniority, one on the right shoulder; and master and commanders (a combined commissioned rank, not to be confounded with the warrant rank of master), one on the left shoulder. These epaulettes were not stiffened over the shoulder, as are those worn now, but hung down like tassels.

This uniform remained in force until 1812 , and is, consequently, that of the Nile and Trafalgar period. ${ }^{2}$

I thought that possibly some light might be thrown upon this matter of uniform by nautical novels dealing with the period; but when one finds Captain Chamier making his hero, in I794, seal a love-letter with a purser's button which did not come into existence until I 807 , one is apt to doubt this sort of authority. Taking it, however, for what it is worth, we learn from Captain Glasscock that, in I 800 , at least one naval lieutenant was to be seen in a blue white-edged coat with straggling anchor-buttons of different dies, a

${ }^{1}$ In contemporary pictures of the officers of the Queen Charlotte (June, 1794), white facings are shown, but in those of the officers of the Captain (1797) this is not the case.

${ }^{2}$ About 1795 Rowlandson was commissioned by Messrs. Ackermann to make drawings of the naval uniform of that date, and ten plates were published in 1799 , which are now very scarce. They represent the admiral, captain, lieutenant, midshipman, purser, marine officer, carpenter, cook, seaman and cabin-boy. 
buff vest, tarred nankeen trousers, and broad-brimmed leather hat. He also speaks of the little white-handled dirk which was part of a midshipman's equipment. and the plain frock which formed the ordinary attire of the purser. If Captain Barker (the Old Sailor) is to be trusted, there was a ship in the Channel about 1825 in which all the officers were to be seen one day in the prescribed uniform of the regulations, the next in peajackets, Flushing trousers and hairy caps, and on the day following in buckskin breeches, top-boots and spurs, to accord with the caprices of their commander.

The Sailors' Dress: I 800 to I 857.-The dress of the seamen at the beginning of the present century had merely by custom-for no regulation existed-hardened down into blue jacket, white trousers and tarpaulin hat. As, however, two capricious factors operated to prevent uniformity, one or the other of these three articles of attire was not unfrequently worn with garments of quite a different cut and complexion. In the first place, unless the rig in which a man joined was very ragged he was allowed to retain it; in the second, the captain's whim had to be considered; and, especially in regard to the dress worn by their boats' crews, some officers exhibited very peculiar taste.

The petticoat was still in use, for Marryat writes of a cutter in the Channel in 1820 or thereabout: "She had plenty of men, all dressed in red flannel shirts and blue trousers; some of them have not taken off their canvas or tarpaulin petticoats, which are very useful to them, as they are in the boats night and day, and in all weathers." Straw hats, introduced first in the West Indies, were common about 1802 ; but a smart sailor of the Royal Sovereign, in I 805 , is pictured as being rigged complete 
in "white ducks, long in the legs and taut in the hips, checked shirt, a round blue jacket with bright buttons, black tie, white stockings, long-quartered shoes, a regular neat-cut low-crowned tarpaulin hat, with the name of his ship painted on the ribbon, and with a pigtail down to his sternpost." It is probable that only an ocean swell, with plenty of prize-money in his pockets, turned out in this rig, which was also that of William when he courted Black-Eyed Susan.

From pictures by Drummond, Cruikshank, and those of a naval officer who illustrated a volume of sketches in I 8 I 5 , checked or striped trousers as well as shirts were affected by seamen, and they frequently ornamented their jackets by sewing strips of canvas down the seams. ${ }^{1}$ A little later, and tight guernseys were common wear, with Kilmarnock caps with a blue tuft a-top. Officers sometimes affected beaver hats like those worn by civilians. The vagaries of some of the captains were very strange, and led to odd difficulties. The captain of the Vemon, in I 840 , ordered his men, on fitting out, to wear red serge frocks with red woollen comforters, but when the ship had been in commission a short time the unforeseen difficulty of keeping up the supply arose, and was eventually overcome by appropriating all the remaining red

${ }^{1}$ The Purser's Instructions of I 824 contain a long list of the various descriptions of slop clothing of which a stock was to be maintained, such as blue cloth jackets, knitted worsted waistcoats, blue cloth trousers, duck trousers and frocks, shirts, stockings, hats, mitts, blankets and black silk handkerchiefs. The issue of these articles was at the discretion of the captain, who could make a man draw such necessaries as he required, if he appeared ragged, provided the value did not exceed two month's pay, but in the case of newly raised men it was directed that they were only to be made to take up clothes if they required them. 
frocks to one watch, the other donning the blue, which were obtainable from the purser. The chequered appearance of the men when on the yards furling sails can be well imagined. In the Blazer, in I845, the ship's company wore blue and white striped guernseys, with

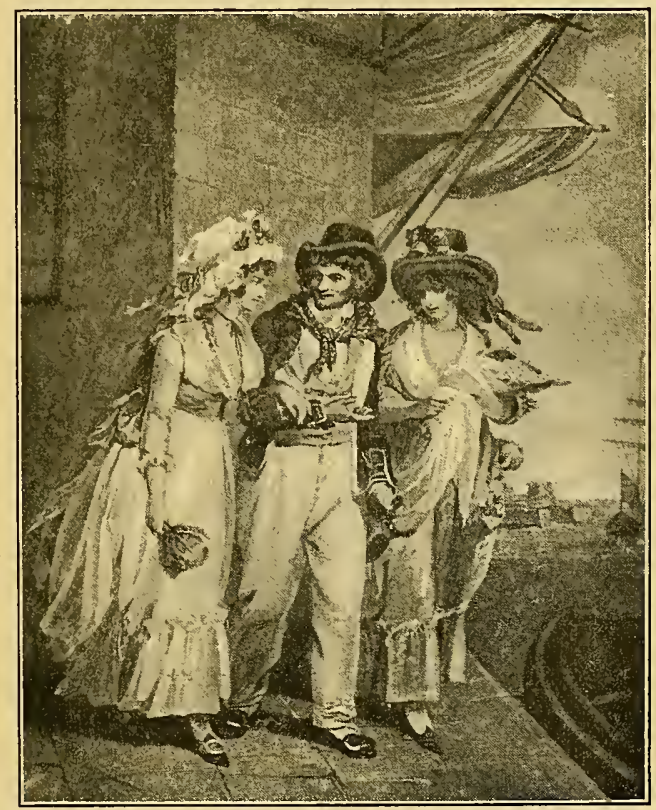

AN OCEAN SWEIL WITH TWO TENDERS. CIRCA I790.

(Wheatley.)

jackets. Commander Wilmot, of the Harlequin, brig, in I 853 dressed his gig's crew as harlequins, and, in I 854 , Captain Wallace Houston, in the Trincomalee, had all his ship's company in red shirts and fancy caps. As these instances are well authenticated, Captain Barker, 
in the "Naval Foundling," was not wildly improbable when he made the commander of H.M.S. Tulip dress his ship's company in green, with an imitation flower reversed for their caps, and his boat's crew in tigerskins to resemble Indians, with short paddles instead of oars.

Distinctive Uniform for all Officers.-On January 22nd, I SO5, a uniform was first established for medical officers, and on June 29th, I 807 , a uniform for masters and pursers, at that time these classes being known as "warrant officers of ward-room rank." 1

In ISI 2 white facings were again introduced and worn upon the dresses of the Trafalgar period. A crown was now placed over the anchor on the button, and midshipmen and mates were to wear it. ${ }^{2}$ All captains and commanders were now given two epaulettes, the distinction to be a silver crown over a silver anchor on those of captains of three years' standing, a silver anchor only for other captains, and plain epaulettes for commanders. Lieutenants to wear one epaulette on right shoulder. ${ }^{3}$

1 The regulations are given in full in Burney's edition of Falconer's "Dictionary."

${ }^{2}$ In consequence of the above direction a representation was made to the Admiralty by the button manufacturers, that, in order to bring the price of the button "within the convenience of the inferior officers, they would suggest that the midshipmen's buttons be made in the same manner as at present, viz., the anchor and crown indented below the plain surface, and not cmbossed, as the captain's, they would thus require less gold."

${ }^{3}$ At this time no patterns or plates were published with the regulations, and captains allowed both themselves and their crews a great deal of licence in the matter. In that capital novel "The Cruise of the Midge," the commodore is dressed in faded nankeen 
On January Ist, I 825, new regulations were issued, and plates published, which are still in the Admiralty. ${ }^{2}$ Waistcoats and knee-breeches of white kerseymere were ordered for all grades, but pantaloons of white or blue cloth and half-boots were also allowed to be worn.

The Master of the Fleet and all officers of civilian grades were to have black grips to their swords, and the blades were not to be blued. Physicians and secretaries wore a dress sword with rapier blade. The lappels of all these warrant officers' coats were blue, and they were distinguished by marks on the collar and buttons. The Master of the Fleet had three anchors (the seal of the Navy Office) on his collar, and the buttons of all officers of his department bore the same device. Physicians had an anchor with a snake twisted round the shank and stock (the seal of the Sick and Hurt Office) on their collars, and all medical men the same device on their buttons. Pursers wore two anchors with cables crossed saltierwise (the seal of the Victualling Office) on their

trousers, cotton stockings and low shoes, a white waistcoat, blue uniform coat with faded gold lace straps on each shoulder to confine the epaulettes, which were only worn on Sunday. $\mathrm{He}$ wore a shocking bad hat, an old white beaver with a very broad brim, the snout of it fastened back to the crown with spun yarn. The first lieutenant's uniform was equally odd. He wore a curious wee hat with scarcely any brim, but garnished with a double strip of gold lace and a naval button on the left side, a uniform coat, very old-fashioned, but with one new gold strap for the epaulette, a white kerseymere waistcoat, and ancient duck trousers. The one epaulette worn by the lieutenant gives us the date, and it is impossible not to believe that these were portraits of two naval officers whom Michael Scott had met in his travels.

1 See Navy List of this date. 
collars, and all the clerical staff the same device on the buttons.

Junior officers who had not previously been accorded permission were now allowed to wear blue instead of white pantaloons, if they wished; mates a button and button-hole of gold lace on the stand-up collars of their coats, and a thin white edge to the coat; midshipmen a white turn-back as before, but the coats were not to be edged with white; mates, midshipmen, gunners, boatswains and carpenters to have swords like the masters, but of such length as may be convenient. Masters' assistants, a rank instituted in the previous year, and volunteers were now given uniform. All officers were ordered cocked hats in full dress or undress, but might wear at sea a round black hat, bound with black silk, with a narrow black silk band and black buckle, and a black silk or leather cockade, with a loop of the same material, and half the width of the whole loop of the full-dress hat, with the appropriate distinctive button of waistcoat size. ${ }^{1}$ The full-dress coats of what are now termed warrant officers had turned-down collars ; they no longer wore knee-breeches, and their buttons had no crown above the anchor. The undress coats of all grades had fall-down collars and lappels to button

- 1 The hat, which had been originally cocked on three sides, with one angle to the front, was made in the nineties with two flaps, one perfectly straight up behind, the other slightly bent in the old fashion to give the angle in front. After I 800 this bend disappeared and both sides went up straight, but much higher behind than in front, while at the corners tassels hung down; this hat was generally, but not invariably, worn "athwartships." In 1825, when the shape of the hat was prescribed, it was made as at present, to be worn "fore and aft." 
across the chest. Commissioned officers were distinguished by their stripes on the cuff, epaulettes or buttons.

Two years later, in 1827 , the full dress was abolished, and knee-breeches were ordered to be worn at DrawingRooms only. The collars of the coats were made white

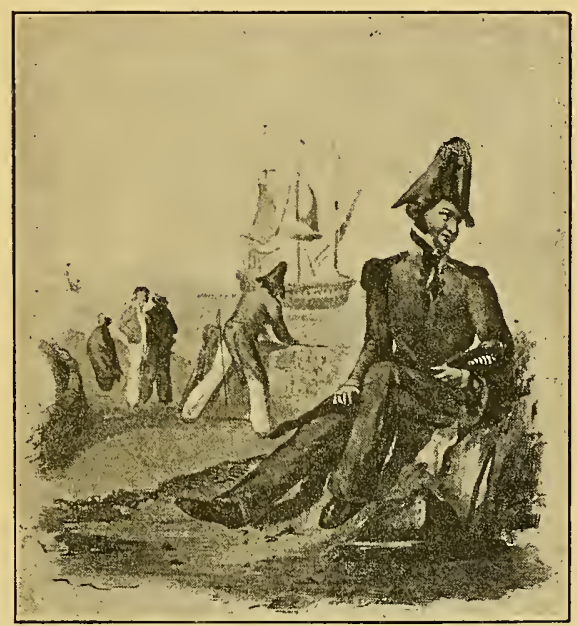

LIEUTENANT. CIRCA IS2S-33.

(Goni.)

instead of blue, and to stand up; the white cuffs were slashed, but the rings round them, which had shown flag rank since 1783 , were done away with. The full dress was re-established, with some few alterations, in I83I.

In 1833 William IV. changed the facings from white to red, and they remained so for ten years. In 1837 a dress for engineers was first ordered, it bcing very similar 
to that worn by the other warrant officers. In I 843 all officers of the executive branch were ordered to wear their buttons double-breasted, officers of the civilian branch to wear them single-breasted, the masters' buttons regular, paymasters' in twos, doctors' in threes; all the devices on the buttons were abolished except that for the engineers, an engine surmounted by a crown, to be worn in fours. The black-handled sword-grips were now restricted to the boatswains, gunners and carpenters. ${ }^{1}$

In 1846 scales, or epaulettes without bullion, were authorized for captains and commanders, and they might be worn on jackets at sea-mates received an epaulette on the right shoulder and second masters the same, but with a different badge. The undress coat of the military branch had pointed flaps in place of lappels, and a gold crown was to be worn over the lace on caps. The next year the scales for captains and commanders were abolished, and a frock-coat was instituted, to be worn

1 The costume for some grades of officers and men of the Royal Navy was painted and etched by J. A. Atkinson, and published in 1813 by J. Murray, Albemarle Street. A set of twelve pictures, illustrating the costume in 1828 , drawn by M. Goni, was published by Messrs. Englemann, Graf, Condel, and Co., in I 829 , being dedicated to His Royal Highness the Duke of Clarence, Lord High Admiral. They represent a rear-admiral, lieutenant, master, purser, warrant officer, midshipman, master's assistant, volunteer of first and second class, quartermaster, cockswain, sailor, and Greenwich pensioner; several of these are reproduced in these pages. A smaller series issued about the same time, signed W. Alais, gives the dress of the Lord High Admiral, an admiral, and a captain. Other plates of costumes were issued under official sanction in I $830,1849,1850$, and I 854 ; all of these were shown in the Naval Exhibition at Chelsea in $\mathrm{I} 89 \mathrm{I}$. 
without epaulettes, but with distinctive bands on the cuffs of the executive officers. Caps were not to be worn ashore in full or undress. In 1856 , at the close of the Russian War, a fresh change was made in the marks on the epaulettes. Mates were given shoulder straps or scales; midshipmen, dirks in the place of swords. The cap-badge was instituted, and mohair bands

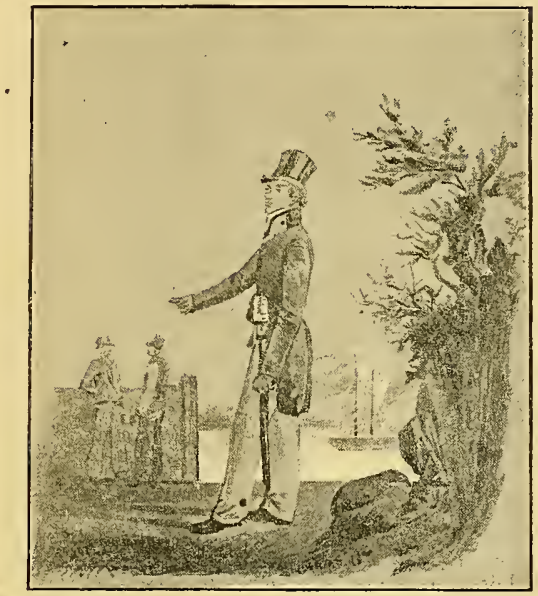

MIDSHIPMAN, I828-33.

(Goni.)

substituted for gold lace. The engineer's button was also abolished.

Seamen's Uniform Established.-In I 857 a uniform for the men was fixed, which was very similar to that now worn, except that by regulations issued in I89I the tarpaulin hat and the blue jacket were done away with. It was some time, however, before the regulations were entirely conformed to, and as late as i 864 some officers 
continued to dress their boats' crews in more or less fanciful rigs.

In 1863 another row of lace, with the curl at top, was given to all officers of the military branch, and the other officers were given the distinctive colours on the sleeves which are still worn-red for medical officers, white for paymasters, and purple for engineers. A blue velvet stripe was also introduced for the navigating branch, but this was afterwards done away with in I 867, and has since been given to naval instructors. At the same time mates got lace stripes instead of braid, and sashes were prescribed for the aides-de-camp to the Queen. These instructions notified that the hat with its lightning-conductor, but considerably lowered in the crown, was now only to be used in bad weather. In I 867 chief gunners, boatswains and carpenters were given a narrow gold stripe, and the badges for petty officers, which had been blue and white, were changed to blue and red. Distinguishing marks were originated this year for gunnery instruçtors and seamen gunners. In 1874 aiguillettes replaced the sashes for aides-de-camp and equerries. In 1877 an additional narrow stripe was presuribed for lieutenants over eight years' standing, and some other officers. Honorary physicians and surgeons to the Queen were granted a black and gold sash. In I 879 a ship jacket was ordered, and buttons to be worn on the sleeves below the stripes. In 1885 , tunics and helmets with puggarees. In 1888 torpedo-men were given badges. In $\mathrm{r} 889$ a monkey jacket took the place of the blue tunic. All these changes can be seen in orders and circulars, in the Navy Lists of the dates mentioned.

It is only of late years that, at the instigation of the 
Duke of Edinburgh, officers and men have been allowed to grow beards. Up to the end of the Great War hair on the face was almost unknown in the Navy ${ }^{1}$ then there came a period when enormous whiskers were worn by the seamen, and officers wore hair on the sides of their faces close-cut in the shape of a mutton-chop. The rule was to have a gangway clean shaved, three fingers or thereabouts in width from the nose, over the mouth, and under the chin, presumably that the hair should not interfere with their plain speaking. Moustachios were at one time authorized in the West Indies, and some captains allowed their own ideas on the subject to lead to strange freaks. Nowadays, officers and men must adopt one of three fashions: they can shave clean; wear beard and moustachios, the former being trimmed close to the sides of the face, and peaked under the chin; or follow the old system and grow whiskers only.

In I 89I-92 very clear and definite instructions on the subject of dress were drawn up by Admiral Bedford, assisted by a small committee, and these, like all the other instructions since 1825 , may be found in the official quarterly Navy Lists. There is now no e.scuse for divergency from the authorized patterns, for examples of every garment are exhibited in the waiting-room

${ }^{1}$ When pigtails came in, and whether they were ever very general, are questions undecided, but a naval officer, writing in I 80 I, decries the fashion as a French one. Admiral of the Fleet Sir Alexander Milne tells me that the last pigtail sailor that he saw was sitting on the coaming of the main hatch, in the Ganges in '23, having his queue combed and cleaned. Captain Glasscock, in his "Naval Sketch-book," says that the pigtail had entirely disappeared in 1826 . 
at the Admiralty, where anyone may see them, and an illustrated manual has been issued, so that uniformity in the costume of officers and men seems at last in a fair way of being assured.

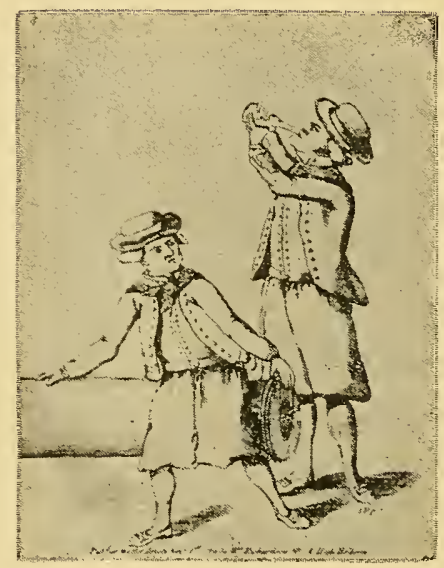

BRITISH SEAMEX. CIRCA I779. (From a contemporary woodcut.) 
APPENDIX

ON THE ILLUSTRATIONS. 



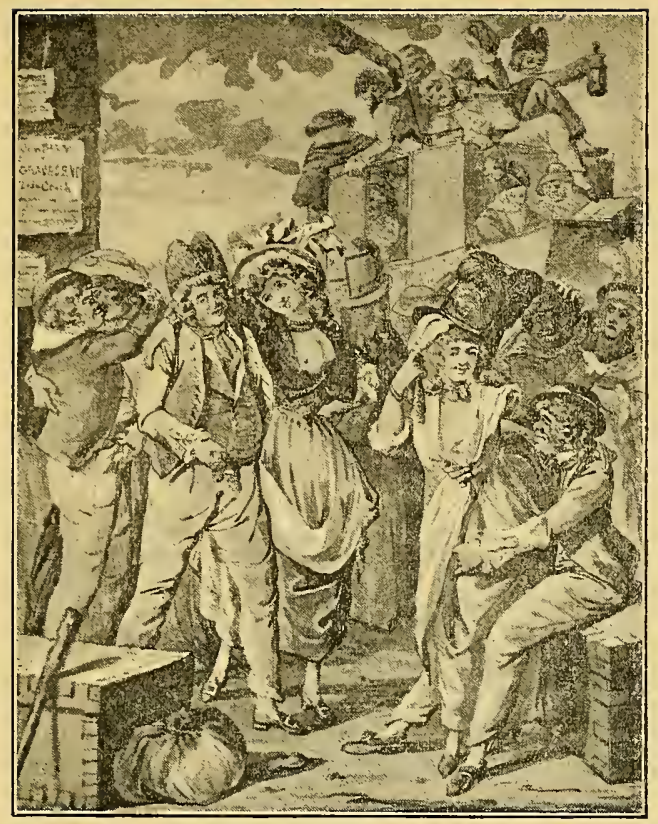

PAID OFF AT CHATHAM, I790.

(Dighton.)

THIS section of the work in its original conception was intended to have for its subject the Navy and naval life as reflected in literature and art. It was proposed to have chapters on the naval historians, the writers on naval law, the writers on tactics and customs, the pamphleteers and lampooners, the biographers, the historians of voyages, the diarists, the naval novelists and play- 
wrights, the exponents of naval character on the stage, the poets and balladists, the marine painters and those who had painted naval portraits and figure subjects, and the caricaturists and humorous artists. But as the materials were garnered it became evident that if this scheme were to be carried out the volume would have to be as large again. Reluctantly therefore the vista was curtailed, and the section consists of explanatory notes on the illustrations, with brief references to the artists whose work has been laid under contribution.

The illustrations are chiefly reproduced from prints and pictures in my own collection or in that of the Print Room at the British Museum. And here I may take the opportunity of thanking Mr. Hull of the department for the advice and assistance he so willingly gave me when making a selection for reproduction. In the Museum the prints are not catalogued under subjects, and therefore, although I went armed with a portentous list of names, I might have spent months in the search for necessary material, had not Mr. Hull come to my rescue. With this gentleman's help I managed in a few weeks to make a fairly complete list of those painters and engravers whose work has connection with our Navy, and I regret to say that there are many who were not represented on the walls of the recent Royal Naval Exhibition at Chelsea.

The principle governing the selection of illustrations for the book has been to use the work of those artists who painted contemporary subjects, and by this means to give a chronological view of art in connection with the Navy as well as to insure, as far as possible, accuracy: It was necessary, however, in dealing with naval history prior to the Stuart period, to make a choice between the 
conventional art which embellishes the works of the old chroniclers, etc., and quite modern attempts at reproducing the vessels of those times. The latter course appeared to be the better, and the pictures of ancient ships (pp. 3, 20I, 209, 21 5, and 229) are from the artistic, and, I believe, trustworthy work of Lieutenant L. Arenhold, of the German Navy.' This beautiful album of pictures is recommended to all who take an interest in naval architecture.

With reference to the ships of the Tudors, there are several well-known pictures which have been reproduced at various times, notably that which forms the frontispiece to the second volume of Sir Harris Nicolas's unfinished "History of the Royal Navy ;" and the print of the Harry Grace a Dieu, in Derrick's "Memoirs of the Navy," which is copied from a series of coloured pictures of ships of that period by Anthony Anthony, some of which are in the British Museum, ${ }^{2}$ and others in the Pepysian Library at Cambridge. It was because these are fairly well known that they were not used; moreover it is probable that the whole of this interesting series will shortly be reproduced and published by the Navy Record's Society.

The earliest English painter whose work has been laid under contribution is Isaac Sailmaker, a not altogether inappropriate name for a marine artist. Little is known about him, except that he was a protéges of Oliver Cromwell, and painted for the Protector the sea battles of Blake and Penn. Possibly this is one reason why his 1 "Die historische Entwicklung der Schiffstypen vom Römischen Kriegsschiff bis zur Gegenwart in 30 Heliogravüren mit erlaüterndem Text." Lipsius und 'Tischer, Kiel und Leipzig.

${ }^{2}$ Add. MSS. 22047. 
paintings are now so scarce. He did not die until $\mathrm{r} 72 \mathrm{I}$, and the picture of the battle fought off Malaga in August, I704, between the fleets of England and France, is the only known engraving of his work (p. I3). Hollar, a prolific artist, who flourished from 1607 to 1677 , did a great deal of marine work, and there are many engravings by him of Dutch ships in the British Museum, but none of English vessels. He was sent to Tangiers in 1669 to make drawings of the forts and defences, and on his way home the vessel in which he took passage was attacked by Algerine corsairs. $\mathrm{He}$ is said to have made a spirited painting of this engagement, but I can find no trace of it.

The Van der Veldes come next in chronological order. The elder Van der Velde began life as a sailor, and was sent to sea by the States of Holland to witness and pictorially illustrate the sea fights between the Dutch and English. He afterwards accompanied Charles II. to England and became marine painter to that king and to James II. His painting of the home-coming of the Merry Monarch (p. 96) is particularly interesting as coming from an eye-witness and a sailor. ${ }^{1}$ His son painted figures as well as ships, and a specimen of his work, taken from a larger picture, and representing a boat action is shown (p. 9). ${ }^{2}$ There was a third Van derVelde, who copied the works of his father and grandfather, even to their signatures it is said, a circumstance which should not be overlooked by those who possess the paintings of these artists.

Another imitator of the Van der Veldes was Peter

${ }^{1}$ Further reference to this picture is made on p. 94.

2 The boat on the left hand is English, as is also the vessel in the background. 
Monamy, who, however, did excellent work of his own, as his paintings at Hampton Court and Painters' Hall attest. He was at his best about $\mathrm{I} 726$, but very little of his work was engraved. The capture of the Spanish manof-war Princesa (p. I7), the original of which is in the Painted Hall at Greenwich, does not give an altogether fair idea of what he was capable of. Among other work done by this artist naval men may like to know that he decorated with ships, guns, and naval trophies a carriage for Byng, Lord Torrington.

A painter of some eminence who flourished about this period was Thomas Baston, who, among other work, did a series of pictures introducing historical occurrences and ships. One of these is the Britannia (p. I $3 \mathrm{I}$, where his name is misspelt Bastion). The historical event represented is not clear, but apparently some notable personages are leaving the ship, for as the barge shoves off, a salute is being fired, while the sailors are manning the yards and rigging, and cheering. The flags are curious. That at the fore is the Admiralty flag, but it bears a motto, "Nec major est Domino." At the main is the Royal Standard, also with a motto, "Post Fulmina Primum." At the mizen is the Union flag of the period. As the barge also flies the Admiralty flag, it may have been that a visit of the Lords Commissioners is here portrayed. This artist appears to have been erratic in his use of flags, for a specimen of his work in my possession shows a ship with the red flag at the fore pierced with the three leopards of the standard.

Following these old masters came Charles Brooking, who was originally a ship-painter at Deptford. Just as he had succeeded in making a name he died, leaving his family in distressing circumstances. His works were 
engraved by Godfrey, Ravenet, Canot, and Boydell. In addition to several pictures of the fleets under Boscawen, Anson, Hawke, and other well-known admirals, he painted a series representing the achievements of the "Royal Family," a title familiarly given to a squadron of privateers named after several members of the reigning house, and commanded by Commodore George Walker. The exploits of this remarkable man have been related by Professor Laughton in his "Studies of Naval History," one of them was the capture of the $N i n f a$, or as she was also called La Nuestra Señora de los Remedios (p. 2 I).

Next we have a group of painters all working about the same time:-John Hood, Francis Swaine, Monamy Swaine, Richard Paton, and Dominic Serres. They cover between them the remainder of the eighteenth century. Dominic Serres was a native of Gascony, born in I72.2. He ran away to sea, and the vessel in which he was serving, being captured by a British frigate, in 1752 , was brought to England, where he became a pupil of Brooking. He was marine painter to George III., and his work is well represented at Greenwich and Hampton Court. The Swaines, father and son, were imitators of the Dutch sea painters, and are mostly represented now by book illustration. Engravings after their work are by no means scarce.

Hood was a shipwright who painted chiefly in watercolours. He is here represented by a beautiful picture of Spithead in 1762 , the vessel in the foreground being supposed to represent the flag-ship of Sir Charles Hardy (frontispiece). A naval battle from his brush was engraved by Houston in 1765 , but it is not in the British Museum. Richard Paton had for his patron Sir Richard Knowles, who took him to sea. He painted numerous battle pieces, 
many of which were exhibited in the Royal Academy. Two of these, Hawke's defeat of Conflans in Quiberon Bay, I759, engraved by Canot, and.Rodney's defeat of De Grasse off Dominica, I782, engraved by Fittler, are given (pp. 27, 46). There are some views of the Royal Dockyards, by Paton, at Hampton Court. He died at the age of seventy-four in I79I.

There were many painters who, beginning work in the eighteenth century, lived into this, and of these several are represented by pictures in this book. Philip James de Loutherbourg, who was born at Strasbourg in I740, was a seaman in the early part of his career. Arriving in England, he became a scenic artist at Drury Lane Theatre, and the painter of numerous historical pieces, which are remarkable not only for their artistic value, but because of the accuracy of the costumes and other details, The cutting out of the French 20-gun ship-corvette. Chevrette, by the boats of the Beaulieu, Doris, Uranie, and Robust, July 2 Ist, I SoI, engraved by Fittler (p. 464); is said to have been painted from sketches made by officers who were present, and many of the figures are portraits. A description of this brilliant affair is to be found in James's "Naval History," ed. I837, vol. iii., p. I48. The changes in naval uniform from I794 to I 8 I 2 , can be traced in Loutherbourg's pictures, and for this reason they are worth attentive study.

J. F. Serres, the eldest son of Dominic Serres, became marine painter to the king and the Board of Admiralty, from I 759 to I 825 , and was employed during the war at a salary of $£$ IOO a month to take sketches of the enemy's coast and shipping. Art was better paid then than in the days when Van der Velde, as marine painter to Charles II., only received $£ \mathrm{I}$ IOO a year. Serres was ruined by the 
extravagance of his wife; a curious story. Thomas Luny began life in Ratcliff Highway, and rather low down in the social scale. In I780, however, he was exhibiting marine paintings in the Royal Academy, and continued to do so up to ISo2. Between I793 and the end of the century he appears to have gone to sea in the Navy with a purser's warrant, and served with Captain, afterwards Admiral, Tobin. Whether he was present at the battle of the "Glorious First of June" is uncertain, but he painted, among many other marine subjects, several of the incidents of this battle and the bringing home of the prizes. About I 8 Io he had a severe attack of paralysis, which deprived him of the use of his feet, and firmly closed his hands so that he could not move his fingers at all. After this, up to about 1835 , he continued to work, although obliged not only to sit in an easy chair all the time, but to hold his brush between the fingerless lumps which had taken the place of his hands. For purposes of delicate manipulation he is said to have held the brush in his mouth. His style is unmistakable. An early specimen is shown (p. 33) in "Rodney's victory off Cape St. Vincent, January 16th, I780," for a copy of which I am indebted to Commander Masterman.

Nicholas Pocock, I74I-I82I, was a master in the merchant navy and had commanded his father's vessels. Encouraged by Sir Joshua Reynolds, he sent to the Academy from Bristol, and exhibited paintings of all the chief battles and engagements of the Great War. The ever-memorable capture of the Spanish 32-gun xebec Gamo by the British I4-gun brig sloop Speedy, Captain Lord Cochrane, on May 6th, I80I, forms the subject of an illustration by this artist (p. 49), the original being in the possession of Thomas Richardson, Esq., who kindly sent 
me a photograph for reproduction. Robert Dodd painted numerous marine subjects from I78I to I809. His work was extensively engraved and very popular. He lived at Wapping, and visited Sheerness and the Nore to make studies. His picture of Captain Bligh being sent adrift from the Bounty was drawn from the description given to him by one of the officers in the boat (p. 69).

The Cleveleys, John and Robert, were presumably brothers. John Cleveley was employed in Deptford dockyard, and attracting the attention of a Royal Academician, who was teaching at Woolwich, became his pupil. He was draughtsman to the Arctic Expedition under Lord Mulgrave, in which Nelson served, and the reproduction of a water-colour on p. 73 shows the boat party of the expedition. He signed himself John Cleveley, junior, but it is not clear why he did so, for his father's name was James. As carpenter the father accompanied Cook on his last voyage. This fact gives interest to the picture of Captain Cook's death on p. 77, for it is signed as having been drawn by James Cleveley and painted by John Cleveley. Robert Cleveley, who flourished from i 769I 809, was marine painter to the Prince of Wales and the Duke of Clarence. He is sometimes called Lieutenant Cleveley, and more often Robert Cleveley, R.N., but there does not appear to have been a naval officer of the name at this date. He painted a very fine picture of the "Glorious First of June," and is said to have. been present on that day, which is quite possible.

Although it is doubtful if Robert Cleveley was in the service, two naval officers at this time did very artistic work. Lieutenant Thomas Yates, R.N., engraved from his own drawings a set of naval actions, which are now scarce. His widow was the beautiful and celebrated 
actress. Yates entered the Navy in 1782 and died in I796; he was shot in a duel. Captain Robert Elliot, R.N., painted several actions and naval incidents about I $784-89$, and some were engraved. The set of war-ships of I780, including the Victory as she was at that date, given on pp. $185,192,235,24 \mathrm{I}, 245$ are said to be by him. With the exception of Loutherbourg and Dodd, the above-mentioned artists almost entirely restricted themselves to shipping, and three later men may be mentioned as doing good work of this description-Knell, Whitcombe, and Huggins. Knell painted in watercolours a set of the war-ships of IS40 for a book called "An Epitome of the Royal Naval Service of England," these are reproduced on pp. 32, 52, 68, I30, IS6, I 88 , I9I, 195. Thomas Whitcombe did the plates of battles and engagements between single ships for "The Naval Achievements of Great Britain from I793-I8I7," and many other illustrations for naval works. Huggins, who was marine painter to William IV., forms a connecting link with the marine artists of to-day, whose work in black and white is familiar to everyone through the medium of the illustrated papers. Of this work I have, by the courtesy of the artists, been able to reproduce several interesting examples. The picture (p. 58 ) which Mr. Melton Prior sketched on the battle-field of El Teb, in the Eastern Soudan, shows us our blue-jackets in action ashore. That of Mr. W. H. Overend (p. 368), painted during the naval manœuvres of 1889 , depicts the Duke of York, as a lieutenant, when in command of No. 79 torpedo boat. The sham fight at Spithead, which Mr. W. L. Wyllie, A.R.A., illustrates (p. 480), will recall the visit of the Colonists in 1886 , and the entertainment given in their honour by the Navy. The Colossus, com- 
manded by Captain (now Rear-Admiral) Cyprian Bridge, was supposed to be attacked at anchor, and at night, by a flotilla of torpedo boats, and a very pretty display was the result. Mr. J. R. Wells, whose work is also represented by some sketches of ships, for which I am indebted to others, has kindly allowed me to reproduce his painting of "Armour-clads at Target Practice" (p. 272), a reminiscence of the review of the mobilised fleet off the Isle of Wight in I889, by H.R.H. the Prince of Wales and the German Emperor. Mr. F. T.' Jane, too, who makes a speciality of torpedo boat experiences, has sent me a sketch (p. 304) made on board one of these craft during a night attack in the manœuvres of I 892 . I should have liked to illustrate by pictures from the brushes of Mr. W. Simpson, Sir Oswald Brierly, and Mr. Villiers respectively, the work of the Naval Brigade in Russia, China, and Upper Egypt, but was disappointed in this respect. Many offers have indeed come to me, to supplement the illustrations, since it became known that I was engaged in the work, but unfortunately too late to allow me to avail myself of them.

Harking back to the eighteenth century we have a group of painters whose work at times is illustrative of naval life, although they are not to be classed as marine artists. Thomas Stothard, R.A., was commissioned by George III. in I 779 to proceed to Portsmouth and to paint a picture of Prince William (afterwards William IV.) on board the Prince George, the vessel in which his royal highness first went to sea as a midshipman. Stothard not only painted this picture (p. 336), which is particularly interesting as showing the first uniform authorized for midshipmen, but two others companions to one another, the first a representation of the men on 
the forecastle of the Prince George, and the second a gun's crew at drill on board the same ship. The forecastle scene, engraved by Ward, is given on p. I53; that of the gun's crew was engraved by Bromley, and they are very fine specimens of this prolific artist's work. Another of his pictures, engraved by Young, is entitled "The British Naval Hero," and represents a young middy leaving his friends to go to sea, the date, $178_{3}$, suggesting that it was painted before the declaration of peace, and as an incentive to the youth of the nation.

Samuel Drummond, A.R.A. (1763-I844), had been a sailor. His father fought for the Pretender in 1745 , and he, when quite young, ran away to sea. It was natural, therefore, that his first picture should be of the sea and of fighting. He painted the "Battle of Trafalgar," and "Duncan receiving the sword of De IVinter," and many other famous episodes and incidents ; but less well known is the picture, engraved by Ward (p. 32), and the occurrence to which it refers. On October Ist, I 809, a French privateer chased the mail packet Windsor Castle, ActingCaptain William Rogers, a midshipman of the Navy, when she was on her way to Barbadoes. At first the packet tried to escape, but finding this course impossible, prepared for resistance. About noon the privateer ran alongside, hailing the packet to strike, and on Rogers's refusal attempted to board. The Frenchmen found, however, that the task was not so easy as they supposed, for they were repulsed with a loss of eight or ten killed and wounded. The privateer then tried to get away, but, the yards of the two vessels being interlocked, without success. Rogers now prepared to turn the tables on his foe, and after discharging into the midst of her crew a 9-pounder loaded with double grape, 
canister, and 100 musket balls, leapt on board, followed by five of his men, and after a severe fight succeeded in capturing his adversary. The Windsor Castle mounted six long 4-pounders and two 9-pounder carronades, and her crew, all told, only amounted to 28 men and boys. The captured Frencl schooner mounted six long 6pounders and one long I 8 -pounder, and when the action commenced carried 92 men, of whom 2 I were killed and 33 wounded. That the heroic Rogers and his little crew should have brought the affair to such a favourable issue reflects the highest honour upon them one and all, and the battle well deserved commemoration on canvas. Those who are interested in naval costume will note the peculiarly shaped hairy cap worn by a sailor just behind Rogers, a cap which apparently enjoyed a vogue among seamen from the days of Boitard to those of Atkinson, or for more than a century.

Henry Singleton's pictures of naval life were few but very characteristic. He painted Nelson boarding the San Josef on St. Valentine's Day, I797, and Captain Trollope aboard the Glatton in the memorable action in I796, which demonstrated the value of the carronade (p. 339). His picture, "The East End of the Town," gives us a glimpse of sailor life in the neighbourhood of the Tower, where Jack, who has come ashore with his pockets well lined with prize-money, appears likely to fall a victim to the attractions of the fair. Francis Wheatley's picture (p. 507) is very similar in treatment, and reminds one of the lines in the "Beggars' Opera,"

"How happy could I be with either, Were t'other dear charmer away!"

Julius Cæsar Ibbetson, who was originally apprenticed 
to a ship-painter of Hull, gained a knowledge of menof-war and ship life when he went as draughtsman to China in Colonel Cathcart's embassy, I788. He was a friend of George Morland, and painted similar subjects. Only two of his pictures among those engraved relate to the sea, "Sailors Carousing," and "The Sailor's Farewell; " they are scarce, and now seldom seen. George Morland did not paint many sea pieces, but he is here represented by "The Sailor's Conversation" (p. 400), where Jack may be supposed to be relating his adventures to a couple of boon companions.

William Daniell, R.A., picked up a knowledge of sea life during a voyage to India, and the representation of the ceremony of "Crossing the Line" (p. I67) is doubtless drawn from the actual occurrence as he witnessed it on board the Hannibal. A. W. Devis also made a voyage as draughtsman in one of the East India Company's vessels, and was wrecked in the Antelope. This is the painter who, after the battle of Trafalgar, went out to meet the Victory and make a facsimile of the cockpit, with portraits of the officers, in the well-known picture. The illustration by George Jones, R.A., of "Smugglers and Coastguardsmen" (p. 47I) is one of a pair by this popular artist, who died in I 869, aged eighty-three, and it exhibits the change in the bluejackets' costume. A curious incident which took place in the Baltic during the Russian War is depicted by E. T. Dolby on p. 463; one of a series of illustrations of the war published by Colnaghi at that time. A party of French soldiers and British sailors are fraternizing on the 6-gun paddler Vulture, Captain Glasse, presumably just after the arrival of the French troops destined for the attack on Bomarsund. 
It would indeed have been surprising if the Navy and naval life, which is intimately bound up with the history of the nation, had been altogether untouched by the caricaturist and satirical painter. But this is not so; on the contrary, we obtain in this direction that which we may search for in vain on the canvas of the marine artists. These latter give us plenty of ships and battles, but we must go to other sources if we wish to see the men who walked the quarter-decks and forecastles of the war vessels as they presented themselves to their contemporaries. There is at the British Museum a splendid collection of satirical and humorous prints, and since a very large proportion of these refer directly or indirectly to the Sea Service, the future historian of the Navy cannot afford to disregard them. Naturally, it was chiefly with a political purpose that these prints and broadsheets were issued, but even thus they throw a light on much which is doubtful in our naval annals. Very few of them bear the name of artist, engraver, or publisher, but there are three men who appear to have had a hand in producing many of them.

R. Attwold, a clever draughtsman and engraver, is notable for his "Naval Nurse, or Modern Commander," a satirical picture representing the captain's cabin of a manof-war about I75O. The captain and his first lieutenant are shown in the newly introduced uniform. The former is taking his ease in a most elaborate armchair, his quadrant, telescope, and pistols hanging on the wall behind him, while a pipe, square bottle, and half-emptied wineglass on the table point to his tastes. Above his head is a swinging compass, and through the stern windows we see a frigate putting to sea. The first lieutenant, a burly fellow who has just entered the cabin, is bowing obsequiously, and from his mouth proceeds the legend, 
"Sir, your commands?" to which the spindle-shanked midget of a captain replies, "See Jack Spritsail have another dozen, damme!" I much regret that this unique picture was spoilt in the process of reproduction, and does not appear here. Apparently from the same hand we have a political lampoon entitled "Next Sculls at the Admiralty," dated I744, and showing the outgoing members of the Board with their possible successors. Here are caricatures of Anson and other well-known naval officers, while on the secretary's table lies a document on which is written "A list of papers between Mr. M[atthew]s and Mr. L[estoc]k." A third and still older print, for it is dated $\mathrm{I} 737$, gives us "The British Hercules" (p. I05), and is the earliest known representation of the British blue-jacket. He bears a scroll, "I wait for orders," and in the background is Spithead with the fleet tugging at its anchors. This was the era of the fruitless negotiations with Spain which ended in war two years later, when the merchants were strongly urging upon the Government the necessity of taking steps to protect our commerce in the West Indies. In I739 Vernon sailed for Porto Bello.

Boitard was also the designer and engraver of many of the satirical prints of this period. "The Sailor's Return," I 744, engraved by Booth (p. 496), shows us an officer of Anson's ship, the Centurion, just returned from his voyage round the world. In the background the treasure captured in the Manila galleon is being conveyed to London, escorted by an armed guard of sailors and marines, while over the waggon waves the British ensign above the flag of Spain, and far away in the distance is the Centurion herself. Boitard also gives us prints representing "British resentment, or the French 
fairly Coopt at Louisburg," I 755, in which are numerous naval figures; Byng's council of war on board the Ramillies which came to the conclusion not to fight, 1756 (p. 85); and "Britain's Glory, or Hawke Triumphant," I759, in which while Hawke and some of the officers are depicted in the uniform of the day as we know it, others wear the uniform coat and with it the kilt or petticoat commonly associated with the blue-jackets only. Some of Boitard's pictures are too coarse for reproduction, notably that of "The Strand in an Uproar"some sailors retaliating for the ill-treatment of one of their messmates in a house of ill fame by throwing the furniture into the streets.

A third engraver who was not above doing a bit of satire or humorous work was Peter Charles Canot, I 7 IO$\mathrm{I} 777$, but he is better known by his engravings after Van der Velde, Monamy and Paton. He was an Associate Engraver of the Royal Academy. The picture of "Greenwich Hill, or Holiday Gambols," I756 (p. 14I), is said to be by him, but it is a good deal more after the style of Attwold, The following verses are given under the picture:

"Ye sweet-scented sirs, who are sick of the sport, And the stale, languid follies of Ball-room or Court, For a change leave the Mall, and to Greenwich resort ;

There heightened with raptures, which never can pall,

You'l own, the delights of Assembly and Ball

Are as dull as yourselves and just nothing at all."

Of course William Hogarth of imperishable fame did not neglect the sea altogether. When he went for his memorable trip round the Isle of Grain he gave us a glimpse of Sheerness dockyard as it was in 1732 , but in two later plates he depicted the sailor as he saw him 
ashore. In "The Stage Coach in a Country Inn Yard," I747 (p. 66), he has put on the top of the coach a sailor and a soldier, the latter a woebegone looking party, who has evidently fared badly wherever he has been. But the sailor is jovial and jolly, although his position seems somewhat insecure to anyone unaccustomed, as Jack is to hold on by his eyelids. That we may be in no doubt as to where he comes from, Hogarth has equipped him with a bundle marked in large letters Centurion. A precisely similarly attired seaman is to be found in "The Times," Plate I., where, bucket in hand, he is assisting to put out a fire.

John Collett was another painter of humorous scenes in the style of Hogarth, and the fact that his father was employed in the Admiralty may have given his art a bias in the direction of subjects connected with sailors. At all events, most of his pictures represent Jack ashore, and many of them, published by Messrs. Carington Bowles and Sayer, of Fleet Street and St. Paul's Churchyard, are not suitable for this book. The picture on p. 432, "A Rescue, or the Tars Triumphant," is said to represent an incident which actually occurred about $\mathrm{I} 768$, when the press-gang, instead of being employed in its proper vocation, undertook to release a young lady friend. of their commander from the custody of the myrmidons of the civil law. If Collett is to be trusted they succeeded most effectually in their endeavour. Under various names as one partner left and another took his place, the printselling firm of Carington Bowles mentioned above produced a great part of the cheap illustrations of the period, and a curious collection of their publications is to be seen in the British Museum Library. It contains specimens of the work of almost all of the artists about to be men- 
tioned, to many of whom the remark made about Collett must also apply.

Gilray, Rowlandson, and Bunbury have all left us representations of the seamen of their time, and Rowlandson of the naval officers. Whether Gilray ever saw any sailors out of London is doubtful, but Rowlandson and Bunbury both went to Portsmouth ; we know the ships they visited, and some of the men they drew. The pressgang was a fruitful subject for illustration to the satirists of those days, and in "The Liberty of the Subject," by Gilray (p. 4I I), we have most likely a scene he had himself witnessed in the neighbourhood of Wapping. It is worth while comparing with the sailors here depicted by Gilray, those in a couple of woodcuts of the same date, I779 (pp. 497, 515), which are signed "I. P." These formed part of a set of illustrations issued by Mr. Richardson, a printseller of High Holborn, or they may have been originally in a book. Those in my possession are marked 2 and 4 , and I have seen a third marked 7 . It would be extremely interesting if the whole set could be brought together again, especially as it is highly probable, these three being of sailors, that among the others were some of the officers. Gilray always drew his sailors in this costume, and, moreover, when he coloured them used the same colours, a bright red and yellow kerchief knotted loosely round the neck being most conspicuous.

Of Rowlandson's work we have numerous examples. In 1784 he took a trip to Portsmouth to visit the wreck of the Royal George, and as in all his pictures we find the costume of this period, even in those which were issued, if not painted, after the uniform of the officers was changed, it may be assumed that this was the only visit 
he made to the port. However, he made good use of his few days there, for in addition to several views of the harbour, the Point (p. I27), and Gosport, he made sketches on board the Hector of the officers of that ship and of the men at work 'tween decks during an imaginary action (p. 373). In describing the picture on p. 30 as "The Ward-Room of the Hector," I have followed the lettering of a print in my possession, but it is more likely intended to represent the admiral's or captain's cabin, for the officers are nearly all of the latter rank. In the last decade of the eighteenth century Messrs. Ackermann the publishers, commissioned Rowlandson to draw ten plates of naval costume. The complete set was not issued until I799, and actually shows the full dress of I797, although, as a proof that the artist was aware that a change had recently taken place, in the only coloured plates I have seen, the white lappels of the coats of the admiral and captain are painted blue, thus making them conform to the later regulations.

Bunbury visited Portsmouth in 1785 , and there made the sketch of the men of the Edgar (p. 3 I5), doubtless from a group that he saw on the beach. The Edgar, Captain Adam Duncan, was guardship in Portsmouth Harbour from April, i 784, to August, I 786 , and the name is on the cap ribbons of the sailors drawn by the artist. The little vignette entitled "Jack's Farewell" belongs to the same period.

Partly contemporaneous with these men we have the Cruikshanks. Isaac, the father, who died in I 8 II, Robert Isaac, the elder son, who died in 1856 , and George, who died in I878. All three did work which has connection with the Navy, and Robert had been to sea as a midshipman in the East India Company's service. 
The elder Cruilsshank did many of the humorous illustrations published under the title of "Lawrie and Whittle's Drolls," and he also appears to have worked for Carington Bowles. A specimen of the kind of thing published in the "Drolls" is that entitled "The Honest Tars and Marines of the Argonaut, contributing nobly against the enemies of old England" (p. III). This is obviously intended to represent an actual occurrence, for underneath the picture we are given, "the original letter addressed to their commander, Lieutenant P. Hue."

$$
\text { "SIR, }
$$

“We the Seamen and Marines of His Majesty's Ship Argoncut, under your command, desire to give Ios. each man out of our wages, to drive before us into the sea all French scoundrels and other blackguards that would take their part.

"We are, your faithful servants,

$$
\text { “* } * * \quad *
$$

"Argonaut, Jan. 3Ist, I798."

Another "droll" is entitled "True Blue, the Jolly Tars of old England paid off at Portsmouth" (p. 198); and a somewhat similar picture by Dighton, also a painter of humorous pieces and caricatures, represents a party of blue-jackets paid off at Chatham and bound on the Gravesend coach "in pursuit of pleasure" (p. 5 19). Many of the "drolls" were headpieces to nautical ballads, and some of these are very natural and artistic (pp. 48, I66). George Cruikshank was assisted by, or worked in combination with, Captain Marryat and Lieutenant Sheringham on some of his naval pictures. The picture of the 
Admiralty Waiting-Room (p. I47) is one of those prepared by Marryat, whose own portrait is said to be depicted in the gentleman leaning against the wall on the left hand.

Henry Alken is more noted for his sporting illustrations than for those having reference to the Navy, but the picture of "Jack's Wedding-day" is characteristic of his style (p. 485). William Heath did many humorous naval sketches, that of the midshipman on half-pay commemorates a state of things which occurred at the termination of the war (p. 98). "When this ship paid off, with many others, at the close of I \& I4," writes Captain Sinclair, who was a youngster in the line-ofbattle ship referred to, "every mate and midshipman went through the ordeal of what was then styled "passing for a gentleman.' If you could not show that you were of gentle blood; or, what was of far more consequence, get some political influence to bear, you were simply discharged to the shore, and were considered to have no farther claim upon the service." A little later, however, and some of the older men of those who were thus discharged were granted a small pittance in recognition of their long service, and thus it was not a very wide stretch of the imagination which pictured a mid on half-pay sitting on his sea-chest with the implements of his art around him, blacking boots for a livelihood.

Heath's sketches of the men employed afloat and ashore in the Preventive Service were drawn from life (pp. 33I, 355). The picture of a press-gang (p. 425), by Hablot K. Browne ("Phiz"), is of course imaginary, and formed one of the illustrations to a book called "Paul Periwinkle," by W. J. Neale, published in I 840 , and sometimes to be seen on secondhand bookstalls; it gives 
a fairly accurate idea of the dress of officers and men at the date to which the story refers.

Several of the old woodcuts, etc., reproduced in the book are unsigned, such as, for example, those of the midshipman's berth in I84I and I854. To the former is attached an "Explanation."

The grog is out, as the black-jack and the broken bottle in the foreground show; the gallant youths before us, therefore, fly to some other recreation. Although an engagement has recently taken place, visible from the wounds of several, frolics are the order of the day, and their sleepy comrades suggest the common trick of blackening the faces of two of the sleepers, that, on waking, each may deem the other the butt. The merry lieutenant (a visitor) with a burnt cork is busily engaged on the face of a young midshipman, who, buried in sound slumber amidst a combination of noises, becomes fair game to all. One midshipman eagerly waits the lieutenant's finishing touch to wake him by dropping something into his open mouth, whilst another has a speaking trumpet ready, and inflates his lungs to start him with a loud halloo. At the same time a young piclkle is busy in front, sewing the coats of two sleepers together, anticipating, from his features, much fun in their suddenly upsetting each other. Even Mungo, though in the background, is not backward in enjoyment ; nay, the midshipman just returned from his watch and hanging up his coat, indulges in a smile, forgetting that empty bottles are his allowance. At the other end, the clerk, whose face has been already smutted, is just being waked by a master's mate, seemingly a little groggy. He tells of the trick that is being played upon the other, and the drowsy clerk, yawning and suppress- 
ing a stretch, proclaims the other a sleepy fellow properly served, while two youngsters smile and whisper at his simplicity. Another master's mate, just returned from a chilling watch as his red face shows, has prudently provided himself with a bottle from another mess, which he exultingly brings in, but is pursued and collared by a midshipman, who seeks to recapture the prize. The confusion of such a scene is additionally illustrated by a medley formed of chessmen, a backgammon board, a desk, a logbook, a horn, etc., whilst the broken candle in the bottle, inundating with tallow the renowned "Hamilton Moore," shows the great care that is generally taken of his valuable instructions. ${ }^{1}$

Although the picture is dated $\mathrm{r} 84 \mathrm{I}$, and was certainly issued in this state about the time of the war on the coast of Syria, a somewhat similar illustration, probably the original of this, was published in I $S_{2} \mathrm{I}$ and inscribed, "Drawn by a Naval Officer." It was strange to me, whose personal experience of gun-room life dates from the sixties, that in both these pictures of the midshipmen's berth there should be persons smoking. Not only were the regulations most stringent on this point when I went afloat, but smokers were much more uncommon than in the present day. The only explanation I can give for this apparent anachronism is that there was in "eighteen hundred and war time," a relaxation of rules which was wholly exceptional.

The illustrations of the six dockyards, dated $1736-39$, are signed, "Sam: and Nathl. Buck, del: et scul: Garden Court, No I, Middle Temple, London." A later set by

${ }^{1}$ Hamilton Moore was the seamanship writer of the earlier part of the century, the predecessor of D'Arcy Lever, Alston, Nares, and others. 
John Milton, engraved by Caton, I760-177I, were exhibited in the Naval Exhibition.

No attempt has ever been made before to illustrate a history of the Navy with pictures by artists contemporary with the events, etc., described, and the list given above must not be considered complete or nearly so. In these final pages the intention has been no more than to indicate briefly the great mass of matter of this kind which is worth study, and the sources from which it can be obtained.

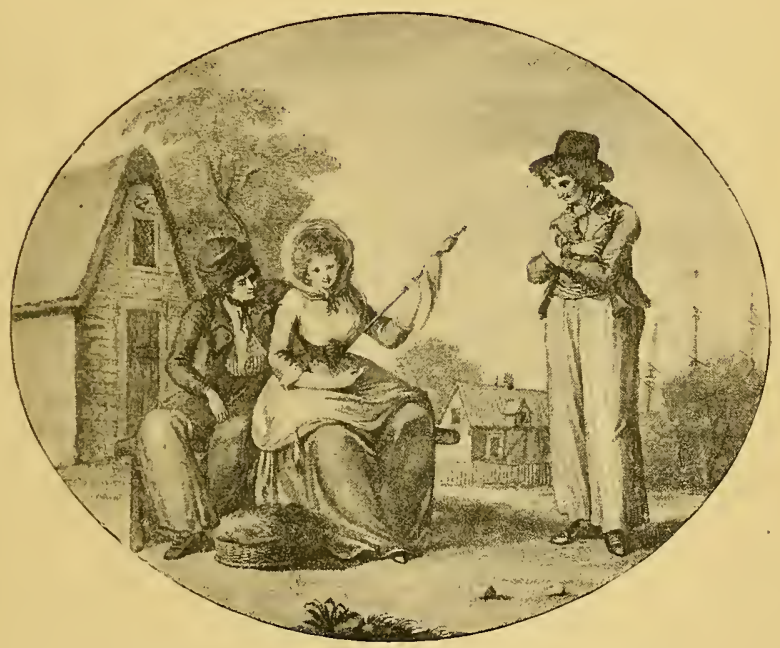

JACK'S FAREWELL, I7 85 .

(Bunbury.) 



\section{INDEX.}

ACADEmy, Royal, I 54 .

Account, general, of the Navy, I27. Accountants in the Navy, duties, pay, etc., 454 .

Action, going into, old and new, 442.

Admiral, and Admiral of the Fleet, duties, pay, etc., 340, 361, $45^{\circ}$.

- Lord High, I06, I Io, 450. mercantile, Iо6.

Rear, duties, pay, etc., 450. use of term, I03, 322 .

Vice, duties, pay, etc., 450.

Admirals, badge of office, I06; flags, origin of, 92 ; seals, 90 .

Admiralty, the, administration of, I I3; badge of, I 82 ; bargemaster of, I5I ; "Black Book" of, I6S ; captains' room there, I50; Civil Lord of the, I12, II 3 ; droits of, I08; flag, 94, I 83 ; High Court of, I03, 167 ; instructions, 178 ; library, I5I ; Lords of, II 2; Office in 1626 , and later, 147 ; seals and marks, I $\$ 2$.

Alais, W., his book of costumes of the Navy, 5I2.

Alcoholic beverages, 138. See also Beer, etc.

Alfred, King, his ships, I78, 203. Algerine rovers, 414 .

Algiers, Lord Exmouth at, 82.

Alken, H., his caricatures, 540; his "Jack's Wedding Day," 485 , 540.

Amboyna, massacre at, 26.

American colonies of Spain, 36 .

- colonies, why lost, 42 .

wars, 40, 47, 432, 435. Sce

also zinder War.

Ammunition, 274.

Anglo-Saxon navy, 317, 3IS. See also under Saxon.

Anson, Aclmiral, 38, 66, I75,

534.

Antarctic explorers, 73 .

Apothecaries Hall and the Navy surgeons, I 703, 395 .

Appointments, sale of, I I9.

Apprentices, mercantile, I 59.

Architecture, naval, 20I; in the days of wood and canvas, 235 ; since, 257 .

Arctic explorers, 72. See also Antarctic.

Arenhold, Lieut. L., his pictures of early English ships, 3, 201, 209, $215,229,521$.

Armada, the, 19, 22, 23, 48S. See also Spanish.

Armour, compound, 287.

- early, at sea, 488 .

— plated ships, $257,28_{3}$.

Armstrong guns, 268.

Arnold-Foster, H. O., on going into action, $44 \mathrm{I}$. 
Art, naval (on naval pictures and prints), 519-543.

Articles of war, I74.

Artificers, modern Navy, pay, etc., 473.

Attwold, R. See Caricature.

Astrolabe, use of the, 22 I.

Asylum, Royal Naval, 158.

Atkinson, J. A., plates of costumes of the Navy, $5 \mathbf{I} 2$.

Australian discovery, 75 .

Austrian Succession War, 38.

BACON on "strength at sea," 20.

Ballast, burying the dead in it, 133 .

Ballasting of ships, 132 .

Band, the ship's, 476 .

Banyan days, 134 .

Barbette turret-ships, 290.

Barfleur, battle of, 34, 35 .

Bartholomew Diaz, I8, 70.

Baston, Thos., and his picture,

H.M.S. Britannia, I72I, I3I,

523.

Batten, Sir W., 344.

Batteries, floating, 285 .

Battle flag, I92.

- of Barfleur, 34, 35 .

— of Beachy Head, 3I, 34.

- off Cape Finisterre, 38.

— of Cape Passaro, 37.

— of Cape St. Vincent, 45.

- of Crecy, I 5.

—— off Dominica, 42.

"—_ of Dorking," 54 .

__ of Harfle'ur, I6.

—_ of "Lespagnols sur mer," I 5 .

—_ off Lowestoft, 28.

- off Minorca, 36 .

_- of the Nile, 45.

- off North Foreland, 29.

__ of Poitiers, 15.
Battle of Quiberon Bay, 12, 37, 39.

— off Rochelle, 15.

— off Saint Mahé, 14.

- of St. Valentine's I)ay, 45.

- of Solebay, 30.

- off the Texel, 30 .

- of Trafalgar, I2, 46, 6I.

Battles of Dover Straits, I 2, 29, 88. Beachy Head, battle off, $1690,3 \mathrm{I}, 34$. Beards, whiskers, and moustachius in the Navy, $5^{1} 5$.

Beer, quality of, 136 ; ration of, . I 36 ; storage of, 132 .

Benbow, Admiral, 357 .

Bermuda, I65.

Binnacle, a, eighteenth century, 207.

"Black Book" of the Admiralty, 168, 169.

“Black-eyed Susan," etc., 506.

Blackwall Dock, I65.

Blake, Admiral and General, 28, $343,345,430$.

Bligh, Captain, and the mutiny of the Bounty, 69, 527 .

Blue, the colour, and the Navy, 318, 486,488 .

- ensign, 92 .

Bluecoat boys and the Navy, 374 .

Bluejackets in the Navy, 506, 534 . $\mathrm{Sec}$ also Blue.

Board of Admiralty, IOI ; constituted, IIO; the Board Room, I 50. See also Admiralty.

- of Longitude, I24.

Boatswains, 318, 329, 376, 404, 47 I, 47.5 .

Boilers, etc., see Steam.

Boitard's prints. See Caricature.

Bombay, 165.

Boreman's Trust, Sir William, 160.

Boscawen, Admiral, 39. 
Bounty, mutiny of the, 69,527 .

Bounty system, the, $423,427,432$, 435 .

Boys in the Navy, 363 ; entry of, outfit, studies, fees, etc., 445, 467 ; signal, 472 . See also Midshipmen, etc.

Breach-loading ordnance, 270.

Brewhouses, I 37 .

Bribery, 386. See also Corruption, Pay, etc.

Brig, a, IS40, ISS.

Britannia training ships for boys, 445.

"British Hercules, The," 1737 (satirical print), I05, 534 .

Britons, fleets of, temp. Roman invasion, 7, 486 .

Broad arrow, the, I $\$ 4$.

Brooking, C., and his naval pictures, 523 ; his "Capture by Privateers," I 747, 2 I, 523 .

Browne, H. K., his picture, "A Press-gang at Work," 425, 540 . Brunel the elder, 293.

Buccaneers, temp. Eliz., 22.

Buckingham, Villiers, Duke of, I 47. Bucks' views of the dockyards, 542 . Bunbury, his naval pictures, $537,53 \mathrm{~S}$, 543 ; his "Seamen of H.M.S. Edgar," I 785, 315, 537.

Burrows, Prof., on the early Navy, 3 IS.

Buscarles, Anglo-Saxon, 317 .

Byng, Sir G., Viscount Torrington, $3 \mathrm{I}, 37,195,355$.

Byng's Council of War (caricature), $8_{5}, 535$.

Савот, $\mathbf{r} 8$.

Cadets, naval, 364 ; training, pay, etc., 445 .
Cadiz, destruction of the Armada at, I9.

Canada, war with the French in, 39. Canot, P. C., his prints. See Caricature.

Captains, 318, 324, 34.3, 367, 371; $38 \mathrm{I}$; modern conditions of service, pay, etc., 448. See also Officers, etc.

Captain's clerk, the, $38 \mathrm{I}$.

- Room, Admiralty, i 50.

Caricature prints, 533; Attwold's " Naval Nurse," etc., 533, 535 ; Boitard's prints, 533; "Byng's Council of War," $8 j, 535$; Canot, P. C., 535 ; Collett, J., 536; "Fighting a Gun in Action" (Rowlandson), 373; Hogarth, 535; of midshipmen, 214, 256 ; "Paid off at Portsmouth," I797 (I. Cruikshank), 198; "The British Hercules," I 737, I05, 535 ; "The Midshipmen's Berth," I45, I 59, 54I ; "The Press-gang", (Gilray), 4II ; "Waiting-room at the Admiralty" (Cruikshank), 147. See also Gilray, Rowland. son, etc.

Carpenter, ship's, $376,408,474$.

Carronade, the, 253.

Cartridge case, ship's, 234.

Chain cables, 252.

Chaplain of the Fleet, 129, 337, 399, 450.

Chaplains' journals, 400.

Charles II., navy of, I08, 353, $38 \mathrm{I}$.

Charters, I03.

Chatham Chest, the, 124, 139, I 55 , $4 \mathrm{I} 5$.

Docks, I00, I64.

Chandos, Sir John, 15.

Chaucer's shipman, 488 . 
Chest, the Navy. See Chatham Chest.

Chivalry, the Court of, I75.

Christ's Hospital, midshipmen from, 374.

Chronometer, invention of the, 255 . Cinque Ports and their navy, I I, 13 , 87, I02, 103, 3I 7, 487 .

Civil Lord of Admiralty, the, II2, II3.

- Service examinations for the Navy, 45I, 454.

Clephan, Capt. Jas., 358 .

Clerk of the Acts, I23.

Cleveley, J. and R., and their paintings, 527 ; “H.M. Ships in the Arctic Sea," I 773, 73; " Death of Captain Cook," 77, 527 .

Clothing of seamen, I43, 491. See also Slops.

Club, Royal Naval, 496.

Coal, petroleum in place of, $3 \mathbf{I} 2$.

Coastguard, 83, I29, 448, 470; divisions of the service, etc., 482 . Cobden, Richard, on the Navy, 55 .

Cochrane, Captain Lord, 526.

Cockburn, Admiral G., 283 .

Cockswain, or cogswain, the, 336 , 406.

Cocoa ration, I42.

Collingrwood, H.M.S., I886, 197.

Collingwood, Admiral, 45.

Colomb, Admiral, on the Navy, 5, 27.

Colonies, the, 55 .

Colours, 177. See also Flags, etc.

Columbus, i8.

Command of the sea, $2 \mathrm{I}$.

Commanders, modern, conditions of service, pay, etc., 448 .

Commemorative names, 188 .
Commerce, defence of, 58; destroyers of, 44 .

Commercial development, $\mathbf{\text { Io. }}$

Commissioned officers, the first, 359 . Commonwealth flag, 94 .

- Navy of the, 379, 386, 394. See also Cromwell, Blake, etc.

Communication with dependencies, 56.

Compartments, water-tight, 29I.

Comptroller of the Navy, I07, II 2.

Conning tower, the, $44 \mathrm{I}$.

Contractors, private, 146 .

Contracts for provisions, I33, 139.

Cook, Captain, 74, 255, 357, 430 ; his voyages as published, 75 .

Cooks, naval, 139, 157, 376 ; and stewards in modern service, their training, pay, etc., 475,484 .

Cordage, marks in, 184.

Cordite, 275 .

Corruption, $38 \mathrm{I}$; in administration, I 2O ; of officers, II 7, I 57, 347. See also Bribery, Contracts, Pepys, Purser, etc.

Corunna, Drake at, I9.

Costume of the Navy, 485 ; plates illustrative of, 5I2. See also Paintings, etc.

Cotton famine, the, 54 .

Council of the Sea, I48.

Court martial, 96, I74, I81.

— of Chivalry, I75.

Cowes dockyard, 165.

Crecy, battle of, I5.

Criminal law of the Navy, 175 .

Cripples as cooks, I39, 484 .

Cromwell, 27, 28, 347, 521 ; his navy estimates, I07; his reforms, 225,416 .

Cross of St. Andrew, 94 ; of St. George, 88 ; of St. Patrick, 95. 
Cross-staff, a, fifteenth century, 325 . Cruikshanks, the, their prints, 538 ; "Paid off at Portsmouth," I797, 198, 539 ; sketch, "Waiting Room at the Admiralty," I $47,539$.

Cruisers, the new, 262.

Customs of the Navy, I22, I67.

Cutter, a, I $\$ 40,52$.

DAmme, engagement at, II.

Dampier, Admiral, 73, 357.

Daniell, W., A.R.A., 532; his picture, “Neptune's Revels," I 67, 532.

Dartmouth training-ships for boys, 445.

Deal, I65.

Death penalty, the, I76.

Decks, under-water, 292.

Declaration of Paris, 60. of war, $6 \mathbf{I}$.

Defensive power, development cf, 283 .

Deptford dockyard, I35, I43, I53.

De Ruyter's Dutch Fleet in the Medway, I667, 29.

"Destroyer" boats, new, 265, 307.

Devonport dockyard, I736, I2I.

Dighton, his picture, "Paid off at Chatham," 5I9, 539.

Dipping the ensign, I79.

Director, of Greenwich Hospital, 129; of naval construction, I27 ; of naval ordnance, I29 ; of transports, 128 ; of works, 128.

Distillation of water, 140.

Dockyards, I07, 123, I43, I 53, I62, 542, 543. See also Portsmouth, etc.

Dodd, R., and his picture, "Mutiny of the Bounty," 69, 527 .

Dolby, E. T., 532; his picture,
"French and English Fraternizing," I $854,463,532$.

Dominica, battle off, I 782,42 .

Double-bottom ships, 29I.

Dover Straits, battles of, 12 16, 1666, I2, 28, 89 .

Drake, Sir Francis, I9, 33, 70, I73, 332, 343.

Dressing ship, 96, I 80 .

Dress of officers and men, 485 .

Droits of Admiralty, 108.

Drummond, S., and his naval pictures, 530.

Dundonald, Lord, his tubular boiler, 301.

Dupuy de Lôme, M., 284 .

Dutch, the, in the Medway in 1667 , 29.

- wars, the, 420. See also under War, etc.

Duties of officers, 177,443 . See also Officers, and under separate heads as Captain, etc.

EAST India Company, I46.

Edward III. at the Battle of "L'Espagnols sur mer," I4, 320.

Electricity, use of, 3 I 2 .

Elizabethan navy, 2 I, I I 7, I3 I, 333, 412,487 ; names of ships, 187 .

Elliot, Captain R., 528 .

Engineer officers, duties, pay, etc., $45 \mathrm{I}$.

- students, I 59.

Engineers of the Royal Naval Reserve, 458 .

Engine room staff, the, 472 .

Engines, marine, 295.

Englemann, painter, 459.

Ensigns. See Flags, etc. Epaulettes in the Navy, 503, 508, 5 I2. 
Equipment of the Fleet, II5. See also Navy, etc.

Esquimalt, establishment at, I65.

Essex and Howard, Lords, and the Armada, I9.

Eustace the Monk, I2.

Examinations for entering the Navy. See under the heads of office.

Exploration ships, 69, 329.

Explorers, great, 7 I.

Exports, annual value of, 56, $5^{8}$.

FALCONER, William, poet and purser, 369,383 .

Felton, 148, 349 .

Fenner, 23.

"Fighting a Gun in Action," I 782 (after Rowlandson), 373 .

Fire-ships, cost of, Ir 7 .

Fish rooms, I39.

- supply of, 134 .

Fishing tackle, 182 .

Flag, honour of the, 178,188 .

- officers, $364,449$.

- signalling, 98 .

Flags, 85 ; admirals', 92 ; of command, 89 ; neutral, 56,60 ; transfer of, 60 ; to denote defeat, 96 . See also Colours.

Flinders, Captain, 75.

Flogging, $173,439$.

Food stuffs, supply of, 54. See also Provisions, etc.

Foreign, alliances, 67 ; depôts, 143 ; intelligence department, 130 ; navies, 67.

Forts versus fleets, 64 .

France, and Spain, in the Channel, 40 ; corsairs of France, 36 ; wars with, 30, 43. See also Wars, etc. Franklin, Sir John, 77 .
Freebooters and rovers in the Thames, temp. James I., 4I 4 . Free trade and the Navy, 54 .

French armour-clads, 285.

— the, in Canada, 39.

Frigates, temp. Seven Years' War, 238 ; I840, 68; I 843 , I I4, I86, 528 .

Frobisher, Sir Martin, 19, 33, 7o, 332.

Froissart, 15.

Froude, Professor, on English seamen, 23.

Function of the Navy, 6.

Funerals at sea, 180 .

Gentlemen volunteers in the Navy, $346,35 \mathrm{I}, 355$.

Gibraltar, 36, 42, r65, rg8.

Gilbert, Sir Humphrey, 22.

Gillingham Fort, 164.

Gilray, James, his naval prints, 537; his "The Press-gang at Work," I 779, 4I I, 537 .

Goni, M., his naval costumes, 403 , $4 \mathrm{IO}, 449,46 \mathrm{I}, 475,5^{\mathrm{II}}, 5 \mathrm{I} 2,5^{\mathrm{I}} 3$. Gosport yard, 143 .

Graham, Sir James, his reforms, I 26. Greenwich, I4I ; the Hill, I4I, 535; the hospital, 124, 129, 154, 428; the hospital school, $15^{8}$; painted hall, I60, 489 ; the palace, I52; the pensioners, $15^{8}$; pensions, 483 .

Grenville, 343 .

Grog, and "Old Grog," 137.

"Guardians of the seas, the," I02.

Guerre de course, $36,44,6 \mathrm{r}$.

Gunboats, 283 .

Gunners, early, 330, 376, 407 .

Gunnery, improvements in, 252 ; schools of, 162 ; training, 44r, 469 . 
Gun-room, 407; and ward-room, 368.

Guns, ships', 267.

Half-pay, 35S. See also Pay, etc. Halifax, establishment at, I65.

Hammocks introduced, 132 .

Harfleur, battle of, I6.

Harp, the, in the flag, 94.

Harry Grace ì Dieu, the, I5I5 (Arenhold), 215.

Harvey's steel armour for ships, 287 .

Harwich, I65.

Hawke, Sir E., 27, 37, 38, 43 I.

Hawkins, Sir John, I9, I 16, 219.

Sir Richard, 488.

Heath, W., his sketches of costume, $98,32 \mathrm{I}, 325,540$.

Henry III., his fleet, 320 .

- V., his fleet, 327 .

- VIII., I9, 487 .

Prince, " the Navigator," I 7 .

Herbert, Earl of Torrington, 3I, 34, IOg.

Hogarth, his naval characters, 66, 535.

Holland, first war with, 1652-54, 27 ; second war, $1665-67,28$; third war, $1672-74,29$; sea power of, 26. See also Dutch.

Hollar, his naval pictures, 522 .

Hong Kong, station at, 165 . Honour of the flag, the, 178, I 88 .

Hood, John, marine painter, 524 .

Hood, Sir Samuel, 4I.

Hosier, Admiral, I33, I37.

" Hosier's Ghost," I 37.

Howard of Effingham, Lord, 19, I32, 332 .

Howe, Sir Richard, I4, 4I.

Hubert de Burgh, I2.

Hudson's Bay, 36 .
Huggins, marine painter, 523 .

Hughes, Sir Edward, 4I, 42.

"Huntsman commanders," I 40.

Hus-carles and. Bus-carles (Anglo-

Saxon) in the Thames, 317.

Hydrographer of the Navy, the,

129.

Hydrography, Navy work for, 79 .

Hymns, singing, I $\$ 2$.

IbBetson, J. C., his naval slietches, 532.

Imperial defence, 55, 64 .

Imports, $5^{8}$; annual value of, 54 .

Impressment, 104, 316, 322, 4I I, $417,423,433,540$; exemptions from, 4I2.

India, gift of sea power, 39 ; naval defence of, 56 .

Instructions for the Navy, I20.

Insularity of our country and naval power, $5^{\mathrm{I}}$.

Intelligence, Office of Naval, 129.

Invasion, 51 ; by Romans, 486 ; by

Saxons, 7 ; by Danes, 8 ; by Normans, 8 ; by the Dutch in 1667 , 29 ; in 1688,31 ; of England, 46 ; of Ireland, 45 .

"Invincible Armada," the. See Armada.

Ironclads, etc., $263,265,277,282$, $285,29 \mathrm{I}$.

Iron and steel clads, 284. See also Armour.

JACK, the (flag), the pilot jack, and the Union Jack, 92, 96.

" Jack Runnymede," Jerrold's, 433.

“"Jack's Quid," old woodcut, 48.

"Jack's Wedding Day," caricature by W. Alken, IS26, 485 . 
James I., navy of, I I 8, 413, 4I4, 487. II., his navy, 359 .

Jane, F. T., his sketches of torpedo boat practice, 529 .

"Jenkins's ear," the story of, 38 .

Jerrold's "Jack Runnymede" and the press-gang, 433 .

Jervis, Sir J., Lord St. Vincent, $45,439$.

Jews, trading on board, 1822, 426.

Jobbery, 395. See also Corruption, etc.

John, King, his navy, I03.

Jollies, the $=$ the Marines, 478 .

Jones, G., R.A., 532 ; his picture, "An Affray with Smugglers," I 840,47 I, 532 .

Journals, ships', 360 .

Junk, salt, I 39.

Jury of mariners, I04.

KEEL hauling, I 72.

Ketch, a, I823, I63.

Kinburn, bombardment of, I855, 285.

King's letter boys, I61, 354. See also Midshipmen, etc.

Knell, marine painter, 528 .

LADY of the gun-room = watchman, 408.

Laughton, Prof. J. K., his "Studies of Naval History," etc., 28.

Law, naval, IO2 ; practice of, 173 .

Laws of Oléron, 168.

Lent, keeping of, 134 .

“L'Espagnols sur mer," battle of, I 5,320 .

Levy of ships, 104.

Libraries, officers, I43 ; seamen's, 142.

Lieutenants, 334, 349, 367, 444 ; modern, conditions of service, promotion, pay, etc., 447, 5 I I.

Lieutenants, Sub-, 375 .

Lightning conductors, 255 .

Lime juice, I4I.

Line-of-battle ships, etc., from old prints, etc., 32, I 30, I 85, 235, 24I, $245,25 \mathrm{I}, 257,259,26 \mathrm{I}, 528$.

Line, crossing the, "Neptune's

Revels" (after Daniell), I67, 532. Lisbon, 165 .

Lloyds' patriotic fund, 158 .

Loblolly boy, the, 398 .

Longitude, discovery of, 405.

Louisburg, 39.

Loutherbourg, P. J. de, his naval pictures, 525 .

Lowering topsails, 178 .

Lowestoft, battle of, 28 .

Luny, T., and his pictures, 526; his "Rodney's Defeat of De Langara," I780, 34, 526.

Machinery, other than for propulsion on Navy ships, 3 Io.

Magellan, I8.

Mahan, Captain, on "Sea Power," $27,47,61$.

Malta, I65.

Manning the Navy, 4II, 463. See also Navy, etc.

- yards, I8o.

Man-of-war, the term, 205.

"Mare Clausum," Selden's, 25, I 78 .

Marine Office, the, I24.

— painters. See Paintings, and names; also Naval Art, 5 I9.

Marines, the, 359, 422, 478 ; en-

listment, pay, etc., 459, 460, 478 .

Maritime law, I 72 .

Marryat, Captain, I47, I 50, 372, 539. 
Masters' assistants, 159.

Masters in the Navy, 332, 342, 374, $375,379,406,46 \mathrm{I}, 509$.

Matthews, his action off Toulon, 38 .

Medical comforts, 182 .

- officers, modern, entry, service, pay, etc., 445 .

Men-of-war in Nelson's time, 243. See also Ships.

Mercantile admirals, Iо6.

Merchant marine, and the Navy, 22, 55, 3I $7,357,4 \mathrm{I} 2,4 \mathrm{I} 5,42 \mathrm{I}$, $428,430,435,457$; value of, 6 o. Midshipmen, 94, I45, I 59, 35 I, 362, $372,374,410,503,513,529,540$, $54 \mathrm{I}$; entry for, modern service, study, pay, etc., 446. See also King's letter boys.

Minorca, battle off, 36 .

Mitchell, Sir D., 357.

Mobilization of the Navy, 480 ; department, I 30.

Monamy, P., and his naval pictures, 523 ; his "Capture of the Princesa," etc., I740, I8, 523 .

Monarchs' names given to ships, I 89.

Monk, General and Admiral, 343.

Monson, Sir William, 20, 343.

Mortality on board ship in Elizabethan and Stuart times, 394 .

Mustard, 138.

Mutiny, $8 \mathbf{I}$; of the Bounty, 69, 527 ; of the Nore, 389 ; of Spithead, I797, 391.

Myngs, Sir C., 343.

NAMES of our ships, 185 .

Napier, Admiral Sir C., 295. "Nautical Almanac, The," 255. Naval Academy, the, I60.
Naval Brigade at El Teb, I884, 59. administration, IOI ; architecture, 20I ; art (naval prints and pictures), 519-543; ceremonies, ISo ; construction, I27; College, Royal, I54; costume, 485 ; Discipline Act, 176 ; Engineers' College, 452 ; history, lessons of, 29, 46; instruction, I6I, 45I ; intelligence department, I29; law, I70 ; lords of admiralty, I 12 ; manœuvres, I 888 , 54 ; museum, $x 60$; nomenclature, I84; officers, 328, 339, 373 ; policy, 38 ; policy, Pitt's, 43; signs, ISI ; stores, I43 ; warfare, conditions affecting, 24 .

Reserve, Royal, 95, I29; entry, duties, retainer, etc., 457 , 477.

Navigation and the discovery of longitude, 405, 408 .

Act, 27, 28, 4I 7, 4I9; repeal, in 1851,420 .

Navy, the, as an instrument of influence and dominion, 19; of France, rise of, 34; board, I I2, I I 5; estimates and expenses, IO7, I17; Office in Crutched Friars, I24, I 5 I ; office, corruption in, I 8 ; its function, 6 ; manning the, successive votes of men, etc., $4 \mathrm{II}$, et seq. ; the medireval, ro ; mobilization, 480; staff, present day, conditions of service, pay, etc. (see under heads, as Lieutenants, Artificers, etc.); Pepys on the, $\mathrm{x}_{34}, \mathrm{x}_{38} 8, \mathrm{1} 74, \mathrm{r} 80, \mathrm{I} 84$; recruiting the, 433 (see also Seamen, etc.); state of in 1608,25 ; seal of office, I83.

the, of to-day, 258 ; the old, 
245 ; scientific appliances, eighteenth century, 255.

Navy Records Society, 316, 521.

Navies, foreign, 67 .

Nelson, 20, 45, 73, I50, 160, 345 ; his ships, 248.

"Neptune's Revels," picture by W. Daniell, A.R.A., 167, 532.

Neutral flag, 60.

New England, charter of, 23.

New York dockyard, 166.

Nile, tattle of the, 45 .

Nocturnal, the, 2 I 2.

Nore, mutiny of the, 393,437 .

Norman, invasion, 8 ; ships, 318 , 322.

North East Passage, 70.

North Foreland, battle of, 29.

North West Passage, 78.

Nottingham, Earl of, 68.

Novels, nautical, on the Navy, 504, 5oS. See also Smollett, etc.

OAK and hemp, the days of, 234 .

Oatmeal, 138 .

Officers, naval, 339, 373; their clubs, 496 ; dress of, $98,145,146$, 1.59, 214, 256, 331, 339, 349, 361, 37 I, 385, 403, 410, 425, 449, 459, $46 \mathrm{I}, 475,484,485,503,5 \mathrm{II}, 5 \mathrm{I} 3$, 540 ; duties of, 123, 177 ; executive, 445 ; of to-clay, $44 \mathrm{I}$; of the Naval Reserve, 457. See also under Admiral, Captain, etc.

Oléron, the laws of, $168,169$.

Ordnance Office, 107, 124, 129.

Overend, W. H., his picture of the "Naval Manœuvres," 1889, 368, 528 .

Painted Hall at Greenwich, 160, 4S9.
Paintings and prints, of costumes, ships, etc. See names of artists and subjects.

Paixhans, Colonel, 284 .

Parker, Richard, mutineer, 437.

Parliament, seamen of the (temp. Charles I. and Cromwell), 4 I 7.

Parliamentary Secretary of the Navy, I1 2.

Passaro, battle of, 37 .

"Paid off at Chatham," 1790, after Dighton, 5I9, 539.

"Paid off at Portsinonth," 1797 (Cruikshank), 198.

Paton, R., marine painter, 524 ; his "Hawke's Defeat of Conflans," I 759, 27, 524; his "Rodney off Dominica," I 782, 46 .

Pay, 335, 358, 366 ; early, 323, 386 ; abuses, 388 ; deferred, 393 , 421 ; increase of, 392, 415, 416; modern pay, see under several heads of office; of officers doubled, 1 10. See also Salaries.

Paying off ships, delay in, II 9.

Paymasters, duties, pay, etc., 454 .

Pay Office, Broad Street, the, I 24 ; riots at, 386.

Peace, of Aix-la-Chapelle, 38 ; of Paris, 39 ; of Ryswick, 35, 63 ; of Wedmore, 8.

Pembroke Dock, 165.

Penn, Sir William, 31, 343.

Pennants, 93.

Pensions, Navy, 157, 459, 483 .

Pepys, Samuel, 344, 352 ; his "price" for a purser's place, 383 ; on the Navy, $94,134,138$, 149, 1 52, 174, 180, 184, 345, $377,395,42 \mathrm{I}$.

Perquisites of officials, 120, 122. Petroleum in place of coal, 312 . 
Petticoats, the sailors', I40, 488 , 497, 505.

Petts, the, naval architects, 222.

Petty officers, 403.

Physician General of the Navy, I27.

Pigtails in the navy, 515.

Pilot jack, 96.

Pilots, 335, 419.

etc., the fraternity of, 333 .

Piracy, 8 .

Pirates, 82,157 .

Pitt, the younger, his naval policy,

43.

Plantagenets, ships of the, 206.

Plymouth Dock, I65.

Pocock, Admiral, 39.

Pocock, J., and his picture, "Capture of the Gamo," 49, 426 .

Pocock, Rev. T. (chaplain), his journal, 400 .

Poitiers, battle of, 15 .

Polar discovery, 70.

Police service on modern ships, 474.

Port Royal, 165.

Porto Bello, 38 .

Portraits, naval, at Greenwich, $4 \delta 8$.

Ports, the home, 476 .

Portsmouth, 15 ; the college, 162 ; the dock, 121, 164.

"Portsmouth Point," 1799 (after Rowlandson), 127.

Powder. See Ammunition.

Prayers, 337 ; public, 182.

Precedence for officers, 180 .

Pressed men, 338, 357, 374, 4II. See also Impressment.

Press-gang, term, 4I3. See Impressment, etc.

"Preventive Service Man,"the, I 829 (after Heath), 33 I, 540.
Prints and pictures on naval matters. See Naval Art, 5i9-543.

Prior, Melton, his picture, "Naval Brigade at El Teb," I 884, 59, 528. Prisoners of war, 128.

Privateering, 22, 24, 36, 4I $3,4 \mathrm{I} 4$, 524.

Prize money, 326, 387 .

Prizes, I9I; Crown share of, ro8.

Projectiles, 275.

Promotion, 35 S.

Provisions, 143; quality of, 132, 137, I40. See also Victualling, etc.

Punishments at sea, $171,326$.

Pursers, 139, 326, 376, 380, 410 , 492 ; their tricks, $3 S_{4}$.

QUADRANTS, 325, 338 .

Queen's bounty, 158 . consultation room, $15 \mathrm{I}$.

- regulations and instructions, 176.

Queenstown dockyard, 165.

Quiberon Bay, battle of, 12, 27, 37,

39.

Quotamen, the, of 1794,436 .

RALEIGH, Sir Walter, 20, 70; on sea power, 65 ; on ships, 2 IS.

Ram, the, 278 .

Rank and command, I77, 504 .

Rank and family in the Navy, 34j, 540.

Ratcliffe Yard, 165.

Rating ships, 243.

Rations, I31, 369. See also Provisions, etc.

Reay, Miss, and the Earl of Sandwich, I50.

Rector $=$ Captain, $3 \mathbf{I} 8$.

Red ensign, 94. 
Religious books supplied to the libraries, 142.

Restoration, Navy of the, 387,395 , 42 I. See also under Stuarts, etc. Revolution of $\mathrm{I} 688$, landing of William of Orange, $3 \mathrm{I}$.

Rochelle, battle off, I 5 .

Rodney, 33, 46, 429.

Rogers, Captain W., 530.

Rooke, Sir George, I3, 36, 4I, 42. Roosevelt's "Naval War of I8 I 2," 47.

Ross, Sir John, 76.

Rowlandson, his naval pictures, 537; his "Ward Room Mess of H.M.S. Hector," 30,538 ; "Board Room, Admiralty," Iog ; "Portsmouth Point," I799, I27 ; costumes of naval officers, $349,36 \mathrm{I}, 37 \mathrm{I}, 385$, $467,484,503,538$; " Fighting a Gun in Action," 1782, 373.

"Royal Family," name of a company of privateers, $2 \mathrm{I}, 524$.

Royal George, the, 240.

"Royal Sovereign, the," I637, (Arenhold), 229.

Kum, I38.

Russell, Mr. Clark, his "Betwixt the Forelands," 342.

Russian War, 1854-55, 63, I 59, 296, 463,532 ; and continuous service for seamen, 440 .

SAILING battle-ships, 215 ; they are displaced, 298.

Sailmaker, I., his naval pictures, 521 ; his "Rooke and Shovell off Malaga," I $3,522$.

Sailors, $335,35^{2}$; and the pressgang, 433; dress from earliest times, 48, 66, 105, I I I , I4I I 146, I66, I98, 31 5, 325, 335, 338, 339,
$37 \mathrm{I}, 373,4 \mathrm{II}, 425,463,467,47 \mathrm{I}$, $475,484,485,493,497,507,5 \mathrm{I} 3$, 5 I6, 5I9, 53I, 532, 534, 537 ; present conditions of service, pay, etc., 463 ; they desert to the Dutch and French through ill-treatment, temp. Restoration, etc., 387, 43I. See also Seamen.

Sailor's pall, the, 96 .

_- a, palm and needle, 203.

"Sailors' Paradise, the" (Greenwich Hili), 1756 , from a contemporary print, I4I, 535 .

St. George's Cross, 88.

St. Lo (or Loe), Captain, 390.

St. Mahé, battle off, I4.

St. Valentine's I)ay, battle of, 45 .

St. Vincent, battle of Cape, 45 .

Saints' names given to ships, I 87 .

Salaries, 106, 108, 128 ; substituted

for fees, 125. See also Pay.

Sale of appointments, II 9.

Sallee Rovers, 24 .

Salt meat, I 38 .

Salutes, I77, I 79 .

Sandwich, Earl of, I5, I 57, 343 .

Saxon Shore, the Count of the, Ior. Saxons and Danes, their ships, 202, $322,4 \mathrm{II}$.

Scale of victualling, I32, I 33, I36. Scarphing, in shipbuilding, 247 . Schoolmasters, ships', 160, 408. Schooner, a, I840, I95, 528 .

Scientific appliances, eighteenth century, 255.

Scott, Admiral R., 292.

Screw propellers, introduction of, 295.

Screws, twin, 298 ; triple screws, 31 I. Sea, command of the, 21 ; council of the, 148 .

$\therefore$ power, I, 23, 36, 41 ; is the 
empire's mainstay, 62 ; its noiseless action, 64 ; its operation, 63 ; its use, 47 .

Sea punishments, 173 .

— the usage of the, 178 .

- water, distillation of, I4O ; for engines, 302.

Seals, of the admirals, 90; of the Admiralty, I82.

Seamen, English, earliest, 3I5; of the sixteenth century, 23; of 1693, 390, 493; from 1740 to I790, 48, I05, III, I53, I66; desert through ill-treatment, 4I6; their grievances, 39I, 4I5; numbers raised for the wars, to I 763, 4I I ; ditto, I765-I800, 432. "Seas, Gnardians of the," I02.

Sebastian del Cano, I8.

Seeley, Professor, on the Navy, 5, I9.

Selden's "Mare Clausum," 25.

Seppings, Sir R., 247.

Sermons at sea, ISz.

Serres, D. and J. F., marine painters, 524, 525 .

"Servant" officers in the Navy, $316,356,363$.

Service, continuous, established, I 852,440 .

Seven Years' War, 1756-1763, 39, 238,494 .

Sheathing ships, Sir J. Hawkins's plan, 2 ז9.

Sheerness yard, 100, 165.

Shell gun, the, 253.

Shells, 276; and wooden ships, 285.

Shelvocke, 73 .

Sheringham, Lieutenant, his naval pictures, 539.

Ship levy, 8.
Ship money, 25, 187 .

- names, 185 .

Shipping, English, and the Navigation Act, 4 Ig.

Ships of war, building, 20I. See

also Naval architecture, etc.

Shipwrights' Company, II 8 .

Shoreham, 165.

Shot. See Ammunition.

Shovell, Sir Cloudesley, I3, 36, 67, $232,356,37$.

Sick and disabled seamen, $\mathrm{r} 54,43 \mathrm{r}$.

— and Hurt Office, I24, I55, 509.

berth staff of the modern navy, 476.

- care of the, 394 .

Sickness in the fleet, 132, 394 .

Signals, 96 ; the service, 472 .

Signs, naval, I8I.

Singleton's naval pictures, 53I ; his

"Captain Strangways mortally wounded," 339, 53 I.

Sinope, shell fire at, 285 .

Slave trade, 36, 48, 79, 8 I, 84 .

Sloop, a, I840, I9 I, 528 .

Slops, and the slop-seller, 143,385 , 491, 506.

Sluys, engagement at, I4.

Smith, F. Pettit, his screw propellers, 295 .

Smoking on board ship, 542 .

Smollett and the Navy, 396, 489 .

Smugglers, I 57, $47 \mathrm{I}$.

Smuggling, 8I.

Social life in the Navy, seventeenth, eighteenth and nineteenth centuries, 366, 540, 54I.

Soldiers on board ship, early, 320 , 330, 4I 4. See also Marines.

Solebay, battle of, 30 .

Somerset House, I 53 . 
Song headings, $1795,48, \mathbf{1 6 6}, 539$. Suuthampton, I65.

Southern Pacific exploration, 74.

Sovereignty of the seas, 5 .

Spain, American colonies of, 36 ; and France in the Channel, 40; maritime power of, 28 ; war of succession in $1702-1713,30$.

Spanish Armada, II 7 . See also Armada.

Spirit ration to officers, 138 .

Spithead, mutiny there, 1797, 391.

Spring Gardens, 154 .

Sprit-topmast, and sprit-sail, 93, 232.

Standing officers, 376 .

"State-the-case" men, 424 .

Steam on board war-ships, 293, 464 ; high-pressure, 309.

Steel-armoured ships, 287 .

Stewards and cooks, modern, duties, pay, etc., 475 .

Stokers, pay, etc., 472.

Storekeeper General of the Navy, 127.

Stores, naval, I43.

Storing water, I 40.

Stothard, T., and his naval pictures, 529; his "On board H.M.S. Prince George," I 779, I 53, 529.

"Strangways, Captain, mortally wounded," picture by Singleton, 339, 53 I.

Striking sail, I78.

Stuarts, Navy of the, 23, 222, 38I.

See also Charles II., etc.

Sub-lieutenants, 162.

Suez Canal, 57.

Surgeon-General of the Fleet, 1703 , 395.

Surgeons in the Navy, 362, 398, 459 . Surveyor of Marine Causes, the, I07.
Swaine, Francis and Monamy, marine painters, 524 .

Sydney, establishment at, 165 .

Symonds, Sir W., surveyor, 245, 247, 295.

Syria, war on the coast of, I $84 \mathrm{I}$, I 45, 54 I.

TABLE money, I77, 360.

Tailoring done by sailors, $\mathbf{1} 46$.

Tanks for water, 140.

Taubmann's Journal, 40I.

Tea, I38.

Tennyson's "Pilot," 4 I9.

Teonge, H. (chaplain), his Diary, $369,491$.

Texel, battle off the, 30 .

Thames and Medway, the Dutch fleet in the, $1667,9,29$.

Anglo-Saxon buscarles in the, 317; freebooters and rovers in the, 24, 4I4.

Tickets, for pay of sailors, 386,389 , 426.

Tickets-of-leave, 425 .

Tobacco, 385,542 .

Tonnage, reckoning, 256 .

Torpedoes, 53, 279.

Toulon, 38, 39 .

Trafalgar, battle of, I2, 46, 6I.

Training ships for boys, 445 .

Transport Office, the, $125,128,154$. Traverse board, a, 266 .

Treasure of the navy, 107, II 7 .

Treaty of Versailles, 42.

Trial of mariners, $\mathbf{1 7 5}$.

Trincomalee, establishment at, 165 . Trinity House, I I 5, 124, 374, 4I 5. Triple-expansion steam system, 304 . Tun and gun-money=prize-money, $3^{8} 7$.

Turret-armed war-ships, 258,289 . 
UNIFORMS in the Navy, 9r, I43, I5S, $485,513,525,537$. Sec also under Officers, and Sailors, dress. Union Jack, 86, ISr.

United States, war with the, I8r2I $815,47$.

Upnor Castle, 164.

Usage of the sea, the, $17 S$.

VAN Tromp, 26.

Van der Velcles, the, and their naval paintings, 522 ; "Boat Action in the Thames," from, 9, 522 .

Vasco da Gama, 70.

Ventilation on board ship, 255 .

Vernon, Admiral, 3S, 137 .

Victory, illustrious ships so named, rgi.

Victualling of the fleet, I3I. See also Provisions, etc.

Office, the, 107, I 54, 509.

yards, 143 .

Vigo, Drake at, etc., 19.

Vikings, ships of the, 3 .

Virginia, charter of, 23.

Volunteers, gentlemen, in the Navy, $346,35 \mathrm{I}, 355,364$. See also Cadets, etc.

Votes of men for the service. See under Navy, manning the.

Voyages of discovery, early, $7 \mathrm{I}$.

WAGES of officers and seamen, 177 . See also Pay and Salaries.

Walker, Commodore George, 524 .

Wallingford House, 148.

Wallis, Sir Provo, 356.

Wapping, 165.

War of American Independence, I $775-\$_{3}, 40,435$. - of Austrian Succession, 38. - of "Jenkins's ear," 38 .
War with Spain (Armada), I9. with the French, I702-I763, 33-39; of the Revolution and Empire, I792-1815, 43.

— with United States, I8r2-I8I 5 , 47. See also Wars.

Vard-room, and gun-room, 368 ; rank, 30, 399, 508 .

Warrant officers, 373, 470, 508.

Wars, 1770-I 800 , seamen engaged for, 432 .

—— the Dutch, 27, 28, 29.

See also minder Battles.

Watchett "or skie coloured cloth" for the navy, 488 .

Watchman, the, 408 .

Water, distillation of, 140 .

Waterloo, 47.

Water-tight compartments, 29 I.

Wellington, Duke of, on the Navy, 52.

Wells, J. R., his painting "Armour Clads," etc., 529.

Whale Island, 162.

Wheatley, F., and his naval pictures, 531 ; his "An Ocean Swell with "Two Tenders," I790, 507, 531.

Whistles, 106, 336.

Whitcombe, Thos., marine painter, 528 .

White ensign, 93 .

Whitehall Palace, I 49.

- Stairs, 160.

Widows of seamen, 156 .

" WVidow's men," 391.

William III., landing of, $3 \mathrm{r}$; his navy, 360.

— IV., 500, 511 I , 512, 528, 529.

Willoughby, Sir Hugh, $7 \mathrm{I}$.

Wives on board, etc., I822, 426.

Wolseley, Lord, on the Navy, $5 \mathbf{I}$.

Wooden war-ships, last of the, $2 \mathrm{~S} 6$; and shells, 285 . 
"Wooden World Dissected, The," I 744, 40I, 405.

Woodes Rogers, 73 .

Woolwich dockyard, I739, 135.

Works, Director of Naval; the, I28. Wyllie, W. L., his picture of the Spithead sham-fight, 528 .
YATES, Lieutenant Thos., 527.

York Buildings, 149.

York, Duke of, his fighting instructions, 97, 49I. See also James II.

York, Duke of (H.R.H. Prince George), as a Lientenant in command, 528 . 






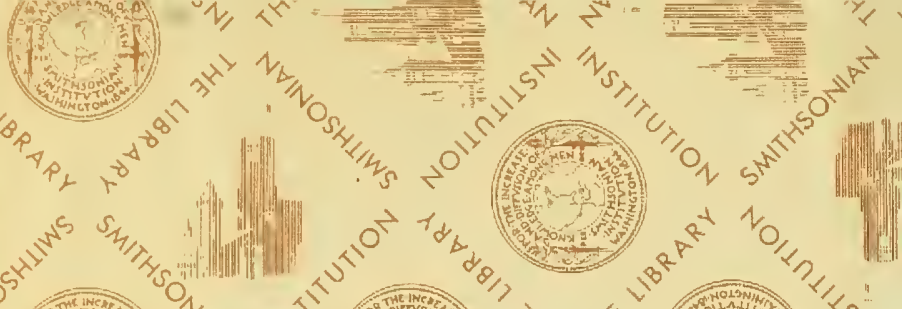




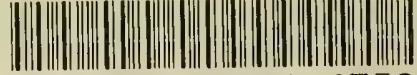 3 $908800626 \quad 6753$}

